Facultad de Filología

Departamento de Filología Inglesa

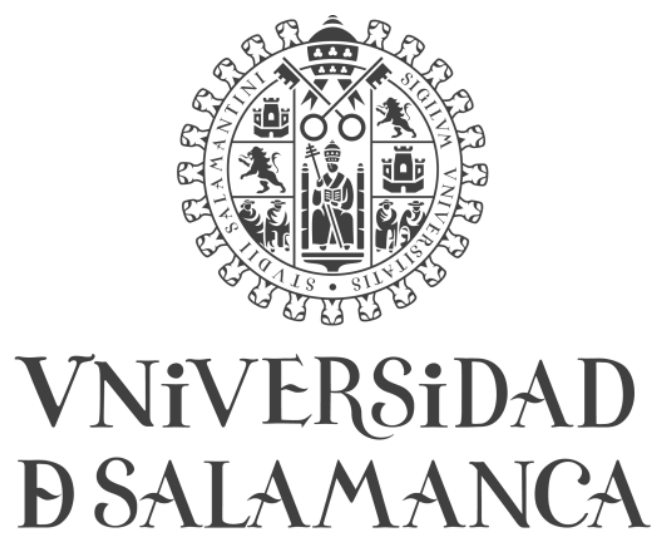

CAMPUS DE EXCELENCIA INTERNACIONAL

$\underline{\text { Tesis doctoral }}$

\title{
Quixotic Readers and Quixotic Writers: \\ Cervantes' Daughters in British Narrative Fiction from Lennox to Austen
}

Miriam Borham Puyal

Director: Pedro Javier Pardo García 



\section{Universidad de Salamanca}

Facultad de Filología

Departamento de Filología Inglesa

\section{Quixotic Readers and Quixotic Writers: \\ Cervantes' Daughters in British Narrative Fiction from Lennox to Austen}

Tesis para optar al grado de doctor

presentada por

Miriam Borham Puyal

Dirección: Pedro Javier Pardo García

$\mathrm{V}^{\mathrm{o}} \mathrm{B}$

Pedro Javier Pardo García

Miriam Borham Puyal

Salamanca, 2012 

In loving memory of Ian Henry Borham,

beloved father, friend and quixotic idealist,

who taught me to read and opened the world of literature to me. 



\section{ACKNOWLEDGMENTS}

As usual, I am going to be atypical as I start this section by thanking Jane Austen and her sister novelists for leading me away from a career as a scientist and into the fairy fields of British eighteenth-century fiction. Even amidst the pressure a $\mathrm{PhD}$ entails, I have enjoyed reading their novels, poems and plays and learning more about their fascinating lives. As Monsieur de Nivelle would have it, "l'historie d'une femme est toujours un roman," and it rings true both for these women writers and their quixotic heroines. All the women novelists included in these pages have been an inspiration. I hope I have done justice to their work and that I can spend many more years researching their narratives.

Being more traditional, I would like to thank my director, Pedro Javier Pardo García, for his suggestions and his minute corrections, but, mostly, for introducing me to some of these female quixotes and for how much I have learned as a scholar over the last three years. Thank you for this enlightening doctoral journey. I am also grateful to Kathleen Wheeler and Gillian Dow, for supervising my research stays at the University of Cambridge and the University of Southampton, respectively, and to all the wonderful staff at the Chawton House Library, for their warm welcome and help.

My family deserves a special mention: I could never thank my mother Maripe and my brother Miguel enough for their boundless and unfailing support. They believe in me more than I believe in myself, and nothing I have achieved would have been possible without their love and care.

For their support and patience throughout the long process of writing the present work I must show my appreciation to my friends. To Daniel and Marisol, for everything: without their advice, help and encouragement the writing of this thesis would have driven me insane. To Alfredo, the "codirector" in the shadows, for the endless journeys, coffee breaks, and geek talks, and for helping me find inspiration for many of the ideas herein contained. To Susana, Mabel, and Vanesa, for believing in me as a friend and a scholar. To Natsuko Hirakura, for her friendship and the wonderful fellowship at Cambridge, and also for her insightful comments on Wollstonecraft and other radical women writers: her knowledge permeates much of this thesis. To George, for making sure I remained as sane as possible while studying my beloved quixotes and for teasing me out of my stress. To Borja, Patricia, Roberto, Ana, Rebeca, Pablo, and Jesus, for helping me survive the process and for sharing their doctoral anecdotes with me: we should write a $\mathrm{PhD}$ comic of our own. To Horten and Samuel, for believing I am better than I can ever dream to be and for loving me in spite of my nerdiness. To all the En Vivo staff 
and to the people from the church at Paseo de la Estación, for taking care of me and helping me laugh my way out of stressful times.

The happy conclusion of this research would not have been possible without the encouragement and the help of my colleagues at the Servicio Central de Idiomas: Mercedes, Isabel, Claudia, Juanjo, Manuel, Sue, and Diana, who have made things easier for me when I needed time to work on the thesis, who have given me strength during the hardest parts and with whom I have laughed many a problem away. Working with them is both a privilege and a pleasure.

I would also like to thank those wonderful teachers and researchers that have inspired me throughout my academic life, from my primary and secondary school teachers to the more recent ones. I must acknowledge the encouragement of many teachers from my old high school, the always aheadof-its-time Ribera del Tajo: with them I learnt much about literature and about how to become a Humanities multitasker (drama club, journalism, narrative contests, concerts). I am also very grateful to many excellent colleagues from the Department of English, the Department of Spanish Literature and the Faculty of Education at the University of Salamanca, together with my BSECS, AEDEAN and AC friends from the UK, Málaga, Almería, Navarra or Valencia; I cannot but appreciate their support, as well as their passion for literature and vocation for teaching, and the good times at conferences I have shared with them. I wish I could name all of them, but it may not be wise (or profitable) to make my acknowledgements as prolific as the thesis itself. I hope to have the chance of thanking them in person soon.

Finally, as always, I thank God for the privilege of doing what I love most and of having all the abovementioned people in my life. 


\section{QUIXOTIC READERS AND QUIXOTIC WRITERS: CERVANTES' DAUGHTERS IN BRITISH NARRATIVE FICTION FROM LENNOX TO AUSTEN}

\section{CONTENTS}

FOREWORD

\section{PART ONE. PARADIGMS: FROM DON QUIXOTE TO THE FEMALE QUIXOTE}

\section{A JOURNEY THROUGH QUIXOTISM ................................................ 11}

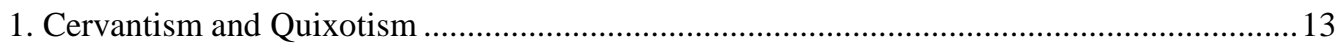

1.1. Realism and Dialogism in Cervantes' Method .............................................................15

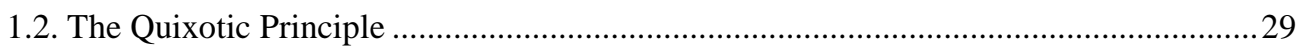

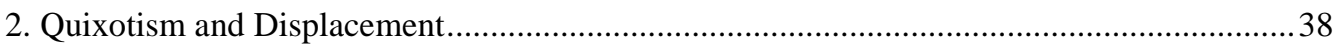

3. Don Quixote's Sally in Britain: from Farcical Fool to Romantic Hero .................................47

3.1. Don Quixote's Destiny: a General View on Two Hundred Years of its Reception ........47

3.2. The Eighteenth-Century Ambiguity: Don Quixote in the Age of Satire and Sentiment 50

3.2.1. Don Quixote against the World and Himself: the Satirical Hero ............................53

3.2.2. Don Quixote's Benevolence: the Amicable Hero ……………………....................57

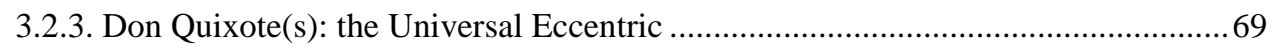

3.2.4. Don Quixote Gains in Sympathy: towards the Sentimental Hero ............................73

3.2.5. From Satirical to Romantic Hero: the Quixote as Enthusiast .................................78

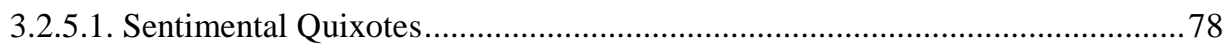

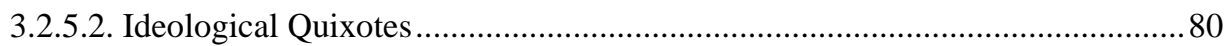

3.2.5.3. Don Quixote Returns to Romance ..................................................................... 83

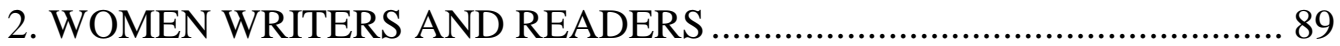

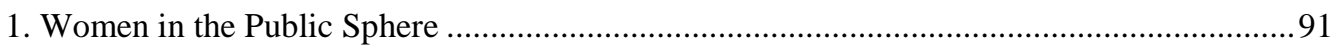

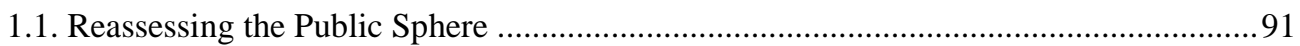

1.2. Visible Women: Female Artists, Intellectuals and Writers in the Public Eye .................98

2. Women and the Novel: the Problems of Gender, Genre and the Nation ............................113

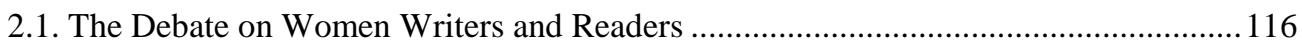

2.2. Women Writers, Romance and the Transnational Novel ..............................................119

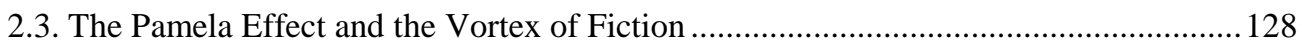

2.4. Taking over the Market: Women Writers' Dialogue with Propriety, Realism and Romance.

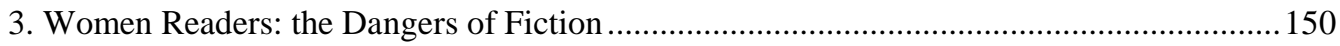

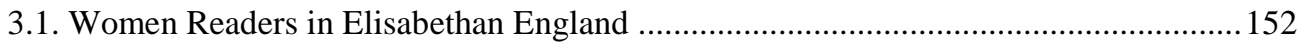

3.2. Reading Women and Women Readers in the Long Eighteenth Century ......................156

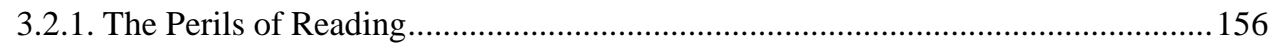


3. EARLY QUIXOTES IN PETTICOATS: ANTECEDENTS TO THE

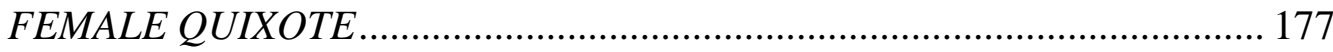

1. Mock-Clelia, or a Cure against "Scudérisme" ..................................................................... 181

2. Quixotes on Stage, or There is no Better Cure than Ridicule ............................................ 195

3. "The History of Dorinda," or the Ambiguities of Romance .................................................2215

\section{CHARLOTTE LENNOX: THE FOUNDATIONAL QUIXOTE AND THE} GENDERED DEBATE ON GENRE ......................................................... 227

1. A New Reading of the World: Romance and the Feminocentric Narrative ........................229

2. The Supremacy of the Novel: Happily Ever After, or, the Death of the Quixote .................254

3. The Dialogic Principle, The Problems of Gendered Genre and the Place of the Woman

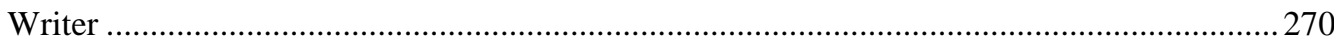

3.1. The Female Heritage of the Novel and the Supremacy of the Heroine of Romance ...271

3.2. The Feminocentric Novel and the Problems of Morality and Plausibility 284

\section{PART TWO. TRANSFORMATIONS: FROM LENNOX TO AUSTEN}

5. A SPANISH KNIGHT IN IDEOLOGICAL AND LITERARY WARS: THE SATIRICAL READING OF THE FEMALE QUIXOTE IN BRITAIN AND

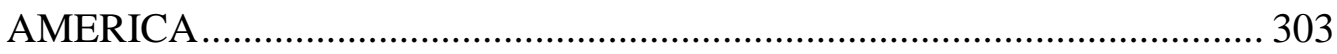

1. Introduction: from Political Satire to Literary Parody …………......................................... 303

2. Radical and Sentimental Francophile Quixotes: Jane West and Mrs Bullock................... 318

2.1. Jane West and the Tales of Revolutionary Times ............................................... 318

2.2. The Dangers of Francophile Quixotism, or the Importance of Female Education in Mrs Bullock's Novels

3. Female Quixotism in America, or, the Seductive Dangers of Literature............................. 356

3.1. Dangerous Readings: the Literary Context of Quixotic Seduction in America ........... 356

3.2. Tabitha Tenney's Female Quixotism, or, the Siege of Virtuous America.................... 372

3.2.1. Quixotic Characterization and Plot ...................................................................... 374

3.2.2. Cervantean Parody and the Birth of a New Feminocentric Didactic Novel.......... 379

4. Modes of (Mis)Reading: Mary Hays and Elisabeth Hamilton ........................................... 400

4.1. Emma Courtney and the Dangers of Sentimental and Philosophical Reading ............ 401

4.2. Good and Bad Reading: Quixotic Readers and the Proper Female Model in Hamilton's

Novels

5. A New Century, a Different War: Literary Satire in the Late Eighteenth Century.............. 449

5.1. Eaton S. Barrett's The Heroine, or, The Best Cure is Always Laughter ..................... 449

5.1.1. The Literary Dimension: Parody and the Return to a Romantic Female Quixote 451

5.1.2. The Political Dimension: an Anti-Jacobin Comic Fiction .................................. 469 


\section{FEMALE BILDUNGSROMAN OR THE DEVELOPMENT OF THE YOUNG FEMALE QUIXOTE ................................................................. 519}

1. Introduction: Defining the Female Bildungsroman …………….....................................519

2. Bridges Towards the Quixotic Bildungsroman ............................................................525

2.1. Didactic Precedents of the Young Reader's Coming of Age: Hannah More's Life Lessons for Women.

3. The Female Quixote of Sensibility: Elisabeth Sophia Tomlins's Revision of the Sentimental

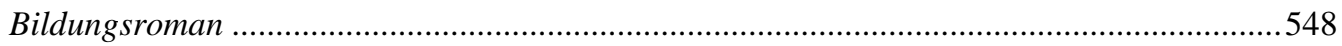

3.1. Sentiment, Knowledge and Literature: a Different Female Quixotism ........................554

3.2. Not a Wife, but a Writer: an Alternative Ending for a Sentimental Female Bildungsroman

4. To See and to Be Seen: the Female Quixote's Discovery of her Place in the World in Mary Brunton's Novels

4.1. Julia, or, the Dangers of Literary Quixotism.

4.2. Laura, or, the Dangers of Romantic and Professional Aspirations

5. Reading to Become Oneself not a Quixotic Other: Maria Edgeworth and the Problems of Self-Perception

5.1. Quixotic Precedents: the Universality of Hobby-Horses in Whim for Whim ................623

5.2. The Problem of Reading and Being Read: "Angelina; or L'Amie Inconnue” ..............627

5.3. Perception and Self-Development in Belinda .............................................................637

5.4. Things are not Always as They Seem: Perceiving Others and Oneself in Leonora ..... 655

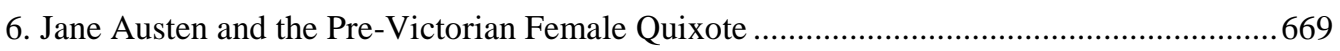

6.1. Northanger Abbey, or Cervantean Games on Quixotic Heroines and Readers .............676

6.1.1. A Journey to Quixotism and Back: the Literary and Social Instruction of a Young

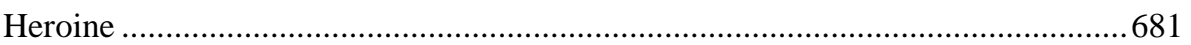

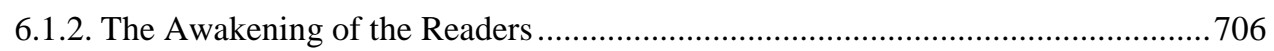

6.2. Moving Towards the Victorian Novel: Other Austenite Heroines ................................. 715

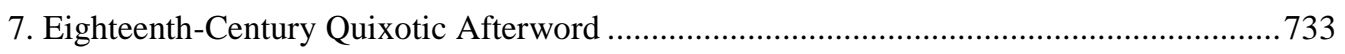

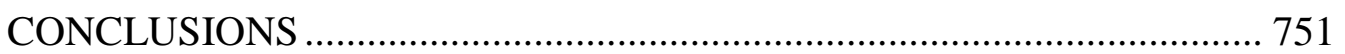

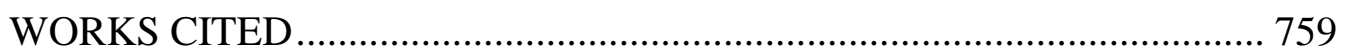





\title{
FOREWORD
}

\author{
The dreamy Don who to the goatherds told \\ Long-winded legends of the Age of Gold, \\ Finds a fair rival in our later days; \\ The newest Chivalry brings the newest Craze. \\ Dear Donna QUIXOTE -and the sex is dear, \\ Even when querulous, or quaint, or queer- \\ Dear Donna, like La Mancha's moonstruck \\ knight, \\ Whose fancy shaped the foes he turned to fight, \\ Mere book-bred phantoms you for facts mistake; \\ Your Wanderjahr will vanish when you -wake! \\ "Donna Quixote," Punch, or the London \\ Charivari, 1894
}

Dear reader, in the same manner Don Quixote had one passion above all others, the thesis you are now holding in your hands is the result of that very same enthusiasm for literature. In fact, what has motivated these pages is probably the best reason for ever considering pursuing a $\mathrm{PhD}$, merely to read, learn and enjoy the subject of study, as well as to spread this enthusiasm to any potential readers that may happen to come across this work. With this in mind, the present project started as a wish to explore narrative fiction written by women in the long eighteenth century. What was lacking was then just an appropriate focus; that is, to circumscribe the topic among the (too) many interesting aspects about these writers and their work.

Fortunately, who was to become director of this project had a very clear idea in mind: to study the figure of the female quixote. Inquiry evinced that there was an obvious unbalance in the research on the female quixote; while other quixotic figures had received ample attention, she was a footnote to books on Cervantes' reception or on women readers, or present only in articles. There was no satisfying monograph that explored the increasing presence of a female quixote in eighteenth-century narrative fiction, its contributions to the establishment of a quixotic tradition in Britain, or its rich rewritings of the quixotic myth. Nor was there a book that placed together all these women 
writers to scrutinise the reasons behind their use of the female quixote in the context of this century's changing perception of women, in general, and women writers and readers, in particular. In order to fill this void, the present study was conceived with a double purpose: first, to provide comprehensive research on the transformations of the quixotic figure embodied in a woman and, hence, to complement previous explorations of the quixotic myth which had forgotten the female quixote; secondly, to offer possible explanations on why this figure became so relevant in women writers' novels and on the ways in which it was employed to reflect genre and gender issues. In conclusion, it aimed to construct the first extensive canon of female quixotes in the long eighteenth century, focusing on the recurrent topoi that appear throughout the century, as well as on how each author created her quixote(s), and on how the differences among quixotic fictions responded to their literary and historical context. This, of course, led to another duality. Research was conducted from two different perspectives: on the one hand, from the point of view of a theoretical approach to fiction, of cervantism and quixotism, of how the quixotic myth reflects the fundamental generic changes of this century; and, on the other hand, of a historical approach to literature, of gender studies, of an exploration into the realities that the complex figure of the quixote embodied. In this sense, the long eighteenth century certainly proved the appropriate field of study owing to the quantitative and qualitative increase of quixotic rewritings, and their influence on later interpretations of the quixotic myth. As the Punch poem and caricature that open the present work make clear, as late as the 1890s the figure of the donna quixote continued to trigger many political and moral associations, and raised conservative fears of the empowerment women found in their readings -an analysis inherited from the eighteenth century.

The structure of the present work has been designed according to the abovementioned considerations. Consequently, the first part entitled "Paradigms" offers, first, an introduction to the concept of cervantism and quixotism, and to the idea of the quixotic myth. It builds on the excellent work of previous scholars and provides a classification of the changes the quixote experiments in eighteenth-century fiction as it progressively detaches itself 
from Cervantes' original character. This taxonomy establishes three categories for the quixote, based on the source and manifestation of their delusion: the literal and literary, whose misconceptions are based on their reading of fiction; the ideological, who reads non-fiction and whose quixotism is defined as an enthusiasm; and the displaced, whose flawed perception of the world is triggered by some innate qualities, as extreme idealism, a characteristic obsession or a romanticised vision of reality. The following section explores the reception of Don Quixote in long eighteenth-century Britain, focusing on the authors that have traditionally been considered the epitomes of cervantism in Britain, Henry Fielding, Laurence Sterne, or Tobias Smollett among them. It reviews prior scholarly work and sketches the influential development these authors did of both Cervantes' narrative methods and his knight's characterization. These considerations then contextualise the generic debate in which later women writers will partake, as well as the varying conceptions of quixotism they will also display. Subsequently, chapter two delivers the wider context of the woman artist at this age, and, more importantly, of the woman writer and woman reader. It explores the biased conception of women novelists, as well as the means by which they defied the limitations imposed on them because of their gender and the ways in which they participated in the development of narrative fiction. Finally, it builds a framework for the understanding of the importance of the woman reader in fiction and how her presence in novels, poems, or plays was caused by the increasing alarm over her influence as consumer of literature and over her gullibility as reader. It concludes by introducing a classification of female readers and establishing the three most important questions to be subsequently answered concerning female quixotes: what, how and why they read.

Subsequent chapters are devoted to the analysis of the works of fiction that conform the corpus of study. The said corpus is the most extensive hitherto compiled, and the main fictions explored in it range from short tales to novels, including some representative plays, in a time frame that goes from the 1670s to the $1830 \mathrm{~s}$, hence covering the whole long eighteenth century. Different chapters are created to accommodate all these heterogeneous works. The first two of these analytical chapters explore the earliest instances of female 
quixotism and how they lay the foundations for later novels, hence establishing paradigms for subsequent authors. Chapter three expounds little known works of fiction, some of which have never been studied in the context of quixotism. The anonymous Mock-Clelia (1678) or Jane Barker's "The History of Dorinda" (1726) are shown to anticipate many of the common places of this tradition. Together with those works of narrative fiction, this chapter includes several plays, so as to provide a wider context for this early female quixotism. Among them, there are well-known works, such as Richard Steele's The Tender Husband (1705) and Richard Sheridan's The Rivals (1775), together with more obscure works featuring a young female quixote: Angelica; or Quixote in Petticoats (1758) or George Colman's Polly Honeycombe. A Dramatic Novel of One Act (1761). These fictions, before and after Lennox, create the appropriate framework to understand some of the latter's antecedents, as well as her subsequent innovations.

Chapter four focuses on Charlotte Lennox, creator of what can be considered the cornerstone of the female quixotic tradition in her praised The Female Quixote, or the Adventures of Arabella (1752). Of all the examples here mentioned, together with Jane Austen's, her quixote is probably the best known and documented. Therefore, in order to provide a different view on her novel, the aim was to inscribe her within the wider tradition of quixotism and to explore the generic and gendered debate that finds expression in it, setting the example for subsequent women writers. Consequently, her development of a romantic quixote and of a comic romance is placed in relationship with Fielding's influential Joseph Andrews. In addition, this chapter hopes to prove that Lennox employed her novel to reflect the shift in literary taste, from romances to novels, and that her use of a quixote responded to her intention to comment on the different genres being discussed at the time, as well as on the role women writers were to have in the transformation of narrative fiction.

Part two, entitled "Transformations," moves on to exemplify how the quixotic figure becomes increasingly different from the Spanish knight and how new authors work on the abovementioned paradigms. Chapter five will display how the female quixote's delusion is now triggered by new forms of ideologically- 
biased fiction or non-fiction, and how the quixote becomes a propagandistic instrument in the literary and ideological wars at the turn of the century. Including British and American novels, this chapter describes the different literary and ideological quixotes, and the political or moral messages they represented. However, it will also explore the ways in which the female quixote proves at times an ambiguous propagandistic instrument, due to the fact that it allows a more subversive subtext to emerge, undermining even the more conservative discourses. The different sections comprise a wide range of narrative fictions, from extremely conservative satirical novels such as Jane West's A Gossip's Story (1796) or A Tale of the Times (1799), and Mrs Bullock's Dorothea; or, A Ray of the New Light (1801), to novels that progressively abandon their satirical intention to return to Cervantes' parody of certain literary genres, such as Eaton S. Barrett's The Heroine, or, The Adventures of a Fair Romance Reader (1813) or Sarah Green's Romance Readers and Romance Writers (1810) and Scotch Novel Reading, or Modern Quackery. A Novel Really Founded on Facts (1824). It also analyses a radical quixotic text and its quixotic response in Mary Hays's and Elisabeth Hamilton's Memoirs of Emma Courtney (1796) and Memoirs of Modern Philosophers (1800), respectively. Moving to the other side of the Atlantic, this study approaches narrative fiction imbedded with the same parodic and satirical intents, although in this case aimed at British fiction and principles. It then explores the ways in which American fiction inherits the traits of the British female quixote and adapts them to its own context. In this regard, the section devoted to American texts offers the context of women readers and the political interpretation of literary seduction in the emerging nation with the analysis of two of its earliest narrative fictions: William Hill Brown's The Power of Sympathy: or, The Triumph of Nature, Founded on Fact (1789) and Hannah Webster Foster's The Coquette; or, The History of Eliza Wharton; a Novel; Founded on Fact (1797). It then moves on to explore two quixotic texts, Leonora de Sansay's little known Laura. By a Lady of Philadelphia (1809), and the foundational American female quixotic narrative, Tabitha Tenney's Female Quixotism: Exhibited in the Romantic Opinions and Extravagant Adventures of Dorcasina Sheldon (1801). 
Finally, chapter six expounds the ways in which novelists such as Elisabeth Sophia Tomlins, Mary Brunton, Maria Edgeworth or Jane Austen resume the coming-of-age theme that was already present in an embryonic form in Lennox, and develop it to create a quixotic female bildungsroman. The chapter starts by providing some early uses of female quixotism in the framework of literature that focuses on the lessons women needed to learn about the world. In particular, it analyses Hannah More's use of it in the didactic The Search after Happiness: a Pastoral Drama (1773). For the context of the female bildungsroman this chapter analyses the matter of erroneous perception in Frances Burney's Evelina or The History of a Young Lady's Entrance into the World (1778), a novel which serves as obvious precedent to subsequent quixotic texts. The analysis of later novels considered quixotic bildungsromane -Tomlins's The Victim of Fancy. A Novel (1787), Brunton's Self-Control (1811), and Edgeworth's “Angelina or, L'Amie Inconnue” (1801), Belinda (1801) or Leonora (1806)- will demonstrate that this genre progressively displaces the quixote away from literary delusion and towards the inexperienced and naïve vision that would characterise nineteenth-century heroines. This displacement reaches its summit with Jane Austen and her novels, from Northanger Abbey (published posthumously in 1818) to Emma (1816). After this last quixotic hallmark, the chapter then concludes with a brief afterword through which to transition into the nineteenth century.

This thesis will then cover a wide and varied range of texts, with the conclusions leaving the reader at the doors of the Victorian female quixote. It thus tries to provide relevant and representative examples of the quixotic fictions of the time, as well as to bring to light some obscure fictions that have not received the attention they deserve from cervantists or even scholars working on gender studies. The corpus is extensive and it can only be justified by the enthusiastic research conducted in order to find original texts and quixotes. One novel led to another, one article to the next, and, as happens with all creatures, this thesis concluded having a life of its own, and it has grown more in length and scope than anyone would have expected. Reality and pragmatism have, happily, avoided this work being any more far-reaching than it already is. Nevertheless, the number of texts and their diversity has made it 
extremely difficult to provide neat categorizations and some novels stand in the borderline between one form of quixotism and another. The chosen structure is the result of careful consideration on what element of the quixotic narrative to highlight in order to place it in context with others; however, certain elements run through all of them and prove that there were common topoi to all of these fictions. This last fact evinces that there was indeed a strong tradition of female quixotism in Britain; a tradition that was built on the intertextuality at the core of quixotism, in which Don Quixote, certain genres, and even quixotic fictions themselves, became hypotexts for others.

The number, the originality, the relevance of these quixotes will be hopefully made apparent in the following pages, together with their importance in the history of British narrative fiction and in the reconstruction of the rich ways in which the quixotic myth has developed and been used since Cervantes first published his masterpiece. As the poem that opens this section asserts, Don Quixote and his heirs certainly found many fair rivals to embody new crazes in long-eighteenth century Britain. 



\section{PART ONE}

\section{PARADIGMS: FROM DON QUIXOTE TO THE FEMALE QUIXOTE}





\section{A JOURNEY THROUGH QUIXOTISM}

It has been said that all philosophy is a footnote to Plato. It can be said that all prose fiction is a variation on the theme of "Don Quixote."

Lionel Trilling, "Manners, Morals and the Novel," 209

Every man has something of Don Quixote in his Humour, some darling Dulcinea of his Thoughts, that sets him very often upon mad Adventures. What Quixotes does not every Age produce in Politics and Religion, who fancying themselves to be in the right of something, which all the world tells 'em is wrong...?

Peter Motteux, Preface to his translation of Don Quixote

This chapter may be considered superfluous by many. After four hundred years of literary criticism on Cervantes' masterpiece, the concept of quixotism would be expected not to need any kind of definition or introduction to its study. However, it is precisely because this term has been used for more than four centuries that its meaning has lost its boundaries, with ever-widening interpretations flourishing from the pages of new works of fiction or new critical books. This avalanche of so-called quixotic narratives is not an exclusively twentieth-century phenomenon; a close examination of the last four centuries of literary history will prove that Don Quixote was as popular a source of inspiration as it is now. Moreover, as we later study the eighteenth century in closer detail, one may even find that some ages seem to have been particularly prolific in their admiration for Cervantes or his work.

The super-abundance and heterogeneity of authors and works that claim a debt to Cervantes proves that what is understood by quixotism is very far from being a unanimous opinion. It will be the thesis subsequently expounded here that its interpretation and ulterior adaptation varies according to where the emphasis is placed, on Don Quixote, the knight, or Don Quixote, the book; or, in other words, to whom writers and scholars turn, the character or the author. It will also be the aim of this chapter to reflect on the divergences that appear as authors widen the spectrum of what is found in Cervantes' novel, moving from 
a very particular conflict to a much more universal experience. Unfortunately, it will most definitely fall short of the aspiration of proving every Cervantist's dream -that "toda novela lleva dentro, como una íntima filigrana, el Quijote" (Ortega, 1987: 116)- but it will hopefully offer a complete and comprehensive theoretical basis for subsequent research on the reception of both Don Quixote and Don Quixote in eighteenth-century Britain.

This more specific research finds its place in the later part of this chapter, which provides an overview on how relevant authors of narrative fiction put that very theoretical basis into practice, within the frame of eighteenth-century literature. Both sections are destined to offer the necessary theoretical and literary context to understand the later analysis of the different manifestations of the female quixote, placing these characters and their creators in relation not only with the general scholarly work on Cervantes and his masterpiece, but also with their quixotic and Cervantean contemporaries. 


\section{Cervantism AND QuiXotism}

In one of the most insightful and personal books ever written on Cervantes and his masterwork, José Ortega y Gasset laid the foundations for much of the subsequent criticism when he stated his intention as follows:

En las Meditaciones del Quijote intento hacer un estudio del quijotismo. Pero hay en esta palabra un equívoco. Mi quijotismo no tiene nada que ver con la mercancía bajo tal nombre ostentada en el mercado. Don Quijote puede significar dos cosas muy distintas: Don Quijote es un libro y Don Quijote es un personaje de ese libro. Generalmente, lo que en bueno o en mal sentido se entiende por "quijotismo" es el quijotismo del personaje. Estos ensayos, en cambio, investigan el quijotismo del libro. (1987: 30)

Here the scholar, maybe for the first time, formulates the distinction between quixotism as characterization and as artistic innovation. He acknowledges the richness of Don Quixote and its capacity to allow adaptation to multiple purposes (1987: 30), but demands the credit owed to Cervantes for his creation. Rejecting extreme interpretations that seem to assume the non-existence of the author in their exaltation of the character, Ortega encourages scholars to balance their view, and divert for a moment their look from Don Quijote in order to place it on the work as a whole; hence obtaining "en su vasta superficie una noción más amplia y clara del estilo cervantino" (1987: 31). ${ }^{1} \mathrm{He}$ thereby establishes a twofold line of study: on the one hand, Cervantes'

\footnotetext{
${ }^{1}$ The best example of the interpretation of Don Quixote as an independent being from his author is, of course, Miguel de Unamuno. In the second edition of his Vida de Don Quijote $y$ Sancho -the title itself very revealing of his reading of the characters- he proclaims: "me siento más quijotista que cervantista y [...] pretendo libertar al Quijote del mismo Cervantes" (2000: 134). On an exegesis of the same book, he goes even further: "Escribí aquel libro para repensar el Quijote contra cervantistas y eruditos, para hacer obra de vida de lo que era y sigue siendo para los demás letra muerta. ¿Qué me importa lo que Cervantes quiso o no quiso poner allí y lo que realmente puso? Lo vivo es lo que yo allí descubro, pusiéralo o no Cervantes [...]" (1912: 301). His exalted defense of the character in the face of the lack of understanding from the narrator/author himself most definitely states the death of Cervantes, whose achievement, Unamuno claims, was totally unconscious: "Mi fe en Don Quijote me enseña que tal fue su íntimo sentimiento, y si no nos lo revela Cervantes es porque no estaba capacitado para penetrar en él. No por haber sido su evangelista hemos de suponer fuera quien más adentró en su espíritu. Baste que hoy nos haya conservado el relato de su vida y hazañas [...]" (1912: 252). In clear opposition to this preference of the character over the author, what Ortega clearly perceives is that Don Quixote is but a very specific condensation of the Cervantean style. Moving then to almost the other extreme, he asserts that what should be called true quixotism is not that of the character, but of the author (1987: 31).
} 
quixotism, his style as detached from his character, and, on the other hand, Don Quixote's quixotism, his nature and his acquired mythic status.

This distinction between Cervantes' mastery and Don Quixote, the character, as a product -however unique and relevant- of the author's imaginative skill would be resumed by later scholars. Although with different terminology, the ideas behind the words are very similar. Hence, R.K. Britton would use the terms Cervantism and Quixotism (1993: 23), Anthony J. Cascardi phrased these concepts as the "new form of discourse" that Cervantes discovered and offered literature and the "Quixotic hero's literary influence" (2002: 77), while Alexander Welsh would talk about the Cervantine method as opposed to his quixotic hero (2002: 80). The first scholar, although not developing the difference in depth, identifies quixotism with a "superficial kind of imitation" of the character (1993: 22), while cervantism means that "somewhat deeper and more significant lessons" have been learnt in the art of writing a novel (1993: 23). This division between a characterization paradigm and a narrative model is continued and developed by Welsh. Stressing as well the twofold influence of Cervantes' work, he writes:

[...] as Cervantes' method offered a flexible model for realism in the novel, his runaway hero, the self-created Don Quixote, became the model of rare heroism in the face of mundane reality. Both resources, the Cervantine method and the quixotic hero, have become closely associated with realism in the novel but need not be invoked in the same text. In truth, allegiances to the method and to the hero have generally been divided, as novelists and their critics have been engaged with the formal and philosophical problems of realism or with justice [...] as an ardent desire. Only very exceptional novels, original in their own right, draw upon both lessons from Cervantes. (2002: 80)

While the present study will later dwell on those novelists, "original in their own right," who are able to merge both allegiances in their work, the division drawn by Welsh will serve as perfect basis to initiate a reflection on what is exactly the meaning of these terms and, later, how they are materialised in the works of different authors. 


\subsection{Realism and Dialogism in Cervantes' Method}

As proved by Welsh's words, the defining characteristic of Cervantes' method is its association with the emergence and shaping of realism in the novel. However, the term realism is subject to semantic confusion and, as Lázaro Carreter points out, "quiere decir hoy mil cosas, a veces contradictorias" (1979: 126). Traditionally employed with the meaning of "representation of reality," this definition is not adequate as reality is relative, it never means the same thing for two different people; therefore, the concept of what reality is, the concept of truth, will also be relative, because it will depend on the author's interpretation of the first (Levin, 1951: 193). ${ }^{2}$ To overcome this relativism in the definition of realism, it would hence become necessary to associate it with a certain way of understanding and representing reality (Pardo, 1995: 382). Two tendencies in the interpretation of reality, which could be considered universal, are those identified by P.J. Pardo as idealism and empiricism, the first united to God as the ideal and ultimate reality, and the later with the substitution of ideas by objects and the disappearance of God as the ruling notion (1995: 385). ${ }^{3}$ Both conceptions of the world are necessarily united to two different ways of depicting such world, thereby being respectively connected to those two modes of representing reality known as romance and realism (Pardo, 1995: 385). One sees the presence of the idealistic vision of reality in romance in what Pardo (1995) has called a double vertical perspective [doble perspectiva vertical]. The first of these vertical perspectives is the one established by Northrop Frye in his seminal The Secular Scripture (1976). In the words of this scholar, the essential feature of romance is that action takes place on "two levels of experience," what he would term the

\footnotetext{
${ }^{2}$ It is not the intention of the present work to offer a thorough discussion on the nature of realism, which others have achieved with brilliancy. See, for instance, the introductory essay on the matter by Levin, already quoted, or, once again, Pardo (1995), especially pages 375390. Therefore, we will only employ those concepts useful for subsequent discussion on the model of realism offered by Cervantes in Don Quixote.

${ }^{3}$ Ortega identifies a perennial conflict between "la 'idea' o 'sentido' de cada cosa y su 'materialidad" "which "aspiran a encajarse una en otra." However, this means the victory of one over the other: "Si la 'idea' triunfa, la 'materialidad' queda suplantada y vivimos alucinados. Si la materialidad se impone, y, penetrado el vaho de la idea, reabsorbe ésta, vivimos desilusionados" (1987: 102). Therefore, both worlds, that of ideas and that of the senses, are presented as opposites and the predominance of one over the other will determine our interpretation of reality and our attitude towards it; an idea which is also immensely relevant for the study of the conflict of idealism and reality one finds in quixotism.
} 
idyllic and demonic worlds, "neither of them corresponding very closely to the ordinary world of experience" (1976: 49). Every aspect of romance is hence subordinated to this division. In this sense, Frye states:

The characterization of romance is really a feature of its mental landscape. Its heroes and villains exist primarily to symbolize a contrast between two worlds, one above the level of ordinary experience, the other below it. There is, first, a world associated with happiness, security and peace [...]. The other is a world of exciting adventures, but adventures which involve separation, loneliness, humiliation, pain and the threat of more pain [...]. Because of the powerful polarizing tendency in romance, we are usually carried directly from one to the other. (1976: 53)

As one may infer from Frye's words, both worlds are projected on characterization, essentially Manichaean and polarized into those heroes and villains (1976: 50), and on plot, which stresses this verticality by means of a transition between the idyllic and the demonic, a "cyclical movement of descent into a night world and return to the idyllic world" (1976: 54).

The second of these perspectives is observed in yet another duality of the diegetic universe of romance, the duality between an inferior, phenomenological world, and a superior, transcendental one. The relationship between them is described by Pardo as follows:

El mundo superior determina y dirige el inferior porque todo lo que en él ocurre es resultado de un designio superior que ordena y dispone y al que son ajenos la voluntad de los personajes de ese mundo inferior o las circunstancias físicas del mismo, por lo que la acción se presenta como una sucesión de acontecimientos imprevistos e inesperados, de aventuras que vienen como llovidas del cielo, como una cadena de coincidencias. (2005d: 43)

This second perspective not only influences plot, but also affects characterization; characters are conceived in terms of the essential or immanent, what is considered to be real, and not of the variable and accidental. Thereby, they are basically archetypes representing some quality or idea (Pardo, 2005d: 43).

Opposed to the verticality that characterises romance, one finds the horizontal perspective of realism (Frye, 1976: 47; Pardo, 1995: 53); that is, realism, and with it the novel as its greatest exponent, discards this vertical organization and 
dwells in the world of ordinary experience, neither above, nor below it. Georg Lukács supported this conception of realism and the novel, stating that the emergence of the latter can only be understood in the context of a change in the structure of human consciousness. According to this scholar,

The first great novel of world literature stands at the beginning of the time when the Christian god began to forsake the world; when man became lonely and could find meaning and substance only in his own soul, whose home was nowhere; when the world, released from its paradoxical anchorage in a beyond that is truly present, was abandoned in its immanent meaninglessness. (1977: 103).

Cascardi also stresses the anthropocentric nature of realism and the new form that appears with it; in his words, it is the form of "epic literature of the disintegrated, disenchanted world" which god has forsaken and where "man had to find meaning within" (emphasis added, 1992: 607). ${ }^{4}$ This change from idealism to empiricism, to resume Pardo's terminology, of course, has an impact on both characters and plot and hence provides the background for the configuration of this new genre. First of all, the former are no longer subordinated to the plot (Riley, 1973: 310), but rather become the narrative focus. They displace their archetypal characterization, their heroic or exceptional nature, and become "individuos particulares y ordinarios con luces y sombras" (Pardo, 2005a: 113). Secondly, the plot does not depend on some kind of superior being or Fate, nor is it moved by chance; what happens is subjected to "una causalidad que tiene sus orígenes en el carácter humano en relación con la sociedad" (Riley, 1973: 310-11). Two important implications derive from this: first, plot is now subordinated to character, meaning the former will depend on the personality of the characters and their interaction (Pardo, 2005a: 113); secondly, what Frye called the and then narrative of the romance has become a hence narrative in the novel (1976: 48). Chance has been supplanted by causality.

However, it would be an exercise of naive oversimplification to believe that the novel merely replaced one perspective with the other in some kind of perfectly delineated and innovative pattern. All new forms of literature necessarily

${ }^{4}$ Other scholars agree with this vision. Jed Rasula identifies the novel as the "image of that world [without God]," reflecting the need for a "new world order" (1999: 129). 
derive from previous ones: in Mikhail Bakhtin's terms, they establish a dialogue with them. According to this scholar, the novel, more than any other genre, is characterised by its dialogic nature and it can therefore be a space in which forms and languages of prior literature are contained. ${ }^{5}$ Later scholars adopted his ideas and developed them further. In that way, Walter Reed, also employing Bakhtinian terms of dialogism and confrontation, identifies this dialogue with previous literary traditions as the main characteristic of what is termed the novel; that is, the essence of the novel is its "ethos of opposition [...] the idea of a novelty confronting literary tradition" (emphasis added, 1981: 3). As McKeon (1987) rightly stated, and Cascardi rephrases, the novel, as it is known now, would be impossible to conceive "outside of its tense and contradictory relationship with romance" (emphasis added, 2002: 9), and its "invention" mainly results from the re-fashioning of literary genres already in place (2002: 59). Once again employing Bakhtin's words, what has taken place is the "novelization" of pre-existing discourses (Cascardi, 2002: 59). In the particular case of the progression from romance to realism, Frye emphasises the presence of the former in the latter through his concept of realistic displacement or displaced myths (1971: 52). The novel adapts the narrative patterns learnt from romance to a realistic context. Frye writes on this matter that in realism one sees the same structures as in romance but "fitting into a context of plausibility" (1971: 136); however, he is also aware of technical problems that arise from that need for plausibility in the presence of romantic structures in realistic fiction. It is to the "devices used in solving these problems" that he gives the name of displacement (1971: 136). Although Frye's notion of displacement will be later expounded in greater depth, it is necessary to bear it in mind because it is essential to understand the Cervantean narrative tradition which will be subsequently discussed. It is also crucial, together with the concepts of romance, realism and dialogism, to undertake the

${ }^{5}$ Dialogism is and will be employed as it is used in the context of narratological studies "to denote the quality of an instance of discourse that explicitly acknowledges that it is defined by its relationship to other instances, both past, to which it responds, and future, whose response it anticipates" (Shepherd, 2011: n.p.). Dialogism is inevitably associated with Bakhtin's work; this scholar first employed the terms dialogizm and dialogicnost [dialogicality and dialogical quality] in his 1929 study of Dostoyevsky, although the most relevant piece of research of those concepts would be his seminal essay "Slovo v romane," "Discourse in the Novel" (1981). 
description of Cervantism. It is in Cervantes' method where one better appreciates the progression towards a new form of fiction and the new relationship between romance and realism which culminates in the appearance of the novel.

Despite the fact that Cervantes' method is characterised by what has been termed realism, with its more striking features of the abandonment of Manichaean characters and the adoption of a plot developed through the notion of causality (Pardo, 1995: 569), the uniqueness of it must be found elsewhere. According to Pardo, "los rasgos más distintivos y característicos de la novela cervantina derivan de la intervención en este realismo de lo que podemos denominar [...] el principio dialógico, que mediatiza las relaciones de la novela tanto con la literatura como con la realidad" (1995: 569). This dialogism or dialogic principle derives from the abovementioned theories of Bakhtin on the dialogic nature of the novel. This scholar characterizes the novel as the genre where a multiplicity of voices, languages and discourses -what he terms heteroglossia ${ }^{6}$ - can be found in dialogue, therefore offering different points of view or ways of interpreting reality usually presented in conflict. Equally relevant for the study of Cervantes' method is Bakhtin's statement that this dialogue can be held with previous literary forms; moreover, he specifically studies parody as a tool employed to incorporate a previous mode of discourse or conception of reality in a critical way, therefore introducing a dialogic conflict between both alternatives. The novel can, thereby, dialogise both reality and literature. Following this line of thought, Pardo develops the consequences for the Cervantean method of the mediation of realism by this dialogic principle. One of them, even if not deriving exclusively from it, is the existence of four dimensions of realism in Cervantes' book and its

${ }^{6}$ This term is a translation of Bakhtin's neologism raznorečre, developed in consonance with his concept of dialogism. As defined by this scholar, language is in constant heteroglot movement, "a process teeming with future and former languages, with prim but moribund aristocrat-languages, with parvenu-languages and with countless pretenders to the status of language which are all more or less successful, depending on their degree of social scope and on the ideological area in which they are employed" (1981: 356-7). Subsequent scholars developed this notion further in their approach to the novel, most famously Kristeva and her notion of intertextuality, and the approach to the text as a mosaic of quotations as seen in "Word, Dialogue and Novel," in Desire in Language: A Semiotic Approach to Literature and Art (New York: Columbia UP, 1980), pp. 64-91; or Barthes' "war of languages," a concept developed in The Rustle of Language (Oxford: Blackwell, 1986). 
transformation into the epitome of what would be known as this new literary genre, the novel.

First, there is romantic realism [realismo romántico], which is that inclusion of the romance in realism through varying forms of dialogue. In this dialogue, Cervantes draws attention to the romantic possibilities of reality, although circumscribing them to the vision and imagination of that one single character, Don Quixote, and to those secondary narrations that appear throughout the novel. ${ }^{7}$ In this way, "la horizontalidad realista se abre a la verticalidad romántica, el romance queda incluido en el realismo como visión individual y como realidad secundaria, y acaba por tanto formando parte de la realidad que describe la obra" (Pardo, 1995: 569). This inclusion highlights the often complex relationship of Cervantes to the genre of romance, which moves beyond the critical parody of it in Don Quixote and culminates in the writing of a romance with his Persiles, although purifying it from the mistakes which he exposed in his masterpiece (Cascardi, 2002: 9). This dialogic conflict is what Bruce W. Wardropper has termed Cervantes' hybridization, his "compendium of all previous literary genres" (1965: 11), in order to overcome them, especially what he calls the "old-fashioned romance" $(1965: 10){ }^{8}$

Secondly, Pardo also describes Cervantes' dialogic realism [realismo dialógico]. The genre of the novel, and, in particular, Cervantes' work is characterised by the dialogue, or contrast, of divergent voices, discourses or perspectives which filter reality and fraction it. In dialogic realism, hence, one finds at work the aforementioned Bahktinian concept of heteroglossia, taking

\footnotetext{
${ }^{7}$ These interspersed narrations provide examples of other forms of romance which, according to Gilman, clearly "contribute to the art of the Quixote" (1989: 89) and are part of this dialogism, for example, the pastoral, in the story of Grisóstomo and Marcela. However, Gilman forgets the Greek romance, which could be found in the stories of Dorotea, Lucinda and their lovers, who are separated and must live a series of adventures involving many misunderstandings in order to finally be together again. These interpolated stories included in the main text, added to the presence of the chivalresque in Don Quixote, cover all main forms of romance.

${ }^{8}$ Despite not explicitly quoting Wardropper, John G. Ardila reaches the same conclusion on Cervantes' inclusion of romance in his work. He states that "Cervantes impregna su novela con todos los subgéneros del romance que eran y habían sido moda durante las décadas anteriores [...]. La nueva novela que se propone imponer como remedio contra los romances se alimenta de todas esas variantes. Cervantes renuncia a lo que él estima la mayor falla de los romances, que es el hiperidealismo, pero toma de ellos los aspectos estilísticos que estima aprovechables, para de este modo crear un nuevo género, la novela, con que purgar y depurar el romance" (2001a: 6).
} 
the concept of dialogue beyond a mere dialogal or dialectical contact, and achieving dialogization in the true Bahktinian sense of the word. Dialogic realism is then the dialogue between divergent visions which are articulated through their respective voices. ${ }^{9}$ These divergent voices or visions are most clearly epitomized by Don Quixote and Sancho, the quixotic and panzaic visions of reality, "el idealismo romántico quijotesco" and "el realismo degradado panzaico" (Pardo, 2005a: 117); they start by serving as contrast and corrector of each other, only to finally become tainted by their antagonist's vision. ${ }^{10}$ In clear parallelism with the dialogue established between the idealistic and empiricist visions of reality of romance and the novel, respectively, Don Quixote's and Sancho's visions of reality contrast and complement each other. Moreover, these perspectives not only dialogue between themselves but also within themselves, therefore establishing in Pardo's words a difference between external and internal dialogization (1995: 569). That is, the different voices in the novel not only establish their perspectives in contrast with one another, but they also reflect on their own epistemological limitations, adding one new turn of the screw to this dialogism. These varying visions of the world "no agotan por sí solas la realidad y no coinciden plenamente con ella porque son limitadas y no pueden atraparla por completo" (1995: 569).

Thirdly, the literary perspective of Don Quixote and its parodic rebuttal by reality results in what Pardo has named anti-literary realism [realismo antiliterario]; a realism that claims its mimetic aspirations in contrast with the previous fictitious literature embodied in romance. Cervantes hence lies open the limitations of that form of fiction: the grandiloquent language, the implausible plots, the idealised characters, and criticises its lack of

${ }^{9}$ Pardo highlights the nature of a dialogic dialogue or discourse: "Un dialogo no es dialógico en el sentido bajtiniano del término si en última instancia es utilizado para la demostración de una verdad monológica, es decir expresable o reductible a un solo lenguaje o discurso, y, a la inversa, un discurso no dialogal puede ser dialógico porque en él laten diferentes voces, otros lenguajes y visiones de mundo ajenos que son citados o incorporados en el propio y con el que establecen un conflicto dialógico. Tampoco hay dialogismo, sino simplemente dialéctica, cuando se expresa una verdad a través de ideas discrepantes o contrapuestas pero no encarnadas en lenguajes o voces diferentes, en la heterogeneidad y heteroglosia de la vida" (2005a: 113).

10 The first scholar to analyse this "sanchificación de Don Quijote" and the "quijotización de Sancho Panza" was Salvador de Madariaga in his seminal Guía del lector del Quijote (Madrid: Espasa-Calpe, 1926), chapters 7 and 8. 
verisimilitude and its falseness (Riley, 1981: 160). For Cervantes, whatever there was of good in romance lost its worth because of its absurdities, while its distortion of truth also hid behind its appeal to the imagination (1981: 172). This relates to one of Cervantes' most relevant characteristics as a writer: his obsession with the nature of truth within literary fiction and his exploration of the limits of verisimilitude in the novel (1981: 33). Cervantes, however, moves beyond mere parody or anti-romantic realism. His achievement is summarised by Pardo thus:

[...] en ese afán por reforzar la ilusión de realidad, por presentar una realidad no literaria en oposición a las visiones o distorsiones literarias de la misma, el realismo cervantino va más allá del realismo anti-romántico y Cervantes introduce en el juego la propia novela, la visión literaria que de la realidad nos da la misma obra que leemos, a la que contrapone una realidad que la supera y desborda, haciendo así el realismo anti-literario doblemente anti-literario -la realidad no sólo frente al román sino también frente a la propia novela. (1995: 570)

As he introduces his own novel into this dialogization, Cervantes exposes its own limitations and provides a reflection of the novel on its own fictional nature and on the relationship between life and literature, history and story, deriving into the fourth, and last, form of realism identified by Pardo, what is called self-conscious realism [realismo auto-consciente] (1995: 570), probably the summit of Cervantes' achievement. ${ }^{11}$

This form of self-conscious realism is at the core of Cervantes' innovation with respect to previous forms of realism which lack that self-referentiality. According to Riley, in a time in which history adopted the vestments of fiction, and fiction was disguised as history, there was a need to separate reality and fiction which came to affect also the literature of imagination (1981: 256). It was hence necessary to differentiate between what could be and what should be, two important concepts in what would be Cervantes' theory of the novel (1981: 258) and which belonged to the realms of history and fiction respectively. Therefore, Cervantes would acknowledge and join the criticism

11 These forms of romantic, anti-literary and self-conscious realism are somehow already contained in Ortega's explication of the illusion phenomenon [fenómeno del espejismo], by which the novel, or realist novel in Ortega's words, describes the process of creation itself, while the novel of imagination portrays only the final product: adventure (1987: 100). 
placed against chivalric romances because of their historic falseness, but also because of their poetic falseness owing to the fact that what should be was achieved with an absolute lack of verisimilitude. For Cervantes, then, fiction should have at least the appearance of plausibility, although never losing sight of its nature as a work of fiction; that is, it should be openly fictional but not have the purpose of becoming deludingly fictitious. Thereby, Don Quixote provides its author's unique comment on history and fiction by means of a deluded character who does not distinguish between what could not possibly be true, what could be true, and what actually was so (Riley, 1981: 263). More relevantly for the new form of discourse he developed, Cervantes placed the Quixote in an envelope of unequivocal fiction (1981: 272). Very appropriately, Pardo has termed this the metafictional paradox [paradoja metaficcional] in Cervantes' novel (1995: 571). ${ }^{12}$ What is essential is the fact that the fictional nature of his work is unequivocal, it is obviously laid out in front of the reader despite the numerous claims to truthfulness offered in the course of the narration. It is not, then, truthfulness in the historic sense, but in the poetic one. ${ }^{13}$ As Riley has explained, there exist two different forms of truth in literature, and in Don Quixote: on the one hand, Cervantes' claim that his book should be considered truthful, which is presented so that nobody can believe such pretension, and, on the other hand, the poetic truth which his novel validates. In Riley's opinion both truths are not confused, but united (1981: 266). Cervantes' novel, despite its attack on romance, is still a work of fiction, and therefore, not historically true. Nevertheless, the author proclaims the poetic truth of his work because it is plausible and, moreover, tenable against

12 This term was formulated and developed by Linda Hutcheon in her seminal Narcissictic Narrative: the Metafictional Paradox (London: Routledge, 1991).

13 In this sense, Wardropper takes his interpretation of Cervantes' concern with verisimilitude too far: although reacting to the excesses of romance, as has been stated, his selfconsciousness annuls the claim that Cervantes desired to "persuade, and if possible to convince, his reader that Don Quixote actually lived and actually did all those things he is reported to have done" (Wardropper, 1965: 5). Rather, Cervantes' claim to historical accuracy is a "joke" (Cascardi, 2002: 66) in which he involves the readers, a critique to the apparatus of the romances of chivalry and the devices they used for that very same claim to truthfulness. Hence, although Wardropper mentions such procedures as the author's claim to truthfulness, the credibility of characters, the references to Annals, Archives or manuscripts, as "the creation of a vast historical apparatus which gives to each chapter the illusion of being historically verifiable" (1965: 5), what seems to escape the scholar is the parodic nature of this apparatus, and the way in which Cervantes deconstructs it, as we will subsequently assert. Hence, Don Quixote offers the "contradictory possibilities of discourse practices," combining the "procedures of 'historical' narration," with a "blatant fictional self-consciousness" (Cascardi, 1992: 613). 
criticism because of its acknowledgement of its own fictional nature. As Riley has stated, Cervantes maintains in Don Quixote a constant exposition of its own fictional nature (1981: 60) and creates a novel "viewed in the round and depicted in the process of becoming: the dynamic interplay of a story, its dramatized tellers and its dramatized readers" (Haley, 1965: 145-46). According to Haley, there are two stories in Don Quixote:

Alongside the supposed history of Don Quijote's adventures, Cervantes' novel presents a supplementary story [...] of how Don Quijote's adventures came to be known and set down, a record of the written stages through which it is claimed they have passed on their way to Cervantes' book. [...] in Don Quijote, this process brought to light has become an integral part of the finished novel. As it unfolds in the margin of Don Quijote's adventures, this secondary tale develops its own entanglements and moments of suspense that have little to do with Don Quijote's insane understanding but everything to do with whether the account of it will be completed and become a book. (1965: 146)

Don Quixote is, then, both a novel and the story of how that novel comes to being; it is fiction but also a comment on fiction itself. It has been identified as the "inauguration" of the mise en abîme in which literature reflects on itself as literature (Rasula, 1999: 132) and as a novel which provides a prodigious metafictional apparatus (1999: 144). ${ }^{14}$

This metafictional apparatus is indeed extraordinary because of the series of procedures Cervantes employs in his self-referentiality or in his foregrounding of the fictional nature of his novel. The self-consciousness found in the novel works at two levels, those of the narration and of the story, or, in other words, the extradiegetic and the intradiegetic. The most important extradiegetical resource is the presence of several authorial voices, which clearly highlights the self-consciousness of Cervantes' work. Through these voices, Cervantes dramatises the act of reading itself, proving that all authors are also readers and therefore subject to a fallible interpretation of that fictional world of which they have become part (Haley, 1965: 148). ${ }^{15}$ Truth is always ambiguous in Don

\footnotetext{
${ }^{14}$ In Gilman's terminology, Don Quixote provides a comment on fiction in a complex game of mirrors in which fiction is created from the ashes of prior literature that has been dissected and destroyed and where Cervantes is "calling attention to the interpenetration and interdependence of criticism and creation in his art of composition" (1989: 142).

${ }^{15}$ Haley develops the idea of the chain of intertwined story-tellers and readers, including the final reader of Cervantes' novel thus: "Consummate rhetorician that he is,
} 
Quixote, it is never simple, but complex and unascertainable: with the multiplicity of points of view Cervantes seems to claim that "one cannot apprehend the whole truth; one can only get glimpses of partial truth" (Wardropper, 1965: 11). Instead of the world of romance in which the existence of magicians or supreme beings could account for the implausibility of events, Cervantes creates a novel that reflects reality in all its complexity and uncertainty and therefore inaugurates the ultimate kind of realism. This realism and the novel that is born from it possesses a circular vision, comprising interpretations from all angles as well as describing reality as fragmented and all points of view as fallible and relative (Riley, 1981: 60). ${ }^{16}$

These divergent interpretations of what is real or even true are expressed again through Bakhtin's heteroglossia, those different voices that permeate the text and dialogue throughout it, in a wonderful dialogic interplay extensively analysed by Ruth El Saffar (1975). There is hardly a better example of the Bakhtinian heterophony than the play between the three authors, namely, Cide Hamete, the Moorish translator and Cervantes' fictional self. They are the narrator/editor, author and translator of the novel (Pardo, 2005a: 123). These voices are employed by Cervantes to stress the self-conscious dimension of his novel, especially to explore its nature as representation and as fiction (Pardo, 2005a: 125).

Cervantes demonstrates a complementary concern with the effect of a story upon its readers, which leads him to dramatize the act of reading as well. Each of the intermediaries who work at telling and transmitting Don Quijote's story functions, at the same time, as a critical reader of a previous version of that story. In all of these cases, narration is conceived of as much in terms of the writer's preparation, reading critically and selecting, as in terms of the telling. Yet none of the intermediaries forgets the reader who follows him in the series" (1965: 148). Cide Hamete, the translator, and the second author are readers of each other's narratives and intermediaries who "foreshadow coming events." They have "read the story before they begin to recount it. They are second-time readers. The reader postulated by Cervantes' book, on the other hand, is a first-time reader for whom the effects that depend upon progressive inference are expressively designed, [...]." (1965: 148-49). This interplay between story, teller and reader once again involves the different layers of the story through which the last reader must find his or her way and critically read the varied layers of fiction as such.

16 Cascardi asserts that, as the novel "purports to be the faithful and realistic representation" of the world, and taking into account the latter is polyglossic, the "totality" of it, and hence of the novel, must be fashioned by "the synthesis of separate and sometimes incompatible parts" (1992: 614-615). In the same line of thought, Mary Gaylord has described Don Quixote as a "textual labyrinth" which possesses a "plot in which declared aims proliferate, collide with one another, even work against themselves." According to this scholar, these contradictory intentions do not aim to force the reader into deciphering Cervantes" "true" authorial purpose, but rather to "dramatize the difficulties inherent in all intending and meaning" (1993: 117). 
What is more, the existence of these sometimes dissenting voices creates that "elusive style" which not simply relies on the presence of those alternative points of view in the narrative, but on the way in which these alternatives are presented, and which aims to keep the reader unsure and off balance (Allen, 1969: 18-19). Readers are confronted with authors who seem as helpless as they are, and are forced to judge characters and situations from the presentation made of them, rather than relying on authorial commentary, which is nevertheless scarce. For that reason, the reader is left with the impression that there is "more to the story" than he is permitted to witness (1969: 16) and must work his way towards his own judgment of events. ${ }^{17}$ This is what Carolyn Nadeau has identified as one of the tenets of the transmission of literary authority found in Cervantes: "the challenge to the reader to take the leap of self-assertion in the act of reading" (2002: 42). This self-assertion, in turn, should take the shape of a challenge to the writer, as the readers "respond to the text, and in this way participate in the creative process" (2002: 48). The role Cervantes assigns to the reader is reflected in the novel itself as each "intermediary" in the story-telling also becomes a critical reader of the others' accounts (Haley, 1965: 148), emphasising this unreliability.

As Haley (1965) and later Pardo (1995) have stated, by presenting the reader with the parallel stories of Don Quixote and Don Quixote, of the knight and of the writing of the novel, Cervantes highlights the nature of his work as representation. In addition, by allowing the three agents involved in the narration to become visible in virtue of their comments on the novel itself, the reader is permitted to see the techniques through which Cervantes the artist manipulates his characters, in the same way the audience observes the puppet show of Maese Pedro and is aware of the string attached to the dolls and the nature of the story they are watching as mere artistic product (Haley, 1965). Contrary to Don Quixote, who does take the puppet show literally, readers cannot -or should not- be then mistaken about the fictional nature of the work they are perusing.

\footnotetext{
${ }^{17}$ Pardo has asserted that this feeling that there exists certain information which is not present in the main body of the text is made obvious by the presence of marginal notes, such as the comment introducing Dulcinea or Hamete's comments on what occurred in the Cave of Montesinos (2005a: 127).
} 
Cervantes develops a self-conscious reflection on his work not only in the narration, the extradiegetic level, but also in the diegetic universe itself. Besides the presence of an omniscient narrator, Cervantes employs more conspicuous self-referential resources when he introduces characters who are readers, not only of other works of fiction -such as Dorotea-, but, in the second part, also of the first part of Don Quixote and of the apocryphal continuation by Avellaneda. Don Quixote thus provides two essential and different layers of fiction that develop a "peculiar interpenetration" between them (Allen, 1969: 69): the fictional worlds of "the 'story' of Don Quixote and his 'real' existence" (1969: 74), or, as Riley would have it, between the book that Don Quixote imagines is being written about him and the one that has actually been written (1981: 312). In what would be the ultimate ironic selfconscious comment on his own fiction, Cervantes introduces the real book in the fictional one and by so doing he introduces the real world, the reader's world, into the novel itself: the first part of Don Quixote is the "only specific object in the phenomenal world of Part II which exists literally, and lies ready at hand for our confirmation of its objective reality, yet it is precisely the presence of this book, Don Quixote, Part I, which violates the realistic terms of that world" (Allen, 1969: 79). The authors' direct address to the readers, together with these illustrations of the fictional nature of the account they are reading, serve to remind them that what they pore over is fiction, that they should not be deluded as his character is, therefore avoiding the accusation he had placed against romance of being a delusional kind of fiction. Even if Cervantes aims to draw his characters as real -or plausible- as possible, he nevertheless wants to make sure that the reader accepts them as artistic products (Riley, 1981: 323).

This last element arrives again at a dialogization of literature and, therefore, completes the circle: it returns to the starting point of Cervantes' realism, the dialogization of romance (Pardo, 1995: 570). In conclusion, for Pardo "el principio dialógico sustituye al de la verticalidad como principio de mediación en la asimilación de la realidad, y también en la asimilación de la literatura, pues de él se deducen las características básicas de la novela cervantina” (1995: 
570). From the effect of this principle on Cervantes' work we arrive at the inclusiveness of his realism, as this cervantist has explained:

[...] sobre el concepto de diálogo Cervantes crea ese mundo de ficción en que pueden convivir principios o actitudes opuestas, en el que dialogan los extremos, y en el que la paradoja, el diálogo de contrarios, es principio constructivo fundamental; y de la paradoja nace esa riqueza, complejidad y polivalencia del universo literario cervantino, su inclusividad. El realismo del Quijote rechaza el román al mismo tiempo que lo incluye, es anti-romántico y romántico a un tiempo; en él la visión romántica quijotesca es criticada y corregida por la visión realista sanchesca al tiempo que aquélla critica y corrige a su vez a ésta; para crear la ilusión de realidad, no sólo se critica el román sino también la propia novela; pero la crítica de la propia novela no sólo sirve para afirmar su carácter realista sino también para socavarlo (la paradoja metaliteraria); y finalmente, en línea con esto, se afirma continuamente que lo que leemos es historia, al tiempo que se demuestra que es ficción (la paradoja metaficcional). (Pardo, 1995: 571)

From these words one can then conclude that Cervantes' method, or Cervantism, is characterised by two terms: paradox and dialogue, which avow for its richness, complexity and polyvalence. This idea is echoed by Ortega when he claims that "el Quijote es un equívoco" (1987: 71). Due to this equivocal nature, every aspect of the novel possesses more than one meaning, and is open to many interpretations, sometimes even apparently contradictory ones. Moreover, in this scholar's opinion: "No existe libro alguno cuyo poder de alusiones simbólicas al sentido universal sea tan grande, y, sin embargo, no existe libro alguno en que hallemos menos anticipaciones, menos indicios para su propia interpretación" (1987: 71). This susceptibility to being subject of open interpretation accounts for the numerous and varying readings and appropriations of Cervantes' novel; in its multiplicity it can appeal to everybody. Hence, it will be this same dialogic and paradoxical nature that will give birth to the multiple interpretations and adaptations before mentioned. In this sense, Cervantes' metafictional game with the reader in which he ultimately tries to solve that "theoretical conflict between poetry and history," by means of jolting the reader's frame of reference (Britton, 1993: 25-26), allows the author to enhance this dialogue between life and fiction, a dialogue essential to understand later appropriations of quixotism, as it lies at the core of what would come to be known as the quixotic principle. 


\subsection{The Quixotic Principle}

Moving beyond the general attraction of the book for readers or scholars, the fact that Don Quixote signifies more than any other work the transition from romance to a new form of realistic representation -as well as from fiction to metafiction- and hence becomes closest to what could be considered the first modern novel, also accounts for its importance in the subsequent development of the genre. ${ }^{18}$ More relevant than its discussed status as first novel, its inclusiveness and its self-consciousness make of Don Quixote "la novela ejemplar, paradigmática, arquetípica, la de más decisiva influencia y la más determinante en la configuración del nuevo género" (Pardo, 1995: 1051). Developing this idea, Pardo states:

[...] la ejemplaridad del Quijote viene dada por su inclusividad: todas $-\mathrm{o}$ al menos casi todas- las posibilidades de la novela quedan recogidas en la novela, todas las direcciones son anunciadas. [...] En el Quijote no sólo están casi todos los hallazgos y descubrimientos del nuevo género, los que explorarán y desarrollarán luego novelistas posteriores; además éstos se muestran de manera obvia, explícita, evidente, y eso indudablemente también hizo la obra ejemplar para los novelistas posteriores, que no sólo pudieron encontrar en el Quijote una enciclopedia de posibilidades que desarrollar de acuerdo con su gusto, temperamento, o habilidad, sino que además no pudieron dejar de hacerlo por la manera explícita en que Cervantes las articula. (1995: 1049) ${ }^{19}$

The encyclopaedic nature of Don Quixote allows for the emphasis subsequent authors and scholars have placed on the trait they considered to be the quintessence of the novel. In this line, Harry Levin stated that the focus of the

${ }^{18}$ It has been previously stated that Levin identifies Cervantes as the first provider of an example for all subsequent novelists, and that Reed identifies Don Quixote as the possible beginning for the dialogization of literary forms which constitutes the essence of the novel. Reed stated that "the novel is a type of literature suspicious of its own literariness" (1981: 4) and is "outside the prevailing literary canon but self-consciously aware of it" (emphasis added, 1981: 27), mentioning Cervantes' book as key to the rise of the novel, due to his creation of a "new kind of imaginative writing" (1981: 27) arising from some of the aforementioned paradoxes and this same self-consciousness. Edward Riley described Don Quixote as a modern novel (1981: 277, 344), while Stephen Gilman identifies Cervantes as the father of the novel (1989: 78-79). Pardo (1995) summarises previous views and also states the possible condition of Don Quixote as the first modern novel, basing his assertion on the aforementioned discussion of realism in Cervantes' book, with special attention to its self-conscious nature.

${ }^{19}$ This idea has been also developed by Harry Levin, who believes Cervantes' book was "destined to figure in the formation of nearly all the other novelists" (1970: 57), by Marthe Robert who in her seminal The Old and the New: from Don Quixote to Kafka (Paris: Grasset, 1963) develops the idea that Don Quixote is the paradigmatic novel of novels or by Lionel Trilling in the famous quote which starts this chapter. 
study of Cervantes should be "not so much on the direct line of Cervantes' impact as the basic process he discovered and its wider employment, $[\ldots]$ the quixotic principle" (emphasis added, 1970: 58).

Defining the quixotic principle requires once again referring to the dialogical principle and the deriving inclusiveness which Pardo saw as the most distinctive characteristic of the Cervantean literary universe (2005d: 54). This inclusiveness allows for the co-existence of those opposing principles in Cervantes' work sustained through irony and the dialogue even among extreme positions, in particular, those of history and fiction, life and literature. Again this leads to the use of the term conflict in its dialogical sense: at the core of the quixotic principle one finds how different ways of perception, different realities, come in contact in a quest for ultimate meaning. In Pardo's words:

The quixotic principle incorporates not just the conflict between the romantic imagination and reality, but also between vision and reality, world and worldview, and of course between different visions and worldviews, and therefore implies a representation of reality as a dialogue of perspectives. (Pardo, 2005e: 98-99)

What is more, in this dialogue of perspectives one is confronted with the difficulty, or almost impossibility, to know the truth about the world or even about oneself, as those systems of meaning we use to make sense of the world prove fallible. This epistemological problem remains the nucleus of Cervantes' novel: the problem of knowledge is ever present in Don Quixote.

The epistemological conflict is, of course, epitomised by Don Quixote. Confronted with a social reality that is slowly losing what he perceives as sound moral values and in which hidalgos such as him are becoming redundant, Don Quixote tries to make sense of the world and his role in it. This quixotic quest for Being then takes the shape of an "ontologically disguised hunger for those values which the rational intellect is unable to guarantee" (Levi, 1956: 136); quixotic madness is then an ethic, a method, a logic, an epistemology which consists "in the assertion of a hope" (1956: 136) for what is rationally absurd or, at least, perceived as so. That hope is founded on a code learnt from the romances Don Quixote reads, in which knights have a particular relevance. Moreover, literature offers an appealing and rather 
comprehensible reality, where readers can distinguish the good and the bad, where they can perceive a meaningful pattern in the development of the action. This is especially true in the romances Don Quixote devours, where the roles of heroes and villains are perfectly delimited and where all characters have a destiny to fulfil and have a clear purpose within the plot. Developing his idea of the "polarized characterization" of romance (1976: 50), Frye states that:

Romance avoids the ambiguities of ordinary life, where everything is a mixture of good and bad, and where it is difficult to takes sides or believe that people are consistent patterns of virtue or vice. The popularity of romance, it is obvious, has much to do with this simplifying of moral facts. It relieves us from the strain of trying to be fair-minded [...] we not only have outright heroism and villainy, but are expected to take sides, applauding one and hissing the other. (1976: 50)

In this regard, literature makes sense of a chaotic world out of our control, where Good not always triumphs over Evil, where those who deserve happiness do not always achieve it. Literature teaches and guides, gives order and meaning to life. It is to what Don Quixote must hold on and rely on for support, especially as he faces adverse situations, or is confronted with events he cannot account for or with instances of his own insignificance. Therefore, the knight looks for and finds in his readings a way to articulate his otherwise belittled existence, as well as the possibility to returning to freedom and the chance of a new start when his life is considered over. ${ }^{20}$ In this sense, one cannot ascribe a mere lack of experienced reading to the old Castilian hidalgo, but rather a purposeful adscription to the rules he finds in literature. In Don Quixote's perception, literature then fulfils two essential functions: first, it motivates men's lives and provides the illusions by which they live, and, secondly, it presents a dichotomy between the given, disillusioning world, and that created by books, with each of them suggesting a different interpretation of reality (Predmore, 1967: 1-2).

The essential characteristic of Don Quixote's fantasies is then their bookish nature (Riley, 1981: 66-67). Don Quixote is, above all, a hero that finally

${ }^{20}$ On this matter, Claude Magris writes: "Maltratado y aún así irreductible, don Quijote tiene fe no en la vida, que no sabe lo que está haciendo, sino más bien en los libros, que no se limitan a explicar la vida sino que también son lo que le otorga a ésta un sentido, sus enseñas." (2005: 110). 
cannot distinguish between life and literary fiction and who therefore tries not just to imitate or emulate literary models, but to absolutely live literature (1981: 68) in an anti-literary world in which his vision necessarily clashes with the more realistic one of the other characters, or of the author and reader themselves. Don Quixote exemplifies Cervantes' concern with the inextricable connections between life and literature, and how they constantly seem to interfere with each other (Riley, 1981: 75), accounting not only for the influence of imaginative literature on people, but for the difficulties of establishing the boundaries between the imaginary and the real (1981: 78). Cervantes' hence develops what Gillian Brown has termed the "quixotic fallacy," which is "confusing life with fiction" and which "attests both to the power of fiction to represent reality $[\ldots]$ and to the susceptibility, whether reasonable or unreasonable, of readers in accepting fictional representations" (1999: 251). The most striking particularity of the quixotic principle or fallacy is hence the ironic conflict between real life and romantic imagination, between the real world and the literary interpretation made of it (Levin, 1970: 58) which, in Cervantes' work, transcends the character itself, and is given expression through that self-referentiality or self-consciousness mentioned before.

In this principle, as occurs in all conflicts, the end entails a process defeat: imagination must be overcome through a process of disillusionment, intrinsic to it, and which becomes the summit of the process of self-awareness and maturation (Levin, 1970: 65). Cervantes portrays the failure of literature as the system used to make sense of the world, the failure of what imagination saw as possible, of what should be as opposed to what could be (Riley, 1981: 305). As is obvious, the embodiment of the abovementioned epistemological problem and final progression toward awakening is Don Quixote. He becomes a symbol of a universal quest for meaning and a system of reference. Quixotism can therefore be characterised as the particular materialization, even embodiment, of all the conflicts one could identify as inherent to Cervantes' work: those conflicts between literature and life, imagination and reality, or idealism and facts. Don Quixote, as the incarnation and quintessence of the dialogue between the aforementioned opposing forces, will acquire a symbolic 
dimension that even transcends Cervantes himself, and will hence lose his status as mere character in the hands of his author, to lead an independent life as one of the myths of Western civilization (Mandel, 1958: 155), a status the knight has held for more than four hundred years. In those four centuries of its reception, as Riley states,

[...] Don Quixote has been continued, translated, imitated and adapted within its own genre, in other genres, and in other media, such as film. It has inspired poets and dramatists, provided material for scores of composers of orchestral music and opera, for choreographers of ballet and dance, for countless illustrators, painters, sculptors and weavers of tapestries. (1988: 105)

In this sense, the mythical status of Don Quixote is essential to understand the richness of the responses to and imitations of Cervantes' seminal novel, as well as its fundamental role in the history of literature and even culture. Nevertheless, despite being key for the study of the quixotic tradition, Cervantean criticism still lacks a definite work on the matter of the quixotic myth that would provide a thorough study on what exactly constitutes this myth and how it has been developed over the last four centuries. The only work that promised to do so was Jean Canavaggio's Don Quichotte, du livre au mythe: quatre siècles d'errance (París: Fayard, D.L., 2005). However, the book does not live up to its promise, as the author merely offers a comment on the varied adaptations, imitations or translations that have appeared in different countries since the publication of the first part until its fourth centenary in 2005. Consequently, rather than using these works to build a sound definition of the myth and its characteristics, it remains another catalogue of works connected in some way to Cervantes' novel. It does offer, though, some useful remarks on the difference between the quixotic myth and other recurrent figures of literary history.

Besides this book, Carmen Caro Dugo (1995) has provided an interesting study of the presence of this myth in the works of Antonio Buero Vallejo, where, if not systematically defining it, she does acknowledge its universal status and thoroughly deconstructs the different components of the myth and the readings done of them. Antonio Buero Vallejo, in his speech of acceptance on receiving the Cervantes Literary Award, refers to Don Quixote as "nuestro mayor 
hallazgo mítico" (qtd. in Caro, 1995: 4) and states that Cervantes' main contribution to literature was that of supplying this essential myth, without which "las letras universales padecerían grave manquedad, y, por consiguiente, lo sufriría asimismo la incierta aventura de los hombres en la Tierra" (1995: 4). He hence not only acknowledges the importance of the myth, but identifies it as something even beyond literature, beyond its "hallazgo estético" (1995: 2). For Buero then, it would be almost impossible to reduce the "eternal life of the quixotic myth to mere literary formulae" (1995: 2), because its universality derives from the light it throws "on man's interpretation of reality at all times" (1995: 4-5) and even from its ethical appeal (1995: 9). Therefore, great authors of all time, including Buero himself, have learnt to apprehend the essence of the quixotic myth and adapt it to their particular time and reality, "without changing what is eternal, universal" in it (1995: 5). By so doing, "by applying the universal myth to a very specific reality," they are able to "address concrete evils of a very specific society, time and circumstances" (1995: 5). In their appropriations of the myth these authors have emphasised one or several of the elements Caro identifies in Cervantes' novel and Buero associates with Don Quixote as important features of the quixotic myth; namely, madness, dreams, isolation, faith and ethics.

In his comment on several myths, Ian Watt also developed the ethical dimension of the myth and included Don Quixote among what he termed the "myths of modern individualism" and compared him with Don Juan or Faust in that his self-centred vision, his turn to knight-errantry to advance his "own psychological and social interests" (1996: 72), creates a conflict with the surrounding world. Watt therefore also identifies traits such as madness, faith or isolation as part of the quixotic myth. As did Buero -and also Riley (1988) or Lucía-Megías (2006) in their more comprehensive works on quixotic iconography- Watt equally identifies not only the psychological, but the physical difference that Don Quixote displays. He asserts that Don Quixote and Sancho then have a double appeal: they have become visual myths (1996: 74), recognizable figures ingrained in the collective consciousness, and also myths with a great psychological appeal (1996: 75), for every reader can identify with 
Don Quixote's noble folly or his heroic aspirations. ${ }^{21}$ He becomes an aesthetic and an ethical myth, as Buero had asserted. This ethical appeal is possible because, as Watt apparently fails to perceive in his rather poorly sustained analogy with Don Juan or Faust, which are highly egotistical characters, Don Quixote's heroic quest is fuelled by that innocence and good will, that faith and ethics, which Buero identified in him. The knight does embody the vision of the modern individualistic man, contrasting his individual perception against that of a uniform society; however, the "modern problems" he addresses are more concerned with "literary consciousness," as Watt would state (1996: 8384 ), or, as has been already mentioned, with the epistemological problem of distinguishing between truth and illusion, between reality and fiction, and with the ethical challenge of living according to one's inner convictions to its ultimate consequences.

Other scholars have also identified this last element as the cornerstone of the quixotic myth and its "survivability" and "recyclability" (Iffland, 1987a: 19). According to James Iffland, Don Quixote's liability to transformation and its "perennial appeal" lies in its capacity to interpellate the collective consciousness, to make people feel "addressed by the masterpiece" (1987b: 23). This interpellation is achieved through what lies at the core of quixotism, what Iffland identifies as its key ideologeme: "the efforts of an 'idealistic,'

${ }^{21}$ Riley comments extensively in his article on Don Quixote and Sancho's “instant and almost unrivaled recognizability" (1988: 105), based on the minute and particular description of Cervantes' portrayal (107-108). This recognizability was evident even in the seventeenth century, when several Don Quixotes, Sanchos, Micomiconas, were seen at different festivals around the world, from Valladolid and Heidelberg to Cuzco and Peru (1988: 107). Nowadays, the scholar reflects, they have become modern icons, and as such, they trigger "a response of recognition from people who only know the textual original by allusion and hearsay" (1988: 108). In the end, Riley concludes: "The Quixote icon gives expression to the idea of the quixotic. This needs no apology. It is the fate of every icon which contains a mythic figure. Such icons evoke first and foremost what they are. There is no longer any need even to remember the original stories they came from. St. George and the dragon, Romeo and Juliet, Dr. Frankenstein's creature: they have detached themselves from the stories they first appeared in. So too have Don Quixote and Sancho. We know them, perhaps, because we can find them in ourselves" (emphasis added, 1988: 115). Megías's research proves even more extensive and thorough, ranging through centuries and countries, and addressing explicitly the creation and development of a quixotic myth through its varying artistic representations. While he agrees that the most universal image of the knight and his squire is an heir of the Romantic imagination, he also asserts that it is indebted to the models of previous centuries. In these models the values and habits of the different ages are reflected, so that these thousands of images create a complex and fascinating network that allows perceiving what previous readers or gazers saw in Don Quixote (2006: 20). However, he also asserts that, at one point, Don Quixote and Don Quixote transcend trends, countries and ages, to become in an extemporal myth (2006: 29). 
'good-hearted,' 'altruistic' individual striving to carry out what we might call his 'inner project' in a predominantly hostile, 'uncomprehending world"' (1987a: 26). This ideologeme -or quixotegeme (1987a: 30)- exercises a "universal interpellation," one capable of hailing virtually any group of whatever ideological stripe (1987a: 26) and of becoming "part and parcel of the 'general culture"' of Western civilization (1987b: 21). Alexander Welsh (1981, 2002) offers the same interpretation of the mythical appeal of the knight, and has thoroughly explained how Don Quixote has become a symbolic figure, such as Abraham or Christ, by means if his status as a representative of innocence and of faith who acts according to a fixed set of principles that often contradict the general view of the world. Just as one finds the sacrificial figure of Christ appear once and again in heterogeneous works, from Dostoyevsky's novels to T.S. Eliot's poems, so does the figure of Don Quixote recurrently surface in subsequent fiction. ${ }^{22}$

In this sense, as Jean Canavaggio has explained, Don Quixote is different from other myths, such as Don Juan or Faust, in that his transformation is greater (2005: 326): Don Quixote becomes less himself in subsequent works, though his trace is still undoubtedly present. Precisely because of the richness of his myth, and his ethic and aesthetic connotations, Don Quixote, the Spanish knight, is transformed in later imitations into somebody different, into a new quixotic character, who in many cases has no obvious reference to that Alonso Quijano portrayed by Cervantes. In the same way one does not read about Christ himself in the abovementioned works, the reader does not encounter Don Quixote, but rather different forms of quixotic figurations [figuraciones] employing P.J. Pardo's terminology-, that is, characters that "no son Don Quijote pero que son como Don Quijote" (Pardo, 2011: 238), hence allowing not just duplications but similes, not mere literal repetitions but the myth's metaphorical displacement [desplazamiento metafórico] (Pardo, 2011: 238).

${ }^{22}$ It is interesting to observe that Ortega also compares Don Quixote to Christ, a symbolic figure that represents the innocence and suffering of men (1987: 30), a comparison that can be traced back to Dostoyevsky and his "imitatio Christi" in The Idiot (Levin, 1970: 56). This author seems to find inspiration both in Don Quixote and Jesus for the wise foolishness of his Prince Myshkin, and acknowledges the former to be the most perfect of all noble figures in Christian literature (Welsh, 2002: 89). However, the greatest identification with the figure of Christ and of Don Quixote as a symbol of faith is done by Unamuno in his Del sentimiento trágico de la vida (1912). He names Don Quixote the "Cristo español" and perceives him as the supreme allegory of freedom and ethics (Zorrilla, 2005: 8-9). 
Therefore, one could conclude with Pardo that the characteristic trait of the quixotic myth is that it forsakes not only the adventures as they appear in Cervantes, but also the knight's identity: it is myth built on analogy rather than repetition (2011: 238). The recurrence of a quixotic character and plot results not from a mere translation of Cervantes' character to a different context but from the application of the quixotic principle to different characters for various purposes, thereby the myth is identified in characters whose features, behaviour and adventures are quixotic because they are analogous with Cervantes' knight (Pardo, 2011: 238). Don Quixote has then acquired the status of a symbol, whose metaphorical displacement will be subsequently developed as a means to account for the progressive removal from the original source of Cervantes and the increased richness of the quixotic tradition. 


\section{QUIXOTISM AND DISPLACEMENT}

Among the myriad of authors that claim to have been influenced by Cervantes, or in which his trace may be found even if unacknowledged, Harry Levin has distinguished two groups. On the one hand, there are imitators (1970: 47), writers who repeat a formula extracted from Cervantes, mainly understood as a characterization pattern and an episodic narration, therefore paying little or no attention to the complexity of Cervantes' method. These authors basically portray characters who aim to live according to the principles acquired from their reading of fiction or non-fiction and who make obvious the inappropriateness of their values in an anti-literary, anti-romantic reality. These quixotic figures literally apply their bookish interpretation to characters and events, and are once and again contradicted by the reality they experience in a series of, more often than not, comic adventures. Despite adding elements of their own to the characterization and context of the quixote's adventures, the complexity, the richness of Cervantes' masterpiece is almost lost in these imitative novels. On the other hand, Levin emphasises the existence of emulators, "those who, not content with exploiting his discovery, pushed on to make advances of their own" focusing especially on "the imaginative process" that Cervantes developed and that they continued and even further advanced (1970: 47). The latter are especially relevant for the study of the development of the novel; they do not merely repeat a formula in a different literary context, they develop innovations of their own following the Cervantean method. These authors enhance the tradition of the novel because of their reflection on the nature of fiction itself, creating new ways of mirroring the creation of the novel within that very same novel. They develop new forms of dialogue between author, characters and readers and their multiple perspectives, hence retaining in a more significant way what Don Quixote had of paradox, of comment on the nature of realism and the impossibility to attain complete disclosure or absolute knowledge.

Whether materialised in imitations or emulations, as will be stated throughout this section, one encounters varied characters defined as quixotic that have 
been created in diverse contexts to fulfil various purposes; however, all of them bear in common this assumed connection with Cervantes' creation. As Elisabeth Frenzel has noted, different people and ages have created their own quixotes to make fun of the spiritual sickness of the moment (1976: 130), while Ortega has stated how they can be also used to embody the characteristics of a national hero (1987: 30). This adaptation of Don Quixote to all times and circumstances responds to the aforementioned appropriation and development of the quixotic myth, or the "ideologemic matrix" (Iffland, 1987a: 30), displacing the new quixotic characters from the context of seventeenth century Spain, from the description of the quixote as an old Castilian hidalgo, and from the mock-heroic adventures he experiences on Spanish ground, transforming the quixote while at times also adapting Cervantes' method to a different literary context.

As times and situations change, a progressive displacement from the original source can be perceived. From the very literal imitation by Avellaneda, inscribed in the same context and using the knight himself as character, adaptations employ figurations, characters that merely bear a resemblance with Don Quixote, weak as it may be, but that somehow are a new instance of the same type of character within a similar plot. These figurations are increasingly removed from the nucleus of quixotism found in Cervantes, becoming more difficult then to trace the vestiges of the quixotic pattern, more so as the great number of interpretations increases the difficulty of studying and defining it. Providing examples from one Russian and five English novels that present what he considers highly representative quixotic heroes -Dostoyevsky's The Idiot, Fielding's Joseph Andrews, Sterne's Tristram Shandy, Goldsmith's The Vicar of Wakefield, Dickens' Pickwick, and Thackeray's The Newcomes-, Welsh observes at least four significant changes in the portrayal of quixotic behaviour and situations:

First, a quixotic hero is not quixotic by virtue of having a squire, since only one of these novels [...] preserves the Sancho Panza figure. Second, a Dulcinea is unnecessary, [...]. Third, books are not the proximate cause of the hero's illusions or of his ideals, since only Parson Adams and the Shandy brothers are addicted to particular books [...]. Fourth, the hero is quite sane, since only Don Quixote and Prince Myshkin are possibly insane [...]. (1981: 13) 
These differences allow for the progressive displacement these heroes have experienced from the quixote of Cervantes' novel. Despite these divergences, Welsh finds that what these characters have in common, what makes them truly quixotic, is that they have become examples of that "wise fool," both admirable and foolish (1981: 11), epitomised in Don Quixote. They are also emblems of the modern hero, whose quixotic heroism is defined by "the cultivation of romance amid incongruous surroundings" (2002: 85), a definition which is at the core of the quixotic myth and which these authors rewrite in their particular fictions.

However, Welsh's study of the quixotic model is limited to the idea of quixotic heroism conceived as the superiority of the character in an undeserving world, and focuses then only on the conflict between imagination and reality or idealism and facts, slighting what remains of the struggle between literature and life, for instance. It is essential to understand how the quixotic pattern has progressed to include that first source of conflict, which was, after all, essential in Cervantes' novel. Even if one can agree with Welsh's reading of the quixotic hero as an idealistic character confronted with the surrounding world or with Pardo's description of the quixotic myth as one of "marginality, alienation, individualism" (Pardo, 2001: 68), whose marginality is characterised by being that of an "upright individual who confronts a corrupted society" (2001: 64), literature as a source for this individual perception cannot be overlooked. Pardo stresses the fact that in Don Quixote his idealism and innocence derive from literary madness, literary in "both its origins (romance reading) and in its effects (the inappropriate imitation of romance literary conventions)" (2001: 64). As a result, after providing extensive studies on a more significant number of examples, Pardo's definition of the quixotic model remains the most inclusive. He identifies it as:

[...] el lector o imitador romántico e inadecuado de ficción, cuya lectura o imitación genera una secuencia narrativa basada en una serie de dualidades: (1) la confusión entre realidad y ficción o vida y literatura, (2) el conflicto entre la imaginación romántica y un mundo hostil a la romantización, y (3) la discrepancia entre un modelo heroico caducado y un contexto anti-heroico. (2011: 238-9) 
Pardo hence includes Welsh's conception of romantic interpretation of reality and quixotic heroism, while he does not forget the first and foremost source of delusion, which is literature. According to Pardo, then, this model finds expression in three semantic centres that the scholar associates with the quixotic experience and which can be considered elements of the myth. These three elements are the literary syndrome [el síndrome literario] or quixotic syndrome "del lector que lee la literatura como si fuera vida y la vida como si fuera literatura;" the romantic imagination [la imaginación romántica], which "concibe la realidad mejor de lo que es y a la que la realidad corrige sistemáticamente;" and the quixotic heroism [el heroísmo quijotesco], which is "inadecuado o alienado tanto por las propias limitaciones del sujeto heroico como por las de la sociedad en la que se ejerce su acción” (2011: 239). Pardo once more evinces the complexity of the quixotic myth and moves on to expound the rich transpositions of the mythical dimension of Don Quixote, this time in his analysis of films rather than literary texts.

Scholars such as Welsh or Pardo thus pave the way for the present analysis of the British appropriations of the quixotic myth. Disregarding the genre or the age, in general Cervantes' reception in Britain moves beyond a mere replica of his most famous character and develops some of the aspects at the core of the myth, adding to it the complexities of the political, social, cultural or literary context in which it is inscribed. In this sense, the British reception of Cervantes can be seen as structured in concentric circles that revolve around the core of quixotism as found in Cervantes. His novel is then like a pebble dropped into a pond: it originates concentric ripples in the water which become increasingly blurred as they are further removed from their centre. At the nucleus of Cervantes' work, one finds a compulsive and inadequate reader who applies to the surrounding world the principles learnt from literature so as to decipher the meaning of life itself. In the first of the concentric circles, there are those works that retain the literary syndrome, or what Susan Staves has called literary quixotism (1972: 193), that is, literature as the source of the quixote's delusion. Whether targeting romances or sentimental novels, subsequent quixotic fictions of this type revolve around the essential conflict at the core of Cervantes' work: the chasm between literature and life, as well as the consequences that 
ensue from aiming to interpret the latter by means of the codes learnt from fiction. Consequently, this first stage of the detachment from Cervantes preserves the Spanish author's parodic intentions: the forms of literature that lead the quixote down the path of insanity or delusion will be ridiculed, criticised or proved inappropriate, and their effects will need to be counteracted by reality or by aesthetically better, more plausible or moral forms of fiction. Nevertheless, these narrative fictions can also convey the ambiguous message found in Cervantes' second part: however obsolete the codes of romance, they can still prove superior to those held by society as a whole. In this sense, the romantic literary code, especially in the case of female quixotes, becomes a set of values different from those of the age in which they live and constitutes the basis for a certain moral idealism that places the quixote above the rest of the characters, as will be seen in examples such as Charlotte Lennox's The Female Quixote and its protagonist, Arabella.

This moral superiority already indicates another shift: an emphasis on the satirical intention of Cervantes and on the ideological interpretation of his knight. Within the second of those concentric circles, even more displaced from the original quixotic novel, one finds what Staves has identified as the ideological Quixote (1972: 201). This quixote compulsively peruses nonfiction works which finally create an idealised vision of reality which will be once again contradicted by the experiences the quixotic character will go through. No longer a consumer of literature, the quixote displays a form of idealism circumscribed to one very particular area, usually determined by the nature of the readings or school of thought the quixote has chosen. Levin, for example, acknowledges that the displacement from a mere parodic quixotism to a satiric one moves from a critique to literature to a critique of life (1970: 64-65), in which "the overriding idea might assume the guise of an ideology to be challenged, of a doctrine which turned its believers into doctrinaires, or a frame of reference which proves inadequate for the phenomena it was intended to cover" (1970: 65). As a result, the quixotic mania becomes related to politics, philosophy or religion according to what the author saw as the madness of the age. Therefore, the conflict in this case develops between reality and an idealism understood as obsession or enthusiasm, a word that 
would become intimately connected with quixotism in the eighteenth century (Close, 1977: 12). ${ }^{23}$ What is more, the quixote becomes more than ever an instrument for satire, whether the latter was aimed at the quixote and his or her foolishness, at the world and its cruelty towards the quixote, or at both at the same time. The quixotic figure is thus transformed into the butt of or the instrument for satire, or even both (Staves, 1972: 194; Pardo, 1997: 134). On the one hand, one encounters the satirical interpretation of the quixote-like figure as butt of the author's attack, found in works such as Samuel Butler's Hudibras (I, 1663; II, 1664; III, 1678) and its later development in Richard Graves' The Spiritual Quixote (1773), which would serve as model for a long series of satirical political or philosophical quixotes in the late eighteenth century. On the other hand, there also exists the coeval development of Henry Fielding's satirical quixotic plot in which the deluded character is seen a morally superior fool who can become an instrument to criticise the surrounding world, as seen in his novel Joseph Andrews (1742). In this last reading, the quixote inherits the heroic dimension of Cervantes' knight in the second part of his novel: Don Quixote's idealism may render him ridiculous, but also admirable. This interpretation would gain strength throughout the eighteenth century and would be developed by several late eighteenth-century novelists.

Finally, one can talk about more conspicuously displaced quixotes, this time employing Pardo's terminology (1997). These quixotic figures are more withdrawn from the Cervantean core. In them one can perceive a more distant assimilation of the quixotic formula and a more obvious transformation into something less recognizable as quixotism, but closer to an experience which all human beings could identify with. The literary element slowly disappears, and quixotism blurs and becomes a much more universal experience, no longer the conflict between literature and life, but between the character's innocence or inexperience and the surrounding world. Consequently, the character's romantic or idealistic vision is intrinsic to his or her nature, and not a consequence of external influence in the shape of fiction or non-fiction. In a

${ }^{23}$ Welsh also identifies eighteenth-century English borrowings from Cervantes as "satires of enthusiasm" (1981: 9) and Paulson uses this word as synonym for the interpretations of quixotic madness or imagination done in this century in England (1998: 9). 
further displacement, in most fictions of this kind the old quixote is transformed into a young and inexperienced character. These young quixotes epitomise and give voice to the problem of knowing the truth about the world and oneself, the problem of apprehending reality which was ever present in Cervantes. In the end, these quixotes will be forced to outgrow their quixotic vision of reality (Welsh, 1981: 16) and find their place in the world. In this sense, the quixotic pattern becomes intimately attached to the idea of bildungsroman or even the novel of manners (Paulson, 1967: 266), in which a young girl must make her entrance into society and adulthood and her notions of what the world must be clash with the reality she will experience. This pattern of what one could call quixotic disclosure is obvious in novels such as Maria Edgeworth's Belinda (1801); Jane Austen's Pride and Prejudice (1813), Emma (1816) or Northanger Abbey (1818); and, in its more heroic turn, in George Eliot's The Mill on the Floss (1860), becoming particularly useful for the development of the nineteenth-century central themes of self-knowledge and disillusionment (Kauvar, 1970; Pardo, 2005c; Welsh, 1981).

In this process of universalization, quixotism will also become a particular mania which no longer requires a literary source, but which nevertheless tints every area of the character's life and is contrasted with a more balanced way of dealing with reality. Madness disappears and the quixotes are placed in a more realistic context and become less extraordinary, more common and easily recognizable as real or plausible characters. In this interpretation of quixotism as mania, one finds the quixote-figure transformed into the symbol of the ordinary obsessions with which all men live. Thus quixotism becomes the universal epistemological problem of interpreting the world on the basis of a set of "fixed ideas" (Welsh, 2002: 86), with or without a literary origin, and the quixote is, once again, that everyday man or woman with his or her own particular obsessions which provide a similar system of meaning to that given by his romances to Don Quixote. This mania then becomes the means of "selfpropulsion;" whether it be "an obsession" or the "noblest of vocations," it is always a "source of forward movement" (Gilman, 1989: 34) that inspires the character and forces him or her into action. This form of displacement is especially obvious in Sterne's Tristram Shandy, where quixotism has become a 
"personal eccentricity" (Britton, 1993: 30) and "dedication to knight errantry has become $[\ldots]$ a hobby-horse, with the strong implication that any gentleman afflicted with much leisure rides or is ridden by a hobby-horse and cannot do otherwise" (Welsh, 1981: 86). In the same way Walter and Toby Shandy perceive life through their different obsessions, any character that rides his or her own hobby-horse, that is driven by a particular moving force, can be read as quixotic, thereby establishing a much more general categorisation. Similarly, Tobias Smollett in his novel Humphry Clinker (1766) redefines quixotism as a form of "originality" (Pardo, 2005e: 103) which manifested itself in different characters by means of their varied and particular idiosyncrasies, such as Bramble's hypochondria or Lidya's romanticism. Both Sterne and Smollett create a world full of quixotes, leading Pardo to assert that "if the self is imprisoned in its quixotism, or the workings of the human mind are quixotic, then quixotism becomes something universal, a feature of the human condition: we are all quixotes [...]" (2005e: 104-5). Our vision is always biased, our perception of the world always flawed and limited.

Therefore, in the end, through these concentric circles and further displacement one arrives at conclusions such as those pronounced by Juan Bautista AvalleArce when he proclaimed that we are all quixotes also in an ethical sense, that we all have in us a "quijotismo interior" (2002: 144), an ideal to which we aspire but we cannot live up to. In that sense, Avalle-Arce describes human beings as "Quijotes frustrados" which have surrendered their dreams to the pressure of circumstances (2002: 144). Hence the appeal of Don Quixote and his adventures: when we read his story, we envy his capacity to continue his fight against adversity while we can also partake in his idealism. Miguel de Unamuno had formulated this thought when he declared that every reader is, in essence, a quixote. According to this philosopher, the quixote belongs to each one of his readers. He expresses this opinion thus:

[...] dejando a eruditos, críticos e historiadores la meritoria y utilísima tarea de investigar lo que el Quijote pudo significar en su tiempo y en el ámbito en que se produjo y lo que Cervantes quiso en él expresar y expresó, debe quedarnos a otros libre al tomar su obra inmortal como algo eterno, fuera de época y aun de país, y exponer lo que su lectura nos sugiere. Y sostuve que hoy ya es el Quijote de todos y cada uno de sus lectores, y que puede y debe 
cada cual darle una interpretación, por así decirlo, mística, como las que a la Biblia suele darse. (2002: 133-134)

What is more, not only is Don Quixote patrimony of his readers, of all those who read it and feel it, but he is also part of those readers who, following Unamuno's example, create a continuous exegesis of Cervantes' novel with the aim of “pensar, analizar, soñar 'su Don Quijote' y convertirse, en solitario y nostálgico juego, en lector y lectura dentro de su personaje" (Zorrilla, 2005: 1). ${ }^{24}$ Unamuno, then, exemplifies the persistence of those "quixotic modes of reading" (Cascardi, 1992: 624) which gave birth to Cervantes' creature and which are common to all readers of fiction. As Ortega pointed out, novel reading leads to becoming lost in fiction, eliminating one's existence and living through the character in print. Readers must therefore first learn to lose themselves in order to be finally able to truly find or read themselves as they accept the challenge of progressing from "reading books to being read by books" (Gilman, 1989: 21-22), a progression epitomized by Unamuno and his ultimate displacement of Don Quixote. As Britton has rightly pointed out (1993: 32), in what would be Cervantes' ultimate irony, as we read the adventures of his deluded character, we all become quixotes.

\footnotetext{
${ }^{24}$ Unamuno's passion for Don Quixote did not abandon him in exile, where he wrote the notes for what would have been published under the name "Manual de Quijotismo," a book in which he once again claimed the greatness of the quixotic identity and where he reflected on don Don Quixote as myth, providing comparisons with Don Juan, Hamlet or Robinson. The fragments of the never-to-be book have been published and it is now possible to read Unamuno's identification with Don Quixote himself and his lifelong admiration for him as he states: "Escribí mi 'Vida de d[on] Q[uijote] y S[ancho]' [...] fue una obra contemplativa, aunque de contemplación activa. Después comencé mi acción, mi imitación de Don Quijote, arremetiendo contra el retablo de Maese Pedro, el rey Don Alfonso XIII. Mi campaña desde 1914; me llamó el rey; golpe de Estado, mi deportación. Y en Fuenteventura concebí esta, otra obra, de acción contemplativa, después de haber hecho el Don Quijote. Esto es una contemplación de mi acción. [...] En este misterio cristiano de don Quijote fundo en uno mi 'Vida de don Quijote y Sancho' mi 'Sentim[iento] trágico de la vida' y mi 'Agonie du christianisme'. Y es la resignación a la muerte, mi testamento y la contemplación de mi obra histórica" (Vauthier, 2005: 39).
} 
3. DON QUiXOTE'S SALLY IN BRITAIN: FROM FARCICAL FoOL TO ROMANTIC HERO

\subsection{Don Quixote's Destiny: a General View on Two Hundred Years of its Reception}

As has been expounded so far, in his nature as one of the essential myths of Western culture, Don Quixote has become ingrained in the public consciousness. Although probably not read by all and, if so, reduced to the mere anecdotes of the helmet or the windmills, most people are aware of the nature of Cervantes' main character and the terms Quixote or quixotic have even become part of the lexis of most European cultures. As one approaches the English-speaking context to perceive the assimilation of these concepts, a surprising coincidence in the definition of such terminology is found. Hence, the Cambridge Advanced Dictionary defines quixotic as "having or showing ideas that are imaginative but not practical or likely to succeed;" the Collins Cobuild states that to describe someone's plans or ideas as "quixotic" is to consider them "imaginative or hopeful but unrealistic," and provides synonyms such as "unrealistic, dreamy, fanciful, idealistic, impractical, romantic;" and, finally, the Oxford English Dictionary defines Quixote as "an enthusiastic visionary person like Don Quixote, inspired by lofty and chivalrous but false and unrealizable ideals." It is interesting to observe that these definitions exhibit a strong influence of the Romantic view which was predominant in the later eighteenth and early nineteenth century and which has obviously pervaded ulterior interpretations, resulting in this extended definition of quixotism as a rather positive feature. ${ }^{25}$ However, the Romantic approach was not the first or only one, nor did it appear spontaneously. It was the result of the progressive transformation of the interpretation of Cervantes' masterpiece, as it was appropriated and then "remodulated" (Iffland, 1987a: 23) by the most diverse ideological or artistic tendencies. If in the previous section the basis of the concept of quixotism and its universal power of interpellation were expounded,

${ }^{25}$ According to Anthony Close (1977: 67) and James Iffland (1987b: 9-10), modern approaches to Don Quixote are mediated or conditioned by the Romantic reading of its protagonist. 
the present one will focus on the reception, appropriation and transformation of the quixotic principle in Britain from its first introduction in the country until the nineteenth century, paying special attention to the long eighteenth century and its essential role in the shaping of the concept of quixotism.

As early as 1606 did the first reference to Don Quixote appear in an English work of fiction, only a year after the publication of the Cervantes' first part (Avalle-Arce, 1989: 59). ${ }^{26}$ This fact has been recurrently quoted by scholars as evidence of the immediacy and importance of Cervantes' impact in England. Cervantists such as James Fitzmaurice-Kelly (1905), E. Allison Peers (1947), Walter Starkie (1950), or Juan Bautista Avalle-Arce (1989) have acknowledged this early response and have claimed that English literature has been the richest in its reception of Cervantes' work, leading the later scholar to assert that "la lengua inglesa es la primera y la que más ha hecho por la gloria de Cervantes" (1989: 59). Fitzmaurice-Kelly established the foundations for this approach when in his seminal and enthusiastic work he stated:

[...] England was the first foreign country to mention Don Quixote, the first to translate the book, the first country in Europe to present it decently garbed in its native tongue, the first to indicate the birthplace of the author, the first to provide a biography of him, the first to publish a commentary on Don Quixote, and the first to issue a critical edition of the text. (1905: 19)

According to these scholars, then, England can definitely "claim to have pioneered the reception of Don Quixote" (Müllenbrock, 1999: 197). What is more, on mere statistical grounds, given the profusion of works which more or less overtly acknowledge the influence of Cervantes, the statement that English responses were more abundant than in any other European country does seem plausible. ${ }^{27}$ However, more relevant than the number of those reproductive responses -translations or editions - is the quality they display, that is, their

${ }^{26}$ Avalle-Arce takes as a basis for his assertion the alleged reference to Don Quixote in the expression "to fight against a windmill" in George Wilkins' play The Miseries of Inforst Marriage.

${ }^{27}$ Nevertheless, Edwin B. Knowles offers some figures which prove that, at least in a very early stage of its reception, the French were richer in versions than the English (1947: 268). This richness is both reproductive, in the shape of translations, and productive, with the appropriation of quixotism in Le roman comique by Scarron (1651-57), as well as in some other narrative imitations, which had a visible impact on subsequent British Cervantean authors. 
depth of interpretation of Cervantes' novel. In addition, it is the presence of productive responses -original productions- which clearly indicates the level of influence on and assimilation in the English literary panorama. Moreover, it is essential to consider the interpretation which each of them offers and how the latter has developed over time. In this sense, other scholars have emphasised the transformation of the approach to Cervantes' work. Edwin B. Knowles, for instance, provides an insightful summary of its appropriation in England and distinguishes four distinct interpretations of Cervantes' novel:

[...] that of the $17^{\text {th }}$ century, which emphasized only the surface farce; that of the $18^{\text {th }}$ century, which, while enjoying the comic values, chiefly esteemed the serious satire; that of the $19^{\text {th }}$ century romantic period, which deprecated both the comedy and satire in order to exalt the deep spiritual implications; and that of the late $19^{\text {th }}$ and $20^{\text {th }}$ centuries, which -most eclectic of all- embraces the earlier views in a more just proportion and sees in the book an eternal human classic of a richly complex nature. (1947: 267)

From a rather simplistic reading in the seventeenth century, to a more complex view in the twentieth century, the reading of the novel and with it the British quixotes have changed according to the age and its values. ${ }^{28}$ Of course, this succinct analysis requires to be developed in full, as it must be obvious that this division in centuries does not entirely account for the complexity and richness of responses which characterises each period. More specifically, it leaves out the outstandingly varied and affluent responses of the eighteenth century. Hence, following in the steps of Knowles (1947) or Pardo (2007; forthcoming 2013a), this chapter will subsequently develop each stage of Don Quixote's reception in the long eighteenth century with special emphasis on the changing conceptions of the novel and the varied responses it originated, so as to provide an adequate context for the subsequent analysis of female quixotism. In order to do so, it will focus, rather than on a strict chronological progression, on the highlighted contributions which shaped the reception of Cervantes' novel,

${ }^{28}$ Although the study of the seventeenth-century reception of Cervantes is highly enlightening for any scholar, this is not the space or the time to provide a comprehensive approach to it, especially when other scholars have succeeded in doing so. In this regard, Dale B.J. Randall's and Jackson C. Boswell's Cervantes in Seventeenth-Century England. The Tapestry Turned (Oxford: Oxford University Press, 2009) is probably the most exhaustive work that has been published. 
paying special attention to the ground-breaking work of eighteenth century novelists, the topic of our study.

\subsection{The Eighteenth-Century Ambiguity: Don Quixote in the Age of Satire and Sentiment}

The eighteenth century has been recurrently described as the Golden Age of the reception and appropriation of Don Quixote in England. This century is without doubt the richest and probably the most complex in its response to Don Quixote, which has led scholars to term eighteenth-century Britain as "an age of quixotism" (Motooka, 1998: 1). Although Knowles had described it as basically an Age of Satire which identified Cervantes' purpose in accordance with the satirical taste of the moment, the interpretation done of his masterpiece is far from unanimous and it mutates throughout the century. Susan Staves formulates the metamorphosis of the process of Don Quixote's assimilation in three stages: first, Don Quixote is still seen as a "buffoon, a madman who belongs in a farce;" secondly, ambiguities start to appear and Don Quixote is a character "still ridiculous, still a buffoon, but who, at the same time is beginning to look strangely noble, even saintly;" finally, at the end of the century "we begin to glimpse the romantic Don Quixote, an idealistic and noble hero" (1972: 193). That is, the seventeenth-century approach still permeates the reading of its descendants, even tinged with the satirical model of the Augustan age, while the Don's inherent ambiguity starts to be acknowledged and developed in order to finally give pre-eminence to the positive traits of the knight found in the original. In this sense, the eighteenth century saw the progressive abandonment of a monological vision of Cervantes' novel and started to perceive the obvious "fundamental ambiguity" (Staves 1972: 194) which conformed Cervantes' Quixote and gave way to so many responses. The quixotic dilemma eighteenth-century writers tried to answer is phrased by Staves thus: "Is Don Quixote a buffoon whose delusion reveals only his insane pride and the total absurdity of the literature which has provoked his quest? Or is he an exemplary figure who refuses to allow his high 
ideals to be sullied by the filthy reality of a fallen world?" (1972: 194). ${ }^{29}$ Cervantes' knight is then in himself an ambiguous character. On the one hand, he is in a certain measure the epitome of that madman Foucault described as the visionary, the idealist, the transition between "d'un en-deça du monde à un au-delà" (1972: 53), the bearer of a certain truth. In this sense, Cervantes somehow returns once again to the Renaissance approach to the mad, who sometimes seem to offer a clearer vision of the world than the sane and whose foibles can be used as an instrument of critique against those of society. On the other hand, he is a fool, a senile, useless man within the utilitarian social values of his age. ${ }^{30}$ Owing to the complex characterization Cervantes created, Don Quixote can be read as an innocent character exposed to a cruel world who remains high above common human moral corruption, or, quite the opposite, as a character who is not above, but below the rest of the world because of his immense foolishness. The latter reading was, as has been said, the characteristic interpretation made in seventeenth-century and early-eighteenthcentury England, while the former one gained strength as the century advanced. In this regard, Staves defines "the two possible extremes of the quixotic figure" (1972: 206). On the one hand, "Don Quixote is a contemptible fool in a satire. He is a character not entirely human, one for whom we are expected to feel little sympathy" (1972: 206). On the other hand, one finds a very positive reading of the quixotic figure, associated, for instance, to the later Romantic approach. Motooka also perceives this duality as intrinsic to the quixote: for her "he is the lunatic who is neither sane enough to be credible, nor insane enough to be easily dismissed;" this fact affects his appropriation and hence, in the eighteenth century, "he ranges from the mad to the romantic, drawing fear, scorn, pity and admiration" (1998: 4). In this respect, Staves states that "treatments of the quixotic idea in the English novel change in ways which are quite parallel to the changes in critical responses to the Quixote himself' (1972: 194); that is, critical approaches to the quixote vary according

${ }^{29}$ E.C. Riley phrases the same questions: "Does Cervantes really tend to suggest that ideals are illusions, idealism folly? Is Don Quixote foolish or heroic to persist in his? How is it that we laugh at a man so wholly dedicated to relieving distress and fighting injustice? Has he simply got his ends right and his means wrong? There are many such questions as these and even more answers to them" (1986: 134).

30 See for instance Asunción Aragón's “Aspectos culturales de la locura en la Inglaterra ilustrada." La cara oculta de la razón: locura, creencia y utopía. (Cádiz: Servicio de Publicaciones de la Universidad de Cádiz, 2001), pp. 23-29. 
to the answers given to the aforementioned questions, and, as Harry Levin has phrased it, they reveal the "readers' special concerns" (1970: 46), in particular their ideological or aesthetic ones. This idea, which has been widely explored in the previous section, summarizes the train of thought that defends the ambiguity and richness implicit in the quixotic figure. The multiple interpretations to which quixotism may be subject must undoubtedly produce innumerable treatments and, therefore, rewritings, of the quixotic idea.

In the eighteenth century, an age of prose, the answer to those questions is better developed in the novel, a space for dialogism in which to cultivate in depth the complexities of the quixotic motif. ${ }^{31}$ Observing then the novels of the age, the answer to the aforementioned questions sometimes takes the shape of extreme responses to the quixotic ambiguity. The quixote becomes, in Staves words, either an ignominious fool or a perfectly sympathetic character. Although both aspects co-exist in the quixotic nature, one has usually been given pre-eminence over the other, and the quixotic character will therefore become either the instrument for satire against the world or the butt of satire itself (Paulson, 1967: 119); he will be a hero in a quest for justice or the target forced to endure practical jokes (Welsh, 1981: 3). Don Quixote is then read at this time as the buffoon or the hero, as the ridiculous or the exemplary figure, as the mad or the visionary. Or even as both, for in this century there were quixotes that maintained the original spirit of the Cervantes' knight and preserved that "vivid albeit dual identity" (emphasis added, Levin, 1970: 47) which was characteristic of the hidalgo. This ambiguity or complexity is the most relevant and interesting element of Cervantes' reception in the eighteenth century; as Pardo has it, this century becomes the melting pot of all possible responses to the Spaniard's masterpiece (2007). This widening of the perspectives on Don Quixote answers for the coeval development of a satirical, a sentimental or a romantic interpretation of the knight, as well as for the

${ }^{31}$ There are, of course, examples of the eighteenth-century reception of Don Quixote on stage. For instance, James Ayres' Sancho at Court; or the Mock-Governor (1742) or Frederick Pillon's Barataria, or Sancho Turn'd Governor (1785). There will also be several characters identified as female quixotes on stage, which will be referred to and analysed in later chapters. For a more thorough analysis of the trace of the quixote on the English stage, see J.A.G. Ardila's "Las adaptaciones teatrales del Quijote en Inglaterra (del siglo XVII al XIX)." Anales Cervantinos 41 (2009), pp. 239-50. 
coexistence of quixotic imitations and emulations, of works as different in quality and approach as Richard Graves' The Spiritual Quixote (1773) or Henry Fielding's Joseph Andrews (1742). Hence, rather than a chronological methodology, the eighteenth century reception of Cervantes' novel benefits from a study of the several approaches which contributed to make of this age the greatest in its welcome of Don Quixote to British territory.

\subsubsection{Don Quixote against the World and Himself: the Satirical Hero}

The first half of the century was dominated by the great names of the Augustan Age, those writers who moulded English Neoclassicism and the taste of the nation prior to the 1740s. These writers were essential in the transformation of the response to Don Quixote, for, as Knowles has pointed out, at the turn of the century, "better people" or, at least, people with a deeper critical approach, were reading Don Quixote's adventures and acknowledging the genius of the work (1940: 109). Swift, Pope, Addison or Steele, all paid their tribute to Cervantes. As Pardo has avowed, "la mejor prueba del nuevo rango adquirido por Cervantes y de la nueva seriedad con que se lee su obra es la utilización creativa del Quijote como modelo satírico por parte de los autores denominados augústeos" (2007: 136). This interpretation of Don Quixote as a satiric masterpiece is explicitly acknowledged by several critics of the age, for whom Cervantes is "set on a pedestal as a master of the genre, together with Lucian, Rabelais, and Quevedo" (Close, 1977: 10), and for whom his naturalness in the "delineation of character, the novelty of his invention, the elegance of his irony, his narrative fertility, his good sense and good taste" are worthy of praise (1977: 13). Steele and Addison, two of the most influential men in the shaping of the public taste through their periodicals The Tatler (1709-1711) and The Spectator (1711-1712), both linked quixotism with that ridicule so in vogue in the early eighteenth century. In number 249 of the latter (December 15, 1711), Addison reflects on humour and ridicule and states:

The two great branches of ridicule in writing are comedy and burlesque. [...] Burlesque is [...] of two kinds; the first represents mean persons in the accoutrements of heroes, the other describes great persons acting and speaking 
like the basest among people. Don Quixote is an instance of the first, Lucian's gods of the second. (1861: 244)

Don Quixote is then identified as an example of that high burlesque which will be brilliantly developed by the Augustans; moreover, it is set as model together with one of the classics, Lucian, hence claiming Cervantes' position in literary history among the greatest authors. ${ }^{32}$ Addison had related the novel to ridicule before, in this case avowing the role that ridicule should have as moral corrector and how Cervantes' employed it with that very same purpose. In number 227 of the Spectator (November 20, 1711), he claims that "ridicule, perhaps, is a better expedient against love than sober advice; and I am of the opinion that Hudibras and Don Quixote may be as effectual to cure the extravagances of this passion as any of the old philosophers" (1861: 141). Cervantes' novel is then at this time perceived as a satirical work characterised by its serious humour -or grave irony-and its didactic purpose. It is significant that Addison names Hudibras, for Butler's work exemplifies his statement: it is a satirical interpretation of quixotism which serves the purpose of aiming to cure the extravagance of enthusiastic Puritanism. Therefore, the reproductive and productive works of this period will follow in Butler's steps and create quixotes which conform to this satiric and didactic intention.

As example of the reproductive reception at this time, one should highlight Charles Jarvis translation The Life and Exploits of the Ingenious Gentleman Don Quixote de la Mancha. Translated from the Original Spanish of Miguel de Cervantes Saavedra (1742). Jarvis criticises Peter Motteux for the "low comic or burlesque vein" of his earlier translation (1742: v). Moreover, he signifies the change in the interpretation of Cervantes' novel when he later writes:

Motteux is so injudicious as to value his version upon this very air of comedy, than which nothing can be more foreign to the design of the author, whose principal and distinguishing character is, to preserve the face of gravity, generally consistent throughout his whole work, [...], and wherein without doubt is placed the true spirit of its ridicule. (emphasis added, 1742: v-vi)

\footnotetext{
32 Ronald Paulson provides other relevant examples of critical works that emphasise the grave irony seen as the quintessence of the Cervantean humour. He mentions, for instance, Richard Owen Cambridge's comment that authors aiming to write a mock-heroic poem should "never be seen to laugh, but constantly wear that grave irony which Cervantes only has inviolably preserved" (qtd. in 1998: 41).
} 
This comic solemnity that Jarvis sees as consistent in the style of Cervantes would also be acknowledged and imitated by a number of writers in the early eighteenth century, among them Jonathan Swift and Alexander Pope. As Pardo has asserted, Swift maybe epitomises the Augustan satiric vision of Don Quixote (2007: 136), both for his prolific use of quixotism and for the Cervantean ironic gravity which permeates his works. In A Tale of a Tub (1704), for instance, he uses madness "no sólo para caracterizar los abusos de erudición representados por el narrador sino también los de la religión representados por los personajes de su narración, que son víctimas de formas de entusiasmo religioso que remiten a Butler y a su utilización del quijotismo," while in Gulliver's Travels (1726), Gulliver ends the narrative as an alienated character in British society owing to his appropriation of the wise horses' ideals (Pardo, 2007: 136). Together with other members of the Scriblerus Club, Swift collaborated in the production of The Memoirs of the Extraordinary Life, Works, and Discoveries of Martinus Scriblerus (1741), in which two quixotic pedants are employed at the service of an attack directed against erudition, which substitutes knight-errantry as butt of the satire. Moreover, the whole work is written in the same grave tone Cervantes' employs to narrate the adventures of his knight, therefore aiming to produce a very similar burlesque romance (Pardo, 2007: 137). On his part, Pope, in his own satire on erudition, The Dunciad $(1728,1729)$, contrasted “Cervantes' serious air" with the "laugh and shake" which come in "Rabelais' easy Chair" (1729: 71), and clearly adopted the former in his own work. This conception of Cervantes' humour as consisting on the aforementioned grave irony and of Don Quixote as model of high burlesque characterizes the English Neoclassical vision. This vision, in Pardo's words,

[...] convierte a Cervantes en modelo de la sátira augústea [...] que caracteriza los excesos de cualquier índole, particularmente de erudición o religión, como una forma de locura y los encarna en figuras quijotescas, siguiendo así en la estela de Butler, pero, a diferencia de éste y en consonancia con la nueva visión, lo hace con seriedad irónica, combinando locura quijotesca con gravedad cervantina. (2007: 138-39) 
Hence Neoclassical writers combine quixotism and cervantism, offering a deeper assimilation of Cervantes' style and character to the Augustan forms and manners.

In addition, at this time the concept of singularity is emphasised and connected to quixotism. In particular, English singularity or originality would shape its interpretation throughout the long eighteenth century. In Jonathan Lamb's words, "by the early eighteenth century the English were strongly aware of peculiarities in their temper which served to distinguish them from the French and which went by the names of singularity and irregularity and later by the more familiar titles of originality and humorism" (emphasis added, 1981: 111). According to Skinner, the "English conviction -in literature and beyond- of their own eccentricity, vestiges of the psychology of the humors and the opinions of foreign visitors together with Dr. Cheyne's celebrated study of the "maladie anglaise"" all contributed to shape the reader's response to the figure of Don Quixote (1987: 52), from Pope or Dryden to Fielding or Sterne. These English quixotic originals or eccentrics would later become humorists (1987: 54) and even morbid sentimental characters (1987: 55), therefore developing those traits considered part of English singularity and hence emphasizing the appropriation of Cervantes' character in the English cultural and literary context.

However, this singularity is not without consequences for the character, for "at all points on the scale, singularity argues some sort of opposition to society and an integrity which is irregular in terms of the social forms it ignores but which is consistent and coherent in terms of private values" (Lamb, 1981: 113). Therefore, Don Quixote would become more than a buffoon to be laughed at for his singularity; rather, he would serve a clear purpose, that of satirizing “desvíos de la norma y la ortodoxia en términos literarios, ideológicos o históricos" (Pardo, 2007: 139). As a consequence, although there is an obvious difference in the interpretation of Don Quixote triggered by the appropriation of the novel within the Neoclassical principles, the early eighteenth century does not completely break with the negative vision of quixotism as a kind of dangerous madness or uncontrolled enthusiasm which can threaten the status quo. In many of these works, one encounters a direct imitation of Cervantes' 
knight, usually a raw embodiment of a particular literary or ideological singularity which becomes the butt of the author's satire. In Britton's words, while before 1740 there was barely a noticeable influence of Cervantes -a statement probably contested at this point-, after 1750 :

What did emerge [...] in the fiction that drew directly upon Don Quixote was, for the most part, a superficial kind of imitation by writers with no outstanding talent, for the majority of whom Cervantes's book offered a comic character whose unique blend of madness, naivety and idealism could be adapted to provide crude vehicles of satirical humour or social comment. (emphasis added, 1993: 22-23)

This statement will become increasingly true as the century advances and the war with France tinctures quixotism. However, despite Britton's generalization, before 1750 there did exist new approaches to Don Quixote. However, for a more significant reading of Cervantes' novel and a more positive approach to its main character, it was indeed necessary to wait until the 1740s, when a new comic but benevolent quixote made its stunning appearance.

\subsubsection{Don Quixote's Benevolence: the Amicable Hero}

Among the myriad of shallow imitations that Britton asserts existed at this time, the eighteenth century will witness the creation of several works of fiction that will mean a swift from a mere imitation of the traits of Don Quixote applied to different contexts and purposes to a significant understanding and use of Cervantes' narrative techniques. In Britton's own words, "somewhat deeper and more significant lessons" were to be learnt from authors such as Fielding or Sterne, to whom scholars must turn to "discover Cervantism (as distinct from mere Quixotism) assimilated and reapplied with crucial implications for the writing of the novel in England, both during the eighteenth century and beyond" (1993: 23). Both authors, together with others such as Tobias Smollett, for instance, emulated Cervantes and by so doing developed the inherent possibilities of the modern novel already announced in Don Quixote, raising the genre to heights yet unknown. While the cervantism of 
these authors must and will be properly acknowledged, it is the change in their conception of quixotism that is especially relevant for the present study. Together with a deeper approach to the novel, these authors would develop richer and more insightful quixotic characters.

This insightfulness, for example, is made manifest in a reading of Don Quixote and his dual nature much closer to what seems to have been the position of Cervantes towards his own creature. In their research on the original conception of the knight, several scholars acknowledge the abovementioned two parts of the personality of Don Quixote, that of naïve and fool, the transcendental and the ridiculous, the innocent character who projects a critique on the cruel society which surrounds him, and the deluded buffoon who receives the critique both of author and reader (Pardo, 1997: 134). Together with Paulson (1967), Staves (1972), Welsh (1981) or Britton (1993), Pardo selects Henry Fielding's The History of the Adventures of Joseph Andrews, and of his Friend, Mr. Abraham Adams (1742) as the novel that inaugurates a new type of quixotism and of Cervantean legacy in England (2007: 139), which will lead to Fielding being considered the "English Cervantes" (Hammond, 1998: 258).

By the time he wrote this novel, Fielding was no newcomer to the production of quixotic works, for he had published a play in 1734 entitled Don Quixote in England, of which the first draft is said to have been written as early as 1729 . In this early play there is already an approach to this changing conception of Don Quixote "not only as a ridiculous madcap, but also as a good-hearted stargazer" (Müllenbrock, 1999: 199). Fielding then begins to develop as early as the 1730s what will be his greater contribution to quixotism: the perception of it as a satirical device through which to "offer a satire either on the visionary who wished to change the world, or on the innkeepers who will not be changed, or on both" (Paulson, 1967: 119). Therefore, though still ridiculing the quixote's singularity, his idealism, by comparison, will make "the crassness of the world stand out in strong satire relief" (1967: 119). Although more skilfully achieved later in his novels, Fielding already presented this innovative reading of quixotism in his play. Don Quixote and Sancho are literally transposed to England -the most direct form of imitation possible- and in their 
English ramble they arrive at an inn where several characters involved in a plot of true love and forced marriages are lodged. The knight will immediately desire to help those in need, and by so doing, he is turned in Fielding's view into a "well-meaning idealist with certain moral values, used as a yardstick to measure contemporary society, which reveals grave shortcomings" (Müllenbrock, 1999: 200), although still preserving his nature as an antiromantic jocular character. Despite his humorous behaviour, Don Quixote becomes then the author's mouthpiece through which to discover the "madness" which reigns in the world, and not exclusively in the deluded Quixote. Therefore, Don Quixote not only is described with foolish and noble traits, but Fielding goes as far as to transform it into "an example to everybody else" (1999: 200). Nevertheless, the new approach to Don Quixote is obviously still not fully developed, and the knight lacks the "psychological plausibility" of Fielding's later characters, especially because both sides of the quixotic character, "one representing the traditional humorous interpretation, and the other presenting serious insights," are not consistently blended into one single character (1999: 201). Besides this changing conception of quixotism, there are other elements of Fielding's later novels already present in the play, such as the juxtaposition of a quixotic and a romantic plot -that of the Don and of Fairlove and Dorothea-, something he will fully develop in Joseph Andrews, as well as the double-reading of the quixotic figure.

Fielding stated that he had written Joseph Andrews "in Imitation of the Manner of Cervantes," and he most certainly had. Müllenbrock has identified several aspects of Fielding's novel which appear to be indebted to Cervantes: first, the confrontation of reality and ideality; second, the novel's structure, with the use of interspersed stories; thirdly, the narrator that makes metafictional comments and satirises English contemporary writers; and, finally, the companionship of Parson Adams and Joseph Andrews, which seems modelled in that of Don Quixote and Sancho Panza (1999: 202). With regard to this last point, Fielding's quixotism, there is an obvious change in the interpretation of the quixotic character in Joseph Andrews. Fielding acknowledges the parodic and satiric dimension of Don Quixote, as seen in the classification of quixotes in the previous section. However, he divides them in two characters: Joseph 
Andrews and his friend Parson Abraham Adams. The former becomes the embodiment of the author's questioning of pre-existing literature as model of behaviour and his exposure of the gap between literature and life, while the latter highlights the chasm that opens between the high principles of the character's literary sources and a world that has forgotten them (Pardo, 1997: $135)$.

Joseph Andrews decides to live his life according to the principles learnt from the letters of his sister, Pamela, the eponymous heroine of Richardson's novel. Therefore, he literally applies her model of virtuousness to his everyday experience, as Don Quixote tried to strictly live out the chivalric principles in the reality of seventeenth-century Spain. The results are very similar to those in Cervantes' novel: the character's literary principles clash with an anti-literary and anti-romantic world. One could recall, for instance, Joseph's attempts to preserve his virtue from the libidinous attacks of the ugly and old maid, Mrs. Slipslop, as an example of his closeness to Cervantes' knight: they both have their high ideals exposed to a degraded reality, and the comic effect is precisely highlighted because of "el contraste entre esa realidad baja y los elevados términos de la retórica, de origen 'pameliano' o caballeresco, de la que hacen uso Joseph y don Quijote respectivamente" (Pardo, 1997: 137). Moreover, they both signify important divergences from the original models on which they base those ideals. According to Pardo:

Esta comicidad, nacida de la enorme distancia entre el mundo literario que evoca ese uso del lenguaje, y el mundo real presentado en una perspectiva realista cercana a la picaresca, se ve incrementada por las transformaciones operadas en los sujetos de esa retórica respecto a sus portavoces originales. Oír a Joseph defendiendo su virtud ante Slipslop o Lady Booby en los mismos términos en que lo hacía Pamela, los de una doncella, no deja de ser chocante y ridículo. [...] produce efectos ridiculizadores similares a los del enjuto y anciano hidalgo manchego expresándose como si fuera Lanzarote o Amadís. (1997: 137)

The literality with which Joseph and Don Quixote try to imitate their models is the source for the humour in the novel, and also for Fielding's reflection on the conflict between reality and fiction, life and literature, which again evokes Cervantes core matter in his masterpiece. 
Nevertheless, there are striking differences between Joseph and the Spanish knight. The former is no longer an old character, and hence his obsession with Pamelian chastity can be more easily outgrown (Paulson, 1967: 120), establishing a model for later young male and female quixotes. Besides his age, he is also closer to the prototypical hero of a Greek romance, from which his love story with Fanny adopts several conventions. He is young and handsome, and he is in love with a young and beautiful heroine. They are divided throughout the novel by a series of misfortunes only to be finally reunited and happily married, a romantic plot and ending which Fielding's followers in quixotism would also adopt. Therefore, Joseph inherits the dual nature of Don Quixote as hero and object of mirth which serves as a parodic instrument and establishes a new paradigm of quixotism in England.

This contrast between literature and reality, together with that between idealism and society's degraded values, is also skilfully portrayed in Parson Adams. Don Quixote's trace is clearly recognizable in Adams; they both expect their readings to provide a convenient guide for the interaction in the world; they both see their expectations contradicted by their experience; their vision of the world is hence corrected by means of their exposure to reality in all its crudity. This connection is sometimes made explicit as, for instance, in chapter XVI, which Fielding opens with a direct allusion to Cervantes' novel, stating that his travellers had left an inn "which they had more Reason to have mistaken for a Castle, than Don Quixote ever had any of those in which he sojourned" (1999: 188). He then subsequently develops Adams' quixotic delusion in the shape of his innocence in the face of worldly manners which, on the one hand, points at his connection with Don Quixote and, on the other hand, emphasises the lack of epistemological delusion, linking Adams with his antecedent but at the same acknowledging the different reading that Fielding is making of the quixotic character. In this chapter Adams states that "Knowledge of Men is only to be learnt from Books, Plato and Seneca for that" (1999: 193), authors he accuses Joseph of never reading. However, Joseph's greater knowledge of genteel society allows him to read men better than Adams does in his veiled literary perception and inexperience, a trait he shares with many later female quixotes. It is here where Fielding's innovation with regard to his 
previous conception of quixotism is displayed: "instead of a Quixote deluded by the absurdities of romance," Adams is a quixote "who is deluded by classical literature, and a Quixote of the ethical rather than of the aesthetic precept" (emphasis added, Reed, 1981: 126). ${ }^{33}$ In this sense, Pardo is right when he asserts that Adams is closer to the 1615 Quixote than the 1605 one, for the Parson is truly naïve to the extreme of being taken advantage of, as is the Don in the second part of Cervantes' masterpiece (1997: 141). Fielding, however, emphasizes the moral dimension glimpsed in Cervantes' novel and hence Adams fulfils a greater role as moral satirist of his society than Don Quixote. There are several reasons for this increased moral role: first, because Adams' delusion changes the moral, nor the physical nature of the world; second, because his ideals have a more respectable source -the Bible among them- and are still highly praised as moral signposts; thirdly, because his nature as a parson and the support he receives from Fielding's narrator makes him a more legitimate instrument for satire against the world; and, finally, his adventures have a more marked moral didacticism, as the characters Adams encounters personify the vices and corruption of society in a much more obvious way that in Don Quixote (Pardo, 1997: 143-44).

One encounters many instances in which Adams's goodness is contrasted with the less honourable behaviour of other characters. Adams, for example, is incapable of employing deceit, even if it is in his own interest, as the reader discovers in his conversation with the bookseller who he desires should buy and print his sermons. In this episode, Adams is so good natured that he expects the bookseller to condole with his miseries and offer a better price at his obvious and urgent need for money, when both parson Barnabas and the bookseller, as well as the author and the reader, have learnt from experience to expect quite the opposite (1999: 111). For his sincerity and innocence, Adams is often laughed at. Moreover, Adams, in his goodness, saves Fanny from being raped, but is finally accused by the rapist and faces a trial. His will to do good to others, to do what is right, causes him great trouble. He is a noble and saintly

${ }^{33}$ Reed continues stating that Fielding provides a hero "deluded not by the native romance but by neoclassical culture itself;" for this scholar, "Parson Adams is a demonstration by example that Nature and Homer are not in fact the same" and that Fielding locates "his own Quixotic novel in the gap between precept and example" (1981: 126). 
character which stresses the parallelism with Christ, Abraham and other sacrificial figures that can be perceived in the quixote -as has been avowed by Welsh (1981: 119-120) or Ziolkowski (1991). Finally, Adams's appalling treatment by the Roasting Squire, who subjects him to all sorts of degrading jests (1999: 247-53), echoing Cervantes' own Duke and Duchess, highlights this saintly nature and Adams's superiority when contrasted with the surrounding world. ${ }^{34}$ By means of his innocence and goodness he becomes an "unconscious truth-telling satirist" (Staves, 1972: 195). His fooled innocence becomes then "satírico comentario sobre la naturaleza depravada del mundo que engaña esa inocencia, que nunca está a su altura y no responde a las expectativas de Adams" (Pardo, 1997: 142).

The Parson then becomes a perfect model of the quixotic figure who is at one time ridiculously and admirably innocent, who is both an idealist in a quest for justice and a victim of injustice, and who is hence employed by the author as an instrument for satire. Therefore, he becomes the perfect embodiment of Fielding's satirical vision of quixotism as aimed at the quixote's mania and at the surrounding world at the same time, perfectly blending the ridiculous and the noble in one character. Fielding's ridicule is not aimed at the character's natural and quixotic goodness and innocence, but to the more formal side of his delusion: to the Christian models that he chooses to follow literally and which are at odd with the world he lives in and sometimes with his own nature (Paulson, 1967: 118). In Adams, Fielding allows his ridiculous mania to mix with the admirable and models his character on Don Quixote, who offered him an adequate prototype for "the man who reacts to stimuli from his basic good

${ }^{34}$ This does not imply, of course, that Adams is not capable of defending his friends or himself with all the might of his fist when there is an occasion in which to exert justice in such a manner. There are several examples in the novel of the power with which the Parson can exercise his physical abilities, one of them being the tremendous blow he delivers with his crabstick to Fanny's ravisher. However, Adams scarcely uses violence gratuitously, and even regrets almost killing the rapist. When he faces Parson Trulliber's unchristian behaviour and even his threats, the author writes: "As nothing could provoke Adams to strike, but an absolute Assault on himself or his Friend; he smiled at the angry Look and Gestures of Trulliber; and telling him, he was sorry to see such Men of Orders, departed without further Ceremony" (1999: 186). Adams defends Joseph, for instance, when a host of an inn tries to "lay violent hands on him," to which he responds dealing "him so sound a Compliment over his Face with his Fist, that the Blood immediately gushed out of his Nose in a Stream" (1999: 144). Although shortly afterwards Adams once again regrets his behaviour and the fact of being the one who struck first, his temper triggers more than one humorous situation. Even if his violence is perceived as part of his quest for justice, the results are as jocular as in Cervantes' original novel every time Don Quixote decides to fight in order to perform some knightly deed. 
nature, often in complete opposition to custom, convention, and even prudence" (Paulson, 1967: 119).

The noble side of his dual nature as buffoon and saintly hero is the key difference with other quixotic characters, such as the degraded quixotes of the previous century, who had more of the picaresque than the knightly in them, who followed no quest for justice, but rather sought to gratify their own desires or to struggle for survival. Because Adams is so irremediably innocent and good, and his treatment so unfair, the dichotomy between laughter, even if sympathetic, and admiration is deeply stressed, thereby introducing a new interpretation of the quixote as an amiable humorist, to employ Stuart M. Tave's term (1960). ${ }^{35}$ It is in Parson Adams that one perceives a turning point in the consideration of the quixote in England. Until that moment, Don Quixote had been satirised, and with him the ideals he stood for; however, Tave rightly states that Fielding "was creating a new concept of Don Quixote" with the creation of honest Abraham Adams, as he was "the first writer in England to make Don Quixote a noble symbol" (1960: 155) and to conceive quixotism as "good nature" (Müllenbrock, 1999: 202) or, more appropriately in the sentimental language of the age, "benevolence" (1999: 203). What is more, with this recognition of the "qualities of humanity, charity and goodness in the character of Cervantes' hero," Fielding is indirectly preparing the way for the later Romantic approach: Joseph Andrews and Parson Adams would inaugurate that movement of opinion that from 1740 onwards would anticipate the Romantic idealisation of Don Quixote (Close, 1977: 13). Although the first idealised quixotes, they would not be the last: Fielding and his benevolent quixotes would leave a traceable and indelible imprint in later writers.

Despite the importance of Fielding's work in the transformation of quixotism, his role as an emulator also stands on his development of what has been termed

${ }^{35}$ Müllenbrook contests Paulson's or Staves' dual reading of Parson Adams as he considers that Fielding supports Adams and relieves him from all responsibility for his mistakes. Hence, this scholar sees the satire directed only towards society and not the extreme innocent and idealist quixote. In his very positive interpretation of Adams, Müllenbrook admits to his "flaws" but considers them "amiable and forgivable," "noble weaknesses and not vices" (1999: 203). However, the fact that he has flaws, such as his strong temper or his inability to understand the world outside his books does create ludicrous situations in which the laugher is directed towards Adams, even if it is attenuated or if it creates an uncomfortable stance for the reader. 
cervantism or the Cervantean method. In this sense, the contrast between reality and idealism is also emphasised in the elaboration of a plot which contrasts the romantic and the anti-romantic by means of inscribing elements taken from the romance in everyday and even degraded situations. In his prologue, Fielding argues for a different form of romance, in this case a "comic form that, though non-metrical, can be 'referred' (his term) to Homer's lost comic epic" (Hammond, 1998: 254). The resulting formula would be a "comic Epic-Poem in Prose," in which Fielding "communicates a very powerful idea of writing that is more general in its application to life, and more credible, than all prose fiction currently extant" (1998: 255). ${ }^{36}$ His label for this new form of fiction would be "comic romance," which Fielding defined in his prologue in the following terms:

Now, a comic romance is a comic epic poem in prose; differing from comedy, as the serious epic from tragedy: its action being more extended and comprehensive; containing a much larger circle of incidents, and introducing a greater variety of characters. It differs from the serious romance in its fable and action, in this; that as in the one these are grave and solemn, so in the other they are light and ridiculous: it differs in its characters by introducing persons of inferior rank, and consequently, of inferior manners, whereas the grave romance sets the highest before us: lastly, in its sentiments and diction; by preserving the ludicrous instead of the sublime. In the diction, I think, burlesque itself may be sometimes admitted; of which many instances will occur in this work, as in the description of the battles, and some other places, not necessary to be pointed out to the classical reader, for whose entertainment those parodies or burlesque imitations are chiefly calculated. (1999: 49-50)

This "species of writing," which Fielding affirms to be hitherto unattempted in the English language (1999: 54), would find acceptance among the great literary critics of the age, such as Samuel Johnson, and has been subsequently and amply studied and defined. ${ }^{37}$ This immersion of a romantic plot into an anti-romantic world in order to achieve a comic effect because of the

${ }^{36}$ On this matter, Pardo states that, although Fielding claimed he was creating a comic epic in prose, "el romance heroico, y no la épica, es el modelo que Fielding utilizó para su transformación cómica en Joseph Andrews" (2006: 79).

37 Johnson wrote in The Rambler no. 4, for March 1750 that "the works of fiction, with which the present generation seems more particularly delighted, are such as exhibit life in its true state [...]. This kind of writing may be termed not improperly the comedy of romance, and is to be conducted nearly by the rules of comic poetry. [...] it is therefore precluded from the machines and expedients of the heroic romance [...]." (1828: 134). On this matter, see Walter Reed's seminal study on the matter of Fielding's generic experimentation in his chapter on Joseph Andrews and the quixotic (1981: 117-36). 
incongruities that arise would become one of Fielding's narrative trademarks. As has been explained, Fielding parallels and emphasises the duality in his own plot, juxtaposing the quixotic and comic, to the romantic; he places this romantic hero in an anti-romantic world to develop the aforementioned concept of comic romance. The romantic nature of Joseph and Fanny's love story is once and again highlighted by the contrast with the anti-romantic nature of the interspersed stories and with the more worldly desires of Lady Booby, for instance.

In his later novel, Tom Jones (1749), considered his masterpiece, Fielding continues to develop this juxtaposition between romance and an anti-romantic reality. In his main work, Fielding unfolds a story that once again bears obvious similarities with the French heroic romances of the time: a beautiful hero and heroine are separated by several vicissitudes only to be finally reunited in marriage. However, in a very Cervantean manner, this romantic plot is comically displaced and set against a very anti-romantic reality, creating a work in which the romantic and the picaresque coexist and dialogize. This is evident in the protagonist himself. Tom Jones has traits of both a hero and an anti-hero: he is presented as of unknown origin, although later he is discovered to be of noble birth; he commits several robberies, although his motives are noble; he behaves indecorously in his relationship with Molly, although he fulfils his romantic destiny by means of his pure love for Sophia and the trials he must overcome in order to be with her. Tom is therefore a mixture of "lo elevado y lo degradado, reúne en sí aspectos de romance y de una realidad anti-romántica que lo dialogiza y que da lugar a un cómico contraste similar al que se produce en el Quijote" (Pardo, 1994: 844). This duality is also present in the surrounding world, and elements of the romantic and the anti-romantic are juxtaposed. This is especially visible in the two women in Tom's life: Sophia and her antithesis Molly, the Dulcinea and Aldonza Lorenzo juxtaposition present in Don Quixote. The duality embodied in these women emphasizes the contrast that existed in Don Quixote's mind between the romantic world of his imagination and the anti-romantic one in which he lives (Pardo, 1994: 844). The two contrasting plots or realities again dialogize and result in that comic 
romance - or mock romance- that Fielding had already developed in his previous novel. The difference with Cervantes' anti-romance is that:

En Tom Jones el romance triunfa, emerge de una realidad mezclada y compleja, al contrario que en el Quijote, donde es una fantasía aplastada por la realidad y sólo sobrevive en una serie de historias intercaladas secundarias. Fielding, como Cervantes, incluye los dos polos, el romántico y el antiromántico, pone el romance en un contexto realista e incluso picaresco para producir un efecto cómico y distanciarse de él, pero la distancia que adopta es diferente, a medio camino entre el respeto y la seriedad de las historias sentimentales intercaladas del Quiote y la burla y la comicidad de la historia caballeresca del hidalgo. Ahí radica la diferencia fundamental entre el antiromance cervantino y el romance cómico de Fielding [...]. (emphasis added, Pardo, 2006: 82-83)

Fielding was not only creating a form characterized by its subversive humour based on that dichotomy, he was also adding other Cervantean elements to his work. In Tom Jones, Fielding achieves his mastery of those narrative devices which were still in a rudimentary form in his previous novel and develops in full Cervantes' dialogic realism. The novel is structured through contrasting pairs that are employed as "método de vertebración dialógica de la realidad" and as means to highlight "el sometimiento de ésta a la percepción subjetiva y la experiencia individual" (Pardo, 2006: 86). Those pairs become the embodiment of opposing perspectives as both reflect the same reality through their divergent points of view. The first and foremost of these contrasts, maybe the more clearly Cervantean, is that between "idealismo moral y materialismo," between Tom and Partridge, who mirror Don Quixote and Sancho (2006: 85), and even between numerous minor characters. In this sense, Fielding develops the dialogical principle and transforms the conflict between literature and life found in Joseph and Adams, into a conflict between different worldviews, whether the idealist and the materialistic, the humanist and the misanthropic, or the Christian and the unchristian, as announced in Adams and masterly developed in Tom Jones. ${ }^{38}$

${ }^{38}$ While Fielding's quixotism is the main focus of the present work, his cervantism is of course relevant to understand the development of his innovative creation of a quixotic figure, hence the succinct analysis offered in prior pages. For a thorough dissection of Cervantes' influence on Fielding and his progress towards cervantism and the dialogic novel, see Pardo (1995, pp. 711-899, and 2006, pp. 70-93). 
Finally, Fielding also explored and developed the self-consciousness which he found in Cervantes. Fielding warns his readers that what they are perusing is fiction and allows them not to forget it, mainly by creating a highly intrusive narrator who "masquerading as biographer and historian, comments upon, and digresses from what he relates as he thinks fit" (Britton, 1993: 28). As Wayne C. Booth (1952) asserted, Fielding was one of a series of authors who developed the self-conscious narrator within the context of comic fiction, with Cervantes as founder, and Scarron, Furetière and Marivaux as worthy descendants. While Booth acknowledges the indebtedness of Fielding's work to this Cervantean tradition, he claims that in Joseph Andrews and later in Tom Jones "the intrusions of the narrator, his characterization, and his discussion with the 'reader' are carried beyond anything to be found in Cervantes" (1952: 175). This narrator transfers "much of the debate and argument in his books from the exchanges between his characters, which Cervantes exploits so brilliantly as a means to indirectly portraying the personalities of his protagonists, to the interface between the narrator and the reader" (Britton, 1993: 28). Booth describes Fielding's narrator as an "omniscient and omnipotent" self-conscious voice, who leaves no doubt that "his intrusions are always carefully employed to serve the requirements of his book as a whole" and that Fielding's "narrative devices are usually functional rather than merely ornamental" (1952: 177). The functions of the narrator's intrusions are enumerated by Booth as followed: they are morally manipulative, they "characterize the potential readers morally" and "manipulate the real readers into the moral attitudes Fielding desires" (1952: 177); they also manipulate laughter, for they insure "a comic response to scenes which in themselves are not necessarily comic, or which are even potentially serious" and are then supplemental to Fielding's other comic devices (1952: 178); finally, they are self-conscious comments on his role as narrator and hence "reinforce every impression given by the story itself that the narrator is a man of great genius and that the book is something wonderful and new" (1952: 179). This last characteristic is more conspicuous in Tom Jones, where it takes the shape of "mock attacks on the reader, previous narrators, or the narrator himself as a man" (1952: 179). Fielding thus also emulates Cervantes in his use of selfconscious realism as a call of attention to his readers, as well as an instrument 
to develop a new kind of writing which will become the foundation for many subsequent novelists.

From his play to Joseph Andrews and later to Tom Jones, Fielding then progresses from quixotism to cervantism, from parody and anti-romance to comic romance, abandoning the quixotic in Tom Jones and emphasising in his masterpiece what Cervantes' work had of dialogic and self-conscious. He was hence the first and more important emulator, and his work would serve as beacon for other novelists who would subsequently develop the possibilities of cervantism he pointed to, as well as his more universal and benevolent concept of quixotism, present in later authors such as Charlotte Lennox or Laurence Sterne.

\subsubsection{Don Quixote(s): the Universal Eccentric}

Laurence Sterne's magnum opus, The Life and Adventures of Tristram Shandy, Gentleman (1759-1767), is evidently indebted to Cervantes and most particularly to his development of self-conscious realism, which Sterne emulates and takes even further than his model. The novel works at two levels, narration and story, as happened with Don Quixote (Pardo, 1996: 212). Tristram, the main character of the novel, claims he is going to narrate the story of his life; however, little is really told about the events which happen to him. The level of narration thus gains predominance over that of the story and the novel becomes the chronicle of Tristram as failed writer (Pardo, 2006: 92). This focus on the narration is achieved by the use of digressions: the novel is full of departures from the story, as the narrator endlessly rambles about the most varied topics. Rather than the sporadic interventions of Fielding's narrator or their circumscription to introductory comments, Sterne's novel itself seems an endless digression, a yet unknown "development of narrative metareflection" (Müllenbrock, 1999: 209). Therefore, Sterne becomes the last and most innovative member in a tradition of self-conscious realism which can be traced from Cervantes, through Scarron or Marivaux, to Fielding. In Wayne Booth's words, the narrator's self-conscious interruptions surpass all previous 
instances and become in Sterne "a force so disruptive that it transforms the very nature of the work" (1952: 185). Moreover, despite apparently lacking unity, it is self-consciousness itself which becomes the cohesive element to the whole novel and it is in that new form of fictional unity where Sterne's greater innovation lies. In relation to Tristram Shandy's achievements in the context of the previous self-conscious comic fiction, Booth has stated that in the novel

[...] Sterne learned [...] not how to create a self-conscious narrator who could disrupt conventional fictional unity; [...]. What he learned was how to employ this kind of narrator to impose unity, of however "loose" or unconventional a kind, on seemingly disparate materials. Sterne's true achievement is in taking forces which had become more and more disruptive in comic fiction and synthesizing them, with the help of older models, into a new kind of fictional whole. (emphasis added, 1952: 185)

Pardo reintroduces this idea when he claims that for Tristram "historia equivale a decirlo todo" (1996: 213); hence, rather than omitting the less relevant details or events and gaining control over his narration, as happens in Fielding's novels, he tries to encompass everything in his experience in the book he is writing. As Pardo has phrased it:

Estamos ante la solución opuesta a la de Fielding a los problemas que plantea la representación de la complejidad y amplitud de la realidad, una representación exhaustiva frente a otra selectiva; pero que exhibe y hace ostentación igualmente de estos problemas, que llama igualmente la atención sobre el proceso de representación, sobre las diferencias entre la realidad y su reconstrucción literaria, al mostrar las dificultades que esta solución plantea. (1996: 213)

Therefore, it is this chaos which provides the most important metafictional comment. Moreover, it becomes the crux of the metafictional paradox in Sterne's novel because “el intento de ser absolutamente mimético, de ofrecer una transcripción exacta y exhaustiva de la realidad, hace imposible la mímesis" (Pardo, 1996: 215). Precisely because Tristram does not follow prior literary conventions and hence does not circumscribe the presentation of experience, the reader is made aware of the fictional nature of the novel and of the falseness of those very same literary conventions (Britton, 1993: 29-30). The novel then becomes a constant reflection on the problems of representing reality; it is a work of fiction which provides a recurrent self-referential 
comment and hence subverts the theory of the novel even further than Fielding (Britton, 1993: 32).

This correlation between reality and fiction, together with the attempt to transpose the tenets of one into the other, as did Don Quixote, transforms Tristram into a quixotic figure; his quixotism is emphasized by his absolute devotion to literature and the writing of his biography, which becomes a quixotic quest (Pardo, 2006: 92). Tristram's obsession with literature is hence what makes him a quixote, although he is not the only one in the novel. As if mirroring Tristram's desire for inclusiveness, Sterne has portrayed a gallery of quixote-like characters, all of which display a very particular mania, or hobbyhorse using Sterne's terminology, which serves as the epistemological filter for reality and hence biases their interpretation of it and how they respond to it what Pardo has identified as the passive and active aspects of their mania (1997: 146). In that sense, their hobby-horses are the equivalent of Don Quixote's madness or obsession with romances, for they become the universal rule for the characters' behaviour (Pardo, 1997: 147). Tristram's obsession, as has been asserted, is the writing of the book the reader is perusing, while his father's hobby-horse is erudition. Walter Shandy constantly formulates pseudophilosophic theories on the most varied -and mostly insignificant- matters. ${ }^{39}$ Toby Shandy's monomania is military history and, more particularly, fortifications, which he even reconstructs in his garden. The narrator explains that he had "almost as many more books of military architecture, as Don Quixote was found to have of chivalry, when the curate and barber invaded his library" (2003: 80). In addition, Toby has his own Sancho-like companion in the shape of Corporal Trim, "the more literal-minded servant to his master's obsession" (Reed, 1981: 143). For these characters, their hobby-horse is who they are, it becomes their identity and permeates every single area of their existence. These manias have in all three Shandys, as in Don Quixote, a literary origin and therefore become a reformulation of the knight's attempt to live through literature and of the quixotic principle, with its conflict between life and literature. However, this multiplication of the quixotic role highlights the

${ }^{39}$ For an interesting and original analysis of "Shandean rationality," see Motooka's chapters on Sterne's novels "Disputing against hobby-horses: Shandean rationality" and "The 'already written' law of 'God and reason"” (1998: 179-97). 
fact that each one of these quixotic characters is a "partial, domesticated, and largely immobilized version of Cervantes' hero" (Reed, 1981: 144). Employing Pardo's terminology, as has been stated in the previous chapter, Sterne's is a displaced formulation, for it is reduced in intensity -it is never madness or hallucination- and in the scenario for the conflict -it becomes much more domestic due to its circumscription to the minutiae of their quotidian experience (1997: 148-49).

Together with the Shandys, Sterne also offers a less displaced and more literal Quixote, Yorick, who in appearance and behaviour is an imitation of Cervantes' knight: his horse is compared to Rosinante, for example, and he himself "comes up to any of the honest refinements of the peerless knight of $L a$ Mancha" (2003: 21). Yorick's quixotism gives the narrator the "highest idea of the spiritual and refined sentiments of this reverend gentleman" (2003:21), and this condoning is in a great degree determined by the way in which Sterne, as Fielding and later Smollett, sentimentalizes quixotism. This is obvious in Sterne's later novel, A Sentimental Journey (1768), in which he projects the sentimental traits already present in Toby on Yorick and develops it as a hobby-horse itself (Pardo, forthcoming 2013a). In this sense, Sterne's Uncle Toby, or his own quixotic parson, Yorick, follow after Fielding's Parson Adams in his nature as an amiable humorist, as would Smollett's Matthew Bramble or Humphry Clinker. They all share Adams's dual nature and trigger laughter and pity. All these characters therefore foretell the positive interpretation of the quixote figure that will become associated with the Romantic movement and which will determine the subsequent nineteenth- and twentieth-century interpretations of the Spanish knight.

Nevertheless, Sterne's greater contribution to the tradition of quixotism is the creation of that quixoticised world in which any individual can be a quixote owing to his very particular idiosyncrasy or eccentricity (Pardo, 1997: 150). Moreover, by creating a fictional world crowded with quixotic figures, he transforms it into a universal experience: in Sterne's conception we are all quixotes, subject to our "personal eccentricity" (Britton, 1993: 29). In Müllenbrock's words, Sterne reduced the stature of Don Quixote, he made him lose his "heroic aura," by endowing average people with quixotic traits (1999: 
209); what follows is that the quixote becomes a character increasingly less particular and easier to identify with. This vision was foretold by the most influential critic of the time, Samuel Johnson, when he stated that "very few readers, amidst their mirth or pity, can deny that they have admitted visions of the same kind [as Don Quixote's]: though they have not, perhaps, expected events equally strange, or by means equally inadequate" (The Rambler, 2, 24 March 1750, 1828: 126-127). The universality of the quixotic experience hence also contributes to the empathy the readers feel towards the knight, for, as Johnson writes, "when we pity him, we reflect our own disappointments; and when we laugh, our hearts inform us that he is not more ridiculous than ourselves, except that he tells what we have only thought" (1828: 127). Quixotism in Sterne then preserves its interpretation as singularity, as eccentricity or mania, but, more importantly, it becomes one than can be universally shared and, moreover, condoned. Close explains it saying that "to interpret the hero's madness thus is to diminish the gap between it and the sane, common-sense experience, and to prompt a more sympathetic response towards it" (1977: 12). These novels are then developing the idea of quixotism as a more common and universal enthusiasm or obsession; an interpretation that would find a particularly prolific response in the later part of the century, as well as in the novels of another important Cervantean emulator, Tobias Smollett.

\subsubsection{Don Quixote Gains in Sympathy: towards the Sentimental Hero}

Undoubtedly, Tobias Smollett is, with Henry Fielding and Laurence Sterne, one of the most significant emulators of Cervantes in Britain in the eighteenth century. His role in the British reception of Cervantes is clear from his translation of the novel in 1755 under the title The History and Adventures of the Renowned Don Quixote. In his translation, often interpreted as a revision of 
Jarvis's (Allen, 1979: 2), Smollett explains in the prologue what his interpretation of quixotism is. ${ }^{40}$ As Pardo has stated, Smollett:

$[\ldots]$ insiste en que Don Quijote es una parodia de los libros de caballerías y no una sátira de la caballería y los valores caballerescos, dando así un giro radical a la interpretación de la primera mitad de siglo y alineándose con la recuperación de la parodia y la exaltación de los valores representados por la figura quijotesca de Fielding [...] Smollett utiliza como argumento para su visión paródica y no satírica de la obra la vida del propio Cervantes, en la que ve un temperamento heroico y una inclinación a la caballería, produciéndose así una heroicización de Cervantes [...] que va unida o al menos discurre paralela a la heroicización de don Quijote que empieza con Fielding [...]. (emphasis added, 2007: 143)

While this positive conception of Don Quixote as hero will be developed in later works of narrative fiction, a Cervantean influence is already traceable in his first novel, Roderick Random (1748), and reaches its summit in the last ones, The Life and Adventures of Sir Launcelot Greaves (1760-61) and Humphry Clinker (1771). In the first novel Smollett develops the Cervantean comic romance with the obvious influence of Fielding in the mixture of satire and romance, of picaresque and quixotism, which has led Pardo to describe it as "romantic picaresque" (2005: 94). In Launcelot Greaves, however, Smollett progresses from romantic picaresques to a quixotic romance (Pardo, 2005: 94). Crossed in love, the eponymous hero decides to become a knight-errant and, very much like Don Quixote, he dresses and acts like a proper knight and is accompanied by a truly Sanchean squire, Timothy Crabshaw. This pair resemble Cervantes' characters in action, but also in appearance, reinforcing the iconic nature that Don Quixote and Sancho were to have in Britain. However, Crabshaw's farcical description at the beginning of chapter two is closer to Sancho's than Launcelot's to Don Quixote, due to the more positive light under which Smollett's hero is described:

He had taken off his helmet, and now displayed a very engaging countenance. His age did not seem to exceed thirty. He was tall, and seemingly robust; his face long and oval, his nose aquiline, his mouth furnished with a set of elegant teeth, white as the drifted snow, his complexion clear, and his aspect noble. His chestnut hair loosely flowed in short natural curls; and his grey eyes shone

${ }^{40}$ For a study of Smollett's translation in the context of his quixotic novels as well as a discussion on the circumstances that surrounded its production, see J.A.G. Ardila's "Intertextualidad general y restringida en el Don Quixote de Smollett." Anuario de Estudios Filológicos 25 (2009): 137-51. 
with such vivacity, as plainly showed that his reason was a little discomposed. Such an appearance prepossessed the greater part of the company in his favour. He bowed round with the most polite and affable address; inquired about his squire, and, being informed of the pains Mr. Fillet had taken for his recovery, insisted upon that gentleman's accepting a handsome gratuity. (1793: 26-7)

Smollett portrays the epitome of a romantic hero, not only in appearance but in deeds deprived of the comic aspects of Cervantes' knight. In order to do so, he has divided Don Quixote's dual nature into two different characters: Launcelot, who inherits the heroic dimension of the knight, and Captain Crowe, who does so with his comic vein. ${ }^{41}$ Hence, Smollett can reinforce Launcelot's romantic heroism and idealism, and use him as instrument of his satire against a world that once again proves undeserving. The positive reading of his quixote is clearly stated from his introduction not only in his attractive appearance, but in his good intentions. Launcelot states that his purpose is "to honour and assert the efforts of virtue; to combat vice in all her forms, redress injuries, chastise oppression, protect the helpless and forlorn, relieve the indigent, exert my best endeavours in the cause of innocence and beauty, and dedicate my talents, such as they are, to the service of my country" (1793: 28). Finally, the knight defends his quixotism not as madness but as an ideal defense of virtue. When another character asks him if he is set up to be "a modern Quixote," and claims that such a figure would make "but a sorry jest, and appear equally insipid and absurd when really acted from affectation, at this time of day, in a country like England" (1793: 28-9), Launcelot answers:

He that from affectation imitates the extravagancies recorded of Don Quixote, is an impostor equally wicked and contemptible. [...] I am neither an affected imitator of Don Quixote, nor, as I trust in Heaven, visited by that spirit of lunacy so admirably displayed in the fictitious character exhibited by the inimitable Cervantes. I have not yet encountered a windmill for a giant, nor mistaken this public-house for a magnificent castle; neither do I believe this gentleman to be the constable; nor that worthy practitioner to be Master Elizabat, the surgeon recorded in Amadis de Gaul; nor you to be the enchanter Alquife, nor any other sage of history or romance; I see and distinguish objects as they are discerned and described by other men. I reason without

${ }^{41}$ Although failing to develop the many similarities between the characters of Don Quixote and Sir Launcelot, Tuvia Bloch has acknowledged the lack of a comic nature in the latter, which he also perceives as having been displaced to Captain Crowe. In particular, he quotes the parallel episodes in which Don Quixote and Crowe block the path of five or six men and are consequently beaten (1967: 106). 
prejudice, can endure contradiction, and, as the company perceives, even bear impertinent censure without passion or resentment. I quarrel with none but the foes of virtue and decorum, against whom I have declared perpetual war, and them I will everywhere attack as the natural enemies of mankind. (emphasis added, 1793: 29-30)

With this speech, Smollett asserts not only his knowledge of Cervantes' novel, but also his purpose: he is not to portray a mere imitation of Don Quixote, nor to adhere to the condemnation of quixotism as madness. His quixotic figure is to be a reasoning and reasonable idealist who will be placed in an anti-romantic world where the values of virtue and decorum have been debased.

In his following novel and masterpiece, Humphry Clinker, Smollett would achieve one of the epitomes not only of the new conception of quixotism as idealism, but also of Cervantean emulation at this time. In this last work of fiction, quixotism refracts and is present in several of the characters that populate the novel. First, Lieutenant Lismahago, who, the reader is told, has the appearance of a Don Quixote, and whose quixotism is no longer romantic madness but "learned monomania" (Pardo, 2005e: 85). Secondly, the eponymous hero, Humphry Clinker, who is a "spiritual Quixote" (2005e: 89), a religious enthusiast whose ideals become obsessions and who is, despite his mania, described as simple and innocent, probably in an echo of Fielding's Adams. And, finally, Smollett's quixotic masterwork, Matthew Bramble, characterized by his closeness to the prototypical "sentimental Quixote" of the age, who is "a man of feeling, benevolence and humour in an unfeeling, malevolent and dishonourable world" (2005e: 86), although his true quixotism lies in his hypochondria, which becomes his leading monomania or obsession and which triggers most of his quixotic behaviour (2005e: 87). Bramble becomes the most complex quixotic character in Smollett's production, combining "epistemological monomania" and "moral benevolence," which echoes Don Quixote's “combination of epistemological madness and moral idealism" (2005e: 88). In him, Smollett has "blended in full Cervantine fashion the ridiculous and the admirable and has thus produced his most accomplished quixote, more so than more evident or literal quixotes like the basically comic Lismahago or the basically serious Launcelot" (2005e: 88). 
Other minor characters also display quixotic traits, for instance, Bramble's sister, Tabitha, an aging woman who aims to find a husband, and Lydia, a young and beautiful girl, who is a heroine that also expresses her romantic conception of life throughout the novel. Both are juxtaposed, and Tabitha's mock love story is juxtaposed to that of the truly romantic Lydia. As Pardo has explained, "Tabitha is to the romantic heroine, here represented by Lydia, what Don Quixote is to chivalric heroes represented by Amadis" and is then "Lydia's quixotic counterpart" in Smollett's “quixotic pattern" (Pardo, 2005e: 96). Tabitha becomes the epitome of anti-romance, stressed by the fact that her suitors are also characterized as quixotic, in particular her husband-to-be, Lismahago. Through this storyline, Smollett not only develops the plot of the comic romance by means of juxtaposing the romantic and the anti-romantic, but the latter is here rendered quixotic rather than picaresque, in contrast with his previous novels (2005e: 96). To reinforce this comic-romantic plot, Smollett also juxtaposes Clinker's anti-romantic plot to Lydia's and finally marries him to Jenkins, although in this case the comic and the romantic are intrinsic to Clinker himself and are not present separately, as happens with Lydia and Tabitha. Therefore, in Smollett's plot the romantic and the antiromantic "inhabit the same fictional universe" (Pardo, 2005e: 98).

In Humphry Clinker, then, there are romantic, anti-romantic, ideological, benevolent, and monomaniac quixotes, all expressing their dissenting points of view coevally through the epistolary method that the author employs to grant the reader the true voice of these quixotic figures and their conflicting perspectives. Therefore, in Humphry Clinker "the quixotic principle incorporates not just the conflict between the romantic imagination and reality, but also between vision and reality, world and worldview, and of course between different visions and worldviews, and therefore implies a representation of reality as dialogue of perspectives" (Pardo, 2005e: 99), much in the Cervantean style. Quixotism becomes a much more universal experience; it is consistently portrayed as a mania or eccentricity, as divergent points of view which are confronted with each other, something Humphry Clinker shares with Sterne's earlier masterpiece Tristram Shandy. Smollett's stroke of genius is then "a kind of summa not only of the different kinds of 
Quixote but also of the different kinds of novel which Cervantes' example spawned in eighteenth-century English fiction, a summa of different interpretations or versions of both quixotism and the quixotic principle" (Pardo, 2005e: 106). ${ }^{42}$ By assimilating the innovations of Fielding and Sterne, as well as by developing the concept of quixotism present in their works, Smollett becomes the third member of the most influential triumvirate of Cervantean emulators in the English language. ${ }^{43}$

\subsubsection{From Satirical to Romantic Hero: the Quixote as Enthusiast}

\subsubsection{Sentimental Quixotes}

The eighteenth century is indeed the age of enthusiasm, whether political, philosophical or religious. This concept permeated all areas of society and, as the century advanced, became a pejorative term that was satirised. This enthusiasm was embodied in fiction at this time in a character whose mind has "magnified and inflated its own workings into ontological realities" (Gordon, 2006: 31), and hence the object of satire was often a quixotic figure that personified that political, ideological or sentimental enthusiasm. Consequently, the quixotic figure multiplied to accommodate the authors' attack on as many extreme attitudes as they saw fit. As Close has stated:

In an age where Enthusiasm and Sensibility were both cultivated and ridiculed, Don Quixote lent itself to being interpreted as the definitive,

\footnotetext{
${ }^{42}$ On the different points of view in the novel, as well as Cervantes' influence on what is called "hibridismo genérico" in Humphry Clinker, see also Ardila (2001a: 11-22).

${ }^{43}$ Bloch does not see Smollett's mastery as a natural progression from Fielding, but rather as a need to overcome his failure to emulate Fielding, and more specifically Tom Jones, in the structure of his early novels. This scholar argues that Smollett attempted to adopt Fielding's manner of narration, but "failed to compose a unified picaresque novel based on a single complicated action as Fielding had done" (1967: 108), hence he changed his technique in his last novel and developed "a few plots, each well within his architectonic powers and each connected with a character belonging to a group on which attention is focused throughout the novel" (1967: 108-9). He finally concludes that Smollett "arrived at the form of his masterpiece through an effort to obviate the difficulties he had encountered during his attempts to achieve the Fielding type of novel" (1967: 113). Bloch fails to bring Sterne into the equation, as well as to perceive the need to approach Smollett's work through the lens of his increased cervantism, which is expressed in the interplay of the romantic and the anti-romantic or the dialogic perspective he maintains throughout the novel which are mastered in his late novels.
} 
universal caricature of these attitudes -i.e. a satiric fable about their power to seduce mankind, in politics or religion or manners, from the path of reason. (emphasis added, 1977: 12)

Following an increased cult of sensibility, there are instances of what one could call sentimental quixotes, such as Sarah Fielding's eponymous hero in The Adventures of David Simple (1744), or Oliver Goldsmith's Dr. Primrose in The Vicar of Wakefield (1766). These quixotes are the product of this Age of Sensibility, and follow the example of those benevolent quixotes found in Fielding and later in Sterne or Smollett. They would reach their summit in Henry Brooke's The Fool of Quality (1764-70) or Henry Mackenzie's The Man of Feeling (1771), in which generous and innocent characters become sentimental and quixotic heroes. As Skinner has recorded, the vision of Don Quixote these authors display is extremely positive: for them he represents the best of human nature, he is a gentleman out of romance (1987: 52). Contrary to what happened in Fielding or Smollett, the element of comedy and even satire towards the quixote sometimes disappears and s/he becomes a paragon of that necessary display of sensibility so in vogue at the time. However, as the age of sensibility faded, in the 1780s and 1790s critical voices raised against what were seen as disabling and unnatural emotions; "sentimentality" then became a pejorative term (Todd, 1986: 8) and authors such as Mackenzie retracted from their earlier praise of sensibility. He suggested in 1785 that the sentimental novel may divert attention from easing real sorrow in the face of a fictitious one:

In the enthusiasm of sentiment there is much the same danger as in the enthusiasm of religion, of substituting certain impulses and feelings of what may be called a visionary kind, in the place of real practical duties, which, in moral, as in theology, we might not improperly denominate good works. (emphasis added, qtd. in Williams, 1970: 330)

Sensibility is consequently portrayed as delusional and disenabling and, more relevantly, again associated with enthusiasm, the word extensively used in the eighteenth century connected to quixotism. The sentimental quixotes then become those caricatures mentioned by Close, those instruments to criticise sensibility's power of seduction over young men, and especially, young 
women, as will be subsequently asserted when analysing the female quixotes of sensibility.

\subsubsection{Ideological Quixotes}

In the later part of the century, all these benevolent and sentimental heroes coexist with a much more ideological reading of quixotism. In a time of exalted enthusiasm and revolution, Don Quixote was transformed into the model to caricaturise any ideological excess and became an instrument in the hands of opposing political, philosophical or religious parties. Because of this, this enthusiast is described as an "ideological Quixote," a character driven by the reading of non-fiction (Staves, 1972: 201), whose delusion is rather political and moral than epistemological and a consequence of abandoning the system of reference that the community shares. This conception of quixotism as vehicle for the critique to a particular political or ideological stance was developed from the satirical vision of the Augustans and found its best expression in Richard Graves' The Spiritual Quixote: or, the Summer's Ramble of Mr. Geoffrey Wildgoose (1773). Graves' eponymous protagonist is a gentleman with property in the country who has an attack of melancholy and decides to start reading seventeenth-century Puritan literature. From this train of reading he adopts the determination to ramble through the country as a preacher, thus searching to spread his enthusiastic religious vision. In this way, Graves develops through his literary quixote "the traditional notion that enthusiasts are fundamentally sick or mad" (Staves, 1972: 200). However, despite his delusion, Staves correctly perceives Graves' premise to be that Wildgoose is a nice and good man who is a "victim of temporary insanity" (1972: 199) and is finally allowed to return to a more commonsensical reading of reality. Incidentally, the goodness of his character somehow contrasts with the surrounding world, which loses by the comparison and is then also the butt of the author's satire, hence becoming indebted to the vision of quixotism developed by Fielding in his Parson Adams.

With this dual satirical aim, against the principles the quixote embodies and also against the world that takes advantage of them, this work instated a 
prolific tradition of satirical quixotes that, despite the above mentioned influence of Joseph Andrews, also recommenced the pre-Fielding negative interpretation of quixotism as those ideas that subvert the status quo and that must be counteracted from within these conservative quixotic fictions. Many of the latter works of fiction acknowledge their belonging to the quixotic tradition from their very title, in which authors' claim the presence of a character with an analogous psychology to that of Don Quixote. This claim is expressed by the word "Quixote" to which has been added an epithet that describes the nature of their delusional behaviour and which circumscribes those ideologies that will become the butt of the satire in the novel. Some examples would be the anonymous The Philosophical Quixote; or, Memoirs of Mr. David Wilkins (1782) and The Amicable Quixote; or, The Enthusiasm of Friendship (1788); or, William Thornborough, the Benevolent Quixote (1791), by Jane and Elisabeth Purbeck. These novels develop the dualistic interpretation of the quixote, with a more positive interpretation of their character's enthusiasm for knowledge, friendship or benevolence, as a mania or form of foolishness that can be overcome without excessively tragic consequences.

This tradition of satirical quixotes would reach its peak at the end of the century, as the events in France following the Revolution and, more specifically, the reign of Terror of Robespierre, prompted a wave of responses in Britain, many of which found their expression in fiction. Between 1798 and 1801, the peak years of reaction, a series of novels appeared which have been counted as part of either the Jacobin or Anti-Jacobin tradition. ${ }^{44}$ One could mention, for example, novels such as The History of Sir George Warrington; or the Political Quixote (1797), also attributed to Jane and Elisabeth Purbeck; or The Infernal Quixote; a Tale of the Day (1801), by Charles Lucas. In these

${ }^{44}$ For an insight into the Jacobin and Anti-Jacobin production at this time see Marilyn Butler's Jane Austen and the War of Ideas (Oxford: Clarendon Press, 1975); Matthew O. Grenby's The Anti-Jacobin Novel: British Conservatism and the French Revolution (Cambridge: Cambridge University Press, 2001); Gary Kelly's The English Jacobin novel 1780-1805 (Oxford; New York: Clarendon Press, 1976); or, W.M. Verhoeven's "General Introduction." Anti-Jacobin Novels. Vol. I. (London: Pickering \& Chatto, 2005). For an analysis of Sir George Warrington or The Infernal Quixote in the context of the late century Anti-Jacobin reaction see Miriam Borham-Puyal's "Your wines are as foreign as your sentiments': the Quixote as Literary and Political Alien in The History of Sir George Warrington, The Infernal Quixote and The Heroine." 1616. Anuario de Literatura Comparada (2011): 111-32. 
narrative fictions, quixotic enthusiasm embodies radical political stances and the source of the young quixote's delusion is found in the philosophical or political writings of French and Francophile authors alike. British quixotes become, thus, the "embodiment of radical political difference," as they "function within empirically derived rational systems, but those systems are not shared by those around them" (Motooka, 1998: 4). ${ }^{45}$ These quixotic novels and their role in the ideological wars of the turn of the century will have a noticeable impact on the tradition of female quixotism, as women become more than ever the embodiment of the endangered status quo and as women writers take over the duty of instructing their women peers through their use of quixotic fictions.

Whether they understand ideological quixotism as an innocuous mania or as a danger for the state, all the abovementioned fictions once again follow Graves, who clearly states the nature of his character's quixotism by the use of the appellation "spiritual." Moreover, they equally take Graves as a model in the fact that their appropriation of Don Quixote is limited to an imitation of his main character, rather than the development of the whole Cervantean method that was present in Fielding, for instance. Quixotism becomes the best embodiment of exalted ideals and is hence placed at the service of a political or ideological message, for these novels do not outstand for an exceptional literary quality, but rather for their role as political propaganda. There are, nevertheless, certain elements in common with Cervantes' novel, for instance, their episodic structure or the presence of an intrusive narrator who utters critical opinions or moral axioms. Moreover, the conception of the quixotic figure in these works is very close to that amicable, philanthropic and romantic enthusiast characteristic of Fielding's reading of quixotism as "high-souled good nature" (Tave, 1960: 160). That is, these quixotic characters, with the exception of Marauder in the Infernal Quixote, are described as "eccentric good-doers" (Ardila, 2001c: 421), as having a good and philanthropic nature which is threatened by their radical political or ideological principles. Their quixotism, then, is a betrayal to that very same nature and hence requires a cure

${ }^{45}$ See Motooka's chapter on quixotism in relationship with the ideas of innovation, cultural change, and more relevantly, revolution, "Turning Authority into Jest. Tyrants, pedants, quixotes and enthusiasts in the early eighteenth century" (1998: 32-73). 
and a return to the original, proper self. Added to this good nature, all of these ideological quixotes, except the old David Wilkins, are characterised by their double role as satirical quixotes and romantic heroes: they are young, wealthy and are involved in a sentimental story that culminates with their marriage to the beautiful and virtuous heroine. Here Fielding's influence is perceived once again: the juxtaposition of the quixotic and the romantic plots in his comic romance is imitated in these novels, together with its bi-directional satire. Therefore, while the quixotes' delusion is satirised by these authors, their prequixotic nature as benevolent and romantic heroes is employed to reflect on the corruption of society and hence to direct the satire also against it. These politically radical quixotes are then linked to the more romantic ones previously developed, such as Charlotte Lennox's Female Quixote or Smollett's Launcelot Greaves. ${ }^{46}$

\subsubsection{Don Quixote Returns to Romance}

The profuse gallery of benevolent and sentimental quixotes of the eighteenth century thus moves towards the vision of the quixote as romantic hero, rather than comic fool, and serves as foundation for the Romantic exaltation of the quixotic figure. As Anthony Close has explained, this shift in interpretation also owes much to the European Romantic movement, initiated in Germany, which left a deep and permanent impress on "several areas of sensibility and thought, including men's understanding of Don Quixote” (1977: 6). This new understanding is then founded on the fact that the German Romantic generation chose Cervantes' novel "as one of the supreme pinnacles of Universal Poetry, an exemplary forerunner of its own art, and a far more serious and significant book than had hitherto been allowed" (Close, 1977: 246). Through the influence of this German generation of Romantics does the symbolism of the ideal and the real become the theme of perspective and reality; through them do the deep links between "Don Quixote and the Volksgeist, the Zeitgeist, the

\footnotetext{
${ }^{46}$ A thorough description of these works and of their place in the English eighteenthcentury reception of Don Quixote is provided in Miriam Borham-Puyal's entry "Quijotes satíricos del siglo XVIII ingles." Gran Enciclopedia Cervantina, Vol. X. Madrid: Castalia, forthcoming.
} 
author's biography, national history, the metaphysical ground of being" (Close, 1977: 244) gain their strength in the works of Romantic British authors and critics.

In this line, the Romantics, and British critics in particular, would emphasise the quixote's "intrinsic seriousness" (1977: 60), that "serious air" that Pope and other early eighteenth-century critics had identified in Cervantes' work (1977: 247), and which they now deprived of its burlesque intention. Romantic critics, such as Lockhart, would interpret Don Quixote and his eponymous hero under the renewed interest in the romance which is made manifest from the $1780 \mathrm{~s}-$ expressed in such works as Clara Reeve's The Progress of Romance (1785)-, which brought the Quixote back to its fields, reading his "chivalric discourse straight, rather than as burlesque" (1977: 59). The quixote then became "romantic and chivalric" (Staves, 1972: 208), and the interpretations done of his figure by Reverend John Bowle, for instance, emphasise his observance of the chivalric code and reverence his idealism, while Reeve herself also seems to find him "venerable" (1972: 210). In addition, Bowle also illustrates the increasingly serious consideration of Cervantes' novel, as he wrote the first critical edition of Don Quixote. His criticism of the novel is permeated by his “immense enthusiasm for Cervantes" (Staves 1972: 209) and his extensive erudition, which lead his friends to name him "Don Bowle" in honour of his almost quixotic obsession with Don Quixote himself. This obsession is displayed by other scholars. Henry Davis Inglis, for example, took that enthusiasm even further and travelled to Spain to follow in Don Quixote's steps, hence becoming once again a palpable example of that identification and empathy with the character that took place throughout the Romantic period. The result of Inglis's journey, Rambles in the footsteps of don Quixote (1837), remains an essential text to understand the Romantic approach to Cervantes.

Romantic critics would interpret Cervantes' novel "as a bitterly ironic epic about the outcast Poet, the heroic Outsider, the victimised Christ-figure; a philosophic epic about the idealising spirit or conceptualising mind before reality; a national epic about a Spain crushed by, or potentially resurgent from its history" (Close, 1977: 249). Therefore, the Romantic approach takes one step further in the eighteenth-century progress from the "hard school" and its 
satire against human enthusiasm to the "soft school" that praised quixotic idealism (Mandel, 1958: 154-155). In the Romantic period there is a more evident shift in the interpretation of Don Quixote from "crackpot" to "saint of idealism" (Staves, 1972: 209), and of quixotism from epistemological error to moral idealism (Pardo, 2007: 148). As a consequence, the quixote is transformed into a "universal type of the idealist, the heroic altruist, the 'symbol of Imagination, continually struggling and contrasted with Reality'," while his enthusiasm becomes the "quintessence of the spiritual" (Close, 1977: 57), blurring the distinction between the quixotes and the sane characters, and between his lucid intervals and the mad ones. The Romantics deny "the radical, and risible, difference in kind between Quixote's lunatic motivation and that of anybody sane" for he is no longer "a case of literary make-believe gone beserk; but one who experiences intensely what others feel more feebly-Enthusiasm, Poetry, the Ideal" (1977: 61). As Staves has asserted of Hazlitt's Romantic treatment of Don Quixote:

[...] satire and distancing dissolve and the quixotic figure becomes wholly sympathetic. Whatever reading he does affects his mind by giving it a tincture of idealism which is perceived as wholly admirable. Some notion of the failure of these ideals to correspond to the realities of the world lingers, but the failure is regarded as unimportant. (1972: 206).

Quixotic heroism then becomes the living out of that Enthusiasm or Ideal, or, in other words, "the cultivation of romance amid incongruous surroundings" (Welsh, 2002: 85). In the hands of the Romantics it is transformed into a "romantic tone and colouring" given to ordinary experience (2002: 92), an ideal vision by means of which characters face and interpret reality. In so doing, they continue to develop Sterne's or Smollett's interpretation of quixotism as a universal experience connected to a personal and particular vision of the world.

This idealism or point of view can have a political reading. An example is found in Charlotte Smith's novels The Old Manor House (1793) and The Young Philosopher (1798). In the former novel, the main character, Orlando, is accused by his father of a "tendency towards romantic quixotism" nurtured by his passion for reading. In Smith's novel all “elements of satire and ridicule 
have vanished" and it is his readings who have helped him become "romantic and idealistic," or "sensitive and good" in Smith's terms (Staves, 1972: 211). In the last-mentioned novel, Smith uses the figure of a philosophical and idealistic hero to highlight the deficiencies of the English system and transforms her ideological quixote from "satiric object to Rousseauistic hero" (Staves 1972: 212). ${ }^{47}$ The heroes' quixotism derives from their Romantic and radical, aesthetic and ideological, idealism, learnt from their readings, and is in permanent conflict with an undeserving world.

Smith takes her positive interpretation of this idealism beyond the satirical writers of the turn of the century, for she does not develop the subsequent disillusionment of the quixote or his need to face the fact that truth is never simple, and that there exists "no system, no book, no philosophic mentor who represents a completely adequate 'guide to life"" (Staves, 1972: 213). However, later novels lose the ideological component and transform quixotism in an even more common experience of illusion and disillusion. The consequent disenchantment to quixotic idealism, inherent to the quixotic principle and the conflict it portrays between the romantic interpretation and the anti-romantic world, will then be developed in subsequent novels in the shape of this disillusionment that the quixotes experience after an initial misunderstanding about their world (Welsh, 2002: 97).

This idealism and the later disillusionment is most often connected in eighteenth-century and later nineteenth-century novels with youth and inexperience -even if at times aided by reading-, and therefore quixotism becomes an even more common experience associated with a state that "can be grown out of" and which is then "quite acceptable, even salutary" (Welsh, 2002: 91). Staves, Welsh or Pardo have seen in Walter Scott's Waverley (1814) the expression of this new conception of quixotism as a youthful romantic colouring and of the quixote as a romantic hero whose idealism clashes with the reality of a world in which the ideals of bygone times he admires so much

${ }^{47}$ Smith's critique of "things as they are" in English society and her portrayal of radical idealism as producing its own physical or ideological exiles is amply discussed in Angela Keane's chapter entitled "Exiles and émigrés: the wanderings of Charlotte Smith." Women Writers and the English Nation in the 1790s. Romantic Belongings (Cambridge: Cambridge University Press, 2000), pp. 81-107. 
have no longer any relevance. In the end, Waverley renounces his visions of romance, and starts his life's "real history" by marrying and becoming a property-owner (Welsh, 2002: 91-92). This very same pattern can be perceived in Jane Austen's novels in which a young girl must overcome her romantic or idealistic expectations of life, and conclude her story with a happy, prosperous and sensible marriage. Quixotism will then also be a very traceable influence in the shaping of the coming-of-age novel (Kauvar, 1970) or even the novels of manners, of which Austen will become the greatest representative. ${ }^{48}$ Moreover, this interpretation of quixotism displayed in Austen or Scott then enroots with the nineteenth-century bildungsroman (Pardo, 2007: 153), with the idea of a male or female youth having to learn and find their place in society by contrasting their world-vision with the reality they experience. This is made evident in George Eliot's The Mill on the Floss (1860) or Middlemarch (187172), in which the process of illusion and disillusionment is described as part of that process of learning and maturation (Pardo, 2006: 100-1).

While the late eighteenth-century and nineteenth-century novels do reveal the assimilation of Cervantes' theory of the novel, their greater influence in subsequent fiction, as well as on the collective consciousness, would be that Romantic approach to quixotism. The quixote becomes the epitome of the outsider, the rebel, the misfit, and hence the archetype for modern heroes against an uncomprehending society (Iffland, 1987b: 12); quixotism as collective ideologeme is then the "impossible dream," the clash between the real and the ideal which all mankind can relate to (1987b: 11). Modern critics, such as Unamuno or Ortega, would echo this interpretation as they see in every man a quixote and in every novel the quixotic principle.

The long-eighteenth century is then a prolix age for the reception of Cervantes' novel, and a strong foundation for its present consideration. It is not only a complex and rich era for the appropriation of Don Quixote, the character, but also the cornerstone to understand all modern appropriations of the quixotic figure and its increasingly positive consideration in the collective

\footnotetext{
${ }^{48}$ Although subsequent references will be made to Austen's novels, for an explanation on the development of the novel of manners from Fielding to Austen, see Paulson (1967: 266$310)$.
} 
consciousness. If Don Quixote has become the icon identified by Riley or the universal model proclaimed by Unamuno, if modern readers and writers can identify with the knight and his madness, it is in part because eighteenthcentury British writers led the way and taught us how.

Despite the achievements of these cornerstones of the unique quixotic and Cervantean tradition in Britain, the eighteenth-century impact on the presentday approach to Cervantes' novel would not be complete without looking away from these works towards another element that enhanced this rich tradition: the recurrent presence of a female quixote in eighteenth-century fiction, to which the rest of the present work is devoted. Those narrative fictions which display a female quixote take a step further in the reception of Cervantes and in the transformation of the quixotic myth, sharing traits with the before mentioned works of fiction, while also innovating and acquiring a value of their own. What is more, as will be stated in the next chapter and throughout subsequent ones, at a time when the figures of the woman writer and the woman reader gained not only visibility, but ascendancy in political, moral, cultural and literary discussions, the female quixote becomes revealing not only of the gendered debates of its time -and of our own-, but, as did her male counterparts, also of the generic ones that have shaped the way in which we nowadays understand narrative fiction. 


\section{WOMEN WRITERS AND READERS}

[...] if you please no reference to examples in books. Men have had every advantage of us in telling their own story. Education has been theirs in so much higher a degree; the pen has been in their hands. I will not allow books to prove any thing.

Jane Austen, Persuasion, chapter 23

"[...] Shall you be at the assembly?"

"I believe not, my Lord."

"No!-why then, how in the world can you contrive to pass your time?"

"In a manner which your Lordship will think very extraordinary," cried Mrs. Selwyn, "for the young lady reads."

Frances Burney, Evelina, Letter LXII

The topic of the present work, the recurrent presence of a female quixote in the literature of this time, raises questions about the reasons why such a figure became so relevant in the works of fiction which appeared throughout the long eighteenth century, especially those written by women. The answer may be found in Dale Spender's assertion:

This was an age when there was a dramatic increase in the size of the female reading public and in the number of female writers. The two were closely interrelated. The more women readers there were, the more women writers were required; the more women writers who emerged, the more women readers they won. Each helped to mould and shape the other, and both created an environment conductive to the development of a literary culture and the success of the novel. (emphasis added, 1992: 13)

The important presence of women writers and readers and their role as producers and consumers in the new mass market of literary culture is essential to understand the figure of the female quixote, with its associations with gender and genre and its use as an instrument to comment on the situation of women within the literary market and society in general, as well as to participate in the discussion on the nature of fiction and reality apparent in the novel and its dialogue with previous literary forms. It is then the aim of this chapter to provide a context for eighteenth-century women writers, and more specifically, 
QUIXOTIC READERS AND QUIXOTIC WRITERS

women novelists, and their female reading public, to understand the complex relationship between literature and femininity, between authorship and readership, between private and public identities, between popular and classical genres, which the female quixotes embodied. 


\subsection{Reassessing the Public Sphere}

In 1962, Jürgen Habermas published his seminal work The Structural Transformation of the Public Sphere. An Enquiry into a Category of Bourgeois Society (which appeared in English in 1989), providing what was probably the most influential account of the emergence and development of the public sphere in Modern Europe. Although the existence of the concepts of the public and the private realms was profusely attested in the previous critical body, as the language of the different spheres particularly permeated from eighteenthcentury conduct books to periodicals, Habermas's work allowed a new impulse to be given to this debate, especially relevant in the discussion of the role women writers were to have in the creation of the new mass culture that developed throughout this century. According to this critic, the eighteenth century witnessed the emergence of an Öffentlichkeit [public sphere] culture, as opposed to the representational one that existed in prior centuries. While this representational culture was shaped by the state and would aim at the control of the public opinion, this emergent public culture had a critical nature, being defined as a space for critical discussion where private people came together to constitute a public which engaged in a debate over the affairs of the state and, hence, served as a check on its power. Following this scholar, the public space has been defined as "an intermediary space, between the intimate sphere of the family and the official sphere of the state" (Eger et al., 2001: 7) and its members as most prominently "readers of the printed word and members of voluntary associations" (Vickery, 2001: 3). Among these, Habermas identified a number of new, urban institutions that flourished in the eighteenth century and that contributed to the development of this public sphere culture, namely saloons or coffee-houses -the spaces he identifies as landmarks in this gradual replacement of the repressive and passive culture for a more liberal and active one-, which highlighted the essentially dialogic nature of this new culture, with 
its constant exchange of opinions in the public arena through the print media or political public debate. ${ }^{49}$

However, his theory, from the very moment of its formulation, raised controversy due to the problems it posed when considering what was understood as "public," what the boundaries of these spheres were and the role played by women in the development of this new public culture. As Eger, Grant, Gallchoir and Warburton have stated, in a time of "transitional ideology between a pre-industrial, aristocratic culture and an industrialised, commercialised culture," the idea of the public was "inevitably contradictory and ambiguous" (2001: 5). Therefore, two broad senses of the term could appear in certain contexts: it could refer to a mass of citizens, or, in its more classical form, in could be employed "to distinguish a body of educated people, usually men, from the mass of common people, 'the vulgar"' (2001: 5-6), hence reinforcing the vision of a political and cultural elite based on the discourse of classical republicanism. ${ }^{50}$ The political implications of both these definitions, and the stated absence of women from public offices or Parliament, has traditionally led to the perception of an "opposition between a masculine public sphere of political power and a sphere of privacy which is much more difficult to characterize, but which almost always includes or overlaps with the domestic" (Guest, 2000: 11). Moreover, it has been argued that his "conceptualization of the public sphere served to relegate women to the confines of the domestic household and denied them a role in the formation of public opinion" (Batchelor, 2005: 4). However, for decades now, the field of gender studies has been taken over by the critical debate stating the validity of this public/private model and the domesticity thesis that has derived from it. As a starting point, it is necessary to state that both conceptualisations of what the public means, where their boundaries are, who they include and who not, are open to discussion. In this sense, the idea of citizenship, with the rights and

\footnotetext{
${ }^{49}$ For a thorough discussion on the concept and complexities of Habermas's definition of the public sphere see Habermas and the Public Sphere. Ed. Craig Calhoun (Cambridge, Mass.: MIT Press, 1997).

50 Habermas's theory has been contrasted with the also highly influential thesis explored by J.G.A. Pocock, in which the model of public political realm is "defined by the discourse of classical republicanism," articulating, in Guest's words, "an unambiguous masculinist concept of virtue limited to a small political elite which excludes most people all of the time and includes its independent citizens only some of the time" (2000: 5).
} 
privileges it entails, is a problematic one. As historians have pointed out, the concept of citizen had not a very precise meaning, even when related to men, and was even more ambiguous when applied to women (Vickery, 2001: 6). Throughout the century, the concept of citizenship was constantly redefined, and played a key role in the late-century political debates. This term allowed then to be rewritten and broaden to include not only men who did not conform to the patrician model, but also women -as can be deduced from Wollstonecraft's writings, for instance. Even before the 1790s' debate on the matter, the idea of citizenship was broader than present-day commentators have actually realised. Amanda Vickery's enlightening works, for example, reassess women's rights and political culture, which has been obscured because of the abovementioned ban from political institutions and because of women's long struggle to be recognised their right to vote. However, though not being able to become public political figures in the sense of holding an office or voting, as private individuals women could participate in political life and exert their influence, thus gaining a public face in the process. In that way, public and private became one space, and the concept of domesticity was no longer at odds with women's role as "political pamphleteer and campaigner" (Guest, 2000a: 52), for in this conception of political domesticity every individual, including women, could participate in the national political identity (2000a: $60)$.

Although there were bold women who exercised a visible form of female participation in even the traditionally masculine public sphere of political power, as Harriet Guest has suggested, more ordinary women could move within a "third site" (2000b: 11) which allowed to see the public sphere and the private one not as mutually exclusive, but rather as constituting a continuum in which women could intensely participate. Guest defines this third site thus:

[...] [it] may take a form derived from Habermas's public-within-the-private; it might take a form suggested by whiggish opposition politics in the 1770s, when the true patriot able to grasp the public good was not usually characterized by involvement in the imminently corrupting exercise of political power, or it might take the form of the capacity to imagine oneself as a citizen possessed of a political subjectivity. What all these forms have in common is that they suggest that the relation between public and private may be permeable, may be fluid. (2000b: 11-12) 
Guest's "third site" comprises then any form of private practice that allowed individuals, in particular women, to have an impact on public matters. Especially with the access of women to printed material, there existed the possibility of "small changes in readers' consciousness of themselves in relation to public issues: to the idea of nation, or even to political debate" (2000b: 12), thus allowing these women to conceive themselves as citizens with a political subjectivity. Those small changes became evident in the position of women, and "some women of liberal education could assume it was their right and duty to have opinions about what happened in the world; they did not see their exclusion from participation in the public life of the nation as natural" (2000b: 14); as a consequence, it is at this time that female debating societies flourish, or that women's participation in petitions to Parliament or in crowd protests augments (Vickery, 2001: 21, 23, 27). This participation in public life, as seems evident, was achieved in ever-increasing ways, especially as this notion of what constituted the public sphere was constantly broadened; as Guest has stated, at this time "small changes in the network of meanings that constitute publicity mean that some women, even as they shop, can imagine themselves as political citizens" (2000b: 13). The concept of what being a female citizen meant was complex and malleable, and offered women the freedom of interpretation which could grant them a greater autonomy of action.

What is also clear in the works published at the time, as will be subsequently made obvious in the comment of the conservative and radical writings of the 1790 s, is that the domestic sphere, that of the family, was itself "construed in terms of political space" (Vickery, 2001: 28) and was fundamental in the shaping of new images of female citizenship, answering to the views so particular of the age of Enlightenment, which considered the family as the core of society. What is more, although in contemporary commentary there existed a "dominant eighteenth-century ideology of femininity" which associated women with the "private sphere, domesticity and leisure" (Jones, 1990: 5-6), this idea of domesticity is far from being simple and constrained. First of all, as has been explained, the public and private came together in the household as the public sphere of politics includes the "supposedly 'private' world of family connections and friendship networks" (Vickery, 2001: 3), in which privileged 
women played such a relevant role. Secondly, the ideal of a domestic woman did not exclude the possibility of exerting her influence out of the boundaries of her house; in fact, the very same language which reinforced the image of the dutiful, pious wife, allowed for the increase of what has been termed the boom in "feminized philanthropy" (Vickery, 2001: 25). This philanthropy was presented as a "form of "social housekeeping'," evincing that "women became increasingly adept at manipulating [the language of domesticity] to pursue a range of activities and assume a set of responsibilities outside home" (Vickery, 1998: 293-94).

This leads to the conclusion that, "at one and at the same time, separate sexual spheres were being increasingly prescribed in theory, yet increasingly broken through in practice" (Colley, 1992: 250). While conduct books, treatises and even works of fiction continued to prescribe this domestic role, women's role in both the political and literary public spheres, following Habermas's terminology, increased throughout the eighteenth century, finding "all kinds of ways in which [to contribute] to the complex network of communications through which public opinion was formed" (Jones, 2000: 6). Of course, the dialectal polarity between home and world, between the idea of women belonging to one and men to the other is a recurrent trope in Western literature since the Classical Age (Vickery, 1998: 6-7), hence the presence of the language of domesticity and the negative image of the idle, redundant, leisuredriven women, does not come as a surprise in the eighteenth century, though its reinforcement leads to the conclusion that it was rather a response to the more general fear about the "rise of luxurious corruption" and the "vicious consequences of wealth" (1998: 5), and, in particular, to the increased visibility of women and the expansion in their opportunities, ambitions and experience. It was, then, "a cry from an embattled status quo, rather than the leading edge of change" (1998: 7). ${ }^{51}$

${ }^{51}$ On the eighteenth-century paradigm of women as belonging to the domestic sphere see, for instance, Ruth Perry's Women, Letters, and the Novel (New York: AMS Press, 1980), pp. 27-62; Bridget Hill's Eighteenth-Century Women: An Anthology (London: George Allen \& Unwin, 1984), pp. 3-12; or the abovementioned work by Vivien Jones, Women in the Eighteenth Century: Constructions of Femininity (London: Routledge, 1990). The debate over the validity of the domestic thesis has taken epic proportions with critics not only contending the role of women in the public sphere, but the existence of any real simply-drawn distinction 
The influence exerted by an ever-growing group of women who participated in the literary and cultural debates of the century also triggered many of the concerns of these moral commentators. Women were as much part of what has come to be regarded as this Enlightened public cultural sphere as men, and they became so through various means: as artists, as intellectuals, as critics and as writers of fiction, hence actively participating in the shaping of the public opinion. Although our main focus is the role played by women writers, the presence of other women in the public arena, their influence in the shaping of culture and the consequences which derive of their visibility, help understand why and how these women came to publish. Moreover, it allows to better understand how they achieved to have "an enormous -and hitherto largely uncredited- impact on the formation of public opinion in England" (Mellor, 2000: 11), while it draws some light over the fears and paradoxes that accompany the role of woman and the role of writer, which are magnified when both are combined in the case of female authors. Once again, although the public space, at least in the theory of the age, was still highly gendered in its conception and although emphasis was placed on women's special vulnerability to scandal owing to the double moral standard of the age, these successful women are evidence that the circumscription of women to a mere domestic role and their ban from the public sphere is as fictional a construction as the contemporary male claims that women were taking over the nation. As

between the spheres in which men and women moved. The latter position has been taken by Lawrence E. Klein in his article "Gender and the Public/Private Distinction in the Eighteenth Century: Some Questions about Evidence and Analytic Procedure." Eighteenth-Century Studies 29.1 (1996): 97-109. He offers an interesting account of the opposed views and claims the need to reassess the notions of femininity and mobility, undermining some of the assumptions which underlie the association between women and the private sphere and stating the existence of a series of publics rather than a single one. His scepticism on the public/private-domestic model and its gendered connotations has its acknowledged basis on Amanda Vickery's “Golden Age to Separate Spheres? A Review of the Categories and Chronology of English Women's History." The Historical Journal 36 (1994): 383-414, in which she once again argues that Georgian women had access to what they considered the public sphere, which took many different shapes. For an illuminating comment on these different approaches, see Guest (2000b), pp. 1-18 or Schellenberg (2005), pp. 1-9. The fact remains that the language of the private sphere and domesticity was factually employed throughout the eighteenth century in relation to women, so that, at least in theory, there did exist certain stereotypes of femininity as passive and private which women had to challenge, hence making it easy to be blinded by the prescriptions which we have in print. However, recent studies make it necessary to reassess the reasons which motivated those writings, the extent to which eighteenth-century women followed these models of the "domestic," and the meaning that concept had for them, as women seemed to constantly challenge in practice what was prescribed in theory. 
Vickery did for the presence of women in eighteenth-century political culture, Vivien Jones has expressed the need for a reassessment of the limited role of women in culture because of new historical evidence (2000: 15). ${ }^{52}$ Under the light shed by these scholars, women were neither excluded from nor radically appropriated the sphere considered public, rather their participation in it as producers and consumers of "intellectual and material goods" became increasingly relevant and decisive. The emphasis on their role as consumers is not coincidental: after all, the distinction between public and private was "born out of the commercial foundations of modern society" (Eger et al., 2001: 1), and answered to the pressing concerns of the modern age. One of these concerns at this particular period was a heated debate on the concept of "taste," with an increased anxiety caused by the matter of who participated in its shaping and a particular emphasis on the role women had started to play. The debate on aesthetics, moreover, was interrelated with moral, social or political issues crucial at this time, and was another important means by which women could participate in political debates (Price, 2009: 12), as the changing taste of the rising bourgeois was very much determined by the sector of the population perceived as the greater consumers of luxurious or artistic goods: women, who even "came to be used as a measure of commercial growth and resulting historical changes" (Clery, 2004: 1). According to Jones, consumption, with its creative and unpredictable nature, was "a site of agency, interpretation, and therefore, potentially, of resistance. And this would be true whether the object concerned were a fashion item or the words of a text" (2000: 13); which, of course, explains the aforementioned reaction of certain male writers, and their

${ }^{52}$ In this sense, although indebted to seminal works such as Elaine Showalter's $A$ Literature of Their Own: British Women Novelists from Brontë to Lessing (1978), Gilbert and Gubar's classic study The madwoman in the attic: the woman writer and the nineteenthcentury imagination título en minúsculas (New Haven: Yale University Press, 1979), or Mary Poovey's essential The Proper Lady and the Woman Writer (Chicago and London: University of Chicago Press, 1984), which will later contribute to my discussion of women writers, I believe their stress on the limited domestic role of women, on the need for female selfeffacement and even anonymity and on the trouble as women of achieving success in the public sphere is overstated and requires a reassessment in the light of the recuperation of all these women artists, philosophers and writers. In this regard, Jones states: "Attention to diversity and particularity has also involved a growing emphasis on female agency: both as a theoretical possibility, and as a historical actuality supported by the growing literary and documentary evidence of women's active involvement at all levels of (print) culture. And it has begun to dislodge some of the familiar narratives about women and literature in this period: asking us to adjust our assumptions about the hegemony of fiction, for example, or to rethink the gendered division between public and private spheres" (2000: 15). 
concern about the female consumer expressed in images of "devouring, unreasonable womanhood" (Vickery, 1998: 5). In a sense, these commentators had a reason to be worried: women did shape the new mass culture from both ends, in a constant two-directional feedback process; women producers and consumers, women artists and spectators, women writers and readers determined the aesthetic tendency of the age and, as a consequence, established "women issues" at the centre of the public debate when their demand for education and entertainment threatened to mould the direction of British culture.

1.2. Visible Women: Female Artists, Intellectuals and Writers in the Public Eye

In 1779, the painter Richard Samuel presented at the Royal Academy a collective portrait, later entitled The Nine Living Muses of Great Britain, in which he represented nine contemporary women: Elisabeth Montagu, Elisabeth Griffith, Elisabeth Carter, Charlotte Lennox, Elisabeth Sheridan (née Linley), Angelica Kauffman, Catherine Macaulay, Anna Barbauld and Hannah More (figure 1). All these women were renowned artists in their chosen fields and epitomised the important network of women intellectuals that was becoming consolidated at this time. The portrait is then an "act of embodiment" which suggests the rise of women's professional activity as well as their role in the formation of aesthetics during this period and their contribution "as the subjects and objects of representation, to an evolving national culture" (Eger et al., 2001: 11). 


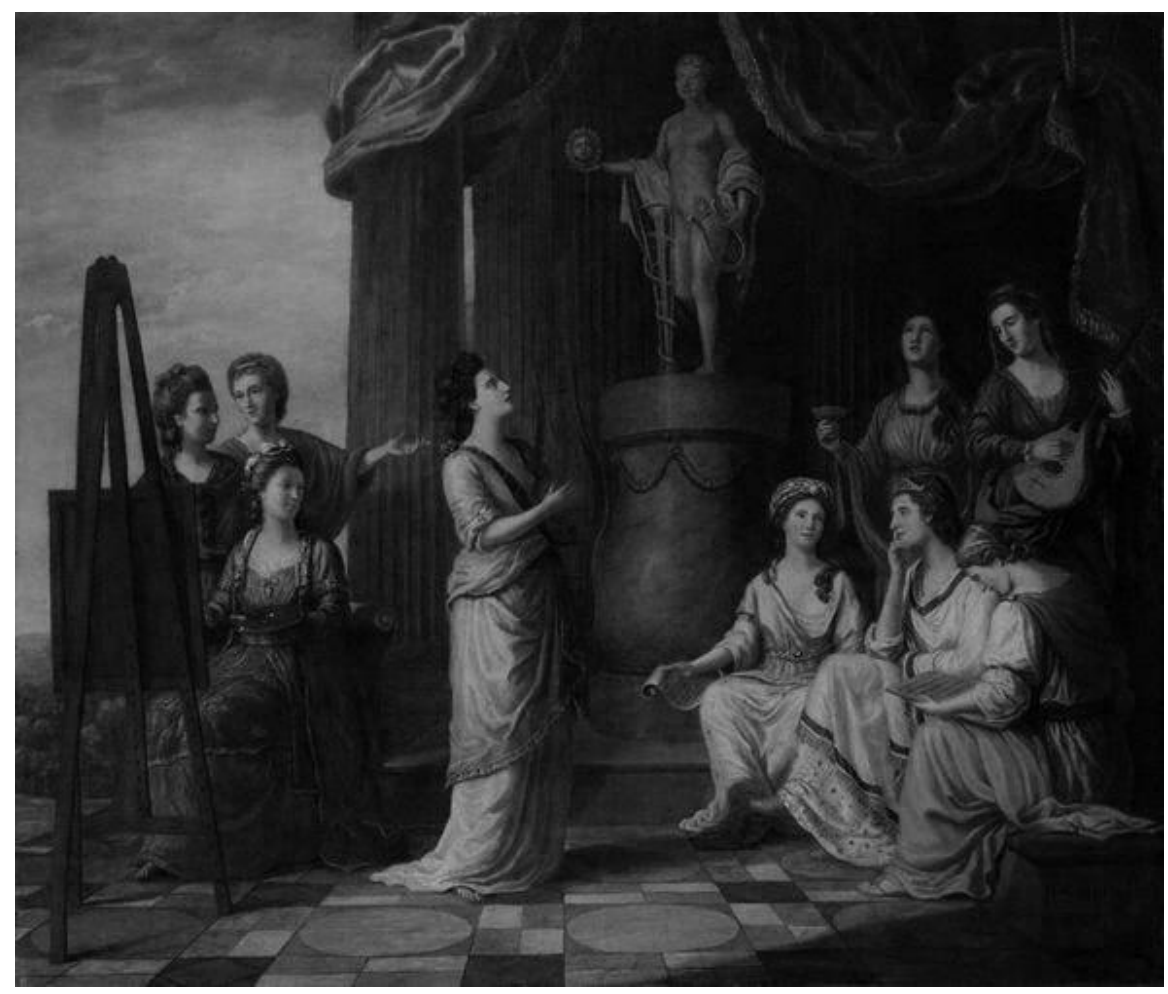

Figure 1. Portraits in the Characters of the Muses in the Temple of Apollo by Richard Samuel, 1778. Oil on canvas, $132.1 \mathrm{~cm}$ x $154.9 \mathrm{~cm}$.

These extraordinary women were praised, while biographical dictionaries began to be published and their names and portraits started to be included in such popular books as Johnson's Ladies New and Polite Pocket Memorandum for 1778 (figure 2). The occasion of their portrait appearing in such an accessible form of print led Elisabeth Montagu to write to Elisabeth Carter stating that Johnson had said "very handsome things, \& it is charming to think how our praises will ride about the World in every bodies pocket" (letter from Elisabeth Montagu to Elisabeth Carter, 24 ${ }^{\text {th }}$ November 1777, qtd. in Eger, 2001: 122). Montagu was conscious of their fame as she continued: "Unless we could all be put into a popular ballad, set to a favourite old English tune, I do not see how we could become more universally celebrated," and she insightfully ascribed it to a general change taking place in the age they were living in: "We might have lived in an age in which we should never have had yet the pleasure of seeing our features, or characters, in Pocket books, Magazines, Museums, litterary (sic) and monthly reviews, Annual Registers, \&c \&c \&c.” (qtd. in Eger, 2001: 122-23). 


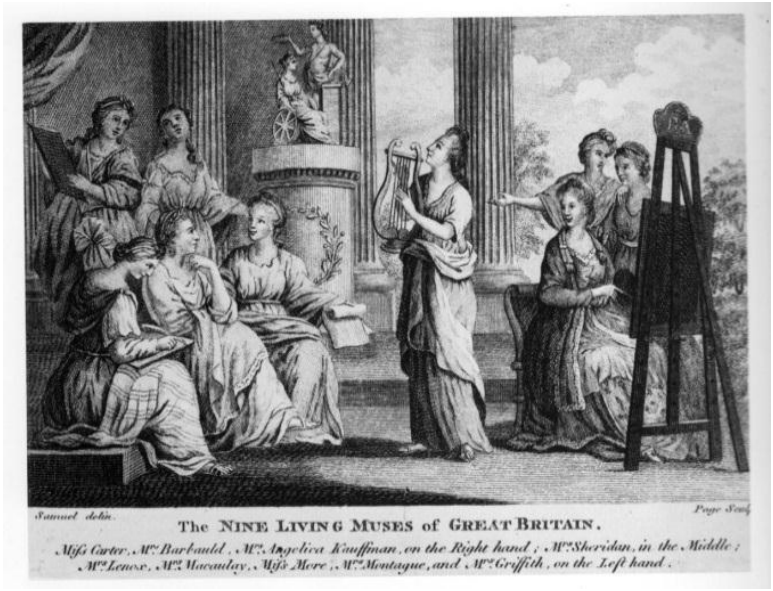

Figure 2. The Nine Living Muses of Great Britain, after Samuel, c. 1777.

Engraving, $12.5 \mathrm{~cm}$ x $10 \mathrm{~cm}$. In Johnson's Ladies New and Polite Pocket

Memorandum for 1778.

From the late seventeenth century, women had definitely started to play a more conspicuous part in British artistic life. Women were visible in several branches of art. Painters such as Angelica Kauffman, favourite with Sir Joshua Reynolds, acclaimed artist and member of the Royal Academy, were successful and respected in their time. Kauffman, together with another thriving artist, Mary Moser, were the only two female founding members of the Academy; despite being still limited in number, they were nevertheless part of one of the most important events in the history of British art. There were also many other painters, miniaturists, and engravers who were contributing to the formation of the new middle-class culture of artistic consumerism. Together with these visual artists, there were also exceptional female musicians who once again contributed to satisfy the increasing middle-classes' appetite for entertainment, especially opera singers such as Elisabeth Linley.

An area in which women developed a fundamental role as producers, enactors and consumers was the theatre. Several female playwrights were highly successful throughout the long eighteenth century. One could name Joanna Baillie or Elisabeth Inchbald, among many others, who were professional and acclaimed writers for the stage, together with many women novelists who would be drawn to write plays to gain immediate success or money, including 
the renowned novelist Frances Burney. What is more, starting with the Restoration and the condoned presence of women on stage, several were the actresses who gained recognition and even admiration despite their exposed profession. Well-known were the names of Mrs Cibber, Charlotte Charke, Mary "Perdita" Robinson, Dorothy Jordan, and, above all, Mrs Siddons. Together with these professional performers, several women writers started their careers as actresses, for instance, Aphra Behn, Eliza Haywood or Elisabeth Inchbald, and even Charlotte Lennox tried a career on the stage before devoting herself to writing. In the same way, many of the actresses also became writers of plays, novels or autobiographies. Although the reputation of the female actor was sometimes said to be compromised by her extremely public display of herself on stage and, more explicitly, by the fact that some of them were acknowledged royal mistresses -as were Robinson or Jordan-, the fact that Mrs Siddons was universally acclaimed and admired, and her talents considered over the possible moral hazard of her profession, prove that, at least in some cases, the muses, especially if tragic and in high performances, were respected as professionals. Finally, the audience itself was in a very high degree female. As Ellen Gardiner has explained, during the Restoration period it became increasingly acceptable for women to attend the theatre, and there they became a "powerful force" in the success or failure of a play (1999: 25). One must credit the playwrights' knowledge of their target audience, so the fact that many of them appeal to women spectators and readers in their prologues and epilogues does illustrate their importance and influence.

Together with these public figures who were granted their fame by means of their professional achievements, at this time one encounters women who became extremely noticeable in the public eye after the publication of their scandalous memoirs. The works of these women granted them visibility though at the very border of respectability, and highlighted the "more negative and unruly forces of the public, whose appetite for gossip was perhaps keener than its desire to effect political change" (Eger et al., 2001: 9). Several women, most famously Constantia Phillips, Laetitita Pilkington, or Lady Vane, exploited that negative side of publicity and wrote their memoirs, in which they claimed their adherence to "“exact Truth', even to the point of revealing all their 'Faults and 
Frailties" (Thompson, 2000: 1), those faults being mainly sexual. Phillips and Pilkington had been exposed by their husbands in court and became producers and products as the story of their lives was consumed by a considerable number of readers which had been attracted by the very public trial. Both felt justified to take the pen in their hands and to tell their own story, in a form of sexually outspoken autobiography which was unknown until that moment. On this matter, Staves asserts that "to publish one's account of one's own life was not the act of a modest woman" (2006: 270) and records the consequences it had for these women writers, as well as the clever and skilful reinterpretation they often did of themselves and their circumstances to manipulate public opinion in their favour. While there was some charge of "gross exaggeration" and of the writers glamorising themselves as the heroines of their own romances (Thompson, 2000: 1-2), they were both praised -by Lady Mary Montagu or John Cleland- and harshly condemned precisely because of their scandalous veracity. These women were very often "one-novel wonders;" their entrance in the public arena came hand in hand with almost unprecedented scandal and with a very skilled play with their role as women of "public Fame" with private sensibilities (Thompson, 2000: 1), which very often transformed them into examples to avoid for later writers.

These women felt and asserted the right to express themselves publicly on the private matters of their sexual and marital lives, but women's opinions were also openly articulated on social, moral and political matters. However true it is that there were restrictions on how women could participate as public figures in the political sphere of their time -as Mary A. Waters phrases it, it is not the same to petition Parliament than to actually serve in it (2004: 14)-, it has been stated that there were still ways in which women could be heard. What is more, some of these voices entered the public sphere with particular boldness and became well-recognised -and, as a consequence, often satirised- public figures. A particular example would be the case of "a Female Moderator," one of the characters sketched and satirised by George Alex Stevens in his $A$ Lecture on Heads (1765), where he comically portrays varied personalities of English society which would be easily identified by the audience he addressed in his humorous lecture. This archetypical woman, identified as a "Moderator" 
or "President of the Ladies' Debating Society" - probably one of the many who appeared between 1770 and $1790-,{ }^{53}$ proves that women were participating in the political debates which were particularly essential at the end of century. At the same time it provides an illuminating instance of the image they projected and the reaction they triggered among the more conservative sector of society (figure 3).

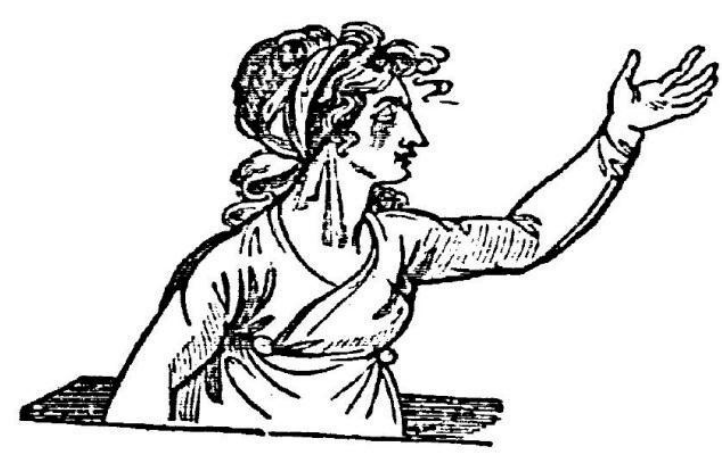

Figure 3. Head of the Female Moderator

Besides the implications of the illustration, with the simple robe and the dishevelled curls and band, which would have been associated in the audience's minds with France, and the classical profile of the woman's face, which could be seen as an added layer of satire against the learned ladies who boasted a classical education, Stevens accompanies it with a very comic explanation of the Moderator's attitude and claims:

[...] she can prove to a demonstration that man is an usurper of dignities and preferments (sic), and that her sex has a just right to participation of both with him: she would have physicians in petticoats, and lawyers with high heads and French curls; then she wou'd have young women of spirit to command our fleets and armies, and old ones to govern the state: -she pathetically laments that women are considered as mere domestic animals, fit only for making puddings, pickling cucumbers, or registering cures for the measles and chincough. If this lady's wishes for reformation should ever be accomplished, we may expect to hear that an admiral's in the histerics (sic), that a general has

${ }^{53}$ Vickery asserts the presence of a large number of ladies' and mixed debating societies which were active in London in the 1770s, 1780s, and 1790s. Building on Donna Andrew's work, Vickery states that there were at least forty eight sets of rooms hired out to mixed or ladies' debating societies in this period. These debating societies were of course affected by Pitt's terror in the 1790s and only those in which non-political topics were debated survived. However, Vickery concludes that "the popularity and scope of debating societies suggests the potential of a public culture both rational and entertaining to which metropolitan women could lay claim" (2001: 21). 
miscarried, and that a prime minister was brought to bed the moment she opened the budget. (1799: 34)

This speech is obviously interesting for its portrayal of female physical incapacity to hold positions of responsibility in society, but it is especially revealing of the awareness women had of their own consideration as domestic citizens and the desire some expressed of having a much more relevant position. However, Stevens is careful to undermine his character's appeal, not only through the obvious comic effect his words carry, but also by opposing this woman's speech to the beliefs of a "woman of sense." Previous to his caricature of the Female Moderator, Stevens addressed his female audience thus:

[...] let not my fair country-women condemn me as an unmannerly satirist; we respect the taste and understanding, as much as we admire the beauty and delicacy of the sex; but surely no woman of sense would suppose we meant to offend her, if we said she was the most improper person in the world to be made a captain of horse, or a member of parliament. (1799: 33)

Hence, Stevens achieves his purpose: women in the audience are bound to agree with his criticism of his fair Moderator, for not doing so would imply not being women "of sense." His President of the Ladies' Debating Society is then obviating her natural unsuitability for the role she claims and working against her own "sense," her own better judgement. Stevens clearly, then, excludes women from the political public sphere on the ground of their very nature and agrees with other contemporary comments, such as the one which appeared in The Times in 1788 claiming that "the debating ladies would be much better employed at their needle and their thread, a good sempstress (sic) being a more amiable character than a female orator" (emphasis added, qtd. in Vickery, 2001: 21), once again associating their conspicuousness with the loss of some of their female qualities, such as their "amiability" or Stevens' "delicacy."

This caricature had many resemblances with actual female figures who equally boldly abandoned the needle and thread, and sought to contribute to the intellectual panorama of their age, proving that female aims at improvement and reform were not at war with their definition as "women of sense." Even if 
not able to become lawyers or Prime Ministers, these women found groundbreaking ways to open new fields for female agency. Among these, we could highlight the examples of Catherine Macaulay, Elisabeth Montagu, Hannah More and Mary Wollstonecraft. While unacknowledged until recently, the contribution of women to the field of history was significant, with the respected historian Catherine Macaulay publishing her outstanding and critically successful eight-volume History of England from the Accession of James I to the Elevation of the House of Hanover (1763-83), contributing to the political public debate with her views on republicanism, and becoming the most recognizable of a series of women who at this time engaged in the discussion of history. ${ }^{54}$ Montagu and the Bluestocking circle were well-known for their intellectual gatherings and their encouragement of female improvement and education. As Cheryl Turner has highlighted, "the Bluestockings provided perhaps the most influential social, intellectual and literary network to include a cluster of women writers" (1994: 107), with all of their members, such as Hannah More, Hester Chapone, Elisabeth Carter, or Montagu herself, rising to become public figures in their own right, as patrons of art, authors of fiction and even social reformers. If the coffee-houses belonged to men or to excessively visible and public women, then the salons, household coteries or epistolary and social networks, as later the printed media, were by right the Blustockings' own public fora for discussion. ${ }^{55}$

The best evidence of the participation of women in the political and literary public debate and in the moulding of aesthetic consciousness, however, would come at the end of the century, more specifically in the 1790 s, when in the

54 See Devoney Looser's British Women Writers and the Writing of History (Baltimore and London: The Johns Hopkins University Press, 2000) for a reassessment of women's engagement in the creation of a historical discourse. For a succinct comment on Macaulay's History of England, see Staves (2006), pp. 321-330. The chapter entitled "Catharine Macaulay: history, republicanism and the public sphere" by Susan Wiseman, in Women, Writing and the Public Sphere (2001), pp.181-99, is a useful basis for further discussion on Macaulay's contribution to public debate.

55 See Markman Ellis's "Coffee-women, The Spectator and the public sphere in the early eighteenth century." Women, Writing and the Public Sphere (2001), pp. 27-52. For the relevance of the Bluestocking circle see Gary Kelly's "Bluestocking feminism." Women, Writing and the Public Sphere (2001), pp. 163-80, as well as Bluestocking Feminism: Writings of the Bluestocking Circle, 1738-1785 (London: Pickering \& Chatto, 1999), in which different critics trace the wide range of their influence through salons, coteries, epistolary networks, literary patronage and social philanthropy, to the early decades of the 19th century. For a comment on the main works of the members of the circle, see Staves (2006), pp. 286-330. 
writings of Wollstonecraft, More or Wakefield, "a common enquiry into the conditions for female improvement is linked to a wider political debate concerning the nature and membership of the state, patriotism, and social ethics" (Sutherland, 2000: 37). This debate on and reassessment of women's role in society could be said to be personified by two women: Mary Wollstonecraft and Hannah More. Taken separately, they contributed to their age's discussion of its most pressing issues from what has been defined as their "radical" and "conservative" approach (Todd, 1989: 2) or their "Egalitarian" and "Matriarchal" points of view (Bannet, 2000: 5), respectively, and have become the symbols for later criticism of the complex attitude towards the role of women in the public sphere. Mary Wollstonecraft's early works dealt with the matter of education and the need for a reform in women's system of learning. As a writer, she published a tract on female education, Thoughts on the Education of Daughters (1787), a book of short moral tales for children's improvement, Original Stories from Real Life (originally published in 1788, and reissued in 1791 with plates by Blake), and a moral novel, Mary: A fiction (1788), which offered some insights into female education and the dangers of excessive sensibility. It is obvious then that she thought that women could not only participate in the debates on education that were especially important at an age of increased demand for education among the rising classes, but also that her works, even if written by a woman, could be particularly influential over her readers. However, her early educational aims were somehow overshadowed by her most famous and active engagement in the debate which followed the revolution in France and the publication of Edmund Burke's Reflections on the Revolution in France (1790). Making use of the public arena and the print media, as did her male counterpart Thomas Paine, Wollstonecraft responded to Burke with the publication of her two most openly political works: A Vindication of the Rights of Men, A Vindication of the Rights of Women $(1790,1792)$. The latter resumed the debate on female education, once again connecting politics and "women issues," and expressed a warm defence of women's intellectual capacities and their need to "identify reason as their prime characteristic and to use it to reject their commercially constructed roles as dependent "cyphers"” (Sutherland, 2000: 43). Her famous critique to the excessive sensibility taught to women, her defence of the equality of the sexes, 
and her controversial view on marriage were the most contended issues and provoked an innumerable number of parodies, satires, and direct answers, granting her the honour of being one of the unsexed females of Richard Polwhele's famous poem of the same title, published in 1798, which satirised radical women philosophers and writers. Many of these parodies would find expression in quixotic fictions, as will be subsequently stated. Together with other women writers, Macaulay or Barbauld, for instance, she became part of an identifiable female political voice which was gained at the end of the century and which articulated "claims to political identity" (Guest, 2000b: $17) .{ }^{56}$

On her part, Hannah More was even more prolific and active in her aim for reformation, leading Anne Mellor to consider her "the most influential woman living in England in the Romantic era" due to the fact that with "her writings, political actions, and personal relationships, she promoted a successful program for social change from within the existing social and political order" (2000: 13-4); hers was perceived as a search for reform rather than revolution or subversion, as Wollstonecraft's views were termed at the time. More's programme for female education was described in her popular Strictures on the Modern System of Female Education (1799), in which she developed the idea of a virtuous and excellent woman, seeking a revolution of manners which revolved around the domestic dominance of women and their moral duties towards the community. More herself was at the centre of some heated debates: her programme to teach the lower classes to read by means of her popular -and profitable- Cheap Repository Tracts was pioneering and created great controversy on the dangers which were implied in improving the working classes' education. Besides her educational programmes, More was a very active social reformer, a member of the Evangelical movement which claimed

${ }^{56}$ Together with Mary Robinson or Charlotte Smith, Barbauld was a very prolific political writer; not only did she publish "Epistle to William Wilberforce" on the evils of the Slave Trade, but she also published three very forceful political orations. For Curran, she epitomises the stance of the woman writer in the 1790s (1993: 189). Applied to these writers, Guest uses the phrase "feminist political voice," clearly with the connotations brought by twentieth century criticism. However, I have preferred not to use this term as it was never employed by these women, and it would be even difficult to contend that, had it been in use, they would have applied it to their writings as, in general, they do not seem to have a particular consciousness of contributing to advance women's rights or of wanting to be identified with a particular female movement rather than to one of general improvement. 
the need for a moral reformation of the upper classes, and a champion of the abolitionist movement, hence exerting a considerable influence on many of the most important areas of debate in the eighteenth century. ${ }^{57}$

More relevantly, despite their differences, Wollstonecraft and More contended the essential role of women and the family as the core of all political change. Similarly to More, for instance, Wollstonecraft restated the Enlightened view of "the family as the unit of the social and moral reproduction of society" (Tomaselli, 2001: 241) and as the "cradle and bastion of a virtuous, heroic and patriotic people" (2001: 254). They both saw, moreover, the condition of woman as the "true and only starting point of social and political change" (Bannet, 2000; Tomaselli, 2001: 241). As Eva Bannet has stated, both positions or groups of women critics "sought, in their different ways, to raise women from their inferior standing relative to men in the household, in cultural representations and in prescriptive social norms, and to refashion women's manners, women's morals, and women's education to these ends" (2000: 7). By so doing, they contributed to the development of the abovementioned new conceptions of the political citizen and of the complex notion of domesticity. From this view of what domesticity meant, women had the "right to be dutiful" and to be allowed to fulfil their duties as "mothers, wives, physicians, nurses, midwives and citizens" similarly to men (Tomaselli, 2001: 248). Among these duties was the sacred one of becoming effective educators, of raising "good citizens." However, as Tomaselli has asserted, "while women could indeed teach men to be great and virtuous, they needed the means to do so" (2001: 254). In a similar view to that of More, Wollstonecraft claimed the need of women to be educated both intellectual and morally so as to be able to

57 Mellor summarizes the impact of her career in five points: "(1) Her writings contributed to the prevention of a French-style, violent revolution in England. (2) They did so by helping to reform, rather than subvert, the existing social order. (3) This reform was fourpronged: it was directed simultaneously at the behavior of the aristocracy, $[\ldots]$ the clergy, $[\ldots]$ the working classes, and at the education and behavior of women across the classes. (4) In an era of greatly expanding imperialism and consumption, she moralized both capitalism and consumption. (5) So profound were these social changes that one can plausibly say that Hannah More's writing consolidated and disseminated a revolution, not in the overt structure of public government, but, equally important, in the very culture or mores of the English nation" (2000: 13-4). The best essay on the importance of More in British culture, and, in particular, of the reactionary and even revolutionary effect of her tracts, has been penned by Mitzi Myers in "Hannah More's Tracts for the Times: Social Fiction and Female Ideology." Fetter'd or Free? British Women Novelists, 1670-1815 (1986), pp. 264-84. 
transform society from their privileged position at the cornerstone of the nation: the household. Nevertheless, despite the common grounds they shared, their positions diverged on the terms in which this transformation should be achieved, and thus exemplified the ambiguous reading of the role of women in the Enlightened discourse of improvement. In this discourse, when it came to the education of female citizens, there existed a "tension between the enlightened commitment to equality, and a discourse of difference and hierarchy; between a progressivist belief in access to education and literature, and a tendency to restrict the terms on which such access might be enjoyed" (Jones, 2000: 5), a conflict especially relevant for the study of narrative fiction written by women in the late-eighteenth century and, more specifically, in that which presents examples of female quixotism. ${ }^{58}$

With regard to their influence on literature, these two women, and, more importantly, the sometimes alike, sometimes conflicting views they embodied on the education and role of women, were in constant dialogue throughout the last decades of the century and determined much of the non-fiction and fiction written at that time. As private individuals, they were openly negotiating "women issues" which became tense, public discussions and hence, by definition, constituted the core of Habermas's model of the public sphere (Backsheider, 2000: $\mathrm{x}$ ). Together with other writers, then, they constructed a body of criticism which was in perpetual development through their exchange of opinions in the printed media -including novels, tracts or even newspapers, with the publication of The Female Spectator or The Lady's Museum, written and edited by Eliza Haywood and Charlotte Lennox, respectively. In this way,

${ }^{58}$ These divergent points of view are evident in other authors. On these differences, Guest states "[they] differ in the notion of femininity: for the latter, women should aspire to be like the professional man; for the former, they should aspire to the ideal of "republican motherhood', a way of uniting public and private responsibilities for women" (2000a: 65). For a thorough analysis of the differences concerning female education and women's rights among Wollstonecraft, Macauley, West, More or Edgeworth, see chapter four, "Women, education and the novel" in Alan Richardson's Literature, Education and Romanticism (Cambridge: Cambridge University Press, 1994), and particularly pp. 167-187. These complex approaches to women's rights and education will be essential to understand the stances of such writers as Edgeworth, Hays or Hamilton when they develop their quixotic narratives and the condoning or condemnation of their characters. For a revealing study of the similarities and contrasts in the ideas exposed by More, Wollstonecraft, Barbauld or Hays related to topics such as women's corruptibility or their need for professionalization, see the chapter entitled "The Dreams of a Common Language: The Strictures on Femininity of Hannah More and Mary Wollstonecraft" in Guest (2000b). See also Richardson (1994), pp. 179-81. 
they created a rich ideological net which relied on its intertextuality with other women's works. These women were, therefore, not isolated or newborn, but already part of the culture (Todd, 1989: 9) and of a tradition of women philosophers and reformers which descended from Mary Astell's, among others, renowned philosophical, educational and, hence, political writings.

Many of these philosophical, moral or educational tracts addressed the issue of what were considered good or bad readings, as will later become especially explicit in the discussion on women readers. Although very often the aesthetic criteria would be circumscribed to what were considered proper or improper readings for lower classes or women, always seen as the most gullible of readers, many women also discerningly dissected well-known genres or particular novels. From this fact one must derive that, despite the modest claims of some of these writers that they did not possess a critical capacity, they did in fact consider themselves capable not only of assessing the merits of a particular work, but of even being prescriptive when it came to suggesting readings to their audience. In this regard, at this time one witnesses the rise of another relevant female figure that was to shape public opinion: the literary critic. Once again fallen into oblivion in the history of literature, several works have deservedly claimed the place that critics such as Joanna Baillie, Anna Laetitia Barbauld, Mary Hays, Elisabeth Inchbald, Charlotte Lennox, Clara Reeve, or Mary Wollstonecraft should have in the study of literary criticism. These women were not accidental critics, but, as Mary Waters has argued, they "saw themselves as professionals and as authorities on a crucial topic, the nation's literature" (2004: 2). They did not choose minor topics either: Lennox and Inchbald published thorough works on Shakespeare, for which they received an ample and equal share of criticism and praise; Reeve wrote the seminal The Progress of Romance (1785); and Barbauld undertook the significant The British Novelists (1810). The latter two writers were especially relevant in the construction of a literary canon which emphasised the relevant moral and political role of fiction. As Price has expounded, both Reeve and Barbauld were aware that "the construction of tradition had profound political and social consequences for the health of the nation" (2009: 15) and, hence, by "rewriting British literary tradition to include narrative fiction, Barbaud and 
Reeve consider that prose fiction and its reading public are crucial to a socially beneficial cultivation of taste" (2009: 17). What is more, by "positioning the novel as hegemonic, their work sheds light on the development of the form as an essential vehicle for aesthetic and political discussion in the 1790s" (2009: 17). In so doing, both critics, together with their abovementioned colleagues, not only entered into a critical dialogue with male critics of the time and "helped redefine aesthetic values often with women and middle-class readers in mind" (Waters, 2004: 23), ${ }^{59}$ but also aimed at creating a coherent programme of production and consumption of literature (Mellor, 2000: 88) in which they extended the literary canon while exerting their opportunities for professionalism and public authority (Waters, 2004: 23). Equally relevant, in the process they raised the novel to its privileged position in the aesthetic, moral and political discussions of the age.

Of course, this shaping of the canon and of the production and consumption of literature by women was not only achieved from an external position but was most effectively developed from within literature as writers of poetry, drama, treatises, tales and novels. It is women's role in the construction of the literary panorama of the age that is crucial to understand the relationship between women and fiction, women and the novel, women and reading, which will be at the core of female quixotism in the long eighteenth century and its conception

\footnotetext{
${ }^{59}$ According to Mellor, "[...] the leading women literary critics of the Romantic era Joanna Baillie, Anna Barbauld, Elisabeth Inchbald, Clara Reeve, Anna Seward, and Mary Wollstonecraft- upheld and aesthetic theory different from but as coherent as those developed by Coleridge, William Wordsworth, Hazlitt, Keats, Percy Shelley, and their male peers. At the same time, as literary critics, they asserted a claim to a powerful cultural authority [...]" (2000: 85). This "alternative aesthetic theory developed by women writers in the Romantic era existed in the discursive public sphere, in powerful dialogue with the competing versions of this 'expressive' or organic Romantic poetics [...] In place of the mirror and the lamp, we might think of Romantic-era women literary critics as sustaining [...] the trope of literature as a balance or scale that weights equally the demands of the head and the heart, of reason and emotion. In their writings this balance or scale is always held [...] by a woman" (2000: 86). For Reeve's dialogue with male critics such as Hurd or Beattie, and Barbauld's similarities and differences with Burke or Coleridge, see Price, 2009: 17-40. In addition, Reeve and Barbauld reassessed the role of women writers in the tradition of narrative fiction; the former with her praise of romance, and the latter with her recognition of women in the history of the novel in her An Essay on the Origin and Progress of Novel-Writing and Prefaces Biographical and Critical, from the British Novelists (1810). For an analysis of Barbauld's contribution to insert women in literary history see Catherine E. Moore's "'Ladies... Taking the Pen in Hand'. Mrs. Barbauld's Criticism of Eighteenth-Century Women Novelists." Fetter'd or Free? (1986), pp. 383-97.
} 
QUIXOTIC READERS AND QUIXOTIC WRITERS

of the quixote as a fervent female consumer of fiction, and, more importantly, fiction written by women. 
2. Women and the Novel: the Problems of Gender, GenRe and the NATION

Returning once again to the reflection by Spender that opened this chapter, the concepts of gender and genre have been inextricably intertwined in the history of the novel, and women writers and readers have become essential to understand the new forms of fiction being developed in the long eighteenth century. Much of the critical discussion on eighteenth-century women writers has focused on the need to reassess the role of women writers in the development of narrative fiction, whether by constructing a parallel history of the rise of the novel and building a family tree of women novelists (Donovan, 1991; Spender, 1986); by asserting the role of romance as a space of agency as opposed to the masculine site of the novel (Doody, 1996b; Langbauer, 1990; Spencer, 1986); by searching for common symbols and constructions women writers used to identify themselves as creative agents (Todd, 1989) and through which they gained cultural ascendency even amidst the predication of domesticity (Armstrong, 1987); by attributing their disappearance from literary history to a revolution of manners, exploring the ways in which female authors employed self-effacement and nothingness to make a stance on their situation as women and writers (Gallagher, 1995; Poovey, 1984); or by claiming the need for a more integrated history of the novel, including both romance and realistic prose, both male and female authors (Ross, 1991; Spacks, 1990; Tompkins, 1976). In this ample body of criticism, too numerous to retell, the discussion on the cultural construction of women -who and what they were, what made them women from a natural and cultural point of view, what their role in society would be- run parallel to that of genre -what romance and this new species of writing later called the novel were and if they could be distinguished from one another-, and collided as both debates came into contact and raised several questions: did a female way of writing exist? Was there a specific genre that belonged to a particular gender? Could the concepts of gender and genre be so clearly delimited? 
What woman was would be explored throughout the eighteenth century, paying attention to the biological and cultural elements that built the notion of gender, ranging from Pope's image of the self-gratifying woman, for instance, to the Age of Sensibility's self-effacing heroine (Ellis, 1996). What is more, as the century advanced and the culture of sensibility permeated all spheres of society, what critics have termed the "gendered transformation of manners" (Ellis, 1996: 27), and with it the cultural construction of the sentimental woman became more conspicuously acknowledged and, as a consequence, also challenged or supported in both fiction and non-fiction. In a similar way, what romance or the novel were would be redefined throughout the long eighteenth century. Both terms would be used indistinctively for most of the century, with even Walter Scott defining his works as "modern romances." Nevertheless, the novel started to be conceptualised and definitions from well-read authors such as William Congreve or Clara Reeve became of common knowledge. ${ }^{60}$ What was meant by romance and novel changed in very much the same way the idea of woman did. In this context, female authors would reflect on their nature and role as women and writers. They would reflect at the same time on genre and how narrative fiction was being rewritten and newly categorised, as well as on the ways in which gender had been used as a factor for that rewriting and for the subsequent development of new genres such as the epistolary novel, the sentimental novel or the novel of manners.

Together with the matter of gender, throughout the eighteenth century another issue came to signify an element of transformation in the history of narrative fiction: the concept of nation. It was at this time when the idea of what a nation is, in the modern sense of the word, was being moulded, and, therefore, the need to establish a national identity seemed crucial. This essential need to define what was British and what was foreign also found its echo in literature. If it seemed necessary to distinguish between a male and a female way of writing, as events in France mounted to the Revolution of 1789 and its aftermath of war and hostility towards Britain, it also became increasingly important to establish differences between the nations at both sides of the

\footnotetext{
${ }^{60}$ The best book on contemporary discussions on the concepts of romance and novel probably remains Ioan Williams's Novel and Romance, 1700-1800. A Documentary Record (London: Routledge, 1970).
} 
Channel and for the fiction written in Britain to reflect the core of British values and beliefs. Women writers, as has been previously stated, were not oblivious to the political atmosphere of their time and participated in the debate by means of fiction and non-fiction written in prose. Female authors would either reinforce or subvert the traditional notions of what being British meant, and, more relevantly, what a female British citizen should be. This last construction was especially relevant at the end of the century, as the image of the domestic woman was transformed into the epitome of the British nation and her role described in and reinforced by narrative fiction, whether from an Egalitarian or Matriarchal, radical or conservative stance and from one particular genre or another. Once again, the rewriting of the nation and of the cultural construction of women would present itself inextricably linked to the debate on genre.

In this regard, if the novel is to be understood in the Bakhtinian terms of dialogue and evolution, women writers have then played an essential role in that continuum from which what, in retrospective, scholars have identified as the idiosyncratic English eighteenth-century novel is but a part, albeit a fundamental one. As Jenny Batchelor has asserted, the history of the novel, constantly under revision, has benefited and will still profit from "undergoing a dynamic representation through the inclusion of women writers, not merely as subordinate figures to an all-male pantheon, but as key creators of the genre, their contributions not confined to critique or to modifications of sexual politics" (2005: 11).

More relevantly for this study, their role as producers and consumers, as writers and readers, as moulders of political thought or cultural and literary taste, and the paradoxes intrinsic to their condition as female authors and to the existence of genres considered particularly feminine, have their echo in the female quixotism portrayed in many of their productions. Therefore, the present chapter will wander through the history of narrative fiction in the long eighteenth century, circumscribing the discussion to those aspects relevant to understand how women writers and readers contributed to shape the fiction produced at this time, whether considered romance or something completely 
new, in order to lay the foundation for our subsequent consideration of female quixotism and its aim in the particular novels object of our research.

\subsection{The Debate on Women Writers and Readers}

If one were to trust the contemporary accounts issued by literary critics or stern moralists on the number of women writers and, particularly, women novelists and their influence on both the market and society as a whole, the resulting picture would indeed amaze by its portrayal of women as almost the sole determining force behind the change narrative fiction and taste in general experienced in the eighteenth-century.

The first accusation against women novelists was related to their overflowing numbers: male critics and novelists, and also some female ones, complained about the incessant appearance of female authors who overcrowded an already highly competitive market in which, as several critics have sated, publishers could pay little, reprint at leisure and have no respect for such thing as authors' rights. ${ }^{61}$ These conditions, equal for both male and female authors, increased the competition and the criticism against the escalating fashion of novel writing. However, most of that criticism seemed indeed directed against women novelists and the fact that they had apparently taken over the market. As Turner (1994) or Raven (2007) have claimed, this accusation lacked solid foundations, for it was on all probability based more on general perceptions than actual data. The statistics developed by these authors evince that figures could be interpreted from two approaches: from a comparative approach to the number of male authors and the amount of publications by them, which would prove that women novelists were not above them in either variable, or from a

${ }^{61}$ In this respect, Cheryl Turner's excellent study on eighteenth century women writers is an example of accuracy and balance in her assessment of the difficulties of female authors in the more general context of aiming to publish novels at this age disregarding the author's gender. On the very often problematic relationship with the publishing houses, see, for instance chapter five "Women novelists and their publishers." Another essential work would be Margaret J.M. Ezell's Social Authorship and the Advent of Print (Baltimore, Maryland: The Johns Hopkins University Press, 1999), in which she studies the development of literary industry and authorship in early modern Britain, providing information of the multiple forms of textual production and the diverse literary careers that authors, including female ones, might follow. A succinct analysis is also provided by Paula McDowell in "Women and the business of print" in Jones (2000), pp. 135-54. 
comparison in the ratio at which numbers of authors from one or either gender increased throughout the century. Despite the fact that there was a common pattern of rise (1725), fall (1740) and spectacular rise in the late 1700s (1780s onwards), statistics tend to show a slightly higher rate of female authors as the century advanced, becoming especially conspicuous in the last decade (Raven, 2007: 104, 109, 116), although nothing so significant as to justify the abovementioned claims. ${ }^{62}$ Therefore, despite the attack on the number of women novelists, the reason for the alarmed reaction to an increase in the number of women writers must lay elsewhere. In Jones' words, the "increased number of publications by women are part of a more general explosion in the market for printed texts, but it is women's writing that is repeatedly singled out for comment: a reaction which raises questions not just about literacy levels, but about what literacy, and literariness, meant" (2000: 4); this literariness, the ability to read and write, then becomes a measure of progress and status and "carries the potential to transcend boundaries" (2000: 4).

Once again, the source of anxiety would then be found in that "cry of the embattled status quo" identified by Vickery and which feared the consequences of women taking over the shaping of the nation and its culture. As has been avowed, changes in medicine, in politics, in cultural constructions, were more conspicuously perceived in the female sphere. The same could be said of literature and the novel market: if women writers and readers established a consolidated dual relationship as producers and consumers they would unbalance gender and cultural power. Moreover, if women writers continued to be critically acclaimed and popularly successful and earned as much as men for their writing, the threat to an oversaturated market was even more poignant (Schellenberg, 2009: 17). Furthermore, the increase in the number of women readers was perceived as a reinforcement of the influence of female authors over the market and, hence, over cultural constructions. As Jones has asserted, "the question of women and literature is a question of power. The proliferation of women's writing challenges the gendered control of knowledge, and in

${ }^{62}$ Many novels were published anonymously with the tag of "by a Lady." Raven doubts the reliability of it and states it cannot be taken at face value to assert the number of women novelists publishing at the time, especially as male authors employed this title-page identity as well, while women writers also published under a male pseudonym (2007: 109). 
doing so it raises questions of sexual difference which go to the very heart of social and cultural identities" (2000: 8). More specifically, in Doody's words, there was a feminization of the novel which also needs to be read in terms of power and control, for by identifying the novel with a primarily female authorship and audience, critics aimed to "limit any damage they may do" because "women [...] are theoretically disabled from bringing concepts into social currency" (1996b: 278). When this proved wrong by the increasing influence women and the novel had on British society, the discourse had to change and find new causes for anxiety.

One of these causes for anxiety was the enhancement in literacy among women, the increase in the number of women readers, which led moralists to express some concern on the susceptibility of what they perceived as the greater mass of the reading public. Despite the general increase in the rate of literacy among both men and women of the lower or middle classes, the rise of women writers and readers from these strata united the two sectors of population which were conceived not only as the wider mass that could transform the taste of a whole nation, but also as the more "susceptible readers," easily deceived by what they read (Grenby, 2001: 13). This welldocumented idea that women readers were not only the more numerous and influential, but also the more gullible among the reading public, allowed critics and moralists to incessantly lecture on the need to regulate and educate these women readers and, hence, to particularly mould the type of fiction that they were to peruse. Therefore, from the need to preserve the minds of the readers derives the moral validity of aiming to prescribe how and by whom fiction was being written.

The claims for the education of women readers, their acknowledged susceptibility, delicacy and lack of instruction in critical literacy, had an enormous impact on the changes that female novelists experienced, both in their consideration as women and as professionals, as well as on the generic transformations undertaken at this time in history. What is more, as cultural and political changes took place, women writers actively engaged in the pressing debates of their age and reflected them in their works, not developing an alternative genealogy of fiction, but becoming part of the general history of 
narrative fiction. ${ }^{63}$ Equally relevant, female authors displayed an extraordinary ability to adapt to the demands of the market and to please their readers' evolving sensibilities, and their desire for either entertainment or instruction, or both. In order to do so, they incorporated foreign and national, male and female influences into their own fiction, together with the pressing demands triggered by the readers' response to it.

\subsection{Women Writers, Romance and the Transnational Novel}

Although early twentieth-century accounts of the development of the novel followed in the steps of eighteenth and nineteenth-century male critics and aimed to offer a teleological and national explanation for the rise of it at a particular time and place, as was the England of the eighteenth century, recent studies have proved that, if one were to accept the Wattian thesis of the appearance of a new genre, it would have to be that of the transnational novel, a genre that was shaped by the unfailing literary and cultural contact between countries such as Spain, Italy, Germany, and, more relevantly, Britain and France. That is, narrative fiction in Early Modern Europe could only be shaped and transformed into what later would be known as the novel by means of “crossing boundaries" (Mander, 2007: 1). This idea of a transnational genre, well documented and established, challenges the view of the birth of the English novel as an isolated event. Instead, it favours a historical explanation which covers the shared history of Europe at this time, with such influential events on the whole of the Continent as the French Revolution, as well as an evolutionary approach to the transformation of a common genre to all countries, the romance, in each and every one of those territories. Rather than placing the conception of the new genre in a particular national and temporal context, or discussing which was the first example of this new species of writing, whether it was Defoe's Robinson Crusoe or Richardson's Pamela, the

${ }^{63}$ In this sense, Batchelor rejects female genealogies of the novel and rather sees the inclusion of women writers in the recasting of the history of the novel as not only offering "a more central place to women novelists as innovators of the form" but as also complicating "both men's and women's engagement with sexual and national politics and with the political philosophies that informed them" (2005: 11), hence enriching the history of the development of prose fiction rather than circumscribing women to a separate one. 
idea of a transnational genre allows to distinguish a greater picture that explains how Heliodorus's or Cervantes' main works became shared influences to French or British authors, or how those later authors themselves became part of a literary network that would nurture the transformations in narrative fiction throughout the century. During the seventeenth century, and with special emphasis after the Restoration and the King's return from France, the literary connections between the countries at both sides of the English Channel moulded the narrative fiction that would influence the whole of Europe. Moreover, without that inter-national connection, the epitomes of what has been considered the English novel, Pamela or Tom Jones, would have never been what they finally became.

However, before a claim to a national novel took place on either side of the Channel, French and British authors acknowledged the two-directional influence and, particularly before the mid-eighteenth century, foreign literary authority was not only openly avowed but praised on the English side. French novellas or heroic romances were consumed in seventeenth-century Britain in their original language or in translation; throughout the long eighteenth century many of these foreign works of fiction were reissued and became part of private and public collections. Their reception was immensely significant if one takes into account the reproductive and productive works which appropriated foreign narrative fiction. It has been made particularly obvious in the case of Cervantes; however, his case, even if maybe the most significant, is not the only one. Most of the foreign authors with a traceable influence in Britain were French, and the number of translations from that language in particular was noteworthy. ${ }^{64}$ Nevertheless, more relevant is the nature of those translations as a source for original creation. As Mary Helen McMurran has brilliantly asserted, translators were also very often novelists who left their own personal imprint on their reproduction in English of the original work or even used translated parts of the foreign work in their own production, some without explicitly crediting the source. For this critic, then, "prose fiction translation was not only a practice of converting French to English, or vice versa, but also

\footnotetext{
${ }^{64}$ See Raven (2007: 120-25) for illustrative tables with the number of translations from French into English between 1750 and 1830, and its comparison to the figures of the novels translated from German in the same period.
} 
a cultural and literary dynamic predicated on translatio" (2002: 51), understanding this last concept in the classical sense both of translatio imperii -the transfer of power from one empire to another- and translatio studii -the transfer of culture through translation, imitation, and adaptation (2002: 51) and hence undermining the idea of a national or monocultural novel, a concept that would clash with the dialogic nature of the new genre.

Besides translation, the productive reception of the French narrative fiction is amply documented both by contemporary critics and by later ones. This dialogism between different literary and cultural sources is present in those works included in the previous chapter, for example; Fielding, as has been asserted, was influenced by Cervantes and Scarron in the creation of his new found narrative style, while Smollett's debt to the former and Le Sage is also evident. Nevertheless, maybe where the French literary influence was more obvious -or at least where later authors claimed it was- was in the work of the triumvirate of female authors that dominated much of the literary scene from the 1660s to the 1720s: Aphra Behn, Mary Delarivière Manley and Eliza Haywood. As Ballaster has pointed out, the precursors of these British authors' amatory or gallant fiction were primarily "French and female" (1992b: 41), French being a language often taught as part of a young girl's education and one that these writers were fluent in. All three were able to contribute to the "flood of translations from the French on the market" (1992b: 41), sometimes adapting the elements and taste to the new audience, sometimes exaggerating certain traits to highlight its French source, hence evidencing their knowledge of the cultural constructions at play, their control to create them and their capacity to satisfy the reading public's demands. Moreover, besides a mere reproductive reception, these authors extensively contributed to the productive appropriation of French fiction.

These influential French amatory fictions adopted mainly four distinct narrative forms: the romance, the petite histoire or nouvelle, the chronique scandaleuse, and the epistolary or letter novel. At this time, however, most references to the romance, associating it with heroism, fantasy, love, and above all, female consumption, point exclusively to the heroic form (Ballaster, 1992b: 42). French heroic romances were indeed extremely popular. Some of these 
well-known romances, amply read in eighteenth-century Britain, were Madame de Scudéry's Clelia, an excellent new Romance (1678), or her Artamenes; or, the Grand Cirus. That Excellent Romance (1690-91), as well as those by Gauthier de Costes de La Calprenède, Cassandra: the fam'd Romance (1652), Hymen's Praeludia or Love's Master-peice. Being That so much admired Romance, intituled Cleopatra (1674) or Pharamond: or, the History of France. A fam'd Romance (1677). These romances usually told the story of heroes and heroines of noble origin said to be taken from the annals of history, who were perfect in every possible way: they were beautiful, intelligent, brave, strong, pure, and honest. They had an incredible resistance to hunger and exhaustion; they never suffered from cold, were never dirty or untidy, and could express themselves with the most elaborated and calm speeches even in the moments of greater distress. They were people of great sentiment; all their emotions were taken to the extreme: they would cry in despair, faint, be lovelorn without limit or reason. To love and be loved gave meaning to their existence, and most plots involved a difficult and long period of courtship in which the lovers were separated once and again by all series of circumstances. Most often, the protagonists were young heroines, many of whom give name to the novel. These heroines fell in love with the worthy hero, but they could never marry immediately because they were separated by cruel pretenders to her hand, by wars to which the hero was called, by the seeming lowly origin of one of the lovers, and by many other random events. Ever and anon it was even the belle's choice to send her lover away in order to prove himself worthy of her hand. It was an instance of courtly love, in which the lady was the object of devoted adoration from the hero, who had to go to great lengths to win her for himself. She was in the position of power in the relationship, as she commanded over the beaux and decided when this long courtship would come to an end.

With a heroine at its core and its emphasis on the particularly feminine plot of courtship, the heroic romance came to be associated with a female epistemology or experience. As Ballaster has asserted,

The two dominant conventions of the French romance, namely bienséance (decorum) and vraisemblance (truth to nature) were closely identified with a form of social practice and epistemological understanding that were assumed 
to be 'feminine'. [...] [the] vital links that the heroic romance established between a gender (femininity) and a genre (the romance) which in the mideighteenth century in Britain was to be turned so effectively against the woman writer, [...] in the late seventeenth and early eighteenth century provided an aesthetic basis on which Behn, Manley, and Haywood were to enter the prose fiction market. (1992b: 43)

Although not based on exact equivalences, the connection between French romances and the work of these early women writers can be said to lie in their association "with peculiarly 'feminine' modes of literary production and consumption" (1992b: 43) that would be subsequently amply criticised by means of the figure of the deluded female romance reader.

Together with theses heroic romances, French authors were also popular for their petite histoire, histoire galante or nouvelle. These were also love fictions, though rather representing female desire than female heroism (Ballaster, 1992b: 49). These gallant narratives differed from the romance both in plot and form. On the one hand, they were still concerned with the lives of aristocrats, but they now focused on more amoral and illicit love stories, hence "the heroic romance's depiction of ideal and rational love was replaced by a vision of the rapacious and destructive power of sexual passion" (1992b: 52). As for its claim to verisimilitude, the nouvelle renounced to the conventions of the romance, "adhering instead to spurious claims to historicity and claiming the status of pure historical 'fact', where the romance had called attention to its own skill in 'feigning"' (1992b: 52). Therefore, despite the fact that the nouvelle remains a feminocentric form of fiction, in many ways it did reverse the conventions of romance:

The feminocentric world of love remains the structural centre and motivating force of history, but the female libido substitutes the desireless heroinism of the romance as the dynamic force in historical process. [...] femininity comes to be aligned with nature, as opposed to culture. Death, ruin, and renunciation become the limited options of the romantic heroine, as opposed to the fantasy of unlimited power that the romance had extended. (Ballaster, 1992b: 56)

Another form of gallant fiction which was highly successful and which shared the abandonment of the desireless heroinism of romance was the chronique scandaleuse or the roman à clef, exceedingly eroticised narratives which 
revolved around a romantic plot, and works of fiction in which the events or characters were inspired by real ones, which the audience was eager to discover. Differently to the nouvelle, this genre played with the alleged truthfulness of its storyline, giving new emphasis to the abovementioned lack of decorum in its plots. Finally, the love-letters, with their "epistemological play between fact and fiction" develop their ambiguity to unknown heights and, even if their fictional nature is obvious, they would become the "trope of absolute sincerity" (1992b: 60-1). The difference in form then leads to the same emphasis on the seeming veracity of what is being told. All these forms of gallant narrative fiction were highly popular at the time; and, what is more important, they all displayed “a 'feminocentric' frame: they simultaneously address and construct an explicitly 'feminine' or 'feminized' realm” (1992b: 42).

Behn, Manley or Haywood chose to write fiction which drew directly from the aforementioned forms of Continental fiction so in vogue at the time. Behn introduced gallant French works in Britain, while Haywood and Manley also imitated the French roman à clef or the chronicles scandaleuses. However, these three English authors did not merely imitate the formulas of their models; in their own original fiction they also aimed to develop the genre further, producing more complex female characters who reflected the gendered cultural construction of their country and age and the difficulty of giving voice to female desire. In this sense, in these early novels by women writers, "the heroines often stood for a self-conscious posture along a continuum ranging from dissident to alienated to rebellious, and they committed resistant even murderous acts" (Backsheider, 2000: 7). Neither did these authors just reproduce the narrative conventions of the French heroic romance, but also tried to innovate from it by creating hybrid narratives which aimed for a greater formal realism and psychological complexity. ${ }^{65}$ As Backsheider has stated,

${ }^{65}$ In that sense, despite their importance as one of the first serious approaches to the work of these women, interpretations such as B.G. MacCarthy's have been amply contended and overcome. MacCarthy claimed that "the example of Mrs Behn led a number of women to embark on professional writing, but it is not to be supposed that these, her immediate successors, made any notable contribution to the novel. While Defoe and Swift were establishing realism, these women rallied to the tattered banner of high-flown sentimentality, and avoided realism as if it were the plague. Mrs Manley and Mrs Haywwod as exponents of 
These fictions by women were filled with stories of intense personal struggles by and between the sexes and featured representations of heroines who were simultaneously object and subject. They attempted to present two (or more) compelling points of view and, even more significant, differing interpretations of events and "reality". They often portrayed these as competing, irreconcilable, or even incomprehensible to the opposing view. [...] Above all, the languages operative in the culture became crucial factors. More than manners, social rituals, and a circle's mores, the prose fictions brought groups, interests, and the discourses of power into juxtapositions that exposed competition, collaboration, and other complex relationships. (2000: 8)

A perfect example would be Behn's Oroonoko, or the Royal Slave (1688). Although apparently a heroic romance with a prince and princess destined to a great but tragic ending, its colonial setting and racial message allows combining a fictional autobiography with a political comment on the state of slavery at the British colonies or on the author's support of the Royalist faction. The dialogism between the voices of colonists and slaves, between East and West, between different genres, between a first and a third person narrative, between an ideal and an empiricist epistemology moves beyond the conventional concept of romance and points to a different species of writing. Despite the fact that its heteroglossia is maybe not yet perfectly developed or integrated, Behn's narrative is certainly ground-breaking and evidences a profound knowledge of the ways in which prose fiction, the role of the woman writer and the nation itself were changing. ${ }^{66}$ On her part, Manley also developed complex narratives in which "party politics, proto-fiction, the literary marketplace, and feminine sexuality became intricately entangled" (Gallagher, 1994: 90). Her use of scandal in works such as The New Atalantis (1709) was placed at the service of Tory's propaganda during the reign of Queen Anne. Her narrators, three allegoric female figures, comment on the

the key-novel and the novella succeeded in debauching these types of narrative fiction to an almost incredible extent. Their artificial and poisonous concoctions were doomed to perish by their very excesses, but they could not, in any case, survive the robust, eager life of Defoe's writings. [...] Not only so, but there was the growth of a conventional reading-public who would no longer subscribe to cynical representations of love" (1944: 194).

${ }^{66}$ On the ideological and narratological innovations in Behn's Oroonoko see, for instance, William C- Spengemann's “The Earliest American Novel: Aphra Behn's Oroonoko." Nineteenth-century Fiction 38.4 (1984): 384-414, in which he analyses the change in the form of narrative fiction and the reasons behind it; Jacqueline Pearson's two-part article "Gender and Narrative in the Fiction of Aphra Behn." The Review of English Studies 42.165 (1991): 4056 and 42.166 (1991): 179-90, which offers an essential interpretation of the use of the intrusive or cross-gendered narrators in Behn's work, including Oroonoko; or Oddvar Holmesland's “Aphra Behn's Oroonoko: Cultural Dialectics and the Novel.” ELH 68.1 (2001): 57-79. 
politics of the age while hiding the authorial persona, emphasising the invisibility of women in politics while providing a voice for them under the disguise of these fictional gossips (Ballaster, 1992b: 115). Therefore, Manley was ironically playing with her own authorship as a woman who satirically exposed political parties but who, at the same time, could not be taken seriously because of her condition of mere woman, not linked to the sphere of politics (Gallagher, 1994: 118). More than her colleagues, Haywood became a successful and popular author of gallant fictions, becoming so identified with the genre as to become the "Mrs Novel" in Henry Fielding's parodic play The Author's Farce (1730). She later took this identification further when she evolved to pen stories of women's self-fulfilment not only as lovers or wives, but as independent workers and authors, including a self-reflexive comment on the hardships of women writers in her essential The History of Miss Betsy Thoughtless (1751). This self-consciousness as women and as writers of narrative fiction is also present in Behn's or Manley's prologues, which provided a narrative framework where they very often made a statement on matters of gender and genre. Behn's prologues to her plays or prose works overtly assert her stance in the debate on the visibility and popularity of women writers and of the forms of fiction they produce, while Manley went so far as to offer a genealogy of narrative fiction in the introduction to one of her most popular works. ${ }^{67}$

Despite its obvious political and literary value, these female authors' narrative fiction has been recorded in literary history mainly because of the importance granted to it by its popularity. These works were reprinted and, if one takes the

${ }^{67}$ For an analysis of Behn's use of her prologues and her conspicuously visible characters it is interesting to observe the complementary points of view of Todd (1986) and Gallagher (1994). Todd's seminal association between women writers and Angellica Bianca's conscious exposure in Behn's The Rover as metaphor of the dangers visibility had for female authors is later developed by Gallagher in her interpretation of Behn's stance as detaching herself from her characters, employing the metaphors of the author-whore or author-monarch to relate to the need for visibility though separating authorial persona and self (1994: 16-17). Behn's prologues stress her financial need and hence serve as excuse for her conspicuousness, which she seems to disclaim (Gallagher, 1994: 13, 16), and, more importantly, they comment on her art and the transformation of drama and narrative fiction (see Todd's introduction to Oroonoko, London: Penguin Classics, 2003, pp. 1-21). 
number of editions available as a reliable source, they were also amply read. ${ }^{68}$ As several critics have attested, Behn's, Manley's or Haywood's fiction was highly popular precisely because it succeeded in fulfilling the demand for romantic fiction at the time, and with their novels of amorous intrigue created what could be considered the "first formula fiction of the market," which reached enormous success (Warner, 1998: xv). ${ }^{69}$ These three authors also recognised the potential of prose fiction as "a powerful way to inform and persuade readers" (Backsheider, 2000: 4); by acknowledging the romantic nature of their writing, as well as their Continental influence, they answered to the demanding taste. In that way they also contributed to shape it, in that everconstant bidirectional dependence between the reading public and the body of authors.

More importantly, their popularity also contributed to create the foundation for a long tradition of narrative fiction written in English in which subsequent authors would employ a feminocentric form of narrative in order to reflect on the political and moral issues of their time. As stated above, political developments rendered the family, and in particular, women, the best epitome of the British nation; consequently, the plot of a persecuted, seduced or ruined innocent young woman was transformed into a recurrent and effective way of delivering a didactic comment. According to Jerry C. Beasley's enlightening analysis of the fiction written by women before the 1730s, not only Behn, Manley or Haywood employed their scandalous feminocentric fictions in order to create often complex political or social comments, but also Jane Barker, Penelope Aubin or Mary Davys, authors often contrasted to the abovementioned triumvirate, developed this tradition of the damsel in distress to address political issues and events or "to center on moral or social concerns that were deeply affected by the political atmosphere of the period" (1986: 217), revealing that in the so-called popular narrative there was definitely more than what first met the eye. At least the present scholar's eye, for their political and moral message was clear for their contemporary audience and has

\footnotetext{
${ }^{68}$ Taking as measure of popularity the number of editions, Haywood was as widely read as Defoe during the 1720s. For instance, in 1719 the two most popular books were Love in Excess and Robinson Crusoe (Backsheider, 2000: 5; Beasley, 1986: 227).

${ }^{69}$ Richetti goes as far as to term Haywood "the queen of fictional passion, the Barbara Cartland or Danielle Steele of her day" (1999: 38).
} 
only been overlooked in recent scholarship. In Beasley's words, these women writers were "storytellers intent upon enforcing a moral point of view which was sometimes also a political point of view" (1986: 234) and were as such identified in their own time. For this scholar, then,

The important thing is to note the depth of these female writers' sensitivity to the contemporary scene, and the insistence with which they perused some kind of reciprocal relationship between the real world they knew and the imaginary worlds they created. Their works vastly extended the reading audience for fiction and, by responding with such urgency to anxieties over broad social and moral issues as they were touched by political circumstance, they did much to form and even sustain current ideal of public virtue [...]. (1986: 234)

However, as the political climate and cultural taste changed, and with them the writing of narrative fiction, for later authors their names became representative of what would be considered a low and popular genre, the romance. So, while they were clearly located in a middle ground between romance and Congreve's novel, they were still consistently relocated exclusively within the romance tradition, because of "the perceived 'femaleness' of their writing in terms of their subject matter, reader address, and narrative voice" (Ballaster, 1992a: 193). Moreover, their immense popularity also made them become the epitome of the woman writer, while, in turn, their creation of French romance-inspired works of narrative fiction allowed associating the genre with the figure of the female author. Hence, contemporary and subsequent male and female authors would see them as the model to praise or to reject, as the measure against which to compare not only their success as authors, but also the moral of their work or its closeness to romance or to Francophile writing.

\subsection{The Pamela Effect and the Vortex of Fiction}

Although the concepts of romance and novel, problematic even nowadays, were used indistinctively throughout the eighteenth century, as the age advanced several critics started to more closely categorise narrative fiction and to draw differences between both genres. In that way, romance became identified as those works of fiction described as flights of fancy, as unrealistic 
accounts mostly of faraway lands and times, or as amatory tales focused on the courtship of knights and noble ladies which embodied aristocratic values. Romance, as McKeon (1987) would later suggest, was then at this time associated with former epistemological and social experiences, with idealism and aristocracy, which would be progressively rendered obsolete by the changes in the individual and social consciousness taking place at this particular time. According to this critic, these changes would then bring a generic transformation as well, and result in what was considered a more empiricist and bourgeois-oriented genre: the novel. Throughout the eighteenth century this theory of rupture with previous genres, although still in a very embryonic stage, was also developed. Romance came to embody the values of a bygone era and social system, that of nobility and almost decadence; in the Age of Enlightenment it also became associated with an idealist epistemology that had little in common with the empiricism that took over British schools of thought; and, as a consequence, realism, in both form and matter, displaced romance's idealism in plot and character. Moreover, romance, with its Continental and, more importantly, its French ascendency, was increasingly linked with a foreign system of values, and with a reality that later conservative authors would take pains to represent as foreign to Britain and to its national narrative fiction, especially from the mid-1740s onwards. Finally, as the Augustan Age praised the classics, romance became the epitome of an easy and accessible, hence popular, genre, requiring no classical instruction for its writing or reading (Spender, 1992: 23).

Under this light, women and romance became linked. One reason would be the limited boundaries of the socially acceptable female experience, which would prevent women from coming in contact or describing in fiction the empirical and male reality that was transformed into the prescriptive norm of what reality or realism meant. Furthermore, the recurrence of an idealist approach both in plot and character in women's fiction made this claim to a connection between women and romance even stronger. Finally, women's scarce access to classical education compared to men rendered them better prepared to write popular fiction than works requiring formal instruction; what is to say, works inspired by the classics. Romances were then perceived as feminocentric texts and, 
hence, as possessing a special attraction for women both as writers and readers, for they could appeal to their female sensibilities or experience. In retrospective, the romances written in Britain in the seventeenth and eighteenth century were then attributed to female pens and described as characteristically feminine both in plot and sensibility.

As the Restoration period came to a close, and the literary and cultural taste changed to conform to what would be known as the Augustan Age, followed by the attempted French invasions and the Jacobite rising of the 1740s, and the subsequent development of the modern concept of nation, the negative categorisation of certain forms of romance increased, and the works of many women writers, with Behn, Manley and Haywood as visible emblems, became symbols of the abovementioned flaws of the genre. As Spender has stated, by the 1740 s "the novel as a genre tended to establish its morality by virtue of disparaging references to the scandalous works of the past" (1996: 215); in particular, this struggle between the moral and immoral group of women writers helped to shape the novel in its modern form. Women's romantically inspired amatory fiction would be perceived as morally pernicious and as culturally popular, hence very distant from the satirical writing inspired in the classics and which in general had a distinctively moral purpose. Some female authors, of course, did stand the accusation of immorality; for example, works by Katherine Phillips, a poetess very often named as Behn's morally acceptable nemesis, were praised for their taste and moral value. Together with Phillips, authors such as Barker, Davys or Aubin, and later Elisabeth Rowe, developed a moral species of writing different to the kind of fiction written by Manley or Haywood. Nevertheless, these more conservative or moralist authors did turn to romance in much the same way as Behn or Haywood did; however, they chose to incorporate in their works the elements of the heroic form of the romance and to highlight what there was of idealistically moral in them. There would hence be two distinct groups of authors who developed their romantic inheritance with a very different emphasis and purpose: the former would develop a moral and didactic romance, while the latter would pen a romance focused on passion. The former authors moreover overtly rejected any similarities with the latter, and joined in the condemnation of their gallant 
fiction; in fact, several of these female authors wrote in response to their colleagues' own fictions, establishing an intricate intertextual web that enriched the literary panorama of the age. ${ }^{70}$

In this literary context, Behn's, Manley's or Haywood's very successful erotic narratives were highly criticised for their inappropriateness, not less so because the morals and taste of these early works of fiction were considered to be very French, while the authors were ridiculed in many a lampoon. Their choice in the development of their literary career determined much of their later reception and made them the authors which subsequent writers would reject as pernicious, many of them directing their criticism against them by means of their use of a female quixote. As for the epithet of popular granted to their work, fiction by women writers who did not conform to the Augustan parameters of classic taste would be discarded as "just another romance;" and many years later Austen would complain in Northanger Abbey that this criticism had not subsided, for women's novels, compared to the Spectator, will still be derogatorily considered "just another novel." This early criticism to fiction written by women already aimed to stress the difference with a more masculine, classic and national species of writing which would reach its summit in the mid-century with one of the greatest editorial phenomena of all times. For Behn's, Manley's or Haywood's loss of critical praise and the association of women with romance would be largely prompted by an immense literary occurrence: the publication of Samuel Richardson's Pamela or Virtue Rewarded in 1740.

Richardson's influence on the history of narrative fiction, or the novel, is sufficiently well-known to require any explanation. In eighteenth-century novel criticism it is almost a commonplace to see the publication of Pamela "as inaugurating a new era in the history of the English novel, whether in the establishment of sentiment as the dominating principle of novelistic fiction or domestic bourgeois values as opposed to aristocratic gallantry as the mainstay

${ }^{70}$ Beasley, for instance, mentions Eliza Haywood's popular Love in Excess as a possible reaction to Barker's Exilius, and Aubin's “tales of piety in action as responses to the more raffish author of Love in Excess" (1986: 229). See as well Jane Spencer's analysis of Sarah Fielding's The Lives of Cleopatra and Octavia (1757) as a negotiation between moral women writers and the scandalous triumvirate (1996: 217-23). 
of novelistic ideology" (Ballaster, 1992b: 197). ${ }^{71}$ The influence of Richardson both as critic and as author on women writers has also been thoroughly expounded and, indeed, to understand the female production of the post-1740s one cannot but reflect on his response towards previous forms of fiction which were associated with a certain cluster of women writers.

First of all, it is necessary to place emphasis on the idea of Englishness, for Richardson has traditionally been read as warmly rejecting those forms of amatory fiction imported from France. His novels seem to develop a peculiarly English moral sensibility; a sensibility closely associated with the middle-class Protestant population. This sensibility is epitomised by heroes such as Sir Charles Grandison, Richardson's model for the new age of sensibility, who rejects his Continental lady on the grounds of her Catholicism and finally marries his British and Protestant choice, which echoes the dichotomy between a Continental and a British lady already found in Pamela in the story of Mr. B's gentleman friend (Doody, 1996a: 93). This nationalistic claim and the ethic of worldly success that his novels preach, in particular Pamela, would be later pointed out as one of his major limitations by writers in America, for instance, who found his novels too localised to be of interest or use to an American readership and too immoral in their portrayal of the heroine's marriage to the rich but immoral rake.

Ironically, as several scholars have evinced, Richardson assimilated the conventions of the feminized forms of continental fiction into his own production (Ballaster, 1992b: 207; Beasley, 233-34; Richetti, 1969, 1999) and produced novels in epistolary form, a genre recurrently associated with women writers. In that way, he dialogued with previous fiction by women and contributed to the increasing feminization of British culture, as is evident in his chaste Sir Charles Grandison, or in Fielding's reversal of sexual roles with his pamelian Joseph. Moreover, by placing at the core of his plot not only an individual which is strenuously negotiating with arbitrary power, but a

${ }^{71}$ Well-known is Watt's thesis on the seminal nature of Richardson's work for the English novel (1957), as well as Armstrong's (1987) defence of him as the founder of what we could term the domestic revolution, which limited but empowered women at the same time. Hers is one of the more detailed accounts on the influence of Richardson on subsequent fiction written by women. 
powerless woman who faces the dangers of male authority, Richardson could develop in greater depth that subversive dialogue with male authoritative literary and ideological discourse that characterises fiction written by women and which, according to scholars such as Donovan (1991), constitutes the basis for the new feminized genre that is the novel. As Beasley has stated, the adoption of the figure of the young heroine in distress is crucial to understand the development of narrative fiction, for none of the "triumphant new fictions" of the 1740s -which include Richardson's and Fielding's novels- "might ever have been written without the prior example of the female storytellers whom their authors simultaneously copied and repudiated" (1986: 234). It is only through the "timely reader acceptance of such subject matter, and of its moralized treatment in a context of imaginative fable" that the emergence of the novel could have occurred as it did and when it did, with the brilliant achievement of a Richardson or a Fielding (1986: 234).

In this sense, it is paradoxical that Richardson's most acclaimed and influential novel is permeated by romance, which would also bring Richardson closer to the author very often perceived as his narrative nemesis: Fielding. Each in its own way, both authors assimilated romance only to create something that they perceived as different, and that, in their eyes, would establish a new and more acceptable tradition. In a very Cervantean manner, in Richardson's novels the idealistic epistemology of romance would be displaced to belong to the character's perspective, "the fabulous and noble actions of chivalric adventure [...] internalized in the emotions and the will of an adolescent girl" (Reed, 1981: 136), while it would be framed in a realistic narration. ${ }^{72}$ Romance and realism, the idealistic and the empirical then dialogue in Richardson's novel in a more fluid and integrated way that in previous attempts of anti-romantic narrative, therefore establishing a strong connection with Cervantes and reinforcing Richardson's place in the continuum that is the history of narrative fiction, as his novel "appropriates, and hence transvalues, romance" (Reed,

72 Although not the place to contend these matters, it is worth noting that this displacement already existed in Behn's Oroonoko: the royal slave's idealistic and heroic interpretation of the world clashes with the female narrator's more realistic view and account of the action, his ideal appearance and nature is also presented in contrast with the degraded society the narrator describes in verisimilar detail. 
1981: 136). ${ }^{73}$ Nevertheless, by the "prescriptive realism" he employs (Doody, 1996b: 287-91), by the limitation of the elements of romance to the feminocentric realm of experience or of the romantic vision only to the young girl's perception, Richardson reinforces this association between women and romance.

Therefore, with this rejection/assimilation of romance, after 1740 the debate on women writers seemed to change, highlighting more than before that the problem lay in what they wrote rather than in the fact that they were writing at all. This shift had its consequences as well on the consideration of the reading public and its exposure to certain (pernicious) forms of fiction. Moralists no longer seemed so concerned about that fact that people should read fiction, but rather worried about what it was proper or beneficial to read and write (Warner, 1998: 8). As novel reading intensified, so did the conservative reaction to it (Williams, 1970: 13-15); furthermore, it was the connection between reading and media culture, between writing, reading and women which increased and caused more anxiety. Therefore, Richardson reformed fiction and "developed replacement fictions as a cure for the novel-addicted reader" (emphasis added, Warner, 1998: 6). In so doing he "aimed to deflect and reform, improve and justify novelistic entertainment" (1998: 6); that is, he aimed to provide prestige to the act of reading and to sanction it as long as it included the perusal of his own fiction. As Sarah Raff (2006: 474-5) has brilliantly asserted, with his didactic novels, Richardson aimed to seduce his readers away from romance and transform them into a complying audience for his didactic fiction on two levels: first, as readers who would take his characters and plots as moral exempla to reproduce in real life; and, secondly, as readers who would accept Richardson as a Pygmalionic figure to love and, hence, whose books they would buy. Therefore, while encouraging the role of women writers in their fiction and non-fiction and while exposing the dangers of absorbed reading, authors such as Richardson still appropriated narrative fiction and gave it a sanctioned prestige, after which women novelists had to re-appropriate the realm of narrative fiction, their authority as writers, and

${ }^{73}$ For a thorough and comprehensive study on how Richardson dialogues with romance and on the cervantism of his masterpiece, see Pardo's "Novel, Romance and Quixotism in Richardson's Pamela.” Atlantis 18 (1996), pp. 306-36. 
prove that they could also produce morally and aesthetically valuable works of fiction, once again seducing their readers by their use of moral exempla. ${ }^{74}$

In this struggle to influence the reading audience and to provide wholesome reading, the main target was clear: the reading woman. At this time, the compulsive consumer of fiction or novel-addicted reader was eminently portrayed as a woman. In addition, women were recurrently identified as the readers who run a greater moral risk by their perusal of fiction. An explanation for this perceived danger would lie in the cultural constructions of what feminine fictions were, and also in the change of reading habits among female readers. As Ballaster has phrased it,

[...] by the mid to late eighteenth century a major shift had taken place in conceptualizing both the expectations and conditions of novelistic consumption in Britain. Although novel fiction remained largely feminocentric in terms of its content and thematic interests (concerned with sexual pursuit and amatory conflict), the 'female form' of the novel was now rigidly conceived as an essentially private one, to be consumed in the boudoir or bedroom for personal pleasure. (emphasis added, 1992b: 206)

The association of women with the concept of sensuousness concluded with the identification of the figure of the pleasure-seeking deluded reader with a female character lost in romances or amatory novellas. This demanded that the pleasures women found in isolated reading were controlled, offering exemplary female characters that would become acceptable role models for female readers, hence the ideally virtuous models of Pamela or Clarissa and their descendants. Although the virtue of such heroines was amply contended both by contemporary and subsequent authors, including Fielding himself and his well-known Shamela or Haywood's satirical Anti-Pamela or, Feign'd Innocence Detected (1741), fiction and non-fiction from the long eighteenth century, an even after that, bear witness to the influence of Richardson's female characters as moral exempla.

${ }^{74}$ While it is true that women writers had to regain their voice and dialogue with the discourse of the fathers, it should be noted that these male novelists did encourage the writing of several women. Richardson was a well-known patron of women writers, and, as Doody has insightfully attested, even his female characters are all writers (1996a: 97). Fielding himself praises women writers, although he also reassesses fiction written by women according to its moral worth. In Tom Jones, for example, he hints at the heightened sexuality of Behn's narrative (1976: 265), while he praises the moral sentimental fiction of his sister (1976: 471). 
To develop his highly moral discourse and exemplary characters, Richardson connected his fiction with the more moralistic one by Rowe or Aubin and, as stated, with heroic romance itself. In Reed's words, his novels "are best seen as radical transformations of romance" which:

[...] appropriate and reassert the values of the older heroic romance tradition in the colloquial expressions of a young servant girl. The aristocratic ethos of heroic romance -moral purity supported by an incredible strength of will in the relationship between men and women- is embodied in the character and idiom of a distinctly lower class in order to triumph over the less noble, more licentious ethic of the chronique scandaleuse that had given the term "novel" a pejorative connotation in early eighteenth-century England. (1981: 135)

In this form of fiction female desire was once again substituted by a form of female heroism that was an offspring of romance. Heroines were once again highly idealized and virtuous women, intent on marrying and fulfilling their duty, and this return to romance seeking for the epitome of an exemplary female character evinces that the domestic heroine and the new moral ideology existed in fiction well before Richardson's impulse of it (Bannet, 2000: 5; Beasley, 1986; Todd, 1989: 9). Amidst his defence of formal realism, Richardson then portrayed idealised female characters who, in their exemplarity, unfortunately often lacked plausibility. ${ }^{75}$ However, the fact that these idealised characters were placed on a verisimilar narrative background has sometimes lead to their description as realistic or "believable" and hence as attainable models to imitate both in fiction and in real life (Brophy, 1991: 243), with mimesis now emphasised both ways: fiction should aim to imitate life, and vice versa. ${ }^{76}$ That is, in Richardson's works "formal realism had come to

\footnotetext{
75 In that sense, as Ballaster has stated, Pamela's plot is as implausible as any of Haywood's (1992b: 198).

76 More specifically, Brophy states that both Richardson and Fielding created "believable women and heroines which their readers could emulate" (1991: 243). Moreover, she claims that Richardson was the most radical and feminist in his positive depiction of "real" women and their circumstances, and goes as far as to assert that "if Richardson's depiction of women had become hallmark of the 'new species of writing' the novel might have become a powerful instrument for changing the way society regarded women and the way women thought about themselves" (1991: 238). She concludes by saying that women writers defended the status quo, despite his example (1991: 263) and that if women writers had followed his model, the novel would have been a space for change (1991: 267). While I believe Brophy is here confusing the concepts of verisimilitude (related to form) and plausibility (related to content) -besides ascribing too much weigh on Richardson's merit by undermining the achievements of women writers before him-, the role of the latter in Richardson's work has been widely contended among critics, as well as his alleged "feminism," with scholars
} 
be equated with moral realism," therefore "the accusation of improbability had come to stand for that of immorality" (Ballaster, 1992b: 198), and proper behavioural models should be emplaced in a verisimilar context.

While Richardson's emphasis on formal realism, announced but not so skilfully developed in previous fiction, changed the manner in which the story was told, the high morality and sensibility displayed by his heroines undoubtedly connect his work with prior forms of romance, and link it to subsequent sentimental fiction, serving as bridge between two forms of fiction traditionally associated with feminocentric values, and moreover successfully developed by women writers throughout the century. For instance, Pamela's defence of her virtue by screaming and fainting during the attempted rape, or her stubbornness in the face of imprisonment resemble the ideal heroines of romance, while the later heroines of sensibility would be her clear descendants. Subsequent heroines will see their virtue and preserved honour rewarded by marriage and a happy ending, following Pamela's example. More conspicuous still is the case of Richardson's later heroine. Even amidst such terrible circumstances as her family's psychological harassment or her rape by Lovelace, Clarissa nevertheless always remains righteously stubborn, epitomising the virtuous though distressed women of sensibility, who having lost her honour can only expect to lose her life, and who would become extremely popular as the century advanced and a recurrent presence in fiction written both by men and women. As will become clear in subsequent chapters, Pamela and Clarissa become the model that many women writers will chose either to contest or emulate, and will, therefore, embody many of the paradoxes of gender and genre constructions around femininity and the romance.

However, despite Richardson's dialogue with romance or even early women's amatory fiction, what was perceived as his innovative species of writing together with his immense popularity both in Britain and abroad, changed the

recurrently responding each other. We could quote, as an example, the debate on the author's feminism among Katherine M. Rogers and Anthony J. Hassall in their respective articles, "Sensitive Feminism vs. Conventional Sympathy: Richardson and Fielding on Women," NOVEL: A Forum on Fiction 9.3 (1976): 256-70 and "Women in Richardson and Fielding," NOVEL: a Forum on Fiction 14.2 (1981): 168-74, which perfectly embody the stance of many critics. 
course of British fiction and became a landmark for subsequent authors. As Warner has brilliantly expressed,

$[\ldots]$ the elevation of the new novel by Richardson and Fielding over the old novel of amorous intrigue produces a vortex or whirpool within the land(sea)scape of $18^{\text {th }}$-century British culture. Where one kind of reading is thrown up, another is thrown down; where one kind of pleasure is licensed, another is discredited. This turbulent vortex of reciprocal appearance and disappearance is mis-seen as the origin of the novel. But in order for the elevated novel to appear, the novel of amorous intrigue must be made to disappear into a gulf of oblivion. Thus birth requires a murder and burial. (1998: 44)

As happens with the establishment of any canon, the exaltation of certain forms of art implies the rejection of others. That is, with the rise of the canonical status of Richardson, among other authors, and his consideration as an exemplary author, other writers could not possibly be included in the same canon. In this vortex, in this shift of taste, Behn's or Manley's narratives will become the effaced other novel from whose "notoriety and political intrigues" later women writers would distance themselves (Keane, 2000: 12), as will be seen in the case of Lennox. These early women novelists' role will now be to become the "negative precedents in the formation of the 'new' domestic novel of sentiment in the mid- to late eighteenth century, of which Richardson was, of course, the pre-eminent example" (Ballaster, 1992b: 198), although not an isolated one in a tradition that could be traced back to Barker, Rowe or Aubin. Retracing its steps to these women writers, the species of writing that would become predominantly popular from the mid-eighteenth century would answer to the increasingly feminocentric society of sensibility placing a woman of virtue at their core. This female-centeredness, however, has been far from proving unambiguous, creating many of the paradoxes that accompany the production of women novelists in the late eighteenth century, as well as determining most of the scholarly work on them. 
2.4. Taking over the Market: Women Writers' Dialogue with Propriety, Realism and Romance

With the abovementioned distinction, at least in theory, between romance and the novel, and with the consequences of the Pamela effect and the vortex of fiction, female texts and writers were threatened with the exclusion from the history of the new genre, for they were set apart from what would be perceived as a classical, male, national and empiric tradition of prose fiction in opposition to a popular, female, continental and idealised one embodied in romance (Ballaster, 1992a: 191). This rupture between genres was however contested by contemporary female critics. Anticipating twentieth century studies, such as those by Frye or Doody, eighteenth-century women critics such as Clara Reeve in The Progress of Romance (1787) and Anna Laetitia Barbauld in British Novelists (1810), for example, claimed that romance and the novel cannot be separated, but conform a continuum in which the latter draws from the former in constant dialogue and evolution. Women critics and writers would then assume that genre developed in an organic way, receiving the influence of prior and even foreign forms of prose, and that female authors and the female readers' response to their works contributed to shape the new species of writing that was gaining both prestige and popularity. Moreover, as warnings against reading started to include not only romances but also novels, critics such as Barbauld or More would state that women could participate in the novel market by producing appropriate works, fit to be perused by young readers without any hinder to their intellect, and, more importantly, to their virtue. Therefore, the debate was clearly established not around if to write, but what and how to do it, and, by analogy, around what and how to read, as will be expounded in the next section.

In this sense, scholars have remained divided in their perception of what this new praise of domesticity and the demand to produce didactic novels implied for women writers and the reach of its constraint in their creative freedom. On the one hand, while acknowledging the empowerment brought by the new emphasis placed on the family and the role of women as philanthropists, essential scholars in the field of eighteenth-century women studies, such as Poovey (1984) or Gallagher (1994), have asserted that it severely limited 
female authors' creative powers, "locking them into a disciplinary domestic sphere" and leading to the need for authorial self-effacement or "disembodiment" (Gallagher, 1994: xx). Ballaster summarises this view thus:

The hegemony of the figure of the virtuous woman in this new novelistic discourse simultaneously provided the figure of the woman with a new cultural authority beyond the purely party political resistance she had represented in the works of Behn and Manley, and severely restricted the possibilities for the woman writer herself to undermine and manipulate fictions of gender identity as she had done earlier in the century. (emphasis added, 1992b: 206)

Moreover, for these critics, the fate of women writers of early amatory fiction in this new moralistic order made evident the

[...] extent to which the dominance of a feminocentric idealization of woman as the signifier of moral purity and incorruptible truth from the 1740s onwards had come to limit her possibilities for negotiation within the world of fiction. Fiction and femininity are now thoroughly at odds. Refining the female form of the novel, making it newly respectable, was also an act of redefinition that severely limited Behn's, Manley's and Haywood's female successors in the genre. Women may have entered the field of novelistic fiction in far greater numbers than they had done in the late seventeenth and early eighteenth century, but they did so in more confined terms. (Ballaster, 1992b: 210)

Despite the fact that they in all probability drew from previous experimentation in genre hybridization from Behn, or that they owed much of their success to the presence of romance or amatory fiction in their works, the male innovators of the British novel had assumedly more prescriptively transformed narrative fiction than any women writer had done at that stage, and as a consequence had placed new constraints and demands on subsequent novelists, especially female ones. Through their "domesticating female individualism" and their idealizing of "the figure of the morally superior woman, these influential mid-century novels succeeded in radically diminishing the possibilities of female selfrepresentation for the women writers that succeeded and imitated them" (Ballaster, 1992b: 208). Women writers, very aware of the shifts in the public taste, found themselves asked to conform to the principles of the Richardsonian model in order to become successful writers, sometimes even to be published. This model, based on a newly defined English formal and moral realism, would also be prescribed by other highly influential male critics -and well-known 
literary mentors for women writers- such as Samuel Johnson. In the latter's opinion, authors had to write about what they knew in order to achieve the highest possible grade of verisimilitude. Hence, as the demand for formal realism increased, so did the pressure on writers to be morally acceptable. The consequence was the increased anxiety on female authors' behalf to be respectable women in order to be acceptable writers, for the contents of their fiction would be associated with their own lives and reputations. If this had already been true of Behn, Manley and Haywood, accused of lewdness both in their fiction and their personal lives, ${ }^{77}$ women writers from the mid-eighteenth century seemed to understand that the path to a sustained success was to be reputable. Women novelists would then avoid identification with disreputable predecessors such as Behn, Manley or Haywood, and pursue identification with morally upright heroines. Although exceptions did of course exist -as the examples of Pinkerton or Clarke attest-, consolidated female writers such as Burney, More, or Edgeworth usually made a banner of their respectability, especially as the aforementioned political and social disruption of the later part of the long eighteenth century triggered a conservative counteraction which circumscribed even more the role of women.

This fact would emphasise a paradox in female authors' role: while associated with romance and detached from formal realism due to their focus on feminocentric issues, as women their experience was clearly limited both on a personal and a professional level, hence, their real subject matter was restricted mainly to the domestic or the sentimental, to those fictions that dwelled especially on courtship plots and the description of manners, on emotional displays and entrées into society. Therefore, these forms of fiction, connected in their subject matter to romance, revealed a "gendered conflict over the 'real"" (Ballaster, 1992a: 47) or "gender-determined definitions of what qualified as the 'real' as opposed to the 'fictional' in this period" (1992b: 193). These spheres of courtship or coming of age were those which women could

${ }^{77}$ Behn was often equated with a prostitute and was said to have had several more or less public affairs, while Manley, who married her guardian only to discover she had stepped into a bigamous marriage and later lived with her publisher as mistress, was condemned in the public opinion because of her scandalous libels, for which she was also briefly imprisoned, as well as because of her hazardous sexual life. Haywood was famously satirized for her irregular sexual history in Pope's The Dunciad (1729). 
feel as their own, and moreover describe without impropriety. As a result, they were those more accepted to be dealt with in fiction written by female authors and, consequently, women writers developed certain forms of fiction, such as the domestic novel, the novel of manners or the novel in epistolary form, in which relevant women characters could gain prominence within the context of a realistic and plausible female context. This feminocentric sphere preserved in fiction written by women constituted a sign of another important element which influenced the production of female authors: the need to provide proper tales with appropriate heroines for young female readers to peruse and, ultimately, to emulate as had been the case with Pamela or Clarissa. Therefore, in the abovementioned forms of fiction, authors portrayed idealised female characters that came dangerously close to types or role models rather than full, three-dimensional heroines. The consequence was of course that women writers run the risk of renouncing to verisimilitude to gain respectability or success as professional authors (Richetti, 1999: 200); or, in other words, to avoid their identification with more pernicious forms of fiction, such as the gallant novellas of the early century, women writers returned to plots and characterizations inspired by heroic romance in order to portray once again its sanctioned realm of female experience and ideal heroes and heroines. These narratives inspired in the idealised and feminocentric epistemology of romance would, in clear agreement with Richardson, display a moral tone and didactic purpose.

This change to a domestic subject-matter and to an alleged didactic purpose can be perceived in the production of such celebrated early novelists as Eliza Haywood. Her transformation as an author, from her amatory novellas to her didactic novel The History of Miss Betsy Thoughless (1751), could be representative of the change in taste and the demands of the market to which a skilled author as herself answered in order to remain published. Betsy, flirtatious, spirited and adventurous as Haywood's early heroines, is reeducated into propriety at the end of the story and set as an example for young female readers. In this sense, Haywood conformed to the pattern of fall and cure of a flirtatious and coquettish young girl, established by authors such as Davys in her popular The Reform'd Coquet (1724), though the former's 
heroine and tone was still less prescriptive and more condoning of her character's mistakes. As the century advanced and the Revolution's aftermath brought a new conservative counteraction, this shift to a more overtly didactic species of narrative fiction was overemphasised and former radical writers also seemed to conform to this pattern of reformed women which united domesticity and didactism. A striking example could be found in Elisabeth Inchbald's wonderfully complex and engaging A Simple Story (1791). Written in two parts, separated by a time-span of several years, while the first part portrays a coquettish, but witty, lively and attractive heroine, Miss Milner, the second part starts with her ruin and the highly sentimental and oppressive story of her daughter, Matilda, inscribed in a plot with Gothic overtones. The humour, ease and liveliness of the first part give way to a constrained plot and narrative style that reflects the changes in ideology and narrative fiction, as well as the ambivalence of the relationship between moral preaching and novel writing (Richardson, 1994: 187). A more conspicuous instance was Amelia Opie's The Dangers of Coquetry (1790). Numbered among the radical or Jacobin authors owing to her association with their literary circle and her early production, she later wrote more conservative prose in which she once again related to Davys and portrayed questionable or disreputable female examples that had to be corrected into patriarchy. Coquettish girls, representative of previous amatory fiction and of the type of heroines portrayed by Behn, Manley or the early Haywood, will be transformed into virtuous girls at the time of courtship, later to become proper wives or subject to a pious early death, that is, to one of the two possibilities for romantic or sentimental heroines.

Therefore, authors align with the moral realism prescribed by Richardson though doing so by returning to romance, as he himself had done, and hence denying the connection with the narrative fiction of dubious morals developed in the early part of the century. Novels written by women would then very often develop this plot of overcoming youthful delusions and maturing in the precepts of patriarchy until the peak in the 1790s of what Alan Richardson has very appropriately termed the domestication of the female bildungsroman (1994: 189-190), which would culminate with Burney's, Edgeworth's or 
Austen's novel of female development. In this sense, these fictions of reformed coquettes would anticipate the later conservative narratives with female quixotes at their core, for the latter's misinterpretation of themselves and their power in courtship is very similar to that of Davy's or Haywood's heroines, and their need to be cured into propriety equally patent. The same could be said of the novels of the late eighteenth century which cured their female philosophers by means of their marriage to respectable men or by an untimely death, as recurrently happened in anti-Jacobin quixotic narratives. Moreover, as was clear with male quixotes and will be so with their female counterparts, the nature and moral tendency of their readings, their association with romance or with amatory and political fiction, will determine the positive or negative reading of their character and the harshness or lenience of their cure. In that way, coquettes and female quixotes would share their role as embodiment of their author's stance concerning narrative fiction.

Despite this move towards a more constrained didactic fiction, the mere existence of these subversive young heroines offers a less pessimistic reading of the change in women's writing and of the impoverishment of their creative freedom, as hinted above. That is, later female authors did respond to changing taste, whether owing to the Richardsonian domestic model and its publishing success, or to the conservative reaction that took over society and fiction, or to both, for the majority of them "found it profitable to cooperate with, rather than resist, a version of the history of the novel as prescripted by men" (Ballaster, 2000: 198). As professional women writers, who were moreover very intent in dispelling the idea of amateurism associated with them, the demands of their publishers and their reading public were not only essential in order to gain popularity, but also to survive on the basis of the pecuniary profits of their literary careers. ${ }^{78}$ However, even if the freedom of early women writers

${ }^{78}$ Part of their claim to professionalism lay in their business-like approach to their literary production. As Mona Sheuermann (1993) has explained, women were aware and concerned about financial matters as proved by the recurrent association between the heroine's distresses in the novels and their financial status. The difficult situation of women and the limited possibilities in the professional market made writing a viable and increasingly respectable job, which granted many middle-class women their means of support. As a consequence, many women writers claimed in their prologues that financial need was the only reason to write; while for many it was true -one could provide the examples of Charlotte Smith with her fourteen children and incapable husband, striving to publish many and long novels, or of Frances Burney's equal attempt to write more than one or two volumes and her skilful 
became, as a consequence, in theory more severely constrained by propriety both in life and fiction, it did not mean that in practice women novelists did not innovate or that they merely reproduced a formula. Women writers learnt to transform that alleged constraint into new opportunities for expression, so as to continue to actively contribute to the development of narrative fiction. What is more, they were often self-confident and ambitious, breaking the stereotype of the demure and self-effacing modest muse (Schellenberg, 2005: 11), as the professionally-oriented career of such women as Sarah Fielding, Frances Burney or even Charlotte Lennox attest (2005: 95).

This balance between propriety and freedom of expression leads to the ultimate paradox of the condition of both woman and writer: while openly displaying their authorial skills, competing in the saturated market of fiction, and claiming a place for themselves as acknowledged professionals, fiction written by women recurrently contained an adherence to values ascribed to the female cultural construction developed throughout the eighteenth century which emphasised female traits such as self-effacement, invisibility, domesticity or subordination to patriarchy, embodied in their highly virtuous heroines or their re-educated coquettes. In that sense, as Ballaster has asserted,

$[\ldots]$ the 'story' of the female protagonist is very different to that of her female author. The female protagonist must seek shelter from the risks attendant on public exposure of her body and her attempts to speak her desire and autonomy publicly: countless novels by women entail a vain or egotistical heroine's learning, often at an extreme emotional or physical cost, the limits of her freedom, in order to prepare her to marry an older, worldly, judgemental, and authoritarian man. By contrast, her author evades the need for a male protector precisely because the novel allows her to enter a form of authoritative discourse without the 'risk' of physical display of her own proper body (the heroine stands as surrogate). (2000: 198)

That is, novels by female authors would preach an invisibility their very same existence was denying; and their "narrative fictions insistently 'plot' the story of the secret empowerment of women through language free from the perils of

bargaining with her publishers in order to support her husband, her child and herself-, others of more privileged contexts wrote for the mere sake of it or so as to develop a professional career. Therefore, as men did, they wrote for two reasons: business and pleasure (Spender, 1992: 16), but did both professionally. 
the spoken word and the attendant visibility (and hence vulnerability) of the body of the speaker: novelistic discourse itself" (Ballaster, 2000: 198). ${ }^{79}$

Moreover, it was not merely the presence of the female author herself behind her message of invisibility which questioned the seemingly compliant message of subordination: within the novels themselves, under what some critics have termed the "cover story" (Gilbert \& Gubar, 1979: 154), an ambiguous subtext emerged in which many women authors challenged some of the conventions that constrained them and their female readers. The means by which this subtext revealed itself were varied and rich. Women writers mastered subversive -as well as innovative- narrative techniques after the example of Behn and her early novelist sisters: the ambiguous or cross-gendered narrators, the fragmentation of the point of view, the heteroglossia or dialogue between dominant and repressed voices, the temporal deviation of the norm or the expression of repressed desire or anger which is later silenced, etc. The possibility of expression given to repressed voices of the Other, whether flirtatious or quixotic women, and their temporal delusion seen as some form of social or epistemological madness, allows for temporary freedom and subversion of the established roles in a Bakhtinian carnivalesque sense of the term madness expressed in the novel as space for dialogism and rebellion. ${ }^{80}$

Therefore, texts which finally reassert the status quo, such as Davys's Reformed Coquet or Haywood's Betsy Thoughtless, as well as the subsequently

${ }^{79}$ Ballaster also refers to the narratives of reformed coquettes as an example of this; in particular, on Davys's novel she states that "it is the female scriptor, in the shape of a narrator explicitly identified as female, who manages to negotiate a space for female autonomy even while she tells the story of her heroine's submission to male authority. The author's 'vanity' about the 'beauty' of her own images is licensed where that of her heroine must be curbed" (2000: 205).

${ }^{80}$ Under this light, quixotic delusion would be a space in which a momentary liberation from constraint is possible, thereby an expression of the carnivalesque. In Rabelais and his World (1968), which included many references to Cervantes, Bakhtin defined Carnival as an alternative life for the people, a "second life" in which they temporarily "entered the utopian realm of community, freedom, equality, and abundance" (1968: 9). More relevantly for the idea of a fleeting liberation, he writes: "[...] one might say that carnival celebrated temporary liberation from the prevailing truth and from the established order; it marked the suspension of all hierarchical rank, privileges, norms and prohibitions" (emphasis added, 1968: 10). James Iffland, following in Bakhtin's footsteps and employing it for the study of quixotism, adduces that Carnival symbolises foolishness, irrationality, temporal madness, and, most importantly, a momentary liberation from all restraint and a subversion of established hierarchies (1999: 165). This idea would be developed further in relation to quixotism as "interspersed madness" in relation to Lennox's Arabella and her quixotic sisters. 
analysed quixotic novels, still allow their heroines a moment of freedom and independence though undermined by the final cure. In that sense, due to the final dominance of the discourse belonging to the status quo, many of these often rushed happy endings have been interpreted as aesthetically and ideologically unconvincing and as a concession to the demands of propriety and of the reading public's moral expectations. The female character's temporal deviation of the norm that would finally be silenced or the dialogue among different discourses, such as those of freedom and propriety, or of romance and the novel, or of British and foreign values, will be essential to understand female quixotism and its ultimate cure, as well as its comment on the issues of gender, genre and even the nation.

Finally, and ironically, the lesson of subversion within patriarchal ideology or the challenge to the more accepted formal and moral realistic narrative frame could also be said to have been learnt, among other examples, from Pamela herself: her manipulation of herself and others as texts, her defence of her virtue and her acknowledgement of her humble position which leads to her real power and control over Mr B, embody the power and influence women writers could achieve from the respectable genres of the domestic novel or the novel of female development and the creation of self-effacing heroines who with their sole existence challenge female invisibility. In the same way Pamela constantly rewrote herself and manipulated the reading of others, women novelists' texts and selves converged to be transformed in the eyes of the reader, moulded in order to achieve their objective of editorial success and moral respectability by means of integrating the changing conception of women both into their fiction and their advertisement of the authorial personae. More relevantly for this study, as will be later made obvious, women writers portraying female quixotic readers who manipulated reality and other characters by means of their control of fiction were also making a claim on their own stance as novelists and shapers of their own readers' response. In addition, by inscribing their quixote's romantic delusions within the frame of the novel, these women writers were also capable of re-appropriating the female discourse that had remained undercover in Richardson's own production. Playing with the figures of fathers and mothers, with male and female discourses, with the romance and 
the novel, these female authors claimed their adherence to a long tradition of narrative fiction which existed before the 1740s and which was predominantly represented by women, hence stating their own claim to authorship.

In conclusion, by placing women at the centre of the narration, Richardson and subsequent writers, both male and female, whether inadvertently or on purpose, transformed their heroines into the most important symbol and agent of the changes in both society and fiction. Paradoxically, this power for cultural, political or social transformation, together with the already stated increase in the number of female readers and writers, triggered an overwhelming and almost panic-stricken reaction from the more conservative sector of the critics -largely male ones- which lead to the, for years, unchallenged view that women had taken over the novel market and to the continuation of the unfailing attack directed to women writers and readers. If it was impossible in an enlightened society to question the need for women to read, moralists or thinkers could at least express their doubts about the appropriateness of the content of the fiction women perused or the aptness of certain women to provide moral exempla for their readers. Therefore, the attack on female literacy continued with renewed virulence against those forms of narrative fiction which appealed only to female sensuousness or feelings, and hence encouraged a passion for love, leisure or immoderate consumption, as well as against those women writers whose lives allegedly epitomised the values of that sort of fiction. This criticism was also dual, for these moral treatises on female literacy also contained a warning for female readers not to spend most of their time reading and not to be misled by what fiction presented before their eyes. The danger of women believing what they read was stated by many critics of the age (Kelly, 1990: 222), and was only made more poignant by the formal realism that was demanded. As a consequence, fiction could not be fanciful in order to prevent female readers' disconnection from reality, but neither could it be extremely realistic -never gross, shocking or sensual-so as to avoid hurting the readers' delicacy, nor openly political or subversive in order to shun the desire for rebellion. Once again, the influence between women readers and writers proves two-directional: women writers felt compelled to provide a proper reading for female youths. 
As was previously sketched, the dangers of the reading of fiction for young women became a recurrent presence in the non-fiction production of the age; furthermore, it was an equally relevant element in the eighteenth-century novel, contributing to the development of a tradition of deluded readers or, in other words, female quixotes. This important presence of women readers in fiction written by or aimed at women responds then not to chance but to the complex relationship between women and fiction, gender and genre expounded in the present chapter. A closer approach to the figure of the female reader in narrative fiction would then complete the cultural and literary context in which to inscribe our subsequent analysis of female quixotism. 


\section{WOMEN READERS: THE DANGERS OF FICTION}

Recalling the Biblical metaphor, if "in the beginning was the Word, and the Word was with God, and the Word was God" (John 1:1), the power attributed to words, and by analogy, to the written word, to create, to mould, to transform reality seems to have existed since the beginning of time. In this vein, reading, and its relationship to or, more particularly, its influence on human behaviour, has been the object of much study and controversy over the centuries. Reflecting on the history of reading, many scholars have acknowledged the importance for their line of study of understanding the "decisive moment of face-to-face confrontation between reader and read" (Johns, 1998: 386). They have then reached the conclusion that there exist "close and multiple connections between texts and human actions" (Chartier, 1987: 6) and that "emotion, which throws the reader into the text and inscribes the text within the reader, thus educates for life, provided that the works are read with attention again and again, meditated upon, and discussed" (1987: 225). Therefore, "if taken seriously, $[\ldots]$, reading can, $[\ldots]$, be a force for changing the reader's actions and behaviour, and a means of 'making sense of', or 'reading', the world" (Bray, 2009: 3).

Perhaps owing to this fascination with the effect of the reading over the reader, with the encounter between the body which reads and the text that is being read, the image of the female reader has a very relevant presence in the history of literature and art. As contemporary books such as Women Who Read are Dangerous (2008) or Katie Ward's very recent Girl Reading (2011) testify, the representation of women in the act of reading, whether in the printed text or in any form of iconography, has permeated all centuries and has reached presentday times. The questions of what is a woman reader, what is implied in this idea and, more relevantly, why this enduring fascination with her, are of paramount importance to understand the abundant and relevant presence of the female quixote in literature. While the answers to what or how women read may vary, while the dangers implied in their approach to the written word may change throughout time, in all instances of female readers "l'acte de 
déchiffrage du texte écrit est une condition sine qua non" (Aragon, 2004: n.p.). Although this statement may seem self-evident, it is important to highlight what it implies regarding the relationship between reader and text, and how women readers will face the text with the aim to decipher it, to actively and sometimes challengingly make sense of it and, at the same time, as Bray (2009) has asserted, to read themselves in or by it.

When studying the image of the female reader, previous research has attempted to systematize its study in order to be able to classify the types of female reader and hence to be able to cover such a wide-ranging topic. Especially coherent, thorough and useful is the classification proposed by Sandrine Aragon in her approach to the image of the "lectrice" in France from the seventeenth to the nineteenth century. Following the model of classic rhetoric, Aragon suggests that five stages should be distinguished and studied when researching texts that introduce a female reader, namely

1-INVENTIO ou le choix de lecture des personages féminins: que lisent les héroïnes? Est-ce que ce sont des lectures imposées ou des lectures choisies librement?

2- La DISPOSITIO ou les objectifs de lecture affichés par ces personnages: dans quels buts disent-elles lire? La lecture a-t-elle un rôle didactique, un rôle de divertissement...ont-elles des desseins cachés?

3- L'ELOCUTIO ou les compétences de lecture attribuées aux héroïnes: comment lisent-elles? Sont-elles rêveuses ou critiques? S'identifient-elles aux personnages de leurs lectures?

4- L'ACTIO ou leurs conditions de lecture: où lisent-elles ? A l'intérieur ou à l'extérieur? Dans leur chambre ou au salon? En compagnie ou seules?

5- La MEMORIA ou ce qu'elles retiennent de leurs lectures et les conséquences de ces dernières: sont-elles conduites vers la voie de la sagesse ou sur le chemin de leur perdition? Quels sont les effets attribués à la lecture ? (2004: n.p.)

These matters provide a starting point for any analysis, more so as they were explored in full by the writers of fiction and non-fiction in the long eighteenth century, at both sides of the Channel. While all stages of reading find a place in the representation of women readers, it is more important to focus on what and what for they read, how critical was their reading and what was their response to it. It will be on these questions that subsequent analysis will be based, once 
again relating the image of the female reader to wider social or political considerations, and, of course, without forgetting its unbreakable bond with the figure of the woman writer which very often gave birth to her.

\subsection{Women Readers in Elisabethan England}

Despite what some eighteenth-century studies may suggest, the trope or figure of the female reader as an ambiguous and recurrent presence in literature and art does not belong exclusively to this period, although it was particularly conspicuous in it. In the Elisabethan era, long before what is termed the long eighteenth century started, the references to or representations of women readers already populated the pages and paintings of English artists. On the one hand, Renaissance women themselves were concerned about the matter of literacy, as their own literary works or their accounts of reading witness. One encounters women who deliberately portrayed themselves as readers, with Lady Anne Clifford's self-representation in "The Great Picture" (1646) as widely acknowledged example: in this triptych she defined herself both by her ancestry and her readings, which include, of course, the Bible, but also books such as Cervantes' Don Quixote or Sidney's Arcadia (figure 4).

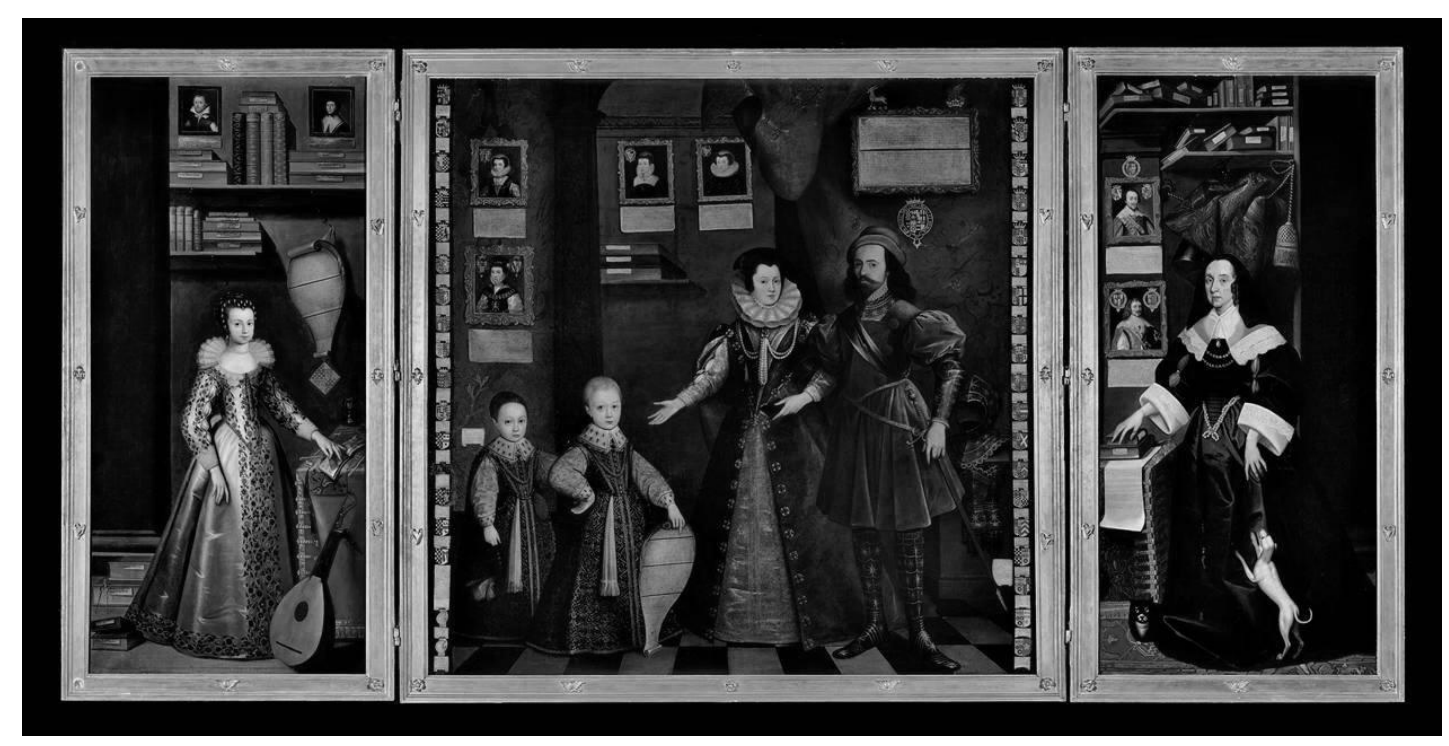

Figure 4. The Great Picture Triptych. Attributed to Jan van Belcamp.1646. Oil on canvas. Centre panel: 254 x $254 \mathrm{~cm}$. Side panels: 254 x $119.38 \mathrm{~cm}$ 
Other women also left some record of their reading, including their taste for romances. A well-known example would be Dorothy Osborne, who left revealing correspondence written between 1652 and 1654 to her then fiancé Sir William Temple in which she provided an exegesis of her reading matter: she ventured her opinions and required his in return. She was a voracious reader, and her letters remain one of the most enlightening documents to understand how women read -often in a household full of people that did not allow for much time or concentration- and what they read -with a list that included several well-known romances. ${ }^{81}$ Moreover, women willingly participated in the debate on the politics of literacy in general and, more specifically, on those concerned with women readers. By so doing, they engaged in a public debate that moved beyond the boundaries of gender issues, and which involved a discussion on class and religion, and contributed to shape what present scholars know of reading policies or practices in early modern England. In this sense, from a very early stage

[...] women writers did participate in the history of reading: in shaping ideas about vernacular Bible reading and its place within the English nation; in developing practical means to increase reading literacy; in conceiving of methods of reading that facilitate the practice of non-conformist faiths; and in fashioning better readers of women's writing. They insist that reading is socially important, within a private devotional practice, within the family, in relationships between women, as well as between women and men, and within the state. Writing about reading provides women with a language with which to fashion a writing voice, and reading provides a topic that is at once appropriate to women and a route through which to engage with the world beyond the household door. (Snook, 2005: 24)

By means of this involvement with the issue of reading, women could assert a certain cultural authority and claim a space for "female voices and readers in the political, literary, and intellectual culture from which they were most often excluded" (Snook, 2005: 4).

${ }^{81}$ Osborne is the best documented example. For an analysis of the role of reading in her letters and her courtship with Temple, see Carrie Hintz's An Audience Of One: Dorothy Osborne's Letters To Sir William Temple, 1652-1654 (Toronto: University of Toronto Press, 2005), pp. 64-86. Nevertheless, there are other cases. Hackett also mentions Lady Briana Harley and the Countess of Warwick as examples (2000: 8-9). Lucas provides more examples (1989: 15). 
On the other hand, women readers were also portrayed as a literary type, as a trope in both works of fiction or moral treatises. Condemning or circumscribing women's reading became a recurrent task for moralists such as Juan Luis Vives in his Instruction of a Christian Woman (1523), Heinrich Bullinger in The Christian state of Matrimony (1541) or Thomas Salter in A Mirrhor mete for all Mothers, Matrones, and Maidens, intituled the Mirrhor of Modestie (1574), just to mention a few examples. Once again, this representation of female reading could be taken literally as meaning the mere increase in the literacy rates and in the number of women readers and writers. ${ }^{82}$ However, it would be almost impossible to dissociate it from "a wide range of concerns around literacy [...] vernacularity, religion, class, and nationalism" (Snook, 2005: 12), including the recurrent anxiety that certain readings, especially romances, raised regarding female sexuality, which also becomes a trope, a metaphor to speak about other matters of concern, such as class values, the concern with sinful idleness or the association of the romance with a form of "political poison." All of them issues that will survive associated to women readers throughout the eighteenth century.

Because literacy was being promoted as part of a basic education, this increasing concern was related rather than to whether or not women should read, to two main aspects: what and how women read. That is, the questions that were raised were with what genres or authors women spent their reading hours, and if they read in solitude or in company, with discernment or with no critical judgement. The main genre under examination -or rather, under attackwas the romance. Vives or Bullinger particularly condemned this genre based on three premises: "that romances exercise undue freedom concerning erotic matters; that women are especially susceptible to the charms of such erotic entertainments; and that the consequent effect of romance upon women will be to make them sexually unruly" (Hackett, 2000: 10-11). Together with the more serious moral warnings of churchmen and educationalists, "by the early

${ }^{82}$ The assumption of this increase is amply accepted though it has proved complicated to measure, as classic studies took the capacity to sign as representative of literacy, not taking into account that reading and writing were taught separately, the first being more common than the second, or that not everybody could read all forms of print. Moreover, the persistence of a tradition of oral reading would allow illiterate people to enjoy works of fiction, poetry or moral treatises as well, despite their inability to read by themselves, a fact also to be considered when evaluating women's access to fiction at this time. 
seventeenth century, foolish female readers of romance had become favourite subjects for satirists and moralists" (Hackett, 2000: 4). A relevant instance would be Sir Thomas Overbury's Characters (1614), in which a chambermaid "reads Greenes works over and over, but is so carried away with the Myrrour of Knighthood, she is many times resolv'd to run out of her self, and become a Lady Errant." Although there indeed existed some real life examples of women translating literary conventions into real practice, both the moralists' and satirists' targets reveal more about their own worries and conceptions of women and romance, about the relationship that was being established between gender and genre, than about women's actual accurate reading practices. ${ }^{83}$

As for the how of women's reading, Sidney himself underscored the value of reading correctly, and by so doing, benefiting from what romance could offer of model for proper behaviour (Lucas, 1989: 29). Moreover, as the famous Querelle de la Rose demonstrated, the same work of fiction, in this case the Romance of the Rose, could be open to more than one interpretation, even a gendered one, as was the case with Christine de Pisan's reading of it in her work Epistle to the God of Love (1399) and her defence of her experience as woman and reader (Lucas, 1989: 32-3). Even Sidney's defence of Amadis as a model of behaviour opposes Vives' criticism of it as pernicious, hence proving that there could be a correct/incorrect, appropriate/inappropriate reading of the same romance. Reader-response then plays an important role when assessing romance and its relationship with its young readers, whether male or female, and when advising the latter to follow the recommendation of older male readers in their choice of fiction or to rely on their guidance in its interpretation. It will be this very same concern with readers' response to fiction, whether romance, gallant fiction, or the novel, or to political or religious treatises, which will condition the subsequent eighteenth century

${ }^{83}$ Hackett, for instance, mentions two ladies, Elisabeth Southwell in 1605 and Arabella Stuart in 1610, who employed a conventional romance trope, in this case the use of a masculine disguise, to elope with their lovers (2000: 8). Despite these examples, as Michael McKeon has pointed out, this attitude is not newly-born in seventeenth-century England, but is a recurrent presence in literature -with its dominant patriarchal frame of mind- throughout the ages. In McKeon's own words: “from Dante on, the fear that women's morals will be corrupted by reading romances is quite conventional, and its articulation may provide evidence less of the rise of the reading public than of the persistence of the anxiety about women" (1987: $52)$. 
consideration of the woman reader and the dangers of unguided, untrained reading.

\subsection{Reading Women and Women Readers in the Long Eighteenth Century}

\subsubsection{The Perils of Reading}

Given the abovementioned rise of literacy and the growing conspicuousness of women writers in the eighteenth-century literary panorama, both as writing entities and as a threatening presence in the texts of men and even some women moralists, it is understandable that the importance attributed to the woman reader also augmented throughout the century, and survived well into the Victorian period. ${ }^{84}$ Taking several contemporary paintings which depict a woman reader as starting point for her analysis, Kate Flint summarises the questions raised by her image throughout the Victorian era:

First, its [the image of the woman reader'] very presence [...] points to the wide range of contexts in which 'the woman reader' was constructed as a discrete topic throughout the period. These included articles in newspapers and periodicals; medical and psychological texts; advice manual for young girls, wives, servants, governesses; educational and religious works; autobiographies; letters; journals; fiction; and verse, as well as paintings, photographs and graphic art. Second, the self-absorption of the readers depicted implies some of the reasons why the private activity of reading tended so persistently to come under scrutiny. It hints at the subject's vulnerability to textual influence, deaf and blind to all other stimuli in her immediate environment. It suggests the potential autonomy of her mind, [...]. The very relaxation of outward social awareness [...] prompts the idea of another element: the eroticism of the female subject for the male spectator or commentator, provoking questions which indicate his own fascination with the

\footnotetext{
${ }^{84}$ Although outside the timeframe chosen for the present research, it is still necessary to acknowledge the essential contribution of Kate Flint or Jennifer Phegley to the study of the Victorian woman reader. The former, in her seminal The Woman Reader, 1837-1914 (Oxford: Clarendon Press, 1993), analyses such influential genres as the sensation novel and the "New Woman" fiction to state how women writers challenged the inherited perception of women as uncritical readers. Phegley in Educating the Proper Woman Reader. Victorian Family Literary Magazines and the Cultural Health of the Nation (Columbus: The Ohio State University Press, 2004) examines the nineteenth-century scene of women's reading and how it still seemed necessary to educate women into proper ways of approaching fiction. In subsequent research, Reading Women. Literary Figures and Cultural Icons from the Victorian Age to the Present (Toronto: University of Toronto Press, 2005), she presents a collection of essays on the representation of women readers and the cultural stereotypes built around them from the nineteenth century to the present, emphasising how the woman reader has become a familiar figure in the public consciousness.
} 
woman's mental processes. What is she reading about? What are her fantasies? [...] Furthermore -and this tended to be the line publicly taken on the subject- what moral, sexual, religious, ideological dangers may lie in a woman's being absorbed by so preoccupying a pursuit? (1993: 4)

Although Flint's excellent analysis of the issues raised by the image of the woman reader belong to the iconography or the literature of a later era, these concerns with women's self-absorption or sensualised reading practices, the awareness of possible moral or ideological dangers of solitary reading, were inherited by the Victorian from the eighteenth century, together with its interest - even obsession, one might say- with the figure of the woman reader and her vulnerability to the seduction of fiction. ${ }^{85}$

In the same way that the image of the woman reader seemed to permeate all forms of graphic representation and of print in Victorian times, so did the debate on female literacy find its way into all forms of fiction and non-fiction in the previous century. As Warner has indicated, the "spectre of the addicted woman reader," leisure and pleasure-driven and lost in this new form of mass entertainment, cast a shadow over many fiction and non-fiction writings (1998:139). According to Richetti (1999: 197), the role of this "woman of leisure" was essential in shaping the cultural and literary panorama of the rising bourgeois and individualistic society, and her influence became a matter of increasing concern. Hence the woman reader, with her multiple moral, social, cultural and political readings, became an increasingly recurrent topos in eighteenth-century moral treatises and, more relevantly, in fiction (Warner, 1998: 140), with her special susceptibility to be misled by literature rendering her a perfect admonitory figure for both young male and female readers (1998: 141). As had happened in the previous century, writers from all areas of expertise or even from divergent political colours addressed the topic of female literacy, and their works became inscribed in a battle of quotes in which authors with different views responded to each other. In this sense, female

${ }^{85}$ Flint traces the origin of Victorian preoccupation with the woman reader to the Renaissance and outlines the common concerns that survived throughout the following three centuries which linked together "preoccupations with bodily and mental fitness;" in her own words, "whilst too great an acquaintance with light reading might lead her sexually astray, either in imagination or reality, it would also distract her from developing intellectually and spiritually" (1993: 23). 
literacy received the same treatment and almost as much attention as any other political or social issue. In this context, well known, for example, was the advice offered by James Fordyce in Sermons to Young Women (1765) or John Gregory in A Father's Legacy to his Daughters (1778), among many other educationalists, both male and female, on female education, and more specifically, on reading. These moralists once again emphasised both the what and the how of women's reading, once more stated the need for educated guidance in order not to commit the mistake of confusing reality with fiction, or vice with virtue. Their works would be subsequently quoted either to be condoned or condemned, and rare was the author who addressed the matter of female education that did not also include an extended comment on female literacy. Novelists such as Hannah More, Mary Wollstonecraft, Jane West or Elisabeth Hamilton, just to mention some relevant examples, also dwelled on the matter of pernicious uncritical reading both in their works of fiction and non-fiction.

As can be assumed, this issue offered a field for great controversy and was never a matter of a black or white stance, but of innumerable shades of grey. More than any other, the matter of what women should read was highly problematical, as Jacqueline Pearson has brilliantly expounded in her study on women's reading in Britain in the long-eighteenth century. According to the results of her insightful research, there is evidence that "all genres of reading, however apparently safe, upset some commentator in this period" and that "almost all genres, however apparently harmless, could be read rebelliously and resistingly rather than compliantly" (1999: 43). From the print material of the eighteenth century, it is certainly true that one derives the impression that any form of reading could be potentially dangerous, surprisingly even including the Bible or conduct books. Of course, there are certain genres more obviously dangerous than others, and romances and novels stand out in a very prominent position, together with philosophy or botany, for instance, as a genre liable to be sexualised (1999: 82). Nevertheless, what commentators feared were the "hidden agendas" of these texts (1999: 86), whether moral or political, and not only their effect on women readers, but also the use made of them by these same readers to legitimise their claims. In this sense, the debate over 
whether romance was or was not an appropriate reading for women, was closely linked to the possibility of interpreting courtly love as an expression of female power rather than stressing what it had of a male-controlled financial transaction or a forced transition into another male-dominated sphere, marriage. ${ }^{86}$

Therefore, the core of the problem lay more on how women read, for "it was not enough to read the right books: they had to be read in the right manner, the right company and the right places" (Pearson, 1999: 152). The criticism aimed at the manner of reading would involve, for instance, an attack on the use of circulating libraries, spaces between public and private spheres and gendered as dangerously feminine in the conservative thinking of the age, or a warning against silent reading as self-indulgent and lacking the family, social and domestic values of reading aloud, as Pearson (1999) or Tadmor (1996) have attested. ${ }^{87}$ Moreover, how women read also involved the question of whether they did so compliantly or resistingly, conservatively or subversively, critically or uncritically, and whether they employed the diverse genres, especially romance and the novel, to validate their aspirations to both authority and authorship. As Pearson has pointed out, contemporary women commentators themselves complained that "the age's mechanisms of discipline and control aimed not at the typical reader but at the extremely vulnerable, uneducated and immature, at the 'ignorant, the silly, and the weak', and so deprived the vast majority of female readers of harmless and enjoyable books" (1999: 86). Nevertheless this being the case, this imaginary projection of the woman reader

\footnotetext{
${ }^{86}$ Courtship is commonly read as a period of power and control for women, not only because women's power of deferral is practised, but because, as Ballaster has evinced, it moved women and their experience into the spotlight. However, it is interesting to witness how this power has been lately reassessed by critics such as Hackett, who highlight the male control over women's choice which was still practiced by parents or guardians in the seventeenth and eighteenth centuries. Nevertheless, it is the romantic heroine's prerogative to challenge the male choice or to subordinate her lover to her wishes, hence providing readers with this ideal of power to imitate, as Sobba Green has evidenced in the book The Courtship Novel in which she describes female quixotes (1991). Once again, reality and fiction differ, though the latter offers a subversive model for the former.

${ }^{87}$ Pearson analyses many references in contemporary fiction and non-fiction to the association between women and the circulating library, to the dangers -mainly sexual- of silent reading, and to the reinforcement of domestic values found in communal reading (see pp. 152-75). Noemi Tadmor provides some case histories of "virtuous" reading aloud as opposed to more controversial silent reading, including the example of Richardson's own household, where the practice of reading was not a "solitary communion of reader and text" (1996: 170), but a "sociable activity" (1996: 171).
} 
became "crucial to the rhetoric of repression throughout the period" (1999: 86) and was particularly intertwined with the concepts of pleasure, danger and delusion.

Concerning pleasure, women readers -as did women writers- often displayed an ambiguous relationship towards reading: the amusement, the enjoyment derived from reading causes uncertainty and guilt, more so under the light of the period's "constant elision of textuality and sexuality, especially in the case of women, whose reading is repeatedly figured as sexual act or seen to reveal their sexual nature" (Pearson, 1999: 87). Reading appears in the eyes of eighteenth-century moralists as a "solitary, transgressive, even masturbatory act whose impulses need to be redirected into a male-dominated, outwardlooking sociality (and, by implication, sexuality)" (1999: 108). Even apparently "innocent reading endangers the female reader, whose deep involvement in a world of imagination makes her vulnerable to male [...] stories of rape and seduction" (1999: 110), as many novels written by women attest. Therefore, while the escapism found in literature may distract women from their domestic duties and concerns, the main danger or peril for the female reader is phrased in sexual terms, the greatest threat being unchastity. ${ }^{88}$ If the text of romances and novels became identified with femininity, so did the female body become identified with the literary text, both potentially transgressive, both subject to conventions that could be followed or forgotten, both under the male gaze that read and analysed them. Especially because of women's connection with the notions of sensibility and emotion, so relevant in Chartier's conception of the relationship between reader and read, women readers seemed to be thrown into the text, while the text became inscribed within the reader and educated her for life. Hence, the recurrent metaliterary comment to be found in novels written by women, which was a comment within the boundaries of fiction itself on

${ }^{88}$ Jan Fergus identifies these two concerns as the more obvious in eighteenth-century moral writing: first, that reading took women away from their household duties, and, second, that the isolation of the reader was morally suspect (2000: 172-3). As she states, "implicit here is a fear of female fantasy or sexual stimulation, crystallising in the prevalent male fantasy that women who read novels will reject ordinary men who love them, cherishing instead a romantic daydream" (2000: 173). She also ascribes this fear to male loss of control over fiction and, hence, their loss of prescriptive power over an unruly audience: "suddenly [...] male writers could not control either the reading or writing of women, and perhaps for this reason imagined threatening scenarios, asking what would women readers do? Become sluts? Run away? Fail to find ordinary men -as opposed to men in novels- appealing?" (2000: 173). 
romances, novels or male/female genres, became indistinguishable from a discussion on women writers or readers themselves. It became a discussion on how women are being read throughout the century, or on what women are thought to be. Particularly so in novels dealing with female quixotism in which the last element of the triangle of female reading is fully developed: delusion.

Many are the heroines who misread romances or novels and who must learn that reality and fiction are two different things, consequently becoming critical and detached readers rather than absorbed, sympathetic or empathetic ones. However, the need to balance sympathy, in order to engage readers and to become popular authors, and the need to be seen as morally acceptable writers who did not delude their audience, left authors a very thin line to walk. Many authors then resorted to the creation of a reading hero or heroine who could engage and teach alike, and whose lessons in reading could provide a role model for real readers, or even the chance for the above mentioned metaliterary comment. In the ideology of the age, the establishment of a good intradiegetic reading model was particularly relevant in the case of women readers. According to what seems the paradigm of the age, female readers do not maintain the "willing suspension of disbelief" only while reading, but carry it further than just during the moment of reading, hence the dangers of allowing a too close identification with literary heroines or a too deeply aesthetic reading of the literary world, in many ways more appealing than the real one. Therefore, catharsis is also required in order to prevent an absorbed reading and to emphasise the perils that this engaged form of approaching literature had for women.

This lesson within literature itself is a consequence of the increasing number and popularity of romances and novels published at this time, a fact that proved that the advice found in conduct books or moral treatises was not being followed. The dangers that were found to lie in women's reading led then to the assumption that it was necessary to fight the poison of this dangerous recreation with its own weapons and hence to provide not only proper or improper models of behaviour for the young readers to respectively imitate or avoid, but also proper or improper models of reading, with which to trigger a self-conscious examination of the reader's choice of genre and mode of 
reading. This proper or improper mode of reading novels, for instance, is already present in Clara Reeve's germinal The Progress of Romance (1785). In Euphrasia's words, in a circulating library a young person may "read indiscriminately" and by that means "both food and poison are conveyed to the young mind together" (1785: II, 77), while Hortensius, the male contender, summarises the dangers of youthful reading stating that in a novel

[...] the seeds of vice and folly are sown in the heart, -the passions are awakened,-false expectations are raised.-A young woman is taught to expect adventures and intrigues, -she expect to be addressed in the style of these books, with the language of flattery and adulation. [...] From this kind of reading young people fancy themselves capable of judging men and manners, and that they are knowing, while involved in the profoundest ignorance. They believe themselves wiser than their parents and guardians, whom they treat with contempt and ridicule: -thus armed with ignorance, conceit, and folly, they plunge into the world and its dissipations, and who can wonder if they become its victims? (1785: II, 78-79)

Hortensius enumerates both the dangers of sensual reading -the passions awakened by novels-, and of delusional reading, of the reader that learns to expect from life what he and, more specifically, she finds in her novels: coquetry, adulation and hence power through which to defy parents and guardians. The final consequences are contempt and even ruin. However, Euphrasia agrees only in part: in her opinion there are "others, which I have shewn you were written as an antidote to the bad effects of them, tho' under the disguise and name of Novels" (1785: II, 85). In the end, Sophronia summarises the discussion stating that the male contender would "prohibit the reading of all Novels in order to exclude the bad ones," while the female one would "make a separation in favour of works of Genius, taste, and morality" and she would even "recommend such methods of preventing the mischiefs arising from novel reading, as are moderate, prudent, and above all practicable" novels (1785: II, 96). The discussion over reading and, more particularly, female reading mirrors the gendered debate of the time. The majority of women writers, as well as of male novelists, contended on Euphrasia's side: novels could be the cure for the poison, even if in appearance they were the same as the venom, and, therefore, their stance as novelists was safe. Equalling the interpretation of novel reading to homeopathy, one could state that in the eighteenth-century the cure to the 
dangers of reading would be brought by a diluted and prescribed dosage of the poison itself, taken in an appropriate manner. And what would be better to cure a deluded reader than to be exposed to the story of another one? Hence, the figure of the deluded female reader became even more conspicuous in fiction, as a "metaphoric" reader (Gardiner, 1999: 11-12), as a practical example of the consequences of a poor choice of readings or of misreading literature for real life: then Iser's implied reader would relate to Genette's intradiegetic one and learn by example, in the myse en abyme of the enunciation that is fiction with a moral exemplum for the reader. In this context, quixotism becomes the perfect formula to develop a story that revolves around the figure of a reader that stands in need for correction and who will finally come to his or her senses, restored to the status quo advocated by the text. Writers can then present the cure of their quixotic character while they ask their own implied readers to become ideal ones, that is, a "seduced, quixotic reader" of the moral text (Raff, 2006: 475) who grasps and approves everything from it. In this sense, the figure of the intradiegetic pedant, sensual, absorbed or even deluded reader, of the female quixote, runs parallel to, and even draws elements from, the reeducated coquette of conservative fiction, adding to the young female protagonist's desire for significance and power another paradox in its moral message of condemnation of female visibility, creativity and authorship. It is then this intradiegetic reader, this "reader within the narrative," who will become the focus of didactic fiction (Ty, 1993: 63), and who is the focus of the present study in the context of the recurrent mise en abyme technique in which reading within the text supposedly reflects the reading of the text, the real reading by the real female reader, while providing a thorough comment on the anxieties of the age concerning women, literature and influence.

Despite this straightforward didactic intention, these representations are not without their limitations and contradictions. As many critics on female reading have stated, it is highly complicated to find a direct link between the literary representation and actual practice of reading (Bray, 2009: 174). Once again, one must assume that these literary representations of reading reveal more about the concerns of writers and publishers towards their reading public and their hidden agendas when trying to educate their readers into fitting certain 
models than about actual reading practices (2009: 27). What is more, independently of whether or not real readers can identify with the fictional ones, the aimed identification can convey a message of resistance rather than submission: for "however much writers might want to 'direct' their readers, and establish an 'instructional identification', 'real' readers, like the fictional ones $[\ldots]$ are active and creative users of texts rather than passive absorbers of them" (Bray, 2009: 177). This is so because reading is always accepting or resisting the author's message, his or her vision of reality and the truth they are presenting, and even not all intradiegetical female readers compliantly accept the texts they peruse. Even among the didactic literary reading models, a critical or subversive reading of texts, whether printed or in human form, is possible. As Bray has asserted, each woman reader displays a repertoire of "interpretative practices and skills;" in his opinion, too often the reading of women "within the eighteenth-century novel has been dismissed as 'unskilled or inadequate', as quixotic misreading" which proves that "[n]ot enough attention has been given to the variety of ways in which heroines read and interpret other characters, especially men [...]" (2009: 24). Although agreeing on the need of a reassessment on female reading and on the wide variety of interpretative practices and skills present in eighteenth-century novels in order to escape overgeneralizations, Bray misunderstands quixotic reading and merges two different concepts of interpretation. Firstly, Bray seems to simplify quixotism to the "identification" with the heroines of the text or the complete loss of grasp on reality, and hence discards this term as applicable to most women readers (2009: 174). Secondly, this scholar employs the ability to read other characters as an indicator of the interpretative and critical reading skills of the heroines, thus conflating two experiences that are not always equivalent. However, as has been amply expounded in previous chapters, neither is complete identification with literary models nor madness the only defining attributes of quixotism. Moreover, quixotism can have its origin in literary or non-literary sources, and is usually perceived as an "interspersed" condition: it affects one particular area of the character's life and not the whole of it. Consequently, the female reader may read herself inadequately, though remaining capable of reading others appropriately. Her uncritical reading may not even be always pernicious: she may learn to read the truth about others by 
means of the models found in her reading, such as the models of heroes and villains encountered in romances. Quixotism cannot be reduced to such a simple formula, nor can the complex message of subversion which it makes possible be forgotten.

\subsubsection{Classification of Female Readers}

Answering the questions posed on women readers, Sandrine Aragon constructed a classification of "lectrices" over the long eighteenth century in France. Her topography would include three stages in the image of the female reader:

[...] de 1656 à 1720, les texts décrivent des lectrices qui se ridiculisent en société, surtout lorsqu'elles lisent en cercles fermés; de 1720 à 1800, la lecture à deux, le modèle pédagogique des lumières, donne lieu à des images de lectrices qui peuvent être séduisantes bien encadrées; tandis que de 1800 à 1856 , les représentations redeviennent très critiques pour des lectures féminines, solitaires donc non contrôlées et jugées socialement dangereuses. (2004: n.p.)

This classification can be perceived to take into account several aspects. First, how they read: in groups, in pairs, in solitude; then, the purpose of the author whether it is comical or tragic, whether it aims at entertainment or at didacticism-; and, related to the previous point, the consequences of their reading: their ridicule, their seduction or even their death. In the first period described by Aragon, she identifies the image of the "prétieuse ridicule," a comic type of female pedant which reads only to display her superior taste and knowledge, and her opposite, the "lectrice honnête," a more positive image of the female reader which appears in gallant romances and which is characterized by her conception of literature as a "divertissement agreeable et instructif" (2004: n.p.). According to Aragon, the comic precious exscinds into two different types at the end of the century: "the jouvencelles romanesques, ou 'vierges folles', et les femmes savants" (2004: n.p.). The former "abordent la fiction sans connaissance littéraire et confondent réalité et fiction," while the latter are older characters who are accused of being "non féminines," but rather viragos, harpies or devils who contend the intellectual authority of men (2004: 
n.p.). Both models absorb their readings but lack critical understanding in order to interpret them and act in society accordingly, therefore exposing themselves to scorn and laughter. In the second stage of her study, Aragon describes a reading heroine at the service of the moralistic aims of the Enlightened writers. In the works of fiction written during this period, "lecture et libertinage font donc bon ménage" (2004: n.p.) and the young readers become easy preys of the libertines. Reading, as Pearson has stated, can transform women into victims prone to seduction. Ridicule then has given way to moral comment, both aimed at the seducer and at the victim, although with supposed sympathy towards the latter. Finally, one is presented with the image of the "lectrices en péril." The works of the nineteenth century grant their reading heroines a tragic rather than comic ending: "la puissance du livre est mise en image mais sans ridicule, la force des images est dans la vision tragique désormais des risqués encourus: la mort, le désespoir..." (2004: n.p.). These heroines do not read in group, but become self-absorbed by their solitary perusal of fiction and remain incapable of adapting to society; consequently, dying becomes the only possible -or plausible- ending in this model of unsuccessful female bildungsroman.

As for the relation of these reading models to quixotism, although in Aragon's study the correspondence is not always made explicit, these reading women could be described as female quixotes. The ridiculous pedants apply literature to life without discrimination; while the model of the mad virgin implies epistemological distortion, the learned lady ascribes to the model of the enthusiast, in this case, of theoretical -and shallow- knowledge. ${ }^{89}$ With regard to the seduced reader, the fact that these women are seduced by the text and by a man who embodies the characteristics of the romantic readings they perform together does relate to the seduction of the world of fiction and the desire to live by its standards which are the basis of literary quixotism. Don Quixote himself is duped by his romances and by the people who play out the fantasies found in his readings: literature shapes the character's perception of reality as the boundaries between one and the other are blurred. In this sense, this model of the seduced woman reader develops in full an element that in others is but

${ }^{89}$ In fact, Molière's seminal play Les Précieuses Ridicules (1658), together with several other works of fiction centred on the character of the precious, have already been studied under the light of the reception of Don Quixote in France. 
marginal: the manipulation of the young reader's romantic aspirations by other characters in order to achieve their purposes. Finally, the endangered or absorbed reader, the solitary woman who rejects her contact with the world in order to live through her readings, and hence becomes unable to (inter)act within society, is related to the Romantic reading of Don Quixote which insists on his delusion as alienation. This later tragic reading is best epitomised by Flaubert's famous Emma Bovary, who not only gave birth to the term bovarysme or bovarism, but also became an "alter-ego de Don Quichotte et le personnage de lectrice le plus célèbre de la littérature française" (Aragon, 2003: 22). This romantic and deluded woman reader embodies all the dangers of female reading and culminates the process of transformation of the female reader in French fiction:

Lorsque Flaubert publie Madame Bovary dans les journaux en 1856, il n'invente donc pas le personnage de la lectrice romanesque mais il synthétise toutes les idées reçues sur la lecture féminine dans ce personnage. [...] Tous les dangers attribués aux romans dans les gravures et les caricatures de l'époque sont réunis dans son personnage: les romans invitent à la rêverie, à l'adultère, ils détournent les femmes de la vie du ménage. Avec Emma Bovary, personnage qui condense tous les poncifs sur les dangers des romans, Flaubert joue ironiquement avec les interdits religieux et les peurs suscitées par la loi Falloux et la progression des lectrices au milieu du XIXe siècle. (Aragon, 2004: n.p.)

Madame Bovary becomes then the paradigm of "l'identification romanesque," as well as of a dissatisfaction that leads to reading as means to develop her imagination and her aspirations (Aragon, 2003: 642, 645), hence linking women's issues on freedom, power and desire with their reading and evidencing that, notwithstanding the manner of reading and how or with what aim that reading is portrayed, there is more to female reading that first meets the eye. Emma also signals the definite transition in the view of the quixote: from Don Quixote and the farcical laughter he triggered in the seventeenth century, to the defender of the "idéal inaccessible" with tragic consequences of the early nineteenth century (Aragon, 2003:667).

Applying this classification to eighteenth-century narrative fiction and drama written in English seems plausible under the light of the cultural and literary exchange mentioned early between France and Britain throughout this century. 
More specifically, applied to the wide corpus of texts which are object of the present study, one could conclude that the types of female readers throughout the long eighteenth century also respond to the pattern of the precieuse, especially in its variant of the mad virgin, together with that of the seduced and the endangered reader. Despite appearing less connected with quixotic literary delusion than with unfeminine pedantry, the learned ladies are also present in narrative fiction -and often in poetry, drama or non-fiction prose as a character which receives the satire of the author for their pedantry and their identification with those unsexed viragos denounced by Richard Polwhele. However, the circumscribed time frame proposed by Aragon, already questionable in French literature, is even more uncertain when transferred to the British setting. The ridiculous pedant, the mad virgin, the seduced reader, the endangered victim of sentiment, all coexist throughout the long eighteenth century, answering as well to the authors' different attitudes or responses to the political, social, cultural, and literary matters implied in the debate on women's reading. Therefore, as will be made evident throughout the present work, the image of the woman reader and of the female quixote is complex and rich. In this sense, the foundational quixote, Lennox's Arabella, is a perfect image of the mad virgin, innocent and lovable despite her folly. Nevertheless, her literary siblings do not always follow the same depiction of the woman reader, and hence create different female quixotes. The comic and the tragic interpretations of the woman reader are respectively present in early works such as Richard Steele's The Tender Husband (1705) and Jane Barker's "The History of Dorinda" (1726), or at the same time in works such as Hamilton's Memoirs of Modern Philosophers (1800), which also presents in Bridgetina and Julia examples of the intellectual and the sentimental quixotes, of the ridiculous pedant and the seduced reader, respectively. Several are also the examples of narrative fictions that introduce endangered readers of sentimental fiction: Elisabeth Sophia Tomlins's The Victim of Fancy (1787), Mary Hays's Emma Courtney (1796), Jane West's A Gossip's Story (1796), or even Jane Austen's Sense and Sensibility (1811). However, they are all very different in their portrayal and use of the quixotic myth. Although related to Aragon's categorization, they all present compelling views of the quixote that respond to very particular literary, political, social or even personal contexts. 
Another relevant taxonomy of female readers has been provided by Bray, who, analysing a corpus of British novels, has divided his study into five models of female readers which could be identified as, namely, the sympathetic reader, the self-centred reader, the critical reader, the struggling reader and the absorbed reader. While the boundaries between one type and another are mostly blurred, this classification again answers to how these female characters read and, in particular, how they respond to the texts and to other characters which they are required to interpret, and, in conclusion, how they relate to themselves and the world. By analysing a wide variety of texts which portray diverse female reading practices, Bray evinces that women's reading is more complex than was thought by the moralists of the age, and that is assumed to be by many scholars when approaching the representation of it in eighteenthcentury fiction.

In the first place, Bray reassesses the concept of sympathy as defined by David Hume in its relationship with reading practices and with the "easy communication of sentiments," the "coming out of oneself" and the ensuing identification with the literary hero or heroine which may have disastrous consequences for the reading characters. This sympathetic reading may be beneficial for the heroine, as in Charlotte Smith's early novels: reading brings comfort and a sense of community. Nevertheless, it can also result in an overidentification with fictional characters or events. Later in the century, this practice of sympathy becomes an increasingly fraught way of reading and one that under the subsequent development of the theory of sympathy by Adam Smith is defined as an "actor/spectator" model. As Bray has acknowledged, this later actor/spectator model "while potentially beneficial for the heroine if exploited skilfully, could also lead to a dangerous form of over-identification and a lack of both critical and moral judgement" (2009: 28). Therefore, the sympathetic reader, if not sufficiently critical or detached, runs the risk of an over-identification that leads to a quixotic approach to both text and reality. This sympathetic reader is introduced, for example, in Mary Brunton's SelfControl (1811), in which Julia identifies with the heroines of her readings and, literally, enacts their behaviour and speech. 
Secondly, Bray describes the self-centred, self-obsessed or responsive reader who cannot read critically, who cannot employ reason in combination with feeling. Within this group one can distinguish two models of self-centred female readers: those vain enough to transform everything they read into a comment on themselves and their emotions -all books talk about them, relate to their own experience: they see themselves as heroines and hence are qualified to act in the same way as those women they read about, so the distortion starts almost before the reading and is condoned by it- and those who immerse themselves in the text and adapt their own lives to what they are reading -they adopt the models of their reading in their understanding of themselves and the world, hence the direction of their literary delusion is the opposite to the previous model, it goes from literature to real life. In summary, while the former kind of reader forwards her emotions and relates to what she reads through her own self, the latter sympathises with her readings and tries to live out what she has read, sometimes consciously, others unconsciously. Both models are used by authors such as Mary Hays or Elisabeth Hamilton, for instance, to promote the need to encourage a more critical approach to reading, in which not only sensation but the intellect is engaged, as Wollstonecraft had famously propounded in her Vindication.

Thirdly, Bray expounds the existence of the frivolous reader, presented mostly in opposition to a more rigorous model of female reader, and states how the former one can be used by female authors both as a defence of a more critical model of female reading and as a stance of their own role as authors and literary critics. These frivolous women read not only in search for enhanced sensations, but also to be in fashion: books are therefore decorative objects, or elements to complete the "improvement" of a lady of fashion, rather than means for instruction or even well-understood and healthy empathy. Bray bases his analysis on Elisabeth Inchbald's fascinating heroine from A Simple Story, Miss Milner, and on how her uncritical reading somehow contributes to her fall, as well as on her daughter Matilda, whose sentimental reading, though more morally uplifting than her mother's, also lacks enough critical judgment to contribute to support her through her difficult circumstances. As Bray asserts, Inchbald does promote reading but encourages a critical approach to it: 
rather than reading voraciously and uncritically, she claims that readers should encounter the text with good sense and a will to profit from it by applying it to their own lives and hence learning from the experience of reading (2009: 98). Therefore, for Inchbald, rather than good or bad texts, healthy or poisonous readings, there exist critical or uncritical, healthy or sickly readers. The same attitude towards reading will be found in those quixotic narratives with more than one woman reader: in Tomlins's novel, or in Edgeworth's Belinda (1801) or Leonora (1806), the reading heroine is contrasted with a negative Other, the shallow woman reader.

The fourth model proposed by Bray is the female reader who struggles for interpretation in a more general sense. According to this scholar, female characters in eighteenth-century novels very often are subjected to fraught readings not only of printed texts, but also of human character. Although this is common to all female readers, as several critics have noted, the question of "reading" or interpretation is particularly important in genres such as the novel of manners or the female bildungsroman, in which the plot heavily depends on the process of illumination of a young girl at her time of entrance into the world regarding other characters and, by extension, her own self. Thus, returning to the previous classification of the forms of quixotism, although in some of these novels one encounters literal quixotes, more often than not one finds displaced ones: female readers that try to make sense of the world by means of systems of reference that prove inadequate because of their romanticised notions or their idealism in the abstract. Hence, the text they are struggling to read is not a printed one, but the world itself, and the instruments they employ to give meaning to their experience is not necessarily found in books, but finds roots in their own inexperience and their misconceptions about society and, more particularly, men. This reading of the world through a veil of romantic expectations or sheer idealism is already present in an embryonic form in Lennox, and will gain presence in quixotic fictions as the works of Edgeworth, Brunton or Austen link with the later nineteenth-century continuation of the quixotic tradition.

Finally, Bray describes the existence of what he calls "absorbed readers." Using Werth's theory of text worlds, Bray describes an absorbed reader as a 
"participant" that identifies with an "enactor" or character and hence believes that she is living in a "text world" (2009: 147). That is, the reader of the text draws parallels between the "discourse" or real world and the "text" one, something easily done because of the deictic quality of the latter, which necessarily refers to the former, and hence she can become immersed in fiction and identify with the character in the novel she is reading. Nevertheless, there are several degrees of absorption and the reader's grasp on reality may vary from full delusion to an escapist form of reading which never loses sight of the fictional nature of the text she is immersed in, what some scholars have interestingly termed an "appreciator," a reader who can become emotionally involved while not losing touch with reality (2009: 153). Therefore, although authors may encourage some form of interactivity with their readers, this does not imply a full immersion or a delusional detachment from reality, something made evident, for instance, in Jane Austen's novels and in her complex representation of a female reader in Northanger Abbey (1818).

Despite their little attention to quixotism per se, Aragon's and Bray's excellent work still provides a basis on which to explore the relationship of the female quixote with the texts she reads, which trigger her erred perception. In addition, they allow to establish what the author of the quixotic fiction envisioned for the awakening of his or her own implied readers. In novels that deal with female readers there are of course two layers to be dealt with, two parallelisms to be drawn: while the quixotic character constructs syllogisms between her reality and that of the books she reads, or between the discourse of history and that of romance, the real reader, the one holding the quixotic novel in her hands, may also construct the same syllogisms between her own world and the textual one, the one the quixotic character inhabits. Therefore, there exist worlds, and subworlds, in constant dialogue with each other, reaching for example even a third layer in novels such as Barrett's The Heroine, where the quixotic heroine reads Don Quixote: the reader reads about a deluded reader who also reads about a deluded reader, and both readers -although belonging to different worldsbecome wiser by their reading. The real reader, the real participant, is then confronted with a complex game of fictional mirrors in which his or her own reading experience is somehow portrayed through an equivalent enactor. 
Despite the fact that Cervantes' masterly metafictional narrative techniques are not equally developed in most of the novels object of this study, the metanarrative comment is implicit in the fact that the reader is reading a book on a reader that either cannot detach herself from her reading, cannot read critically and wisely, or cannot even distinguish between life and fiction, which is a risk the reading participant is taking as well, therefore highlighting the need to separate both life and fiction by means of the example provided by that mise en abyme that is quixotic fiction. Thereby, while conveying plausible and engaging reading characters and plots, authors never lose sight of the fictional nature of their work, nor allow the reader to do so. Nor do they permit female reading practice to remain uncommented or unchallenged.

It is in this dealing with the reader's response, with the didactic authority of the female narrator/author and with the message that the novel aims to convey that differences will be found among the numerous quixotic novels produced throughout the eighteenth-century. In order to systematically analyse the various female quixotes that constitute the corpus of this study, and to understand the complexity of the trope of the quixotic woman reader, it is essential to keep three aspects in mind. First, what they read -fiction, nonfiction, or no literal text at all- in order to identify the flawed systems of reference with which they try to make sense of their experience as readers and as human beings and, therefore, to classify them as literary, ideological or displaced quixotes, the latter not readers in a literal sense, but rather flawed idealistic interpreters. This will also allow a comment to be made on the different forms of fiction and on the choice of genre by the author. Secondly, how they read, what their response to those sources is. This intradiegetic response will provide the mirror for the implied reader's own response to the same sources the quixote peruses, or, more importantly, to the quixotic work of fiction itself. Moreover, the how becomes essential to understand what the quixotic novel reveals about the female reader's education in general and her training in critical thinking in particular. All of the abovementioned models of female reader response, as well as those described by Aragon, have in common that these female readers lack critical judgment in their approach to reading and often adopt erroneous systems of reference to make sense of literature and, by 
analogy, of life. Hence, while the authors that create these women readers may condemn one particular genre more than another (philosophical tracts, romances, amatory fiction, etc.), they agree on the criticism to the limited intellectual resources that women are provided with when needing to confront their reading. Relating again to the contemporary debate on the nature of women, this limited reasoning could be perceived as genetic or as cultural, and, consequently, the solution would be different: either a very limited range of reading and a strict male supervision, or a better education, particularly in rational thinking. The great majority of women writers defended the latter option, for what use would be to write a novel that provided a proper model of female reading if behaviour could not be modified by a rational perusal of that same novel? Finally, it is important to consider why or what for they read; in other words, are they seeking enlightenment or sensation, instruction or power? Are they subversive or compliant readers and, hence, women? Depending on the characters' aim, so will the author's cure to their misreading develop and so will the consequences it triggers both for them and for the surrounding characters also vary, ranging from clearly conservative and patriarchal endings or to more ambiguous and subversive conclusions. That is, the way to convey their character's education through the novel and the degree in which the message of resistance or of acceptance should be ingrained in the reader's mind varied from one author to another. As a result, the sympathy or the ridicule to which their characters were subjected, or the happy or tragic ending they were granted, also diverged from one novel to another, depending on whether the quixotic reading was perceived as a youthful foible easily re-educated or a dangerous recreation. This aspect, of course, is also linked to how the novel related to the predominant patriarchal plots and to the subversive or compliant message that it tried to convey. It then leads to the question of how disruptively unfeminine the quixote becomes, how far she goes in her abandonment of domesticity and in stepping out of the traditional roles assigned to women and, as a consequence, if she can be allowed to return to a proper role at the end or not. Finally, it also relates to the narratorial and moral authority held by the novelist: in the particular case of women writers, to their claim to moral authority as didactic writers, and to their right to authorship and visibility, despite their gender. 
The present work will then classify the female quixotes of eighteenth-century narrative fiction taking into account these three elements, what, how and what for they read. These three elements will allow to place the female quixotes within the three contexts provided so far: the generic debate of their time, of which the quixotic authors in the previous chapter also partook; the discussion on women readers and, consequently, the need for literature to be didactic, to be an awakening call for its implied readership; and, finally, the empowerment women found through literature, whether as quixotic writers or quixotic readers. These elements will thus permit to explore the rich ways in which the quixotic myth is adapted and employed in those narratives featuring a woman reader. 



\section{EARLY QUIXOTES IN PETTICOATS: ANTECEDENTS TO THE FEMALE QUIXOTE}

[...] I wish'd sometimes to be of Don Quixote's Sentiments, that I might take the Tops of Chimneys, for Bodies of Trees; and the rising Smoke for Branches; the Gutters of Houses, for Tarras-Walks; and the Roofs for stupendous Rocks and Mountains.

Jane Barker, A Patchwork Screen for the Ladies, 67

Despite the fact that many scholarly works dealing with the matter of female quixotism place the cornerstone of its tradition in Britain -and abroad- in the publication in 1752 of Charlotte Lennox's The Female Quixote, and although Lennox's masterpiece is indeed essential to understand the rich presence of female quixotes in long-eighteenth century Britain, the truth is that the tradition of female quixotism, with its common places and milestones, started much earlier, a century before Lennox's novel.

As has been mentioned in passing in the previous chapter, in 1614 sir Thomas Overbury's Characters were published posthumously. Included in this book of satirical portraits was a reference to a female quixote: a chambermaid that becomes obsessed with her reading of romance. This stereotype of a maid "reads Greenes works over and over, but is so carried away with the Mirror of Knighthood, she is many times resolv'd to runne out of her selfe (sic), and become a lady errant" (1856: 101). That is, only ten years after the publication of the first part of Cervantes' masterpiece, only three after the first English translation, and without even time to read the second one, British authors were already starting to satirise the image of the female romance reader by means of the quixotic formula: a reader who becomes obsessed with romances and believes she can live out the adventures she so admires. The pattern is reproduced with not much alteration, in the fashion of the more shallow and burlesque reading of the character of Don Quixote in the novel's early reception in Britain. Although later instances of female quixotism will develop 
a more complex representation of the quixotic character, the critique to romance as a genre and to the figure of the female romance reader that Overbury presents already announces some of the common places that will subsequently be introduced in many of the works dealing with female quixotes. In the context of Overbury's portrayal of the maid as an idle, imaginative, lovefocused and impudent creature who is in close relationship with her master and mistress, the critique to romance can be interpreted as doubly aimed: not only is it directed towards its perniciousness for the propriety of women, who, notwithstanding their social level, should not fantasise about wandering through the country on their own, but also towards its exaltation of aristocratic values and the breaking of class boundaries that would come from a chambermaid acting above her station or even abandoning her duties to obsessively peruse romances. In this sense, it is interesting to note, moreover, that this particular chambermaid reads romances not focused on the female experience of courtship, but rather on the more male-oriented narration of knight-errantry. Consequently, her claim would be not to become a court Lady but a knight-errant, joining therefore in a very conspicuous way those two crossings of boundaries, gender and class. ${ }^{90}$ As a consequence, the satire directed to the female reader is also dual: on the one hand, she abandons her station in life as woman, and, on the other, as maid. In both cases, the danger is that she will forget her duty as the container of virtue and as a servant. As happened with Stevens's sketch of the debating lady, the fact that such a portrait of a female romance reader is included in a book of well-known satirical types would mean that it was not uncommon to find that kind of satire directed towards women readers, a fact that makes sense in the seventeenthcentury debate on female literacy. What is more, this reference to deluded reading is included within an unflattering portrayal of a licentious and frivolous maid, hence adding the charge of quixotic romance reading to other stereotypical bad qualities and reinforcing what will become the traditional association of low classes, and particularly women, with gullible or over-

${ }^{90}$ Although later criticism will focus particularly on the form of heroic or amatory romance which portrays a woman at its core, the reading of chivalric romances focused on the figure of the knight-errant by women is not uncommon. Scholars such as Pedro M. Cátedra, for example, state that "la importancia de la lectura femenina de los libros de caballería es lo que desencadena una buena parte de las censuras de los mismos por parte de los moralistas, desde Juan Luis Vives" (2007: 45). 
imaginative romance reading (Grenby, 2001). Even if one assumes, as some scholars have done, that a maid could not afford Greene's Pandosto or other chivalric texts such as The Mirror, and that she borrowed her lady's or master's books, this harsh criticism still evinces the social boundaries that were established using literary taste, and that a satirical comment on romance could be thus executed by its association with a certain class (Davis, 2003: 26). ${ }^{91}$ By linking romance with the lower classes and by satirising both, Overbury could discredit this genre and reinforce the dangers its perusal would have for upperclass readers, whose taste would moreover equal that of their servants.

In addition, even in this rather laconic reference, there is an implicit attack on the figure of the woman writer as well. While Greene's works are many, it is a work by another author, the Mirror, which triggers her quixotism; a fact emphasised by the use of "but" in the above cited quotation: the maid obsessively reads Greene, but it is the Mirror which finally triggers her wish to wander as a knight. Of course, it is no coincidence that this particular book was a well-known translation by a woman writer. Written by Margaret Tyler, The Mirrour of Princely Deeds and Knighthood (1578) is a translation of Diego Ortuñez de Calahorra's Spanish romance Espeio de principes y cavalleros (1555). In her preface, Tyler acknowledges to have been a servant in a wealthy household, as well as an early reader of romances (Krontiris, 1988: 19). This translation is not only the first to be performed of a Spanish romance into English, but also the first attempt by a female author to reproductively write a romance. After Tyler, readers would have to wait for Mary Wroth's Urania (1621) to have a productive attempt at romance by a woman, and a very successful one for that matter. Although not a creative task, Tyler's choice is still relevant: she decides to translate a chivalric romance "at a time when other English women writers mainly translated religious works (conforming to the notion that female education should promote pious living) and when treatises

${ }^{91}$ Davis states that "inevitably, one comes to suspect that identifications of this sort are more concerned with a sort of cultural policing, sketching artistic preferences in an attempt to delineate social boundaries, than any real attempt to represent the sorts of people that read romances. That is not to say that chambermaids never read The Mirror of Knighthood; they may well have done so. But comments such as Overbury's ought not lead us to discount the possibility that her mistress -and, quite plausibly, her mistress' husband- were reading it too" (2003: 27). Of course, taken at face value, these identifications are suspicious of gross exaggeration or of a biased description; however, it is that partiality which proves relevant for the literary and social comment hidden behind the satirical sketch of a romance reading maid. 
and handbooks on education stressed the dangers of allowing eager female students to read foreign tales of love and chivalry" (Uman and Bistué, 2007: 298). She strongly defends her election, criticising in her forward and witty preface ("Epistle to the reader") that women were maybe allowed to read romance, but not to study it, and states women's right to pen stories and translations (Schleiner, 1994: 22). ${ }^{92}$ In addition, she chooses Ortuñez's romance, which has been amply recognized as a text that challenges many conventions regarding women and that portrays appealing settings for a relative female freedom and power. ${ }^{93}$ In conclusion, by connecting his romancereading chambermaid with Tyler, a romance-writing servant, through a subversive chivalric text, Overbury cleverly fosters the association of romance both with lower classes and women, and emphasises the dangers of allowing the latter to be at both sides of the literary market, as authors and consumers.

Despite the interest of such an early appearance of a female quixote in literature written in English, the presence of the deluded female reader is merely anecdotic, if only because of the briefness of its presence. In order to provide a basis for the subsequent analysis of Lennox's masterpiece and the novels that sprung after her example, this chapter will consider three more relevant sources for her later portrayal of Arabella and for the foundation of a canon of female quixotes: first, two already acknowledged plausible literary models for Lennox, Subligny's Mock-Clelia and Steele's play The Tender Husband, ${ }^{94}$ and then a work heretofore not studied under the light of her connection to Lennox, Jane Barker's "The History of Dorinda."

\footnotetext{
${ }^{92}$ For a thorough comment on Tyler's preface, her defence of the woman writer and romance as space for rebellion see Krontiris (1988) and Oppositional Voices. Women as Writers and Translators of Literature in the English Renaissance (London, New York: Routledge, 1992).

${ }^{93}$ On the undermining of sixteenth-century ideology and cultural practice concerning women which existed in the original text and was approvingly preserved by Tyler see, once again, Krontiris (1992) and Schleiner (1994).

${ }^{94}$ Subligny's work is mentioned as a source for some of the episodes in The Female Quixote by Dalziel (1973: xvi), Doody (1989: xxiii), and Looser (2000: 107). Steele's play is said to be a likely literary model for Lennox, for instance, by Kenny (1972: 201) or Doody (1989: xxiv).
} 
In the seventeenth century, the relevance given to the figure of the female quixote seemed to increase and her place from a minor character to a main one gradually took place, although, as happened in the case of male quixotes, France seemed to be more productive in its early reception and appropriation of Cervantes' character than Britain. At this time, the influence of works of fiction imported from France is strongly felt and a relevant female quixote appears in the British literary panorama in the shape of a translation from the French: Mock-Clelia, or Madam Quixote, being a Comical History of French Gallantries and Novels, in imitation of Dom Quixote (1678), originally written by Adrien Thomas Perdoux de Subligny in 1670 under the title La Fause Clélie. Histoires françaises galantes et comiques. Despite the absence of an explicit reference to Don Quixote in its French title, the translator made that connection evident in the English name, which transforms it perhaps in the first overt reference to a female quixote and hence in one of the landmarks for later authors. From its very title, the translator has pointed at what will be the aim of the author: to mock the ten-volume Clélie, Histoire Romaine (1654-61), the famous historic romance set in fifth-century Rome written by the equally famous Madeleine de Scudéry, and to do so "in imitation of Dom Quixote," openly avowing Subligny's source of inspiration as later Fielding would do.

The novel presents a group of noblemen and women who tell each other short stories, identified because of their subject matter as amatory novellas, and the structure of the whole work then reminds more of Bocaccio than the actual narration of Don Quixote's adventures. ${ }^{95}$ Whereas the interspersed stories had less relevance to the whole of the narrative than the account of the quixotic adventures in Cervantes' work, in Mock-Clelia the short stories gain weight and take over the quixotic narrative. Nevertheless, the story of the false Clelia does frame the narration and provide unity to the whole novel. This false Clelia of the title is Maidemoiselle Juliette d' Arvianne. Young and beautiful, she

\footnotetext{
${ }^{95}$ Sánchez Tallafigo more graphically describes this work as a "Decamerón portátil,
} galante y novelesco de historias breves de tono picante" (2006: 122). 
attracts the attention of the Marquis of Riberville at Vaux. At the approach of a young gentleman, the lady screams he is come to ravish her and flees. After the Marquis's search for her she is found hidden in his home and he perceives her mental disorder when she proclaims to be Clelia herself. Enamoured and willing to discover the lady's identity, the Marquis listens to the story of her life told by the very same man who was her alleged ravisher; in fact, the Count of Sarbedat, a cousin who wished to marry her. As the novel unfolds, interspersed with the stories the gentlemen and ladies tell, Juliette's madness leads her in turns to very comic and very dangerous situations, in which the Marquis acts the role of hero.

In the few passages devoted to his Madame Quixote, Subligny already establishes some important foundations for what would be the subsequent tradition of British female quixotes. The first and most emphasised aspect is that the genre that has caused Juliette's distemper is heroic romance, and, more particularly, Scudéry’s Clélie:

She was about that time a Maid of fourteen years old, one of the most charming persons in the World. They came afterward to Paris, where she read Clelia; and as she read it, Monsieur de Scuderi, ${ }^{96}$ said she a hundred times, hath foretold in this Romance, the Adventures that I should meet with. She could not forbear to admire that surprizing resemblance between the Adventures of Clelia and her own; for two years together she perused them day and night; during which time her Lord left her not without other pastimes. (1678: 22-23)

The reading of Scudéry's work becomes an obsession, which, as happened to Don Quixote, takes over her days and nights. However, her prospect of marriage and the "magnificent and great Treats" (1678: 23) which her Lord bestows on her for a time seem to prevent her becoming completely absorbed. It will not be until she falls ill with a fever after her marriage is averted that her madness will appear; her cousin explains that "a Fever supervening so discomposed her mind, as by little and little she came at length to imagine her self to be Clelia" (1678: 24). When the Marquis asks for her name, Juliette replies:

\footnotetext{
${ }^{96}$ Madeleine de Scudéry sometimes wrote under her brother George's name; as a
} consequence, the author of her romances is very often gendered male. 
Know generous Stranger, that I am Daughter to the valiant Clelius, who was forced to fly to Carthage, thereby to avoid the fury of the last of Tarquins, and who upon his return contributed so much to the liberty of Rome. My Name is Clelia, and my Actions are so famous, that none but they who live in the most distant Countreys can be ignorant of them. (1678: 11)

When the Marquis pleads to hear her story, she recounts the events found in Scudéry's romance in thorough detail. Employing Bray's terminology (2009), she has become the most extreme absorbed reader. Juliette has shifted from being read by the text, to reading herself in it, in an understandable delusion: assuming another name, another personality, another life, once again resembles Alonso Quijano's change of identity for a more glorious one, and it provides Juliette with a story of fame and love now denied to her. Instead of dead parents and a fiancé who abandons her in her madness, hers is a story of glory and adventure which gives meaning to her life of suffering.

Although aided by her melancholic disposition and the fever, romance has then become that dangerous poison which can cloud a youth's judgment. As Aragon has asserted, Juliette is a good example of a vierge folle: "elle est 'entêtée' du roman $[\ldots]$ et son cas deviant pathologique, elle est surveillée, soignée car sans cesse, elle rechute et pense vivre les aventures de Clélie" (2004: n.p.). This pathology is suffered by other heroines of the time, and is described by Aragon as the malady of a "visionary:" 97

Juliette, elle, a mordu dans la pomme de La Clélie et elle est condamnée á la folie, elle est visionnaire, chimérique: elle alterne périodes d'excitation et d'apathie. Cette schizophrénie, que les contemporains reconnaissent comme la pathologie de la "visionnaire" est bien connue à l'époque, alors que les maisons d'internement se mettent en place. (2004: n.p.) ${ }^{98}$

Despite the description of her quixotism as a pathology, in clear imitation of Don Quixote's circumscribed madness, Juliette's delusion is only triggered by those words, scenes, characters or events which remind her of her favourite

${ }^{97}$ Another example would be Antoine Furetière's Le Roman bourgeois (1666) and his heroine, Javotte, a deluded female romance reader who believes herself a heroine and the seductor Pancrace a hero after reading L'Astrée. For a more thorough analysis of other works of this period with a mad female romance reader as protagonist, see Aragon (2003).

${ }^{98}$ For a more detailed account on the conception of the mad as visionary and of the treatment they received at this time in history, see Foucault's Histoire de la folie à l'âge classique (1972), chapter 2. 
romance and can subside if the source of her delusion is not mentioned or in sight. Her cousin explains that her distemper never holds her "above ten or twelve hours, and then for two days space there appears not the least alteration in her kind; she is as rational as any other, sings divinely, and is full of charms in conversation" (1678: 14); however, "do but speak to her of the Romans, or let her but see any object that may revive her fancies, she falls immediately again into extravagancy" (1678: 25). A relevant example of her interspersed distempered imagination happens during their visit to Fontainebleau. At the sight of the King's troops camped there, Juliette's fits return because their tents "being made in the same manner as the Roman Tents are painted, [...] afforded new matter to the Imagination of Clelia to work upon, who without strict examination of the comparisons she made, took the Camp for that of King Porsenna, where she was detained as Hostage" (1678: 267). Although the Marquis achieves to distract her with different amusements,

[...] he could not hinder but that the sight of the Tents, which resembled still the engraven Tents in the Romance of Clelia, revived again her former imagination that she was kept in hostage, and that taking an opportunity to save her self, [...] rode at full speed towards the Canal which she took for the Tyber, and whereinto she threw her self, that she might swim over in imitation of Clelia whom she believed her self to be. (1678: 268)

This passage, which will be later reproduced in Lennox's novel and more jocularly in Barrett's, evidences that Juliette's delusion is also an active one, not merely focused on understanding the events of her past, but also searching to replicate the heroic acts of the woman she believes to be.

Once her "fits" of madness are over, she acts and reasons as any other person of her acquaintance, she can charm her company again and even become once more a suitable object of adoration for the Marquis:

The indisposed Beauty was now come to her self again, and fully settled; [...] she received them with so much civility, and so composed a mind, that no body could judge her subject to the extravagancy that she commonly fell into. The Ladies were no less surprised with her Beauty, than the Marquess had been, and confessed they had never seen so much sweetness in a Face, such charms in a Mouth, nor so much grace in the actions and behaviour of any Lady. The Marquess considered her more than all the rest, and felt the same flame that the first sight of her had kindled in his heart, again revived; though the knowledge of her Distemper had almost stifled it. (1678: 51-52) 
The Marquis's fluctuating passion proves that this intermittent malady may thwart the chances of love, courtship and, eventually, marriage of an otherwise perfectly eligible and rational girl. The episodic nature of her delusion leads her to be called the "witty indisposed Lady" (1678: 56), uniting in her both reason and madness. The idea that Juliette is a rational being is stressed by the uncommon fact that she is aware of her quixotic malady and she is conscious of the follies she commits during her fits; at one point she is ashamed to look at the Marquis because "she knew that he had been a witness of her last Fit and remembred (sic) very well everything that had passed between them" (1678: 52). The Count explains that her malady is a form of melancholy proceeding from the "reflexion she makes of her misfortune," "for she is very sensible of it, and that is the thing that troubles her most, and the most singular symptom of her Distemper" (1678: 14). This, of course, emphasises the idea that it is indeed a condition that Juliette cannot prevent, a form of literary schizophrenia which she must suffer to continue as long as elements of real life resemble those found in fiction.

In this line, her interspersed delusion is somehow excused not only by the difficult situation in which her madness appeared, but also by those same striking resemblances found between Juliette's and Clelia's stories. The epistemological effort needed to accommodate Juliette's life to the patterns of romance is hence much less than was required in Don Quixote's claim to romantic heroism. Essential then is the construction by the author of a conventional romantic characterization and plot for his female quixote. Firstly, there is a displacement in age in the quixote, from the old Spanish knight to a young lady. In addition, Juliette is a wealthy, noble and extremely beautiful woman, a "ravishing Beauty" described in the fashion of romances: "she had a Majestick Presence, an incomparable Neck, and the Face of an Angel; which surprised the Marquess, having never before beheld so charming an Object" (1678: 2). Juliette also behaves in the manner of a true heroine, as a silent and unattainable object that darts "languishing looks" and answers "only in sighs" (1678: 2,3). Consequently, there is a romantic transformation of the quixotic figure into a heroine who embodies the attributes of the romantic love object. This romantic conception of the quixote will be subsequently adopted by 
Lennox and by most of her later imitators, who will portray young, innocent and well-established girls in their quixotic narratives. Secondly, as part of this romantic transformation, there is also a romantic hero, in this case the Marquis. At his first encounter, he foretells the meeting "presages an Adventure of consequence" (1678: 2), and behaves as a hero would do, falling into fits of rapture at her beauty and of jealousy at her ravishments, persecuting Juliette's alleged kidnappers throughout the novel. After Juliette's first disappearance, the narrator identifies him as a romantic hero, stating "he had too bravely begun the Evening, not to play the Hero of Romance" (1678: 5), and calling him "the poor Knight errant" (1678: 6). What is more, there do exist rivals to the love of the fair one, among them her cousin, the Count. When he recounts his cousin's story, he asserts: "I must trace a little back the History of the Father of my Heroine, I call her so, said he, smiling, because she has made me act the part of a Romance-Squire with you" (1678: 18). Thus, while acknowledging the resemblance of Juliette to the heroines of romance, he also admits the role both men are playing in her fictional reading of the world. Moreover, as will be made clear in his story of Juliette's disgrace, he acted the part of a romantic villain, carrying her away on the day of her wedding. Therefore, when Juliette begs the Marquis to rescue her from her ravisher, her claim works on two levels: the literary and the real, the metadiegetical layer of Scudéry's romance and the diegetical one of the quixotic novel. Finally, as Juliette's story is being told, the similarities with Clelia's, and hence its romantic scaffolding, are highlighted by both the Marquis and the Count. At the adoption of a poor unclaimed boy by her father, the Marquis exclaims: "There is Clelius indeed" (1678: 19). Later, when the required moment of revelation arrives, that is, the cognitio scene so recurrent in romance in which this boy is discovered to be the son of an English nobleman, hence removing the obstacles to his marriage with Juliette, the Count states that "here is again a subject of application for our Clelia" (1678: 21), and that "she was a real Clelia, that saw her Aronce owned to be the Son of King Porsenna" (1678: 22). On the day that Juliette must marry her lover, an earthquake occurs to prevent the wedding; in the Count's words, yet "another strange resemblance to the Romance of Clelia" (1678: 23). The Count finally avows his full participation in the writing of the real life romance that Juliette experiences, stating that "the 
Adventure of that Lady might in all respects resemble that of the Roman Clelia, my jealousie (sic) led me at the very hour of that disorder [the earthquake], towards the Countrey (sic) house where the Wedding was to be held, that I might endeavour to carry away Juliette" (1678: 23). This abduction is the cause of Juliette's fever, her subsequent madness and the loss of her lover.

As a consequence of those parallelisms between Juliette's reality and the text world of Clelia, it is plausible, and to certain extent logic, that she may draw the comparison between the heroine's situation to her own. As the Marquis states, "she has reason in the comparison, if she have none in the application" (1678: 19). That is, Juliette's mistake is to continue to apply the patterns of romance to reality and to try to imitate literature in other aspects of her life. However, the relationship between romance and reality is a complex and fraught one; once Juliette has established that romance describes the same events she has experienced -the lost and found son, the long awaited wedding hindered by a natural disaster and her own abduction-, and that it moreover does so in the profuse and often verisimilar detail which romances offer, her delusion simply applies the formula backwards: instead of fiction aiming to verisimilarly reproduce or imitate life, it will be her life that will imitate romance. If, in accordance to Northrop Frye's terminology, there has been a displacement of Scudéry, in which "the imagination has to adapt its formulaic units to the demands of that world, to produce what Aristotle calls the probable impossibility" (1976: 36), then Juliette reverses that displacement and hence her imagination adapts her reality to the demands of literature, or, in other words, her imagination adjusts the world of the senses or of experience to the literary one, interpreting what she sees by means of the system of reference found in romance.

This raises questions on the dangers of romance, on the plausibility of its plots and the verisimilitude of its form. Within the Count's story -the narrative within the narrative-, in order to strengthen the truth of his narration he asserts that "there is nothing of Romance in what I am about to tell you" (1678: 19). Hence, Juliette's extraordinary life story, so often compared to Clelia, is distinguished from romance, from fiction, from what is not true. It may resemble romance, but it is reality; therefore, the discourse or real world of the 
characters must remain separate from the text world of romances, though ironically stressing how much they have in common and how the latter refers to the former. This subtle device of verisimilitude, actually working in both directions (Clelia and Mock-Clelia) is even more dangerous for young female readers. If Juliette had not been able to read her own story in the romance, she might not have employed it in order to later mould her behaviour on its premises. Nevertheless, she would have still been exposed to the risk of mistaking what she read for the truth, owing more than to the content matter, to the form in which it was presented. As Ballaster asserted, the aim of seventeenth-century French romance was to achieve vraisemblance, or truth to nature (1992: 43), for which they engaged in long and meticulous descriptions of geographical locations, historical events or characters, mixing fact and fiction in such a convincing way that History and Romance were blurred for the uncritical, uneducated-or deluded-readers. Hence, as stated before, it was the fact that spurious invention and implausible events were intended to be portrayed in a verisimilar manner and not to be acknowledged as fiction, which alerted moralists to the dangers of romance and which will be amply attacked by means of quixotic fictions. While in Subligny's work, as will be in Lennox's, this attack is complicated by the similarities of their own characterization and plots with romances, other authors will develop more straightforward burlesques in the train of Cervantes, which expose the chasm between the character's romanticising and the reality that she experiences.

These considerations are, of course, further complicated as one leaves the subworlds of reality and fiction at the characters' level and enters the worlds of reality and fiction belonging to the author and the readers. According to Aragon, "les romans comiques se plaisent à jouer avec les personages de lectrices, bergère extravagante ou romaine, à la suite d'une identification Romanesque trop puossée. Ils reprennent les grand succès du siècle qu'ils parodient, ils prétendent ainsi dénouncer l'illusion romanesque" (emphasis added, 2004: n.p.). Despite the claim to this critique of romantic illusion, Subligny himself is writing a romance, Juliette's story, and within that frame 
he also presents several shorter romances. ${ }^{99}$ He conspicuously names his creation a "Romance" and, moreover, provides in his preface some clues as to what he criticises of this genre and what his intention might have been in writing his Mock-Clelia and in creating a female quixote deluded by romance. His aim seems to be to attack the venom of "scudérisme" which affects both French social and cultural life, and in particular its excesses of verbal pompousness and its flagrant transgressions of the historical frame (Sánchez Tallafigo, 2006: 121). In the preface, the statement is made that this particular work intends to be something different to the already existing romances and to those still being written in France under the auspice of this scudérisme. The author asserts,

It remains now that I speak to the new way of writing which may seem to be introduced by me. There was but few before me who thought upon giving French names to their Hero's. And it is to be feared that some Romantick heads finding the name of a Marquess of Riberville, Mirestain, Franlieu, and others, instead of that of a Tyridates or Cleantes, will at first commence an action against my Book. But I beg pardon of these nice and delicate Wits, if I make not, to comply with their humour, those whom I intend for French Gallants, Grecians or Arabians. I am a plain man and give everything its true name. (emphasis added, 1678: n.p.)

In his statement, it is highlighted that there is a trend which abandons the historical romance, set in far-away lands and peopled by exotic heroes and heroines, and which brings romance much closer to home. This "half-way house of fiction" (Williamson, 1984), this romance displaced from past to present in which the boundaries of romance and novel blur, which revolves around amatory plots and which will become a recognizable influence in Behn, Manley and Haywood, presents characters closer to the reader's experience, easier to recognise and to relate to. What is more, the last sentence, in which the author claims to give everything "its true name" becomes especially relevant as an assertion of authenticity in contrast to the remote heroic romances. This avowal becomes more poignant in the following paragraph:

I add my humble Petition to those whose names may have any conformitie (sic) with these which I have invented, that they would not think I had design

99 The fact that the stories are called "novels" and that the word is used in the title, only indicates its literal translation from the French nouvelle. As stated before, the term "novel" to refer to a new species of writing different from romance will appear later. 
in it. They will easily see by the small resemblance that is to be found betwixt their adventures and those of my stories, that it hath been rather chance than intention. And let the worst come to the worst, I bring no Gallants on the stage but for their own advantage. (1678: n.p.)

The need to disclaim similarities with real-life people's "adventures" in advance does point to the fact that these stories do actually resemble those amorous intrigues and adventures known to take place among the nobility. The author's irony in his rejection of "intention" and his defence of "chance" as the cause for any similarities indicates that his work has a certain proximity to a roman á clef and that the events retold are echoes of those which may have occurred in reality. There exists, therefore, a claim to greater plausibility in the stories because they are inspired by those "French gallants," which receive their "true name" rather than remaining hidden under foreign references. Moreover, these comic romances do not always bring the Gallants on stage for their own advantage: the heroes and heroines of these stories are far from being the high moral exempla of heroic romances. They are not ideal characters, nor do they act in accordance with high principles; the gallants they resemble and the adventures they live are far from following the tenants of heroic courtly love.

In relation to the desire to achieve vraisemblance, in the preface the author also disclaims the intention to provide the long and exhaustive descriptions of Scudéry's work. He states that "there may be found perhaps in the management of the Romance, some kind of little punctilio's omitted. I may appear a bad Geographer in it, as to the Neighbourhood and Precincts of Paris, and a worse Chronologer as to the order of time. But in regard that is not the thing at which I aim'd" (1678: n.p.). His descriptions of Vaux or Fontainebleau are not thorough, but neither are they required to be for they are places existing in the reader's own world and close to his or her experience, and they have moreover received their "true name." In contrast, there is an implicit critique to the fact that Scudéry provides wrong references to the discourse or real world of her readers. This is made obvious in the abovementioned episode at Fontainebleau. Juliette recognises the tents as Roman because of the description offered in her romance; however, Scudéry's description of the Roman tents was most 
probably inspired by the sight of the French ones. Once again, Juliette reverses Scudéry's displacement and sees the French as imitating the true Roman ones, hence triggering her fit and leading her to mistake the Canal for the Tyber, once again confusing the probable source of the author's inspiration with its fictional conversion. Therefore, there is an implied critique to the vogue of representing true landscapes, and by analogy, people, as different countries or characters, a characteristic which becomes the source of delusion for young Juliette. In this sense, Juliette need not travel as far as Rome to identify the Count as a Roman ravisher, she might just read him as what he is: an impudent French rogue.

Nonetheless, Rome and contemporary France are presented in a closer connection than could be suspected. Early in the book, the Count had complained that "perhaps if no body should ever speak to her of Rome or the Romans, her Cure might be more easie (sic)" (1678: 14). However, people do speak of Rome because classical example or authority needs to be quoted in order to sustain an argument. Speaking on female constancy, an old male Judge, in order to illustrate his point, states that "Lucretia was the most steadfast Lady of Rome, and yet she yielded before she killed herself' (1678: 178). Juliette, "who heard ill spoken of Lucretia, took up the cudgels and told him, that he ought not to injure the reputation of that Roman Lady, and that in good earnest he was mistaken; for the poor young Lady was by degrees falling again into her Fits" (1678: 178). The Judge, who does not perceive her madness, maintains that she killed herself because she "granted what was desired from her" (1678: 179), in reference to her virginity. Juliette eagerly contends the falseness of his accusations until the Judge "began to be vexed, thinking she designed to make him ridiculous" (1678: 179). Therefore, he aims to conclude the debate by resourcing to ancient authority and the following exchange ensues:

He told her [...] that in Titus Livius, and in all the other Historians, who had spoken of that Roman Lady, what he said appear'd upon record; but she made him answer, That Titus Livius, and the rest lyed, and as he was about to open his mouth to say something, Go, go, said she, all in a rage; that is an infamous Calumny, and no body but an old corrupted Senator like your self, who hath always been in the Faction of the Kings, and is an enemy to the Liberty of 
People, would have in that manner dishonoured the memory of Chastity it self. (1678: 179)

The narrator continues to inform the readers that, although "there was ground enough to suspect, that she who made such reproaches, had not her wits in a right frame" (1678: 179), the Judge was incapable of perceiving so. Instead, he starts to construct parallels between what Juliette has accused him of and contemporary events in which he has participated. He starts to imagine that "she upbraided him for having been loyal to the King, during the Siege of Paris, whereas the melancholick (sic) Lady took him for a Roman Senator" (1678: 180), and therefore answers transforming the referent from a literary to a real one, telling Juliette "that he did not at all repent his being against the Rebels, and that he would be a Servant to the King to his last breath" (1678: 180). This confusion redoubles the laughter of the company, which sends the Judge into a rage and he storms out of the house. In this scene, Subligny seems concerned with "recognizing the romances' relationship to French contemporary life" and their contemporary significance (Doody, 1989: xxiii) in the midst of the contemporary ancient versus modern conflict on authority and its reflection in the gendered debate on history and romance. Although Subligny's final message seems to be to undermine the feminocentric reading of history through romance by the jocularity of the scene and the madness that triggers such a reading, nevertheless, the attempt to accommodate history once more within a patriarchal reading is not perfectly achieved, for the male judge of history proves incapable of dialoguing with Juliette. His discourse is monolithically fixed by his recourse to classical authority and cannot incorporate any divergent point of view nor admit to his sexualized reading of history. In the face of Juliette's resisting reading of history, he leaves in anger and is perceived as defeated in the discussion. The representative of the ancients in the debate departs, and the representative of a new system of interpretation allegedly remains: the monological discourse is then contended by the subversive female romantic discourse. ${ }^{100}$ Neither Juliette nor the

${ }^{100}$ According to Aragon (2004), Subligny, Furetiére and other representatives of the anti-romanesque literature of this time intend to criticise romantic illusion by addressing a male and classically-educated audience, defending the value of the classics in the face of the "literature mondaine," and by consequence, they "interdire l'accès à la lecture aux jouvencelles 
gentleman can distinguish history from romance in their conversation because the referents appear to them the same but they are not: the talk of kings, of the liberty of people, relate to contemporary issues and to the facts of romance which in disguise relate to the same kind of events. The similarity of the language of history and romance therefore raises questions as to the veracity of both, and this debate on the gendered reading of these genres and the resisting reading of the patriarchal truth of historical accounts will be recurrently addressed by means of female quixotic fictions. As previous studies have evidenced, this passage, with all its implications, would have its more elaborated and profound replica in Arabella's discussions on historical female figures (Doody, 1989: xxiii; Looser, 2000: 107-108), and will even find its echo in Austen's Northanger Abbey.

In conclusion, a close examination of Subligny's work undermines the statement that he merely aimed to create a parody of Scudéry's work and an attack on the "folie Romanesque." Firstly, criticism to these forms of historic romance is moderated because of Juliette's illness, for her quixotism is always described as a distemper caused by a fever, that is, with a medical explanation, rather than as a whim that can be cured by a fever and a close-to-death experience, as will be the case with later female quixotes; what is to say, that only highly deluded readers could mistake fiction and reality. One could assume that Subligny was addressing female readers, for those "Romantick heads" which so ardently read heroic romances would in all probability be mostly female, and these romance readers would more easily acknowledge the references to Scudéry's original source or would more probably identify with the heroines of their readings, according to the belief of the age. However, the fact that Juliette is described as medically mad undermines the possible moral for young female readers and does not allow a comment on reading practices or on the use of literature to wilfully shape reality. Secondly, and more relevantly, Subligny's parodic intention is undercut not only because of Juliette's similarity to the literary Clelia (Doody, 1989: xxiii), but because throughout his

sans formation." However, Subligny's little concern with the condemnation of female reading, for Juliette is mad not because of reading alone, the ambiguity of this passage debating classical authority, his own creation of "literature mondaine" which gains more relevance than the classics (Don Quixote) which inspired him, certainly undermine his intention. 
work he too closely reproduces the elements of what he aims to parody -in language, characterization and plot- and the ironic distance is then virtually nil (Sánchez Tallafigo, 2006: 122). In this sense, the French "fause" is maybe better applied than its translation, "mock:" Juliette is a close rewriting of Clelia rather than a parody of her. As a consequence, Subligny's work is not then a simple attack on "Scudérisme;" as Sánchez Tallafigo has asserted, it has many Cervantean elements, such as "los ataques a la falta de escrúpulos de los autores, a la composición de la fábula, a la verosimilitud de los relatos, los guiños metaliterarios y la loca libresca" (2006: 122), and these are inscribed in his struggle to detach himself from previous forms of romance and to create something new. In this sense,

Su principal mérito descansa en la originalidad de su arquitectura, en plena transición de formas novelescas: desde los romans interminables hacia la novela corta, la obra muestra la voluntad renovadora del autor que se ampara en el Quijote como referencia intermitente, constatando la conciencia de la novedad compositiva del Ingenioso Hidalgo. (Sánchez Tallafigo, 2006: 122)

Although this dialogue between genres and the accommodation of the new narrative structures or formulas are still imperfectly achieved, Subligny's work establishes Don Quijote as a model of generic renovation that later authors on either side of the channel would continue to employ.

Thereby, despite its lack of reflection on women's freedom or empowerment by means of their romantic colouring of the world and themselves, which would characterise most subsequent British female quixotic narratives, MockClelia is still a model not only for the characterization of the quixote as a young heroine but also for the use of quixotism as a means to reflect on literary matters and, in particular, on romance and its relationship with truth. In the context of the transnational exchange of novels and given the popularity of Scudéry's Clelia, it is not far-fetched to believe that this romantic antiromance was well-known and well-read, and that it served as inspiration for subsequent British authors, such as Steele or Lennox, who both included Clelia as one of the quixotic character's favourite readings and who even reproduced some of the parodic passages of the mock-version of Clelia in their own works. 


\section{QuiXotes on StAge, or THeRE IS NO BETTER CURE THAN RIDICULE}

Romances, novellas, or later novels are not the only genres that claim the figure of the female quixote for their purposes. The quixotic reading of the world and its consequent misunderstandings, whether comic or tragic, suit the stage and there are early examples of female quixotes in British plays. One could mention, for instance, William Cartwright's play The Lady-Errant (1636-1637), which employs the same epithet Overbury had and which also portrays a woman that reverses gender roles. Davis describes it as "a parody of romance material, featuring as it does an Overbury-type female quixote, Machessa, who has taken upon herself, in a startling reversal of gender roles, to attempt 'adventures' such as rescuing knights who are 'imprison'd or inchanted" (2003: 185). This "burlesque figure of Machessa, the warriorwoman," as Jane Farnsworth has defined her (2002: 387), in a very quixotic fashion decides that her name must be "Monster-quelling-Woman-obligingMan-delivering Machessa." Together with her female squire, Philaenis, they embark in mock-heroic adventures which provide the comic effect for an otherwise grave Platonic play, with clear political overtones to which the quixotic woman-warrior and her burlesque approach to war also contribute. Highly amusing and disruptive, one can see echoes of Machessa in later heroines, such as Barrett's Cherubina.

It will be necessary to wait until the early eighteenth-century to find another British female quixote on stage that will become the main character and a relevant influence for later works of prose fiction: Biddy Tipkin in Richard Steele's play The Tender Husband; or the Accomplish'd Fools (1705). One of Steele's successful and long-running plays, which continued to be staged until 1802 (Winton, 1967: xii-xiii; Kenny, 1971: 198-199), it tells the story of two "ladies errant" (1967: 7), in the author's explanation, two women who are mistaken in their ways, young Biddy and Francophile Mrs Clerimont. Biddy is a young girl who has read many romances and believes herself a heroine, and who, using her heroic prerogatives, will reject her father's choice of husband and finally marry a man who adjusts to the romantic description of a hero. 
Biddy is a voracious reader of the heroic romances of Madame de Scudéry and other French authors, and the names Philocles, Artaxerxes, Oroondates, Statira, Cassandra, Astrae or Clelia fill her speeches. These readings are those that later Lennox's Arabella will peruse in bad translations, and they have the same effect on both of them: to be "governed by the nonsense of French romances" (Kenny, 1971: 201). Moreover, Steele's quixotic reader lays the foundation for important elements of the female quixote's characterization that will become recurrent in subsequent works. First of all, once again there is a displacement from Don Quixote to a more plausible heroine of romance: Biddy is young, rich and attractive. In addition, she has been raised almost in solitude, isolated from the world; consequently, her readings have become her only means to imagine what the world is like. In words of one of the characters, "the young lady by being kept from the world has made a world of her own. She has spent all her solitude in reading romances; her head is full of shepherds, knights, flowery meads, groves and streams, so that if you talk like a man of this world to her you do nothing" (emphasis added, 1967: 38). Biddy is an instance of the inexperience that will characterize female quixotes: a lack of worldly knowledge because of their young age and because of their confinement, which is related to their condition as women.

It is hence that inexperience, and not any form of psychological distemper, that will explain her quixotic condition. As a consequence, Biddy's literary delusion inaugurates the conception of female quixotism understood not as a sensorial distortion which mistakes windmills for giants, but as that romantic colouring or reading of reality which Pardo has identified as characteristic of the young romantic female quixotes (2005c: 357-58). Miss Tipkin reads the world through the eyes of romance. At one point she is scolded by her aunt for calling the wind "the fanning gales," or for stating that a fallen tree had "a spirit imprisoned in the trunk," or that a cloud "had a flying dragon in it" (1967: 29). After this scolding, Biddy retorts: "what eyes had you, that you could see nothing? [...] What noble descriptions in romances had been lost if the writers had been persons of your gust" (1967: 29). Miss Tipkin and her aunt echo Don Quixote and Sancho, with the romantic vision of the former, and the realistic and down-to-earth one of the latter. Although both Biddy and 
Don Quixote share the creation of a reading of the world based on romance, the young heroine's senses are not altered, for she does perceive the wind, the tree and the cloud; as a consequence, she does not reach the levels of epistemological distortion of the Spanish knight but rather establishes correlations or syllogisms between literature and reality. In fact, she employs appearances as basis to develop those syllogisms: if a man looks like a romantic hero and speaks and behaves like one, in all probability he may be a hero from romance. In this sense, Biddy would never mistake Humphry, the country boor, for a knight, in opposition to Don Quixote's transformation of Maritornes into a lady, for example. Biddy might be described as a vierge folle, but there is no true madness in the manner in which she consciously and consistently employs romance to shape the world or to explain it.

Her romantic colouring of reality begins with herself. In a pattern followed by many subsequent female quixotes, she will transform her identity by means of a different name and a claim to a more noble origin. Unlike Juliette and her transformation into Clelia, Biddy does not assume an already existing heroic identity, she does not inscribe herself into an existing romance, but writes one of her own. As Alonso Quijano did, Biddy rejects her name and with it her anonymous and conventional existence. In a conversation with her aunt, Miss Tipkin complains: "How often must I desire you, madam, to lay aside that familiar name, Cousin Biddy? I never hear it without blushing. Did you ever meet with an (sic) heroine in those idle romances, as you call 'em, that was termed Biddy?" (1967: 28). She then falls into a comic reflection on the importance of a heroine's name and the connotations it evokes about that lady's person and behaviour:

[...] the heroine has always something soft and engaging in her name, something that gives us a notion of the sweetness of her beauty and behavior. A name that glides through half a dozen tender syllables, as Elismonda, Clidamira, Deidamia; that runs upon vowels off the tongue, not hissing through one's teeth or breaking them with consonants. 'Tis strange rudeness those familiar names they give us, when there is Aurelia, Sacharissa, Gloriana, for people of condition; and Celia, Chloris, Corinna, Mopsa, for their maids and those of lower rank. (1967: 28) 
With a greater parodic intent is the following scene between Biddy and her suitor, Captain Clerimont, conducted:

BIDDY. [...] but if you ask my name I must confess you put me upon revealing what I always kept as the greatest secret I have, for would you believe it -they have called me, I don't know how to own it, but they have called me, Bridget.

CAPTAIN CLERIMONT. Bridget?

BIDDY. Bridget.

CAPTAIN ClERIMONT. Bridget?

BIDDY. Spare my confusion, I beseech you, sir, and if you have occasion to mention me, let it be by Parthenissa, for that's the name I have assumed ever since I came to years of discretion.

CAPTAIN CLERIMONT. The insupportable tyranny of parents, to fix names on helpless infants which they must blush at all their lives after! I don't think there's a surname in the world to match it.

BIDDY. No? What do you think of Tipkin? (1967: 36)

When her aunt proudly expounds the Tipkin's female genealogy, which includes a Bridget, a Margery, a Sisly or a Winifred, Biddy rejects the "barbarous genealogy" and tells her relative that "I needs (sic) tell you I am not satisfied in the point of my nativity. Many an infant has been placed in a cottage with obscure parents till by chance some ancient servant of the family has known it by its marks" (1967: 29). Biddy then invokes the traditionally romantic cognitio in order to possibly -and plausibly according to the standards of romance- claim a higher birth, although Steele does not develop this parodic possibility further, as later Barrett would do. Finally, her transformation also resembles Quijano's in that it is completed by the use of the hyperbolic language of romance which renders her unique, different from and unintelligible for other characters, in particular, for Biddy's aunt who repeatedly pleads her niece to "forbear this idle trash and talk like other people" (1967: 27) or to "learn to act and speak like the rest of the world" (1967: 30).

Romance also helps Biddy make sense of the world around her and provides her with patterns of behaviour she can pursue. In her intent to follow the idealised principles of romance, Captain Clerimont aptly describes her thus: "A 
perfect Quixote in petticoats! [...] she governs herself wholly by romance; it has got into her very blood. She starts by rule and blushes by example" (1967: 38). Even when she fancies herself in love, it is by following certain romantic standards which at the same time explain her emotions but also encourage them in an artificial and mock-literary way:

Oh, Clerimont! Clerimont! To be struck at first sight! I'm ashamed of my weakness. I find in myself all the symptoms of a raging amour: I love solitude, I grow pale, I sigh frequently, I call upon the name of Clerimont when I don't think of it. His person is ever in my eyes and his voice in my ears. Methinks I long to lose myself in some pensive grove or to hang over the head of some warbling fountain, with a lute in my hand, softening the murmurs of the water. (1967: 47-48)

Once again Biddy distances herself from heroines like Juliette: she does not act believing herself to be one of her admired heroines of romance; instead, she imitates their behaviour, acting by example, which proves once again that her rereading of herself and reality is a self-conscious one. In this sense, romance is particularly helpful as a guide to one of the most relevant moments in life for young, unmarried girls: the period of courtship, the core of heroic romance and of an eligible girl's life. First of all, it provides guidance as to who the suitor should be: a hero that responds to the conventions of heroic romance. When Captain Clerimont meets these requirements, because he acts and speaks like a romantic hero, and, more importantly, because he has the appearance of a romantic hero, Biddy's syllogisms necessarily conclude that he is indeed a hero who can fulfil the role of her suitor in the romance she is writing about herself. Secondly, romance offers a pattern of courtly love and of the period of courtship which places women in a position of temporal and almost unlimited power over their lovers and their lives. When Clerimont declares his love and his intention to marry her and father her children, Biddy's outraged answer clearly acknowledges how she hopes her experience resembles what she has learnt to expect from her romances:

Oh, fie! Whither are you running! You know a lover should sigh in private and languish whole years before he reveals his passion; he should retire into some solitary grove and make the woods and wild beasts his confidants. You should have told it to the echo half a year before you had discovered it, even to my handmaid. And yet besides - to talk to me of children. Did you ever hear of an (sic) heroine with a big belly? (1967: 37) 
Courtly love is pure and unearthly; therefore, physical contact, and more so procreation, is a forbidden element, substituted by long years of service and devotion. As a consequence of the long period of time required for courtship, women may prolong their visibility and significance, and delay the moment in which they must renounce to their own will in favour of their husbands'. Conscious of this reality for women, Biddy claims her right as heroine to extend their courtship, and, consequently, her adventures. When Clerimont continues to press for a prompt marriage, the following conversation ensues:

CAPTAIN CLERIMONT. [...] Consider, madam, you are environed by cruel and treacherous guards which would force you to a disagreeable marriage; your case is exactly the same with the Princess of the Leontines in Clelia.

BIDDY. How can we commit such a solecism against all rules? What, in the first leaf of our history to have the marriage? You know it cannot be.

CAPTAIN CleRIMONT. The pleasantest part of the history will be after marriage.

BIDDY. No! I never yet read of a knight that entered tilt or tournament after wedlock. 'Tis not to be expected; when the husband begins the hero ends. All that noble impulse to glory, all the generous passion for adventures is consumed in the nuptial torch. I don't know how it is, but Mars and Hymen never hit it. (1967: 60)

While Biddy tries to lengthen her heroic prerogatives, Clerimont aims to achieve his supremacy as husband by reversing the roles of powerful/powerless in the change from courtship to marriage, transforming the hero into a husband, and the heroine into a wife. In the end, she marries her fictional hero and is granted a traditional ending for the romance she has written for herself, "the whole story of my amour to this my nuptial day, under the title of 'The Loves of Clerimont and Parthenissa"” (1967: 76).

However, it is a bittersweet ending, for Clerimont is not the hero in love Biddy reads in him: he is a fortune hunter who takes advantage of her romantic delusion. The fact that she is "governed by romance," that she unquestioningly follows the strictures of her readings, transforms her into an easy prey for unscrupulous characters. Captain Clerimont, much in the train of Cervantes' Duke and Duchess, employs the language and the conventions of romance in order to rewrite himself as a hero and to gain both Biddy's love and fortune. 
Clerimont himself states that Biddy's attraction resides in her fortune (1967: 15) and that he is provided with the means for engaging her heart, because he has been "a great traveler in Fairyland" and claims: "I know Oroondates; Cassandra, Astraea and Clelia are my intimate acquaintace" (1967: 16). Using his knowledge of these popular heroic romances, he manipulates Biddy. When she scolds him for mentioning marriage and pregnancy, Clerimont can achieve her pardon by quoting examples from her readings: "Thus Oroondates, when Statira dismissed him her presence, threw himself at her feet and implored permission but to live," to which Biddy answers in the same manner: "And thus Statira raised him from the earth, permitting him to live and love" (1967: 37). What is more, Clerimont can aptly employ other conventions of romance so as to escape the long years of service to his lady:

BIDDY. [...] But I can't think of abridging our amours and cutting off all farther decoration of disguise, serenade, and adventure.

CAPTAIN CLERIMONT. Nor would I willingly lose the merit of long services, midnight sighs, and plaintive solitudes, were there not a necessity.

BIDDY. Then to be seized by stealth!

CAPTAIN CLERIMONT. Why, madam, you are a great fortune and should not be married the common way. Indeed, madam, you ought to be stol'n; nay, in strictness, I don't know but you ought to be ravished.

BIDDY. But then our story will be so short.

CAPTAIN CLERIMONT. I grant it, but you don't consider there's a device in another's leading you instead of this person that's to have you; and, madam, though our amours can't furnish out a romance they'll make a very pretty novel. Why smiles my fair?

BIDDY. I am almost of opinion that has Oroondates been as pressing as Clerimont, Cassandra had been but a pocketbook. But it looks so ordinary, to go out of a door to be married. Indeed, I ought to be taken out of a window and run away with. (1967: 61)

In this passage, Biddy once more displays her naivety and innocence in the real world: she reads being stolen or running away as a prolongation of her romance. She ignores the real implications of it and remains oblivious even to the terrible reality of ravishment, while Clerimont, as a true connoisseur of the world and a rake, is dangerously intent in his words, even if he finally only leads Biddy to an elopement and a foolish marriage. In this regard, Miss 
Tipkin, in her role of young quixote and because of her innocence and ingenuity, positively contrasts with other violent, scheming, or stupid male characters: with Sir Harry, Humpry's abusive father who aims to force her into marriage to his son, with Clerimont who aims to gain her fortune and almost achieves her ruin, or with simple Humphry, who is very glad he "can hardly read" (1967: 60).

Maybe because Biddy is such an engaging character, Steele does not contrive anything worse for her than a deceitful marriage and the continuation of her quixotism. Despite the fact that critics such as Kenny (1971: 192) perceive the final marriage as a reward, it does remain an ambiguous one. First of all, Steele offers no real closure for the quixotic plot; there is no cure to her quixotism to be rewarded with marriage, as will happen in subsequent quixotic narratives, in which cure comes before the nuptials and the latter are the final closure of the female quixote's story. In Biddy's case, marriage happens still as a consequence of her quixotism and is therefore yet part of her delusion. Secondly, Clerimont is not the hero/mentor who is truly in love with the heroine and who will contribute to save her from her mistakes, as will be the case with later more influential female quixotes: Biddy marries the villain of the story, and not the hero. As Doody has stated, "Steele, like other male creators of female Quixotes, emphasizes the folly of the girl's delusion, and [...] the girl is customarily humiliated or tamed by some man more informed, worldly, or socially skilled" (1989: xxiii). Although he does not tame her or her quixotism, she has nevertheless been fooled by this more worldly man and has been manipulated in order to achieve her fortune. In conclusion, her defiance to her parent's choice of husband and her decision to rewrite her position of submission into one of power by means of her romantic reading of the world is neither fully condemned nor condoned.

Much of this ambiguity is explained by the form and style of Steele's work. Under the tenets of the Augustan reception of Don Quixote and its consideration of the novel as a masterpiece of satire described in chapter one, the author shared his friend Joseph Addison's opinion that Don Quixote was a model of high burlesque and very efficient as a corrective for any form of enthusiasm, especially those of a literary origin. In addition, Steele seemed to 
agree with the role played by ridicule in the exposure of those same uncontrolled enthusiasms or passions. In this play, the author therefore uses humour in order to criticise those works of fiction which are full of "improbable lies" and which, as Mrs Tipkin states, are used "to corrupt young girls and fill their heads with a thousand foolish dreams of I don't know what" (1967: 30). This condemnation of pernicious fiction and its dangers for young female readers moves beyond romance and includes all forms of fiction which are morally questionable. In this sense, Clerimont's use of the plot of the ravishment and his mention of the novel, allow Steele to criticise those amorous nouvelles in which intrigues, elopements and sexual promiscuity were a recurrent presence and whose alleged difference in content and form -their assumed greater plausibility and verisimilitude, for example, in the description of shorter and more mundane courtships- rendered them even more dangerous. Despite this criticism, the tone is light and not overly moralistic, and Steele develops his critique not from a poignantly satirical stance, but by means of comic effectiveness (Winton, 1967: xxi) and complaisant entertainment (Kenny, 1972: 191). This comic and benevolent intent is stated by Addison in the prologue:

Our author, to divert his friends today,/ stocks with variety of fools his play,/ and that there may be something gay and new,/ two ladies errant has exposed to view:/ the first a damsel traveled in romance,/ the t'other more refined; she comes from France. Rescue, like courteous knights, the nymph from danger,/ and kindly treat, like well-bred men, the stranger. (1967: 7)

Steele hence creates a benevolent parody of romance and a sympathetic portrayal of his quixote in petticoats, allowing the audience to laugh at and to sympathise with Biddy at the same time. Once again, the fact that Addison addresses a male audience highlights what the play has of comic entertainment at fools' foibles, rather than a didactic work with a moral message for the reading ladies.

Steele's creation of a benevolent satire aimed to entertain a male audience is also emphasised by his creation of and criticism against the second "lady errant," the second mistaken woman, Mrs Clerimont. Intertwined with Biddy's plot is a love triangle which comprises Clerimont Senior, his wife and his 
lover, Lucy Fainlove. Mrs Clerimont, amply and constantly criticised by her husband because of her flirtatious and rebellious French ways, is tricked by him and Lucy, disguised as a man, to compromise her honour and hence to have to submit in shame to her husband's will. In the end, Clerimont loses his lover, for she marries Humphry, the boor, while his wife intends to reform but does not completely renounce her French taste. While not deluded by her readings, Mrs Clerimont is portrayed as a shallow creature and a fool because of her Francophile behaviour. In her husband's words, "that was her turn from her infancy; she always had a great genius for knowing everything but what it was necessary she should. The wits of the age, the great beauties and short lived people of vogue were always her discourse and imitation. Thus the case stood when she went to France" (1967: 11). In the same manner Biddy has a turn for romances, Mrs Clerimont has had a turn from her early childhood to vanity and fashionable discourse, and similar to the quixote's imitation of heroic behaviour, is this coquette's imitation of the shallow conduct and taste of the age. In addition to Mrs Clerimont's natural turn of mind, her husband has unwittingly enhanced her coquetry by taking her to France:

She brought me a noble fortune and I thought she had a right to share it; therefore carried her to see the world, forsooth, and make the tour of France and Italy, where she learned to lose money gracefully, to admire every vanity in our sex and condemn every virtue in her own, which, with ten thousand other perfections, are the ordinary improvements of a travelled lady. (1967: 910)

In clear parallelism to Biddy, Mrs Clerimont will be involved in a scheming plan in which her foibles are used against her in order to gain advantage of her: Fainlove dresses as one of the "pretty gentleman" so in fashion and nurtures her vanity. With this scheme she intends to break their marriage, while Clerimont aims to catch "her a little enlarging her innocent freedoms, as she calls 'em," making it possible to "discard her" (1967: 10). However, Mrs Clerimont remains constant to her husband and grants Fainlove only the accustomed liberty of French gallants: those stolen kisses also conventional in amorous romances. It is only in appearance that she might be ruined because of these French manners; actually, it is more her absurd obsession with looking glasses, rouge, fake eyebrows, fashion or the company of fops, that is 
comically satirised by Steele, as her honour is preserved. Her gambling and vanity are the faults she is cured of by her husband's forgiveness, but her virtue was only ever endangered by Clerimont's trap, of which he repents. In the end, she is reconciled to her husband, though her Francophile taste -including the ridiculed eating of frogs (1967: 74)- remains and her wifely submission is still questionable under the light of her speech to Biddy: "I congratulate, madam, your coming out of the bondage of a virgin state. A woman can't do what she will properly till she's married" (emphasis added, 1967: 73). Once again, Mrs Clerimont is a comically sympathetic character who, though ridiculous, is not dangerously deluded and is therefore different to the more endangered and disruptive Francophile quixotes of the turn of the century. Steele's final moral, pronounced by Clerimont Senior, once more emphasises the benevolent treatment of this lady errant: "You've seen th'extremes of the domestic life,/ a son too much confined, too free a wife;/ by generous bonds you either should restrain,/ and only on their inclinations gain;/ wives to obey must love, children revere,/while only slaves are governed by fear" (1967: 76-77). Nevertheless, despite this benevolence, the implied need for "bond," "restrain" and control over wives' inclinations still conveys a patriarchal message, disguised in the comicality of the play.

Although the interest of the present work is narrative fiction, it is relevant to highlight that Steele would not be the last playwright to perceive the potential of quixotism for the stage, and other plays would appear throughout the eighteenth century bearing the imprint of Steele's play, and later Lennox's novel, becoming then intertwined with moral tales and novels in the game of intertextuality that is the tradition of female quixotism in England. A play which acknowledges its debt to both is the anonymous Angelica; or Quixote in Petticoats (1758), which portrays a young and beautiful girl, Angelica, deluded by her reading of French romance, and who is courted by a rake, Careless, who employs his knowledge of romance to manipulate her in order to win her consent for a marriage against her father's wish and choice. Lennox's influence is explicitly acknowledged in the advertisement, in which the author boldly explains that he "feels himself under an indispensable obligation to inform the public that the character of Angelica and the heroic part of Careless, is not only 
borrow'd, but entirely taken, from the female Quixote, of the ingenious Mrs. Lenox (sic)" (1758: n.p.). Several are the similarities: Arabella's romantic language and the speeches in which she quotes the example of preceding heroines, such as Statira or Mandana, are amply imitated (1758: 14-15, 19); her outrage at the custom of allowing men to kiss her is reproduced in Angelica's (1758: 14, 16); and the setting of an elaborated romantic pantomime in order to fool her, which resembles Sir George's later hiring of an actress to manipulate Arabella, becomes the core of the plot (1758: 20-25). Interestingly, Angelica develops more fully the parodic device of having the heroine's maid attempt to properly use the language and conventions of romance, which is present in Lennox's Lucy, but more hilariously contrived in Angelica's maid, Maria. First, she confuses the name of the hero Artaban, for "Arterburns" (1758: 32) and then fully imitates her lady's style of courtship with Careless' servant, George:

MARIA. Indeed, Mr. George, you are very impertinent to talk to me of love. I am of my lady's opinion; I think as how it is very presumptuous in you to tell me so: she says, that your Alexander's, nor your Arterburn's, never told their mistresses so. - Pray did Paroquetes ever suffer her lover to affront her in such a manner.

GEORGE. Paroquetes! Why, who the devil was she?

MARIA. Why, she was the daughter of Christmas Gambols, and the sister to Statira.

GEORGE. [...] I am oblig'd to you, madam, for your intelligence (bowing) But, faith, Maria, I think you are almost as mad as your mistress -but, child, we have a much newer way of making love now-adays. (1758: 34)

After some more fine speeches in between "languishing" and "sighing" (1758: 35) the affair is conducted in a more conventional manner.

Together with Lennox's, Steele's influence is strongly felt throughout the play. Not only does the title clearly evoke Biddy's description by Clerimont, but in the author's dedication to David Garrick he admits that the producer rejected his play owing to the "elegant manner in which Sir Richard Steele has handled the same subject in his comedy of The Tender Husband, or Accomplished Fools" and in his dedication to the ladies he pleads they feel for Angelica "what once they felt; when great sir Richard Steele,/ to celebrate th' immortal 
Tipkin's praise,/ courted the muse [...]" (1758: n.p.). Garrick did indeed have motive to reject the play because of its similarities with Steele's, and influence at times becomes plagiarism, for several speeches resemble very closely fragments from the earlier play. More importantly, the conclusion of the plot, in which Angelica marries her scheming lover; the development of a parallel and more conventional love story for the stage; and the comic effect which is mainly achieved by the mock-romantic scenes conducted by the hero and by the use of comical stock secondary characters -although instead of the country boor and the angry father, the author offers the old and lustful suitor and the low-class couple of maid and footman who comically echo their lady's and master's affair-, all evoke Steele's play. Angelica ends in the accustomed manner of a comedy: rebelling against her father, Angelica escapes the fate of marrying old Gripes, the three couples marry, Careless inherits a fortune by the sudden death of a relative, and the father forgives his two daughters for their elopement and marriage.

Another play which is indebted to Steele is George Colman's Polly Honeycombe. A Dramatic Novel in One Act (1760). Polly is a novel reading young girl who follows previous heroines' examples and rejects her father's suitor, Mr Ledger, escapes her father's imprisonment and attempts to elope with Mr Scribble. There are several elements which are recurrent. First, there is an arranged marriage to which the girl rebels. In this case, Mr Honeycombe has chosen a businessman who is as much a monomaniac as Polly: instead of seeing the world through the veil of romance, he interprets it in terms of numbers and profits. When he speaks love to Polly he does so in commercial terms: "I have an account to settle with you, Miss -You're on the debtor side of my books;" "over head and ears in my debt, Miss!;" "suppose we should compound this matter, and strike a balance in favour of both parties" (1761: 11). To praise Polly he states that he likes the "omniums," notwithstanding the "premium" he gives for them (1761: 12), and he speaks of marriage as an agreement that must be signed and sealed, "without loss of time, or hindrance to business" (1761: 12). At one point, he must employ more ordinary language: "then in plain English, Miss, I love you- I'll marry you" (1769: 11), only to conclude saying "there's the sum total" (1761: 12). After expressing her 
abhorrence in the strongest terms, Polly concludes thus: "you are a vile book of arithmetic; a table of pound, shillings, and pence---You are uglier than a figure of eight, and more tiresome than the multiplication table---There's the Sum Total" (1761: 13). The heroine can therefore also adopt her suitor's discourse and employ the conventions of Ledge's monomania against him.

Despite her wit, Polly is also manipulated because of her delusion. Mr Scribble employs the language and plot of novels in order to press for her elopement; in the end, he is also proven a scheming man in search for a fortune, for he is no gentleman but a clerk. Resembling the quixotic Dorinda, protagonist of Jane Barker's tale "The History of Dorinda" (1726), and the later Charlotte in The Political Quixote (1797), who were manipulated by their footman, Polly is fooled by a man without money and below her social class, her honour compromised and, as with Barker's heroine, her life united to him in marriage. Owing to the fact that Scribble wore a footman's livery in order to enter the house unsuspected, this connection to other quixotic heroines is made more evident. Polly resembles these other heroines, as well as Biddy, in her innocence, for she interprets the elopement only in terms of fiction, as the "finest adventure" (1761: 22) she has lived in her otherwise uneventful life.

There are other elements in Colman's work which have an important recurrence in plays, novels and tales. First of all, there is the presence of a tyrannical patriarchal figure, Mr Honeycombe. Harsh and violent, he literally imprisons his daughter and deals with her marriage as a commercial transaction. In the same manner Angelica's decision was in a high degree motivated by her father's poor choice, Polly's rebellion is oriented towards this form of tyranny as well. Secondly, Mrs Honeycombe is an instance of the absent or ineffectual mother that will become a constant and important part of female quixotic narratives. ${ }^{101}$ Persistently in vapours, she cannot reason nor guide her daughter, and her passivity contributes to Polly's misbehaviour and final elopement. Finally, and more importantly, there is a change in the source

101 See Zunino et al. "Present, Absent, and Mythical Mothers: Mother-Child Relationships in English Literature from the 16th to the 19th centuries." New Perspectives on English Studies. Ed. Marian Amengual, María Juan and Joana Salazar. Palma de Mallorca: Ediciones UIB, 2009, pp. 235-54, especially Borham-Puyal's contribution "Absent Mothers and Present Literary Godmothers in Female Quixotism," to which subsequent references will be made. 
of Polly's delusion: instead of romances, she reads contemporary novels. As authority to elope, she mentions the heroines of Dick Careless or Tom Ramble; she compares Scribble's style of writing to that of Bob Lovelace, Clarissa's admirer; when Ledger wants to speak love to her, she compares their situation to that of Clarissa and Soames and her cruel treatment of him to that of many other heroines; when she sees Scribble in her room she was as much surprised as when "Sophy (sic) Western [...] saw Tom Jones in the looking glass" (1760: 19); her beauty is compared to other heroines', such as Pamela, Clarissa, Amelia, or Sophy, created by Richardson and Fielding; and in her final rejection she portrays $\mathrm{Mr}$ Ledger "as deceitful as Blifil, as rude as the Harlowes, and as ugly as Doctor Slop" (1760: 29), characters from Tom Jones, Clarissa and Tristram Shandy respectively. Interestingly, Colman's quixotic heroine profusely quotes examples from Fielding's or Richardson's novels in similar situations to those in which previous heroines quoted romances. For instance, when Polly is locked up she recalls the fate of Clarissa and Sophy Western; she hides pen and paper from her cruel father following Clarissa's example; when Scribble is discovered to be a clerk, she refers to Tom Jones' revealed identity as a "gentleman's son” (1761: 28); and, finally, Polly declares she will follow Booth and Amelia, as an example of a romantic marriage in the midst of adversity (1761: 29). These examples highlight the romantic elements which survive in all these novels in particular and in the eighteenth-century English novel in general, and evidence that Colman does not distinguish them from other pernicious novels.

Colman's criticism to the moral of novels and his didactic intention in writing his play are conspicuously stated in his preface, his conclusion and the final epilogue. In the preface the author contends that his ending is deliberately not a conventional happy one, in which the parents finally come to terms with their daughter's rebellion and accept her union to Scribble (1761: iv-v). Moreover, in the shape of a letter from his mother, Colman expresses his worry at the reading of novels by young girls, and mentions the possession of Miss Betsy Thoughtless, the New Atlantis and the catalogue of the circulating library as a symptom of danger. His mother then concludes the preface with the hope that his farce "may do some good on the Giddy Girls of this Age" (1761: vii). His 
prologue is even more revealing: tracing the source of romance to Spain and France, Colman satirises the common places of heroic romances exposed in quixotic fictions, for example, the implausible deeds of knights or the magical occurrences. He then acknowledges Cervantes' role in destroying the reign of this genre: "this Fiend to quell, his sword Cervantes drew,/ a truly Spanish blade, Toledo true:/ Her talismans and Magick Wand he broke-/ Knights, Genii, Castles-vanish'd into smoke" (1761: n.p.). However, romance is substituted by its sister, the novel, and the criticism shifts from an attack on implausibility to one on moral impropriety: "and then so sentimental is the Stile,/ so chaste, yet so betwitching all the while!/ Plot, and elopement, passion, rape, and rapture,/ the total sum of ev'ry dear-dear-Chapter" (1761: n.p.). The conclusion is that " "tis NOVEL most beguiles the Female Heart./ Miss readsshe melts-she sighs-Love steals upon her-/ And then-Alas, poor Girl!-good night, poor Honour!” (1761: n.p.). Mr Honeycombe emphasises the same final moral as he concludes that "a man might as well turn his daughter loose in Covent-garden, as trust the cultivation of her mind to A CIRCULATING LIBRARY" (1761: 31); while Polly's message of subversion learnt from the aforementioned novels is ironically reasserted in her speech for the epilogue, which takes the shape of a battle cry for rebellion against fathers and husbands, terminating with an address to the male audience: "beat You the French, but let your Wives beat You" (1761: n.p.). Both the critique to the circulating library mentioned by Polly as source for her novels (1761: 6) - and the connection of literary subversion to the conflict with France will also recurrently become a part of works dealing with female quixotism and the dangers of novel reading.

Finally, another relevant novel-reading heroine on stage is R. B. Sheridan's Lydia Languish in his play The Rivals (1775). Lydia is a young girl of seventeen who reads numerous novels from the circulating library and who attempts to conduct her love affairs in the manner of sentimental novels: with the opposition of her family, with an elopement and with a subsequent life of poverty and romantic love. She decides to reject the choice of her aunt and to renounce to her inheritance so as to live in distressed paucity with her beloved Ensign Beverly. This Ensign is in reality Captain Absolute, who poses as a poor Ensign to adapt to Lydia's "singular taste" (1775: 2). Her aunt and Sir 
Absolute intend the Captain and Lydia to marry and a series of comical misunderstandings ensue until the Captain is unmasked and Lydia rejects him. In the end, the Captain is on the verge of fighting a duel with Lydia's other suitors, she confesses her affection for him and they are happily reunited.

Lydia is immediately identified as a reading woman, for she is introduced to the audience "sitting on a sofa with a book in her hand" (1775: 5) when Lucy brings the books she had requested from the circulating library. Throughout the book, Lydia plays out the plot she has designed following the examples found in her readings: she feigns a letter to start a quarrel with Beverly, for all lovers must do so; at her first meeting with the Captain under his real character she prepares to act according to the example of other heroines: "I have heard of girls persecuted as I am, who have appealed in behalf of their favoured lover to the generosity of his rival; suppose I were to try" (1775: 50); her love scenes with Beverly/Absolute resemble the highly sentimental scenes of her readings, in which he determines "to rescue her from undeserved persecution" and she asks him if he consents "to forfeit that portion of my paltry wealth?-that burthen on the wings of love?," to which he answers in much the same romantic language (1775: 51). As for her elopement, she states "there had I projected one of the most sentimental elopements!-so becoming a disguise!-so amiable a ladder of Ropes!-Conscious Moon-four horses-Scotch parson-with such surprise to Mrs. Malaprop-and such paragraphs in the News-papers!" (1775: 84). Her quixotism is a form of idealism that triggers the belief that she must act the story of literary heroines against all odds: she rebels against her lack of free will to choose her husband, and against the matrimonial market which sets a price to her hand. She states: "I lose most of my fortune, if I marry without my aunt's consent, till of age; and that is what I have determin'd to do, ever since I knew the penalty.-Nor could I love the man, who would wish to wait a day for the alternative" (1775: 8). First of all, she rejects her aunt's principle that she has no business thinking or choosing for herself, for "thought does not become a young woman" and neither do preference or aversion in matters of matrimony (1775: 11); as a consequence she defends her own choice of lover as her supreme act of rebellion. Secondly, she desires her husband to renounce to her money in order to live in love and sentimental distress; 
however, implicitly, she also rejects a system in which women are valued according to their matrimonial price, in which dowries are as strong as any attraction, as happened previously in Biddy's case. Her fears are not unfounded: Sir Lucius confesses he needs her money (1775: 35) and Absolute, though being a sincere lover, is ready to set the romance aside to endure "wealth and comfort" (1775: 69), and to lengthen his game until a time in which they may not lose Lydia's fortune (1775: 19). After the discovery, she realises that her romantic plot has been transformed into a conventional courtship, and instead of "the prettiest distress imaginable" she finds herself "a mere Smithfield bargain of at last" (1775: 84). Her sentimental elopement will be substituted by “flimsy preparation with a bishop's licence, and my Aunt's blessing, to go simpering up to the Altar; or perhaps be cried three times in a country-church, and have an unmannerly fat clerk ask the consent of every butcher in the parish to join John Absolute and Lydia Languish, Spinster!," and therefore concludes "O, that I should live to hear myself called Spinster!" (1775: 84).

Quixotism, conceived in terms of this idealistic transformation of her possibilities, is described more as whim or fancy, than madness. It is identified as a "singular taste" (1775: 2) and as "caprice" (1775: 50, 84, 85), as a stubborn and "absurd" romantic turn of mind that leads her resolutions (1775: 73). That she is conscious of her rebellious reading of her role in society is made clear at the end of the play, when she discovers Absolute's charade. She acknowledges he has been "humouring" her romance (1775: 70) and asserts that "while I fondly imagined we were deceiving my relations, and flatter'd myself that I should outwit and incense them all-behold! my hopes are to be crush'd at once, by my Aunt's consent and approbation!-and I am myself, the only dupe at last!" (1775: 70). Her romantic plotting provides the means to deceive her family, but also renders her vulnerable to being manipulated, as she realises at last. Finally, in accordance to the description of her delusion as a mere whim, she is reasoned out of her romantic folly by another female character's counsel, who entreats her "not to let a man, who loves you with sincerity, suffer that unhappiness from your caprice, which I know too well caprice can inflict" (1775: 85). Julia's speech points at the parallel love story 
that develops throughout the play, and which involves a highly sentimental and morose man, Faulkland, whose caprice also drives Julia away. Therefore, Sheridan doubly stresses the nature of Lydia's quixotism as a capricious turn of mind, and has both Faulkland and her cured at the end, the former by reforming his "unhappy temper" and the latter by "having checked in time, the errors of an ill-directed Imagination, which may have betray'd an innocent heart" (1775: 100).

As can be derived from the abovementioned elements of characterization and plot, Sheridan finds his influence in Biddy, but also in Polly. Lydia shares with the latter their passion for novels and the extensive list of readings with which the circulating library provides them. Among these readings one can find several well-known titles of the so-called age of sensibility, including Sterne's A Sentimental Journey or Mackenzie's The Man of Feeling, together with Smollett's novels Peregrine Pickle, Humphry Clinker, and Roderick Random. As happened in the treatises of the age, good and bad readings are differentiated, and Lydia herself is aware of the accusation of improper morality or of excessive sensibility against some of the works she reads, for when her aunt is coming into her room she hides Smollett's and Mackenzie's novels, as well as The Innocent Adultery, Lord Aimworth, and Ovid, and replaces them in sight for Mrs Chapone's works, Fordyce's Sermons, Lord Chesterfield's Letters and The Whole Duty of Man (1775: 10). Sheridan's play seemingly contains the recurrent criticism against the circulating library for offering young girls reading material in which they may find both good and bad models of behaviour, and the circulating library is identified as a source for "diabolical knowledge" (1775: 12). However, the criticism towards female literacy, or against any form of female knowledge, seems directed only at how it grants them the example of rebellion against parents and guardians, and is expressed mainly by Sir Anthony Absolute and Mrs Malaprop, Lydia's aunt. The former, a violent and one-time rogue who bullies his son and threatens him with his disinheritance, expresses the greatest condemnation to women's learning. In his opinion, young girls' having a will of their own is a "natural consequence" of teaching them to read (1775: 12). His plan of education, if he were to marry again, would be the following: 
[...] the extent of her erudition should consist of her knowing her simple letters, without their mischievous combinations; -and the summit of her science be- her ability to count as far as twenty.-The first [...] would enable her to work A.A. upon my linen;--and the latter would quite sufficient to prevent her giving me a shirt, No. 1 and a stock, No. 2. (1775: 12-13)

Sir Anthony's evident misogyny, reinforced by his comparison of marriage to gaining an estate and of Lydia to "live stock" (1775: 29), or his suggestion to Mrs Malaprop not only to imprison Lydia but also to deprive her of food to tame her will (1775: 14), transform him in the eighteenth-century version of a tyrant, undermine the validity of his radical stance and detach him from what seems the author's position on the matter. ${ }^{102}$ Mrs Malaprop also states that she does not think "so much learning becomes a young woman" (1775: 13); however, her ridiculous speech, full of jocular lexical inaccuracies and foretold by her name, ironically becomes a defence of at least some learning as part of a lady's accomplishments.

This ineffectual criticism, together with the mildness of Lydia's quixotism and its domestic and comic nature, contributes to the benevolent treatment Sheridan does of his heroine, who is also granted a cure by means of love and marriage and a conventional happy ending. Sheridan resembles Steele or Colman in their amiable portrayal of their heroines' uneventful lives, their desire for romantic adventures in the face of sometimes excessive parental control and their exposure to greedy suitors and the marriage market. Nevertheless, he also shares the patriarchal and conservative plot in which a deserving heroine such as Lydia, who suffers no worse delusion than to believe that she can command her destiny, must be fooled and tamed in the end to adapt to the only proper role society allows for her: that of wife.

102 After all, R.B. Sheridan was the son of a highly educated woman himself, the celebrated novelist Frances Sheridan, whose Memoirs of Miss Sidney Bidulph (1761), besides a publishing success, was an often quoted novel for its morals and later for its complex representations of women's restraint and power by means of their virtue. 


\section{3. “The History OF DORINDA,” OR THE AMBIGUitiEs OF ROMANCE}

Returning to the field of narrative fiction, another striking antecedent to Lennox's quixote is to be found in the work of Jane Barker (1652-1732). Known as the "Galesia trilogy," Barker's most popular works were Love Intrigues: or the Amours of Boswil and Galesia (1713), A Patch-Work Screen for the Ladies; or, Love and Virtue Recommended in a Collection of Instructive Novels. Related after a Manner intirely (sic) New, and interspersed with Rural Poems, describing the Innocence of a Country-Life (1723) and The Lining of the Patch-Work Screen: Design'd for the Farther Entertainment of the Ladies (1726). Galesia, a spinster, a poet, a healer and an intellectual, has been identified as Barker's alter ego and her story of intellectual, professional and authorial aspirations has been read as Barker's reflection on her own career as this "heroine-writer of the autobiographical romance" (Spencer, 1983: 168). In the first part of the trilogy, Galesia in old age retells the story of her youthful amour with Boswil and she conspicuously identifies herself with a heroine of romance. Nevertheless, her story does not end with any of the typical alternatives to a heroine's story, neither is she seduced and ruined, nor is she married. Instead she remains single and "she attributes to herself the characteristics of heroines whose destiny she does not share in order to make her single life seem equally valid as another kind of heroine's destiny" (Spencer, 1983: 170). By not fulfilling a heroine's traditional destiny, she transforms her narrative into "the tale of a different kind of success" and the "thwarted romance-heroine becomes the heroine-poet" (1983: 171). This heroine-poet is the one who develops before the reader's eyes in the next two books. Galesia is the author-surrogate that pens and frames the many inset narratives, the many patches, which form the books. These works of narrative fiction are essential to understand the production of Barker herself, her relation to romance, to the fiction of her time and to the conception of the woman writer and reader. Although Barker's excellent poetry deserves ample attention and has fortunately been thoroughly studied, it is her stance towards romance and the new forms of narrative fiction which becomes relevant under the light of her depiction of a female quixote in her own fiction. 
Among the collection of tales found in the Lining, there are several references to women's romance reading. More specifically, in the one entitled "The History of Dorinda," which its narrator identifies as a "Romantick Adventure" (1726: 103), Barker portrays a female quixote. Dorinda, a young girl of wealth and beauty, devours all forms of fiction -romances, novels and plays-and, as a consequence, marries her footman, who wastes her money, sells her son and debases her by transforming her in his mistress's maid. Finally, in her desperation she attempts to commit suicide. It is with this final step that the tale commences, when the gentleman who is retelling the story sees a woman jumping into a lake and must rescue her from drowning. At her recovery, Dorinda recognizes the man as a former object of her coquetry and starts to recount the story of her misfortune. In the end, a twist of fate reunites her with her lost son.

Barker does not provide as much detail as other authors on the exact nature of her heroine's readings. There is barely a mention to titles, or authors, only to genres. However, Dorinda does offer an identification of the nature of her delusion in accordance to what will be the prevailing trend in the tradition of female quixotism:

\begin{abstract}
It was such Romantick Whimsies that brought upon me the Ruin and Distress in which you behold me; I had read Plays, Novels, and Romances, till I began to think my self a Heroine of the first rate; and all Men that flatter'd, or ogled, me were Heroes; and that a pretty well-behaved Foot-man or Page must needs be the Son of some Lord or great Gentleman. (1726: 106)
\end{abstract}

First of all, Dorinda perceives her quixotism as a romantic enthusiasm or foolishness which has a literary origin. Then she analyses how the influence of those romances, novels and plays operate on her mind: she thinks herself a heroine. Once more, she does not identify with a particular heroine, transforming herself into another fictional character; rather, she romanticizes her own life by means of those same parallelisms drawn by other female quixotes. Dorinda is young, beautiful and wealthy; she has no parents and has admirers and handsome servants; her syllogisms thus work because the referents in both the real and fictional worlds can be made to correspond: she has many of the attributes of a romantic heroine, hence she could be one. This 
correspondence triggers others concerning the surrounding world: if she be a heroine, the men who court or serve her may be beaux or noblemen in disguise.

Her quixotism is at first more subversive and breaks the boundaries of the domestic circle in which later quixotic fictions tend to be inscribed. Dorinda confesses "I affected to seek Adventures of diverse sorts; amongst the rest, I went mask'd and unaccompanied to the Play-House" (1726: 106). ${ }^{103}$ In her romantic use of the word "adventure" Dorinda displays her different system of reference: while she refers to an exciting event, in eighteenth-century Britain "adventure" connotes in this context a sexual liaison. Dorinda then resembles Biddy's innocence in the way she fails to understand the implications of her actions or even her words. The same word has shifted its referent, and Dorinda's more literary interpretation of it evinces once again the unfitness of romance as a system of reference in contemporary Britain -even if it proves less sexually-charged and hence indicative of the quixote's purity of mind. ${ }^{104}$ Barker's repentant heroine later acknowledges her mistake when she states that "amongst all my Freaks and romantick Frolicks, I preserved my self from the great Offence; But that is not enough; [...] For such conduct as mine, was as dishonourable in the Eyes of the World, as if one was a downright Prostitute; and not only dishonourable, but ridiculous" (1726: 107). Even if with time and experience she abandons her dishonourable behaviour and becomes encircled in a more proper sphere, her romantic folly persists:

Time and absence help'd me to overcome my Folly and I became more sedate, so as not to ramble alone to Plays, nor to be seen in Places unfit for young Gentlewoman; nevertheless, a Romantick Humour hung long upon me, that if any worthy Country-Gentleman made his Addresses to me, I set him in the rank of Justice Clod-pate, or Justice Calf in those Comedies, and fancy'd their spruce young Footman some Prince or Hero in disguise, like Dorus in Sir Philip Sidney's Arcadia. (1726: 108)

103 Masquerading or attending a masquerade will be recurrently employed in eighteenth-century literature as a dangerous recreation for young girls which fosters illicit or improper intercourses. Schofield (1990) has established how this inclusion often hides a message of social or literary subversion, as will be subsequently explored. Well-known examples would be Miss Milner's fondness for them in A Simple Story, associated with her coquetry and disregard for a strict moral code. Other quixotic narratives such as Barrett's The Heroine or Green's Romance Readers also portray scenes at a masquerade and connect them both with their heroines' literary delusions and with social disruption (see chapter five).

${ }^{104}$ The same divergence in interpretation between the romantic reading of the word "adventure" by the female quixote, and the more mundane one of the worldly characters is thoroughly developed in Lennox's novel (see chapter four). 
Dorinda employs fictional types in order to interpret the characters around her: worthy country gentlemen will be ranked with the unattractive characters from comedies, while handsome footmen will be identified as disguised heroes of romance. Appearances will once again be read by the standards of fiction, reaching its summit in Dorinda's proposal of marriage to her own footman, Jack. After becoming engaged to a respectable gentleman, Dorinda's attempts to favour Jack lead her fiancé to break the engagement. As a result of this event, Dorinda decides to marry the former. In order to justify her decision, Dorinda's resorts once more to the romantic convention regarding the unknown origins of the hero:

Then again, my romantick Brain would make me imagine, that he was of an Origin; (if known) above what he appeared: for he had been a Beggar-boy, taken up at my Father's Gate, and was bred up in my House, $[\ldots]$, nor would he ever be persuaded to tell his Name, nor from whence he came. (1726: 111)

In imitation of Cervantes' knight, Dorinda tries to accommodate reality to her romantic expectations, but her senses are not distempered and this accommodation becomes increasingly fraught and difficult to sustain. In the midst of the world's censure at her behaviour, Dorinda starts to question her perception of Jack, her reading of his character, and claims that she "would draw that Curtain from before the Eyes of my Reason, and behold him as the poor Beggar-boy Jack, whose business it had been to clean the Dog-kennels" (emphasis added, 1726: 111-12). The metaphor of the eyes of reason is recurrent in the vocabulary of the age and of course relates to the danger of a distorted perception which comes from the deluded reader's clouded judgment. Dorinda then states that she can finally see through the romantic veil that had blurred her interpretation of reality, although this literary screen persists in the first stages of her marriage. When Jack suggests moving to a house in the country, Dorinda attempts to maintain her romantic illusion and, concerning her future abode, she asserts: "I was a little pleased, hoping my Romantick Notion was come true, and that I should find something a little tolerable and decent, Suitable to his Person, which was truly handsome" (1726: 115). However, reality once again proves her wrong and the veil is lifted forever. 
Interestingly, it is not only Dorinda's gaze which is of importance in the tale: other characters' perceptions of her are equally relevant, especially with regard to her quixotism and her virtue, in a pattern that will become recurrent in later narratives of female quixotism. In Dorinda's words, Jack reads her as "a kind of Romantick Humourist, (as I really was)" (1726: 113); he therefore insistently presses her to a rapid marriage, as the heroine claims, "to make sure work, e'er I chang'd my mind" (1726: 113). In order to preserve Dorinda's favour he employs "many fair Words, mix'd with Sighs and Tears [...] for he having been bred up in my Father's Service, and reading many pretty Books, could speak well enough" (1726: 110); as a consequence, he can use a romantic attitude and rhetoric to convince her even further. Dorinda is rendered a malleable fool owing to her romantic delusion, an appealing prey for fortune hunters, as later Lennox's, Tenney's or Mrs Bullock's quixotes will be. In addition, Dorinda will be considered an outcast due to the moral implications of her actions. Other characters' readings are essential to appreciate her situation. As doubts of her decision start to haunt her, Barker's heroine understands that the consequences of her folly cannot be reversed because of the weight of appearances in a society dominated by the concept of female virtue. She asserts that "not knowing how to undo what my Folly, or rather Whimsie had begun: [...] but having thus far exposed my self to him, and my Servants, and in them to every body" (1726: 110), and having been "shut up with him," she knew her "Honour (as to outward appearance) was lost" and that she "was more liable to Contempt than in being his Wife" (1726: 113). Despite the fact that she remains virtuous, appearances are enough to force her into an unhappy marriage so as not to compromise her honour further. Dorinda's code of interpretation is flawed and appearances become deceiving; in Barker's tale society's code of honour and virtue proves equally defective and solely based on appearances. It also has tragic consequences for women, as Barrett's Cherry or Bullock's Dorothea will later learn.

With its highly moral tone and clear didactic purpose, this tale has been defined as "a cautionary tale of the disruption of power relations in class and gender that can occur when a young woman confuses romance and real life" (Wilson, 1997: xxxvi). In this sense, Barker imitates Cervantes in that she does not 
condemn romances per se, but the uncritical reading of them performed by young female readers. This is stressed by the existence of other female characters in the Lining whose extravagant behaviour is attributed to their readings. In the tale prior to Dorinda's, readers learn of a young Lady who had escaped her father's house and travelled disguised as a gypsy. By chance recognised by his father's steward, she is finally reunited with her family, her lover and happily married to the latter. After the happy conclusion, readers are told that

The Company were much diverted at this Story, tho' they blamed the Young Lady for her strange unparallel'd Enterprize, saying, that surely she had been reading some ridiculous Romance, or Novel, that inspired her with such a vile Undertaking, from whence she could rationally expect nothing but Misery and Disgrace. But Heaven was gracious and merciful, in preserving her from sinking into the most odious Infamy. (emphasis added, 1726: 102)

Although the term "ridiculous" is applied to those forms of fiction, it is necessary to highlight the use of the word "rationally:" in this paragraph the opposition is made again between reason and romantic notions, and how the latter may lead to disgrace precisely because reason is clouded as to the consequences of those undertakings in imitation of romance. The fact that this section precedes Dorinda's story renders it an introduction to the subject of deluded romance reading, later expanded and qualified in order to highlight the dangers of uncritical reading. In Barker's tale this gullible reading of any genre can become dangerous for young readers, and the emphasis is placed on the absence of a critical train of thought. Dorinda's lack of education or guidance is emphasised from the beginning of her story, with the explanation of the absence of parents or mentors and with the description of her behaviour as a coquette in search for a husband. What is more, it is implied that this uncritical reading does not allow her to rationally assimilate the moral of her readings and perceive the proper behaviour to be imitated. If she had followed the more virtuous examples from her readings, she would have escaped the censure of the world and an unhappy marriage. In this respect, Barker's heroine commits her greater mistake precisely because she does not follow the conventions of romances: instead of remaining at an unattainable position for her lovers and developing a plot of courtly love, as heroines of romance would do, she places 
herself forward and confesses her love for Jack, to the point of proposing marriage. As Cervantes had already made evident, despite its implausibility, romance depicts a world of high ideals that contrasts with the debased and cruel world of reality. Barker reintroduces Cervantes' reflection at the end of Jack's story -in which he not only sells his own son, but also kills his mistresswhen her narrator, Galesia, asserts that:

Amongst the Old Romances, said she to her self, we find strange and improbable Performances, very surprising Turns and Rencounters; yet still all tended to vertuous Ends, and the Abhorrence of Vice. But here is the Quintessence of Wickedness designed and practiced, in a special manner, in the story of Jack Merchant [...]. (1726: 128)

This defence of the virtuous examples encountered in romance finds greater relevance in the context not only of this work, but of the whole trilogy which Barker wrote around the figure of this female reader and writer of romances, Galesia.

Owing to these concerns on "improbable Performances" and "vertuous ends," Barker's relationship to romance even in her interspersed tales is nothing but complex, especially in the context of the associations discussed in chapter two between women authors and romance, together with the moral and aesthetic implications that this connection entails. Employing what has been described as an "innovative, protean work that anticipates the novel but is structured in the framed-nouvelle format" (Donovan, 1997: 972), Barker's work could be understood as a dissertation on the different forms of the romance, incorporating in her work romance itself along with a critical commentary on it (Schofield, 1990: 76). Her criticism, however, as stated above, is narrowly directed to the improper morals that might be found in certain forms of narrative fiction. In this respect, highly revealing is Galesia's previous consideration on the virtue found in old romances, as well as her reflection in Lining on the difference between past and present forms of fiction:

Those honourable Romances of old Arcadia, Cleopatra, Cassandra, \& c. discover a Genius of Vertue and Honour, which reign'd in the time of those Heroes, and Heroines, as well as in the Authors that report them; but the Stories of our Times are so black, that the Authors, can hardly escape being smutted, or defil'd in touching such Pitch. (1726: 129). 
Barker is here positioning herself as author in line with Aubin or Rowe in the praise of romance and its presentation of virtue and honour as a moral example that may not defile either the readers that peruse their adventures, or the authors that conceive them. In contrast, she refers to contemporary stories that do not introduce such moral standards and that hence prove detrimental for readers and writers alike. One cannot but conclude that Barker is implicitly detaching herself from defiled female authors such as Behn, Manley or Haywood and from the "stories of our times" -the fictions of amorous or political intrigues-, while defending her own recourse to romance in her prose fiction. ${ }^{105}$ Relevant in this regard is Galesia's Horatian desire to detach herself from the modern metropolis and from contemporary society and retire to live in solitude, alienated from gallant society but immersed in her composition of herbal remedies and literature. While in London and in the midst of her father's matrimonial arrangements for her, she refuses to "act the Coquet" (1723: 40) and later exclaims: "I wish'd sometimes to be of Don Quixote's Sentiments, that I might take the Tops of Chimneys, for Bodies of Trees; and the rising Smoke for Branches; the Gutters of Houses, for Tarras-Walks; and the Roofs for stupendous Rocks and Mountains" (1723: 67). This assertion is not mere wishful thinking: Galesia has become of "Don Quixote's sentiment" by transforming a degraded society which has lost bygone values and which diminishes women to commodities into a feminocentric universe which is seen through the veil of the moral of heroic romance. In addition, she has become a quixote herself in the sense that she rejects the conventions of genteel society, rejects the stereotypical behaviour of women and decides to live by her own standards, many learnt from romances. She rejects the role of the coquet, which in quixotic narratives is often opposed to the more innocent figure of the female quixote, and embraces the role of heroine-poet; consequently, she

${ }^{105}$ The polarization Philips/Behn, sometimes expressed in the alias Orinda/Astrea, has been amply documented, and extensively quoted is Barker's assertion in A Patch-Work: "One [a lady] asked me, if I lik'd Mrs Phillips, or Mrs. Behn best? To whom I reply'd, with a blunt Indignation, that they ought not to be nam'd together" (1723: 44). Although one of Behn's narratives is rewritten in Barker's own work, the fact that it is in the shape of one of her more scandalous texts and that Philips is praised as a literary and moral model throughout the trilogy do provide foundations for claims such as Spencer's when she states that "Jane Barker is careful to place herself on the side of the reputable woman writer. Katherine Philips is contrasted with Aphra Behn, and Barker's disapproval of the type of writer Behn represents is made clear" (1983: 178-79). 
discards the form of fiction that the coquette embodies to embrace romance, something that will also be evident in Lennox's later novel.

Despite this praise of virtuous narratives, Barker herself presents the reader with stories of adultery, bigamy and murder, and even a rewriting of Behn's "History of the Nun; or, the Fair Vow-Breaker" (1689). However, she is very careful to highlight the terrible consequences of sexual illicitness (loss of honour, venereal diseases, death) or of those marriages which spring merely out of duty (poverty and unhappiness), while her references to bigamy or murder have provided interesting political subtexts to be read. ${ }^{106}$ Therefore, Barker partly founds the defence of her authorship on the values which her tales reflect, and on the didactic value they have, especially for female readers. In both titles and prefaces, Barker addresses her female readers and states that her purpose is to instruct and entertain alike. Moreover, and as the history of Dorinda best explains, she intends to provide not only amusing and didactic readings for the ladies, but also a reading model. Galesia is portrayed as a constant and passionate reader, and some of the stories are taken from books she is seen reading in solitude, a symbol of the "beginnings of print culture" that will be so relevant for women readers and writers alike (Donovan, 1997: 975). More relevantly, Galesia is a self-critical reader aware of the possible dangers of reading in isolation. In A Patch-Work she states that "Part of the Company, who knew a little of my Bookish Inclinations, would endeavour to relieve that Silence which the Ignorance of the Town laid upon me; and enter into a Discourse of Receipts, Books, and Reading" (1723: 44). After a blunder committed in one of these conversations, Galesia explains:

By this Blunder, Madam, said Galesia, you see how far one is short, in Conversation acquired only by Reading; for the many Plays and pretty Books I had read, stood me in little stead at that Time; to my great Confusion; for though Reading inriches (sic) the Mind, yet it is Conversation that inables (sic) us to use and apply those Notions and Riches gracefully. (1723: 44)

${ }^{106}$ Particularly enlightening is Kathryn. R. King's study of the patchwork narratives under the light of Barker's alliance to the Jacobite faction and her dissection of the bigamy trope as the expression of "the troubles of the subject divided between de jure and de facto husbands/sovereigns," employed together with the trope of illegitimate intercourse to deepen "her analysis of Jacobite existence in a time of defeat, compromise, and political illegitimacy" (2000: 165). Barker did not limit her political writing to narrative fiction, and also wrote a royalist allegory in the form of a heroic romance, Exilius: or, the Banish'd Roman (1715). 
This episode emphasises the limited use that literature may have in providing the necessary instruments for the interpretation of men and manners, for social interaction, if it not be accompanied with experience and conversation. Dorinda lacks any person with whom to converse and apply the notions learnt from her readings not only gracefully, but rationally. Galesia, in comparison, becomes the symbol for a virtuous and informed female heroine, reader and writer, and further bonds these three characters. Barker provides another turn of the screw by her "clever manipulation of a narrative structure that simulates actual conversation" (Wilson, 1997: xxxvii), which not only offers the chance to claim greater truthfulness, but also portrays the dialogue between Galesia and her interlocutors about literature and life as a reflection of Barker's own dialogue with the female readers of her nouvelles, whom she addresses in her prefaces.

The moral justification of romance, the dialogue her tales establish with romances of the past, and the way in which Barker weaves her autobiographical fiction with romantic conventions, reveal her vindication of her work and her career as author because rather than in spite of the association between women readers and writers and romance. As King has asserted, "the central patch-work metaphor [...] projects the image of a community of female readers and writers and implies a strategy of authorial ownership" and "it is especially suggestive in the way in constructs professional novel-writing as an emergent form of women's work" (1995: 79), as an emergent form of these interwoven romances written and read by women. Moreover, by expanding the metaphor to include not only the screen, but the lining, that is, the layer of cloth attached to the inside of the patch-work in order to make it stronger or to make it hang better, Barker draws attention to the process of writing itself and to how she carefully structures her work as an author. This transposition from needlework to writing is highlighted in a Patch-Work when Galesia finds her hostess has created a patch-work "most curiously compos'd of rich Silks, and Silver and Gold Brocades" (1723: a5r) and is completing a screen with her maids. Galesia is then asked to contribute to the screen, but when she opens her trunks and boxes "they found nothing but Pieces of Romances, Poems, LoveLetters and the like" (1723: a5v). Her hostess decides that these textual patches 
should be arranged to compose a screen; therefore Galesia places the stories together to wave her screen, while explaining at the same time how each textual patch came into being. Hence,

A Patch-Work Screen for the Ladies thus alternates between text and commentary to construct, patchwork fashion, two stories -the story of Galesia the poet as a young woman and the story of the making of the patchwork screen- and to imply a third: the story of the making of a book to be published under the title A Patch-Work Screen for the Ladies and sold in the London literary market. Writing for print publication emerges as an extension of traditional forms of women's work. (King, 1995: 80)

As a consequence of this continuity established between "traditional feminine activities and those of the new print culture," her "text-textile analogies" also serve her interest of promoting a community of female readers, a female audience for her works (King, 1995: 82). Her preface to A Patch-Work is very revealing: in it women of different political parties come together, and are compared to the different patches that create the screen, or even to the "clashing of Atoms" which at last united create the "glorious Fabrick of the Universe" (1723: v-vi). ${ }^{107}$ Barker therefore depicts this female literary community as harmonious and influential, and she confidently addresses it as her ideal readership. She relies on the support to be found in female readers for female writers as they attempt to write "instructive novels" after "a manner entirely new," in which the inherited tradition of the framed-nouvelle or collection of short stories moves toward "a new form where the central focus is on the 'history' and development of the central, female protagonist" (Donovan, 1997: 975). This new form or this new central focus will culminate with the female bildungsroman, which has a relevant exponent in the story of the female quixote.

In conclusion, the works of Subligny, Steele and Barker are essential in their role as foundations for the appropriation of Cervantes' Don Quixote and his transformation into a young female romance reader, with the subsequent

107 Donovan states that the patch-work composition then reflects the "social and economic reality" of women and thus "thematically and formally" it critiques "the authoritative word of the fathers -establishing the critical, polyvocal, 'patch-work' perspective that is essential to the novel's identity" (1991: 462). On this subversion of the discourse of the father in Barker's work, see also pp. 452-54 and 461 of the same study. 
creation of a more plausibly romantic heroine. They also manifest the complex interpretation of quixotism and the rich employment of the female quixote. While Subligny portrays a deranged quixote who literally aims to embody a heroine from her romances, Steele and Barker establish the recurrent reading of female quixotism as a romantic colouring of reality in which the young quixotes read their lives as a romance and adapt their perception of the world to literature. All three authors highlight the importance their heroines' youth and inexperience have in the appearance and development of their quixotic delusion, and how it is a lack of critical reading which triggers much of their quixotism. They also coincide in emphasising how dangerous their romantic delusion is for the most important experience in a young girl's life: courtship and marriage. More relevantly, they anticipate another recurrent feature of this tradition, the need for a cure, and allow perceiving how the process and culmination of that awakening to reality might differ from one author to another: the degree of ridicule or punishment will vary according to how disruptive the quixote is perceived to be, or how dangerous for her virtue her quixotism becomes, notwithstanding the blame placed on a lack of education or of guidance. A correspondence will then be established between the weight placed on the didactic purpose and moral tone of the quixotic work, and the tragic or comic consequences their delusion will have for the young quixotes. The purpose and tone may range from Steele's comic entertainment to Barker's tragic instruction. This comic or tragic interpretation of quixotism will be reintroduced in later quixotic novels, while in certain examples both readings may converge.

Owing to the fraught relationship of genre and gender found in these works, one must conclude that from its origins the tradition of female quixotism offers an adequate stage from which to question the relationship between literature and life, between formal and moral realism, between women and romance or romance and the new forms of fiction. These reflections on the critical or uncritical reading of literary works and on the difficulties of women readers and writers will be common places in later works, proving that these early examples of female quixotes serve as sources for Lennox's novel and for her paradigmatic heroine, as well as for her descendants. 


\title{
4. CHARLOTTE LENNOX: THE FOUNDATIONAL QUIXOTE AND THE GENDERED DEBATE ON GENRE
}

\begin{abstract}
Upon the whole, I do very earnestly recommend [The Female Quixote], as a most extraordinary and most excellent Performance. It is indeed a Work of true Humour, and cannot fail of giving a rational, as well as very pleasing Amusement to a sensible Reader, who will at once be instructed and very highly diverted.

Henry Fielding, Review of The Female Quixote, Covent Garden Journal, march 24,1752
\end{abstract}

Charlotte Ramsay Lennox (1729/30-1804) has become an increasingly studied and relevant figure in the study of the history of English literature, both as an example of a successful woman writer and as the creator of the foundational female quixote. Moreover, she has gained progressively more importance as the history of the novel has widen its perspective to acknowledge the role women writers had in the development of prose fiction and in the heated debate on gender and genre that took place as a consequence of the dichotomy romance/novel delineated by critics of the age. In the midst of this debate stands her masterpiece, The Female Quixote or, the Adventures of Arabella (1752), which remains to this day her most accomplished and successful work. In her novel, Lennox not only recapitulates some of the topoi from earlier quixotic narratives, but also develops them further and deepens what they allow of comment on the generic transformation that was taking place in the mid-eighteenth century. As in no other work hitherto, Lennox's female quixote would become an alter-ego of the woman reader and writer and a milestone for subsequent women novelists. In this sense, Lennox has been rightly hailed as one of the "early mothers of the novel" and one of its "earliest critics" (Thomson, 1992: 113).

Under the light of these considerations, this chapter will focus, firstly, on Lennox's creation of her quixotic character and narrative, on her Cervantean inheritance filtered through Fielding and other authors, and on the ways in which she lays the foundations for the subsequent tradition of female quixotic 
fiction. Secondly, it will dwell on the Cervantean generic dialogue that is established in her work, on her quixote's romantic narrative within the frame of her novel, and, more relevantly, on how she employs it to perform her particular comment on romance and the novel. Finally, it will aim to relate this generic dialogue with the coeval debate on the place of women as producers and consumers of prose fiction, placing Arabella in the light of romantic author-surrogate for Lennox by means of her corrected romantic rewriting of reality and her appropriation of the male authority of the Richardsonian sentimental novel. It will then hopefully strengthen the hypothesis that women writers employed the figure of the female quixote within a wider Cervantean tradition that included the authors studied in chapter one, and utilized it as a relevant instrument for their own self-validation as authors and literary critics, as expounded in chapter two. 
1. A NeW Reading of the World: Romance And the Feminocentric NARRATIVE

From the first pages of Lennox's novel, in which Arabella, the only daughter of a wealthy and haughty Marquis, is described as motherless, raised in the country, and addicted to reading, it is easy to perceive some of the recurrent elements in the canon of female quixotism: the early isolation, the absence of the mother-figure and the choice of romances as favourite reading from an early youth. These three elements appear closely connected at the beginning of the novel. Little is known of the Marchioness, except for her marriage to the Marquis, which follows another recurrent fairy-tale plot:

[...] the Marquis, though now advanced in Years, cast his Eyes on a young lady, greatly inferior to himself in Quality, but whose Beauty and good Sense promised him an agreeable Companion. After a very short Courtship, he married her, and in a few Weeks carried his new Bride into the Country, from whence he absolutely resolved never to return. (1973: 6)

The beautiful girl marries the nobleman and lives happily ever-after in his castle. However, the Cinderella story of the Marchioness intertwines with the romantic plot of her daughter; as a consequence, she dies of childbirth three days after the delivery of Arabella to fulfil another of the romantic conventions: the absent mother-figure. Nevertheless, the narrator informs us that the romances that later Arabella will read belong to her unfortunate mother: "the deceased Marchioness had purchased these Books to soften a Solitude which she found very disagreeable; and, after her Death, the Marquis removed them from her Closet into his Library, where Arabella found them" (1973: 7). Therefore, these romances allow Arabella to bond with the absent mother through their common experience and readings, and thus the female community of readers finds expression in this literary legacy. In a way, then, Arabella reclaims her maternal inheritance, both literally and figuratively, by her appropriation of her mother's romances (Doody, 1989: xxi) and of the heroic stories of what could be termed her literary sisters or godmothers, for by their example they make possible Arabella's adventures (Borham-Puyal, 
2009). ${ }^{108}$ This sense of female community is emphasised by the recurrent use of the plural pronoun "us" to refer to herself and all other heroines in general, which the narrator informs the readers is a common custom among heroines (1973: 10).

Romances also attach Arabella to her mother in that they lessen the same maleimposed solitude that oppressed the Marchioness. The narrator states that

[...] the surprising Adventures with which they were filled, proved a most pleasing Entertainment to a young Lady, who was wholly secluded from the World; who had no other Diversion, but ranging like a Nymph through Gardens, or [...] Woods and Lawns in which she was inclosed (sic); and who had no other Conversation but that of a grave and melancholy Father, or her own attendants. (1973: 7)

Her enclosure and lack of appropriate companionship explain the attraction of these French romances, which, unfortunately, she can only read in "very bad Translations" (1973: 7). At a moment in life in which childhood gives way to adulthood, for Arabella is only seventeen, romances provide a substitute guide for her mother to make sense of the world and her role in it. What is more important, the appeal of the particular French heroic romances which Arabella so obsessively peruses springs from the importance they allocate to what is perceived as the core of the female realm of experience, love and courtship. ${ }^{109}$ Derived from her extensive reading of these French works and the "Manner of her Life," "her Ideas [...] and the Objects around her, had taken a romantic Turn" and Arabella, "supposing Romances were real Pictures of Life," draws from them "all her Notions and Expectations" (1973: 7). These expectations

${ }^{108}$ Debra Malina asserts that romances stand as both "evidence and emblem of the repression of the mother" by the patriarchal figure, and that "in her reading of them, [...] Arabella has already performed a political act of recovering and allying herself with the absent mother in defiance of the father" (1996: 279), hence emphasising this sense of female literary community and tradition.

${ }^{109}$ Dalziel explains their lure for Arabella thus: "French romances are typical of the genre, in that they take love and war as their subjects and represent them in what we recognize as ideal rather than real forms; but they have certain specific qualities which make it plausible that they should be accepted by a young lady as guides to conduct. Mlle de Scudéry in particular concentrates on love rather than war, and makes the experience of her heroines very important. They are pictured in ideal terms; they are of high birth, and impossibly beautiful, wise, and good; they are the objects of universal admiration and love but, though apparently endowed by fortune with every imaginable gift, are destined to suffer a great variety of distresses before achieving a happiness which is as perfect as everything else about them" (1973: xiii). 
relate to the area of female expertise which these romances highlight and therefore she learns to believe "that Love was the ruling Principle of the World; that every other Passion was subordinate to this; and that it caused all the Happiness and Miseries of Life" (1973: 7). It will therefore be in sexualised terms that her quixotic reading of herself, other characters and the rules of society will be conducted.

As a consequence of her romantic reading, in Lennox's work there exist two coeval narratives: Arabella's romance and the novel in which it is inscribed and which recurrently counteracts her literary reading of herself, of her companions and of society in general. Owing to the novel's theoretical claim to present "things as they are," this correction will go beyond a matter of generic supremacy, and will involve a comment on the mistaking of literature for reality. However, the differences between genres, between reality or the world as presented in the novel and illusion or the world as presented in romances, will become at times difficult to perceive and the novel will be shown as much closer to her precedent than could be first expected, providing the basis for the subsequent analysis on Lennox's approach to the generic debate.

This approximation between the world of romance and of the novel is evident in the characterization of the main character. Arabella's reading of herself as a romantic heroine is the most easily sustained of her quixotic delusions. According to the aristocratic values of romance, her high birth and wealth are in harmony with her heroic role. Moreover, her beauty and accomplishments also equal those of any heroine:

Nature had given her a most charming Face, a Shape easy and delicate, a sweet and insinuating Voice, and an Air so full of Dignity and Grace, as drew the Admiration of all that saw her. These native Charms were improved with all the Heightenings of Art; her Dress was perfectly magnificent; the best Masters of Music and Dancing were sent for from London to attend her. She soon became a perfect Mistress of the French and Italian Languages, under the Care of her Father; [...]. (1973: 6-7)

Arabella is thereby endowed with all the advantages given by genealogy and providence, those of rank and beauty, as well as all the accomplishments money can buy. She does not even have to change her name for an appellation 
more in the fashion of the heroines from French romances, as Biddy had done. In consequence, one could almost say that she has but little choice to become a deluded heroine, because she has so much of one. Moreover, seeing in herself a great degree of what she saw in the charms of the heroines, Arabella makes easy parallelisms between what their fate was and what hers must be:

Her Glass, which she often consulted, always shewed her a Form so extremely lovely, that, not finding herself engaged in such Adventures as were common to the Heroines in the Romances she read, she often complained of the Insensibility of Mankind, upon whom her Charms seemed to have so little Influence.

The perfect Retirement she lived in, afforded indeed no Opportunities of making the Conquests she desired; but she could not comprehend, how any Solitude could be obscure enough to conceal a Beauty like hers from Notice; and thought the Reputation of her Charms sufficient to bring a Croud (sic) of Adorers to demand her of her Father. (1973:7-8)

Arabella equates being extremely beautiful with becoming a universal object of admiration and, thereby, a heroine. That is, her syllogism would work thus: if beautiful girls who are also rich and powerful (A) become heroines (C), and I (B) am beautiful, rich and powerful (A), therefore, I (B) am bound to be a heroine (C). In this sense, the parallelisms she draws between fiction and reality are better founded than those of Don Quixote, and her reimagining herself as a heroine seems more plausible than that of the hidalgo as a knight. More than Cervantes, Lennox's heroine then recalls Barker's or Fielding's more romantically plausible characterization of their quixotes, and even the latter author praised the greater credibility of the young quixote compared to Cervantes' knight in his abovementioned review. As Amy Pawl has asserted,

[...] Lennox has no desire to deflate Arabella's pretensions and instead is dedicated to buoying them up, to increasing their plausibility in the reader's eyes.

For Arabella makes a far better lady of romance than Don Quixote does a knight. Her creator has endowed her with tremendous advantages: she is the daughter of a nobleman, she is immensely rich and beautiful, and she does live in a castle. Her imagination need only change the world, whereas the lean and aged Don Quixote has the much greater task of reimagining himself. (2000: $150)^{110}$

${ }^{110}$ An early account of Arabella's plausibility is provided in Fielding's well-known and profusely quoted review in The Covent-Garden Journal for March 24, 1752, in which he 
What seems more important, Arabella not only is a plausible "lady of romance," but, again in Joseph Andrews's train, a perfect sentimental heroine. She is beautiful, virtuous and with the capacity to easily and profusely display her emotions as later novel heroines will also do: she swoons, she is reduced to tears by the smallest incidents, and she makes herself ill with grief after her father's death. ${ }^{111}$ The heroine of Arabella's romance and Lennox's novel are hence the same, a fact that is later emphasised when Arabella instructs Lucy on how to relate her romance, starting with her illustrious birth, then skimming through her first eight or ten years of life and explaining how her early "Sallies of Imagination" made those around her conceive "marvellous Hopes of my future Understanding," finally concluding with an "accurate Description" of her person (1973: 122): the same pattern that Lennox has followed in her heroine's introduction. The romance contained in the narrative frame of the novel mirrors the novel which mirrors romance.

Both in the romance and the sentimental novel, the cornerstone of a heroine's story is courtship and her definition in it as object of adoration in relation to her suitors; consequently, Arabella's most recurrent misinterpretations necessarily occur in relation to men and how they respond to her appearance. In the midst of her heroic delusion, Arabella depicts a world full of ravishers and beaux, of wicked souls and noble spirits; due to her heroic interpretation of reality, all men in her acquaintance are madly in love with her, and either have evil designs on her or are willing to marry her. It does not signify how far from the behaviour of previously known romantic characters they seem to be. If they contradict her expectations, she consciously searches for another example in her readings which may explain their behaviour, in what scholars have identified as her "exegetical energy" (Gordon, 2006: 54); that is, she employs the same syllogisms she used to read herself as a heroine of romance. Her delusion is very soon made obvious with her gardener Edward and her

states that Lennox's quixotic imitation surpasses its original in that the incidents she portrays are "less extravagant and incredible" and are not carried "beyond the Common Life," while there is nothing "even in her Character, which the Brain a little distempered may not account for" (qtd. in Small, 1969: 96). Interestingly, Fielding accuses Don Quixote of coming too close to the romances which he ridicules, but does not avow for the obvious same closeness to the object of parody in Lennox's novel.

${ }^{111}$ See in chapters five and six the reference to some sentimental heroines and quixotes. 
portrayal of him as a nobleman in disguise, rejecting his title to humble himself and live close to her in order to "have an Opportunity of declaring his Passion for her" (1973: 22). That is, if in romance heroines are pursued by noble suitors, and these suitors work under a humble appearance, then, as Arabella is a heroine, Edward under all probability must be one of the noble beaux she is bound to find in her heroic life. The novel's narrator sets the record straight: Edward "had lived in several Families of Distinction," moreover "he had a good Face; was tolerably genteel" and had "an Understanding something above his Condition" and "a great deal of secondhand Politeness" (1973: 22). Therefore, the novel provides a plausible explanation for Edward's alleged superiority of breeding, resembling Barker's own explanation of the behaviour of Jack. However, as Don Quixote's or Dorinda's, Arabella's hold on her romantic delusion is persistent. Not even when confronted with Edward's real nature as a thief she is willing to admit her mistake. In a similar episode to Don Quixote's defence of Andrés, the young peasant who is being beaten by his master, Arabella is shocked to discover the head gardener giving several blows with a stick to the distinguished hero for having stolen some fish from the pond. She has him released, after which the hero "sneaks off, with an Air very different from an Oroondates" (1973: 24). The accusation so openly challenges her view of Edward, that "it was some Time before she even reconciled Appearance to herself," although, fortunately for the advancement of the plot, in words of the narrator: "she had a most happy Facility in accommodating every Incident to her own Wishes and Conceptions" (1973: 25) and disregards the evidence of her senses (the carps he had in his hands) in order not to shatter her romantic expectations. When Lucy recalls this piece of evidence, Arabella angrily replies "still will you wound my Ears with that horrid Sound? I tell you, obstinate and foolish Wench, that this unhappy man went thither to die; and if he really caught the Fish, it was to conceal his Design from Woodbind [Edward's superior]" (1973: 26). This angry speech resembles Biddy's exasperation at her aunt's realistic account of objects, which also becomes ugly sounds to her romantic ears. Finally, when Edward leaves she attributes it to "some new Design he had formed to obtain her," though the reader is told that "among the Servants" it was said that he "feared the Discovery of more Tricks, and resolved not to stay till he was disgracefully dismissed" (1973: 26). This 
early adventure not only provides one of the best examples of Arabella's constant and conscious dialectic re-reading of reality, in which the worlds of fiction and reality are forced to resolve their differences, but also of Lennox's parodic intention in her novel, by pointing to the wide gap that exists between Arabella's romantic interpretation and the mundane reality of events. In this sense, the jocularity of Arabella's reimagining of Edward indeed resembles Cervantes' or Fielding's humour, and anticipates Austen's. As the novel advances, however, the boundaries will blur, and her parodic and satiric intention will prove increasingly ambiguous.

Another example of the quixotic dialectic accommodation of the world of romance and of reality is presented in the episode of the highwaymen. On their way to Bath, Arabella and her companions see "Three or four Men of a genteel Appearance, on Horseback" (1973: 257), which Arabella takes "for Persons of Quality [...] and thought they came questionless, either upon a good or a bad Design, yet it cannot be doubted, but that their Birth is illustrious; otherwise they would never pretend either to fight in our Defence, or to carry us away" (1973: 259). Arabella's senses are in perfect working order, as she sees what everybody else does; however, her interpretation of her sensory data diverges from her companions' processing of it. In Motooka's words:

Since the laws of romance have determined that ladies travelling with male companions are likely the victims of ravishments, and that well-dressed men on horseback who approach such ladies are often knights intent upon delivering them, Arabella interprets her observations according to the dictates of probability [...]. Relying on romance rules of conduct, Arabella is sure that the riders could not be robbers, for their illustrious births, as evidenced by their participation in the noble conduct of succouring maidens or carrying them off, are too exalted for so base an occupation. (emphasis added, 1996: 258)

Once again, one is confronted with the strict rules of romance which attribute to people of different ranks, different roles within the plot. If the appearance of these men is illustrious, then so must their birth be; thereby, they cannot belong to such an unworthy profession as that of robbers. They must rather be ravishers, an occupation which ironically seems to be more respectable for noblemen according to the rules of conduct found in romance. More importantly, though, Arabella employs the same syllogisms of appearance 
which she used for herself: the outer shell determines much of the role of those around her. Motooka further explains that "her assumptions about the men's condition serve also as her evidence," and therefore "the strength of her belief alone -her unwillingness to see things in any other way- supports her analysis and conclusion" (1996: 258). When her relatives inform her that they were highwaymen who intended to rob them of their money, Arabella exclaims:

How! [...] Were these Cavaliers, who appeared to be in so handsome a Garb, that I took them for Persons of prime Quality, were they Robbers? I have been strangely mistaken, it seems: However, I apprehend there is no Certainty, that your Suspicions are true; and it may still be as I say, that they either came to rescue or to carry us away. (emphasis added, 1973: 259)

Adding the same emphasis as Motooka to Arabella's words, one perceives that all interpretations are lacking the presence of certainty, as they are all supported by probability, although what is probable varies from the romantic to the more realistic narrative of the novel. Again in Motooka's phrasing, "there is a method in Arabella's madness, and that method looks strikingly similar to the empiricist epistemology employed by her 'rational' companions" (1996: 260). That is, for Arabella the rules of romance render it more probable that the men she sees are good or bad knights, while her companions' experience tells them it is most plausible that they are robbers. Once again, Arabella interprets the information provided by her senses in relation to others according to the laws of romance, only to be challenged -and at times parodied- by the common frame of reference of reality which her companions, the reader and the narrator share. ${ }^{112}$

Arabella is not only led to err when it comes to male characters; her reading of the other women in the novel is also subordinated to the conventions of romance and their roles as confidant, friend, fellow heroine or lady in distress, are assigned accordingly. Arabella sees in Lucy a knowing recipient of her

${ }^{112}$ For a different analysis of this passage and how it epitomizes Arabella's active reconciling between fact and fiction, see Gordon (2005: 134-5). Gordon emphasizes the "active process" by which Arabella accommodates romance and reality and concludes that female quixotism is particularly, and dangerously, resilient, for "there seems no way to dispute a system so capable of 'reconciling' or 'accommodating' anything to itself, since any 'Object' or evidence presented turns out to (or is made to) re-confirm what the individual already believes" (2005: 137). 
confidence and a versed servant in the laws of romance, but Lucy is a naive observer and the voice of reality which challenges Arabella's romantic interpretations. She is to Arabella what Sancho is to Don Quixote, and Fielding himself compared both characters in their "fidelity" and "simplicity," although Sancho's comicality remains unchallenged by Lennox's creation (qtd. in Small, 1969: 95). Despite being less masterfully portrayed, Lucy is indeed the Panzaic comic counterpart of her lady, and, in the train of Sancho, her misappropriations of the language of romance or her mistakes when acting under her romantic mistress's orders transform her into a ridiculous, though endearing, character. As the squire, she sometimes proves wiser than her quixotic mistress and in her down-to-earth approach to life she even accepts a bribe or two from Arabella's first beau. Similarly to Sancho, her gullibility sometimes finds expression in excessive apprehensions and terrors. In addition, she also follows in the Spanish squire's quixotic transformation, highlighting the shifts in the dialogue of epistemologies already present in Cervantes' novel. At first, Lucy challenges her mistress's interpretation by her faithful account of Mr Hervey's or Edward's behaviour, while at the end of these adventures she becomes almost as quixotic as Arabella. She is a gullible companion who “always thought as her Lady did" (1973: 26) and who trusts Arabella's opinion even if it contradicts her own. Therefore, Lucy gradually loses her insight into reality, and she learns her role as a romantic female companion, asking her mistress to prevent another alleged suicide attempt from Edward "by laying your Commands upon him to live" (1973: 26). However, Arabella's romantic interpretation sometimes leads her to judge Lucy unjustly, and to compare her with mercenary servants from previous romances (1973: 99), to harshly scold her for not understanding her romantic allusions or for failing to remember exactly what she said and did in order to provide a record for posterity. Despite these shortcomings and her comic failure to repeat Arabella's long speeches or to pronounce the complex terms or names of romance, Lucy resembles Sancho in that she is faithful even when she does not understand, crying when her mistress does or despairing when she is in danger, and never betraying her lady as all the other maids do throughout the novel. Unaware to Arabella, Lucy comes closer to the romantic ideals of a good female companion than anybody 
could expect, while Lennox employs her colloquial speech for obvious parodic purposes, again ambiguously approaching romance.

Miss Glanville, Arabella's cousin, is perceived by the quixote as the female confidant and friend; as a woman with whom to converse and share one's experience. Arabella highlights the abovementioned heroic aspiration to female community, to the $u s$, in her search for a female companion. However, her expectations will be disappointed in Miss Glanville. When Miss Glanville is first introduced to the reader, she is portrayed thus:

As Miss Charlotte had a large Share of Coquetry in her Composition, and was fond of Beauty in none of her own Sex but herself, she was sorry to see Lady Bella possessed of so great a Share [...].

Arabella, on the contrary, [...] did not fail to commend her Beauty: a sort of Complaisance mightly in Use among the Heroines, who knew not what Envy or Emulation meant.

Miss Glanville received her Praises with great Politeness, but could not find in her Heart to return them. (1973: 80)

Charlotte does not have heroic selflessness nor can she perceive Arabella's sincerity and good nature, and throughout the novel her jealousy and envy in her interaction with Arabella is stated. Miss Glanville's role seems to be to stress the impropriety of Arabella's behaviour, that is, her faux-pas when it comes to interacting in the manner accustomed in contemporary society. Moreover, she is particularly unfair to her cousin's character, when, instead of helping Arabella to discover her mistakes, she maliciously participates in the cruel gossip which starts at Bath after her cousin's ridiculous behaviour, giving "new Poignancy to their Sarcasms, by artfully disclosing the bent of her Cousin's Studies, and enumerating the many Absurdities they had made her guilty of" (emphasis added, 1973: 322). In contrast, Arabella's blunders are innocently made and never intentionally directed against her cousin. After another episode of misunderstandings, Miss Glanville is once again resentful and hypocritical in her approach to Arabella, and decides to "appear still to be her Friend, that she might have more Opportunities of revenging herself" for what she perceives as her veiled accusations (1973: 90). Again, she appears to be what she is not and develops a subtle double-narrative of friendship and 
animosity, providing Lennox with a contrasting character to her idealised heroine and her romantic values; a contrast whose implications will later be developed in more detail and which will be imitated by later women writers.

Another female character of her romances which Arabella aims to construct is the "afflicted heroine" (1973: 68), the lady in distress. Arabella encounters Miss Grove at church and invites her to her house in order to become better acquainted; the lady is bored because Arabella's conversation was "neither upon Fashions, Assemblies, Cards, or Scandal” (1973: 68), although Arabella mistakenly interprets her absent-minded attitude as springing from some "very great Affliction" (1973: 68). Surprised once again at the lack of spontaneous confidence in relating her adventures, Arabella resolved "as was the Custom in those Cases, to oblige her Woman [...] to relate, her Lady's History to her" (1973: 69). Miss Morris, the lady's maid, shocked at this request, is finally convinced and relates the story of an early elopement with her writing master, debt, two illegitimate children and an arranged wedding. Instead of a romance and a lady in distress, Arabella encounters a scandalous narrative, the story of a fallen woman. When Miss Groves discovers Arabella's conversation with her servant, she leaves in anger, attributing her rude liberty to her country ignorance and ill-breeding (1973: 78). Astonished, Arabella is left clueless as to the nature of her affront, and later in the novel she still insists in defending Miss Groves from Charlotte's censure stating that she must have been secretly married to her lover and that her writing master was undoubtedly a nobleman in disguise, which would have excused her elopement owing to the illustrious heroic examples she would be following (1973: 141-42). Despite the goodness of her intentions, Arabella's idealistic reading contrasts with Miss Glanville's better knowledge of the world and provides the foundation for Lennox's parody of her romantic expectations. However, by including this "subtextual 'Ruined Woman"” story (Thomson, 1992: 117), only too common in fact and fiction, Lennox also contrasts the ideal and pure vision of her quixote with the tainted reality of women who granted illicit favours, proving that the quixotic interpretation -and behaviour-is clearly preferable.

Finally, Arabella's romantic reading of reality is most blatantly and ridiculously contradicted in her adventure in London's Vaux-Hall gardens. The 
narrator explains that an officer had brought his mistress to the gardens under a man's disguise, both were intoxicated and, while he remained unconscious, she was discovered to be a woman and another man, in order to divert the company, drew his sword at her. Arabella interprets the news that a man has drawn his sword at a lady in disguise under the light of many examples from her romances and hence runs to aid the unknown lady. At her arrival, the woman is "trembling at the Apprehension of the Sword," while the man is kneeling at her feet "making Love to her in Mock-Heroicks for the Diversion of the Company" (1973: 335-36). As Don Quixote would have done, Arabella interprets the scene literally and tries to help the lady, whose aspect persuades her that her "Quality is not mean" and whose condition and disguise show that she must be "unfortunate" (1973: 336). She consequently exposes herself to the "Whispers and Scoffs" of the spectators and to Glanville's increasing vexation, who scolds her for her madness in making that "Rout for a prostitute" and for calling such unwanted attention (1973: 336). The adventure ends with a fight between the officer and the jester, and the flight of the ladies in terror. This event leads sir Charles Glanville, Arabella's uncle and guardian, "who had several Times been in doubt whether Arabella was not really disorder'd in her Senses" to conclude she "was absolutely mad" and to consider whether he "ought not bring a Commission of Lunacy against her, rather than marry her to his Son, whom he was persuaded could never be happy with a Wife so unaccountably absurd" (1973: 339). However, there is little difference between this episode and the abovementioned one with the highwaymen, or with Arabella's constant comparisons between London's scenery and Rome's, which are recounted only some days before (1973: 334). ${ }^{113}$ Arabella's senses are not deceived: she perceives, as does everybody else, the woman in disguise and the man with the sword; the difference, once again, lies in her literary system of reference and her lack of experience in the world, which lead her to read the scene as a plausible heroic situation. Nevertheless, the disruption her folly causes is greater than in previous examples, hence the "Absurdity of her Behaviour, and the Ridicule to which she expos'd herself whenever she went" (1973: 339) trigger the possibility of her being declared mad and interned in a

${ }^{113}$ This reading of London in its similarity to Scudéry's and other French romancers' "Rome" resembles Subligny's mock-Clelia's reading of Paris under the same light. 
mental institution. The stricter condemnation of Arabella's quixotism is then not based on the difficult accommodation between romance and reality, but on its social consequences and on what it implies to Arabella's, and by analogy her future husband's, reputation. The greatest danger of female quixotism is thus introduced as how it affects the core of women's value in society: their role as preservers of virtue and their family's honour. While Joseph Andrews served to make fun of this concern by means of his Pamelian obsession with virtue and its contrast with a debased society, for Arabella and all female quixotes this preoccupation with honourable appearances and their interaction within such an unheroic reality has important implications and consequences. Hence the greatest difference with male quixotes even in comic narratives so similar as Fielding's and Lennox's is that the threat of ruin or of losing the chances to marry are real for the female quixote, notwithstanding how benevolent the approach of the author or how virtuous the tenets of the heroic romance the quixotic figure chooses as axiological guide. This is the reason why the reading of male suitors is the most recurrent feature of female quixotic narratives: on it depends the happy or tragic ending of the quixote, her marriage to a hero or her ruin in the hands of a villain.

This important reading of female honour tinctures Arabella's interpretation of men and, in this sense, not all of Arabella's romantic reading and classification of other characters proves absolutely detached from the plausibility of the world of the novel. For instance, when Mr Hervey, a gentleman visiting the country, gazes at her in church, she concludes he must has fallen desperately in love with her and will soon take some course of action to gain her. Although not in the romantic extremes she imagines, Hervey indeed decides to attempt to gain advantage of her nil knowledge of society and men to obtain her favour. Arabella instructs Lucy how to behave, in spite of which the poor maid cannot prevent a series of misunderstandings taking place between her and Hervey. As his letter is sent and returned unopened, Hervey and Lucy play the part of conspirators in the love plot, by means of a bribe and the exchange of messages. Having been instructed to relate to her mistress the gentleman's reactions, Lucy states that he does not despair at the return of his letter, but rather laughs. After some effort, Arabella reconciles this event with the 
precepts of romance and avows his strange behaviour is due to madness caused by rejected love: "Doubtless, resumed she, having taken a little Time to consider of so strange a Phænomenon, he laughed, because his Reason was disturbed at the sudden Shock he received" (1973: 15). In the same way, when he recovers from illness it is because she has commanded him to do so, or at least she believes it was her power over him which made him sick and then well again. In those two instances, Arabella is clearly mistaken, as when he approaches her on horseback and she interprets he is come to kidnap her. As a consequence, she has her men attack and reduce him, while she accuses him of aiming to carry her away by force. At this moment, however, Hervey allows the similarities between the world of romance and of reality to be highlighted. First, he threatens to stab Arabella's servants before her face, hence justifying her accusations of violence; and, secondly, the narrator explains he started to be apprehensive that the whole affair may prove a very serious one, for he was aware that "an Attempt of that Nature upon an Heiress might have dangerous Consequences" (1973: 20). In Hervey's experience of the world, the kidnapping of an heiress is not only possible, but punishable. Moreover, the common truth of female sexual vulnerability underlies both fantasy and fact (Thomson, 1992: 116) and, at least in this case, justifies Arabella's resistance to admit her error.

More importantly, Arabella's reading of Mr Glanville as the hero of her romantic story is not as far from reality as her other constructions. At first, she believes he is merely an imposed suitor whom she is ready to reject following previous examples of heroic parental disobedience. However, his appearance, once more, is what renders him adequate for the role of hero, as Arabella "could not help betraying some Surprize at the Gracefulness of his Figure" (1973: 28) and, as the narrator observes, "she had too much Discernment not to see Mr Glanville had a great deal of Merit; his Person was perfectly handsome; he possessed a great Share of Understanding, an easy Temper, and a Vivacity which charmed everyone" (1973: 30). Her reading of him as a hero is made obvious when she invokes his name in the midst of her fear of being abducted by Edward or in the final moments of jealousy at his alleged passion for another woman. The reader is constantly reminded that he is actually madly in 
love with her, which is the essential quality for a hero of romance. And, more relevantly, Glanville becomes a solicitous suitor and, thus, illustrates the power that Arabella has acquired in her status as romancing quixote. For Pawl, Arabella "succeeds [...] by getting others to enact her romance fantasies for her" (2000: 152), while Bannet also sees her true power over men as depending "on her ability to inspire them with a desire to ingratitate themselves with her by imitating her model" (2007: 562). Glanville is the primary victim of her success and control of the romantic narrative: "he does (twice) take up his sword for her, and he does suffer a protracted and anxious period of courtship, which stands in pointed contrast to his initial, complacent marriage proposal [...]. We are certain that Glanville has been deeply affected by Arabella when we catch him speaking her language to himself” (Pawl, 2000: 152). In Malina's words, "Glanville has begun to take seriously the terms of romance which Lennox parodies. He has begun to play the role Arabella writes for him" (emphasis added, 1996: 280).

After his initial arrogance and complacence, Glanville adapts to her fictionalised world and becomes part of the plot Arabella had designed for herself as a heroine. He allows this transformation of his role to occur, and is an active part of it. The novel offers many examples of this rewriting. Glanville attempts to read her romances to be able to imitate Oroondates, and later saves Arabella's books from being burnt by the Marquis and presents his deed in a mock-heroic style. He accepts her commands to leave the room or not to speak love to her, and after the episode at the gardens, he tries to appease Arabella by telling her that the distressed lady left in safety with her favourite lover, hence employing her own language and romantic plotting. This is not the first instance of Glanville's adoption of the romantic language and conventions; after listening to the story of Orontes and Thalestris, he tells Arabella "to shew you [...] that I am capable of doing as much for you; I will, if you insist upon it, seek out for some Cave, and do Penance in it, like that Orontes, provided you will come and fetch me out of it, as that same fair Queen did him" (1973: 127). When Arabella replies that he should rather justify himself in the eyes of the world, Glanville adds: "I'll convince you of my Innocence, by bringing that Rascal's [Edward] Head to you, whom you suspect I was inclined to assist in 
stealing you away" (1973: 127). To prevent Arabella's visit to the sick Sir George, Glanville assumes the language and actions of romance: he employs the example of Orontes's jealousy, and he counterfeits his rage and his despair, ending with a threat to die at her feet if she resolves to go (1973: 189-90). Early in the novel he had resolved to "accommodate himself, as much as possible, to her Taste, and endeavour to gain her Heart by a Behaviour most Agreeable to her" (1973: 46). Glanville then appropriates the principles of romance in order to effectively court Arabella, aiming to manipulate her notions in his advantage. Therefore, this rewriting of his role as hero is very closely related to the essential part he plays as suitor in Arabella's romantic plot of courtship. He finds himself forced to wait and endure a painful courtship, if not dangerous until his final duel with one of Arabella's scheming suitors, at least embarrassing. In order to obtain Arabella's love, Glanville is forced to play by her romantic rules and finally succeeds in the role of hero who marries the heroine. In this regard, Glanville is more a hero of romance than the male mentor model to be found in later novels of manners or comingof-age novels: he does not re-educate Arabella in order to overcome her quixotism, but almost becomes re-educated himself and merely plays the role of lover to grant Arabella her deserved happy ending. In the end, he simply expects to be able to marry her once the "Whims her Romances had put into her Head, were eraz'd by a better Knowledge of Life and Manners" (1973: 340), and he places his trust on her friend the Countess, on "whose conversation he grounded all his Hopes for her Cure" (1973: 340). Throughout the novel, Arabella remains impervious to his discourse and is therefore granted more agency with respect to her suitor in Lennox's narrative than in later anti-Jacobin quixotic fictions, for instance, in which lover and mentor become one and the same. Arabella's reformation will require more than just a romantic hero, and she will thus anticipate the more complex awakening of the female quixotes to be found at the turn of the century.

Also anticipating subsequent female quixotic narratives, Arabella's reading of the world does not circumscribe to characters, but also to manners. Arabella embodies the codes of behaviour of romance in which a lady may welcome her lover with an embrace, but not a kiss (1973: 29); in which a lady ought not to 
accept professions of love (1973: 44); in which she may dismiss her older relatives from her room (1973: 63); or in which she may ask for a lady's history with no embarrassment. She believes that the axioms she lives by are proper codes of behaviour which cannot be surpassed by those of the present age, as her conversation with Glanville evidences:

[...] Cousin, interrupted Glanville, [...] do not suffer yourself to be governed by such antiquated Maxims! The World is quite different to what it was in those Days; and the Ladies in this Age would as soon follow the Fashions of the Greek and Roman Ladies, as mimick their Manners; [...]

I am sure, replied Arabella, the World is not more virtuous now than it was in their Days, and there is good Reason to believe it is not much wiser; and I don't see why the Manners of this Age are to be preferred to those of former ones, unless they are wiser and better: However, I cannot be persuaded, that Things are as you say, and that when I am a little better acquainted with the World, I shall find as many Persons who resemble Oroondates, Artaxerxes, and the illustrious lover of Clelia, as those who are like Tiribases, Artaxes, and the presuming and insolent Glanville. (1973: 45)

When Arabella finally enters the world, and travels to Bath, London and Richmond, she finds evidence that present manners are not always "wiser and better." Especially in her visit to Bath, Arabella becomes a social commentator who wisely expresses her opinion on raillery, and hence silences an impertinent Beau (1973: 269), and on scandalous gossip. In this last matter, she compares the "histories" of romance and their virtuous examples to the accounts of "Vices, Follies, and Irregularities" which compose present-day conversation (1973: 277). Finally, in a chapter acknowledged by the author in its title as of "the Satyrical Kind" (1973: 278) Arabella becomes an unwilling satirist of the shallowness of society. In this sense, she echoes Fielding's other quixote, Adams, and Lennox thus unites in one single quixotic character the parodic and the satiric, as Cervantes had done. At Miss Glanville's opinion that the Rooms, the Parade, and the "Parties of Pleasure" afford sufficient employment to "leave none of one's Time to lye useless upon one's Hand," Arabella answers:

I am of the Opinion, [...] that one's Time in far from being well employ'd in the Manner you portion it out: And People who spend theirs in such trifling Amusements, must certainly live to very little Purpose.

What room, I pray you, does a Lady give for high and noble Adventures, who consumes her Days in Dressing, Dancing, listening to Songs, and ranging the Walks with People as thoughtless as herself? How mean and contemptible a 
Figure must a Life spent in such idle Amusements make in History? Or rather, Are not such Persons always buried in Oblivion, and can any Pen be found who would condescend to record such inconsiderable Actions?

Nor can I persuade myself, added she, that any of those Men whom I saw at the Assembly, with Figures so feminine, Voices so soft, such tripping Steps, and unmeaning Gestures, have either signalized either their Courage or Constancy; but might be overcome by their Enemy in Battle, or be false to their Mistress in Love. (1973: 279)

At this Miss Glanville replies that gentlemen have no place in wars, for the business of fighting belongs to the officers, to which Arabella aptly replies that "then every fine Gentleman is an Officer [...] and some other Title ought to be found out for Men who do nothing but Dance and Dress" (1973: 279). A more detailed critique to these men "sunk in Sloth and Effeminacy" (1973: 280) ensues, which raises protests on the severity of Arabella's censure, who then concludes that "when Actions are a Censure upon themselves, the Reciter will always be consider'd as a Satirist" (1973: 280). Her superior learning, which is recurrently emphasised throughout the novel, and her defence of virtue place Arabella and her obsolete values above the rest of the company. In clear parallelism to her obsolete code of dress, which is only ridiculed by envious characters, and which, the narrator tells the readers, enhances the dignity and grace that awes the company into silence and respect, Arabella's values may belong to ancient times, but their moral worth when contrasted to some of the manners of eighteenth-century England is still acknowledged.

Arabella's accredited moral superiority and her role as unconscious instrument for satire, gives her quixotism its most striking addition, that of a new axiological dimension, which had only been slightly perceptible in Cervantes and had been later more thoroughly developed by Fielding, and which will become the most important feature of subsequent nineteenth-century female quixotic narratives. This new dimension, identified and thoroughly studied by P. J. Pardo, is based on this negative perception of reality when contrasted with the better world, from the quixote's perspective, of romance. In Pardo's words:

El quijotismo no es simplemente una percepción errónea de la realidad sino una valoración negativa de la misma, un conflicto entre la aspiración individual y el entorno social, la expresión y el síntoma no sólo de un proceso de engaño y desengaño sino de una situación de descontento, inconformismo, 
insatisfacción con la realidad [...]. La visión quijotesca entra así en colisión con la realidad que rodea al personaje pero no con la del propio del personaje, que es claramente superior al medio. (2005: 358)

This makes them "piedras de toque morales" (Pardo, 2004: 1636) and, therefore, as Adams, the means to criticise the shortcomings of society. As explained in chapter one, Adams's Christian values served to highlight the shallowness, hypocrisy, greed or selfishness of the society he lived in and, thereby, to implicitly satirise its members. In the same line, in the episodes located in Bath or London, the centres of fashionable society, Arabella's beliefs make the romantic world seem superior to the shallow one in which the rest of characters dwell.

As an ideologue of romance and qua heroine, Arabella then acts in compliance with the moral code extracted from her readings, no matter how manifestly they contravene those of her age. However, their obsoleteness and present inadequacy is also repeatedly pointed out. This is made especially evident in matters concerning male and female honour. At her request that Glanville kill her enemies and Miss Glanville's subsequent worry at the consequences, she tries to calm the latter stating that "the Law has no Power over Heroes: they may kill as many Men as they please, without being called to any account for it; and the more Lives they take away, the greater is their Reputation for Virtue and Glory" (1973: 128), to the extreme amazement of Miss Glanville, who cannot think of it but as a "strange Kind of Virtue and Courage indeed, to take away the Lives of one's Fellow-Creatures!" (1973: 127-128). Arabella's romantic creed bases women's worth on their beauty, virtue and number of conquests, and men's on their strength, bravery and unrequited devotion to their fair ladies. She states,

By your Discourse, Miss, [...], one would imagine, you knew as little in what the good Reputation of a Lady consists, as the Safety of a Man; for certainly one depends intirely (sic) upon his Sword, and the other upon the Noise and Bustle she makes in the World. The Blood that is shed for a lady, enhances the Value of her Charms; and the more Men a Hero kills, the greater his Glory, and, by Consequence, the more secure he is. If to be the Cause of a great many Deaths, can make a Lady infamous; certainly none were ever more so, than Mandana, Cleopatra, and Statira, the most illustrious Names in Antiquity; for each of whom, haply, an hundred thousand Men were killed: Yet none were ever so unjust, as to profane the Virtue of those Divine Beauties, by casting 
any Censures upon them for these glorious Effects of their Charms, and the heroic Valour of their Admirers. (1973: 128-29)

These values become for her the basis of this other space, this other world; a dreamt world in which women and men are distinguished by their power and their submission, respectively, in love. Love is all that matters in romance, and the greater concerns of heroes and heroines is earning and granting that love; it is in the act of accepting or rejecting suitors that women found their long denied power. These claims based on such obsolete social codes as those of an almost feudal lord-servant relationship in courtship, bring the strongest censure over Arabella's actions and, therefore, serve a double purpose: first, they are employed as a critique of Arabella's romantic power-driven aspirations, and second, as a means to criticise contemporary society's exclusion of women from any kind of active, decision-making position. In Christine Roulston's words:

\begin{abstract}
By operating within a self-referential frame, the law of romance can produce its own system of signification, just as Arabella endlessly reproduces her particular romance sequence, regardless of social "reality". On the one hand, it is precisely this denial of social responsibility which the novel is critiquing, but at the same time it highlights the dilemma of occupying a female subject position. Since Arabella is excluded from legitimate structures of power, fantasising a female role with power becomes a critique of contemporary social conditions as much as of Arabella herself. (1995: 34)
\end{abstract}

In this line, her romanticising is expressed not only in relation to the morals and manners of the age, but also with regards to women's aspirations. Romance provides a space in which women are treated as privileged and autonomous beings, and their individual aspirations to power are not contradicted by society's impositions. In Spacks words, romances provide Arabella "with enabling fictions to express the truth of her desires" (1988: 541): her desire for Conquests, her desire to be obeyed, her desire to have her story known. However, these aspirations clash with the view society holds of women and their possibilities in life.

One of the possibilities romance implies for women is mobility. In general, Arabella is a purely domestic quixote, whose status as a lady does not enable 
her to roam the wide world in search for adventures. Contrary to Don Quixote, whose main aim was to leave his home and live incredible and dangerous adventures, the world of physical action is closed for Arabella. Amy Pawl is right when attributing this immobility to her gender, as she argues that, in contrast with other authors such as Fielding or Sterne, who replicate the crude physical slapstick of Cervantes, the Augustan ideals of feminine decorum did not allow such unsuitable adventures to befall on a lady (2000: 148), emphasising once again the abovementioned essential difference between male and female quixotes. However, Arabella forever lives under the fear, and the hope, of being abducted and forced to travel far from her reduced circle. In that way, she imagines "an enforced and therefore feminine type of mobility, in which confinement and abduction are the keys to adventure and the world" (Pawl, 2000: 149), that is, a kind of mobility which is imposed on her, so she does not voluntarily break with the prevailing laws of female decorum. Unaware of the real consequences of abduction as did Biddy before her, paradoxically enough, Arabella conceives it as an almost liberating possibility:

I am certain, that if any Chance should conduct me into Macedonia, I would not leave it until I saw the Valley of Tempe, so celebrated by all the Poets and Historians.

[...] Well, interrupted Sir Charles [...] I hope my Niece does not propose to go thither.

Not unless I am forcibly carried thither, said Arabella; but I do determine, if that Misfortune should ever happen to me, that I would, if possible, visit the Valley of Tempe [...].

Then I am persuaded, replied Sir Charles, you'll never see that famous Vale you talk of; for it is not very likely you should be forcibly carried away into Turky.

And why do you think it unlikely, that I should be carried thither? interrupted Arabella. Do not the same Things happen now, that did formerly? And is any thing more common, than Ladies being carried, by their Ravishers, into Countries far distant from their own? May not the same Accidents happen to me, that have happened to so many illustrious Ladies before me? (1973: 260261)

Arabella believes being abducted is plausible according to the example set by previous heroines; she sees it as a chance to travel to her dreamt places, and no danger seems implicit in her ravisher's plans except that of taking her far from 
her well-known ordinary world. Nevertheless, her uncle believes her travelling just as unlikely as her being carried away. Arabella's quixotic desire for mobility in a world she perceives as fixed and limited then does not find an echo in real life.

However, the most disruptive reading romances allow is Arabella's commanding position as object of adoration and, therefore, her construction of the period of courtship as a space for subversion and rebellion. Contrary to other forms of amatory fiction, romance's greatest danger "is not so much the threat of sexual corruptibility, as the assumption of female power" (Roulston, 1995: 32). Arabella constantly expounds the need to award a favour only to the man who has accomplished innumerable services and waited long years for her hand. After finally granting Glanville permission to love her, the process of courtship is thus described:

[...] by the Laws of Romance, when a Lady has once given her Lover that Permission, she may lawfully allow him to talk to her upon the Subject of his Passion, accept all his Galantries, and claim and absolute Empire over all his Actions; reserving to herself the Right of fixing the Time when she may own her Affection: And when the important Step is taken, and his Constancy put to a few Years more Trial; when he has killed all his Rivals, and rescued her from a thousand Dangers; she at last condescends to reward him with her Hand; and all her Adventures are at an End for the future. (1973: 137-38)

This romantic deferral of marriage and enlargement of the prerogatives of the ladies in courtship has been amply identified as one of the main attractions of romance as a genre for women. In Christine Roulston's words, the conflict which underlies the novel is Arabella's use of romance to "abuse" the only period of female agency and autonomy, courtship, and to make herself unattainable, reaching the conclusion that "the fiction of this unattainability is then maintained through the conventions of romance, leading to control of the narrative fiction" so that "Arabella becomes inscribed as author within her own fiction" (1995: 31). However, it is a very different picture to the reality of courtship and marriage which the Marquis or Glanville hold.

As Arabella evolves from adolescence to adulthood, the need to become a wife to a respectable man increasingly pressures her with the obligation to renounce to all her heroic aspirations, in order to become an invisible being of the realm 
of the private and to end her adventures. At this point, Arabella is read as just a marriageable woman, a desirable conquest. First of all by her own father: the Marquis wishes to impose a previously chosen suitor on his daughter, and expects a ready compliance from her. The Marquis introduces her cousin Glanville to Arabella as "the Man who I design for your Husband" (1973: 39), being his reason that he knows better than her how to obtain her happiness: "I expect you will endeavour to obey me without Reluctance; for, since you seem to be so little acquainted with what will most conduce to your own Happiness, you must not think it strange, if I insist upon directing your Choice in the most important business of your Life" (1973: 42). As to her acceptance of that arrangement of marriage, he expresses his opinion in very strong terms: "I am surprised at your Treatment of a Man whom, after all, if ever you intend to obey me, you must consent to marry;" "Your Cousin is worthy of your Affection, and you cannot refuse it to him without incurring in my Displeasure" (1973: 54). Arabella is bound to obey and she expresses this lack of power on several occasions; she says, for instance: "I am not allowed a Will of my own" (1973: 43), or "my Affection is not in my Power to bestow" (1973: 54). Moreover, she is due to do so in the timeframe also established by her father, for the Marquis tells his nephew: "I will allow you [...] but a few Weeks to court her: Gain her Heart as soon as you can, and when you bring me her Consent, your Marriage shall be solemnized immediately" (emphasis added, 1995: 31). Roulston calls this "the model of control" sought by parents and emphasises how different this timeframe is from the one in romance, as well as how in the Marquis's vision "the idea of consent appears to be superseded by the concept of property" (1995: 31). That is, Arabella is the means through which profit may be obtained. She is read as passive and compliant in the eyes of her father, but also of her suitors, who expect a short courtship and a ready disposal to love. Arabella's most worthy lover, Glanville, and her uncle, employ once and again the terms of gain and loss when referring to matrimony. Sir Charles, for instance, suggests to Glanville that "since [Arabella] was to be his Wife, it was his Business to produce a Reformation in her; for, added he, notwithstanding the immense Fortune she will bring you, I should be sorry to have a Daughter-in-law, for whom I should blush as often as she opens her Mouth" (emphasis added, 1973: 64). Even Glanville himself talks about 
Arabella in the following terms: "her Character was so ridiculous, that he could propose nothing to himself but eternal Shame and Disquiet, in the Possession of a Woman, for whom he must always blush, and be in Pain" (emphasis added, 1973: 116).

The fact that the period of courtship in eighteenth-century England is another area of control for patriarchal figures is stressed by the anger the Marquis displays at Arabella's refusal. He forces her to write an apologetic letter to Glanville, and the narrator describes the Marquis as "excessively angry with her," rising in "a Fury," "leading her to his Writing-Desk" and ordering her to write, to which Arabella complies in tears (1973: 40). The second example resembles Cervantes' novel, for the Marquis, angry at the harm Arabella's romances have done to his marriage prospect for her, decides to burn all her books, an event which the narrator relates as well in a mock-heroic tone, lamenting the fate of those illustrious heroes and heroines who "by an Effect of a more cruel Tyranny than any had ever experienced before, were going to be cast into the merciless Flames" (1973: 55). Although the identification of the Marquis with a tyrant is a comic one, his violent action, intruding in Arabella's chamber and destroying her romances, is still presented as an act of aggression justified by his paternal authority. In truth, the Marquis may be somehow justified in his vexation, for the narrator has already stated that Arabella has no reason to reject Glanville, except that she has many "Examples of heroic Disobedience," for "what Lady in Romance ever married the Man that was chose for her?" (1973: 27), a statement that later Barrett or Austen will mockingly echo. However, his desire to be obeyed against her will, leads Arabella to try to find in her romances examples to condone her escaping her house; although she is incapable of recalling any. Despite the limited scope of action posed by heroic romance in this sense, Arabella has already defied by means of her quixotism what male relatives and suitors expected from her: absolute compliance. ${ }^{114}$

114 This reading of courtship as a space for rebellion and of Lennox's text as a subversive message against patriarchal oppression by means of quixotism as an excuse for speaking in "what the dominant culture has suppressed" (Gordon, 1998: 500), has been defended by many other scholars, such as Langbauer (1984), Ross (1987) or Doody (1989). Others, such as George Haggerty, offer a half-way interpretation of these passages: Arabella 
Because of her choice of romance and its liberties when women's power in love is concerned, Arabella can read the world as an oppressive place and rewrite it as one centred on courtship, where she can enact the fantasy of female power. Therefore, she writes a romance for herself which she expects, moreover, to bring her fame and transcendence; her romantic adventures will rescue her from oblivion and invisibility and give her a place in an otherwise patriarchal his(s)tory. However, despite the critique to society's constraints, it will be this romantic system of signification, visibility and power which will be questioned and which will make it mandatory that the quixote finally be corrected and cured.

resists her father and her hard "stifling life" and achieves to "embarrass, if not subvert, the patriarchal energy" that aims to diminish her scope of action, exposing, if not absolutely achieving to challenge patriarchal power (1998: 124-8). In his later research, Gordon modifies his defense of quixotism as conveying an intrinsically positive message and rejects his previous Foucaultian interpretation of quixotism and madness as a liberating space (2005: 128-30). 
2. The Supremacy of THE Novel: Happily Ever AfTER, OR, THE DeAtH OF THE QUIXOTE

Despite the positive reading of romance and her romantic quixote, Lennox is not writing another romance herself, but a new species of narrative fiction, what would later be more appropriately termed the novel. Therefore, in the context of that vortex of fiction which demanded the fall of romance in order to raise the novel by comparison, Arabella's romantic narrative is incorporated into the frame of the novel so as to both ascertain the dialogue the new genre establishes with it, and to criticise what were perceived as its inadequacies. Therefore, the parodic novel about a female quixote Lennox is writing, the narrative frame she builds around Arabella's romantic rewriting of reality, is presented, in Langbauer's terms, as what romance is not (1984: 29), and as what this new form of realistic fiction should be in clear contrast with romance.

Although Arabella's romantic reading has been preserved throughout most of the work, the increased social disruptiveness it causes at her entrance into the world and the dangers it entails both for the heroine, the hero and the necessary happy conclusion in the shape of marriage, lead to the final moment in which the quixotic heroine must be cured from her delusion. These dangers increase as the narrative progresses and are once again associated to the greatest critiques to romance, its implausibility and the obsoleteness of its axiological codes. While her credulity with regard to romantic events such as lovers in disguise or attempts of ravishments are usually employed mainly to achieve comic effect, at least in two occasions they represent authentic danger for the heroine. First, one evening Arabella believes Edward has returned to carry her away. In panic she flees her house in the middle of the night, falling and fainting in the fields. Found by a gentleman travelling in his chaise, she seeks protection from him. He is "glad at having so beautiful a Creature in his Power" and "helping her into the Chaise, drove off as fast as he could" (1973: 100). Once more, Arabella seems impervious to the danger: 
Arabella suffering no Apprehensions from being alone with a Stranger, since nothing was more common to Heroines than such Adventures; all her Fears being of Edward, whom she fansied (sic) every Moment she saw pursuing them: And, being extremely anxious to be in some Place of Safety, she urged her Protector to drive as fast as possible; who, willing to have her at his own House, complied with her Request; [...]. (1973: 100)

Fortunately, chance has the chaise overturn and Arabella escapes being ruined. However, the incoherence of romantic codes, which render common travelling with strangers but not accepting declarations of love from relatives, is exposed by this adventure.

The second adventure which almost has a tragic ending takes place very close to the end of the book. While walking with some ladies in Richmond, Arabella sees several men on horseback approaching. She takes them for ravishers and decides to imitate Clelia's example, therefore she throws herself into the Thames in order to display "in a Manner truly Heroick" the sublimity of her virtue and the grandeur of her courage to the world (1973: 362). Arabella's delusion is different to Juliette's, the heroine of Mock-Clelia, in that she does not mistake the Thame for the Tyber, or herself for Clelia, but acts in imitation of her, transforming the English landscape into the setting for romance and searching not only for escape, but for the fame of the Roman heroine: for her heroic act, Clelia gained not only immortality, but a statue of her was erected to commemorate her deeds (1973: 62). Despite the difference in the degree of delusion with Juliette, the consequences of this excessive desire for fame are also extreme: she creates a commotion, falls ill with a fever and almost dies.

Another recurrent danger, which authors before Lennox had also explored, is the young quixote's liability to be manipulated, usually in order to gain her consent to an elopement or marriage. In two occasions does Sir George aim to employ his knowledge of romance to manipulate Arabella. First, when he constructs an elaborated story of love and misfortunes to rewrite himself as a romantic hero in the eyes of Arabella. His implausible adventures -wittily introduced by the titles of the chapters- cause mirth among the company, except for Arabella, who reads them literally. Unfortunately for Sir George, he commits the unpardonable blunder of appearing inconstant in his love for his 
previous mistress, and therefore Arabella rejects his "prostituted vows" and any further address (1973: 251). In his second attempt, Sir George creates a more intricate text: he hires an actress to play the role of the Princess of Gaul and to reproduce by her acts and speech all the conventions of romance. When Arabella first encounters the lady she is set in a deliberately romantic tableau: sitting in the midst of vegetation, reclined on the shoulder of her attendant and profusely delivering sighs, tears and complaints. Asked to tell her story, the Princess immediately complies with the rules of romance, which require "an unbounded Confidence upon these occasions" (1973: 348) and constructs another romance within the romance. The story of the Princess is ironically stated by the narrator as "more worthy indeed to be styl'd an Adventure than all our Fair Heroine had ever yet met with" (1973: 341), an irony which highlights that what the Princess presents as her real adventures are once again only spurious replicas of literature and that the adventures Arabella claims for herself are reproductions of the histories of other heroines that do not belong to her. The beginning of the Princess's story resembles very closely Arabella's own infancy: the powerful father, the castle, the isolation, and the commencement of her adventures at an early age (sixteen in this case). Moreover, her unfaithful lover, Ariamenes, is identified by her as Glanville, reinforcing the parallelisms Arabella is to draw from their respective stories. In the end, returning full circle to Arabella's romance, she and Lucy are left in exactly the same situation as the false princess and her attendant: on the ground, crying and exclaiming against the cruelty of a treacherous lover. In a very Cervantean manner, as the number of textual worlds which correlate augment, the confusion between appearances and reality increases. This romance within the novel has consequences for all levels of the narrative: in Arabella's romance she rejects Glanville and it leads to her attempts to find the princess, which is why she is near the waterside where she finally jumps. In the novel's narrative framework, Arabella's new romantic plot makes Glanville suspect Sir George, and in a final moment of confusion and rage, leads him to fight a duel with him and almost kill the Baronet. ${ }^{115}$

115 Malina identifies the story of the Princess as the only instance in which Lennox "withholds information about the reality that Arabella misreads," expecting the reader to "quickly decode as no reality at all but a fiction" (1996: 283), in a game in which the reader 
The accumulation of these tragic events signal the epitome of Arabella's quixotic disruption and the approach of closure, and the final chapters summarise the failings and dangers of romance that have been expounded throughout the novel. While many scholars have interpreted Arabella's cure as imperfectly achieved, Lennox contrives a process of awakening which highlights the three areas in which romance has blinded Arabella and in which she must come to terms with herself in order to achieve her due happy ending: she has been deluded emotionally, intellectually and socially. Therefore, Lennox transforms her quixotic narrative into a coming-of-age or development novel in which the young woman must mature in these three areas; a pattern latter brilliantly developed by Burney, Edgeworth or Austen, for example. This maturation is signalled in the novel by different epiphanies, different episodes in which the female quixote must awake to her delusion in these important areas of her experience. Arabella's first moment of awareness is related to the core of the female heroic experience: love. When she believes Glanville is the Princess's treacherous lover, the reader is witness to her greatest moment of emotional epiphany:

Our charming Heroine, ignorant till now of the true State of her Heart, was surpriz'd to find it assaulted at once by all the Passions which attend disappointed Love. Grief, Rage, Jealousy, and Despair made so cruel a War in her gentle Bosom, that unable either to express or to conceal the strong Emotions with which she was agitated, she gave Way to a violent Burst of Tears. (1973: 349)

This final moment of despair underscores previous examples in the novel in which Arabella refuses to acknowledge the increasing importance of Glanville in her romantic plot and her feelings for him. The strict laws of romance, which demand impassibility and the suppression of the lady's affections, have rendered Arabella blind to the state of her own heart.

Secondly, Arabella's otherwise extremely laureate intellect has also been confounded on the particular matter of her mania. At one point, Miss Glanville speaks of the "intervals" in her cousin's madness in which she displays a "reasonable way of thinking" (1973: 309), which once again resembles Don does. 
Quixote's or Juliette's sound reasoning whenever romances are not the subject under discussion. ${ }^{116}$ In this sense, Arabella is very often praised by one of the greatest censors of her folly, Sir Charles, who states that when out of her "Whims, was a very sensible young Lady" (1973: 314), or by Glanville, who constantly asserts that she has wit beyond any of her sex. However, her reason has also been blinded to the dangers of romance and to the impossibility of employing it as system of reference in the world. Therefore, it becomes necessary to attempt the "cure of Arabella's mind" (1973: 368), for which Lennox contrives first the intervention of a wise and learned Countess, and finally a very rational disputation with a Doctor of Divinity. In this last conversation, Arabella pleads the Doctor "I conjure you discover me to myself" (1973: 370), emphasising that quixotism has disabled her mostly from knowing her "self" (Gordon, 2005: 131), as well as her willingness for a correction that implies reasonable arguments.

Finally, after a second to last chapter full of sense, Lennox adds one more element to her quixote's cure: mortification at the improprieties she has committed. After her intellectual awakening, Glanville decides to allow the repentant Sir George to acknowledge how he had attempted to impose on her credulity and therefore "add to the Doctor's solid Arguments the poignant Sting of Ridicule which she would then perceive she had incurred" (1973: 382). After hearing Sir George's recital, Arabella remains "wholly absorb'd in the most disagreeable Reflections on the Absurdity of her past Behaviour, and the Contempt and Ridicule to which she now saw plainly she had exposed herself" (1973: 383). As Langabauer has asserted, ridicule has great relevance in the cure and the plot alike, and it conditions more the characters' response to Arabella than the readers', exposing her to the former's mirth and the latter's sympathy (1984: 33; 1990: 69-71). Contempt and ridicule concern her relationship with others, with the society she lives in, hence her acknowledgment of the mistakes she has made trigger her reestablishment in that same society, which the reader has been made to wish particularly because

116 As the earliest critic, Fielding also identified the interspersed delusion of Don Quixote and Arabella in his review: "both characters are accordingly represented as Persons of good Sense, and of great natural Parts, and in all Cases, except one, of a very sound Judgement" (qtd. in Small, 1969: 95). 
of her exposure to ridicule. However, the acceptance into society requires she assumes once again her role as submissive protégée and fiancée. She then apologizes to her guardian for the inconveniences caused, and renounces her position in courtship by telling Glanville, "with a Look of mingled Tenderness and Modesty:"

To give you myself, said she with all my remaining Imperfections, is making you but a poor Present in return for the Obligations you generous Affection has laid me under to you; yet since I am so happy as to be desired for a Partner for Life by a Man of your Sense and Honour, I will endeavour to make myself as worthy as I am able of such a favourable Distinction. (1973: 383)

The language of power has turned into "modesty" and "obligation", and she has changed her previous syllogism for the following: if it is proper for women in eighteenth-century England (A) to do a good marriage and become wives (C), and I (B) aim to be respectable and proper (A), then I (B) should marry my best option, Glanville, and become a wife (C). Arabella, by accepting her contemporary role as woman and wife, also finds a place in society. Lennox ends her novel of female development with its accustomed wedding, after which the heroine becomes a wife and disappears from the romance and the novel alike.

In this regard, one could state that Lennox lays the foundations for what scholars have termed the female bildungsroman. The term bildungsroman is, of course, complex and its boundaries have not yet been perfectly delineated. On the matter of the female bildungsroman, the debate remains more unresolved. The terms coming-of-age or development novel are recurrently employed in its place, signalling that the concept of formation for eighteenth-century women was necessarily different to Wilhem Meister's, Goethe's eponymous hero in what has been traditionally considered the first example of the genre. In her enlightening study on this tradition in English fiction, Lorna Ellis identifies The Female Quixote as something different from a bildungsroman owing to the fact that it does not focus on self-reflection or on a happy acceptance into society, for once Arabella renounces her quixotism she disappears, not negotiating her agency within eighteenth-century society (1999: 75, 83). However, as asserted above, the three elements which Ellis signals as the core of the female 
bildungsroman, agency, self-reflection and social integration, are present in Arabella's cure, although still in an embryonic form and still subject to a very limited interpretation of agency. In addition, to reinforce this claim to the foundation of a female novel of development, a close examination of the novel would suggest that Lennox was consciously creating something similar, yet still different, to the one developed by Haywood in The Life of Betsy Thoughtless (1750), which Ellis names the germinal and prototypical example, and probably well-known by Lennox given her similar narrative, The Life of Harriot Stuart (1751), which seems to suggest an adherence to this tradition by the very use of the term "life" in the title. As hinted in chapter two, Betsy actively struggles to become an integrated member of society through her travelling, her writing and her search for a husband, finally renouncing her agency as an author and, in particular, as a coquette. Arabella's quixotism also involves actively rewriting her story through the tenets of romance, negotiating her space and visibility in society, and finding a hero to fulfil her heroic destiny as his wife. Nevertheless, her adherence to the strict rules of decorum transforms her into a less rambling and disruptive character, while her nature as a perfect sentimental heroine requires less of a corrective and a rewriting to be accepted into society. The difference, therefore, lays, firstly, in the fact that Lennox writes a quixotic female novel of development, in which the process of self-awareness is enriched by the need for an epistemological correction to the quixote's literary, and not only idealistic or youthful, expectations. Secondly, Arabella is a laudable character in many aspects and, consequently, the necessary process of development and cure relates mainly to her quixotism. In this regard, her natural good qualities and her virtue also allow questioning the fact that she finally requires to be chastised. Arabella is, then, a more complex character than Betsy and, consequently, Susan Carlile's assertion that "Lennox marks the transition between Eliza Haywood and Frances Burney" (2004: 390) as an early woman novelist seems appropriate, especially as the latter has become synonym with the narrative of a young lady's entrance into the world and her subsequent story of maturation and integration.

Unfortunately, this integration almost always culminates with the end of the heroine's story. In the train of a true bildungsroman, Arabella's romancing is a 
constant negotiation of her identity and her agency in society, while her cure indicates that she has accepted the terms offered by society: her agency, ironically, is her non-agency as a wife and mother. ${ }^{117}$ Therefore, Lennox's ending, as will happen in later female quixotic narratives, reinforces the status quo disrupted by Arabella's quixotism, and presents marriage and disappearance as the epitome of social integration, even if she allows her quixote to question it and even if she subtly criticises it herself by means of this quixotic fiction. This highly conventional and patriarchal ending is hard to understand, then, if it is not perceived in the context not only of the gendered, but the genre debate that was taking place at the moment in which the novel was published. In Steele's work Biddy achieved the traditional fairy tale ending without having to disclaim her quixotism; that is, in the play the wedding takes place as part of the romantic plot Biddy has constructed and in which Captain Clerimont plays his part in order to gain her fortune. In Lennox's work, however, in order for the novel to have its happy ending, the quixotic romance must have a tragic one: Arabella can only live happily ever after in the eighteenth-century novel, if the romantic quixote dies. The female quixote's death may be metaphorical and not literal as in Cervantes' work; however, it is still compulsory for the closure of the plot. Arabella must therefore substitute one form of fiction for another. In both romances and the type of fiction that Richardson claimed to have inaugurated, the happy ending is that of the fairy tale: marriage. The difference lies in how the characters arrive at their happy conclusion. Lennox obviously intends to reward Arabella, the heroine of the

117 Although he never employs the term bildungsroman, Gordon emphasises how quixotic novels with a heroine at their core can be read as this story of personal self-knowledge and happy or tragic acceptance into society. First of all, he indeed identifies quixotism as a form of "colouring" or "interpreting" of reality: "[...] the internalized filters deposited by romance in each quixote's head both prevent these figures from seeing the 'reality' before their eyes (which all around them see 'in common') and ensure that they see, instead, a reality of their own making. The primary object invisible to these female quixotes is their own deluded mind" (emphasis added, 2005: 131). Quixotism not only prevents women knowing their own minds, it also endangers the core of their female experience and development from childhood into adulthood; as this scholar states, "the practice of quixotism [...] prevents young women's 'natures' from unfolding according to their proper trajectory" (2005: 132). This trajectory being courtship and marriage, "these tales reaffirm marriage to a proper suitor as the natural telos for all young women" (2005: 132). Therefore, the failed interpretation of their own mind, nature and story requires the process of awakening that will become recurrent in female bildungsroman; in Gordon's words: "the object the female quixote misunderstands most is herself. These texts show that the female quixote consistently misvalues herself, having learned from romance to see herself as a 'heroine' rather than, as the story eventually teaches her, as a "wife"' (2005: 131). 
novel, with a successful acceptance into society, but, as a consequence, Arabella, the heroine of the romance, must submit to the rules of the society which the novel tries to faithfully reproduce and abandon her romantic reading of the courtship plot.

Despite the message of the supremacy of the novel, this conclusion and the implied relationship between romance and the new form of narrative fiction is a fraught one, as the chapter with the Doctor of Divinity attests. In this second to last chapter, the matters of verisimilitude, plausibility and morality come together and Lennox theorises what she has attempted to subtly convey throughout her work. This chapter is probably the most controversial in the novel, and the criticisms towards its haste or unskilled composition, as well as the role that Johnson or Richardson played in it, are too numerous to recount. ${ }^{118}$ If scholars have considered this rational conversation ill-managed or implausible as a means to dismiss Arabella's quixotic delusion, it is necessary to be reminded that it is only part of her process of self-discovery and cure, albeit an important one. What is more, it is relevant to notice the importance that Lennox attributes to the rational cure of her quixote, which seems in harmony with the attention Arabella's wit has received throughout the novel and which becomes, together with her beauty, her most recurrently praised characteristic. More than any other author in the canon of female quixotism, Lennox focuses on the intellectual powers of her heroine, and in this particular chapter employs them to once more defend the reason behind quixotism, as well as to construct a thorough comment on narrative fiction.

\footnotetext{
${ }^{118}$ For further discussion on this topic, see for instance Small (1969) or Duncan Isles's afterword in Margaret Dalziel's edition of The Female Quixote (1973, pp. 420-27). Both scholars offer a thorough description and analysis of Lennox's relationship with Johnson and, conversely to prior belief that pointed at Johnson as the author of the abovementioned chapter, they both attribute it only to Lennox. In this respect, Isles argues that "there is no absolutely no contemporary suggestion of his having written it; linguistically, there appears to be nothing in it that a good writer familiar with Johnson's style could not have achieved; structurally, the dialogue and argument are far below Johnson's standard" (1973: 421). It seems more plausible, as he suggests, that she discussed the conclusions with him. In addition, Isles accounts for much of the narrative shortcomings both of the last books of the novel and of this chapter in particular. He also provides evidence of Richardson's and Johnson's contribution with corrections or suggestions to the original plan of the novel. On the opposite side of the spectrum is Staves, who defends Johnson's authorship of this chapter, as well as of the dedication (2006: 266).
} 
The discussion is divided into two parts: the first dwells on matters of appearances and examples; the second, on the inadequacy of romances as models of behaviour because they are deficient in truthfulness, plausibility and morality. In the first part, Arabella evidences her wit and her discursive powers, sometimes outwitting the Doctor with her knowledge of the "Laws of Conference" (1973: 371) and her Lockean empiricist arguments. On the matter of her recent adventure in the river, Arabella establishes that her senses are not confounded and once again relates to the logical system of interpretation which she has employed throughout the narrative. She asserts, "Human Beings cannot penetrate Intentions, nor regulate their Conduct but by exterior Appearances. And surely there was sufficient Appearance of intended Injury, and that the greatest which my Sex can suffer" and adds that it remains for the Doctor to show "that in giving Way to my Fears, even supposing them groundless, I departed from the Character of a reasonable Person" (1973: 371). The Doctor agrees that suspicion must arise from comparison and that one must judge the future according to the past; where there is no experience, "this Power of Prognostication, may, by Reading and Conversation, be extended beyond our own Knowledge: And the great Use of Books, is that of participating without Labour or Hazard the Experience of others" (1973: 372). The conclusion is that Arabella may, nay, should act by example owing to her lack of experience. Nevertheless, she has chosen the worst possible models: "the Authority of Scribblers, not only of Fictions, but of senseless Fictions; which at once vitiate the Mind, and pervert the Understanding; and which if they are at any Time read with Safety, owe their Innocence to their Absurdity" (1973: 374). Arabella consequently demands him to prove "first, That these Histories you condemn are Fictions. Next, That they are absurd. And Lastly, They they are Criminal" (1973: 374).

The first distinction between truth and fiction allows Lennox to distinguish between two different forms of fiction, which resemble Cervantes' indictment on the verisimilitude of chivalric romances. On the one hand, the Doctor identifies "those Tales which are told with the solemn Air of historical Truth" and which "if false convey no Instruction" (1973: 377). Those romances that claim veracity and which nonetheless contradict "ancient Histories" (1973: 
378), according to the Doctor cannot be defended and their own falsehood is a reason to reject these fictions. On the other hand, those authors who did not expect "to be credited" and who acknowledged their works as fiction are not to be blamed. In addition, these works of fiction can convey a more important form of truth than a fidelity to historical facts: "emotional verisimilitude" (Thomson, 1992: 124), the truth of men and manners, the moral truth. As the Doctor states,

Truth is not always injured by Fiction. An admirable Writer of our own Time, has found the Way to convey the most solid Instructions, the noblest of Sentiments, and the most exalted Piety, in the pleasing Dress of a Novel, and, to use the Words of the greatest Genius in the present Age, 'Has taught the Passions to move at the Command of Virtue'. (1973: 377)

The writer in question is, of course, Richardson, while the whole chapter brims with reminiscences of Johnson. Echoing Richardson's and Johnson's precepts for fiction, the novel -or the anti-romance-, is self-consciously fictional, but also highly didactic in intention, uniting the Horatian utile and ducere. As seen in chapter two, Richardson conceived fiction as a suitable vehicle to instil moral sensibility in his readers, while this instruction should always be conveyed in the robes of formal realism, of plausibility.

This Richardsonian emphasis on realism leads to the second argument against romances: they are absurd because of the implausible occurrences they describe. In the Doctor's words, "the only Excellence of Falsehood [...] is its resemblance to Truth," and hence romances are liable to criticism not only for their "historical Failures," but because of their "physical or philosophical Absurdities" (1973: 378). By depicting men with extraordinary strength or women with the power to kill with a frown, these fictions disfigure "the whole Appearance of the World" and represent "every Thing in a Form different from that which Experience has shewn;" and, as a consequence, "it is the Fault of the best Fictions, that they teach young Minds to expect strange Adventures and sudden Vicissitudes, and therefore encourage them often to trust to Chance" (1973: 379). These supernatural heroes or impossible events, and the importance of chance for the development of the plot, should be substituted by more plausible characters or happenings which may mirror the truth of 
experience, for nothing "is more different from a human Being, than Heroes or Heroines" (1973: 380). The implausibility of romances is the most recurrent accusation throughout Lennox's novel. For instance, Sir Charles considers romantic stories "very improbable Tales" (1973: 62) and compares them to children's fairy tales (1973: 63), and the Countess highlights that what may have been possible "several thousand Years" ago is not to be found in contemporary society (1973: 326).

Finally, as Arabella avows, it is of "more Importance to detect Corruption than Fiction" (1973: 376) and, therefore, morality is the most important matter of the discussion. The abovementioned conversation in which Arabella and Charlotte discuss the need for bloodshed is a practical example of the obsolete morality of romance that later the Countess will expound. According to this learned lady, judging the deeds of romantic heroes "as Christians," readers "shall find them impious and base, and directly opposite to our present Notions of moral and relative Duties" (1973: 329). Custom has changed, and "the same Actions which made a Man a Hero in those Times, would constitute him a Murderer in These" (1973: 328). This attack to the morality of romance makes "some Impression on the Mind" of Arabella (1973: 329), though at the time of this lecture the lack of experience which she later gains hinders the fulfilment of Arabella's cure. ${ }^{119}$ While the Countess dwells on the unchristian principles of romance in general, the Doctor rather emphasises the bad example this genre provides for its female readers. As the Doctor explains, proper fictions must have a didactic purpose, for "books ought to supply an Antidote to Example" (1973: 380). However, the code of honour offered by romances and its impossible model of female power render them dangerous to the moral of their readers, especially women; romances "give Fire to the Passions of Revenge and Love" which the "Labours of Reason and Piety" ought to suppress (1973: 380). The Doctor expounds the amorality of romances as they "soften the Heart

${ }^{119}$ The narrator states that, although the Countess's arguments made an impression on Arabella's mind, this impression "came far short of Conviction;" Arabella was "surpriz'd, embarras'd, perplex'd, but not convinc'd. Heroism, romantick Heroism, was deeply rooted in her Heart; it was her Habit of thinking, a Principle imbib'd from Education. She could not separate her Ideas of Glory, Virtue, Courage, Generosity, and Honour from the false Representations of them in the Actions of Oroondates, Juba, Artaxerxes, and the rest of the imaginary Heroes" (1973: 329). Arabella needs the emotional and moral correction that will come from experience and that will shake her "Heart" and "Principles". 
to Love, and harden it to Murder," as they teach "Women to exact Vengeance, and Men to execute it" and they instruct women "to expect not only Worship, but the dreadful Worship of human Sacrifices" (1973: 380). The following critique moreover places romances in opposition to the theory of sympathy so influential in the eighteenth-century, which saw the aim of fiction as a means to expand the capacity of its reader for sympathy (Gallagher, 1994: 172). In the Doctor's words:

It is impossible to read these Tales without lessening part of that Humility, which by preserving is us a Sense of our Alliance with all human nature, keeps us awake to Tenderness and Sympathy, or without impairing that Compassion which is implanted in us as an Incentive to Acts of Kindness. If there be any preserved by natural Softness, or early Education from learning Pride and Cruelty, they are yet in danger of being betrayed to the Vanity of Beauty, and taught the Arts of Intrigue. $(1973: 381)^{120}$

Fiction should awaken the sympathy of the readers so as to enhance their empathy and their capacity to learn by example, and hence display that same sympathy and compassion in the face of real-life distress. Moreover, especially for women, fiction should present models of humbleness, modesty and innocence, contrary to the vanity and intrigue displayed in the romantic plots of courtly love. Therefore, although Arabella can justly claim that she has read romances "without Injury to my Judgement, or my Virtue" (1973: 374), her morals have been damaged as she acknowledges at last: she admits that blood has already been shed for her; hence, she believes that her experience proves to reflect the dangers the doctor states.

The final cure and disappearance of the sympathetic quixote, together with the arguments on gender and genre which it provides, stress the ambiguity Lennox's obvious parody of romance contains. As stated above, Lennox develops Fielding's use of the quixote both as butt of and instrument for satire, although she unites the two in only one quixotic figure. Arabella is the butt of Lennox's satire by means of the parody of her romantic expectations and, in

${ }^{120}$ Once more, the implied criticism to the dangers of romance is doubly-aimed both at their content and at Arabella's deficient education, for it should be noted that pride was learnt before the reading of romance: it was taught by the Marquis himself, who recognises in Arabella his own faults. After forcing his daughter to write a billet to Mr Glanville, he found "a great deal of his own Haughtiness of Temper in it" and "could not resolve to check her for a Disposition so like his own" (1973: 40). 
that sense, she is like Joseph Andrews. On the other hand, her goodness, innocence, and idealism, especially when contrasted with her nemesis, the shallow Charlotte, reduce her ridiculous nature and allow her to become at times an explicit, at others an implicit satirist against the surrounding world, as Adams was. In this sense, Arabella answers to the definition of "true quixotic heroes" offered by Welsh. In this scholar's words, these heroes "champion ideals that we value, but are nevertheless ridiculous: their idealism attracts love and respect despite our laughter or despair; they are courageous and concerned for others; the bare possibility that such virtues are ridiculous makes the portrayal of quixotic behaviour problematic as well as moving" (1981: 16). Despite the admiration she incites, as Adam did, despite the fact that she has many qualities of a romantic heroine, as Joseph had, Arabella must be cured and erased from the narrative once she abandons the liminal space granted by her romancing, once she renounces her liberating quixotism.

In addition, romance, as a genre, is criticised as dangerous and its influence erased at the end; however, it not only has allowed Arabella a space for freedom, but Lennox has developed the kind of generic dialogue with it that Cervantes and Fielding also employed, as described in chapter one. In this regard, the ambiguity towards romance as a genre focuses also on its form: the conventions, language or characterization of romance that the Doctor has criticised and which Lennox has equally buoyed and parodied throughout her novel. Not only are her characters very close to romantic heroes and heroines, but Lennox also employs at times the same language she has mocked. What is more, her plot evidences that novel conventions do not merely resemble those of romance: they live from them, adopt them and claim them as their own, as she probably learnt from Richardson himself. However, she moves beyond her mentor. In Mary P. Martin's words, "locating both novel and romance in its pages," Lennox's work expounds that "the opposition between genres [...] is far from stable" (1997: 52); she hence uses romance to "unsettle the distinction between the two genres, raising questions about the very characteristics of the novel which her own conclusion seems to confirm" (1997: 52). By her use of quixotism and the narrative she creates to incorporate romance into the frame of the novel, romance then becomes more than a parodic object, it is 
transformed into a pretext for a "metafictional discourse" which "allowed for the thematization of fiction without undermining the plausibility which the tale itself denominated the perfection of fiction" (Gallagher, 1994: 179). Lennox's purpose seemed not to be to "disencumber the novel of the 'unreal' but to allow for the new form's self-presentation as the regulation and explicit fulfillment of what had previously been an unruly because unacknowledged practice" (1994: 179). That is to say that Lennox's dialogue with romance enables to place fiction itself at the centre of her debate, while it also permits her to present the novel, in opposition to romance, as a genre that can selfconsciously reflect on its own fictional nature without hazarding its claim to plausibility precisely because it acknowledges its unreality, its fictionality, which romance did not do. With her development of the same dialogic principle and metaliterary discourse that characterized Cervantes' novel, Lennox, hence, becomes an important heiress of the Spanish author and an essential link in the tradition of his reception in Britain.

In this sense, Lennox, despite her championing of Richardson, allows Fielding to play a relevant part in the literary influence noticeable in her novel, not only by appropriating essential traits of his quixotic characterization, but also by developing his concept of comic romance and his approach to romance in her parodic narrative, as explained above. Lennox's parodic narrative, different from the gravity of romance, but offering a ludicrous inclusion of the latter genre, is an obvious descendant from Fielding's conception of this "new species of writing." What is more, according to Martin, Lennox equally follows Fielding by adopting other Cervantean characteristics from this novelist:

[...] Fielding is everywhere: in the shared nod to Don Quixote [...], in its selfconscious play with its own fictional status (an acknowledgement that is anathema to Richardson), evident, as in Fielding, in chapter titles that call attention to the volume's material status and the progress of its story, and in the ironic narrator who presides over the novel and its readers alike. (1997: 51)

These titles, which include an overt reference to Cervantes, which highlight the conventionality of the prose that "goes on after the accustomed Manner" or that repeatedly address the readers and anticipate their reactions and expectations, 
as in Fielding's novel, emphasise the fictionality of the story at the same time that they highlight the ample knowledge of romance the readers and Arabella share, and how romantic conventions are ingrained in the very structure of the novel. The same can be said of the self-referential comment contained in the text itself. At one point, the author withholds information in relation to the cause of Arabella's final indisposition; Lennox states that the "Reader, whose Imagination is no doubt upon the Stretch to conceive the Meaning of these Two extraordinary Accidents [the duel and the news that Arabella is ill], may be left no longer in Suspense" (1973: 360), signalling how the process of accommodation readers develop in order to make sense of the story is very similar to Arabella's, and how Lennox is playing with their own expectations: instead of a more plausible cause for her indisposition, she offers her expectant readers the fully romantic explanation they seem to anticipate. In this sense, her text is Cervantean, for in its parody it "highlights the creative agency of the authorial source" and its ironic self-comment or even self-critique involves not only the novelistic discourse, but the "addresser and the addressee," asking the latter to progress through the different (mis)readings and weigh all claims to truth within the fictional world (Uddén, 2008: 444).

By means of her inclusion and parody of romance, Lennox hence unites the appropriation of romance by Richardson in Pamela or Clarissa, and Fielding's overt parody in Joseph Andrews, and openly reclaims and transforms it to create a Cervantean comment on itself and on the contending traditions of prose fiction at war in the eighteenth century literary panorama. In addition, by "eliding the distinction between novels and romances, and dismantling the oppositions on which it depends, Lennox undermines the lesson in genre that would write women's narratives out of the novel" (Martin, 1997: 59) and hence provides once of the most compelling accounts of the gendered generic distinctions at play. 
3. The Dialogic Principle, The Problems of Gendered Genre and the PlaCE OF THE WOMAN WRITER

In line with the previous section, the dialogue of genres and the conclusion of Lennox's novel have raised some questions among scholars: if she condemns romances, why is Arabella such an attractive and positive heroine? If the world of the novel triumphs over the world of romance, why is Arabella positively contrasted to other female characters that represent that world, especially Miss Glanville? If Lennox is to defend her stance as woman writer, why condemn a genre so closely associated with female authors and why do so by means of a Johnsonian Doctor rather than the learned Countess?

These questions lead to the recognition that she is in fact rewriting within her novel two types of fiction: on the one hand, the heroic romances epitomised by Arabella, which display virtuous female models, but which are nevertheless not faithful to historic truth, implausible and morally obsolete; on the other hand, the less idealistic and more worldly gallant fiction embodied by Charlotte Glanville, in which events are represented as more probable but equally pernicious to the morals and, moreover, the virtue of their female readers. In opposition to both previous traditions of feminocentric prose fiction, she allies herself with the kind of fiction developed by Fielding and Richardson. However, her defence of the values of heroic romance also state her connection to her -and their- own literary mothers, such as Barker, in her use of conventions of the heroic romance in her prose fiction, although as part of an attempt to overcome its limitations. In addition, as the following section hopes to prove, while detaching her own from the gallant fiction of previous authors, she avows not only its existence, but its contribution to the development of the new genre, even if as a moral negative contrast. ${ }^{121}$ The heroine of this new form of fiction should then be neither the quixotic Arabella, nor the coquettish Charlotte, but the reformed Arabella of the end of Lennox's novel; in clear

${ }^{121}$ Gallagher is one of the first scholars to appreciate the importance of scandalous fiction in Lennox's novel and how it provides the hidden subtext for her work; the scholar states that Lennox creates a in her novel a "generic 'screen memory' [...] to conceal its truly scandalous history" (1994: 180). 
parallelism, the resulting didactic and realistic fiction, and consequently the status of Lennox as author, should spring from the dialogue with previous forms of feminocentric and female-penned prose fiction.

\subsection{The Female Heritage of the Novel and the Supremacy of the Heroine of Romance}

Lennox's stance in the generic debates of her century, her approach to both heroic romance and the gallant novellas that were written before her, and her use of them in the generic dialogue that is at the core of her novel, are epitomised by the construction of two pairs of characters, a man and a woman, who embody different genres and their interaction.

At Bath Arabella meets Mr Selvin and Mr Tinsel, men who represent two divergent characters very often portrayed in eighteenth-century fiction: the erudite pedant and the coxcomb. These two men read Arabella's discourse in a very different manner, "Mr. Tinsel, declaring she was a Fool, and had no Knowledge of the World, and Mr. Selvin convinc'd she was a Wit, and very learn'd in Antiquity" (1973: 281). In addition, both gentlemen engage in a heated dispute about the merits of Arabella and Charlotte:

Certainly, said Mr. Selvin, in Support of his Opinion, the Lady has great Judgement; has been capable of prodigious Application, as is apparent by her extensive Reading: Then her Memory is quite miraculous. I protest, I am quite charm'd with her: I never met with such a Woman in my Life.

Her Cousin, in my Opinion, reply'd Mr. Tinsel, is infinitely beyond her in every Merit, but Beauty. How sprightly and free her Conversation? What a thorough Knowledge of the World? So true a Taste for polite Amusements, and a Fund of Spirits that sets Vapours and Spleen at Defiance.

This Speech bringing on a Comparison between the Ladies, the Champions for each grew so warm in the Dispute, that they had like to have quarrell'd. However, by the Interposition of some other Gentlemen who were with them, they parted tolerable Friends, [...]. (1973: 281)

In a novel so concerned with the dialogue of genres, and with the relationship of heroic romance and the gallant novella with plausibility and morality, this attribution of a "champion" to each lady and the description of their reaction to 
Arabella's romancing as either praiseworthy learning or unfashionable conversation, seems far from coincidental. Selvin and Tinsel do not only mirror what the critical approach of implied readers might be to her quixote, but Lennox will introduce these male characters in conversation with Arabella to continue to develop the Cervantean dialogic principle, the dialogue of different genres and epistemologies, in order to validate her novel as an inclusive space for all these previous traditions, as well as to reinstate the moral worth of heroic romance as Cervantes himself had done and to vindicate what were conventionally considered female traditions of fiction as predecessors for her novel.

In this train, Mr Selvin, Arabella's gullible, naïve and quasi-quixotic champion, is a ludicrous character who

[...] affected to be thought deep-read in History, and never failed to take all Opportunities of displaying his Knowledge of Antiquity, which was indeed very superficial; but having some few Anecdotes at Heart, which he would take Occasion to introduce as often as he could, he passed among many Persons for one, who, by Application and Study, had acquired a universal Knowledge of ancient History. (1973: 264)

Equipped with quotations from Herodotus, Thucydides or Plutarch he proudly confesses "I read no Authors, but the Ancients [...] I cannot relish the Moderns at all: I have no Taste for their Way of Writing" (1973: 267). He is, in this sense, as Arabella, a quixote "armed with quotations" (emphasis added, Pawl, 2000: 143), and all their conversations become a dialectical battle in which these citations are uncritically employed and which are usually won by Arabella. For example, on the matter of Julia, daughter of Augustus Caesar, Mr Selvin does not dare to contradict Arabella, "whose extensive Reading had furnish'd her with Anecdotes unknown almost to any Body else" and "by his Silence confess'd her Superiority" (1973: 273). Very different is the position of Glanville, which is subsequently described thus:

But Mr. Glanville, who knew all these Anecdotes were drawn from Romances, which he found contradicted the known Facts in History, and assign'd the most ridiculous Causes for Things of the greatest Importance; could not help smiling at the Facility with which Mr. Selvin gave into those idle Absurdities. For notwithstanding his Affectation of great Reading, his superficial knowledge of History made it extremely easy to deceive him; and 
as it was his Custom to mark in his Pocket-Book all the Scraps of History he heard introduced in the Conversation, and retail then again in other Company; he did not doubt but he would make a Figure with the curious Circumstances Arabella had furnish'd him with. (1973: 273)

Overwhelmed by the torrent of examples quoted by Arabella, Selvin must confess that he has not read her historical sources and that he has not read Monsieur de Scudéry, whom he first mistakes for an ancient author. ${ }^{122}$ This conversation, which ends with Mr Selvin being satirised by the company, evidences Lennox's critique once more to the unquestioned authority gained from reading. Arabella "believes she presents incontrovertible ancient fact," while Mr Selvin "does not recognize a fabricated ancient authority" and is "uneducated in modern political history and literature" (Looser, 2000: 106), therefore the satirical aim of this passage is directed against both characters and their misreading (2000: 108-9). ${ }^{123}$

The lack of education in both Arabella and Selvin, their quixotic obsession with one form of reading, leads to their confusion of fact and invention, of history and fiction and enables Lennox to discuss, as had Subligny before her, the fraught relationship between romance and History. The conclusion of these characters' debates is that historic romances are dangerous only because of Arabella's -and Selvin's, for that matter-absence of a deeper form of learning. If approached for amusement, as the Doctor will later indicate, and not as source of learned authority, romances are a valid form of fiction. Arabella's romance would not fool Mr Selvin if he did not possess such shallow knowledge, nor should her or Lennox's fiction fool learned readers who approach the text critically. Both Arabella and Selvin are "easily deceived" by historical romance because of their bookish learning which is not supported with more rational instruction; they are both examples for the readers so as not

122 Scudéry is recurrently identified as a "he" in Lennox's novel. Although some scholars have pointed out that she might not have realized the fact that it was Madeleine rather than George who was writing the romances (Langbauer, 1984: 48), it seems more probable that she employed a male historian on purpose to highlight, for instance, Mr Selvin's ignorance on whom he believes an important ancient authority (Looser, 2000: 106), something more difficult to achieve if Lennox had proposed a female historian. See also Dalziel's note on the acknowledged authorship of Madeleine which Lennox could have easily known (1973: 392).

${ }^{123}$ Gallagher identifies Selvin as the butt of Lennox's satire in these passages (1994: 190); however, they are both equally mistaken in their use of literary authority and they are both equally gullible because of it, therefore the satire is doubly aimed. 
to become gullible in their approach to literature. Thereby, Lennox opposes the uncontested authority of fiction or history; quotations alone cannot support an argument if they are not also founded on reason and a dialectical process of accommodation of opposing points of view.

What is more important in the context of Lennox's gendered generic debate, Selvin evinces that ancient authority has to be approached critically because it can prove as biased as the reading of history performed in romance. As was the case in Subligny's work, the gendered view of history is present in Lennox's novel. The abovementioned conversation on Julia starts when Arabella is compared with the Roman princess: she interprets this comparison as a compliment, while Mr Selvin finds it injurious, for he believes Arabella excels "that licentious Lady" (1973: 272). Mr Selvin and Arabella then debate on the chasteness of the Roman princess in the following terms:

I never heard Licentiousness imputed to the Daughter of Augustus Caesar, said Arabella; and the most her Enemies can say of her, is, that she loved Admiration, and would permit herself to be beloved, and to be told so, without showing any Signs of Displeasure.

Bless me, Madam, interrupted Mr. Selvin, how strangely do you mistake the Character of Julia: Tho' the Daughter of an Emperor, she was, pardon the Expression, the most abandon'd Prostitute in Rome; many of her Intrigues are recorded in History; but to mention only one, Was not her infamous Commerce with Ovid, the cause of his Banishment? (1973: 272-73)

Arabella defends the princess from the "strange Terms" Selvin employs: although not the most "reserv'd and severe Person in the World," although "not altogether so austere as she ought to have been," Julia was nevertheless "absolutely chaste" and "a most virtuous Princess" (1973: 273). Both employ the word "strange" to identify how foreign the other's discourse is to them and how far away they are from enabling a dialectic process between them; both use superlatives and absolute readings of the female character and her sexuality, from the "most" abandoned prostitute to the "absolutely" chaste and the "most" virtuous. Selvin and Arabella then aim to defend their stance in the polarised interpretation of the "virgin versus whore" which seems to define female agency in history; notwithstanding its description in serious history or in romance, women's "sexual reputation is the most relevant historical detail" 
(Looser, 2000: 107) and evidences the biased and gendered construction of history.

As a consequence, despite the fact that Lennox once more highlights the lack of veracity in historic romances by means of Mr Selvin's reading of history, she also employs him to emphasise the fact that the romantic reinterpretation of women in history sometimes provides a better example for female readers, consequently validating its inclusion in her novel by means of Arabella's quixotism as a more virtuous source for her delusion. Once again, morals triumph over veracity in the condemnation or praise of fiction. In Looser's words, the point of these exchanges on history is not just satire "but proper instruction, which may be derived from either history or fiction" (2000: 109). In Lennox's novel, and in Subligny's antecedent, the "protagonists' misunderstanding of and respect for historical women (despite their infamous sexual pasts) may be seen on one level as accidental wisdom" for what their misreadings "illustrate is that young women who are not taught about the sexual innuendo surrounding female historical figures are 'protected' in some senses but are not kept from making fools of themselves" (Looser, 2000: 109). Despite the Doctor's final condemnation of the moral of romance concerning murder, historic romances tame the patriarchal sexual reading of history and present a feminocentric rewriting of it, which creates a fiction of sexual unattainability and hence provides a better example for young female readers. In this regard, although "fiction may cover over historical 'fact' [...], certain kinds of fiction are also capable of revealing history's blindnesses," or "what might have been or should have been" (Looser, 2000: 109). That this is Lennox's message is confirmed by the relationship between the romantic concept of history and the eighteenth-century one, which is presented by means of a conversation between Mr Tinsel and Arabella which follows immediately after the discussion on the contended chastity of Julia.

Mr Tinsel, the Beau, is described as "what the Ladies call a Pretty-Fellow, a dear Creature, and the most diverting Man in the World" (1973: 264). Disgusted by the seriousness of Arabella's behaviour and her criticism to his fondness of raillery, he devotes himself to Miss Glanville. Both Mr Tinsel and Miss Glanville become the epitomes of the type of fiction which centres on 
displaying that "thorough Knowledge of the World," describing the manners of polite contemporary society. The divergent notions of "history," the different systems of reference to build their discourse, are presented when, asked by Arabella to relate the histories of some of the people present at the Assembly, Mr Tinsel narrates a series of scandalous examples, which very much differ from Arabella's "Hope of hearing something which may at once improve and delight me; something which may excite my Admiration, engage my Esteem, or influence my Practice" (1973: 274). Disappointed by the stories he tells, she condemns his conversation, to which Miss Glanville replies that is was her who desired to hear "Histories about the Company" (1973: 277). Proving the different meaning of the word according to romantic authority, Arabella replies that she desired "a pleasing and rational Amusement, for such I Imagin'd Mr. Tinsel's Histories might afford;" instead, she encounters a "Detail of Vices, Follies, and Irregularities" (1973: 277). The contemporary language both Charlotte and Tinsel employ, although more adequate to their time, reveals the moral degradation reflected by literature. Arabella's anachronistic use of words such as "history," "adventure" or "favours" is placed in opposition to Charlotte's or Tinsel's employment of them; yet it is Arabella who is made unintelligible for others and the language of romance is the one parodied (Langbauer, 1984: 37). The sexual connotations that these words have now acquired, and the willing participation of Miss Glanville and Tinsel in the construction of stories which employ them, are a reflection of the values they and gallant fiction stand for.

This is particularly evident in the case of Miss Glanville, who stands as Arabella's more significant dialectic Other. Because of Charlotte's shallow nature, mirrored in her champion Mr Tinsel, the situations in which she is involved includes only "sprightly and free Conversation" instead of the serious and rational one of Arabella. While she is at Richmond, Arabella is unable to relish the company of young women of fashion with an "insipid Conversation" (1973: 341). The type of woman these ladies represent is set in opposition to Arabella's heroic models, and is epitomised by Miss Glanville herself:

As for Arabella, whose Taste was as delicate, Sentiments as refin'd, and Judgement as clear as any Person's could be who believ'd the Authenticity of Scudery's Romances, she was strangely disappointed to find no Lady with 
whom she could converse with any tolerable Pleasure: And that instead of Clelia's, Statira's, Mandana's, \&c. she found only Miss Glanville's among all she knew. (1973: 340-41)

As even the Doctor of Divinity must later acknowledge, reality fails to equal the ideal models of romance, at least if the standard of society is to be a Miss Glanville. This negative model extends not only to her form of conversation, but also to Charlotte's "Taste for Polite Amusements" and "Fund of Spirits," which are repeatedly displayed in negative comparison with Arabella's more rational and sober entertainment of reading and conversation.

Once more displaying her condition as Cervantes' daughter, Lennox portrays two characters with colliding epistemologies in order to develop the dialogic principle at the core of her novel, a principle better exemplified in conversation. As the novel unfolds, both women are seen to share different approaches to interpretation, the quixotic and the worldly, the idealistic and the empiricist, the romantic and the novelistic, and therefore they are unable to understand each other. This is no better evidenced than in the conversation on adventures and favours to lovers in which they both engage. When Arabella asks Charlotte to recite her "many Adventures" in the confidence women hold in romances, Miss Glanville angrily denies any, of course, employing the contemporary meaning of the word as sexual liaison (1973: 87). Arabella finds this very extraordinary, for she believes "there are few young Ladies in the World, who have any Pretensions to Beauty, that have not given Rise to a great many Adventures; and some of them haply very fatal" (1973: 88), to which Miss Glanville pertly replies: "If you knew more of the World [...] you would not be so apt to think, that young Ladies engage themselves in troublesome Adventures: Truly the Ladies that are brought up in Town are not so ready to run away with every Man they see" (1973: 88). Although this statement has been somehow contradicted earlier in the novel by the story of Miss Groves, the confusion between Arabella's frame of reference and Charlotte's provides a comment on the differences between varied forms of prose fiction, between the language they employ and the events they represent as plausible or even proper. In Lennox's novel, the language of romance permits the construction of an alternative reality, "one which reveals that the struggle for agency is a 
struggle for language, and for who can control the way in which actions are to be read and interpreted" and it is often "language itself rather than the material world which becomes the site of the conflict" (Roulston, 1995: 34).

These divergent uses of language and the different codes of propriety they represent are underscored by the ensuing comments on the favours a lady should or should not grant a lover. While Arabella finds it proper to grant a present after years of service, but never to allow a kiss, Miss Glanville's principles, according to the customs of the age, are reversed. In that regard, Arabella's innocent comments on the examples of the strictly virtuous heroines of her romances are perceived by Charlotte -and the reader-, as an indirect critique to her coquetry and her modern values:

Miss Glanville, who could not imagine Arabella spoke this seriously, but that it was designed to sneer at her great Eagerness to make Conquests, and the Liberties she allowed herself in, which had probably come to her Knowledge, was so extremely vexed at the malicious Jest, as she thought it, that, not being able to revenge herself, she burst into Tears. (1973: 89)

As Motooka has pointed out, while Arabella's interpretation is "assured, absolutist, essentialist" (1996: 262), finding it difficult to perceive the contending discourses at stake, Charlotte, in her wider knowledge of the world and "attuned to the conflicting presence of other people's narratives" (1996: 261), which can destroy her image by the implications of those improprieties she has committed, has a "tactical" interpretation method (1996: 262) which accepts that representation is not "always plain, that literal meaning cannot always be trusted" (1996: 261). In Motooka's analysis of this passage, her conclusion is that Charlotte "tends to overread (inferring intentional slights and wilful competition from Arabella's romantic folly and artless beauty), while Arabella underreads (accepting romance narratives as self-evident stories)" (1996: 261). What, in principle, and according to Motooka's interpretation, places Charlotte in a position of advantage over Arabella, turns against her in Lennox's novel.

These contending manners of interpretation and the moral difference between Charlotte and Arabella are later highlighted in another conversation in which their particular follies and flawed perceptions are displayed. After a debate on 
Miss Grove's "history" perceived from the perspectives of scandal and romance, the following conversation ensues:

Indeed, Lady Bella, said Miss Glanville, smiling, you may as well persuade me, the Moon is made of a Cream Cheese, as that any Nobleman turned himself into a Writing-master, to obtain Miss Groves-

Is it possible, Miss, said Arabella, that you can offer such an Affront to my Understanding, as to suppose, I would argue upon such a ridiculous System; and compare the Second glorious Luminary of the Heavens to so unworthy a Resemblance? I have taken some Pains to contemplate the Heavenly Bodies; and, by Reading and Observation, am able to comprehend some Part of their Excellence: Therefore it is not probable, I should descend to such trivial Comparisons; and liken a Planet, which, haply, is not much less than our Earth, to a thing so inconsiderable, as that you name-

Pardon me, dear Cousin, interrupted Miss Glanville, laughing lauder than before, if I divert myself a little with the Extravagance of your Notions. Really, I think, you have no reason to be angry, if I supposed you might make a Comparison between the Moon and a Cream Cheese; since you say, that same Moon, which don't appear broader than your Gardener's Face, is not much less than the whole World: Why, certainly, I have more Reason to trust my own Eyes, than such whimsical Notions as these.

Arabella, unwilling to expose her Cousin's Ignorance, by a longer Dispute upon this Subject, begged her to let it drop for the present [...]. (1973: 142-43)

In this passage the reader finds contending modes of interpretation and rhetoric, referring once more to Cervantes and the dialogic principle of his masterpiece. On the one hand, Charlotte is the empiricist who believes the account about Miss Groves from the "Eye-witnesses of all her ridiculous Actions" (1973: 140); therefore she rejects Arabella's romantic interpretation and employs an improbable comparison to highlight the absurdity of her cousin's interpretation. On the other hand, Arabella interprets Charlotte's words in a literal way and pedantically answers to her raillery. As Mary P. Martin has indicated, “Arabella's absurdly literal reading of a common cliché seems of a piece with her faith in romances: just as she is unable to recognize their fantastic excess as fiction, she cannot even comprehend figurative language, unaware that words might even mean something else than they say" (1997: 55). Therefore, one could conclude, with Martin or Motooka (1996: 262), that Arabella's blunder, together with her assured and pedantic answer, position her as the butt of the satire. However, Miss Glanville's blunder reverses the roles of instrument and butt of satire. Although Charlotte does 
indeed mimic Arabella's "literal understanding in order to rally her cousin's quixotic folly" (Motooka, 1996: 262) in this second speech, her empiricist perception of the moon and her lack of any study on the subject which may aid her in understanding her misinterpretation, seems to contradict her early stances against Arabella's literalness. Martin contends that as she "gaily displays her ignorance, becoming the unwitting object of her own raillery, Arabella's status in the satire is shifted, and new value granted to her learning and intelligence," proving that "while Arabella is admittedly sometimes foolish, she is never a fool" (1997: 55). The roles are reversed, and it is now Arabella, with her bookish notions, who can counteract appearances and more adequately read reality. ${ }^{124}$ Moreover, the moral authority in this discussion is emphasised by Arabella's unwillingness to expose her cousin's ignorance, in clear contrast with Charlotte's attempts to ridicule her. Arabella's romantic and naive reading of Charlotte and her discourse offer the grounds of a dual satire aimed both at the quixote, and at the worldly and uneducated coquette and evidence the fraught relationship between both epistemological and narrative discourses. It moreover proves that language is far from being the "straightforward tool of philosophical empiricism" (Thomson, 1992: 117) that characters surrounding Arabella believe it is, for its meaning is unstable and prone to manipulation or change according to custom. As the Countess explains to Arabella, "tho' the Natures of Virtue or Vice cannot be changed [...] yet they may be mistaken; and different Principles, Customs, and Education, may probably change their Names, if not their Nature" (1973: 328). Although Arabella, as a quixote, is proven mistaken, nevertheless, her asexual and naive interpretation of these words is a defence of her character and of the unaware sexual state in which heroic romances have preserved her. The morals of the heroic romance are again contrasted with the novella of scandal or

${ }^{124}$ The present interpretation of this passage agrees then with Martin's and contradicts Motooka's conclusions that "Charlotte's remarks show her awareness of the instability of interpretative systems, particularly the quixotic excesses of empirical method when challenged by truly divergent perspectives" (1996: 262) or that "no other character manages to parry with Arabella so acutely and successfully" (1996: 262). Charlotte is very often rendered speechless by Arabella, and her ignorance in matter of astronomy, geography or even history are evidenced throughout the novel and compared to the wider learning of Arabella, while it is Charlotte who displays an excess of misinformed empiricism in this passage. For another revealing conversation in which Charlotte's dialectic advantage gained by her extensive knowledge of the world once again turns into a critique to her lack of formation, see pp. 183-84 in Lennox and Martin's analysis of the passage (1997: 56). 
intrigue, which is embodied by Miss Glanville and her male counterpart, $\mathrm{Mr}$ Tinsel. $^{125}$

The "knowledge of the world" that Charlotte and Mr Tinsel display and their relish for coquetry, raillery, scandal or intrigue contrast with Arabella's innocence. Lennox's narrator identifies Mr Tinsel as a Beau and Miss Glanville as a woman with a "large share of Coquetry in her Composition" (1973: 80); both are recurrent and stereotyped characters of the gallant or scandalous novellas and their values are meant to represent those of contemporary genteel society. ${ }^{126}$ They engage in raillery and gossip concerning the people at the assembly or Miss Groves, and Charlotte artfully contributes to the gossip relating to Arabella (1973: 322). Once more, Motooka comments on the difference between Charlotte and Arabella and states that,

Miss Glanville recognizes her own artfulness. In so doing she demonstrates a level of self-consciousness that distinguishes her from the female quixote. Arabella is quixotic while Miss Glanville is not, precisely because it is the inability to recognize artifice that defines the quixote. Thus, in the contrast between the artless Arabella and the artfully aware Charlotte, Lennox depicts the pronounced interpretative differences that must be reconciled in order that the novel's plot may be effectively resolved. (1996: 256-257)

${ }^{125}$ It is interesting to note, with Langbauer, the exposure Fielding himself did of the misapplied meaning of words and the moral danger it implied. Relevantly, she quotes as an example his ironic definition of "honour" as "duelling" in The Covent Garden Journal (1984: 36n15), which would serve as an example as well in The Female Quixote, for it is the preservation of honour in the contemporary sense which triggers Glanville's duel and which explains the real-life and literary proliferation of duelling in the eighteenth-century.

${ }^{126}$ Glanville himself positively contrasts Arabella's unattainability with the more "wordly" attitude of reputed coquettes of contemporary English society: "Though [...] you are very severe in the Treatment you think it necessary our Sex should receive from yours; yet I wish some of our Town Beauties were, if not altogether of your Opinion, yet sufficiently so, as to make it not a Slavery for a Man to be in their Company; for unless one talks of Love to these fair Coquets the whole time one is with them, they are quite displeased, and look upon a Man who can think any thing, but themselves, worthy his Thoughts or Observation, with the utmost Contempt. How often have you and I, Sir George, [...] pitied the Condition of the few Men of Sense, who are sometimes among the Croud of Beaux, who attend the Two celebrated Beauties to all Places of polite Diversion in Town? For these Ladies think it a mortal Injury done to their Charms, if the Men about them have Eyes or Ears for any Object but their Faces, or any Sound but that of their Voices: So that the Connoisseurs in Music, who attend them to the Ranelagh, must stop their Ears, like Ulysses, when the Siren Frasi sings; and the Wits, who gallant them to the Side box, must lay a much greater Constraint upon themselves, in order to resist the Soul-moving Garrick; and appear insensible, while he is upon Stage" (1973: 148). Small (1969: 75) and Dalziel (1973: 400) identify those two beauties as the celebrated Gunning sisters; according to Walpole, the world talked of nothing else but these beauties, who were nonetheless supposed to be "lacking in sense and knowledge of the world" (Small, 1969: 75). 
Arabella is presented as superior because she is not as scheming as Charlotte; although she speaks the "coquette language of power" (Gordon, 1998: 505), she regrets the pain her beauty must have unwillingly caused. ${ }^{127}$ There are many instances of Miss Glanville's mastery at manipulation: she wilfully manipulates her cousin's delusion and Mr Selvin's naivety to engage them in a misunderstanding and hence to expose her folly and to attract Mr Tinsel's attention to her persona, despite hiding her motivation under the disguise of "good Intentions" which fool both Arabella and Selvin (1973: 288). Her greatest intrigue arrives almost at the end of the novel, when she discovers Sir George attempts to take advantage of Arabella's quixotism and decides to repay him in kind: she bribes one of Arabella's maids, then dresses as her cousin to meet the Baronet in the gardens to expose his inconstancy. These series of misunderstandings are, of course, very recurrent in the gallant novellas she represents, in which lovers employ unfaithful servants or disguises to advance the sentimental plot.

The critique that Charlotte, and by analogy Mr Tinsel, aim against Arabella is her poor adequacy to the rules of genteel society and the impossibility or impropriety of applying her romantic manners or moral code in eighteenthcentury England. However, the values they stand for are shown under a negative light. Mr Tinsel is ridiculed by the narrator, with the abovementioned epithets he is granted, and satirised by Arabella's criticism to effeminate men. In clear parallelism with Arabella, compared with Mr Tinsel the almost quixotic, well-read and innocent Selvin also shines in comparison. Throughout the novel, Charlotte is negatively compared to Arabella both intellectually and morally. However, the satire against her moral values goes beyond mere coquetry and gossip; it is Miss Glanville, not Arabella, who causes the final bloodshed by her amorous intrigue. More plausibly than the epic battles of

${ }^{127}$ Gordon emphasises the role of unawareness in Arabella's character and concludes that Lennox's novel sets "its traditional romance plot $[. .$.$] in a representational environment$ ostensibly hostile to romance, the world of self-interest, without permitting this world to taint the fundamental fact of romance: the two lovers' disinterestedness" (1998: 513). On the other hand, in his particularly condemning analysis of Lennox's novel and character, Paulson considers Arabella "a monster of egotism and self-interest" (1967: 276). Although he will later come closer to Paulson's position, Gordon at first contends this view when he states that Arabella is more often "controlled" than "controlling" for not being aware of others' plots (1998: 505); however, as stated above, her power is precisely to unconsciously force the romantic plots, if not the self-centered ones of Charlotte. 
heroic romance, in gallant novellas wronged or jealous lovers duel. In Charlotte's and Arabella's conversation on the dubious morality of sending Glanville to kill for her, Miss Glanville asserts: "I should not be sorry to have a Duel or Two fought for me in Hyde-Park; but then I would not have any Blood shed for the World" (1973: 129). This incongruous speech prompts Glanville's laughter and Arabella's smile at "the harmless Kind of Combats her Cousin was fond of" (1973: 129). What neither realise at the time is that because duels are in fact more probable, they are more harmful; while in Arabella's romance there is no possibility of a bloodshed, in Charlotte's and Sir George's enactment of romance a duel almost ends in tragedy. Duelling was condemned by the law and by Christian morality, and was abundantly criticised both in and out of narrative fiction. After the duel, Sir Charles is worried about the consequences for Glanville and advices him to leave the country (1973: 366), while Charlotte sees herself as the cause of the misfortune and loses her usual gaiety.

Charlotte's epistemology may be correct in general, but her education and morals are wrong, while Arabella is mistaken but she is however a model of the virtuous and accomplished woman, a duality Lennox inherits from Cervantes and Fielding. The ambiguity of quixotism then serves the double purpose of creating a parody of the aesthetic failures of the virtuous heroic romance and of developing a satire against the more sexual moral shortcomings of the gallant novella. The difference in the ending of both is evidence of the different critique aimed at the forms of fiction they represent: Charlotte and Sir George are "only married in the common Acceptation of the World; that is, they were privileged to join Fortunes, Equipages, Titles, and Expence," while Arabella and Glanville "were united, as well in these, as in every Virtue and laudable Affection of the Mind" (1973: 383). While both are reformed and achieve the happy ending, it is only the virtuous heroine of heroic romance who can become the true heroine of the novel. In this sense, Lennox could be seen as enrooting her fiction with those female authors such as Barker who incorporated a romantic heroine or romantic tenants in their fiction, preserving the virtuousness found in romance and also employing it to transform fiction and to create more modern heroines for the new style of prose 
fiction they were developing. Therefore, by "deftly exploiting the traditional association of romance with female readers and writers" and by "using romance strategically to critique the definitive terms of the new genre," Lennox can claim the novel too as "women's writing” (Martin, 1997: 46). However, as seen in Barker's work, the need to balance the plausibility and the morality of fiction lead to more complications, especially in the case of the woman novelist.

\subsection{The Feminocentric Novel and the Problems of Morality and Plausibility}

Charlotte Lennox did not escape the debate on women writer's moral and aesthetic authority which permeated the long eighteenth century. A writer of unclear origins, the early history of her life seems to have been a romantic rewriting of her own family and circumstances. A poet, novelist, translator, journal editor, and an actress, Lennox epitomises the complex position -as well as the success- of the professional female author.

Lennox's early work was in general well received, although it raised some doubts about its morality. Two pieces of her work were outstanding in this respect, her poem "The Art of Coquetry" and her first novel The Life of Harriot Stuart (1750). The former appeared in 1750 in the Gentleman's Magazine and was addressed to female readers. The aim of it seemed to be to teach them how to attract men and how to seek power in courtship by inspiring love, while never feeling it themselves. The responses were not altogether favourable, as Small or Levin have recorded; while there existed several poems published in that same magazine praising other instances of Lennox's poetry, a specific poem which appeared in January, 1751 was entitled "Advice to the Novice in Love," and subtitled "Occasioned by reading the art of coquetry, by Mrs Charlotte Lennox." This poem "intended to arm 'honest wretches' against the wiles of the 'tutor'd fair inspir'd by Charlotte's pen" (qtd. in Small, 1969: 8), or, in other words, to "avenge men against the female 'tyrants' who '[n]ow vers'd in coquetry of novel mode,/ Inspir'd by Charlotte's pen, inforce (sic) their power"' (qtd. in Levin, 1995: 272). That is, her poem was considered 
negatively influential over her female readers' minds. This interpretation is supported by other written testimonies. Both scholars quote as an example Mrs Elisabeth Carter writing to Miss Catherine Talbot the following:

[...] do you know anything of a Mrs. Charlotte Lennox, who is publishing by subscription? One or two of her poems were printed in the last Magazine. For the edification of some of my young friends, we read one of them on the art of coquetry, at which they were much scandalized. The poetry is uncommonly correct, but the doctrine indeed by no means to be admired. It is intolerably provoking to see people who really appear to have genius, apply it to such idle unprofitable purposes. (emphasis added, qtd. in Levin, 1995: 272-273)

In this letter, Lennox's quality as a writer is not questioned, but her propriety is. As a woman she is read by other women looking for "edification" and the proper "doctrine." Emphasising this matter further, three years later, Miss Talbot, in a letter to Mrs Carter, would resume the topic thus: "But do now write me an essay upon this sort of vanity, and its too frequent consequence, coquetry. Not the art of coquetry like Mrs. Lennox, but an edifying essay proper to be put in the hands of the Muses" (qtd. in Small, 1969: 10).

This proper essay seems to have been intended in Lennox's first novel, which offers the account of the adventures and maturation process of Harriot Stuart, a lively girl and a literary prodigy, with whom her own story seems to have much in common. The family description, the life in America and the trip to London in order to live with a wealthy aunt at least suggest a certain autobiographical source for the novel. ${ }^{128}$ Maybe because of this identification with her heroine, the fact that Harriot attracts the attention of all men in her acquaintance and must endure the pursuits of many dishonourable men did not help improve Lennox's reputation in the eyes of some of her critics. Small describes Harriot as "extraordinarily vain and forever conscious of the impression her looks and speeches are going to make upon others" (1969: 125), while Levin identifies her as "a romance-reading, self-confessed coquette who

${ }^{128}$ For an account of Lennox's life see Phillipe Séjourné's The Mystery of Charlotte Lennox, First Novelist of Colonial America (1727?-1804) (Aix-en-Provence: Editions Ophrys, 1967); Small (1969, pp. 1-63); Shevelow's entry in A Dictionary of British and American Women Writers (1987), pp.196-8; Hugh Amory's more complete entry on Lennox in the Oxford Dictionary of National Biography (Oxford University Press, 2004; online edn May 2009, <http://www.oxforddnb.com/view/article/16454>); or Susan Carlile's "Charlotte Lennox's Birth Date and Place" (2004). Lennox's life still lacks a definite authoritative work, although hopefully such a want will be answered with Carlile's forthcoming biography. 
enjoys her power over men" (1995: 273), and who is finally redeemed into marriage and submission. Harriot is then an antecedent to Arabella as a romance-reading heroine who is deluded as to her consequence in the world. And yet there are important differences, for, as Gordon has stated, "romances turn Harriot less into a victim, vulnerable because of her romance fantasies, than into a 'coquette' [...]: from romance Harriot learns to value power and how to gain it" (1998: 501-502). In addition, she encounters overtly dangerous adventures: several times she finds herself on the verge of being raped and at one point she must even stab her aggressor. Although Harriot remains unfailingly virtuous and the novel ends with the same moral lesson Lennox's quixotic narrative possesses, the vivacious tone of the narration, the sympathy with which Harriet's follies are presented and, probably, the similarities with Haywood's coeval Betsy Thoughtless, granted Lennox accusations of certain "impropriety" in these early publications (Levin, 1995: 271). Lady Mary Wortley Montagu, for instance, wrote the following in a latter dated 1752: "I was [tired] with the memoirs of Miss H. Stuart; who, being intended for an example of wit and virtue, is a jilt and a fool in every page" (emphasis added, qtd. in Small, 1969: 126). Another example is to be found in the Monthly Review: "[...] this work affords nothing great, or noble, or useful, or entertaining. There [is not] [...] anything that will strongly fix the attention, or greatly improve the morals of the reader" (emphasis added, qtd. in Small, 1969: 126). Moreover, Harriot is not only a reader, but a writer. As Galesia before her, she is a poetess who must also deal with the inappropriateness of being a public woman; the poems included in the novel are Lennox's and hence the association between Harriot and her author increase. In the same manner Lennox received several answers to her poems alluding to her as a sexually available woman, ${ }^{129}$ Harriot finds herself in danger because a male reader has interpreted one of her poems on love too literally. The fact that the novel is a first person narrative, which leaves little room for ironic distance, also stresses that parallelism with Lennox herself (Levin, 1995: 274).

In this regard, Lennox's subsequent novel, The Female Quixote, could be seen as responding to this unfavourable criticism and the accusations of levity

\footnotetext{
${ }^{129}$ See Levin for some examples of these replies (1995: 272).
} 
against both the author and her previous body of work. Creating in Charlotte Glanville Arabella's most significant Other, separating the romantically deluded heroine and the coquette into two different characters, she could praise the virtue of the quixote and condemn the frivolity of the flirt. Moreover, as seen in previous sections, by means of her quixotic fiction and the epistemological and generic dialogue that it entails, Lennox could gain the necessary distance to provide her required moral comment as well as her reflections on fiction. As Cervantes or Fielding did with the contrast between Don Quixote's, Adams's or Joseph's obsolete but sound morals, and the surrounding world, Lennox could then reject the form of fiction which portrayed those sexually conspicuous female models, she could deny the authority of those pens that "condescend to record such inconsiderable Actions" as those of the ladies of fashion criticised by Arabella (1973: 279), embodied by Behn, Manley or even the reformed Haywood, ${ }^{130}$ and follow Barker's Galesia and Richardson's Pamela in their appropriation and rewriting of the conventions of heroic romance in order to construct a didactic tale of sexual unattainability, and hence to inscribe it into a more plausible and verisimilar narrative, which could also be morally acceptable in eighteenthcentury standards. In that way, her authority as a didactic writer was established, and both her and her text could be read as models of propriety.

As Levin has indicated, this separation from the earlier tradition of scandalous female novelists and her alliance with the new species of narrative fiction is emphasised in her subsequent novels (1995: 281), which are characterised by an even greater "serious and moral turn," becoming increasingly didactic and "leaving behind her forever the frivolity of the 'Art of Coquetry' and the gaiety of the Female Quixote" (Small, 1969: 19). In Henrietta (1758), for instance, the protagonist reads her dead mother's own didactic account of her life, as well as reading Joseph Andrews several times and rejecting Manley's and

${ }^{130}$ Despite the didactic purpose these three authors claimed in some of her prologues and the exemplary story of a reformed coquette Haywood portrayed in her novel, the accusations of immorality against the fair triumvirate of wits continued, supporting Warner's claim that they were used as the negative "other" (1998). Staves develops this idea in her analysis of Lennox's novel identifying its satire as aimed to the gallant romance of Behn, Manley, and Haywood. She states that "Lennox wants to go back to reclaim the concern of romance with virtue [...] and, at the same time, [...] to construct a new women's fiction against that of the earlier transgressive women writers," especially against the scandal chronicle (2006: 267). 
Haywood's novels. In the serialised Sophia and in Euphemia (1790), the virtuous protagonists read in moderation and only moral books. While in her first novels the act of reading is metaphorically inflaming, in the later part of her novelistic production "reading becomes more impersonal and more proper, an act that disciplines its female reader's behaviour" (Levin, 1995: 285). This increasingly stern morality concerning reading was a "perfect marketing strategy:" "she made reading, and reading her, not only permissible but necessary to her female readers," for "her novels could teach them to 'regulate' rather than 'suppress', 'restrain' rather than 'subdue"” (Levin, 1995: 285). By promoting reading within certain quantity or generic boundaries, Lennox safeguarded her career as author, and, more relevantly, as a proper one that could educate her female readers. However, in the process, Lennox discourse becomes increasingly monologic as she abandons the dialectic of the quixotic fiction, and, consequently, her novels increasingly lose their nature as spaces for female agency that her masterpiece was. In particular, they lose the possibilities for greater intellectual and authorial agency that reading and its subsequent quixotic delusion seemed to grant heroine and novelist alike.

This enabling purpose of reading is already perceived in Arabella. Reading is a crucial part of her education. At the age of four, the narrator tells the readers that the Marquis discovered in his daughter an "uncommon Quickness of Apprehension, and an Understanding capable of great Improvements" and resolved to "cultivate so promising a Genius with the utmost Care" and to "render her Mind as beautiful as her Person was lovely" (1973: 6). However, this utmost care materialises in the ordinary and shallow accomplishments of a genteel woman so criticised by Wollstonecraft: reading, writing, music, dancing and the passive learning of modern languages -passive because it could be used to read, and not usually to be employed abroad or in any form of employment. The reader is then told that "it is not to be doubted but she would have made a great Proficiency in all useful Knowledge, had not her whole Time been taken up by another Study" (1973: 7). This study is, of course, the obsessive consumption of romances, although as the novel unfolds, the reader discovers that Arabella must have also read books on History, Philosophy and even Astronomy in her father's library. In spite of this great amount of study, 
the advantage of education she could gain as woman would have been to become the model of an accomplished young lady as Miss Glanville is. Charlotte, a product of this form of superficial female education, is "incapable of thinking or acting outside the very narrow sphere of activity with which they have been taught to concern themselves" (Smith Palo, 2005: 225). Miss Glanville's role as woman of fashion is to evidence how "this preoccupation with fashion and public diversion renders women insipid and consumes valuable time that could be devoted to study" (Smith Palo, 2005: 222), contrary to Arabella, whose early confinement and her voluntary enclosures throughout the novel in order to read on her own, preserve her from that insipidity and shallowness. Her quixotism is then a protection against becoming an eighteenth-century lady of fashion. The absence of any rational educational development has rendered Charlotte, employing Wollstonecraft's terminology, "a creature of sensation" that cannot exert her intellectual powers, in clear opposition to Arabella's mental capacity displayed in the aforementioned discussion on the comparison of the moon with the cream cheese.

Despite this defence of Arabella's reading, her rejection of romance as an adequate reading for her heroines in subsequent novels seems to suggest that Lennox adhered to Fénelon's or Richardson' rejection of romance as part of a rational course of study for young minds. ${ }^{131}$ However, Lennox has not reached in The Female Quixote the unambiguous moral stance of her later novels with regard to romance, and its role in Arabella's unique education and superior understanding is once more equivocal and inherited from Cervantes, Barker or Fielding. On the one hand, she obviously acknowledges Fénelon's assertion that romances "give a visionary turn" to women's understandings (Smith Palo, 2005: 212). On the other hand, in Lockean terms, this romantic quixotism allows the simple ideas she passively receives through her senses to gain complexity "when she begins to separate, compare, and combine the impressions she gains from fiction and those she acquires from real life"

131 Salignac de la Mothe Fénelon, a French moralist, wrote the popular Traité de l'éducation des filles, published in France in 1687 and first translated into English in 1707. His work was very well received and appeared in numerous forms and reprintings throughout the eighteenth century at both sides of the Channel. Lennox seems to have been familiar with his work for she published a translated abridgment in The Lady's Museum. For an enlightening summary of the debate on the role of romance in female education in the seventeenth and eighteenth century, see Smith Palo (2005), pp. 209-13. 
(Smith Palo, 2005: 206). Because her quixotism means a youthful delusion that is overcome by gaining experience, the fraught accommodation of her romantic ideas to the reality that surrounds her in which she must "continually exercise her powers of interpretation and imagination," contributes to "the development of her intellect" (Smith Palo, 2005: 207), as well as to the maturation process of the young and inexperienced girl. These powers of interpretation are, for instance, relevant in the discussion with Selvin or with the Doctor. Parenthetically, one should point out that romances not only enhance her rhetoric, but also provide the basis for some of her most praised arguments: Arabella's speech on raillery is after all borrowed from the romantic heroine Euridamia in Artamenes itself, although, as Dalziel has pointed out, Lennox's heroine adds new arguments and even creates the simile of wit shining as the stars do (1973: 406).

More importantly in the context of such a self-referential work, Arabella's romantic quixotism becomes the cornerstone of her imaginative and creative powers. Lucy, who is not quixotic, is scolded by Arabella for confessing she cannot "make a History of nothing" (1973: 305). Arabella, however, can do precisely that: create a story using the material from romance. Her most conspicuous example of authorship comes under the enlightening title of "Some curious Instructions for relating an History." Confined in the female space of the closet, Arabella asks Lucy to relate her life, as any heroine would ask her maid. The dazzled maid asks: "How can I make a History about your Ladyship?," to which Arabella answers that there would be no need to make a History, for there are "Accidents enough" in her own life to afford matter for a long one, all Lucy has to do is "to relate them as exactly as possible" (1973: 121). Arabella then expounds the need to relate the minute details of her last ten years of life, and provides a pattern to relate such events as her illustrious birth and her adventure with Edward. In this passage, Arabella proves her desire to become the author of her romance, to write her own tale. By creating her own story, Arabella broadens the boundaries of her uneventful life and is moreover breaking the limitations imposed on her as a woman to employ her education, based mainly on her reading. 
A woman's education, comprising the abovementioned accomplishments as well as screen making or sewing, aimed at creating a model of domesticity: all her excellences would be performed within an enclosed circle, at home or at assemblies where to sing, dance or play. Educationalists defended in their majority the domestic thesis: women could better employ their intellectual and sympathetic powers as wives or mothers. Once again, the debate focused on how to define the private/public spheres and how to circumscribe what was or was not proper for women to perform in them, as seen in chapter three. With her character's dual nature as a lady quixote, that is, a romantic heroine and a delusional fantasiser, Lennox partakes in this debate presenting both sides of the argument. On the one hand, Arabella's education has taken place in a domestic realm and has transformed her into a domestic woman, who only with reluctance leaves her home or her gardens, who would rather read or talk than walk with beaux or dance, and who will, therefore, become a better wife and a better heroine for the didactic novel that Lennox has written. On the other hand, as stated above, Arabella's education allows to challenge the restricted prerogatives of women and to appropriate traditionally male spaces, such as oratory, history or even writing, in her quixotism. Her immasculated discourse is acknowledged by representatives of patriarchy such as Sir Charles, who “express'd much Admiration of her Wit, telling her, if she had been a Man, she would have made a great Figure in Parliament, and that her Speeches might have come perhaps to be printed in time" (1973: 311), and who, full of "Signs of Admiration" at another of her speeches, states that "she speaks like an Orator" (1973: 269) or even "as learnedly as a Divine" (1973: 314), an opinion mirrored in her discussion with the Doctor. The appropriation of activities viewed as masculine is mirrored by Selvin's shame "at seeing himself posed by a Girl, in a Matter which so immediately belonged to him" (emphasis added, 1973: 265). Moreover, it is expressed in Arabella's admiration for the Amazons and the debate on the appropriateness of women's participation in battle (1973: 125-26). In this regard, Lennox's novel "raises the possibility that educated and intelligent women might be capable of functioning in public roles generally reserved for men" and it suggests that "learning invests women with the potential to transform public space and their roles within that space" (Smith Palo, 2005: 227). 
Despite the display of these possibilities of female learning, Lennox's conclusion seems once more to deny those possibilities by the final silencing of women which society seems to impose in order to grant their happy acceptance into society. Notwithstanding their learned or unlearned status, their role as heroine of a heroic romance or a gallant narrative, women are finally silenced into propriety. However, Lennox's novel, by its use of the quixote owns a subtext that tells a different story: by assuming the same prerogatives as previous heroines and developing her intellectual and creative powers, the female quixote not only appropriates the same male discourse and space, but transforms it into an even more feminocentric one. And, by analogy, so does the woman novelist.

The development of this appropriation and transformation of the masculine discursive space is embodied in the non-story of the Countess and in the story of Arabella herself, the failed and successful tales of female authorship, respectively. The Countess seems to epitomise the story of the woman novelist, and, in particular Lennox. One trait she shares with women writers, for example, is that she is criticised for being too learned, which sets her apart from other women (1973: 333). Well-read in romances and very fond of them in her youth, the Countess can retell their conventions and employ the romantic language with proficiency. Moreover, she can make use of them to dialogue with Arabella, the young female reader. Her romantic knowledge is so thorough that her use of it makes Sir Charles believe she holds "as strange Whims in her Head" as his niece and that she is "more likely to make Lady Bella worse than better" (1973: 330). Sir Charles, a soldier who acknowledges not to have read much, is corrected by his son, who proves a greater reader of fiction and characters: he defends the creation of a female romantic dialogue between both women of which his father and himself are excluded in order to cure Arabella. Despite this initial employment of romance in a female dialogue similar to Barker's, as stated above, midway through her brief appearance, the Countess abandons her romantic discourse because she describes it as obsolete: what was plausible thousands of years ago is no longer so (1973: 326) and the moral tenets that were acceptable, are nowadays aberrant to Christians (1973: 328-29). However, she also evinces that notwithstanding the absurdity or 
obsoleteness of romance, it still makes a woman's story possible. When Arabella asks to hear her adventures, she expounds the prerogatives of the new form of fiction:

The Word Adventures carries in it so free and licentious a Sound in the Apprehensions of People at this Period of Time, that it can hardly with Propriety be apply'd to those few and natural Incidents which compose the History of a Woman of Honour. And when I tell you, [...], that I was born and christen'd, had a useful and proper Education, receiv'd the Addresses of my Lord -through the Recommendation of my Parents, and marry'd him with their Consents and my own Inclination, and that since have liv'd in great Harmony together, I have told you all the material Passages of my Life, which upon Enquiry you will find differ very little from those of other Women of the same Rank, who have a moderate Share of Sense, Prudence and Virtue. (1973: 327)

In her rejection of romance, instead of the quixotic negotiation with it, the Countess's becomes a herstory of nothingness: the plausible story of a woman of virtue and sense is no-story at all, it is a contradiction in terms, a conclusion that would not only put Arabella's story to an end, but would also contradict both the romance and the novel that have been being written up to that moment. ${ }^{132}$ As a consequence, she disappears to look after an indisposed absent mother (1973: 330), and Glanville's and Arabella's hope that the latter will profit from her conversation is denied; the Countess then becomes herself an absent and ineffectual literary mother. ${ }^{133}$ The implication seems to be that the message of nothingness which society imposed on proper women and the new form of moral fiction it demanded from its heroines would make it necessary not to write at all, or to do so adopting self-erasure or a present absence as strategy (Roulston, 1995: 38).

${ }^{132}$ For Uddén, the Countess is a "fictive existence" that represents the Doctor's "life in its true state" (2008: 453); in her words, "this may be life, but it is no narrative" (2008: 453), highlighting the Doctor's parodical emphasis on the boredom and "unnarratability" of women's lives, which mocks "the reduced mimeticism that was prescribed for women writers" (2008: 445).

133 Isles has explained the disappearance of the Countess in structural terms and as part of Johnson's advice (1973: 418-27). Although a possible explanation for the pages that Lennox apparently still needed to fill, it does not account for the fact that the Countess is not recovered for the last and conclusive discussion or her substitution for a Johnsonian doctor. Malina explains the brief presence of the Countess as part of a chain of repressed/absent mothers, and states that if Lennox left "traces of the almost-absent mother" it was for the following reason: these mothers "mark Arabella's deprivation of a maternal influence, as the doctor leads her into the man's world of rationalism" (1996: 290). 
In this sense, Arabella's quixotic romancing enables her once more to have a story at all, while it also allows Lennox to write a novel that moves beyond a mere patchwork of romance or a sentimental domestic tale. In order to appropriate the new and authoritative discourse and to validate the female voice, Arabella and Lennox must not only recover the inheritance of the absent mother, both the Marchioness and the Countess, but effectively usurp male discourse as well. As the parallel narratives of Arabella and the narrator unfold, the similarities of structure, characterization and plot with romance become evident, together with Arabella's commandeering of modes of discourse and forms of fiction perceived as masculine. Resuming the metaphor of the Amazons, Lennox does not renounce the "Softness in her Person" nor write with "very masculine Hands" (1973: 126), although she still embodies the Amazonian claim for female agency. This female claim is represented by the Marchioness's romances: usurped from her closet after her death, they are taken to her husband's library. It is in this overtly male space that Arabella finds them and reclaims them for her own closet. It is the male intervention which has made reading at all possible or which has rendered romances available to the young reader, but it is her subsequent appropriation of them for her private consumption in the epitome of the female space which triggers her creative powers to function and to start her quixotic rewriting, hence becoming an author herself and allowing Lennox's own fiction to develop. In parallel to this event, one could say that Cervantes, Richardson or Fielding, Lennox's literary mentors and hence father-figures, brought the romance out of women's closets and gave it the necessary prestige to become part of the library, and by so doing they permitted Lennox to connect with the absent mothers of that new species of writing, such as Barker, Aubin or Rowe. This particularly literary family leaves Lennox, as Arabella, in need to negotiate their inheritance: the dead Marchioness and Marquis allow Arabella the freedom to write her romance; in a fraught and dual Elektra and Oedipal complex, the mothers and fathers of the novel need also to be overcome in order for Lennox to create the unique form of prose fiction that is her Female Quixote.

This claim to both male and female, novelistic and romantic heritage and its fraught accommodation is well exemplified by Arabella's negotiation when she 
is trying to decide whether or not to leave her home to escape her father's authority. In this passage, Arabella aims to escape the "Tyrannical exertion of parental Authority, and the secret Machination of a Lover, whose Aim was to take away her Liberty, either by obliging her to marry him, or by making her a Prisoner" (1973: 35). The narrator states that Arabella was irresolute as to escape "for the Want of a Precedent [...] for an Action of this Nature" and that "she did not remember to have read of any Heroine that voluntarily left her Father's House, however persecuted she might be" (1973: 35). She must exercise her exegetical energy with special care: finally, reasoning that previous heroines could not escape because they could be suspected of eloping with a favoured lover, she concludes that not having a beau, her honour would be safe and she could therefore escape her father's tyranny with her fame unharmed. Although there are no precedents in romance which condone such behaviour, ironically, there is a well-known one in the epitome of the new form of didactic fiction: Clarissa's escape from her parents' house. As Todd has asserted, contemporary readers were prone to be familiar with the reference to Richardson's masterpiece and to the manner in which Lennox's heroine questions it (1989: 153). Moreover, they might be aware of the manner in which this passage and the one in Clarissa possess a particular generic and moral ambivalence. In Roulston's words,

Clarissa here is being simultaneously invoked and denied, as a narrative which is implicitly being read within the romance paradigm and yet which violates its codes, for a virtuous heroine does not leave her father's house. The heroine of Clarissa therefore performs an act without "precedent" in romance, and hence paradoxically Richardson's novel cannot serve as a model text for Arabella. At the same time, however, Clarissa's dramatic escape marks the moment which borrows most explicitly from the romance form, framed as it is as a fanciful adventure narrative of virtue in distress, with Clarissa succumbing to imaginary fears. (emphasis added, 1995: 26)

Ignoring the laws of romance and of eighteenth-century propriety, but at the same time borrowing the narrated events from the romance form, Richardson's heroine advances the plot with a highly improper action which might be recalled as an inadequate example for further female readers. Moreover, Clarissa's imaginary fears lead her to escape with a man who is not her lover, hence she is not escaping for love or the protection of a marriage; as a 
consequence, Clarissa's act seems difficult to explain. Lennox, by allowing the reader to partake in Arabella's claim of the authority of romance and her negotiation of its meaning, provides a plausible explanation of an amoral act. At the same time, she highlights the ambivalence existing in Clarissa itself as a romantic anti-romance and the fraught accommodation the father of the novel does of his female inheritance, for this passage evidences that "the novel is not quite so credible, nor the romance so pernicious [...] and the value of the lessons to be learned from each cannot always be predicted" (Martin, 1997: 52). Despite this ambiguity, Lennox still intended to utilise Richardson's novel as the final touch in Arabella's awakening, as a model text to cure romantic readers; in the end, she followed his advice and dropped the idea, not to overshadow her own text with his. ${ }^{134}$ Nevertheless, with this reference to Clarissa and her intention to highlight its didactic function, Lennox justifies the ambiguities of her own approach to romance and the validity of an, at times, unclear moral discourse. In addition, Lennox underscores the difficulties of claiming to construct irreproachable perfect models of behaviour or moral universes. $^{135}$

In the famous chapter which leads to her cure, both Arabella and the Doctor stand as mouthpieces for Lennox on these matters of plausibility and morality. Arabella abandons romance and appropriates the form of discourse of the Doctor, while the latter's voice, an echo of Lennox's, also claims the adherence to the new form of fiction that Lennox's novel has been endorsing. In this chapter, Lennox literally and metaphorically appropriates the male voice and discourse to own the space of this new species of writing, still under the long shadow of men authors. Moreover, she does not only prove she owns this space in her own work, but evinces how she claims it as a particular feminocentric genre. First, it is the product of the dialogue with two previous fictional

\footnotetext{
${ }^{134}$ For the discussion of Richardson's suggestion and the relevance of Clarissa in The Female Quixote see Isles (1973: 18-27), Langbauer (1990: 74-75) and Roulston (1995: 25-26).

${ }^{135}$ Thomson also raises the question of the fictional depiction of women, and asks: "if the novel is to be deprived of Arabellas and is left merely with Miss Glanvilles, how can it fulfill the highest aim of fiction, its didactic purpose? And where are woman writers and readers to look for role models?" (1992: 120). As is stated, the new novel is full of Arabellas: female characters who comply with the cornerstone of female decorum, the preservation of the most strict virtue. The problems and paradoxes of the didactic portrayal of female role models, with particular attention to Arabella, are thoroughly explained by Deborah Ross, to whose study subsequent references will be made.
} 
heritage lines which even male critics and authors have identified not only as feminocentric, but also as penned by women, and which Lennox's novel also epitomises by means of two female characters whose interaction creates much of the plot and generic dialogue. In this sense, her novel is a compound of the different feminocentric narratives: heroic romance, gallant novellas, and even cautionary tales of ruined women, as in the inset story of Miss Groves. Superseding them is the sentimental novel of Richardsonian inheritance which is gaining ascendancy and which partakes in the alleged emasculation of culture. Secondly, as stated in chapter two, it is a female character who can better incarnate the tenets of the new domestic thesis in and out of fiction and who can better exemplify the increasing relevance of sensibility and sentimentality. Moreover, as a woman author, Lennox can provide a better knowledge of the domestic experience and of the female character. Reappropriating the arguments that had condemned her for the close identification between her authorial self and her heroines, Lennox vindicates her role as adequate instructor of young female minds not in spite of, but because she is a woman and a female reader herself. While both Arabella and Lennox do indeed claim the male space of discourse, neither of them completely loses her female voice, which they regain in the sentimental conclusion of the novel. Arabella remains the epitome of eighteenth-century femininity, which is highlighted by her passive and virtuous role as heroine of romance, and in the end she is presented as the paradigm of the heroine of sentimental fiction, also a feminised and feminocentric genre. She achieves what she desired: "by virtue of her redefined femininity -to inhabit the public sphere" (Spacks, 1988: 541).

Developing the parallelism between Arabella and Lennox, in addition to this redefined femininity and its claim to visibility in the new culture and literature of sensibility, Arabella has also proved her right to agency by being a better writer of romance than any of the male characters around her. First, her intentions are more didactic than theirs: Glanville employs the romantic conventions he has learnt from Arabella's discourse to attempt to gain her hand in marriage, while Sir George tries to lure her by his two romantic plots. Both employ fiction as seducer of young girls, with Sir George's life story even approaching at times the tenets of the seduction plots of gallant fiction, rather 
than the courtship plots of heroic romance (Roulston, 1995: 35). His history of the attempted seduction of Dolly Acorn, the milk-maid, disguised in the story as Dorothea, the shepherdess (1973: 214-16), not only recalls Cervantes' novel and his exposure of the manipulation of his Quixote by those who know the conventions of fiction, but also states the dangers of those stories which inflame the passions under the costume of fiction. Besides his amorality, Sir George is indeed identified as the worst kind of author, because he creates one of the most flagrant implausible situations in his romance -living ten months on sighs and tears (1973: 239-40)-, ${ }^{136}$ which even Arabella recognises as impossible, and, more importantly, because he comically acknowledges his grand literary aspirations, which results in his satirical comparison with the improper and mercenary authors of Grub-Street and later with the coffee-house critics that reject the fiction of Young, Richardson or Johnson (1973: 25253). ${ }^{137}$ Arabella's autobiographical romance, as told to Lucy, is more plausible and aims only for fame, not money. She also intends it to be a moral example for her readers and condemns Sir George's inconsistency precisely because it contradicts the high ideals of romance. Lennox, detached as well from the literary commerce of Grub Street hackney writers and patronised by that elite of fiction, states her supremacy over the kind of writers Sir George represents.

${ }^{136}$ A reference which recalls Cervantes' own comic response to the same sort of implausibility when Sancho, worried as usual about mundane matters such as food and the inappropriateness of his meal for a knight such as his master, receives the following answer from Don Quixote: "Hágote saber, Sancho, que es honra de los caballeros andantes no comer en un mes, [...] Y aunque se deja entender que no podían pasar sin comer y sin hacer todos los otros menesteres naturales, porque en efeto eran hombres como nosotros, [...]. Así que, Sancho amigo, no $[\ldots]$ quieras tú hacer mundo nuevo, ni sacar la caballería andante de sus quicios" (2001: 117-8). Sir George's romance is then closer to the flawed genre that Cervantean texts parody than Arabella's; in addition, both quixotes prove less gullible and more reasonable than other characters expect, knowing when not to take the romance out of its "quicios."

137 In a Fielding-like manner, after Sir George's romantic invention, Sir Charles exclaims: "it is a pity you are not poor enough to be an Author; you would occupy a Garret in Grub-Street, with great Fame to yourself, and Diversion to the Public", to which Sir George responds: "I have stock enough by me, to set up for an Author Tomorrow, if I please: I have no less than Five Tragedies, some quite, others almost finished; Three or Four Essays on Virtue, Happiness, \&c. Three thousand Lines of an Epic Poem; half a Dozen Epitaphs; a few Acrostics; and a long String of Puns, that would serve to embellish a Daily Paper, if I was disposed to write one" (1973: 252). Mr Glanville then concludes: "you are qualified for a Critic at the Bedford Coffee-House; where, with the rest of your Brothers, Demy-wits, you may sit in Judgment upon the Productions of a Young, a Richardson, or a Johnson. Rail with premeditated Malice at the Rambler; and, for the want of Faults, turn eve its inimitable Beauties into Ridicule" (1973: 252-3) to which he follows with a reproduction of some criticisms to the language, content and ethics of these novelists, which constitutes Lennox's greatest and more overt defence of their work and attack to the censure of the new form of prose fiction. 
She appropriates romance, she dialogues with it, but always exposing its nature as fiction and never stretching her readers' gullibility beyond plausible limits, not even when it comes to her romantic heroine's exemplarity. In addition, following the steps of Richardson's claims, her intention is highly didactic, not merely mercenary.

While in her later novels Lennox sacrifices plausibility to morality and aims to create flawless heroines, in her first two novels she proved that didacticism requires of a verisimilar and mixed character with whose defects and subsequent re-education the reader might identify. The Female Quixote becomes a transition to her later novels, and embodies the paradoxes of moral fiction; it raises questions about how the reader is meant to identify with unmixed, ideal characters who, as the heroes and heroines of romance, do not resemble any living people; how the reader might be expected to learn or copy artlessness, innocence or sensibility, which are to be praised if natural and condemned if artificial (Ross, 1987: 467-68), ${ }^{138}$ a paradox that is mirrored in the novel by Arabella's garden and her curls: they are both artfully contrived to seem natural or artless (1973: 6, 9). Lennox has it both ways and with her female quixote she portrays a flawed yet exemplary character; a woman that needs to undergo a process of re-education and maturation, but who nonetheless incarnates the best virtues of a lady; a character that can be read both as a warning and a model (Ross, 1987: 466), as a "scarecrow to frighten women away from the fertile fields of romance and back onto the straight and narrow paths of duty and virtue" (Pawl, 2000: 158). Arabella's quixotic "failure to conform appears sometimes like a vice, sometimes like a rare virtue" and this inconsistency allowed Lennox to challenge the Johnsonian concept of a "model moral universe" (Ross, 1987: 470); instead, together with other women novelists of her time, she "persisted in presenting the real universe, showing its unfairness without advocating rebellion" and beginning to "focus on the moral problems resulting from trying to live in an imperfect world" (1987: 470), especially in one that set such incongruent restrictions on

138 As Ross has pointed out, Fielding parodies this impossibility in Shamela: the author was "perceptive enough to point out that giving the artless angel a point of view of her own automatically makes her inconsistent and hypocritical. His Shamela, in consciously pretending to be unconscious -literally, when she pretends to faint- is any woman trying to imitate the childlike heroine of eighteenth-century fiction" (1987: 469). 
women in general, and on women readers and writers in particular. Arabella might be a quixote trying to live her idealistic fantasies of female visibility, but the reader is left wondering whether Lennox might not be one too concerning her aspiration to authorship.

Lennox's quixotic narrative, standing at a moment of genre and gender transition towards a new sensibility, a new model of didactic fiction and a new heroine, with the paradoxes they both entailed, remains a complex text in which the fundamental elements of the tradition of female quixotism are developed. Besides the complications of her gender and role, Lennox adds all the complications of a deep self-reflexive fiction: by means of her quixote, Lennox offers a thorough comment on women's education and their possibilities within the public sphere; she establishes the paradoxes of the woman writer, who must concede silence and invisibility to her heroines while claiming the male public space of authorship for herself; she provides a generic reflection on the antecedents of the mid-century new species of writing and exposes the difficulties and paradoxes of what would come to be known as the novel. This generic and gendered problematic will be reproduced in subsequent quixotic fiction. Lennox, daughter of Cervantes, Barker, Haywood, Richardson or Fielding, will become the literary mother of Edgeworth, Hamilton or Austen, claiming a privileged place in the tradition of female quixotism and, consequently, in the history of prose fiction. 
PART TWO

\section{TRANSFORMATIONS:}

FROM LENNOX TO AUSTEN 



\section{A SPANISH KNIGHT IN IDEOLOGICAL AND LITERARY WARS: THE SATIRICAL READING OF THE FEMALE QUIXOTE IN BRITAIN AND AMERICA}

It was said by Fletcher of Saltoun, 'Let me make the ballads of a nation, and I care not who makes the laws.' Might it not be said with as much propriety, Let me make the novels of a country, and let who will make the system?

Anna L. Barbauld, Essay on the Origin and Progress of Novel Writing, 1810

We are most of us like Don Quixote, to whom a windmill was a giant, and Dulcinea a magnificent princess: all more or less the dupes of our own imagination, though we do not all go so far as to see ghosts, or to fancy ourselves pipkins and teapots.

Thomas Love Peacock, Nightmare Abbey, 1818

\section{INTRODUCTION: FROM POLITICAL SATIRE TO LITERARY PARODY}

Quixotism and satire go hand in hand in the history of literature. More particularly, narrative satire in the Romantic period, with its gallery of exalted heroes and dangerously gullible fools, becomes a fertile field for the study of the reception and appropriation of the quixotic figure. Taking into consideration their targets, Lisa M. Wilson divides the novelistic satires of the Romantic period into three loosely grouped categories, all of which present relevant instances of quixotic figures. First, she identifies both the Jacobin and the anti-Jacobin political novels of the revolutionary 1790s, which employ satire as a weapon of debate and which, in addition, utilise the "satirical methods of Sterne and Smollett" (2007: 39 n22). An important element of these satirical methods is the portrait of deluded quixotes -enthusiasts or monomaniacs-, who embody the political or moral idiosyncrasies to be defended or attacked, whether the quixote is presented under the positive radical light or the negative anti-radical reading of enthusiasm. Secondly, Wilson identifies the period between 1810 and 1818 as particularly prolific in 
the appearance of the "most prominent satirical novels satirising novel writing" (2007: 39n22). As the political tension gradually subsides, analogously the political satire is progressively substituted by literary parody, and the source of the quixotes' delusion becomes once more mainly narrative fiction. Finally, until 1826, she identifies a number of satirists who published "parodies of, or satires on, Scott and Byron" (2007: 39), identifying these authors' work as the origin of their characters' quixotism. In the latter two kinds of satire, while the primary targets are literary, she also recognises the important "elements of political, social, and even personal satire" (2007: 39n22). Therefore, throughout the later part of the century, the novel remains a complex and challenging vehicle for aesthetic and ideological messages; an instrument moreover expertly owned and developed by many skilled women satirists in the Romantic period.

In the midst of the revolutionary years, and more conspicuously in their aftermath, British authors were inscribed in one of the most influential ideological and literary battles: the well-known war of ideas fought by two fractions, the radical and anti-radical, which came to be known as the Jacobins and the anti-Jacobins. ${ }^{139}$ Neither of these two factions was perfectly delineated and even their designation is still open to controversy, with the epithets of liberals and conservatives or loyalists serving as the wider banners with which all kinds of authors identified, or even under which different writers found themselves unwillingly placed, especially in the case of the former group. ${ }^{140}$ The Jacobin faction was a negative construction in which the conservatives grouped authors that seemed not to share their view of society and politics; on the contrary, the anti-Jacobins more overtly identified themselves as such even among their differences and shared several traits in their writings (Butler, 1987: 88; Grenby, 2001: 206). Most of the resulting fictions of this war, in fact, would ascribe to a conservative reading of society and, though very different in

${ }^{139}$ This war and its participants have been amply described by critics such as Marilyn Butler in Jane Austen and the War of Ideas (Oxford: Clarendon Press, 1987 [1975]) or Matthew O. Grenby in The Anti-Jacobin Novel: British Conservatism and the French Revolution (Cambridge: Cambridge University Press, 2001).

140 On the ambiguity inherent in these terms see Gary Kelly, The English Jacobin novel 1780-1805 (Oxford; New York: Clarendon Press, 1976), pp. 1-2; or Claudia Johnson, Jane Austen: Women, Politics and the Novel (Chicago; London: University of Chicago Press, 1988), p. xxi. 
tone and answering to different moments in the reaction against radicalism or the effects of the French Revolution, they would all share their message of the condemnation of any assault on the British status quo. Many of these writings were actually novels. If literature was, in words of contemporary critics, that "great engine" that "well or ill-conducted" could support or overthrow any civilized state by its influence on its readers (Mathias, 1800: 141), it seemed essential to provide the latter with an appealing imaginative form in which history could be marshalled to instruct and guide them. This form became the novel, which soon was regarded as the perfect "means of inculcating correct ideas" (Harvey, 1977: 290). The conservatives, who prior to the 1790s had been the greater critics of the novel, once they realized the potential it had in advertising their cause and counter-arguing the radicals fictions of the time, were content to cease attacking it, and even to endorse it (Grenby 2001: 24). This endorsement led to an overflow of anti-Jacobin novels, all of them with one most crucial aim, that is, to counteract the ill-use that the radicals had done of the genre through their pernicious works of fiction. In words of one of the most popular conservative women writers, Jane West, in her novel The Infidel Father:

The rage for novel does not decrease; and, though by no means think them the best vehicles for 'the words of sound doctrine'; yet, while the enemies of our church and state continue to pour their poison into unwary ears through this channel, it behoves the friends of our establishments to convey an antidote by the same course; especially as those who are most likely to be infected by false principles, will not search for a refutation of them in profound and scientific compositions. (emphasis added, 1802: n.p.)

Conservative discourse then built a series of metaphors to describe the differences between both kinds of novels, for instance, the contrast between novelistic poison and antidote, between foul and nurturing literary food (Wood, 2003: 14-15). These rhetoric devices emphasize, first, that genre was very often identified with ideology, and, secondly, that the novel was increasingly perceived as a malleable container that could respond to varied ideologies and purposes. Moreover, quotations such as this highlight the intertextual play which took place between these works of fiction, with the anti-Jacobin novels responding to, or more often parodying, themes, plots or characterization from 
radical texts. Lisa Wood, for instance, sees conservative and radical women writers engaged with one another in a number of related matters, namely, in "a struggle over gender and class ideologies; a debate over the meaning of central terms and concepts, such as 'rights;' and conflicts over the parameters and form of the novel" (2003: 13). This response to radical writing affected both matter and form. Conservative women writers, for instance, not only argued against revolutionary philosophy by incorporating polemic passages in their own novels, but also emphasized the "formal characteristics of conservatism," that is, "they reinterpreted revolutionary plots, used authoritative third-person narrators, sanitized their style to avoid excess (and therefore potentially revolutionary) rhetoric, and decentered the subjectivity of the protagonist, in an effort to counter the 'poison' of revolutionary narratives" (Wood, 2003: 74). April London, for example, identifies this intertextuality as the most poignant characteristic of anti-Jacobin fiction, defining the relationship between both radical and anti-radical novels as "symbiotic to the point of parasitism;" she considers intertextuality as "ubiquitous in relation both to form and meaning" as it ranges from "satire through characterization; $[. .$.$] through quotation; [\ldots]$ through place; [...] and through plot" (2000: 77). Anti-radical novels hence establish a dialogue with previous works, integrating their discourse only to attempt to subordinate it to the ideological message they proclaim, subverting it through a parodic use of their conventions. This dialogism could be seen, of course, as also inherited from Cervantes' Don Quixote through the influential British quixotic tradition. Don Quixote sustained his illusions through the use of quotations extracted from his readings that could sanction the propriety of his behaviour and beliefs, allowing Cervantes to parody chivalric romances. Eighteenth-century anti-radical quixotes also employ this literary authority to validate their delusions, and hence provide the ground for the author's attack on "political romances," "combining an attack on the public domain of radical politics with censure of the various narrative forms through which radical principles are expressed" (London, 2000: 73), even suggesting that radical writers themselves are "unable to grasp the distinction between the real and the illusory" (2000: 74). This quixotic parody is thus employed so as to oppose the cankerous origin of the unattainable and dangerous ideas anti-radicals were to 
satirize for the reader's benefit; although the authors sacrifice the potential of Cervantean dialogism in the process.

That is so because, when taken as a whole body, anti-Jacobin novels did share a common and coherent strategy for their shaping of the reader's mind. Antiradical novels share a didactic purpose which influences the shape of their narration. According to Wood, anti-revolutionary didactic fiction "strove toward a single meaning and complete closure," and, consequently, "narrative voice, plot, character, prefatorial material, and even style, are constructed to produce a repetition of the didactic 'message' promoted by the text, on several narrative levels" (2003: 16). With regard to narrative voice, some of the strategies identified by Wood that conservative fictions share are: 1) the use of embedded statements which implicitly support the text's moral basis; 2) value judgements that indicate the appropriate readerly response; 3) investing the narrative voice with authority, whether by the creation of an "ideological supersystem" or by the use of a patriarchal chorus, by the repetition in the shape of the implied author's, narrator's and chorus's patterns of repetition, or by interpolated stories which restate the moral of the main text (2003: 66-68). Moreover, conservative novels very often substitute the potentially revolutionary first-person narrative with the "use of a distant, third-person narrator" which avoids the "potential subversiveness of the personal voice, replacing it with an unidentified, conservative voice of authority" (2003: 74).

With respect to characterization and plot, anti-radical novels also present a coherent strategy, namely: "an ostensibly objective representation of the French Revolution as barbarous; a caricaturing of British radicals as selfserving hypocrites or dupes; and a presentation of Jacobinism as an assault on wealth and status" (Peace, 2005: viii). These three features were recurrent conventions in anti-Jacobin fiction, while satire would become their predominant mode of discourse. More relevantly, they would turn to quixotic satire in particular, and the "novel of the late eighteenth century, with its cast of victims and quixotes, rakes and manipulators, could not have been better suited" for their political purposes (Grenby, 2001: 11). As hinted in chapter one, these satirical novels had their clearest antecedents first in Samuel Butler's satirical attack on Puritanism in Hudibras (I, 1663; II, 1664; III, 1678) and later 
in Richard Graves and his development of the quixotic satirical plot in the The Spiritual Quixote (1773). Graves' quixotic "victim of temporary insanity" reinforces the traditional notion, established by authors such as Butler himself, "that enthusiasts are fundamentally sick or mad" (Staves, 1972: 199, 200), while nevertheless still allowing for the possibility of their superior moral nature, which Butler did not. Butler's less idealistic interpretation of the quixote co-existed as well throughout the century with Fielding's vision of the quixotic Adam in Joseph Andrews (1742) as a morally superior fool who serves as an instrument in the hands of his creator to criticise the surrounding world; or even with Sterne's conception of quixotism as an innocuous mania or hobby-horse, as portrayed in his Tristram Shandy (1759-69). The subsequent Romantic age, in which the dialectical and literary battle takes place, carries this dichotomy one step further with the radicalization of both the "hard school" and its satire against human enthusiasm, and the benevolent or "soft school" that praised quixotic idealism (Mandel, 1958). That is, in the Romantic period the quixotic tradition would display the coeval portrayal of the ridiculous quixote of Cervantes' first part, usually in anti-radical fiction, and the heroic idealist of the second, mainly in radical novels. Therefore, the deeply-rooted tradition of quixotism in British literature, with the ambiguous role of the quixote developed particularly in this last part of the century as both butt of and instrument for satire (Staves, 1972: 194; Pardo, 1997: 134), provides an excellent context in which to frame the critique of opposing political ideas.

In addition, answering to the previous dichotomy of target of and instrument for the satire, anti-radical narratives will introduce two distinct groups of characters. On the one hand, the quixotes, a series of dupes of the new political or philosophical movements and what are seen as their unattainable, when not utterly absurd, aspirations and, on the other hand, the unscrupulous manipulators who embody the dangers posed by the radicals' ideas, who contrast with the innocent quixote and who will be the main target of the author's attack. The first are those credulous quixotes who "accept the radical programme of perfectibility and innate goodness" and who, nevertheless, can appear motivated as well by a quixotic "desire for heroic status" and "self- 
aggrandizement" (London, 2000: 75). Therefore, appropriating the radical and Romantic notion of the quixote as "an idealistic young man pursuing virtue in a society corrupted by court government and culture" who moreover required a revolution to change the world (Kelly, 2001: 146), anti-radical authors subvert the unquestioned positive reading or sanctification of quixotism and present the quixotic figures as fools and as a danger for their own country. Anti-radical authors then respond to idealistic radical characters shaped by William Godwin, Thomas Holcroft, Charlotte Smith, Mary Hays, or Mary Wollstonecraft, and even include these novelists themselves among their ridiculous and deluded creations. ${ }^{141}$ Many novelists, then, would subscribe to this reading of quixotism and would choose an ideological quixote (Staves, 1972: 201) -this enthusiast misled by the perusal of non-fiction publications who came to embody certain political ideals- as the vehicle for their satirical portrayal of opposed ideologies to their own and for the conveyance of a message of moral, social, or political reform. A clear example can be found in Sir George Warrington, whose eponymous hero is identified in the title of the Purbecks' novel as a "Political Quixote." Having perused the tracts by Tom Paine and other radicals, he decides to put their theories into practice with disastrous consequences. In the end, he is restored to his senses and his estate. The second group is that of the "self-interested and often criminal" radicals who manipulate the quixotes and who "write themselves into positions of authority" but are never deluded into reading the world any differently than it actually is (London, 2000: 75-6). Therefore, the abovementioned radical novelists or philosophers, very often including Tom Paine, could not only appear as deluded fools, but as deluding dangers for innocent citizens, depending on the more or less comic intent of the novel in question. In the Purbecks' novel there is another clear example, Mr Davenport, a rogue who pretends to be a radical and employs Godwin's or Paine's ideas to manipulate Sir George for his own benefit. His treachery almost has Sir George killed, however, his intentions are unveiled and he is harshly punished in the end. Precisely because of this portrayal of radicals as a group of "intriguers,

${ }^{141}$ See Kelly (1989: 63) and Wood (2003: 54) for some examples of this somewhat shallow characterization, which Kelly also identifies as in the tradition of Butler or even La Bruyére. 
conspirators, and seducers" who aim to dupe the innocent quixote to gain some benefit, anti-radical novelists recurrently portray their quixote as a young member of the landed gentry, as Sir George, and, moreover, they repeatedly gender it female, “since 'woman' had long been a figure for the subvertible, seducible element in a social class and since the villain [...] aims to subvert the state by subverting 'domestic woman' and domesticity” (Kelly, 2001: 146).

This focus on women influences the third area of similarity in the bulk of antiradical novels: plot. Anti-radical novels will portray the different ways in which radical notions imply an attack to bourgeois values, wealth and status, the foundations of British stability and progress. This attack may be framed within a historical narrative, focusing on events such as the Irish rebellion of 1798 or employing metaphors such as the Puritan wars of the previous century, to point out the grand-scale effects of the revolution. More often, though, they may dwell on the impact radical notions have on the core of British society: the family. Within the intellectual and cultural discourses of Enlightenment and Sensibility developed at this particular time in history, the war of ideas develops a series of "rhetorical topics, especially subjectivity and domesticity in relation to ideas of community, region, and nation" (Kelly, 2001: 4). The discourse of domesticity, with women at its core, serves as framework for the articulation of ideologies at this time. This is so because of the role women still played as preservers of virtue and estate:

Since women in both upper and middle classes continued to serve the economic function of transferring property from one man to another, the 'virtue' assigned to them was predominantly private, restraint of the erotic 'passions' ensuring the stability and integrity of the family as a property trust continuing through the generations. Female 'virtue' meant sexual chastity guarding those subordinated within their own class against seduction by social superior or contamination by an inferior. Female 'virtue' was moral propriety concealing and defending the material property, social interests, and cultural power of 'their' class. (Kelly, 2001: 5-6)

Moreover, with Burke's extended metaphor of a chivalric defence of the status quo in his famous portrayal of Marie Antoinette and his use of figures of woman, domesticity and the domestic affections as "the foundations of community, state, and nation" (Kelly, 2001: 16), these rhetoric devices permeated the printed war in the subsequent myriad of responses to his 
influential Reflections on the Revolution in France (1790) and led to the creation of what Mellor termed the "family-politic trope" and the creation by many women writers of what this critic termed the "counter-public sphere" (1993: 84). This focus on domesticity was expressed in the development of a domestic plot, which was highly formulaic and which could respond to a series of patterns: 1) the sisters' plot identified by Spacks (1986) in which two female characters are contrasted in order to display a moral lesson, for they are distinguished by their euphoric and dysphoric ends; 2) the commentary on Rousseau's Nouvelle Hélö̈se in which a sexually promiscuous woman is ruined by her actions; 3) the plot of education or the conversion narrative in which a subversive youth comes to terms with the need to become a domestic woman in the end; and 4) the historical plot with which sometimes these narratives were combined, for example, the Irish rebellion mentioned before (Wood, 2003: 68-9). Each of these narratives revolves around a story of courtship and a successful or thwarted seduction. In conservative novels, "virtuous and religious femininity becomes [...] the moral and practical prophylactic against radical philosophy" (Wood, 2003: 36). As Wood explains,

If the heroine is seduced $[\ldots]$ by the revolutionary and anarchic "systems" of the philosopher villain, the resulting social disorder is corrected only by her death. The seduction itself figures, at a domestic level, the penetration of French philosophy into the British social formation. The patriotic woman resists this penetration, by adhering to standards of modest and domestic femininity, and to the doctrines of the established national church. Femininity is thus intimately tied to the preservation of the state, the family, and the national church. (2003: 36)

As Armstrong has attested (1987), this highly politicized courtship plot permeated the long eighteenth-century and was even conspicuously played out in Richardson's novels. However, the politicisation of the tropes of courtship or marriage achieves its peak during these revolutionary and post-revolutionary years. This domestic plot will be recurrently developed by authors as different as West, Hamilton, or even Lucas. Even such an overtly political novel as The Infernal Quixote (1801) employs this rhetoric of domesticity, with a story of proper courtship opposed to one of seduction as metaphor of an ideological choice. The radical villain, Marauder, seduces Emily with the use of French novels, and, more importantly with Wollstonecraft's Vindication of the Rights 
of Women. Godwin's scandalous memoir of his wife, and the equating of her philosophy and her sexual openness, which was augmented by her greatest censors and by conservative novelists, associated radical women with promiscuity and ruin. In addition, the villainous philosopher abducts and attempts to rape the virtuous Fanny. On the other hand, Wilson Wilson, the hero of the novel, instructs Fanny with Hannah More's Sacred Plays, preserves her virtue, and honestly marries her. Emily and Fanny have the possibility of choosing between both men, and the implications of their choices have the usual consequences: ruin or happy marriage. Women will thus become the epitome of the deluded radical quixotes, seduced by aristocrats and lower-class rogues alike, who intend to use radical and literary notions to gain advantage of the young female quixote. The consequences of their deviation from the path of custom will depend on the comic or pathetic nature of the quixote, and may take the shape of high ridicule or harsh punishment, such as utter ruin and ostracism, or even death. In Kelly's words, the quixotic plots of this time follow the subsequent pattern:

The 'Quixote' falls or is led into repeated errors of misreading, comic or pathetic, until false consciousness is purged by a shocking revelation or a wise mentor (usually male) who re-educates the protagonist in professional middleclass critical consciousness of self and society. [...] Cultural conflict is plotted as false and true courtship, threatened seduction or contamination of the protagonist, terminated by marriage to a professionalized gentleman or (less often) a gentrified professional. (2001: 146)

This pattern would have been familiar to readers by means of previous quixotic narratives, in particular, Lennox's, from which these anti-radical quixotic novels probably inherit this plot of delusion in courtship, epiphany and final integration into the status quo.

Nevertheless, despite this common literary ascendancy and among this apparent uniformity, there is still space for variety in the approach to quixotism. For instance, in the origin of the young quixote's delusion, whether novels or "philosophy," transforming her in a literary quixote or a "fair enthusiast" of the new radical philosophy, and her delusion in "imaginative fantasy" or "metaphysical" speculation (Kelly, 2001: 146-7). There is also a change in the degree in which anti-Jacobin authors ascribed to the "hard 
school," that is, the degree in which the critique of the authors was expressed either towards the female quixote's foolishness or the cruelty and absurdity of the radical principles, would vary according to the moment in which the novel appeared and to how negatively the abovementioned self-aggrandizement affected the established social conventions. Hence, there would be a change in tone as the narratives attach or detach themselves from the decisive political events of the late eighteenth and early nineteenth century and as the quixotic figure shifted from a positive to a negative interpretation and vice versa, as will be stated through the examples found in the subsequently analysed novels. In the case of the female quixotes, their awakening and cure will be developed differently according to their resistance or submission to seduction and how disruptive their quixotic behaviour becomes under the light of the code of propriety. Moreover, the female quixote, usually depicted by a female author, will also permit to more deeply develop the debate around woman writers which intensified during this ideological war. The focus on domesticity also became a tool in the hands of female authors to claim their space in the literary panorama and their authority as writers and moralists; after all, women were not only the main symbol of the domestic discourse, but also the main producers and consumers of the domestic novel. In this sense, while the emphasis on psychological development will have to wait until the female bildungsromane of Brunton or Edgeworth, the presence of a female quixote, not only by means of the dialogue with radical notions and forms that quixotism implies, but also with its condemnation of women's visibility written by a public woman writer, avoided the monological literary and ideological discourse that conservative novelists pretended, and demanded a sometimes fraught reading and interpretation of these compelling texts.

Together with the more conspicuously political reading of narrative fiction, other authors aimed their satire at more literary targets. Rather than the infectious contagion of political ideals or radical morals, they denounced the proliferation of poorly composed or implausible literature. Therefore, these authors imbedded their novels with a great dosage of literary criticism and employed many of the strategies of political satire in order to awake their readers to the dangers or the ridicule of uncritical reading. Literary vogues, 
such as the passion for Gothic or horrid romances, Scottish novels in general and Scott's in particular, or Byronical poetry, are transformed in these narrative satires in as foolish an enthusiasm as radical ideology. Two of the best-known and representative examples are Thomas Love Peacock's Nightmare Abbey (1818), and Austen's posthumous Northanger Abbey (1818), to which subsequent references will be made. Peacock stated that his novel was a "comic romance" with which he was "amusing himself" with the "darkness and misanthropy of modern literature, from the lantern jaws of which" he would endeavour to "elicit a laugh" (Joukovsky, 2001: 121-22). He moreover asserted that he wrote it out of the need to "make a stand" against the "encroachments" of the "black vile" for he could not consent to the "systematical 'poisoning' of the 'mind' of the 'Reading Public'," in particular through the means of works such as Childe Harold (2001: 123). In order to develop this comic romance, much in the manner of Cervantes and Fielding, ${ }^{142}$ Peacock presents a quixotic figure in the shape of a young intellectual who is seduced by bad role models to "engage in fashionable perspectives that advocate solipsism and withdrawal," which hence lead to his "lived romanticism" (Vargo, 2007: 11). This quixote is Scythrop, a gentle satire on the idealism of Peacock's friend, Percy B. Shelley. Wounded by disappointed love, he recurrently goes to a ruinous tower to sit on a "mossy stone," with a "canopy of ivy, with an owl in it, over his head, - and the Sorrows of Werter (sic) in his hand" (2007: 56). In this stereotypical Romantic setting, his quixotism is fuelled rather than corrected. Taking Shelley as model, Peacock offers the following description of his character's transformation into a quixote:

He had some taste for romance-reading before he went to the university, where, we must confess, in justice to his college, he was cured of the love of reading in all its shapes; and the cure would have been radical, if disappointment in love, and total solitude, had not conspired to bring a relapse. He began to devour romances and German tragedies, and, by the recommendation of Mr. Flosky, to pour over ponderous tomes of transcendental philosophy, which reconciled him to the labour of studying them by their metaphysical jargon and necromantic imagery. In the congenial solitude of Nightmare Abbey, the distempered ideas of metaphysical romance

${ }^{142}$ In his "An Essay on Fashionable Literature" (1818) Peacock stated: "CervantesRabelais-Swift-Voltaire-Fielding-have led fancy against opinion with a success that no other names can parallel" (qtd. in Vargo, 2007: 216). 
and romantic metaphysics has ample time and space to germinate into a fertile harvest of chimæras, which rapidly shot up into vigorous and abundant vegetation. (2007: 56)

Satirising the Romantic taste for solitude, romance and the spiritual -or the metaphysical-, and equating the latter two as food for a distempered brain, Peacock provides a satirical Romantic quixote who not only allows him to parody the literary conventions of Gothic narratives or Romantic musings, but also to satirise some of the ideological tenets that radical Romantics supported. In this regard, Scythrop becomes troubled with a "passion for reforming the world" and builds "many castles in the air" peopled by "secret tribunals, and bands of illuminati," who are transformed in his febrile mind into the "instruments of his projected regeneration of the human species," and of his intended institution of a "perfect republic" (2007: 56-7). Uniting the literary and the ideological, the Romantic and the radical, Scythrop sleeps with a copy of "Horrid Mysteries" under his pillow and dreams of "venerable eleutherarchs and ghastly confederates," only to awake to mornings wholly spent in "his study, immersed in gloomy reverie" (2007: 57). From this reverie springs his treatise "Philosophical Gas; or, a Project for a General Illumination of the Human Mind," of which he sells only seven copies, "seven golden candlesticks with which [he] will illuminate the world" (2007: 58). Peacock jocularly parodies the tracts of his time, and points at the importance of the reception a work has by the "reading public" and the need for writers and readers to engage in a critical dialogue, owing to the fact that the former have the power to influence the latter.

Scythrop's quixotism, and the novel's satire of the literary and intellectual panorama of the age, is framed by the caricatures Peacock portrays of several characters related to the literary and philosophical world that Shelley inhabited. Despite the fact that he denied representing private characters of specific individuals, Peacock does satirise a series of specific figures, and, more importantly, their ideas and opinions: Mr Flosky (Coleridge), an enemy of common sense who christens his eldest son "Emanuel Kant" (2007: 77); Mr Toobad, a manichean Millinarian (J.F. Newton, a friend of Shelley who inspired ideas for his Queen Mab and his vegetarianism); the Reverend Larynx, 
a general stereotype of the worldly clergyman; Mr Asterias, who believes in mermaids; Mr Listless, the fashionable reader; and My Cypress (Byron). All these characters engage in discussions in which their own particular hobby horses clash with each other, and evidence the truth of the quotation that opens this chapter: everyone is a quixote or an enthusiast (2007: 120). Moreover, their dialogues, reproduced as if they were characters in a play, highlights the fact that they have not yet learnt to escape their pernicious "subjectivity and solipcism" by the need to test their ideas and those of others through "a process of dialogue" (Vargo, 2007: 37), a lesson female quixotes will also be required to learn.

Peacock therefore employs all these characters, together with his quixote, to highlight his discontent with modern literature, in particular the state of novels, poetry and reviews in 1818 (Vargo, 2007: 27), which have become not only endogamous and uncritical, with the same authors reviewing their own poems in the press, but also a compendium of horrid clichés (2007: 70-71). Peacock focuses his attack on German literature and on the myriad of Gothic romances and tragedies which are published at the time, with their instances of the supernatural, the excessively sentimental, and the indulgence of selfabsorption. Scythrop's nature as a parodic sentimental and Romantic hero, incapable of choosing between two women, is highlighted when at the end of the novel he does not fulfil the destiny of a Wertherian hero and, instead of committing suicide as was his intention, he gets drunk with Madeira and assumes a course of general misanthropy. In the same line as Peacock, other male and female novelists, such as Eaton Stannard Barrett or Sarah Green focused on literary targets, whether in the shape of a particular genre or of a specific author and his or her literary works. As Peacock had done, these writers employed their female quixotes in order to parody the most conspicuous -and usually jocular- characteristics of this precise genre or author, at the same time they satirised a society that had the taste for such unpalatable literature or that presented worse flaws than those of the unassuming but deluded quixotic figure. 
Taking those two trends into account, the more overtly political and the more conspicuously literary, this chapter will then highlight the employment of satire as the main weapon in the war of ideas, analysing a number of anti-radical and anti-Godwinian or Wollstonecraftian satires and their response to radical quixotic narratives. Furthermore, it will include the later satires on novel writing, in which the political target is still present, but has faded into the background, and has been substituted by parodies or satires on such prominent targets as Scott or Byron. Finally, although this chapter will focus mainly on the anti-radical fiction published in Britain which aimed to attack Francophile philosophy as dangerous to the status quo, it will also describe the appropriation done by American authors of the quixotic figure to satirise British ideological and literary standards and to warn of the dangers that the corrupted notions inherited from Britain posed for the developing new country, the United States of America, embodied in the young and deluded female quixote. In these novels, British colonial conservatism -together with the fortune-hunting adventurers that were drawn to the New World- become in turn the butt of American novelists' satire, once again highlighting the malleability of the novelistic and quixotic discourse.

As this chapter will hopefully prove, these ideological and literary female quixotes, with their successful or thwarted stories of courtship, provide a relevant and rich link in the tradition of female quixotism in Britain, as they developed a plot which "was dominant from Frances Burney to Jane Austen at least" (Kelly, 2001: 146). In this regard, once again the existence of so many, and so varied, instance of female quixotes, evinces that it was an important part of the British literary panorama of the eighteenth century and that the quixotic myth was not only alive, but continuously becoming enriched as a new century approached. 
No nation has preserved its political independence for any long period after its women became dissipated and licentious. When the hallowed graces of the chaste matron have given place to the bold allurements of the courtesan, the rising generation always proclaims its base origin.

Jane West, Letters to a Young Lady, 1806, I, 56-7

As this chapter intends to mirror the progressive displacement from political satire towards literary parody, it seemed appropriate to commence with the two women novelists who more conspicuously build a political discourse by means of their quixotic narratives. Jane West and Mrs Bullock share their unambiguous stances against Jacobinism, as well as their more conservative discourse where women are concerned. Both effectively employ the courtship plot and the quixotic story of awakening learnt from Lennox, intertwined with political comments and even historical narrative frames, in order to convey their ideological and moral message for an audience of women readers. At the same time, both contribute to the rich tradition of female quixotes with some unique elements that will be later adopted by Barrett or Austen, establishing them as links in the chain of writers studied in the present work.

\subsection{Jane West and the Tales of Revolutionary Times}

Jane West (1758-1852) is probably one of the most prolific and well-read antiJacobin writers. Also a poet, essayist, playwright and occasional translator, her didactic novels and conduct literature epitomise many of the anti-radical tenets, textually answering to Godwin and Wollstonecraft, for example, and fictionalising their moral and political discourses. Most notably, two of her novels, A Gossip's Story (1796) and A Tale of the Times (1799), revolve around young girls deluded by sentimentality and by its use in favour of the "new philosophy" of radicals, respectively. The heroines of these novels, 
Marianne and Geraldine, can be identified as quixotes because they are avid readers who interpret the world through the sentimental veil they have acquired from the novels they peruse, and who behave according to the set of principles their readings provide. In addition, both novels share similar narrative devices, with the presence of a heterodiegetic narrator, Prudentia Homespun, who aims to provide the conservative ideological supersystem, and with the dichotomy between an exemplary and an anti-exemplary female character, the latter identified with the quixote. Moreover, West's novels provide an ample literary framework in which their heroines' delusion can be inscribed, with references ranging from classics such as Milton or Shakespeare, to the omnipresent Godwin, sometimes voiced by the heroines, sometimes by the narrator. In line with other anti-Jacobin quixotic fictions, West will identify characters with their readings, and will employ these literary references and quotations to trigger associations with the ideologies they represent. Finally, both novels intend to offer a moral closure that reinforces the novel's supersystem, ascribing to the hard school of quixotism in the heroines' unhappy endings. Endings which, once more, are not completely successful in their message against quixotism because of the good and innocent nature of the quixotes which still allows the attack to be directed against their defenceless circumstances or the plotting of other characters.

In A Gossip's Story Prudentia tells the story of the Dudley family, who arrive in her village at the beginning of the story. The family consists of Mr Dudley, a gentleman and a merchant, and his two daughters, Louisa and Marianne. Having lost their mother at an early age and separated in childhood, Louisa was rationally brought up by her father, while Marianne was spoilt by a doting and sentimental grandmother. Reunited in their adolescence, the novel will follow the entrance of both women into maturity and marriage. Employing the stock plot of the euphoric and dysphoric development of two sisters, the rational and the sentimental one, West's novel has recurrently and insightfully been compared to Austen's Sense and Sensibility (1811) both in characterization and plot, and in its parodic approach to sentimental literature. Elinor and Marianne in Austen's novel are physically and psychologically modelled on Louisa and Marianne, while some stock situations of sentimental novels are employed by 
both authors. ${ }^{143}$ In West's novel, as in Austen's, the rational sister will become the exemplary heroine. Louisa is a woman who from "her earliest years discovered a disposition to improve both in moral and mental excellence," and who received moral instruction "enforced by example" (1798: 15). Moreover, she had the advantage of "having commenced her education under a female eye," therefore acquiring "soft touches of refined elegance" as well (1798: 16). Not as handsome as her sister, but owner of a pleasing countenance, her moral value grants her a happy conclusion in the shape of marriage to the worthy hero, Mr Pelham, first rejected by her sister for his anti-romantic nature. On the other hand, Marianne experienced her grandmother's "affection rising to agonizing sensibility" (1798: 17) and grew into a woman of sensibility herself. In a description that later Austen would echo, Marianne appeared "uncommonly attractive," "her features were formed with delicate symmetry, her blue eyes swam in sensibility, and the beautiful transparency of her complexion seemed designed to convey to the admiring beholder every varying sentiment of her mind" (1798: 18-9). Her sensitive nature is recurrently displayed in an expressive physiognomy, and the narrator tells us that "her looks expressed what indeed she was, tremblingly alive to all the softer passions" (1798: 19). While Louisa's sensibility and sympathy are moderate and exemplary, Marianne's suffers from an excess of what in principle is a virtue, therefore turning it into a "vice" (1798: 44), into a form of "enthusiasm" (1798: 54) that has been carried too far. Louisa and her father partake in many sentimental scenes, although their morality is not put into question because their Christian standards and self-control avoid sentimental excesses. In Marianne, this excess has not only been nurtured by her deficient education, but also by her favourite course of study. Marianne "had long been an attentive reader of memoirs and adventures, and had transplanted into her gentle bosom all the soft feelings and highly refined sensibilities of the respective heroines" (1798: 39). The verb "transplant" serves to explain the nature of Marianne's delusion: she acts by example of her literary heroines, her behaviour is completely shaped by it. Recurrently described as "whimsical," a word often

\footnotetext{
${ }^{143}$ For the obvious similarity of plot or characterization between the three novels by West mentioned in this chapter and Austen's production, see Butler (1987), pp. 98-101 and 104.
} 
associated with quixotism, West moreover overtly identifies her heroine as a quixote when she entitles chapter X: "Humbly dedicated to the improvement of all fair Quixotes in heroism" (1798: 90), in which Mr Dudley reasons with Marianne on her romantic whims and her exalted sensibility, which, respectively, do not allow her to perceive the worth of her suitor and do not prepare her to encounter the storms of life with Christian fortitude. Consequently, Marianne's quixotism is in line with the conception of the quixote as an enthusiast which was dominant at the time; in this case, her form of enthusiasm likens her to the sentimental quixotes presented in chapter one, for instance, Mackenzie's man of feeling. Marianne's is an excessive and unnatural expression of sentiment, which blinds her to reality and to her duties within society. As happened with other sentimental quixotes, her delusion or whim, though of a more benevolent kind than ideological quixotism, still prevents her successful interaction in the world and must be cured. Throughout the first volume, Marianne's quixotism is presented as a whim of youth, as a "romantick turn" of a young lady's mind (1798: 106), and as such, in the recurrent pattern of female quixotic narratives, time and marriage are expected to achieve a reformation that would bring Marianne to her senses (1798: 108). As the narrator states of her wise suitor, Mr Pelham, he had:

[...] enough of love to be convinced, that the sweetness of her temper and the goodness of her heart would conquer the little errors which a romantick propensity had engrafted upon her inexperienced mind; at least would prevent them from ever giving pain to an affectionate husband. He hoped a little commerce with the world, to which she was almost a stranger, would divert her thoughts from their present train, and he anticipated the agreeable prospect of her laughing in a few years at her former enthusiasm. (1798: 54)

Although this speech would hint at a possibility of reform and happiness in the train of Lennox's Arabella, the context in which West is writing apparently demanded a more engrained moral message. Sensibility has lost the positive connotations it had at the time Lennox or even Mackenzie were writing, and in the conservative discourse of the late eighteenth century it becomes a pejorative term associated with excessive moroseness, self-indulgence, or female sexuality and, more importantly, with French radical philosophy and with novelists such as Wollstonecraft (Ellis, 1996; Todd, 1986). The cure, the 
moral closure had to be then contrived in accordance with this context and not with the previous less ambiguous use of the term sensibility, or even with Austen's more benevolent conclusion, given by the temporal and ideological distance of the early nineteenth century.

This harder development of the quixote's cure is once more related to the core of women's experience, courtship and marriage. After rejecting Pelham because of her unrealistic romantic expectations, Marianne narrowly escapes a "dreadful accident" when her horse runs away with her and she is rescued and carried home by the attractive Clermont and his father, while she repeatedly faints due to the shock (1798: 200-1). In an episode and a language that parodies romantic conventions, West's narrator ironically exclaims of Marianne and her new admirer:

\begin{abstract}
Never was such a wonderful coincidence of opinion! Both were passionate admirers of the country; both loved moonlight walks, and the noise of distant waterfalls; both were enchanted by the sound of the sweet-toned harp, and the equally soft cadence of the pastoral an elegiac muse; in short, whatever was passionate, elegant, and sentimental in art; or beautiful, pensive, and enchanting in nature. (1798: 205)
\end{abstract}

This passage, which Austen subsequently adopts and even further derides after all, to fall from a horse is more heroic than to merely twist one's ankle, as her own Marianne does-, exposes the shallow basis sentimentality provides for a young girl's perception and ultimate happiness. Allured by her sentimental delusion into believing Clermont a congenial soul, Marianne engages in an unhappy union and concludes her narrative in misery. On the contrary, Louisa, whose perception of Pelham is correct and who has truly heroically sacrificed her feelings for him in order to remain true to her sister, receives her reward. In one final touch to the sisters' characters which Austen will also imitate, while Louisa refrains from expressing her misery in public at her engagement with a man she is going to marry only out of duty, Marianne dissatisfies her guests by her sentimental self-absorption in her own grief after nurturing it with yet another four long volumes of a sentimental novel (1798: 80). In addition, Louisa exerts an active kind of sensibility, as she "visited the sick, consoled the afflicted, instructed the ignorant, and reproved the idle" (1798: II, 62), while 
Marianne's unhappiness swallows all other considerations. Therefore, emphasising the dangers of sentimentality to all areas of female duty, as a daughter, a wife, a hostess, and an active social being, West develops her Manichean moral.

However, this Manichean ending proves problematic by the positive light under which Marianne is placed, especially in the first volume of the novel. Prudentia highlights this ambiguity when she states that:

In [Marianne's] character I wish to exhibit the portrait of an amiable and ingenious mind, solicitous to excel, and desirous to be happy, but destitute of natural vigour or acquired stability; forming to itself a romantick standard, to which nothing human ever attained; perplexed by imaginary difficulties; sinking under fancied evils; destroying its own peace by the very means which it takes to secure it; and acting with a degree of folly beneath the common level, through its desire of aspiring above the usual limits of female excellence. (1798: 47)

Whereas later quixotic heroes or heroines in anti-Jacobin fiction, such as Mrs Bullock's, are clearly disruptive in their moral and social discourse and are accordingly punished, Marianne's delusion is of a more benevolent kind and, while not happy, she has escaped the worse fate of many of her sister heroines, including West's later Geraldine. Marianne's amiability does not distance her from her exemplary sister Louisa enough to be perceived as two very different models and the fact that, as later Austen's Marianne, she remains married to the least of all romantic heroes seems punishment enough for their youthful foibles.

More importantly, despite her intention to provide a coherent and stable supersystem, West's moral framework is also somehow undermined by the very nature of her narrator. West's alter ego, Prudentia Homespun, is a formidable presence in her novels until 1811, when the author writes to a friend that she is "dead and buried," leaving the real West to appear from behind her narratorial mask. West's narrator is a conservative banner starting from her very name: the obvious Prudentia referring to one of the female characteristics that her narrative will preach -and which the narrator acknowledges in herself-, and the surname Homespun referring to her domesticity. In addition, such a family name triggers literary associations, and it has been pointed out 
that it is probably indebted to Henry Mackenzie's journal The Mirror, which featured a story about a "plain country gentleman called John Homespun and his efforts to preserve his family from aristocratic corruptions" (Gilroy, 2005: viii). In the introduction to A Gossip's Story, a third-person narrator identifies Prudentia as the author of West's previous novel, The Advantages of Education, or, the History of Maria Williams (1793), ${ }^{144}$ and the very novel the reader is at that moment perusing. Moreover, this introduction builds the recurrent rhetoric of female authorial justification: this surrogate novelist writes neither for pecuniary advantages, nor for the general applause or approbation (1798: xii-iii). Later introducing herself in first-person speech, Prudentia states that "as my annuity is regularly paid, and my family consists of only myself, a female servant, and an old tabby-cat, I have but little domestick care to engage my attention and anxiety" (1798: 1). Becoming then a perfect justification of the female writer -who does not forget her domestic duties and who is not moved to write by any mercenary motive-, she possesses other qualities which render her a perfect alter ego for West and, in her own words, a "very excellent gossip:" "a retentive memory, a quick imagination, strong curiosity, and keen perception" (1798: 2). These qualities answer to what her aims in writing are, namely, to speak of "human life as it is," to meliorate "the temper and the affections" and not to dazzle the imagination nor inflame the passions (1798: xii). A member of an agreeable society of single ladies which meets thrice a week to comment on their neighbours (1798: 2), Miss Homespun defines herself as an observer of human nature who confines herself "to the delineation of the lights and shades of human character" (1798: 4).

Moving closer to Fielding in her desire to hold a mirror to readers in their closets -as well as in her conspicuous dialogue with those same readers by means of her metanarrative comments, moral judgements, interspersed tales and self-explanatory chapter titles- Miss Homespun is one of the best examples of an intrusive narrator who provides the ideological supersystem which the characters' more limited or biased perceptions and notions can be set

${ }^{144}$ In this earlier novel there is already, as stated by Spencer, a "mockery of the typical sentimental novel with its emphasis on love and its perfect heroine" that enlivens an otherwise heavily moralistic novel (1987: 320). 
against. West's narratorial persona would then become part of the quixotic tradition that connects Fielding and Austen, for, though not as masterly achieved as in the abovementioned authors' works, her female narrator is still a "savante in accommodations between individual psychology and the often ungenerous and foolish expectations of society" (Sobba Green, 1991: 116). In this sense, Prudentia's warnings that "even words and actions are often deceitful guides" and that "people frequently step out of themselves" (1798: 10), set the tone for her exposure of the difficulties of perception when biased by "ingenious confidence, sanguine passions, and prompt decision" (1798: 11), or, in the case of her quixotic heroine, a sentimental education and a romantic disposition. In addition, she generalizes the errors of judgement to include the young and the old, women as well as men, and, by analogy, society as a whole. In West's novel interpretation is fraught even if not biased by a literary veil. In this sense, it is possible, once more, to perceive the traces of Prudentia's discourse in Austen. West and Austen question the individual's reliance on his or her own perception; in their description of their heroines' growing awareness of themselves and the world they both expose "how dangerous it is to trust private intuition or passion in forming judgements of others" and how "objective evidence should be preferred to private intuition" (Butler, 1987: 101). Even the perception or the judgement of West's most sympathetic, moral or insightful characters is only validated after evidence appears to support them. In addition, it is not supported by the omnipresent narrator and authorial alter ego unless it complies with the Christian moral supersystem, which is more evidently and intrusively present in West's narrative than it will be in Austen's. Both authors depict female characters that need to make the right or wrong ethical choices balancing their selfish passions to their Christian principles of selflessness and duty towards others. However, although also present in Cervantes, Fielding and Austen, Christian values are in West's novel offered as the only epistemological and behavioural system of reference which is not subject to the ironical comment of the narrator. West's novel is written with a clear didactic purpose that the aforementioned authors did not display, and the need to reinforce the moral and monological supersystem she provides for her readers undermines the Cervantean dialogic heritage of her novel, while 
she still provides relevant examples of the appropriation of the quixotic myth as political and moral instrument in her work.

Nevertheless, in a very Cervantean manner, Prudentia herself is questioned as source of authority. As Austen would later state in Emma, complete closure is very seldom found in life and absolute truth is rarely possible. Prudentia proves at times an unreliable narrator who erodes the seemingly consistent discourse of the novel and forewarns the reader of the fallibility of impressions, even her own. Very early in the novel she writes: "perfection belongs to no human institution, and I will own that sometimes we may be wrong" (1798: 3). This assertion and the fact that she is, after all, a gossip, hence basing not only her authority on observation but hearsay, undermine her reliability. ${ }^{145}$ Moreover, in the frequent metanarrative comments, Prudentia unveils her novel as fiction, as a construction in which truth and invention find a space in which to merge. The author asserts in her dedication that her tale harbours under the "disguise of an artless History" (emphasis added, 1798: 3), what is a story retold by an old spinster is truly a crafted narrative. This claim she highlights with chapter titles such as "The author shows that she studies climax or gradation of character" (1798: 10), or "The author endeavours to get rid of the serious humour which contaminated the last chapter" (1798: 51). In addition, she opens to the implied reader the manipulation of narrative material which novelists undertake in order to achieve their ideological or pecuniary purposes. For example, chapter XII is entitled "Extremely useful to the author, giving her the opportunity of filling her book, contrasting her characters, and displaying great critical acumen" (1798: 111). In this chapter Prudentia continues to address her readers and, about to reproduce a "legendary tale" in the midst of her narrative, she concludes with the following comment:

As my narrative is not now at a very interesting period, I am inclined to hope my critical readers will allow me the Gossip's privilege of digression. I will promise them, that my poetical episode shall be as conducive to forward my main plot, as secondary characters and flowery illustrations are, in the most approved productions of my contemporaries. Besides the usual advantage of filling my volumes, those, who choose to skip over adventitious matter, will at

${ }^{145}$ Gilroy mentions the fact that her name may be a veiled reference to the silly and sentimental trash-novel female reader Harriet Homespun in Samuel Jackson Pratt's Pupil of Pleasure (1776) (2005: xiii) to emphasise the fallibility of Prudentia as narrator and as embodiment of the didacticism of the novel. 
one glance know where to begin again. The moral may recommend it to the few, who still love to nobility clad in the respectful robe of virtue; [...]. (1798: 115-6)

West not only points at the nature of her tale as an artful fiction, but she even calls to attention the same book the reader has in his or her hands, something Austen will also do at the end of Northanger Abbey. In this sense, West undermines her didactic intent: if, as stated in several contemporary treatises and as analysed by Raff (2006), the reader had to be seduced into a quixotic imitation of worthy models, West's approach to Fielding's call of attention to the reader to become aware of the fictional nature of the tale she is perusing annuls that effect. In the same manner that Pelham unsuccessfully attempts the "sighing Strephon," and only achieves to give the "idea of an ironical creature" when he employs an "assumed character" and a "language foreign to his heart" (1798: 109), West does not seem to claim a close reproduction of her characters, not even the exemplary ones. This uncritical imitation would only create an unnatural creature, like Pelham's Strephon. Rather than a mere domestic plot in which models are provided to allure the readers into quixotic imitation, West decides to exhibit a mixed character like Marianne, a deluded but sympathetic quixote, and does not consider it a "disservice to the general cause of morality" (1798: 47). Anticipating possible censure, West's narrator states that there are no evils in "impressing upon the minds of youth, as soon and as deeply as possible, just notions of the journey they are about to take, and just opinions of their fellow-travellers" (1798: 47-8). Therefore, more than a tale of female self-development towards marriage or redemptive death, West provides her insightful vision into a wide range of characters and manners, so that her young readers become aware of what lies under their fellow-travellers. Moreover, she does so by openly avowing the fictional nature of her tale, avoiding quixotic imitation and enhancing a critical and conscious reading of her novel as a mirror in which human nature will be exposed and from which the reader may gain some wisdom about herself and the world. In this sense, West detaches herself from other coeval conservative authors and anticipates later women novelists such as Edgeworth or Austen by her desire not to merely cure a quixote who embodies a particular train of thought or genre in order to 
seduce her readers into adopting her own system of reference, but to cure her quixotic readers by making them aware that they are readers of fiction and that imitation of good models cannot spring from a quixotic delusion, but from a rational adoption of a certain code of values.

Despite this intention, as the political situation became more tense and the need to take sides more pressing, West continued to develop narrative fictions that nevertheless conveyed a conservative message, even radicalising and politicising her use of quixotism in her next novel, A Tale of the Times (1799), in which she explicitly equates "domestic discord with national chaos" (Ty, 1993: 16). Resuming the dichotomy between appropriate and inappropriate female readers of texts and manners which she developed in her previous two novels, the heroines in A Tale are Lucy Evans and Geraldine Powerscourt, sisters in the metaphorical sense that they are both guided by the wise advice of Mrs Evans. Lucy, who the narrator tells us, had "read much" and "thought more," develops greater leisure for study and reflection and, consequently, her "mind imperceptibly acquire[s] superior energy" (2005: 40). She concludes her story by marrying the model of sensitive masculinity, Henry Powerscourt, for whom she has repressed her feelings throughout the novel, and becoming together with her husband the guardian of Geraldine's children when the latter dies. As did Louisa, Lucy is the first to acknowledge her feelings to herself and the one having to repress her emotions, while the hero is later to awaken to her love, in a pattern followed by several of Austen's gentlemen and ladies. On her part, her friend, though benefiting from the advice of Mrs Evans, is nonetheless spoilt this time by a doting father. Geraldine, possessing a romantic disposition, falls in love at the age of seventeen with the charming and handsome Monteith at a ball. Her romantic fancy will lead her "like Pygmalion" to become "deeply enamoured with the creature of her own imagination" (2005: 43), her husband, who, in turn, is seduced into such vices of affluence as gambling or infidelity. Disappointed by her unromantic husband and marriage, Geraldine will turn to and become deluded by Monteith's shallow sister, Arabella, and her friend, the villain of the story, Fitzosborne, who allures her with false friendship, false sensibility, and false principles, aided by French "system" (2005: 159) and literature, including one of the anti-Jacobins' favourite targets, Rousseau's 
Heloïse. While, as Butler has pointed out, before 1799 the heroine was her own worst enemy, in the peak of anti-Jacobin reaction there is no longer a "single character in error, but the dupe of a villain; and her mistake is seen as something that affects the community as a whole" (1987: 104). That is, while Marianne's story allowed reflecting on the fallibility of all human perception and judgement, in particular when not guided by education, knowledge of the world, or Christian principles that serve as valid system of reference, Geraldine's story dwells on how perception can and is manipulated by scheming characters who embody political and moral tenets in opposition to the implied author's stance, hence the political reading of West's later novel. Geraldine' quixotism implies, then, a displacement from Marianne's, not only in the source of her delusion, which now includes non-fiction political readings, but in the manner in which she develops as a quixote. Geraldine starts the novel as a literary and romantic quixote: she has romantic expectations about her husband -the creature of her own imagination-, about her life and her marriage which will be contradicted by reality. Instead of becoming disenchanted by this chasm between fiction and fact, Geraldine persists in her delusion and is further seduced into quixotism by a new form of fiction, the French novel, and by a new ideology, Jacobinism, both embodied in Fitzosborne and both leading to the ultimate destruction of women's virtue and political stability. The young quixote has then not learnt the lesson from her previous romantic illusions: that books and characters must be critically judged. Moreover, by displacing her fantasising from chaste courtship and marriage, the epitome of romantic female quixotism, to the sexualised realm of French narrative fiction, Geraldine has become immersed into a much more dangerous form of delusion. West thus resumes the dichotomy between romance and a more scandalous form of fiction that Lennox had developed in her novel, once more highlighting that the quixotic delusion originated by romance at least preserves women's honour. In a pattern that later Green would also adopt, West's quixote renounces a more acceptable and safe illusion in order to fall a victim of a more dangerous literary and ideological allurement.

In this sense, the innocent Geraldine is duped into engaging with Fitzosborne in a friendship, in a "dangerous intimacy" (2005: 83) that will prove fatal to her 
reputation and her life. This intimacy is represented mostly by the act of writing, by the correspondence she starts with him and the fact that she reads those letters in private. Geraldine then develops a "fatal delusion" (2005: 266) which subverts the limits between reality and fiction and in which appearances and their interpretation play a key role in her downfall. As Gilroy has indicated (2005: xvii), this blurring of the boundaries is highlighted in three particular episodes. First, when Geraldine is playing the harp, Fitzosborne orchestrates a sentimental tableau: he weeps and he melodramatically meets her eyes to prove his sensibility. Secondly, at the opera, when the villain uses appearances against Geraldine's honour. Finally, at a masquerade, the epitome of antiJacobin representation of untruthfulness and subversion, when they appear as Perdita and Florizel, originating questions on the nature of their relationship. Finally drugged, kidnapped and raped, Geraldine is abandoned and later violently abused by her husband. Following Clarissa's example, the heroine then slowly moves towards a pious death, while, in a final ironic twist, the Francophile Fitzosborne commits suicide to escape the guillotine to which he was condemned on his return to Paris. Equating private and public spheres, the ethical and the political, West develops the core of anti-Jacobin discourse in her introduction of the British family as not only the basis of stability, but as the greater victim of a lack of principles or their contamination by aristocratic debauchery or French philosophy. The fact that the story of Geraldine's downfall, which starts in 1789 and reaches its climax during the Reign of Terror, mirrors contemporary political events only emphasises this aspect of the "family-politic" trope.

However, despite the clear anti-Jacobin message that West hopes to convey, once again, the positive nature of her deluded heroine creates conflicts, to which contemporary critics more openly responded than in previous novels. ${ }^{146}$ Geraldine is a "guiltless" heroine, who commits her mistakes unintentionally (2005: 272). Moreover, in many ways she is an exemplary heroine: she bears her husband's foibles with patience, she aims to achieve his reformation and she even practices an active kind of sympathy with the villagers of her little

\footnotetext{
${ }^{146}$ For the contemporary reception of the novel, see Gilroy (2005), pp. 389-98. These unfavourable reviews at the terrible ending of an otherwise exemplary heroine resemble the rejection of some readers to Richardson's own depiction of Clarissa's fate.
} 
"colony." However, she is at fault in one aspect: she possesses vanity, she aims to gain recognition for her work outside the more restricted domestic sphere of her household. Vanity is then her "ruling foible" (2005: 151), and the source for that "self-aggrandizement" that London identified as typical of anti-Jacobin quixotic figures (2000: 75). The novels and tracts she reads have inflamed her imagination with pictures of perfect heroines who achieve ideal love and with notions of the intellectual superiority of women, who are above the narrowness of custom. Fitzosborne fuels her perception of herself as a worthy object of sentimental adoration and as an independent woman worthy of admiration. According to the supersystem of West's novel, a more humble or realistic approach to her role as woman and citizen would have prevented her delusion and subsequent fall. Nevertheless, compared with other heroines to be discussed later, Geraldine is still an exemplary wife and mother who is ruined against her will, and as contemporary critics asserted, West's moral may have been more effective if the heroine's repentance and return to her home had granted her a happy ending and her husband's reformation, for her punishment is indeed unequal to her mistakes.

West's novel is ambiguous in one other respect: its approach to fiction and to domesticity. A Tale of the Times is probably one of West's most intertextual novels and all quotations and references to works of fiction are cleverly employed to either advance the plot or to trigger associations in the reader which highlight the moral tenet of West's own novel. First and foremost, Fitzosborne fulfils the anti-Jacobin premise of repeating Godwin's ideas throughout the novel. Moreover, as the novel unfolds, West compares her villain with Milton's Devil, Shakespeare's Iago or Richardson's Lovelace. According to Gilroy, "these allusions expose his dark designs to the reader but, at the same time, Fitzosborne accrues the undeniable glamour of these complex figures" (2005: xvi). Therefore, enriching her own text with these allusions, West also incorporates all the complexity and ambiguity of those prior characters. In addition, she highlights the deluding nature of these particular figures: how they manipulate discourse to achieve the fall of women by means of their husbands' jealousy, of their appeal to women's vanity, or of their moral and sexual corruption, all of which are strategies employed by West's villain. 
These previous literary characters hide lies under the appearance of truth and hence epitomise the deluding nature of the Francophile philosopher and his seemingly well-intended system of reasoning. Fitzosborne employs literature as well to achieve his purposes: he uses Wieland to frame several improprieties in the novel; he convinces Geraldine of faults in Johnson's Rasselas, hitherto her favourite author, which signals a change in her British taste; he asks Geraldine to fetch him a volume of Rousseau from her husband's room knowing she will discover a letter from his mistress, which not only points to Fitzosborne's use of the novel, but also to Monteith's own debauched principles. Finally, and more significantly, the reference to other works of fiction frames the most immoral episode in the novel, the scenes at the masquerade: several ladies point out that "the adventures of the third Eloisa would soon be published," that the book would be called "Werter (sic) the Second, with a different catastrophe," or that it would have a "Chapter on Botany" or astronomy (2005: 195). These references allude to other immoral texts or authors: not only Rousseau's La Nouvelle Heloise but also Hays's Memoirs of Emma Courtney, whose heroine was described as a "third Eloisa" in the Monthly Review (1797: XXII, 449); Goethe's Werther and Wollstonecraft's own identification by Godwin as a female Werther; and even to Powhele's critique to botany as a fashionable female pursuit among ladies such as Mary "Perdita" Robinson, the actress and courtesan linked also to Geraldine by her choice of costume. In addition, after this episode, Fitzosborne appeals to Geraldine to obviate such insidious remarks; to which she answers that he is "always tilting against those windmill giants" (2005: 196). Her comment allows the readers to perceive Cervantes' novel as one of the hypotexts of West's narrative, as well as to perceive how in Geraldine's distorted perception Fitzosborne has become the exalted idealist that radicals perceived in Don Quixote.

As Wood has attested (2003), the novel in its dialectic nature always challenges the possibility of avoiding ambiguity, especially the anti-Jacobin novel that nurtures from its intertextuality. While West warns her readers about the dangers of perusing fiction, the number and quality of her literary citations show that West is a prolific and conscientious reader herself, in particular of 
works of fiction written by men which she later inscribes and frames in her own text. In addition, she is obviously familiar with the radical texts of Godwin, Hays and Wollstonecraft. Once more, parody may attack a genre, but it nevertheless requires its somehow subversive intrusion as a hypotext. Similarly, West amply criticises the circulating library and its contents, while, as a professional author, she is aware that her own works are highly in demand in them. ${ }^{147}$ Finally, as Wood highlights (2003), the fact that conservative women writers are publishing novels at all is a challenge in itself to the antiJacobin supersystem that many of them claimed to defend. West's defence of the thesis of domesticity in Geraldine's tragic story is somehow contended by the very fact that she is writing a novel, which is already a contradiction difficult to reconcile with the anti-Jacobin discourse on women's invisibility and modesty. In the end, West had to trust that her claim to a consistent ideological supersytem, and to her unwillingness to achieve money or fame through her narratorial persona, were enough to ensure that her novels remained undoubtedly didactic and her stance as a woman writer undoubtedly within an accepted interpretation of the domestic. Moreover, she had to trust that her authority as a moralist was enough to draw readers to her novels so as to awaken them to the distinctions between fact and fiction, so as to instruct them in the reading of texts and manners, and, as a consequence, so as to cure them from their potential quixotic imitation of the narrative fiction they had in their hands.

2.2. The Dangers of Francophile Quixotism, or the Importance of Female Education in Mrs Bullock's Novels

In 1795 a novel entitled Susanna; or, Traits of a Modern Miss; a Novel was anonymously published in London. ${ }^{148}$ It depicted a young woman of seventeen,

${ }^{147}$ Gilroy records how one of her most fervent admirers and friends, Bishop Percy, must wait in Brighton to be able to read A Tale, despite the fact that he records in his letters that there are "three circulating libraries," because "the demand for [her] novels is very great in them all" (2005: vii).

${ }^{148}$ Unfortunately, all remaining copies were in a deteriorated state which prevented their digitalization and my access to them so as to include the novel in the present work. For a summary of the plot I have relied mostly on the Corvey collection webpage: <http://www2.shu.ac.uk/corvey/cw3journal/Issue\%20two/Susannah.html>. 
Susanna Bridgeman, who, after leaving boarding school with only superficial accomplishments, becomes a subscriptor to a circulating library and has her mind turned by romance. Rejecting her father's sensible proposed suitor, fantasizing about the romantic Lord Morven, and becoming recurrently deluded with the use of romantic conventions by his scheming servant, $\mathrm{Mr}$ Thompson, Susanna fulfils many of the common places of quixotic fiction already present in Steele or Barker. Moreover, she is fooled by her old school friend, Miss Dawson, who is a kept mistress and with whom she commits many indiscretions. She is also pursued by her fortune and finally marries the old, and apparently rich, Lord Pearson, who takes her to his Gothic castle. In this new situation, Susanna adapts her quixotic delusions and starts to interpret reality through the filter of Gothic conventions, becoming convinced that the house is haunted. Some servants make use of her superstitions to fool her, hiding behind a tapestry and speaking to her in a ghostly voice -a scene which Barrett later echoes. In the end, those same servants pillage the house. After this, Susanna trades her focus of enthusiasm: charmed by a young stranger, she starts a platonic friendship with him until her husband discovers them together and he is unveiled as Mr Thompson. Sent to stay with her mother, Susanna then dresses and acts as a Quaker for a time until her renewed friendship with Lord Morven results in her abandonment of such humble way of life and she returns to the boast of her riches. Enraged at her spending money he perceives as his own, her husband forces her back to the castle and treats her like a true Gothic heroine: she is locked in her room and must escape by drugging the servant at her door with laudanum. Accompanied by her faithful maid Lucy, an echo of Arabella's own Sancho-like servant, Susanna flees the castle under heavy rain and becomes delirious with a fever. In the recurrent plot of female quixotism, her physical recovery will also signal the start of her progress towards awareness and the regret of her past follies. The plot reaches its end with Lord Pearson's emigration to the Continent and his agreement to separate in exchange for money. When Susanna's mother dies not long thereafter, the twenty-two year old heroine is left rich and with a new enthusiastic pursue: Methodism. With this final hint at Butler and Graves, the novel closes brimming with references to other milestones of the quixotic tradition. 
Susanna does indeed seem to draw from many previous works, and, as critics attested, one of her main influences was probably Lennox's Female Quixote, although amalgamated with a greater amount of ridicule and unsophisticated humour. In an early comment on the novel, one could read in The Critical Review that:

The writer of Traits of a Modern Miss seems to have had in view Mrs. Lennox's celebrated Female Quixote: but the characters of Susanna and Mrs. Lennox's Arabella are by no means equally interesting: the mistakes of the latter are the errors of genius, - and superior minds will ultimately correct themselves. But the weak, versatile Susanna is characterised as a ridiculous compound of affectation and vanity: her frailties have not even the excuse of sensibility, nor her follies the charm of vivacity. Those who love ridicule may be entertained with this work, which is written with humour.-It may also be read with advantage by any modern miss, who may be exposed, by habits of indolence, an uncultivated mind, or negligent guardians, to the temptation of committing similar absurdities. (1795: XIV, 113)

The British Critic also emphasised the humour of the novel and its somewhat predictable nature in the light of previous quixotic fictions:

The difficulties into which poor Susanna is plunged, by taking all her ideas of life from modern novels, are well imagined, and exhibited with some humour, though perhaps carried rather too far. The catastrophe is touching! Susanna becomes a Methodist, not an unnatural termination for such a career, has her rhapsodies, her manifestations, and inspirations, and grows too sublime for her author's pen. (1795: V, 175)

The heroine suffers from ennui, a lack of education, a passion for reading and the most dangerous of female weaknesses, vanity, a combination which also proved fatal for many other female quixotes, especially coeval ones such as West's. However, Bullock seems to return to a more shallow reading of the quixote as a vehicle to ridicule any system of reference or thought, and Susanna's flights of fancy, ranging from romances, to Gothic novels, to Quakerism, to Methodism, prove that anybody aiming to conduct herself by strict codes of conduct without any rational questioning will become a foolish quixotic character. The few critics that have acknowledged the existence of this novel have also perceived this variety of targets; for instance, George Watson, in his extensive Bibliography of English Literature describes the novel as a "Female Quixote device" which presents a "variety of targets burlesqued: 
pastoral, Gothic, Methodist, romantic cottage life, Bardolatry, Clarissa" (1971: 1968). Quixotism is then extended to include not only a literary delusion, but also a religious or even a philosophical one, as when Susanna establishes a platonic friendship with her unknown admirer, much in the fashion of Rousseau's French heroines. Nevertheless, the focus is mainly on reading and, particularly, on romance and those genres which directly spring from it, such as Gothic fiction. At one point, the novel refers to "a species of novels, lately very much in fashion, which possess (in addition to the usual folly of such works) all the improbabilities of ancient romance; books, that tell of beautiful damsels, who have been confined twenty years in caverns; of murders, ghosts and ruined castles" (II, 191, qtd. in Tarr, 1946: 3). Susanna's attempts at living out the tenets of such improbable fiction will be the preferred target of the author.

The same author will continue to employ quixotism to attack literary and philosophical systems in another novel: Dorothea; or, A Ray of the New Light, published anonymously in London in 1801. That these novels are connected has been recently ascertained by critics who have noticed that they were both attributed to a Mrs Bullock in the publisher's catalogue of books of 1814 and who have even been able to establish a certain similarity between both novels which further supports this authorial connection. ${ }^{149}$ Although nothing is known about this novelist, the authorship of these novels is currently well established among scholars and both will be considered works by Mrs Bullock.

Dorothea tells the story of its eponymous heroine, a young, beautiful, wealthy girl who is very fond of reading radical novels and treatises, and who adopts Godwinian ideas on general good, property and marriage, and employs them as guiding system for her own individual behaviour. Educated by a governess who has developed her own new mode of education, she is little prepared to approach her reading critically and acquires grand notions of philanthropy that clash with the more conservative and Christian notions defended by her suitor, Sir Charles Euston. Almost deluded by a conniving disciple of the new philosophy, Thomas Williams, she nevertheless marries Euston, but her notions

${ }^{149}$ See Peter Garside "Update 1" (April 2000-May2001) to The English Novel 17701829: A Bibliographical Survey of Prose Fiction Published in the British Isles <http://www.cf.ac.uk/encap/corvey/articles/engnov1.html>. 
on female independence make her marriage unhappy. Moreover, Dorothea's wish to follow Wollstonecraft's advice to breastfeed her child leads to the baby's death when she is incapable of doing it, rejects a wet nurse and leaves it in the hands of a vicious woman who poisons it to punish her. After a series of misunderstandings concerning her honour, she leaves her home and establishes herself as a teacher in a small school for low-class girls. Her system of education backfires and, beaten by one of her pupils, Dorothea remains seriously injured and helpless until Sir Charles comes to her rescue. Finally reunited with her husband, she reforms and lives a happy and conventional life as his wife. While Dorothea achieves her happy ending, Williams, who has been one of the instigators of the Irish rebellion, dies in the hands of one of the victims of his philosophy, while all the other characters fooled by philosophy or all the women who have proved a dubious moral behaviour are also strongly punished for their crimes.

Dorothea is early presented as a female quixote by the use of certain language associated with quixotism in the eighteenth century. According to the narrator, in a time when moderation and common sense have been substituted by a general quixotism of "Enthusiasm" and "the fervour of philanthropy," Dorothea joins the ideological "war" by "putting on the whole armour of opposition," opposition not directed at one particular train of thought but "to all established opinion," and by becoming a "champion of liberty and democracy" (2005: 3). With this reference to enthusiasm and knight-errantry, Bullock sets the frame in which the reader can easily recall the well-known tradition of quixotism, to be reinforced in the second and third volumes, in which Dorothea's mistakes have more serious consequences, by the use of the terms “our lady-errant" (2005: 163), or "absurd quixotism" (2005: 99) and "Quixotic weakness" (2005: 109) with regard to her nature as an "enthusiast" full of Utopian schemes (2005: 101). Echoing other eighteenth-century writers, the narrator states that her heroine is mounted on her "hobby-horse" (2005: 112) and that she is moved by "the unchecked pursuit of a phantom, unknown to common sense" (2005: 167). As the novel unfolds, Bullock develops her antiJacobin discourse and evinces how this ideological quixotism or enthusiasm 
endangers Dorothea's position as daughter, wife, mother and benefactress of the poor.

As an introduction to her quixotic story, the narrator devotes the first chapter to explaining why Dorothea is a miss prepared to become that knight-errant of the new philosophy: she is spoilt by doting parents and educated not by her meek mother but by a Francophile governess who instils in her notions of liberty, liberality and the oppression of the working classes, while not developing her critical judgement. As a consequence, she becomes a "female philosopher" (2005: 6) who remains unchecked by her parents' amazement at her uncommon wit, therefore linking Dorothea with a contemporary parody of a female philosopher, Hamilton's Bridgetina. Dorothea's quixotism reaches its peak at the age of sixteen, when "her mind teeming with philanthropy, became occupied with plans of general emancipation, which agitated her fancy, and whirled through her imagination with chaotic confusion" (2005: 7). Dorothea and Bridgetina then share one other characteristic: their superficial and confused approach to the new philosophy. The narrator thus expounds on the origin of Dorothea's philosophical train of thought:

[...] Dorothea did not rhapsodize with Rousseau, or reason with Voltaire, nor did the arch sceptic Hume make part of her library; but she drew her knowledge from a fund more enticing, because less dry: she studied works adapted to her meridian; the labours of those, who, having dipped into the originals, and presuming on the ignorance of the multitude, propagate, at second hand, and in new dresses and decorations, the opinions and doctrines they have thus picked up.

The rights and wrongs of women made great impression on her mind, and she felt every instant inclined to assert her rights, and rise above her wrongs. She wept over the sublime ebullitions of Godwin's dear son, Caleb Williams; and was convinced by the precepts and examples of Citizen Holcroft, that her mind, teeming with energy, ought no longer to repose under the clouds of common life. (2005: 7)

All her acquired principles are then second-hand rewritings of original thoughts that Dorothea will also reproduce as uncritically and ridiculously as Godwin, Holcroft and other radical novelists had done.

While this is also true of other anti-Jacobin warning figures, Dorothea differs from other quixotic heroines in that she makes her claims for power obvious, 
and does not employ a subtext hidden in the prolongation of courtship. According to Grenby, this focus on women's rights in the radical discourse is recurrently utilized as an attack to the new philosophy as "a plot to destroy the family by subverting women" and also a "cover for wicked individuals to perpetrate their predatory financial, sexual and also ideological campaign against innocent women" (2001: 90), both approaches being at the core of the friendship between Williams and Dorothea. Induced by Williams into reading all new works on "politics, religion, and morality" and educated by him in the tenets of equality, these ideas took "full possession of her mind and heart" and "she read and believed" (2005: 17). And, as she believes, she starts to act. As the novel unfolds, Dorothea will recurrently employ the radical language of equality in opposition to the terms "slavery" or "submission" with which she characterises the duty of a daughter or a wife, although her own good nature prevents her from radically opposing her loving parents (2005: 42). Even at the moment of accepting Sir Charles, Dorothea states that she is "willing to consent to an union, stipulating only for liberty in her opinions," to which her now fiancé responds with a certain chagrin at his mistress not adopting "the feminine grace of modesty" and instead "majestically giving a categorical answer to his question" rather than a modest blush, "making a mere matter of business his proposition and not even avowing her affection" (2005: 44). However, Dorothea will learn that her mother's warnings were true: once married, women must adopt their husbands' opinions and give up their own (2005: 46), they must fulfil their duty and yield to their husbands, and never expect them to "give up to a woman, except in the way of compliment before marriage" (2005: 47). Once the period of courtship is over, women must render their will and opinions, a notion that had inspired all female quixotes to lengthen this period of their lives. In marriage they are later cured and reeducated, and Sir Charles, assuming the role of male mentor characteristic of female quixotic plots, expects to be her "protector" in the world, to dispel her inexperience and illuminate her with his experience and influence (2005: 51). However, Dorothea is more resolute than previous heroines; she goes a step further and expects to preserve her liberty in her marriage, which has disastrous consequences for everybody involved. On her wedding day she states that she has entered into a contract in which she hopes not to become her husband's 
"bondswoman," but in which she wishes to retain "the entire control of her actions," for she will not be "commanded or catechised" but treated as an "equal." In addition, she threatens to "break" for ever the "chains" Sir Charles may be tempted to make appear (2005: 58). Her entrance into the world abates for a time her ideological flame, although her correspondence with Citizen Williams newly inflames her spirit (2005: 67), resuming even more defiantly her position and restating the anti-Jacobin notion that uncontrolled written communication can prove dangerous for a young married girl. When her husband demands her to go to court to be introduced to the king, Dorothea and Sir Charles engage in a dialectical battle of power in which the latter's vision of marriage as exertion of male "power" and female "obedience" is challenged by Dorothea's defence of her own personal freedom and her equality with her husband (2005: 70-1). After her mother's commendation on her deathbed to become a dutiful and proper wife, and to make her husband's will her rule of conduct, Dorothea "almost resolved to follow" her advice (2005: 77), although not fulfilling a complete restoration to decorum. Piqued by Williams into proving that she is not the slave of her husband, she risks her reputation meeting him in private, against her own sense of propriety (2005: 120) and is then fooled by him into new depths of delusion.

In this regard, Bullock follows the tradition of anti-Jacobin quixotic fiction, and Dorothea is the dupe of many mock-philosophers. First, Thomas Williams, a surname that recalls Godwin's famous Caleb Williams; and, secondly, Sophia, a cruel and scheming woman who perceives the "Quixotic weakness of her benefactress" (2005: 109) and determines to profit from it, deceiving her by utilising the language learnt from her readings and attempting to ruin her to gain Sir Charles's favour. Despite Dorothea's quixotic Utopian scheme of helping her reform after being accused of killing her own child, Sophia still attempts to harm her. The consequences of Sophia's manipulation are the death of Dorothea's baby and her subsequent escape from her house and her husband's protection. Fooled by her female protégé, Dorothea is exposed to her husband's suspicions, and a series of misunderstandings ensue after which she decides to escape her unfeeling husband, whom she is made to believe is not 
concerned about their baby, a baby that ends "a victim to systematizing, and the sacrifice of mistaken principles" (2005: 151).

Although adversity traditionally triggers the epiphany that leads to the quixote's cure, once more Dorothea's delusion proves particularly resilient. For a period, in a rural cottage in Wales, the narrator describes her quixotism as unabashed, for "the warmth of her imagination, and the heroism she assumed, supported our visionary under all the inconveniences of this arrangement; but as the fervour subsided, she was tormented by a most worldly feeling of regret" (2005: 157). However, Dorothea then starts another quixotic endeavour: she opens "a little seminary with five damsels" (2005: 158), as she feels it her duty to liberate them from ignorance and teach them how to read. The disastrous consequences which follow -her robbery and attack, her moneyless and helpless situation- start her final awakening, and make her exclaim against her "madness and presumption" and the manner in which she has been "blinded by the subtle reasonings of imaginary philosophy" (2005: 179). In the meantime, her husband hears of her distress and runs to her aid, considering that:

His plans of domestic felicity had been destroyed by a visionary system of independence; he saw her led away by Quixotic dreams of liberty and equality, which obtain so much in the present day even with stronger heads than our heroine's; and that she had created a standard of perfection, which she was striving to reach. But these were youthful mistakes, and he would have looked forward to the moment (that he had no doubt must arrive) when she should discover the futility of her attempts, and endeavour to regain the path from which she had deviated; [...]. (2005: 189)

This discovery and endeavour are finally achieved and the narrator asserts that "our heroine [...] had learnt, in this short taste of adversity, how weak and helpless a creature she was, with all her mighty boast of energy and usefulness," and that while "happiness had been offered to her acceptance" she had turned away from it in "pursuit of a bubble of independence, which was no sooner obtained, than it burst in her hand, and left her overwhelmed with regret and despair" (2005: 193). Reunited and reconciled with her husband, she asks for a veil to be drawn over her follies and to be allowed to prove that she is no longer "the idle visionary, who followed her system though it led to destruction" (2005: 195). The narrative concludes with Dorothea's 
transformation into the ideal anti-Jacobin female model. As a reformed heroine she has now:

[...] sought her happiness in a path where it is most certain to be found -in the performance of her duty as a wife and a mother, having consented, without reluctance, to abdicate the rights of equality, and to let the world go on in its old course; whilst she confines the energies of her mind within the gentle bonds of domestic cares and pleasures, and employs her active spirit, not in awakening discontent and rebellion amongst her poorer neighbours, but in ameliorating their situation [...]. (2005: 196)

With this moral the novel concludes, and the narrator asserts: "the ray of light which had illuminated the mind of our heroine for so long a time, being now totally extinguished, my task is almost at an end" (2005: 196). Bullock's awakened heroine is then an example for the implied reader, and her story only possible while deluded. To emphasise her didactic intent, the narrator concludes her story with the following address to her readers:

And now, dear reader, if you are a modern philosopher, the best wish I can offer is, for your speedy deliverance from the energetic sublimity of your incomprehensible dogmas; but if you are, like myself, a pupil of the old school, be contented, I beseech you, to thank Heaven for your ignorance, and above all things shut your eyes against the delusions of that ignis fatuus the NEW LIGHT! (2005: 197)

The Monthly Review recognized Bullock's anti-revolutionary didactic intent and the only criteria it employs to validate her novel is precisely its use of the genre as a means to convey a moral message. It describes the novel as

[...] an Anti-Godwinian production, exhibiting a story so constructed as to place sometimes in a ridiculous but mostly in an odious point of view, certain strange principles originally laid down by Mr Godwin in his "Political Justice"; and to induce mankind to regard with suspicion and hatred the disciples of what is pompously and sarcastically called the New Philosophy. (1802: XXXVII, 425)

Moreover, it validates this political use of the genre with the common argument that "novels having been employed as the vehicles of these opinions, it will be deemed fair to have recourse to the same means for their refutation. $[\ldots]$ it is easy when invention is invoked, to imagine characters and incidents 
that shall honour or expose any system;" finally concluding that this particular novel attempts

[...] to delineate the folly of making a regard for the general good the leading motive of individual action; of cherishing wild notions of the advantages of unsophisticated nature; and of diffusing Mr Godwin's ideas respecting property, promises, and gratitude, among the vulgar; -a task which the author has executed with some ingenuity, though not with absolute correctness. (1802: XXXVII, 425)

Once again, Bullock's satiric intention conditions the quality of her writing, and her novel becomes an anti-Godwinian, anti-Holcroftian fiction and one of the best examples of anti-Jacobin parasitism in terms of their use of elements from radical thought or fiction to develop their quixotic parody.

At two points in the narration Bullock overtly employs scenes from Holcroft's early radical novel Anna St. Ives (1793). Dorothea utilizes the principles of Godwin's philosophy to console one of her father's employees, Thornton, who has been dismissed for his appropriation of his master's money. As a summit to her benevolence, the narrator describes the following scene:

[...] the illustrious shade of Anna St. Ives flashed before her eyes; and not finding it convenient to press her rosy lips on Edward's forehead, after the manner of that lady: she left a velvet kiss on his hand as she parted from it $[\ldots]$.

A kiss! A kiss? Lord, yes to be sure, gentle reader; the kiss of pure sisterly friendship and affection -but not you nor I, or any body else, who had never studied modern philosophy, or received the new light, might have stood, as Edward did, thunderstruck at such a mark of friendship; aye, and have been as ready as he was to misinterpret the whole scene. Miss Melvile offering to share her fortune with him; interesting herself in his fate; commanding him to remain; and kissing his hand! all this for sisterly affection, or simple friendship: pshaw! A man must be a fool to be blinded with such jargon. (2005: 24)

With this narratorial intrusion the inappropriate and even ridiculous nature of the original scene in which Anna kisses her suitor, Frank Henley, becomes even more evident, as well as the consequences of setting this young man "to castle-building" above his station (2005: 24). This castle-building ends in his theft of her dowry and his escape to France, though he is drowned while attempting to cross the Channel. The narrator's moral conclusion once again 
resembles divine retribution and exposes the consequences of youthful delusion. The second scene mocks Anna's choice of marrying Sir Coke Clifton instead of the man she loves, the impoverished Frank, to advance the general good in society. In Bullock's parodic rewriting, Dorothea, despite her ideological conversion and her wish to imitate Anna's sacrifice, struggles to consider "how she might bring political justice and her own inclinations to an amicable agreement" (2005: 42) and engages in a humorous inner debate between her own wishes and her philosophical inclinations (2005: 43). In addition to these scenes, in his rejection of Dorothea's marriage, Williams combines the tenets of his new philosophy with the language of sentimental or Gothic novels which radical ones also employ (2005: 56). As Grenby has insightfully asserted, this textual appropriation of both philosophical ideas and novelistic devices allows Bullock to discredit both and to equate "the unrealistic, absurd ideas of the new philosophers with the unrealistic, absurd patterns of the novel" (2005: xviii). In this sense, "to be a new philosopher is much the same thing as being that other object of early nineteenth-century satire, a "novel-reading miss"' (2005: xviii). In order to stress that parallelism in absurdity of both philosophy and novels, Bullock's female narrator moreover directly addresses radical philosophers and novelists from the pages of her novel. She exclaims, for instance:

[...] come now ye sceptics and look at your pupil. [...] The misfortunes that have assailed her, what are they? she has merely lost her money; that dross which ye despise: one arm, only one, is rendered useless; but the other is strong and able: what! shall the energy of philosophy evaporate, because the injured limb happens to be the one most commonly used? arouse thyself, redoubtable spirit of truth and reason, and the left hand shall be as the right! we are above such trivial distinctions. She is destitute of food too; but is the human mind to be conquered by starvation? shall the ridiculous and debasing clamours of the appetite, palsy the efforts of the soul? forbid it pride, forbid it philosophy. (2005: 180)

The ridiculous expectations of radical philosophers, epitomised by Godwin's farfetched notions and by the unnatural events that befall the heroines of certain forms of fiction -who, as later Barrett will also point out in his quixotic parody, can resist pain, desolation, poverty and hunger sustained by their willare openly attacked by Bullock's narrator. 
However, despite the inclusion of novels in Bullock's attack to radicalism, as the paratext of editorial notes and the quotes in the text itself attest, the main work brought under inspection is still Godwin's Enquiry Concerning Political Justice. His work is presented by the literal or travestied quoting of it that Dorothea and Williams, the would-be philosophers, perform throughout the novel. Bullock then comments on Godwin's magna opus by a variety of means: through the abovementioned editorial notes, direct or indirect quotations, narratorial censure or even other characters' comment on certain Godwinian ideas. A particular example is provided at Dorothea's first reading of Political Justice. The narrator mockingly mentions the "immensity of its conceptions, and the incomprehensible grandeur of its dogmas" (2005: 18), which Dorothea finds "impossible to comprehend" (2005: 19), later engaging in a discussion with Williams on what seem Godwin's ideas on immortality. Another jocular attack to Godwin's principles is introduced in the use made of them by Williams and Dorothea to, respectively, advance and reject a marriage between them (2005: 35-6). The core of Bullock's critique to his work is its absurdity and its intrinsic contradictions, which, referring to his own amended editions, she points out must be even obvious to the writer himself. This fundamental message the author voices in the character of Sir Charles, the male mentor and representative of the reasonable and informed conservative patriarchy which Bullock reinforces as the novel unfolds. After the wedding, when Dorothea as usual quotes Godwin, Sir Charles states: "if the author, on whom I perceive you place great reliance, did not himself, like many other venomous reptiles, present an antidote to the poison he disseminates, he would indeed be most extensively mischievous" (2005: 66). And as part of his bride's process of awakening he proposes to "read his tract together," for he is sure her mind "is so open to conviction" that when he has shown her how "decidedly his own tenets contradict themselves, how wild are his theories, and how unjust are his conclusions" she will cease to quote his opinions as her guide (2005: $66)$.

Bullock not only comments on the absurdity of the radical discourse, but also on the manipulation of terms and facts it implies, which is another common place in the tradition of quixotism: how language is unstable and open to 
interpretation, distortion and misapplication. When Williams is exposing his philosophical deeds to Dorothea, he "forgets" to mention the less heroic consequences of his system: the abandonment of his wife and child (2005: 129). Dorothea, facing the rudeness of her pupils, finds in radical language a way to manipulate reality; she hides the truth by "bestowing on their vulgar impertinence certain high sounding names, such as candour, dignity, truth, ingenuousness, and free agency, which should therefore be encouraged, rather than repressed" (2005: 159). This, of course, is a veiled critique to radical novelists and their lack of insight into the delusion of their principles, or their consequences. Bullock reinforces her attack with the depiction of the utmost negative consequences of the misunderstood philosophy. Replicating a passage in Godwin's Caleb Williams in which the freed prisoners exert their new gained freedom, Bullock has her own Williams liberate a group of prisoners sentenced to death. These criminals then engage in gruesome crimes and brutally murder a whole family seemingly out of sheer evil (2005: 94). The only surviving member, the now deranged mother, ends up stabbing Williams to death in an ironic twist of fate (2005: 187).

Bullock employs Godwin's philosophy as a "springboard for wider discussions of education, of the proper role of women in society, of criminality and the penal code" (Grenby, 2005: viii). In this regard, Bullock distinguishes her novel from the current of anti-Jacobin fiction in several ways; in particular, by means of its intensely virulent attack not only on philosophers and socialclimbers, but on its transgressing heroine: only after extreme emotional and physical suffering is Dorothea cured and allowed to return to her husband and a happy life as a conventional married woman. Portraying a more disruptive quixotic heroine than any of her predecessors and more dangerous consequences of philosophical quixotism for female virtue, family and nation than her sister novelists, Bullock contrives a sadistic plot of punishment/chastising and awakening to equal her heroine's wild philosophical notions. As a contemporary critic noticed, many "pretended professors" of modern philosophy "have carried certain wild maxims to an extravagant length." In particular, the critic states, those axioms concerning women have reached unprecedented heights; "to take the needle and the rolling-pin out of 
the female hand, and to fill it with the fasces and the halbert," this critic asserts, "would be ridiculous, unless they and the man changed vocations; for somebody must mend stockings, and somebody must make pie-crust." According to this reviewer, in Bullock's novel "the rights of woman [...] have been deservedly laughed at" while the author "holds his mite to the ridicule, and in some places not unsuccessfully" (Critical Review, 1802: 238). This open and mostly unambiguous attack on women's rights as formulated by Wollstonecraft or Godwin characterises Bullock's plot, leading Grenby to term this novel the "most resolutely anti-feminist anti-Jacobin novel" (2005: ix). Very understandably, then, the abovementioned contemporary critic misgenders her, referring to the author as one who holds his mite, despite the fact that the narrator addresses her countrywomen with the claim "let $u s$ be wives, glorying in the performance of our duty: let $u s$ be mothers, ready to sacrifice all for the dear helpless beings we produce, and who rest on $u s$ to defend and to instruct them" (emphasis added, 2005: 54).

Bullock's narrator is female, and she calls for a female community of dutiful wives and mothers. In order to enforce her appeal, the narrator directly addresses her female audience and through several pages expounds on the example of Mary Wollstonecraft's life as presented by Godwin in his memoir; she compels them not to fall prey to radicals who aim to make them their victims, as they themselves have become victims of their own delusion (2005: 52). She pleads her readers to learn from the female philosopher's tragic example, and even contends that, had Dorothea had access to that work, she would have been awakened by the "obvious comment on the prevailing doctrines" that Wollstonecraft's posthumously works provided (2005: 54). This remark states the power of the very own radical texts to expose their danger and their detachment from reality. Bullock plays with radicals then as both deluding and deluded, something she has also exposed through the character of Williams and Dorothea. This reference also frames the novel in its historical and literary context: Dorothea's story is inscribed around the mid-1790s, her readings are mostly texts published in 1793 and the edition of Political Justice she quotes is the 1796 version. The fact that the narrator has read the Memoir published in 1798 evidences that she is writing from a temporal distance that 
allows her to present an informed view of the development of events and even of those philosophers that in the dawn of the terrible occurrences of the late 1790s were still not fully blamed for the danger posed by their principles. The consequences of the implementation of the new philosophy are paralleled then in fiction and in reality, and the narrator acts as a commentator on narrative and factual events alike, pointing out the similarity of her textual quixote with those real-life followers of radical ideology which she makes strikingly obvious in her final appeal to her implied readers as possible quixotic "modern philosophers."

In its historical framing, Bullock's narrative becomes detached from the tradition of female quixotism and its focus on the courtship plot, and comes closer to the most reactive anti-Jacobin quixotic novels written by men, Lucas among them. In addition to the crude humour and punishment which Bullock develops in her novel, critics may have been disconcerted by the fact that the domestic plot is intertwined with many political and social contemporary issues: the Irish rebellion is amply described and its consequences have an important impact on the development of some of the subplots. ${ }^{150}$ Though the narrator claims that "the history of the rebellion $[\ldots]$ is a subject of too much importance to be treated at large in a work of this kind" (2005: 182), the Irish rebellion still plays an important part in the plot; its replica takes up several chapters in the second and third volumes, and diverts the narrative from the more domestic plot of Dorothea's troubles. While still retold from a confined interest in the "proceedings of our philosopher" (2005: 182), Williams, this piece of intrahistory moves beyond a domestic plot focused on marriage which was the epitome of what was perceived as feminocentric anti-Jacobin writing. In this coexisting storyline, Williams joins the United Irishmen and orchestrates what can be seen as a smaller mutiny that echoes the later full rebellion in 1798: radicals liberate prisoners who later cause havoc in the streets of Kilkenny, a plot which even recalls important political realities, such as the Gordon Riots or the Fall of the Bastille (Grenby, 2001: 117), or even the

${ }^{150}$ For the representation of the Irish revolution in Bullock's and Lucas's work in its context within the stereotypical anti-Jacobin discourse, see Grenby (2001), pp. 58-59. 
highly violent and true revolts in certain towns of Ireland. ${ }^{151}$ In this sense, Bullock ascribes to it the same importance male anti-Jacobin novelists did and shares some common strategies in her approach to it with the coeval The Infernal Quixote: first, the revolutionary ideals are treated as an "intoxication" that spreads among the lower classes (2005: 88); secondly, the rebellion is advanced by men such as Williams, not truly interested in the enhancement of society but in their own personal gain and who "seduce" their listeners and lead them to violent acts (2005: 88). Besides providing the novel with the appeal of contemporaneity, the Irish rebellion is a warning to an English-reading public, who could at the same time perceive the Irish as Same and Other, domestic and foreign alike: the rebellion is then close enough but still avoidable. In this sense, to provide a greater moral and political warning, Williams is more strongly punished than Dorothea: he dies while she has the chance of being restored to health, wealth and stability. Williams, perceived as foreign to the nuclear family at the centre of the plot and to the interests of the nation, is eradicated as the threat Bullock describes him to be. Dorothea regains her place as a domestic woman, as one of the collective "us" that the narrator had previously employed. Nevertheless, this optimistic ending in an otherwise brutal narrative still allows the threats that lie ahead if revolutionary ideals are promoted in England to be perfectly exposed for the benefit of Bullock's reading misses. In this regard, the novel presents these female readers with discussions on matters that conservatives had often described as beyond the comprehension or the benefit of their fair readers. Bullock's narrative also qualifies the conventions of the anti-Jacobin domestic plot aimed at a female audience with its informed opinions on the penal system and reasoned criticism on Godwin's notions, which distinguishes her from other less political female

${ }^{151}$ Owing to the growing discontent among the working classes, the fuse for rebellion was lit in 1780, when Lord George Gordon called for the repeal of the Catholic Relief Act of 1778 and a return to the repression of Catholics. On 2 June Gordon a crowd of 60,000 went to the House of Commons to present a petition stating that the legislation encouraged 'popery' and was a threat to the Church of England. Anti-Catholic riots ensued in London, lasting for many days, as the masses vented their anger. Protests were violent and aimed at Catholic targets, such as homes and chapels, and a distillery owned by a Catholic in High Holborn. They also seem to have expressed a more general frustration: prisons and the Bank of England were attacked. With no regular police force, the army was called in to restore order and King George III issued a proclamation to suppress rebellion in the kingdom (The National Archives Website, http://www.nationalarchives.gov.uk/, accessed October 2012). 
anti-Jacobin authors, and makes her female quixote a truly ideological one, rather than a romantic or sentimental heroine read only in sexual terms.

And it is in that truly ideological, or philosophical, nature of her quixote that Bullock somehow undermines her anti-feminist conservative message. First of all, because Dorothea's nature is not corrupted: her delusion is circumscribed to this "new light" which ironically veils her intellect, while her heart is still in its right place. Even after she leaves her home, her sister-in-law states that

[...] however Lady Euston might be misled by the effervescence of youthful fancy, heated with the pernicious doctrines then in vogue; yet, $[\ldots]$ her heart was full of affection to her husband, and the natural sweetness of her temper was such, as fitted particularly to shine in the 'cool sequestered vale' of domestic comfort. (2005: 163)

More relevantly, Dorothea is never seduced; there is never any real danger to her virtue. Even her husband admits the purity of her mind and her superiority to the "dominion of any such degrading passions" as may have led her to an improper attachment to Williams (2005: 189). Rather than merely defining women by their sexuality, and their division into corrupted and uncorrupted as a metaphor for her political message, Bullock develops a thinking and active individual whose behaviour does have actual political and social significance. Women are political beings because their actions have consequences beyond their own bodies or their honour, even beyond their family or their home. ${ }^{152}$

Furthermore, Bullock rejects the stereotype of women as creatures of shallow vanity, moving away from her earlier Susanna. In her ideological delusion, Dorothea does not behave like a shallow woman of fashion nor is she convinced by the reasons that would appeal to such a superficial female character. When her sister-in-law, Lady Audley, tries to use the arguments of fashion and celebrity to achieve Dorothea's consent to appear in court, the heroine rejects a celebrity that would exert the need to "desert" herself (2005: 71). Dorothea must be persuaded by forceful thought and experience, because, though mistakenly, she nevertheless still struggles to reason. Because she can

${ }^{152}$ Even Sophia, who is sexually corrupted from an early age and who uses sex as an instrument to obtain her goals, is condemned rather because of her unnatural behavior as a mother and as a human being than because of her indiscretions. It is of the former that the she repents before committing suicide. 
think on her own, hers are "errors of genius," not of an affected female sensibility, so she can return to reason and to her place in society fully convinced of her errors of judgement and behaviour by a superior mind. Moreover, she is not a passive heroine either, and even her own mother exhorts her to use her "more active spirit" for good (2005: 76). When her mother is on her death bed, Dorothea complains against not having being told before of her illness so she could perform her "duty," her "daughter's services" (2005: 76). In addition, Dorothea's independent spirit and mind find a way to actively escape Williams while the later Mrs Williams, whose "characteristics were meekness and submission" and who offered "no opposition to his will" (2005: 84), awakens when it is too late. As a woman, Dorothea is at times even more appealing than Lady Audley, the domestic role model, in that she is stronger in the face of weakness, while the former has her mind "distracted" by her grief for the loss of her husband, and allows despair to take "possession of her senses" (2005: 115). It is only when injured, starving and alone that Dorothea finally surrenders to desperation, and even then she does not lose control over her mind. Furthermore, once she is restored to common sense and to her proper place, Dorothea engages in a more reasonable active philanthropy and even her husband seconds "her plans of benevolence" with the less fortunate (2005: 196). Her knight-errantry has then found a more appropriate channel to be expressed.

Finally, Bullock's extremely conservative discourse is undermined through her defence of the cause of female education she develops by means of her quixote. The conclusion of Bullock's novel seems to be that women should be educated, they should be taught to read, but, more importantly, to think critically. This is evidenced both by the poor educational system developed by Dorothea's governess, Madame la Rolles, and by the heroine herself, who decides to address her teachings to the mind, "rising above the Gothic resource of A B C learning," the old and barbaric notion of simple and useful learning, and instead reading lectures on "the divinity of truth, and the doctrines of political justice, till her scholars were almost as wise as herself" (2005: 160). This is the same educational model her governess had used on her and which Dorothea had used against Madame to have her fired when education contradicted the 
new philosophy she had been instructed in. Following a similar pattern, the consequences of her quixotic enterprise are not what Dorothea expected; the girls, having learnt this "flossophy" (2005: 160) challenge their parents and start a domestic rebellion in their homes with negative consequences on house economy, and a moral one that has consequences on their reputation. In addition, her most advantaged pupil applies her philosophical teachings to become pregnant and to convince her lover to rob and violently attack Dorothea. The conclusion seems to be that if Dorothea had been better educated, she would have been a more adequate educator in turn; if she had been taught to read critically, she would have taught her pupils, first, to read, secondly, to do it with a sound judgement; and, finally, had she been brought up with strict religious notions, she would not have encouraged her pupils to abandon the instruction of their religious mentor, the curate of the village. This episode, which probably echoes the Blagdon controversy involving Hannah More and her Sunday school project, ${ }^{153}$ does not condemn female education; on the contrary, it restates the value of performing it appropriately.

In this sense, the novel condones the fact that a woman may write to instruct the female readers she addresses in its introductory paragraph. The opening of the novel is immensely revealing of Bullock's purpose:

When our reformers of the present day set out in the career of destruction, overturning all those barriers which experience and wisdom have been for ages erecting and repairing; when through the breaches they make, a torrent of vice and folly rushes in to overwhelm and destroy all those soft and gentle ties which have hitherto surrounded the names of mother, wife, and daughter; when, not content with annihilating the power of reason in the stronger sex, they undertake to emancipate women from the domination of religion, gentleness and modesty: is it not time to shew the deluded victims of modern philosophy, that whilst they open the door to the new light, conjugal peace, filial affection, retiring grace, and every feminine virtue shrinking from the blaze, take that moment to depart, never more, alas! to return. (2005: 3)

${ }^{153}$ Blagdon was a small village in Somerset where More and her sisters opened one of their schools for the poor. Besides accusations of Methodism and the accusation of the abandonment of female decorum by More, the schools were accused of teaching Jacobinism. As Grenby has noted, Martha More recorded some accusations which find their way into Bullock's text; Martha stated that "the day the school was opened [it was said that] there would be the beginning of such rebellion in England as had taken place in Ireland and France" (2005: xiv). Taking into account More's emphasis on reading, and, more importantly, the reading of her moral treatises as opposed to Dorothea's radical teaching and readings, it seems possible that Bullock was not only aware of the controversy -which was well-known and followed in the press of the time- but that sided with More's stance that women from the lower classes should be educated as long as it was in the ways of the "old school." 
Bullock not only restates the need to counteract the poison with an antidote, but she erects herself as the mentor who can show the proper path to her female audience of wives, mothers and daughters. More clearly than any other work, Dorothea appeals to its reading misses and presents a narrator that, as part of that community of female writers and readers, of the collective "us" mentioned above, can educate her implied pupils. Throughout the novel Bullock employs all the common strategies of anti-Jacobin fiction to reinforce the authority of her female narrator.

Bullock utilizes the recurrent authorial comments, parenthetical addresses to the reader in brackets or direct harangues, and the first and last paragraph of the novel emphasise the narrator's role as educator of the potential female philosophers which are reading her pages. The narrator calls attention to her control of the story, making her presence even more conspicuous by metanarrative explanations which forward or rewind the plot to different moments in the various subplots; the novel is full of explanations such as "that we may not again return to so unpleasant a subject, I think it right to look a little forward, and relate the events that succeeded" (2005: 164) or "of Sir Charles readiness to do this the reader cannot doubt; it is therefore needless to pursue their dialogue verbatim" (2005: 195). Furthermore, she reinforces her authority by presenting her facts not as gross exaggerations or fictional constructions, but as events which are founded on plausible circumstances. Bullock uses personal letters, to which she attaches the heading of "copy," to convey the impression of being a transcript, and, more importantly, she places herself in a historical context which will come to prove the veracity of her arguments. Her narrator wonders whether "when future ages shall look back with unprejudiced eyes on the prosperity and abundance, which at this time were flowing upon us," they will not "think the historian is relating an improbable fiction, who adds to these annals the history of that mad and republican spirit which roamed about amongst the multitude in the years 1794 and 1795." To this question, the narrator humbly states that she is willing "to sacrifice individual rights for general credit, and to wish for the honour of [her] country, that posterity may condemn all such accounts as impossible and untrue," though she adds "as to me, who expect only to exist my little day and 
then be thrown on the shelf, neglected and forgotten, I may write of the things that are to those who can bear witness with me of their truth" (2005: 128). This reference of course includes those reading her novel in 1801, after the actual Irish rebellion of 1798. Despite these devices, Bullock's novel is clumsily developed in many aspects -there are some mistakes in the plot, the dialectal speech of some characters is not maintained consistently through their conversation, her intent is too obviously counterrevolutionary to allow a deeper interplay of history and fiction or to allow her novel to become more than a mere political tract- and the fact that there was never a second edition attests that it may not have been a popular work even in her own time.

In spite of these considerations, Bullock's novel possesses an intrinsic value to the tradition of quixotism and to the study of the satirical quixotes at the turn of the century for its portrayal of an ideological female quixote and a more political plot than many of her female contemporaries developed. Moreover, it is relevant because of the novel's subversion of its own strict conservative supersystem with arguments on female education and social duties, which result in a widening of the limited sphere in which women could act. As Grenby has stated, Bullock believes in the status quo, in things as they are, and Dorothea plays out these notions by going nowhere but coming full circle, by "returning to the place from which she started, becoming, as it were, her enervated and subservient mother" (2005: xxvi). However, Dorothea is not her mother: the narrator tells us that she takes part in the education of her children and that she has become active outside her home, improving her own community (2005: 196-7). In addition, she has proved that wives and mothers are not unnarratable heroines. The fact that Dorothea has performed her quixotic journey is already evidence that things are changing, and that quixotism has once again provided that liminal space between adolescence and adulthood, between freedom and constraint, between renovation and convention, in which the young female quixote has gained full agency and visibility even if only temporarily. No matter how conservative the discourse in which quixotism is framed might be, quixotism will always bring to it its elements of subversion and escape. Furthermore, it provides the heroine with the chance to become a model for other female readers who dive into her 
RADiCAL AND SENTIMENTAL FRANCOPHILE QuiXotes: JANE WEST AND Mrs BULlock

quixotic narrative for a temporal exodus to that threshold between reality and fiction that allows them to escape their own world of constraint. 
3. Female Quixotism in America, OR, the Seductive Dangers of LITERATURE

Virtue, Virtue alone....is the basis of a Republic.

The subjects of novels are by no means accommodated to our present manners. They hold up life, it is true, but not as yet life in America. [...] as yet, the intrigues of a British novel, are as foreign to our manners, as the refinements of Asiatic vice.

Dr Benjamin Rush

I say then that national Morality never was and never can be preserved without the utmost purity and chastity in women [...] without national Morality a Republican Government cannot be maintained. Therefore my dear Fellow Citizens of America, you must ask leave of your wives and daughters to preserve your Republick.

Democracy is Lovelace and the people are Clarissa [...]. The artful villain will pursue the innocent lovely girl to her ruin and her death.

President John Adams

\subsection{Dangerous Readings: the Literary Context of Quixotic Seduction in America}

As attested by the aforementioned statements by President John Adams and the physician, moralist and educator, Dr Rush, in North America the development of the "family-politic" trope also found its place in political rhetoric. As was the case in Britain amidst the ideological and literary wars, family was the core of the newly-independent American nation and their emblems were, once again, its female members and their virtue. Particularly in the context of the creation of a political faction known as republicanism, to which Adams belonged, the ideas of virtue and ideology were intertwined. As Kerber (1980) has attested in her study of Revolutionary America, there existed a notion of republican motherhood, which equalled civic duty in the sense that women should be raised to uphold the ideals of republicanism and to pass on republican values to the next generation. Adopting the Roman republican model, the virtue of American women was set up as the moral barometer of the whole nation, and the nostalgic ideal of the Roman matron, an exemplary citizen in her role of wife, mother and philanthropist was held as the mirror in 
which young American women should seek to find themselves (Bannet, 2000; Kerber, 1980; Wood, 2005). Relevantly, throughout the long eighteenth century, not only the rhetoric of virtue, but also allusions to literary works that revolve around it, permeate political speeches -as in Adams's second comment above- evidencing that novels and politics go hand in hand and contaminate each other's discourse, and emphasising the moral and ideological subtext almost always hidden in the more entertaining form of the novel.

Precisely because the novel could be used to convey more than aesthetical messages did moralists and authors themselves develop the same debate on the novel and its appropriateness which had taken place in Britain some years before, especially concerning the more vulnerable members of society: women. While there would still be dissenting voices which absolutely condemned the reading of romances or novels, while conduct works that circumscribed female learning and reading were still immensely popular -including the omnipresent tracts by Fordyce or Gregory-, American novelists would more overtly defend the need to enhance women's education, and to include reading in any educational programme undergone by young ladies. In order to support this last argument, novelists would once again adopt the self-condoning argument of the need to counteract the poison with its own appealing form. In particular, American writers would explicitly condemn romances and its association with fancy, and, in particular, with women's proneness to be subject to their emotions or distempered imaginations. In opposition, the novel would respond to a more "truthful" and hence "useful" representation of reality, which would in turn answer to the New England Puritan heritage (Mulford, 1996: xxi). Novels would appeal to the reader's common sense or reason, and would therefore counteract the extravagant, old-fashioned and morally questionable notions epitomised by romance. Romance would become intertwined with the plot of seduction that British novelists had developed: once the young reader's fancy was inflamed, the rake had only to employ her delusion to his advantage. Reading romances then precluded ruin. In addition, for American authors, as for British ones before them, romance would appear as something foreign and subversive to their own nationalistic and moral values: by ruining women the rakes also undermined the basis of national stability, as seen in the before 
mentioned anti-Jacobin novels. However, in another turn of the screw, it is not only romance, but also novels which can be associated with foreignness and moral decay. In the same manner romance had been associated with France, so are novels imported from Britain considered to be dangerous for the emblem of the status quo, female virtue.

In this line, at a time when quixotic fictions are identified as a "locus of contradiction" that allowed early-republican authors to "explore and articulate the complex double-consciousness that permeated both the literary and political landscape of the period," as well as a "formative genre" that "crossed the boundaries of established fictional forms" to interrogate the possibility of "an autonomous American identity and a differentiated American art" (Wood, 2005: viii) the fact that many quixotes at this time are women is extremely relevant. As it did during the revolutionary period in Britain, this fact emphasises the abovementioned discourse that fused expectations about gender, genre and the building of the concept of nation, also explained in chapter two. These quixotic women are conceived as cautionary figures who appear misguided in their mimetic approach to literature. However, it is not the fact that they mimetically reproduce what they read that is dangerous, it is the unsuitability of the models they have chosen which renders them aliens to their own society and, finally, ineffectual citizens. As Gillian Brown has phrased it:

[...] the waywardness of quixotes' reading arises from the fact that their reading doesn't accord with peer perceptions and valuations of literary and real objects. The quixotic reader fails to conform with the local standards by which an individual lives as a member of a given society -she doesn't share the same sense of reality. Far from being too mimetic, she fails to be mimetic enough -that is, mimetic of what everyone else mimes. She is, we might say, mimetically incorrect. So the quixotic fallacy would appear to be a fable about solipsism and the function of the quixotic fallacy in early America would appear to be proscription of both any remaining pro-British sentiments and any objections to the republican processes of building a union. (1999: 259) ${ }^{154}$

However, there could be a hope of cure for the female quixote by developing a plot in which the quixote's senses were restored and she was happily accepted within a society again congenial with her own expectations. That is, early

${ }^{154}$ Gordon also perceives this epistemological separation as the underlying basis of female quixotism and its dangers as presented by Lennox and Tenney: the quixotes do not share the perception the surrounding characters have in common (2005: 131). 
American quixotic fiction searched for a positive pattern of female bildungsroman that reinforced the discourse of unity and uniformity as this new society emerged. As Brown has insightfully commented:

American identification is demonstrated in the narrative plot transforming the quixote into an exemplary citizen. What is crucial to the fables of quixotism is not the repudiation or elimination but the conversion of the quixotic reader. As the object of conversion -conversion into a model worthy of emulation- the quixote commands both sympathy and respect [...]. The reinstatement of conformity inevitably results in the quixotes' acknowledgment of their folly and endorsement of reality. Ultimately quixotic mimeticism leads to social mimeticism, with the quixotes joining and affirming a common reality. (1999: 260)

In this sense, even the epitomes of British moral narrative fiction could appear as the source for the delusion and ulterior ruin of the young and innocent female characters portrayed by American authors. For instance, an American poet, John Trumbull, wrote in 1773: "Harriet reads, and reading really/ believes herself a young Pamela" (qtd. in Brown 1999: 251). The main problem of believing oneself a Pamela or a Clarissa, the most recurrently mentioned literary female models in eighteenth-century North America, was that women could "forget the circumstances of life in America" (1999: 251). As was the case with the quixotic heroines of West, and later, Barrett, Green or Hamilton, the foreign narrative fiction American quixotes read leads them to fantasise about a self and a society that is not in accordance with the one they live in. Although the political implications are subtly conveyed in the threats women's loss of virtue has for their families and their estate, the novels revolve around feminocentric plots of courtship and seduction and how their quixotic delusion ultimately enables their fall. These novels recurrently establish the connection between female virtue and reading, and how literary seduction may preclude a physical one.

In this regard, with their own seductive appeal for young readers looking for a moral in a pleasing dress, novels could therefore serve as a moral warning with regard to the greatest crime against women and the ethics they embody: seduction. In fact, some of the more relevant examples of early American novels dwell extensively on the matter of female seduction by a rake. In these novels, literary seduction is symbolised by or culminated in the actual physical 
fall. Two pertinent examples stand out in eighteenth-century American narrative fiction, William Hill Brown's The Power of Sympathy: or, The Triumph of Nature, Founded on Fact (1789) and Hannah Webster Foster's The Coquette; or, The History of Eliza Wharton; a Novel; Founded on Fact (1797), two novels that serve to illustrate cotemporary opinions towards women readers and the dangers of fiction, and that, consequently, provide a context for female quixotism on the other side of the Atlantic. Despite the usual employment of the tag "founded on fact" as a mere device to provide reputability to a work of pure fiction, both novels actually have as a source true-life events which were amply known throughout the New England territory and which their readers would have immediately recognised in their narratives. In 1788 the papers talked of the death of a young and genteel lady of puerperal fever in an inn; this lady was later discovered to be the welleducated and poet Elizabeth Whitman, who, pregnant and unmarried, had left her home to give birth in anonymity, dying a few days after delivering a stillborn child. Whitman, connected to the clerical and intellectual elite, known for her "wit, intelligence, and her charm," seemed completely out of place in an inn, seduced and abandoned (Davidson, 1986: viii). As Carla Davidson has pointed out, the mysterious circumstances of her life and death led to the transformation of her story in a cautionary tale for young ladies, when journalists and moralists started to construct a literary version of Whitman's story, conjecturing on her character and her circumstances, trying to make "meaning -their meaning- of her otherwise perplexing end" (1986: viii). Her story became a moral warning against reading; as could be seen in a newspaper of 1788, she was described as "a great reader of romances, and having formed her notions of happiness from that corrupt source, became vain and coquetish (sic)" (qtd. in Davidson, 1986: x). That this version of her story was widely spread is evidenced by the fact that Jeremy Belknap, a clergyman and historian, pointed out the story to Rush, so he may use it in some of his "moral Lectures to young Ladies," highlighting that Whitman "was handsome genteel \& sensible but vain \& coquetish (sic), a great reader of Romances" (qtd. in Mulford, 1996: ix). In the context of the rising debate on the dangers or benefits of female education and of the association of the novel as a genre with female readers, these early accounts of Whitman's story of fall and death, of 
her transformation into the epitome of "The Fallen Woman," served a dual purpose: to criticize any "intellectual pretensions that a woman might possess," and to condemn "the novel as a new literary form which particularly fostered just such pretensions in its women readers while simultaneously sanctioning any promptings toward licentiousness;" Whitman then becomes "a case study of a woman first misled by her education into a taste for novels and then corrupted through indulging that unwholesome appetite" (Davidson, 1986: ix). The aforementioned two novels fictionalising Whitman's story, then expose the complicated relationship between fact and fiction, between the actual Whitman and the one created by the moral story that was circulated, to offer a comment on novel writing and reading, on women's education and on the moral health of the American nation.

William Hill Brown (1765-1793) writes an epistolary fiction often identified as the first American novel. In it, he explores different variants of the plot of seduction. Besides the main -and forthright- didactic plot, Brown employs techniques similar to that of the British conservative authors and reinforces his supersystem by including in his main narrative three interspersed stories which reinforce his discussion of the evils of seduction. All these stories, including rape, incest and death, emphasise the dangers of immorality for the succession of families and their wealth. In the context of this moral discourse and preparing the way for later American female quixotes, Brown refers extensively to the power of literary seduction. He includes a reference to "the story of Miss Whitman" in the midst of a chapter exclusively devoted to his characters' discussion on women's education and reading. Including an extensive footnote in which her fictionalised story and pieces of her repentant writing are included, Brown echoes the newspapers when he states that "she was a great reader of novels and romances, and having imbibed her ideas of the characters of men, from those fallacious sources, became vain and coquetish (sic), and rejected several offers of marriage, in expectation of receiving one more agreeable to her fanciful idea" (1996: 23). Heard only from the margins of the novel's paratext, Whitman's voice is subordinated to the implied author's. Within the narrative itself, Mr Holmes and his daughter-in-law, the moral spokespeople in the novel, assert that her story is "an emphatical 
illustration of the truth" that "an inflated fancy, not restricted by judgement, leads too often to disappointment and repentance," reaching the conclusion that "many fine girls have been ruined by reading Novels" (1996: 24-5). This ruin is a consequence of how novels mislead innocent and inexperienced female readers in their ideal presentation of men: having acquired from novels their ideas on the "faithfulness of friendship" or the "constancy of true love," they will be disappointed; moreover, being "unconscious of deceit," the young reader "will be easily deceived -from the purity of her own thoughts, she trusts the faith of mankind, until experiences convinces her of her errour (sic)- she falls a sacrifice to her credulity, and her only consolation is the simplicity and goodness of her heart" (1996: 23). Brown then portrays a more benevolent approach to the deluded readers, whose libraries are "overrun" by novels which are "built on a foundation not always placed on strict morality, and in the pursuit of objects not always probable or praiseworthy" (1996: 21). By means of his moral alter egos, Brown offers the remedies to this moral and epistemological confusion of literary origin: "immoderate reading" is counterbalanced by "conversation" in which to put the ideas extracted from reading to the test of an informed exchange of opinions. In addition, other genres should be perused: a knowledge of history unites instruction and entertainment, while poetry "enlarges and stretches the mind, refines the taste and improves the judgement" (1996: 26), even in such an unfeminine form as satire, which is "the correction of the vices and follies of the human heart," so that a woman may "read it to advantage" (1996: 27). Later, the hero of the novel, Mr Worthy, criticises the fact that women's reading is often limited to novels, and, more importantly, novels that are confined to shallow topics as dress, balls, or such other "edifying topicks" (1996: 29). He deplores the effect they may have on female readers' minds thus:

I will not dispute whether the Novel makes the woman, or the woman makes the Novel; or whether they are written to engage your attention, or flatter your vanity. I believe the result will shew (sic) they depend, in some measure, upon each other; and an uninformed woman, by reading them, only augments the number of their futile ideas. The female mind, notwithstanding, is competent to any task, and the accomplishments of an elegant woman depend on a proper cultivation of her intelligent powers; a barrenness -a sterility of conversationimmediately discovers where this cultivation is wanting. (1996: 29) 
In this regard, not all novels prove pernicious, and Brown defends those that "contain excellent sentiments" (1996: 21), which, with the abovementioned enhancements to women's education, can be beneficial for their female readers. He praises methodical reading (1996: 22) and "those books which teach us a knowledge of the world," which "are useful to form the minds of the females, and ought therefore to be studied" (1996: 25). Brown's work dialogues with many prior works of fiction, from Shakespeare's plays, to the more sentimental poems by Ossian or Goethe's Werther, including references to Sterne, Swift, Milton, Dryden or Pope, and even transcribing his own poetry. His hybrid form of prose fiction then allows both the defence and the condemnation of the novel, distinguishing between educational and pernicious fiction, and hailing once again the principle of utile et dulce.

These ideas are recurrently voiced by Mrs Holmes in her letters to her young friend, Myra. After sending her a work entitled "A Lady of Quality's Advice to her Daughter," which she does not recommend to her "as a Novel, but as a work that speaks the language of the heart and that inculcates the duty we owe to ourselves, to society and the Deity," Mrs Holmes continues thus:

DIDACTICK essays are not always capable of engaging the attention of young ladies. We fly from the laboured precepts of the essayist, to the sprightly narrative of the novelist. Habituate your mind to remark the difference between truth and fiction. You will then always be enabled to judge of the propriety and justness of a thought; and never be misled to form wrong opinions, by the meretricious dress of a pleasing tale. You will then be capable of deducing the most profitable lessons of instruction, and the design of your reading will be fully accomplished. (1996: 53)

Opposing the experience of this informed female reader to that of Whitman, Mrs Holmes then concludes: "hence you will be provided with a key to the characters of men: To unlock these curious cabinets is a very useful, as well as entertaining employment" (1996: 53). A lady's knowledge of the world, still restrained, can be expanded by her reading, which provides the critical reading of textual bodies so relevant for the preservation of her virtue. In addition, Brown's Mrs Holmes also distinguishes between American and British productions, and the relative truthfulness of descriptions or values portrayed in the latter. Again in a letter to her young female protégée she states: 
I am sometimes mortified to find the books which I recommend to your perusal, are not always applicable to the situation of an American lady. The general observations of some English books are the most useful things contained in them; the principals parts being chiefly filled with local descriptions, which a young woman here is frequently at a loss to understand. (1996: 53)

Furthermore, British novels fail to commend female education as they should. Mrs Holmes writes to her "dear friend" that she is "sensible of the ridicule sometimes levelled at those who are called learned ladies," although in her opinion her friend should not be "apprehensive of acquiring that title" (1996: 56). More importantly, she places the source of this ridiculous portrayal of the learned ladies in Britain:

This ridicule is evidently a transatlantick idea, and must have been imbibed from the source of some English Novel or Magazine - The American ladies of this class, who come within our knowledge, we know to be justly celebrated as ornaments to society, and an honour to the sex. When it is considered how many of our countrywomen are capable of the task, it is a matter of regret that American literature boasts so few productions from the pens of the ladies. (1996: 56)

The "dear friend" who has been reading these moral letters, both Brown's and Holmes' addressee, is encouraged to become not only a learned lady, but maybe to contribute to the literary panorama of the New World. The female reader is then made aware of the difference in transatlantic ideals and the supremacy of American advancement of female education and even female authorship. Of course, not all literary imports are absolutely pernicious, although all can be subject to qualification, and a female reader may find a spark of truth even in the work of Swift, who, "not celebrated for delicacy or respect" towards women, nevertheless provides in his letter to a lady the satirical portrait necessary to enhance self-reflection and an appetite for instruction (1996: 56-7), both an antidote to literary poison. In summary, Brown advocates the importance of female education and of extensive reading as an important part of it, claiming that "among all kinds of knowledge which arise from reading," a principle of "self-correction" or "the duty of selfknowledge is a very eminent one; and [...] the most useful and important" (1996: 27). Making explicit the emphasis on self-awareness of Austen's and 
Edgeworth's later novels, in his early and influential work of fiction Brown highlights the pattern of delusion and awareness that later American novelists will develop in overtly quixotic female characters.

Many of these topics will be developed more thoroughly and will be better integrated into fiction by Hannah Webster Foster (1758-1840) in The Coquette; or, The History of Eliza Wharton; A Novel; Founded on Fact (1797), one of the most popular and reprinted novels of the time. In her epistolary novel, Foster fictionalises the history of Elizabeth Whitman. In a very interesting reconstruction of true events, Foster does not adhere completely to the sketchy vision of the papers or of early moral writings, and aims to convey a more plausible psychological portrait of the fallen woman by means of her letters. The protagonist of the novel, Eliza Wharton, a very thinly veiled reference to Whitman, is a beautiful, charming, witty, accomplished and even sensible young woman, with one flaw: her fanciful whims. This fancy, inflamed by flattery and gaiety, nurtured by a love for the fashionable pleasures of the world and by a desire to enjoy them in freedom until it is the time to relinquish them in marriage, slowly precipitates Eliza to her downfall. At the beginning of the novel, Eliza expresses her relief at being released from an early arranged marriage by the death of her first suitor, the Reverend Mr Haly, whom she had taken care of in the last months of his life. Entering the world under the supervision of her relatives, the Richmans, she soon becomes a popular addition to any society. Courted by the Reverend J. Boyer and by the rake Major Peter Sanford, she will be torn between duty and propriety, and her own inclination. ${ }^{155}$ The novel then displays her complex reasoning in order to decide, while hoping to prologue her freedom as a single woman. In the end, she enters into an engagement with Boyer, who, nonetheless, seeing her in a private interview with Sanford, rejects her and later announces his engagement to a more suitable woman for a man of his position and aspirations, repeatedly pointing out to Eliza her frailties. In the meantime, Sanford marries for money and makes his exemplary wife miserable. In the end, he achieves Eliza's

${ }^{155}$ Haly and Boyer recall Whitman's own suitors, reverends Joseph Howe and Joseph Buckminster. The identity of Sanford still remains a conjecture, although it is probable that Foster knew it, given her husband's family connections with the Whitman's (Davidson, 1986: $\mathrm{xi}$. 
seduction and the heroine ends like her real-life namesake, while Sanford, bankrupt and condemned by society as a whole, flees the country.

Despite this apparently straightforward representation of the Whitman story, Foster challenges many of the stereotypical assumptions about reading women that early accounts portrayed. Although she is a great reader of novels, Eliza's misperceptions or misconceptions are not explicitly formulated as the consequence of her readings alone. While in her last distracted state she asks her friends for plays and novels, for her mind cannot endure serious reading (1996: 193), before that the reader has been told that "she discovers a fund of useful knowledge, and extensive reading, which render her peculiarly entertaining" (1996: 140). The most important part of Eliza's faulty perception of reality is, first, her reading of her possibilities in society as a woman, and, secondly, her reading of Sanford under the popular belief, represented in many novels, that "a reformed rake makes the best husband" (1996: 146), the presupposition that Foster's novel most ardently aims to deny. Although not explicitly called a quixote, Eliza's delusion takes the shape of a romanticised vision of reality, which springs from literature and an overactive imagination alike, aided as well by her inexperience. For most part of the novel, Eliza's train of thought is referred to with words often associated with quixotism, such as "error," "fancy" or "imagination," and her aspirations to female freedom or to a reformed rake as a husband are identified with "delusions of fancy" (1996: 145, 149), an "ignis fatuus" (1996: 149) or "phantom" (1996: 113), which she pursues and of which she must awake. Eliza very honestly asks Boyer to delay their marriage, and claims:

Self-knowledge, sir, that most important of all sciences, I have yet to learn. [...] I have looked but little into my own heart, in regard to its future wishes and views. From a scene of constraint and confinement, ill suited to my years and inclination, I have just launched into society. My heart beats high in expectation of its fancied joys. My sanguine imagination paints, in alluring colors, the charms of youth and freedom, regulated by virtue and innocence. Of these, I wish to partake. [...] I recoil at the thought of immediately forming a connection, which must confine me to duties of domestic life, and make me dependent for happiness, perhaps too, for subsistence [...] I would not have you consider me as confined to your society, or obligated to a future connection. Our short acquaintance renders it impossible for me to decide what the operations of my mind may hereafter be. You must either quit the subject, or leave me to the exercise of my free will, which perhaps may coincide with your present wishes. (1996: 126) 
The emphasis on Eliza's self-knowledge and her desire to gain experience so as to decide what she wants her place in society to be, highlight the before mentioned idea that the focus on a reading woman leads to a story of female development and, ultimately, to a euphoric or dysphoric story of social integration. In this plot of self-discovery, once more built around a period of courtship, the perception of the good and bad suitor is essential. In this sense, the epistolary form, once again, serves the purpose of displaying the difficulties of reading others under the deceitful veil of language and emphasises one of the main questions of the novel: "to what extent does language construct us all?" (Mulford, 1996: xlviii). Sanford, for instance, employs all his rhetoric weapons to seduce Eliza, and she cannot read him adequately. In the early stages of Sanford's courtship, Mrs Richman warns Eliza:

I do not think you seducible; nor was Richardson's Clarissa, till she made herself the victim by her own indiscretion. Pardon me, Eliza, this is a second Lovelace. I am alarmed by his artful intrusions. His insinuating attention to you are (sic) characteristic of the man. [...] Your own heart is too sincere to suspect treachery and dissimulation in another; but suffer not your ear to be charmed by the syren (sic) voice of flattery; nor your eye to be caught by the phantom of gaiety and pleasure. (1996: 134)

This reference to Clarissa forewarns the tragic ending, while the delusion of the senses is emphasised with recurrent allusions to Sanford's charming words, or to Eliza's blindness to his immoral nature. Foster employs the semantic field of vision to refer to her heroine's delusion, something recurrent in later novels of female development, especially those with a quixotic figure at their core. Her more insightful friends state that "she is strongly blind to the vices and imperfections of this man. Though naturally penetrating, he has [...] cast a deceptious mist over her imagination, with respect to himself" (1996: 194). Even the intelligent Eliza opposes the "scrutinising eye of a refined understanding and taste" to her fancy for Sanford (1996: 175), although the latter finally wins. Julia Granby, the exemplary model in the novel, has a more penetrating eye for Sanford and she becomes the greatest advocate against the plot of the reformed rake.

As her fall becomes eminent, Eliza's mind is increasingly distracted and rendered useless by her extreme sentimentalism and morose romanticism, 
which would make "a very pretty figure in a novel" (1996: 190) but which propel her ruin. Her blinding affection is substituted by the "indulgence of melancholy" and immobility which is compared to a "cloud which hangs over [her] imagination" (1996: 195). Julia mentions that "her mind is surprisingly weakened" and that she yields to her "own imbecility," renouncing even to her favourite pastime, writing (1996: 211). Finally, the number of references to her madness reaches its peak at the end of the novel, when Eliza has been ruined and she must face the consequences of it. Only when death approaches does Eliza fully awaken and recover her senses enough to enforce a moral on Sanford and to regain her lost piousness. Foster then portrays delusion as the consequence of inexperience, innocence and lack of reflection to counteract fancy, especially when fuelled by literature; however, she reverses the traditional pattern of the young girl's awakening by proving that her contact with the world can be even more damaging for her, both physically and mentally: the virtuous and romantic Arabella has become Miss Glanville or Miss Groves, the innocent quixote has turned into a fallen woman. Dead to society, Eliza regains her senses and herself, if only to abandon once again the world, this time literally.

Finally, adding to these matters which other American quixotic narratives will resume, Foster hints the political implications of Eliza's fall. At one point her mother, the epitome of pious and domestic virtue, comments on Eliza's concept of freedom and constraint in the following terms: "what [situation] is not [dependant]? Are we not all links in the great chain of society, some more, some less important; but each upheld by others, throughout the confederate whole?" (1996: 136). For a time, Eliza is a member of that confederacy and there is hope for her to become a truly republican matron, just like Mrs Richman. An exemplary wife and mother, Mrs Richman is described as "truly Roman; and what was more [...] truly republican" (1996: 139); a statement reinforced after Eliza and her participate in a debate on politics, defending that patriotism is not “a masculine passion only" (1996: 139). However, Eliza's sin and death, alone and far away from her loved ones, reveals how she has failed to fulfil her duty as daughter, wife, mother and even citizen, for, as wife either of a pastor or a gentleman she could have enacted the charity for which she is 
known (1996: 144). The seduced Eliza then loses her place in society and even her voice as a writer, which gradually disappears until it is completely erased by her death.

With their feminocentric narrative fictions and their discourse on the dangers of reading, Brown and Foster then built the context and set relevant precedents for subsequent novels in which a female quixote would be placed in the spotlight. Although Tabitha Tenney's Female Quixotism (1801) is the best developed and well-known example, there are others which resume very explicitly the topic of seduction by literary imitation, as is the case of Leonora de Sansay's Laura. By a Lady of Philadelphia (1809). An extraordinary woman, a survivor of an abusive husband and even a political conspirer, ${ }^{156}$ Sansay claimed that her most important novels, including Laura, were partly autobiographical and, in her preface to the latter, she employs the device of the claim to authenticity stating that "with the exception of a few slight deviations, which were thought indispensable, the following narrative is a faithful account of real occurrences" (2007: 156). Moreover, as her scandalous life story was probably known, she claims her wishes would be gratified "should the little book interest, and have a tendency to promote virtue" (2007: 156). Indeed, her novel becomes one of those quixotic cautionary tales that became a hallmark of early American literature.

Laura tells the story of two women deluded by the romantic notions acquired from their extensive reading. First, Laura's mother, Rosina, is entrapped in a nunnery in Lisbon against her wish. The brother of her most dear friend, Cecilia, comes to the nunnery to deliver a letter from his sister, who wishes in it that "the spirit of knight-errantry would seize him, and that he might bear you from your hated prison" (2007: 158). After reading the "story of some beautiful lady delivered from enchantment by a valiant knight" (2007: 160), Rosina elopes with him to America. Married to him, after he dies she is nevertheless disclaimed by his family and her friend, and she is left to experience the hardships of poverty and single motherhood, treated like a fallen

\footnotetext{
${ }^{156}$ For a brief account on Sansay's extraordinary life, see Jennifer Ban Vergen's text "Reconstructing Leonora Sansay" <http://www.a-w-i-p.com/index.php/2010/01/03/ reconstructing-leonora-sansay> or the introduction to the Broadview edition of Laura (2007).
} 
woman despite her widowhood. Her "extreme beauty $[\ldots]$ industry, and domestic habits" (2007: 161) make another man propose and, although this time she marries not in love, she performs her duty as wife and mother. Nevertheless, she overindulges the daughter from her first husband, Laura; with her she "shared every sentiment of her heart" and even instils in her daughter exalted "holy visions" (2007: 162). However, when Laura is only fifteen, Rosina is seized with an illness and dies, not without exclaiming: "Ah why can I not live to direct thee -to save thee from the dangers to which thou wilt be exposed!" (2007: 162).

Appropriating the language of sentiment, Laura is left without "sympathy," for no one else's heart can she claim "kindred" (2007: 163), while the seclusion in which she has lived, gives her a shade of melancholy; behaving like a sentimental heroine, she then seeks for loneliness and dwells in her grief. In her solitary walks she is marked by Belfield, a young medical student, who approaches her when having to flee to her assistance. He is thoroughly described with all the clichés of a hero of romance and behaves like a man of feeling, returning to the place where they had met, and crying and exclaiming in a highly sentimental language. With Belfield, "a new world of feeling opened before her" (2007: 171). The narrator explains that "of the world she knew nothing but what she had learnt from books. With those books Belfield had supplied her. From him she derived her improvement, and to him she returned her acquired ideas, newly modified and embellished by all the imagery with which a glowing fancy adorns an interesting subject" (2007: 171). The main work that Laura peruses under Belfield's supervision is Pope's "Letter of Eloisa to Abelard:"

She read [these books] with avidity and infinite pleasure, but it would be vain to attempt describing the effect produced on her ardent imagination by Pope's letter of Eloisa to Abelard. In every passage she discovered sentiments of which she felt herself susceptible, and to experience, even during a short interval, the tenderness, the passion, the transports of Eloisa, she thought would be cheaply purchased by a life of torture. Fatal illusion! which was still more fatally augmented when she heard the eloquent, the pathetic voice of Belfield, repeat the tenderest, the most impassioned lines of that dangerous poem. (2007: 167) 
Laura then mimetically identifies with Eloisa, making Belfield her object of adoration. Her lover becomes the object of her obsession, he becomes her quixotic dulcinea. To him Laura repeats Eloisa's words to Abelard "not on the cross my eyes were fixed, but you" (2007: 172), emphasising the abandonment of sanctioned Christian morality in her delusion. At the same time, differing from other quixotic narratives, Belfied is the one who enables her quixotism, thus not fulfilling his role as mentor. She tells him "I am your creature" (2007: 172). According to Brown, this passage highlights one of the tenets of American female quixotism, inherited from Steele, Barker or Lennox:

\begin{abstract}
One of the predominant worries about women becoming quixotic readers was that they would then be easily subject to seduction and ruin. Once a woman thought herself Pamela or Eloisa, she became susceptible to anyone willing to play Mr. B or Abelard to her heroine. Quixotism thus could facilitate seducers in doing what they would with women, but interestingly, only if seducers would enter into those women's literary expectations. While quixotic women may become literally more manipulable in tableaux designed to approximate romances already familiar to them, their susceptibility depends upon seducers meeting their literary demands - by conforming to the manners and matter of their sexual imaginations. Even if Belfield initiates Laura's seduction by furnishing her with a guidebook for erotic love, his plan can only succeed if Laura finds "pleasure" in the "transports of Eloisa". (1999: 256)
\end{abstract}

That is, while Belfield opens the door to Laura's quixotic obsession, it is her own sexual susceptibility which engrains her fixation for her lover. Moreover, it is the actual possibility of living her literary experience which characterises Laura's quixotism. As Brown has asserted, "objections to quixotic and pornographic reading, then, register anxieties not about the role of fiction in life [...] but about the uses of the similitudes between fiction and life" (1999: 257), and while other quixotes are characterised by the incongruity between life and their literary expectations, "in the case of Laura, by contrast, her experience is continuous with her reading, indeed overdetermined by it -the story of her life is an old story" (1999: 257).

Notwithstanding Laura's eagerness to perform the part of Eloisa, Belfield also plays the role of Abelard to perfection, even reciting to her his own words in the poem. Surprised by her "flights of genius" and delighted "with the charms of her imagination," he "bowed involuntarily before the work of his own hands" (2007: 172). Belfield is one of the Pygmalionic figures portrayed in 
narratives of seduction, in which both the proper and improper suitor aim to seduce the young quixote into their worldview and set of principles, as happened in Foster's novel or in any of Austen's. It is indeed Laura's obsessive and secret love for Belfield which will lead to her ultimate fall. She elopes with Belfield into the country, where she finally loses her virtue. After a series of misunderstandings, they are separated and Laura, treated with unkindness and being exposed to the gossip of the world, finally finds refuge with another abandoned woman, Sophia. Belfield is pardoned and reunited with her. A secret marriage takes place. Nevertheless, Laura's reputation is sullied by the secrecy of her union, and Belfield finally dies fighting a duel to defend her honour. Laura is left like her mother at the beginning of the story: a widow and a mother who has to fight for survival in an unsympathetic society with only her "intuitive wit and wisdom" to guide her (Drexler, 2007: 33).

Despite the positive light under which deceived women are placed, the required moral conclusion necessarily undermines the possible subversive reading of the novel when the narrator states that "perpetual uneasiness, disquietude, and irreversible misery, are the certain consequences of fatal misconduct in a woman" (2007: 222). However, the novel does reinforce its argument of women's defencelessness by the fact that it is more ruthlessly merciless with the male seducer, the enabler of the heroine's quixotism and fall, who dies in a duel he is forced to fight to reclaim a reputation that Laura had lost for his own unwillingness to claim her publicly as his wife (Drexler, 2007: 33). Despite Belfield's love or the fact that he finally marries Laura, the result of literary and sexual seduction is once again isolation and then death, the impossibility to become acceptable and accepted members of the community, particularly in the case of Sansay's suffering and romantically-deluded women.

\subsection{Tabitha Tenney's Female Quixotism, or, the Siege of Virtuous America}

Still little is known about Tabitha Gilman Tenney (1762-1837). Of the scarce information existing, it is relevant to point out that she is said to have been raised in a "Puritanical, bookish, and secluded manner" (1992: xxiv); that she 
married Samuel Tenney, fourteen years her senior, at twenty-six; that she wrote a conduct book for young women entitled The New Pleasing Instructor in 1799; that she followed Tenney to Washington when he was elected Senator in 1800; and that her most famous work, Female Quixotism: Exhibited in the Romantic Opinions and Extravagant Adventures of Dorcasina Sheldon was published anonymously in 1801. After her husband's death in 1816, Tabitha apparently devoted her life to needlework and did not seek further publication. ${ }^{157}$ Female Quixotism follows its novel-reading protagonist, the motherless Dorcas Sheldon, from her youth to her old age. It focuses on Dorcas's quixotic passion for British novels and her performance of literary plots which revolve around the quest for a romantic hero. Dorcas, who changes her name to the more romantic "Dorcasina," encounters a series of suitors which she quixotically reads under the tenets learnt from fiction, becoming the dupe of wicked pranksters and fortune hunters, and even of her very own friends, who aim to use her delusion to protect her from others. In the end, Dorcasina returns to her identity as Dorcas and as an unmarried philanthropist who warns other young girls against the dangers of reading.

Resuming the common places of female quixotism inherited from Lennox and the British quixotic tradition, Tenney, however, does not portray a mere quixotic buffoon, but constructs a complex character that can be read as a cautionary figure for those readers who equally refuse to "grow up," who equally escape their civic duty as women by means of "un-republican ideals or distinctly un-American attachments," as well as a tragic example of the difficulties of trying to "grow into the republican ideals of womanhood available to her," of trying to develop a "quest for individuation" in the midst of society's pressure to become a self-sacrificing wife and mother (Wood, 2005: 166). Tenney's text, thus, inherits all the complexities of the quixotic tradition, together with those that the ideal of republican motherhood imposed on women readers and women writers, both seen as "two sides of the same 'quixotic' coin" (Wood, 2005: 172) in America's new republic as it had been in

${ }^{157}$ Biographical references are scarce; a very brief account appears in A Dictionary of British and American Women Writers 1660-1800 (1987), p. 302, while the best account still remains Nienkamp and Collins biographical sketch in their introduction to the novel (1992), pp. xxiii-xvi. 
Britain. Consequently, her novel provides relevant insights into the literary and political issues of her time, as well as a relevant instance of the use of a quixotic fiction as the locus for their discussion in early-republican America.

\subsubsection{Quixotic Characterization and Plot}

As stated above, Tenney inherits many of the traits of her narrative from Charlotte Lennox's Female Quixote. The similarities are obvious. Firstly, the absence of the mother figure at the age of three; the heroine's romanticised reading of the world; the interspersed nature of their delusion, limited to courtship and love; the fact that both quixotes have a Sancho-like companion, that they reject their father's proposed suitor, or that they have been endangered by their perusal of foreign literature, whether French romances or British novels. However, the disparities are maybe more relevant to understand the context of the blooming American novel and Tenney's contribution to the tradition of female quixotism. First of all, while Arabella is a true romantic heroine, Dorcas is never more than a parody of one. Dorcas's childhood years are retold in parallelism with Arabella's, with her instructors and her quick improvement, but this only serves to highlight the subsequent unromantic contrast. Instead of a being introduced with all those charms "with which almost all our heroines of romance are indiscriminately decorated," Dorcasina is described as of a "middling stature, a little embonpoint, but neither elegant nor clumsy" (1992: 5). In addition, her features are "remarkable neither for beauty nor deformity," in short, "she was a middling kind of person; like the greater part of her countrywomen; such as no man would be smitten with at first sight, but such as any man might love upon intimate acquaintance" (1992: 5-6). Dorcas is not the exception, but everywoman; Tenney then places at the centre of the novel an ordinary heroine, which stresses both the possibility of every female reader to identify with her quixote, and the sense of individuality built within a community: the quixote stands out because of her delusion, but she is just like anybody else. 
The most striking and important difference with Arabella is that Dorcasina's story has the most unromantic and pathetic ending imaginable for a sentimental heroine: neither dying nor marrying at her prime, but decaying into old age and ridicule, Dorcasina remains a less ambiguous parodic and didactic instrument than Arabella is. In addition, Dorcasina is a much more adventurous heroine than Arabella: she forces action to take place and hence challenges the conventional conceptions on female decorum and boundaries within the domestic sphere. The quixote and her faithful Betty do not spend much time delivering flowery speeches on romance, but rather live adventures in which they are abducted, locked up, beaten or cross-dressed. In their adventures, Dorcasina and Betty encounter men from all social strata and the narrative of their adventures then provides a wider window to American society than the one Lennox's upper-class and domestic heroine's circumscribed range of action offered British readers to perceive their own social milieu.

In this sense, what is truly innovative about Tenney's novel is how it resembles the original novel by Cervantes more than those by other female emulators. ${ }^{158}$ For instance, Tenney's portrait of an old quixote defeated in her quest and cured of the illusion which fuelled her life, comes closer to Cervantes' more thorough anti-romantic message. Moreover, the pathetic description of an old woman trying to behave like an attractive heroine who can make any man fall in love with her is parallel to the ridiculous notion that an elderly man can act as a knight. In this regard, even the descriptions that Tenney offers of her ageing heroine resemble Cervantes' portrayal of his hero. Dorcasina is represented in old age as follows:

She had [...] been deprived of all the flesh her bones were ever clothed with; and her skin was sallow and full of wrinkles. Her front teeth were all gone, and her hair was quite white. In short she looked older than many women of

${ }^{158}$ Heiser, one of the earliest critics of Tenney's novel, acknowledges the closeness of her imitation of Cervantes: "The novel is thoroughly American in setting and characters, although the novels satirized are English. The extent to which the heroine insists upon going in self-delusion, the contrast between imagination and the senses in mistress and servant, the absence of heavy moralizing, and the numerous examples of direct parallels of action, attitude, and expression make Female Quixotism an engaging imitation of the Spanish classic. Don Quixote is, at least in original conception, a satire of an extreme literary vogue. The typical eighteenth century sentimental novel shifts the emphasis from hero to heroine. Female Quixotism is a close imitation of the original and recurring theme of Cervantes' satire, with changes dictated by the age and the literary excesses Miss Tenney found ready-made for her adaptation." (1947: 413). 
sixty. To appear [...] young and airy, she was dressed in a delicate muslin robe. Her hair [...] was curled, in imitation of a wig, all over her head; and to conceal its natural whiteness, was loaded with powder. (1992: 234)

The only difference is that Don Quixote starts his narrative as an old man, whereas Dorcasina's increasingly pathetic stance develops in front of the reader, therefore imprinting a greater emphasis on Tenney's didactic message for young female readers. Another similarity with the knight is that, despite the message against her delusion, Dorcasina and Don Quixote share their idealistic nature and their desire to help others. Dorcasina enthusiastically performs many works of charity even before her final philanthropic transformation, and, under her quixotic delusion, even aspires to end with the slavery in the States. In this sense, mirroring Don Quixote, from the start she is not only a romantic quixote, but also a benevolent one who is also imposed upon by the object of her pious charity (1992: 15). In addition, Dorcasina's madness is also an interspersed one, and she is a dutiful daughter and house manager, who divides her time "between her father, her domestic duties, and her novels" (1992: 125).

In the same line, the similarities between Sancho and Betty are also emphasised, concerning their appearance and character alike. At the beginning of the novel, Betty is introduced as "a few years older than her mistress: she was a good-hearted, honest creature, possessed of a tolerably good natural understanding; but very ignorant and extremely superstitious" (1992. 8). She shares with Sancho the physical proneness to mishaps, the malapropisms, the superstitious terrors, the use of popular sayings in their speech, the aspirations beyond their station or the progressive adoption of the deluded vision of their masters. Betty starts correcting her mistress's mistakes, perceiving the deceitful nature of her lovers and that they are "less solicitous about her person than her property" (1992: 29). Moreover, she trusts "the ocular demonstration she had that her mistress was far from being beautiful" (1992: 113) and perceives some of the tricks others try to play on Dorcasina. She can read through the improbable absurdities of some of the love letters she receives and denies understanding how a man could "go crazy for love" (1992: 127), hence becoming the voice of unromantic common sense. She is astonished at her otherwise sensible mistress's lack of propriety and she even openly rejects the 
romantic tenets found in books. However, as another victim of her mistress's pranksters and as her faithful companion, the limits of fiction and reality slowly blur for her as well, and she comes to believe that they have been truly kidnapped or that her lady can actually inspire flames of passion in her suitors, for Dorcasina cannot help it if "the men will fall in love with [her] upon sight" (1992: 109), and if they attempt to seduce or abduct her. In addition, she later adopts her mistress's romantic quixotism as her own, and expects two handsome men, both above her station or possibilities, to be in love with her. First of all, she believes a gentleman, Mr Cumberland, to have come to the house to court her. To reason her belief she employs the dialectic accommodation Dorcasina recurrently employs in her quixotism. She says to herself "there has (sic) been such things in the world before now, as a gentleman's marrying a servant maid" (1992: 208), which, of course, recalls Richardson's famous Pamela. This, together with Betty's own vanity, turns her head completely so that "her ideas were now as wild and extravagant as ever those of her mistress had been" (1992: 209). So "intoxicated," she revolts against her servitude and is involved in a practical joke in which another servant uses her infatuation to play with her and her supposed lover, again employing cross-dressing to create a series of comical misunderstandings. Then she falls in love with the handsome servant John, also her mistress's object of adoration. In these particular cases, both lady and maid believe themselves the love object of the same man, evidencing how delusion has operated on both and made them forget what is due to their age and position.

Moreover, Betty also resembles Sancho in that she follows Dorcasina's quixotic whims to the minute detail, despite the consequences. For instance, at Dorcasina's request, she abandons her reluctance and her sense, and she dresses up like a man to perform the hero in Dorcasina's romantic tableau at a grove. Her appearance is ridiculous, and her speech in imitation of a lover is ludicrously inappropriate. Her clothes make her the joke of all the other servants, who, mistaking her for a thief, finally discover her in their master's clothes. Chagrined, she climbs a tree to hide from view, she later falls down when a storm frights her; she then believes she has seen a ghost, and runs home, making an even sadder spectacle of herself at her arrival. This episode, 
as well as subsequent kidnapping and fighting scenes in which she is involved, all recall Sancho's mishaps and the jocular consequences of his superstitious ignorance. The latter is something for which even the deluded Dorcasina scolds her repeatedly throughout the novel, again in an echo of Don Quixote's interspersed lucidity and of his reprimands to Sancho on his ignorance. At a certain point, Dorcasina and Betty cross questions, and the former talks about her imagined lover while the latter is talking about ghosts (1992: 110). Each perceives the other's flawed perception but not their own. Dorcasina, who is rendered "deaf" and "blind" by her romantic folly (1992: 188), still cannot help but smiling at her maid's uninformed terror of the "savage Indians," among whom, she believed, they would have been "scalped, or, perhaps, roasted alive" (1992: 138), and she openly states Betty's own epistemological distortion when she asserts her maid's terror "generally magnifies molehills into mountains, and harmless people into evil spirits" (1992: 186). With such attention to the humorously Panzaic maid and the constant dialogue between Dorcasina's and Betty's epistemologies, Tenney indeed resembles Cervantes and develops further the possibilities of the Sancho-like female companion that Lennox had hinted at.

The similarities with Cervantes' novel move beyond characterization. Tenney's infliction of what Welsh defined as "practical jokes" on her quixote and her maid are imbibed from the Knight's and Sancho's appalling treatment by strangers, friends and author(s) alike: Dorcasina and Betty experience the same kind of physical and emotional torture as their male Spanish counterparts. Dorcasina and Betty, with all their naivety and good will, must survive in a degraded reality in which a wide range of rogues from all classes, nationalities and backgrounds try to take advantage of them, either to gain some financial benefit or just to have a laugh, which again connects Tenney's narrative with Cervantes' (Gámez, 2005: 106). Even at the moments in which masquerade is used by Dorcasina's friend Harriot, who dresses up as a man to seduce her away from marrying her servant, deceit is used to play with her illusions and to sport with her madness, in the same manner Sanson Carrasco had some fun of his own while attempting to cure Don Quixote with a knightly defeat. These interactions with different characters and the quixotic response to them usually 
constitute separate adventures, and in that Tenney also inherits the episodic structure of Cervantes, who, in turn, borrowed it from romance itself. While Tenney's narrative is not as episodically structured as Cervantes', she also moves from adventure to adventure, eliding the time that elapses in between.

In another similarity derived from that series of pranksters, the picaresque realism of the harsh and cunning world Tenney presents in opposition to her heroine's idealism is also characteristic of the Cervantean novel, and links Tenney's characterization and plot to other Cervantean authors such as Fielding. In the manner of Parson Adams, Dorcasina is cruelly fooled and even physically punished, proving that the surrounding world falls short of the quixote's goodness: Tenney's quixotic heroine will once again become a satirical instrument in her hands. However, again following Cervantes and some of his eighteenth-century emulators studied in previous chapters, Tenney also emphasises that her quixote is a valid butt of her satire because of her persistent delusion. In this regard, Tenney's comic intention goes further than previous female authors in her derision of Dorcasina's quixotism to achieve her humorous aim. Only to mention one of the numerous examples, at one point, Dorcasina, already an old maid, rides into her village and loses her wig: bald and wilted beyond recognition, she becomes the amazement of the town before she is finally thrown off her horse (1992: 257). Dorcasina's stubborn adherence to her quixotic illusion forces the recurrence of these episodes until she is finally humiliated when the last fortune hunter acknowledges his deceit and states that she is an old woman whom nobody would marry but for her money. Dorcasina's and Don Quixote's final avowal of their defeat in their aspirations leads to the concluding restoration of their senses.

3.2.2. Cervantean Parody and the Birth of a New Feminocentric Didactic Novel

Despite these structural similarities, what is more important is Tenney's development of a Cervantean parody of romance, whose traits she masterfully and jocularly includes and subverts in her novel. In addition, Tenney parodies a wide range of situations common to romances which are also employed in 
eighteenth-century British narrative fiction, that is, she parodies any element which she perceives as implausible, ridiculous or condemnable, often highlighting the similarities between romance and the new species of fiction that had been developed in eighteenth-century Britain. Tenney's text brims with references to British novels; from direct references to the title of some of Dorcasina's readings, such as Smollett's Roderick Random, to the employment of names taken from Richardson's novels. Very early in the novel, for example, Dorcasina even names the baby daughter of her neighbours "Harriet Caroline Clementina, being the names of persons, whose history she had taken great delight in reading" (1992: 15), persons who happened to be the heroines of Richardson's Sir Charles Grandison. More importantly, Richardson's or Smollett's characters are employed by the female quixote as example to sanction her conduct, including Harriot Byron, Sir Charles Grandison or Roderick. Furthermore, the hyperbolic language of sentimental novels is also jocularly reproduced in many romantic letters exchanged between Dorcasina and her mock sentimental and heroic lovers. Dorcasina, as Don Quixote, Joseph or Arabella, believes she can conduct herself in society with her readings as guide and, consequently, she interprets the surrounding world and herself under her romantic epistemology and will ultimately stand corrected. In this regard, Tenney's novel resembles Joseph Andrews or The Female Quixote in their parodic approach to romance -in Tenney's case approaching romance in itself as a genre and also its traceable influence on the novel.

While the butt of Tenney's attack is mainly Dorcasina's idealistic adoption of the reality of these novels and her belief that their description of love and marriage is applicable to her own world, as happens with all quixotic narratives, part of the satire is aimed at the romantic core of fiction for its questionable tenets and presentation. British sentimental fiction is no exception in this case. Tenney's narrative dialogues with prior British novels and, in particular, with their representation of women and their treatment of courtship and marriage. For instance, in a scene in which Dorcasina and a fake suitor meet in the middle of the night, escaping parental prohibition, Tenney's narrator asserts that "it would require the pen of a Richardson to describe the ecstacy (sic), and raptures of this meeting: but as mine pretends to no such 
powers, they shall be passed over in silence" (1992: 85). Another important example is Richardson's and Fielding's approach to the abduction scene, in itself an evidence of dialogue with previous genres, which also finds a space in Tenney's novel. Tenney's imitation/subversion of sentimental scenes of this type finds its jocular expression in Dorcasina's abduction by her fake lover Philander. After clandestinely corresponding with him and agreeing to meet him in her garden, she is kidnapped and, as Richardson's heroines had been, confined in an isolated house and provided with "pen, ink and paper" to write to her father (1992: 134), to whom she addresses a sentimental letter in which her vanity and romantic folly are once again exposed. Notwithstanding her ridiculous behaviour, instead of waiting and writing until she is raped, Dorcasina escapes through a window and manages to return home, even if it is only because her kidnapper allows it as part of his joke. At the other instance of abduction in the novel, Dorcasina escapes from her persecutors and rambles through fields and woods in the middle of a stormy night. As later Austen would do, Tenney places her quixotic heroine in a context similar to the ones found in her readings only to put them to the test of reality, of a more plausible development and outcome, and also a more comic one. Novels are, in consequence, mainly reproduced in order to prove how different fiction proves from the more debased -and comic- reality of Dorcasina's experience. For example, in the abovementioned comical abduction, Dorcasina's adventure is, indeed, very different to that of any sentimental heroine: her abductor is part of a joke orchestrated by a scholar who wants to amuse himself at the quixote's expense. Moreover, instead of fainting fits or tears, there are scenes worthy of Cervantes himself: Dorcasina and Betty are beaten, tied, and forced into a cart; after being pinched and punched, Betty fights back and even throws her tormentor out of the cart (1992: 139). Dorcasina, stiff and in pain after the events of the night, reaches the following romantic conclusions:

[...] the very same accident has formerly happened to Harriot Byron, though she was, to be sure, rescued in a different manner; and Dorcasina's satisfaction would have been complete, had O'Connor chanced to have been her deliverer. Her vanity, which before needed no addition, was now raised to the highest pitch; and she began to think, if she thus killed people, at a glance, it would be her duty, whenever she appeared in public, to veil her charms. (1992: 140) 
Her heroically phrased praise of her own charms highly and comically contrasts with her reality as an ageing fool which has been the object of a cruel prank.

Over and again, then, Dorcasina employs literary language and mimics literary scenes taken from these readings; that is, she insists on interpreting the world and herself by means of an epistemology adopted from literature. In her imitation of what she reads, Dorcasina moreover accentuates the "adjacencies and analogies that fiction provides," she underscores the differences between the heroines she emulates and her own actual situation, providing the comedy that springs from the discrepancy between her real and her imagined standings (Brown, 1999: 258). In this sense, as much as Dorcasina ignores the limits of both fiction and life, she also highlights those limits, "displaying how identity conventionally relies on distinctions" (Brown, 1999: 258). Furthermore, because of the conventionality of those distinctions, by reading her experience under the light of her favourite novels, Dorcasina "bespeaks an equivalence recognizable only to herself" for which she is "at odds with her community, which sees merely disparity: the aberration of a not especially attractive, aging woman thinking she is a romantic heroine" (Brown, 1999: 257).

As is the case with most female quixotes, Dorcasina's misreading focuses on courtship and offers a space for female agency which she would not have possessed otherwise. All her adventures commence in her considerations on the adequacy of a (supposed) lover. This adequacy is, of course, measured against literary standards; therefore, Dorcasina will distinguish between those suitors whom she can accommodate to the patterns of her favourite novels and those whom she cannot. As Brown has asserted, Dorcasina displays the typical syllogistic thinking of quixotes and, therefore, makes persons "proxies of characters" (1999: 262), in order to live her romantic fantasy about herself as a heroine, in which the hero plays an indispensable part. Accordingly, in Lang's words:

[...] reading and love in Female Quixotism are inseparable from masquerade, deception, and confusion. Acts of attempted discernment (attempted because Dorcasina, the novel's most ubiquitous reader, fails to read discerningly) are accompanied by acts of resistance to being discerned and the consequences warn the larger audience - namely, us - about the absence of clarity. For 
Dorcasina to read successfully, both literally and interpretively, she must overcome her own resistance and also the resistance presented by the masquerading character. (2009: 126)

Therefore, Dorcasina's epistemological struggle in the novel revolves around the need to discern what male characters are hiding, overcoming her own romantic veil and the suitors' own manipulative devices. What is at stake in this struggle for interpretation is Dorcasina's virtue and, ultimately, her inheritance, for her wealth and land might end in the hands of undeserving characters that are not what they claim to be. For Tenney, then, a major problem with imitation was "that it allowed strangers to pass in the new world as what they were not and, thus, to marry into well-established American families by imposing on naive girls or on their socially ambitious parents" (Bannet, 2007: 562), thus aligning her narrative with the conservative political reading of quixotism developed by anti-Jacobin authors at the turn of the century. In her own conservative reading of novels and politics, Tenney adopts a similar vision of the dangers of class mobility posed by quixotic naivety in the face of roguery and deceit, and consequently portrays these dangers in fiction. ${ }^{159}$ In a similar manner to how British authors employed the domestic plot of courtship to identify the good and bad suitors with the sanctioned and condemned moral choices the readers had, Tenney's comment on appearances, social strata and the economic, political and moral dangers of inadequate alliances is effectively conveyed by means of the ample variety of suitors that siege the innocent and wealthy Dorcasina.

The first one is O'Connor, an Irish criminal who pays his way into America. The narrator states that this "import" should have not arrived "considering what mischiefs have been occasioned to this country by its being an asylum to European convicts, fugitives from justice, and other worthless characters" (1992: 17). One of these mischiefs is his possibility of passing as an Irish nobleman, instead of the natural son of a nobleman's steward, which he really

159 In this sense, according to Brown: "the novel demonstrates how the cultural context in which one lives can shape and direct the operation of consent. It is fine for Dorcasina to go on loving romance novels (sic) so long as that love does not disrupt the distribution of wealth and class position in her community. Once she has renounced her custom of translating novelistic visions into social relations, her wealth remains inaccessible to all fortune-hunters" (1999: 265). 
is, and seducing Dorcasina in order to "obtain possession of her person and future fortune" (1992: 18). At their first interview, O'Connor entertains her with the account of "the customs and manners of Europe, and of all the British modern authors of the greatest celebrity" and dwells "with particular pleasure on the writers of novels" asserting that "they alone described the passion of love in its true and genuine colours" (1992: 26). He thus embodies the style and sentiment of those same British authors whose writings he employs as his guide to deceive Dorcasina. O'Connor is in this sense recurrently contrasted to Lysander, the only model of a proper and American suitor that Tenney draws, as will be later expounded. Betty, who has always regretted that her mistress rejected the latter, explicitly compares the true virtues of one with the romantic impudence of the other, while Dorcasina draws a comparison based on their closeness to her romantic ideal of a lover, which is much more flattering for O'Connor (1992: 28). However, it is Lysander's honest letter which unveils O'Connor as what he truly is; echoing the narrator, Lysander states that he most probably is "an impostor from Europe; too many of whom, I am sorry to say, are found in this country" (1992: 72). Despite the evidence piled against him by Lysander, Dorcasina accommodates this reality with her romantic notions: Lysander in her mind is jealous and his exposure of her lover is just a trick to prevent their marriage. Once again, in line with anti-Jacobin narrative fictions and their use of the courtship plot to hint at political implications, this serves the purpose of contrasting American and foreign characters in their relationship to truth. Mr Sheldon exclaims in exasperation: "will you persist in giving less credit to one of your own countrymen, whose character for probity is well known and acknowledged, than to a foreigner, whom nobody knows, and who has nothing to recommend him but his own bare assertions?" (1992: 76).

His exasperation is evidence that Dorcasina is not the only one whose vision will be unveiled by this adventure. O'Connor's almost successful seduction opens the eyes of Mr Sheldon to the effects of Dorcasina's lack of experience: born and raised in retirement, with an "almost total ignorance of the world," she judges people by the innocence and rectitude of her own "virtuous and unsuspecting heart" (1992: 147). On the other hand, Mr Sheldon, who knows 
people experimentally perceives from the very beginning that O'Connor aims at her heart, her person, and, more importantly, at her father's estate (1992: 48). In addition, this adventure awakens him to his failure as a parent, for he recurrently regrets "now it was too late, his having indulged her in perusing those pernicious books, from which she had imbibed the fatal poison, that seemed to have, beyond cure, disordered every faculty of her mind" (1992: 50). Her disorder indeed reaches the summit of its paroxysm: at her lover's beating in a scene of mistaken identities worthy of Shakespeare himself, she tears her hair and beats her chest "like a distracted woman" (1992: 56), and then she contrives a scheme which was

[...] one of the most extravagant that had ever yet entered the romantic imagination of a love-sick girl, and such as no lady, in her senses, would have attempted to execute, who was not blinded to all sense of propriety, and regard to reputation. She was, however, so far gone with the novel-mania, that it appeared a proper attention to a lover, who had suffered so much for her sake. This was no other than to pay him a visit, in the evening, at his lodgings. (1992: 57)

The long prelude to the description of this unwise action sets the tone for the condemnation of it and its subsequent punishment: Dorcasina is chased and falls in the mud, her clothes are torn and stolen by her chasers, and she is finally lectured by her friend Mrs Stanley, who now also discovers the full force of her friend's madness.

Throughout the whole dealings of the scheming O'Connor, which take up most of the first volume, Dorcasina exerts her ability to accommodate all events to her literary models. In her closet, her private space for reading, she turns over her favourite authors and "found numerous instances of persecuted lovers, cruel parents, and tyrannical guardians;" "to find herself precisely in the situation of many sister heroines afforded her more consolation than [...] she would have derived from any other source" (1992: 80). This capacity for accommodation and self-delusion will require a powerful awakening, and Dorcasina's vision of her lover is finally unveiled to O'Connor's true nature after she sees him in a situation which she could never make sense of even in her quixotism: she watches him receive the harsh and public punishment of a criminal and falls into a "strong hysteric fit" (1992: 144). While she still tries 
to accommodate this reality to her romantic expectations of him, her father provides evidence of his nature as an "abandoned villain, gambler, and highway robber," after which she finally awakens to the "deceit in mankind" (1992: 147) and, in particular, to the "deceit and falsehood [...] concealed under so fair an exterior" (1992: 148). She is then awakened by the pain and mortification of finding herself "the dupe of such an arrant impostor" (1992: 148) and reminded by Betty that she should grow wiser by this experience.

Before this final awakening concerning O'Connor, a second suitor has already presented itself in the form of the non-existent Philander. Mr Smith, a scholar recently arrived in town, hears about Dorcasina's delusion and decides to unashamedly and repeatedly "amuse himself at her expense" (1992: 110). Defined as a "wag" (1992: 104) and a "merry son of Momus" (1992: 107), the Greek god of mockery, his pranks are always intended only to seek entertainment, and not any personal gain. Adopting the pen name of Philander and writing epistles full of romantic nonsense, he creates in Dorcasina's mind the image of a young lover madly enamoured. She is "charmed" with the style of his romantic epistles, which equal O'Connor's. Moreover, the fact that he remains hidden and leaves the messages in a grove further inflames her imagination, for this manner of communication had "something in it so romantic, so out of the common way, and so much to her taste, that her curiosity, to know who could be the author, was raised to the highest pitch" (1992: 111). This leads to a series of thwarted plans to discover him and to the final kidnapping. Although his tricks offer some of the most amusing passages in the novel, the scholar never intends to defile her and the only consequence is a greater amount of ridicule and physical humour played on mistress and maid alike. He moreover contrasts with the "pert, conceited, foppish" barber who is made to believe by Mr Smith that Dorcasina is in love with him and that, hence, he will soon be rich (1992: 117). He, therefore, plays them both with hurtful physical consequences for all involved. Betty forcefully beats the barber, obtaining a victory for once and coming off "with flying colours" (1992: 127), like sometimes Don Quixote and Sancho did, but then her victory, as also happened with the Spanish characters, backfires and the barber takes his revenge when he participates in the mock abducting. Finally, Philander's 
hyperbolic style of writing and romantic intentions once again serve to reflect on the nature of the texts he chooses as a model to seduce Dorcasina with her own quixotism; when her father discovers what has happened, he rebukes her for believing his pretensions, for "the very extravagance of them carries the demonstration of their falsehood" (1992: 143). Told by the penitent barber of all the tricks that had been imposed on her, Dorcasina's mortification then completes a temporal cure and she

[...] confined herself pretty much to the house, for several years; employing her time, as usual, in the duties of the family, and in promoting the happiness of the best of fathers; endeavouring, by her attention, her cares, and her affection, to banish from his mind, as well as her own, that she had ever known such persons as Philander and O'Connor. (1992: 151)

However, a second volume must be written and Dorcasina, whose extravagant romanticism lied dormant, still believes herself in love with other men even after the old age of forty. This time, in a common place of the tradition of female quixotism, she is tricked by a servant into eloping with him. This conviction to do something improper again finds its source in her readings, in which she "recollected that she had read of numberless young ladies, who had taken a trip to Scotland, when their parents were opposed to their union with a favoured lover" and which give such an "air of romance and adventure" to eloping, that she agrees to take this step (1992: 168). Once Dorcasina has abandoned her home, she discovers her lover to be a servant, and she abruptly awakens "from a pleasing dream" (1992: 194). Her romantic adventure is then deflated of all its allure and again proves a debased reproduction of sentimental literary conventions. After this adventure, her friends hope she has learnt "wisdom by experience" (1992: 200) and that she will now be "as rational a woman in regard to love and marriage, as she was in every other respect" (1992: 203). Despite their hopes, even at such a late age, wisdom is yet to be acquired and some years later another lover crosses her way.

After her father's death, she is confined to bed for a long time and the first sign of her recovery is when she asks for her novels. Having recently found Roderick Random, which had "lain untouched in her closet for more than twenty years," and having perused it with great avidity, she finds that the 
eponymous hero of Smollett's novel had, under the very same name of John Brown, lived with Narcissa as a servant only to finally marry her. From this she concludes that her servant, also named John Brown, "must likewise be a gentleman in disguise" (1992. 227). John will demand the greatest exertions of the powers of accommodation the quixote has; in the case of Dorcasina, this is achieved because, as the narrator explains, "her increased years, instead of destroying her early romantic prejudices, only served to strengthen and confirm them; and she arose from her bed of sickness with ten times more extravagant ideas than before she had entertained" (1992: 230). She can therefore go to great lengths of delusion to defend her vision of the young and handsome John as a gentle lover of hers, even if his speech evidences his total ignorance of polite language, in general, and of the sentimental language of novels, in particular (1992: 238). This confusion triggers many ridiculous mistakes and scenes, including a very unromantic fall down the stairs in which both the now old lady's physique and pride are injured.

Finally, Dorcasina is fooled by Harriot pretending to be a noble lover and she is kept captive by her friends in order to avoid her marriage to John. This plot, which again recalls Cervantes' novel, is designed and carried out by Harriot herself, for she perceives that all the remonstrances of her parents will not cure the infatuated Dorcasina (1992: 251). Dressed as her father when he was a young officer, she presents herself as Montague and, with the help of Dorcasina's faithful and wise black servant, she contrives to trick her away from John. Nevertheless, not before a long period of double courtship takes place in which Dorcasina finds herself "exactly in the situation of Sir Charles Grandison" with a "double, not a divided love" (1992: 276). In the end, Dorcasina is kidnapped with the consent and participation of all the Stanleys; this abduction, conducted in a most serious manner, further deceives Dorcasina into believing it is not a sham like her first one (1992: 282). In addition, it offers her the opportunity to live more adventures, like escaping from her coach and from her persecutors through the fields and woods. In the end, she is confined without novels for months in a retired house in order to complete her cure. 
Nevertheless, she almost falls prey to a worse man: another fortune-hunter, having heard of her delusion, manages to access her in her confinement and to effectively woe her. Whaeton, who under the name of Seymore passes for a school-master and a Christian, is another representative of the dangers of foreignness. Having spent much time in France, he has imbibed "all the demoralizing, and atheistical principles of that corrupts people," and, at his return to America, has squandered his money in all forms of dissipation and even abandoned his wife and five children in the utmost distress (1992: 297). This "modern philosopher" (1992: 298) fully performs as a sentimental hero; however, arrested by his creditors, he will be the one to open Dorcasina's eyes to her folly -and her age. Questioning him on his motives for deceiving her, Dorcasina receives the following answer:

[...] it was your money, and my necessities that induced me to deceive you; and you, credulous old fool, so greedily swallowed the grossest flattery, that it would have been difficult to avoid imposing on you. Ridiculous vanity, at your age, with those grey locks, to set out to make conquests! I have really so much regard for you, as to advise you to give up all thoughts of that kind, and to assure you that any man would be distracted to think of marrying you except for your money. (1992: 315)

As will later happen to Cherry in Barrett's novel, it is the exposure to this deception that will finally cure Dorcasina from her romantic expectations, triggering a thorough consideration on her long list of suitors and restoring her to the reason she displays in all other matters. This reasonable train of thought is very readily exerted when Betty and Dorcasina offer a brief digression on the dangers of reading Paine and the terrible consequences it has for American households, in particular over men who leave their families in order to experience the pleasure of the flesh or even abuse wives and daughters to the point of distraction. Dorcasina concludes that "those pernicious sentiments, the growth of other climes, have found their way to this once happy country, so justly celebrated for the domestic felicity of its inhabitants," adding "may heaven prevent the further progress of Jacobinism, atheism, and illuminatism; they all seem to be links of the same chain" to which Betty adds her "amen" (1992: 316). This last speech evinces that the innocent and pious Dorcasina and Betty, even in the midst of their own delusion, prove clearly superior to many 
of the men that surround them. In particular, by ascribing the consequences of reading French philosophers to the delusion of men and its effect on innocent women, Tenney clearly detaches her heroine from philosophical quixotism and hence breaks with the anti-Jacobin tenet that women are the more easily seduced victims of Jacobinism.

Dorcasina's romantic ideals are also displayed in her relationship with less objectionable suitors, providing a more striking interpretation of how her quixotism has disabled her from achieving a happy conclusion to the story of courtship, from her integration into society as a wife. Although her romantic folly has been thoroughly displayed in these adventures involving despicable lovers which mainly operate when patriarchal and protective figures are absent, the novel also offers what seem two good suitors: Lysander and $\mathrm{Mr}$ Cumberland, both sanctioned by the representatives of patriarchy, but who fall short of Dorcasina's perfect ideal of marriage. Early in the novel, she rejects her father's choice, Lysander, because he speaks to her just like his "grandfather might write, were he, at the age of eighty, to take into his head to marry" (1992: 13), therefore, not at all like a true hero of romance. He falls short of Dorcasina's romantic standards when his letter is compared to those "in her favourite authors" and is found wanting in "style and sentiment;" moreover, he does not flatter her at all, the fact that chagrins vain Dorcasina the most (1992: 13). By speaking the truth and his true feelings for her, and not attempting to deceive her, Lysander loses the blind quixote. ${ }^{160}$ In this sense, while Dorcasina's “ideas of matrimonial happiness were too exalted ever to be realized," Lysander then stands for Tenney's ideal model of an anti-romantic marriage, in which "violent raptures" subside and a more permanent and reasonable basis is needed to achieve happiness (1992: 14). Dorcasina then misses her chance of obtaining a true lover and of fulfilling her romantic aspiration of a blissful marriage. In addition, she may have lost the chance of achieving greater goals as a citizen and as an abolitionist one, in particular. Lysander embodies the values of Southerners with which Dorcasina is not at

${ }^{160}$ Lang reads Lysander in a very negative light as another embodiment of marriage as financial transaction; however, his affection for Dorcas and his letter prove that he is a man of some feeling despite his control over his emotions. In this sense, he resembles Foster's $\mathrm{Mr}$ Boyer. 
ease; in particular, she rejects his position concerning slavery. At first, she decides to reject him, but then Betty and herself quixotically reason that it would be an opportunity to bring her abolitionist ideals into Lysander's household and properties. However, her dreams do not end there:

She then indulged herself in the agreeable, humane, but romantic idea, that, being the wife of Lysander, she should become the benefactress of his slaves. She even extended her benevolent reveries beyond the plantation of her future husband, and, wrapt in a glow of enthusiasm, saw his neighbours imitating his example, and others imitating them, till the spirit of justice and humanity should extend to the utmost limits of the United States, and all the blacks be emancipated from bondage, from New-Hampshire even to Georgia. (1992: 9)

Dorcasina pictures herself as an ideological quixote and, coming very close to Don Quixote's knightly deed in liberating the galley slaves, imagines herself the heroine of a quixotic quest of national importance. Nevertheless, Dorcasina will never fulfil her duty as wife, nor as champion of abolition, for Lysander is finally and fully dismissed as a lover. Tenney's approach leaves, in any case, some doubts about the suitability of a marriage to a slave owner.

Almost thirty years later, when Dorcasina is approaching fifty and her bloom has definitely disappeared, another apparently respectable suitor courts the quixotic heroine. Mr Cumberland, a landowner and businessman, approaches Dorcasina even more conspicuously than Lysander for her money and land. Cumberland's approach to the lady is nothing but mercantile, resembling Ledge's speeches to Polly Honeycombe or Sir Charles' language in Lennox's novel. After observing and examining her person in a very critical manner, the narrator describes his ideas thus:

He was not at first greatly pleased with it; but after considering a thousand a year, he looked at her again, and thought her quite tolerable. Her having lived in so retired a manner was another recommendation, as she would not be likely to be so expensive a wife as one bred in the city. He observed, moreover, that she worked all evening, and he flattered himself, from this circumstance, that she would make him an industrious wife. In short, he went to bed thoroughly satisfied with her; and without any suspicion that he should meet with the least difficulty in obtaining her. (1992: 205)

However, he does indeed face difficulties placed by his anti-romantic conception of marriage. When he discusses the "business" that is his interest, 
Dorcasina vexedly tries to induce him to "speak in a less mercantile style" (1992: 205). However, Mr Cumberland insists that he cannot become fond of any woman, before he knows if they are "like to make a bargain or not" (1992: 206). Dorcasina rejects him and explains her reasons to her father in the following terms: "he has come here to make a bargain, as he calls it, just as if he had come to purchase an estate, without feeling for me any of that tender passion which makes the delight of married life, or inspiring me with the least of it for him" (1992: 207). She furthermore rejects her father's argument that, at her age, she cannot inspire or experience that passion and that she must seek for a more "rational kind of happiness" (1992: 207). Dorcasina then remains fixed in her determination and Mr Cumberland is erased from the story not without a further and more explicit condemnation of his mercantile style of dealing with women. Rejected by Dorcasina, that same evening he proposes to Harriot in the following terms: "Come, shall we make a bargain? I am rich, and you shall ride your coach" (1992: 218). After having some fun at his expense, Harriot comically concludes that she will not marry him if she cannot be allowed to flirt and make conquests, for "smart young girls" do so "especially when they are going to marry rich old husbands" (1992: 219). In the face of Mr Cumberland's astonishment, she continues: "why, do you think they marry old men from affection? No such thing, I assure you; it is only to spend their money genteelly for them, to dress, and to be admired" (1992: 219). While the offended lover leaves, Harriot and Dorcasina reflect on his behaviour and Dorcasina proves a better judge than her father in this matter when she asserts that "a pretty husband, truly, [...] my father had picked out for me; that could, in the course of one evening, so easily transfer his affections from one object to another. But I did not want this proof to convince me that the man was not capable of loving with ardour" (1992: 219). ${ }^{161}$

161 Although one must agree with Gordon's analysis of Tenney's novel as aiming to portray a cure for her deluded heroine as a moral warning for her implied readers, he undermines the richness of Tenney's novel, and her model, Lennox's The Female Quixote, by transforming them into works that "never permit a moment's uncertainty about the validity of the female quixote's mistaken beliefs" (2005: 131). Those moments of uncertainty, such as Dorcasina's more adequate reading of Mr Cumberland or of Lysander's adherence to slavery, which were already present in the second part of Cervantes' novel, indeed transform Lennox's or Tenney's works into compelling novels, rather than mere tracts in which to defend a conservative literary or ideological supersystem. 
There are more suitors whom the novel only mentions in passing. The narrator asserts that there have been other men that refuse to court Dorcasina because she reads too much, and those that do so because she reads at all. Although Tenney subtly criticizes this last approach to female reading (1992: 14), the fact remains that, because of her quixotism, she is left a heroine without a hero and, hence, the expected conventional happy ending of the novel is never reached. However, Tenney's final transformation of Dorcasina into Dorcas signals at least a ray of hope for her quixote and her women readers. A first glimpse of Tenney's benevolence towards her otherwise harshly treated quixote is that, despite her recurrent misreadings and mishaps, Dorcasina remains pure and beloved; consequently, she does not represent only a satire against "the American reader/ citizen," but also "the humanity of such a character" (Lang, 2009: 123), again emphasising the duality of the quixotic figure in the eighteenth century. This is also highlighted by her final cure and transformation into a different kind of idealist: no longer a romantic quixote, but a fully philanthropic one. ${ }^{162}$ While her quixotism had provided an otherwise invisible domestic woman with visibility and action $-\mathrm{a}$ fact reinforced by the skips in the narrative from suitor to suitor and Dorcasina's disappearance in the meantime--, Dorcas's final philanthropy offers a more appropriate context and activity for female agency. ${ }^{163}$ After her senses are

${ }^{162}$ Brown reads a political conservative message behind this transformation: "Always celebrated for her charity to the poor, Dorcasina now particularly tends to the maintenance of those who have fallen in class position. She thus serves the principle of aristocratic values rather than the notion of social mobility that so many of her previous actions have promoted, however unwittingly. If her quixotism initially gave scope to her own and others' individualistic impulses, it ultimately comes to serve a conservative reaction to the progress of democratic values, consolidating the wealth of the gentry" (1999: 265).

163 Gordon interprets Lennox's and Tenney's endings in accordance, as harsh condemnations of their characters' romantic principles and, hence, their quixotic nature. In his opinion, "no matter how sympathetically we might understand the oppressions that lead them to embrace romance as a solution, these texts severely chastise their imaginative distortions of reality and treat their remaking of the world not as a creative response but as an illegitimate one that demands a cure" (2005: 141). While agreeing with his interpretation of quixotism as a delusion that demands a cure to allow the quixote's reintegration in society, nevertheless, his generalization may need some qualifying, for Lennox and Tenney, as well as most authors included in this study, contrive a different degree of condemnation or tolerance towards their character's quixotism, whether romantic or ideological delusion. Lennox's appropriation and inclusion of romance into her own narrative fiction, together with the presence of Miss Glanville, has already been asserted to undermine her condemnation of romance. In Tenney's case, Gordon might come closer to the truth. Tenney jocularly ridicules her quixote's romantic follies throughout her novel and provides the harshest and most anti-romantic ending imaginable. Nevertheless, after Dorcasina's cure from her romantic quixotism, Tenney contrives a more sanctioned form of illusion and transforms her romantic quixote into a 
restored, the narrator states that she turned "all that enthusiasm, which love formerly inspired, to acts of benevolence and charity" (1992: 323). In her own words, she becomes a philanthropist who supports "those who, by misfortunes, and without any blameable misconduct of their own, have been reduced from opulent or easy circumstances to indigence" (1992: 324), a change reinforced by her return to her original name, Dorcas, a woman in the New Testament known for her good deeds towards those less fortunate and, in particular, for her skill at sowing clothes for poor widows (Acts 9: 36, 39). This choice of name has deeper meanings than the mere Biblical allusion, so important nevertheless in Puritan New England: as several scholars have pointed out, Dorcas is the Greek version of Tabitha, the author's own name (Gámez, 2005: 108). Dorcas and Tabitha share their philanthropic views and actions in one aspect in particular: female education and their contribution to it through their writing.

While still under the delusion of novel reading, Dorcasina produced many love letters which were another instance of her imitative approach to the language and conventions of sentimental novels. In Wood's words, she plays the compiler, printer and publisher of her own narrative when she collects O'Connor's letters under the title Letters from my dearest O'Connor before marriage (2005: 189). As Dorcas, she writes a letter to her friend Harriot, now Mrs Barry, in which she exposes her delusion, her awakening and her now anti-quixotic or detached reading of novels, which amuse but do not delude her. In addition, she regrets the effects of a bad education on her understanding, and advises Mrs Barry on the education of her future daughters, proposing a sound education and knowledge of the reality of the world to counteract the possibility of misreading both works of fiction and the nature of men (1992: 323-25). Addressing Mrs Barry and Tenney's implied female readers alike, Dorcas and Tabitha emerge as didactic authors for women who end their narrative with a highly moral address to their audience. ${ }^{164}$ In this regard, the

different sort, a philanthropic enthusiast, a condition that still allows her character agency and visibility.

${ }^{164}$ In this sense, Lang's assertions on Dorcas's absence of further reading or writing require some qualification. This scholar asserts that "[Dorcasina's] writing of love letters and reading of romance novels run parallel to each other; when she finally gives up the idea of marriage she also gives up reading and writing texts of love and courtship. Thus, her final letter 
moral stance of the novel again seeks to impulse readers to live by the standards they find in Dorcas's letter or Tenney's novel, and hence to imitate a set of principles exhibited in those pieces of narrative fiction. As Dorcas ends her narrative with a letter, so does the author or compiler commence with another one addressed to her fair audience. In it, the narrator employs another technique resembling Cervantes: the argument of the true story that is being reproduced. According to this compiler, she met Dorcas and heard her story at Mrs Barry's house, deciding to reproduce it for the ladies' use. Echoing Cervantes, and making the connection with his novel explicit, the narrator states:

I am sensible you will find it a very singular and extraordinary piece of biography, and that you may suspect it to be a mere romance, an Hogarthian caricature, instead of a true picture of real life. But, when you compare it with the most extravagant parts of the authentic history of the celebrated hero of La Mancha, the renowned Don Quixote, I presume you will no longer doubt its being a true uncoloured history of a romantic country girl, whose head had been turned by the unrestrained perusal of Novels and Romances. (1992: 3)

By this spurious claim to authenticity, Tenney proves quite the opposite: that her work is indeed fiction. She avoids fooling her readers and calls their critical attention to the moral warning of her tale. The narrator wishes that by observing the bad effects of these readings on Miss Sheldon, "who was in every other respect a sensible, judicious, and amiable girl," they might avoid "the disgraces and disasters that so long rendered her despicable and miserable" (1992: 3). This lesson is further highlighted by the shift of emphasis from romantic to benevolent quixotism. Dorcas's new philanthropic enthusiasm is then a better ideal than her romantic quest for a husband, and, with this redirection of her quixote's aspirations, Tenney reflects what seems a tenet of early American quixotic fiction: properly directed idealism is not to be condemned, but promoted. According to Brown,

The imperative to reorient the quixote does not at all disregard individual freedom of choice as it seeks to define the horizons of that choice. The

suggests not only an end to writing but also an end to reading and, her intention in imposing this limitation, an end to misreading" (2009: 137). While it is true that Dorcas qualifies her mode of reading and offers advice to check the effects of misreading, there is never a condemnation of reading or writing. Tenney, as most Cervantean authors, does not disregard all reading, only a certain genre or a certain uncritical way of reading. 
exhibitions of the quixotic fallacy that appear throughout early American fiction often display neither distrust of mimeticism nor disrespect of the errant reader, whose faulty identifications often appear an admirable idealism or a perfectly comprehensible misunderstanding. This benign attitude toward the quixotic reader denotes a crucial function of quixotism. It protects and affirms individual consciousness even as it maintains standards for social harmony among individuals. Reiterating the liberal doctrine of individualism, quixotism in its early American manifestations reflects the difficult endeavor of respecting individuality while also tethering individual understanding to external measures formed through agreement among numbers of individuals. (1999: 267)

Thus exalting individuality, but also the need to belong to and enhance a flourishing community, quixotism became an excellent vehicle for authors to convey the struggles of the emerging nation and its inhabitants. Moreover, it allowed women writers, such as Tenney, to dialogue with and even to subvert a male literary tradition and propose her own. In a scene which recalls Lennox's use of the female space of the closet, Mr Sheldon at one point intends to commit "to the flames every novel within his daughter's reach," though he is prevented from doing so because most of them are in her closet, to which he cannot gain access except through her room (1992: 89). Echoing Lennox, British novels by men are then appropriated by Dorcasina and Tenney, and inscribed in the female space of the closet and the didactic novel. Dialoguing with Cervantes, Richardson, Fielding, or Smollett, Tenney not only evidences her ample literary knowledge, but also establishes her authority as a novelist by their inclusion in her narrative and her own criticism against their novels. Dialoguing with other Cervantean emulators by means of her quixote's delusion, Tenney becomes then an important author in the tradition of female quixotism, and of the didactic novel as well.

In this sense, it is relevant that, once again, Tenney presents in the first page of her novel the figure of the absent mother, although in this case not as the representative of the romantic or sentimental tradition, but of the didactic narrative fiction that Tenney herself is writing. The female compiler states that Dorcasina

[...] had the misfortune to lose an excellent mother, whose advice would have pointed out to her the plain rational path of life; and prevented her imagination from being filled with the airy delusions and visionary dreams of love and raptures, darts, fire and flames, with which the indiscreet writers of that 
fascinating kind of books, denominated Novels, fill the heads of artless young girls, to their great injury, and sometimes to their utter ruin. (1992: 4-5)

While it is Dorcasina's father who instils in her the passion for novel reading and are his novels and his library which seduce Dorcasina's mind, her mother stands for the common sense or rationality that the reformed Dorcas and the female compiler recommend in their respective letters. Despite the fact that the narrator claims that almost all novelists are "sister novel writers" (1992: 5), the works of narrative fiction quoted in Tenney's work are written by men. The difference between them, for Tenney, seems to stand in the fact that women writers can advise their female readers from the perspective of one that shares her education or limited experience. The narrator tells the reader that:

Miss Dorcas Sheldon, either from nature or education, possessed nearly the same taste in books as her father, with this difference only, that novels were her study, and history only her amusement. Mr. Sheldon, who himself had experienced nothing but pleasure in the time spent in reading the former, unfortunately indulged his daughter in the full latitude of her inclination; never considering their dangerous tendency to a young inexperienced mind; nor the false ideas of life and manners, with which they would inspire a fanciful girl, educated in retirement and totally unacquainted with the ways of the world. (1992: 6)

First of all, the narrator questions whether Dorcasina's taste is natural or has been acquired by the force of education, or, in other words, cultural pressure. It implies that a taste for novels is not intrinsic to women. Secondly, this early statement places the weight of Dorcasina's delusion not so much on the genre itself, but on her lack of a serious and thorough education and on the failure of (male) authors to understand the circumstances of the majority of their readers and the possible effects their fanciful pictures of life and manners may have on them. As Mr Sheldon states when he curses "those poisonous, those fatal novels:" "would to heaven people could find some better employment, than thus turning the heads of inexperienced females! Would to heaven I could have foreseen the fatal consequences of allowing you a free access to them" (1992: 144).

In opposition to this lack of guidance for a young girl, Tenney provides a proper model of a young female girl in the sensible and lively Harriot, whose 
mother, Mrs Stanly, prevents her reading any novels in order to avoid her becoming a quixote like Dorcasina (1992: 180). Moreover, these two female figures prove very different to the female model portrayed by male British authors: Mrs Stanly is a reasonable and effectual mother, who does not impel her daughter to marry as soon as possible. In addition, she voices the idea that being a virtuous old maid is sometimes preferable to marrying "barely for the sake of having a husband" (1992: 180), which echoes Dorcasina's own destiny. On her part, Harriot is not the passive beauty that most heroines are: she is more agreeable than attractive, she actively plots and participates in the scheme to prevent Dorcasina's marriage and she expresses her own feelings and opinions freely and forcefully, always with a satirical sense of humour which exposes the frailties of those around her. Instead of reading novels, she has gained her knowledge from her observation of life, therefore avoiding the unnatural or too high representations of characters and situations that would have distorted her perception (1992: 221). In her own courtship, she represents common sense which is expressed in the matter-of-fact style that the narrator employs to describe her feelings: when she receives Barry's declaration her heart "went pit-a-pat" upon perusing his letter and she then refers him to her parents (1992: 224). Their permission granted, "the business between them was soon arranged" and he was received as a lover (1992: 224). This transaction indeed contrasts with Dorcasina's flourished letters and declarations. In addition, Harriot's story does not conclude at the point most romanticallyimbibed narratives do, but it includes the life of the heroine after her wedding day to extend the subject matter of the feminocentric narrative beyond courtship, the core of romance and of romantic quixotism as well. Harriot's married life, full of tragedies such as losing her mother, her infant and much of her fortune at sea, or having to face trials such as her own life-threatening fever at the death of her child, her husband's illnesses, or a robbery by her domestic, depicts a more realistic portrait of matrimony than the romantic raptures that Dorcasina has learnt from her novels (1992: 321). Harriot, even as the exemplary anti-quixotic heroine of the novel, does not live the romantically perfect conclusion of the sentimental heroine either: marriage and motherhood differ in Tenney's novel not only from the ideal pictures portrayed in British novels, but also from the idealistic portrayal of republican motherhood that 
conservative American narratives sanctioned (Wood, 2005: 182). Tenney attempts to bring fiction closer to a realistic representation of life in order to rebuke an ideal that women could not expect to fulfil or experience.

This final contrast with Harriot's life story concludes Tenney's deflation of romantic expectations and the narratives that buoy them in their women readers' imaginations. In this analysis of the dangers of reading, Tenney demonstrates that she has assimilated the discourse of previous novels, such as Brown's or Foster's, and that she is writing a cautionary tale from which her young female audience can benefit. Consequently, she not only parodies romance and its trace in certain novels, but also hopes to provide an alternative form of narrative fiction, always featuring a heroine at its core. All the elements that have been so far analysed in relation to Tenney's narrative -her relentless satire against the quixote and her readings, the anti-romantic closure of her courtship plot, the conversion of her quixotic heroine into a socially acceptable woman philanthropist and the development of an exemplary (and active) heroine of the new domestic novel in Harriot- highlight that Tenney's quixotic novel, as did Lennox's, aims to produce a more plausible and moral feminocentric form of narrative fiction, of which the reformed quixotic Dorcasina, the sensible and philanthropic Dorcas, stands as best emblem. 


\section{Modes of (Mis)REAding: MARy HAYS AND ElisABETH HAMiLton}

I shou'd have been born a century earlier or later. The age of chivalry might have suited me, or the age of reason -but, in the present motley times, I am an alienan awkward being.

Mary Hays in a letter to William Godwin, 1796

I have sometimes suspected, that all mankind are pursuing phantoms, however dignified by different appellations.

Memoirs of Emma Courtney, 148

It is only by the love of reading that the evils resulting from associating with little minds can be counteracted. A lively imagination creates a sympathy with favourite authors, which gives to their sentiment the same power over the mind, as that possessed by an intimate and ever-present friend: and hence a taste for reading becomes to females of still greater importance than it is to men, or at least to men who have it in their power to choose their associates.

Elisabeth Hamilton, Memoirs, 1818

In the context of the heated debate on female novel-reading and its dangers, two women novelists, among many others, wrote novels which explicitly addressed the relevance of novel-reading for their young heroines' education and future happiness or social integration. Mary Hays and Elisabeth Hamilton, though separated by their political and moral principles and hailed as the embodiment of the Jacobin and anti-Jacobin discourse of the time, nevertheless responded to a common concern, the education of their female readers, by means of quixotic narratives in which the embedded reader reflects the implied reader's approach to the text and can, therefore, serve as either warning or example. For these authors, there were two models of female reading, the active and the passive, which involved "two contrasting understandings of the interaction between the text, the self, and the world" (Binhammer, 2003: 5). On the one hand, they present the following model of a passive reader, a reader that:

[...] equates the self with the text (you are what you read); thus, the world of the text becomes her world. She reads transparently, incapable of doing anything but mimicking novels; therefore, she collapses reality with imaginative fiction, herself with the heroine, and her valet with her lover. The 
consuming reader enters a dangerously delusive state, one that ensures her sexual vulnerability; for she is also an embodied reader, and the words simultaneously become sensations she feels. The moralists' metaphor of novels as poison is apt for this model of reader. (Binhammer, 2003: 5)

On the other hand, the active female reader "distinguishes between real and fictive worlds and by reading with her mind creates a critical distance that allows interpretive thinking;" moreover, how the active reader participates in the reading "determines that text's meaning," therefore, "Hays and Hamilton begin to unpack the how of this active female reader to ask important questions about the condition of women in the culture" (2003: 5).

However, as critical readers of each other's novels, Hays and Hamilton engage in a textual war in which the former's novel, Memoirs of Emma Courtney (1796) will find its parodic and satirical replica in the latter's Memoirs of Modern Philosophers (1800), engaging in an even more complex game of embedded readers and fictional mirrors, and in a richer debate on the role of women in eighteenth-century culture. This chapter will analyse both authors' quixotic narratives and how, from their divergent positions, they both sought "to encourage an active, critical way of reading, which neither foregrounds the self nor subsumes it entirely to the text" (Bray, 2009: 58), and how they aimed to do so "by integrating the critical attacks on the novel into their novels and by interrupting and revising the model of female reading they assume," distinguishing between "what a woman reads and how she reads" and ultimately transforming "the female reader from a consumer into a critic" (Binhammer, 2003: 2), with varying degrees of success.

\subsection{Emma Courtney and the Dangers of Sentimental and Philosophical Reading}

Mary Hays (1759-1843) remains one of the key figures to understand the dialectical battles that were being conducted in the late eighteenth century. Siding with the Dissenters and later with the so-called Jacobins, she participated in some of the more heated debates on philosophy and gender that the newspapers recorded in the 1790s. In response to Gilbert Wakefield's 
attack on public worship she produced a pamphlet in its defence, Cursory Remarks on an Enquiry into the Expediency and Propriety of Public Worship (1792), under the pseudonym Eusebia. The pamphlet was amply praised, went into a second edition and granted her the attention and support of the Dissenting circle. A year later she published her also acclaimed Letters and Essays, Moral and Miscellaneous, in which her views on female education and, more specifically, female reading were extensively dealt with. ${ }^{165}$ Hays wrote articles for the reformist The Cabinet (1784-5) and the Monthly Magazine during 1796 and 1797, forcefully joining in debates about the female intellect. Under the influence of Claude-Adrien Helvétius, one of the main philosophical inspirations in her body of work, she insisted on the recognition of environmental and educational influences (Brooks, 2004: n.p.), therefore also ascribing to Godwinian theories that character is shaped by the environment, and not inherited. ${ }^{166}$ She published two novels, Memoirs of Emma Courtney (1796) and The Victim of Prejudice (1799), which she advertised as a novel expounding "the mischiefs that have ensued from the too great stress laid on the reputation for chastity in women." She also wrote books for children and an acclaimed Female Biography, or, Memoirs of Illustrious and Celebrated Women of All Ages and Countries (6 vols., 1802), the first of which was dedicated to her friend Mary Wollstonecraft in the form of an eulogy. Her most radical work was the Appeal to the Men of Great Britain in behalf of Women (1798), in which she argued that there were no scriptural or rational arguments to justify the continued subjection of women (Brooks, 2004: n.p.).

A woman of strong ideological convictions and committed to such reformist causes as "gender, the new science of mind, and abolition of slavery" (Walker, 2006a: 165), she befriended some of the most thriving thinkers and writers of her time, including Robinson, Priestley, Blake, Godwin and Wollstonecraft. This latter radical couple subsequently mentored her at different stages of her career, and Hays became with Wollstonecraft a member of that "new genus" of professional women writers who counselled and supported each other (Walker,

165 See Gary Kelly (2001), pp. 82-91, for a comment on Hays's participation in the public debate and the responses to her writings.

${ }^{166}$ For a detailed description of the war of ideas that Hays conducted in the pages of the Monthly Magazine on Helvétius and epistemological theories, see Walker (2006a): 166-71. 
2006b: 17). Hays's public defence of Godwin and Wollstonecraft and her own radical ideals on freedom and gender-related matters -such as women's rights or the defence of their active sexuality and intellectual powers- transformed her into a recurrent target for anti-Jacobin satire, as articles and novels presented ridiculous caricatures of her or blatantly attacked her ideology and morals. In particular, her forthright depictions of female passion were satirized in her characterization as Bridgetina Botherim in Memoirs of Modern Philosophers (1800) by Elizabeth Hamilton and as Lady Gertrude Sinclair in Edmund Oliver (1798) by Charles Lloyd.

One of the main reasons behind this virulent and long-lasting criticism is to be found in her novel Memoirs of Emma Courtney (1796). This first-person epistolary narrative focuses on the life story of its eponymous heroine which she retells to her adopted son, Augustus Jr, a victim of excessive passion to whom she addresses the cautionary tale of her own experience. In her letters, Emma describes her early education, her intellectual aspirations, and, more relevantly, her unrelenting and seemingly unrequited passion for Augustus's father. Emma tells the story of how Augustus rejects her advances, and, after much uncertainty, she finally discovers he was secretly married and could not, therefore, accept her proposals of marriage or even cohabitation. In consequence, she marries another suitor and gives birth to a daughter, Emma. Reunited with Augustus Sr. after he has a fatal accident near her house, she has the opportunity to receive his declaration of love before he dies in her arms. Her distress makes her forget her "conjugal, maternal, duties" (2000: 202), while jealousy drives Emma's husband to debauchery and suicide. After some years in which she educates young Emma and Augustus in harmony, her daughter dies and Emma is left with only Augustus's son as addressee of her letters.

The fact that the novel is written from a first-person perspective allows the reader to have a full insight into Emma's reasoning and feelings, and, therefore, more than in any other quixotic novel, the whole of Hays's narrative fiction is devoted to this minute representation of the process of becoming a quixote and the development of a quixotic mind in its inner workings and in its relationship with the surrounding world. Contrary to Barrett's later use of the 
first-person narrative as a parodic device, or to the more common employment of a third-person narrator to frame, counteract or comment on the quixote's deluded perception and subversive discourse, Hays's novel offers one of the first and most thorough explorations of the female mind and heart, of the "sentient female self" (Walker, 2006a: 133), anticipating the psychological realism of the later quixotic bildungsromane of Edgeworth, for instance. In her articles and letters, Hays had always expressed her interest in and knowledge of the epistemological theories of not only Helvétius or Godwin, but also Locke, Hartley or Hume, as well as her radical ascription to the defence of women's emotional and intellectual capabilities. Her novel is then an exploration of her philosophical and feminocentric concerns, an empirical study of the radical theorization on the "science of the mind." In that sense, the use of a first-person point of view responds to Helvétius's theories on the shaping of character and to a Jacobin emphasis on the value of subjective personal experience (Bray, 2009: 63), in this case, the moulding of Emma's character and her analysis of her personal experience, which develop under the reader's gaze.

As Bray has insightfully asserted, an essential aspect of that "subjective, personal experience" which is investigated throughout the later eighteenthcentury Jacobin novel is reading (2009: 64). Recalling examples from other epitomes of feminocentric Jacobin fiction -Wollstonecraft's novels- Bray states that in radical fiction 'the heroine's 'character' is often shown to be influenced by an early 'passion' for reading, and the extent to which it is indulged or regulated" (2009: 64). In the context of the radical research into the new "science of the mind," reading is then a fundamental topic. Hays had already explored the matter in previous fiction. In Letters and Essays, Hays includes a short tale, "Henrietta," which revolves around female reading and its consequences. The eponymous heroine is a young girl who reads heroic romances, who "like Mrs Lennox's female Quixotte [...] entered the world, flushed with fallacious hope," and viewed "every object through a false and dazzling medium," and who "drew all her ideas of life from the over-charged pictures in her favourite books; susceptible from nature of lively impressions" (1793: 104-5). A sensibility learnt from these readings gives way to the loss of 
her virtue and to extreme suffering, only to be restored to reason and a more spiritual and philosophical course of improvement in the end. Also in this work, another piece, Letter VII to Mrs---, entitled "On Reading Romances," reveals Hays's approach to reading, and, in particular, female reading. Written as advice to a mother, Hays asserts that she understands her motherly worry at her daughter's taste for reading; nevertheless, she should not be "too much alarmed $[\ldots]$ at [her] predilection for novels and romances; nor think of restraining her by authority from this her favourite pursuit; as by so doing, [she] would probably lose her confidence, without correcting her taste; in which case the mischief might indeed become serious" (1793: 86), an idea that later Sarah Green would also develop in her quixotic novels. For Hays this passion is then natural in youths, and she claims that she has "scarce ever known an amiable young mind that has not been a little tinctured, with what 'the sons of interest deem romance';" however, "if the first steps into life are marked by coldness, and caution, such a character will never possess any other than negative virtues, though it may incur few hazards" (1793: 88). This coldness and caution, qualities her later Emma does not possess, will avoid the disappointments due to be experienced by the idealistic and romantic young mind; nevertheless, the consequences for the character will be even more damaging. In Hays's way of thinking, reading allows these young readers to exercise all their powers of sympathy, to awaken their souls and their minds to what, otherwise, they would not know, including their own minds and characters (1793: 88). Despite this warm defence of reading, Hays denies that she is recommending the "indiscriminate perusal of romances and novels" (1793: 90), and strongly encourages the mother to let the choice of her daughters' books be free, but to read with them, to converse with them and to accustom them to "critical, and literary discussions" (1793: 90-1). These communal female gatherings then resume the images of the reading and debating female community that Barker had portrayed at the beginning of the century, and echo the radical ideals of debating female societies. Hays strongly emphasises the need to educate both children and women, in the case of the latter so as to properly educate the former (1793: 91), and provides a list of recommended readings for her friend's daughter, in which sentimental novels predominate. However, while Goethe's Werther and Rousseau's Heloïse are 
not praised as appropriate models, Richardson's Clarissa is highly commended, among other things, because "in contemplating the perfect model, the imagination is raised, and the soul affected; we perceive the pencil of genius, and while we admire, catch the glorious enthusiasm" (1793: 95). Another recommended reading is Henry Mackenzie's Man of Feeling, from which young readers could move to periodical essays "which are continually interspersed with lively, and entertaining narrations, and where instruction comes in the dress of amusement" (1793: 96-7). From thence, readers should transfer to biography, which can "at once excite our sympathy, engage our affections, and awaken our curiosity," which can at once "amuse and instruct" and, hence, "generate a taste for historical reading" (1793: 97). Finally, "the mind expanded, and liberalized by tracing the fate of nations, and the rise and fall of empires, will proceed to studies still more interesting; to philosophical, political, moral, and religious truth," and, as a consequence, "the love of information will by innumerable associations, become at length almost disinterested, and every interval from active employment will be devoted to mental improvement" (1793: 97-8). This course of reading, and, to an extent, the plot of "Henrietta," will be reproduced in Memoirs. In addition, Hays will also aim to achieve what she stated in her review of West's A Gossip's Story: that the combined powers of reason, imagination, and affection in fiction could and should instruct readers (Walker, 2006a: 171).

As a consequence of this interest in reading, in Hays's novel it occupies a particularly relevant position. In Memoirs "not only what is read, but the way the heroine reads is shown to be formative;" specifically, "Emma's reading practices are heavily influenced, like her general outlook, by the philosophy of Helvétius, and especially by his emphasis on the importance of feeling and passion," and, as a consequence, "her early reading is characterised by vanity and lack of control" (Bray, 2009: 64). This self-centredness and lack of control will become the source of her quixotism: a literary enthusiasm that transforms love and desire into her ruling passions, tincturing the perception of herself, and, as in all female quixotic narratives, influencing her interactions with her suitors. Emma will read her life like one of her novels, and will conduct herself in the manner of a sentimental heroine. In this exploration of female quixotism, 
Hays describes in meticulous detail Emma's course of reading, and, more importantly, her emotional and intellectual reaction to it. Therefore, the sentimental experience of reading is also essential to understand Emma and her quixotic response to literature and life.

Consistent with her theory that "we are all creatures of education" (2000: 42), subject to the "irresistible power of circumstances" (2000: 44), Emma commences her narrative with her family background and her intellectual, emotional and literary inheritance. Motherless and neglected by a debauched father, Emma grows under the care of her uncle and aunt. From Mrs Melmoth she acquires the "susceptibility" to which she will become a "martyr" (2000: 48), owing to her extreme fondness and to the education in sensibility she provides. Emma describes her aunt and uncle thus:

Mrs Melmoth [...] had great sensibility, [...] and a refined and romantic manner of thinking, acquired from the perusal of the old romances, a large quantity of which, belonging to a relation, had, in the early periods of her youth, been accidentally deposited in a spare room in her father's house. These qualities were mingled with a devotional spirit, a little bordering on fanaticism. My uncle did not exactly resemble an Orlando, or an Oroondates, but he was fond of reading; [...] by which means he was a tolerable proficient in the belles lettres, and could, on occasion, quote Shakespeare, scribble poetry, and even philosophize with Pope and Bolingbroke. (2000: 45)

From her sentimental and literature-quoting relations, Emma acquires her early taste for fanciful fiction. Uniting the male and female literary heritage, Hays recalls Lennox's use of “old romances" in her heroine's literary education, although she provides a more thorough account of Emma's romantic education than her predecessor did. That Emma has read romances is clear from the comparison drawn between her uncle and the same heroes Arabella worshipped; a literary taste that, as happened in Lennox's novel, she has acquired by means of the women in her family. Her romantic and sentimental aunt reads for her children "stories from the Arabian Nights, Turkish Tales, and other works of like marvellous import," which have an impact on young Emma: "the more they excited vivid emotions, the more wonderful they were, the greater was [her] transport" to the point that they become her "favourite amusement, and produced, in [her] young mind, a strong desire of learning to 
read the books which contained such enchanting stories of entertainment" (2000: 48). Emma quickly learns to read and her undiscerning relatives perceive this as "the dawn of future talents." However, Emma acknowledges her lack of discernment even when perusing less marvellous literature: she could read aloud "Pope's Homer, and Thomson's Seasons, little comprehending either" (2000: 47). She adds that "emulation was roused, and vanity fostered," already pointing at her self-absorbed reading.

Nevertheless, Emma is not only a passive reader: she is an active one, in the sense that she literally enacts her readings. As she states:

Every day I became more attached to my books; yet, not less fond of active play; stories were still my passion, and I sighed for a romance that would never end. In my sports with my companions, I acted over what I had read: I was alternatively the valiant knight - the gentle damsel - the adventurous mariner - the daring robber - the courteous lover - and the airy coquet. Ever inventive, my young friends took their tone from me. (2000: 48)

In her enactment, Emma has already crossed the gendered boundaries established by literature and built a fantasy of gender equality which does not correspond with reality. Emma plays more male than female roles, more active than passive characters, and attests her later quixotic claim to the traditional male spheres of knowledge and sex. ${ }^{167}$ This challenge to gender conventions is emphasised in her following assertion that she "hated the needle," the conventional symbol of women, and that she amused herself with "various, fantastical, and endless" resources instead (2000: 49). Therefore, rather than appropriating the symbol of the needle, as Barker's Galesia had done, Emma rejects it and substitutes it for the pen.

${ }^{167}$ According to Binhammer, Emma's "play literally enacts the reduction of world to text and herself to the characters in her romances; but her acting in the world as if it were a novel involves more than a simple translation of text to life, or heroine to self. Her re-stagings interrupt the gender identifications assumed by the model of passive reading. Not constricted by her sex, Emma feels equally free to play both knights and damsels, robbers and coquets. The attacks on the novel assume that a young woman reading about airy coquets and valiant knights will become a coquet, and not a knight; but Hays shows Emma refusing these identifications and ultimately figures reading ambiguously. On the one hand we could understand Emma as the victim of indiscriminate and accidental reading who dangerously collapses the text into reality. On the other hand we could see her as an active reader who literally re-enacts the text, and who does not read gender transparently, which reveals the dissonance between her imaginative desires and the life of a woman in the world" (2003: 7). 
However, Emma once more reflects the regulations society is to impose on her education, when, by command of her father, she is taken to a boarding school, where her "actions were all constrained," she "was obliged to sit poring over needle work" and her "body was tortured into forms, [her] mind coerced, and tasks imposed upon [her], grammar and French, mere words, that conveyed [her] no ideas" (2000: 50). In this context, fiction becomes a site for freedom and Emma recurrently escapes this confinement through literature: she "sought and procured books" while she also "satirized [her] tyrants in doggerel rhymes" (2000: 51), announcing her positioning as author. Moreover, she continues to apply literature to life. For instance, in what could be seen as another veiled reference to Lennox, Emma conjures in her imagination all the tragic accidents she had ever heard or read of, and imagined her relatives subject to robbers on the road (2000: 51).

After the death of her uncle, her aunt sinks into melancholy and Emma embarks in another course of literary escapism. She confesses her "avidity for books daily increased," therefore, she subscribed to a circulating library and "frequently read, or rather devoured - little careful in the reflection - from ten to fourteen novels in a week" (emphasis added, 2000: 53). At this point, Emma already speaks of her reading in terms of an addiction: she avows she retained her "passion for adventurous tales, which, even while at school, [she] was enabled to gratify by one of the day-boarders, who procured for [her] romances from a neighbouring library, which at every interval of leisure [she] perused with inconceivable avidity" (emphasis added, 2000: 54). In these passages, Hays employs the recurrent metaphors associated with women and the novel: the immoderate appetite, the undiscerning consumption of the female reader who devours novels without acquiring from them any instructive nurturing, and the uncontrollable passion that requires gratification.

Once again, it will be a representative of patriarchy, the father, who will direct the female mind away from a free wandering through the "fairy fields of fiction" and into the path of history and science (2000: 55). After examining her on her readings, Mr Courtney perceives that Emma is in danger of becoming a quixote like Lennox's and tells his daughter that her fancy "requires a rein rather than a spur" and that her studies must be of a "soberer 
nature" in the future, to avoid her mistaking his "valet for a prince, [his] house for a haunted castle, and [his] rational care for [her] future welfare for barbarous tyranny" (2000: 55). Recalling the common places of the tradition of female quixotism, readers would recognize Lennox's novel as the hypotext from which these examples are taken from, and they would assume the dangers Emma is incurring in. To her disappointment, Emma finds the cases of her father's extensive library locked At first, she resents her exclusion from the titles that are withheld from her behind the glass cases, and the fact that she will be guided in her reading by $\mathrm{Mr}$ Courtney, who provides her with Plutarch's Lives (2000: 56). However, as she reads this last book, Emma's attention becomes forcibly arrested, her curiosity excited, her enthusiasm awakened, and she concludes her reading with a mind "pervaded with republican ardour," "sentiments elevated by a high-toned philosophy" and a bosom "glowing with the virtues of patriotism" (2000: 56). Emma's reading of history proves as inflaming as her previous perusal of narrative fiction; moreover, she still expects life to conform to the ideals she has learnt from Classical exemplary figures. She can soon contrast fiction and reality, though: at her father's dinner table she realises what a poor figure one of her Grecian heroes would have made among modern men of fashion (2000: 57).

In addition, she awakes to the problematic reading of women under romantic tenets, and how the latter may be employed to prolong women's role as mere objects. As Lennox placed the critique to Arabella in the mouth of the beau $\mathrm{Mr}$ Tinsel to question its validity, so does Hays voice society's view through a ridiculous coxcomb who regrets the fact that the lady reads and who states that reading will "spoil all her feminine graces," for "knowledge and learning, are insufferably masculine in a woman -born only for the soft solace of man!" (2000: 57). In his opinion, "the mind of a young lady should be clear and unsullied, like a sheet of white paper, or her own fairer face: lines of thinking destroy the dimples of beauty; aping the reason of man, they lose the exquisite, fascinating charm, in which consists their true empire; -Then strongest, when most weak" (2000: 57). Women, only capable of aping or mimicking the reason of men, lose their own nature in the process, as well as their only claim to power: their position as weak objects of adoration that require the protection 
of a man. However, both Mr Courtney and his daughter reject this interpretation. The former, in particular, explicitly rejects this allusion to the position of women in romance when he asks the coxcomb not to persuade Emma that the "age of chivalry is not yet over; and that giants and ravishers are as common now, as in the time of Charlemagne;" "168 in addition, he states that "a young woman of sense and spirit needs no other protection" than her own self, asking once more not to "flatter the girl into affectation and imbecility," for the town already provides enough "blank paper" (2000: 58). Consequently, he rejects both the models of Arabella and Miss Glanville. Mr Courtney then voices Hays's rejection of the traditional plot of romance which includes a passive woman, as well as of the imposed imbecility on women by means of social expectations. He also provides the opportunity for Emma to follow the course of reading Hays had recommended in her moral letters: he now entrusts Emma with the keys to the bookcases and she ranges through them with redoubled delight. Under her father's direction, she starts a "course of historical reading;" however, while at first she perused these ancient accounts with "pleasure and enthusiasm," soon they became too complicated, corrupt, luxurious, licentious, perfidious, mercenary, and she turns from them fatigued and disgusted to return to poetry and fiction, in order to recreate her spirits once more (2000: 59). Once again, in a recurrent common place of female quixotism, history and fiction are contrasted, and, while the veracity of the former is valued, its exposure of women to immorality becomes its greatest danger.

After this course of historic reading, Emma moves on to theology and ecclesiastical history. As a consequence, she enters "deeply into polemic divinity" and her mind becomes emancipated, full of doubts and the will to reason freely and methodically (2000: 59), a will and a capacity increased by her perusal of the field of metaphysical enquiries and of Descartes in particular (2000: 60). However, the greatest impression on her mind is triggered by a novel: Rousseau's Heloïse. Emma describes her reading experience thus: "with

168 As Brooks has indicated, this reference relates to Burke's lament that the "age of chivalry is gone" in his depiction of the revolution in France as the destruction of those chivalric principles (2000: 58). Hays then equates Burke's discourse with the foolish opinions of the coxcomb. 
what transport, with what enthusiasm, did I peruse this dangerous, enchanting, work! - How shall I paint the sensations that were excited in my mind! - the pleasure I experienced approached the limits of pain - it was tumult - all the ardour of my character was excited" (2000: 60). Differently to heroic romance, Rousseau's novel offers a less virtuous and more sexual storyline which awakes Emma for the first time to her own desires as a woman. This awakening is expressed in the use of terms such as "transport," "pleasure," "tumult," "ardour" or "excited," and in Emma's broken syntax, which signals her uncontrolled reaction and her lack of words to organise and immediately make sense of her experience. Hays then portrays exactly what moralists dreaded about reading this kind of novels in isolation: the freedom to experiment unrestrained passion, as seen in chapter two. This intimate sensuous experience is again repressed by the patriarchal figure, the father; in Emma's words: "Mr Courtney, one day, surprised me weeping over the sorrows of the tender St Preux. He hastily snatched the book from my hand, and, carefully collecting the remaining volumes, carried them in silence to his chamber" (2000: 60). From his library, to Emma's hands, and back to his chamber, the literal transferral of the texts evokes the contemporary gendered struggle over cultural and literary authority. However, the authority of the father is ineffectual in this case: not only is he too late to avoid the appropriation of this dangerous narrative, but his re-appropriation of it after Emma has only read the initial volume does not allow her to read the warning implicit in Julie's tragic ending. ${ }^{169}$ It is, therefore, Mr Courtney's doing that "the impression made on [Emma's] mind was never to be effaced" and that "it was even productive of a long chain of consequences, that will continue to operate till the day of [her] death" (2000: 60). The impressions caused by her reading, then, are overtly identified as the source of her later course of action.

169 This opinion is supported by Nicola Watson, who states that: "Emma never benefits from the corrective re-insertion of Julie into patriarchy" (1994: 46). Binhammer glosses this scene in the following terms: "Her father's confiscation of Rousseau's sentimental novel prevents Emma from reading its didactic warning against sexual transgression. Instead, Emma is sexually awakened and experiences the first transports of desire. Unintentionally, her father's library has given Emma knowledge of female sexual agency, and this phase of Emma's reading life ends with the failure of patriarchal prohibition. Simply dictating the what of female reading is not enough to save Emma from its dangers; a woman is never entirely immune to the accidental text and she needs critical skills, not prohibition, to safeguard her virtue" (2003: 8-9). 
In addition, the circumstances of her personal life -the death of her aunt and father- leave Emma with no guidance except that of the philosopher $\mathrm{Mr}$ Francis. Her aunt's last cautions are to check her "ardent and impetuous sensations," to aspire to "rational independence," to avoid the "illusions of imagination" becoming the "auxiliaries of passion" instead of the aid to "truth and virtue," to learn to read people, and to learn to suspect when her judgement might be in danger of becoming the dupe of her affections (2000: 62-3). However, this does not cause such an impression on her mind as her reading, and Emma is left "a continual victim to the enthusiasm of [her] feelings" (2000: 62).

From this course of reading it becomes evident that Hays has exemplified in fiction the principles she expressed in her previous works. In Emma Courtney she writes that "reading with both feeling and reason can lead to understanding and increased self-knowledge" and that Emma's reading, "for all its faults, demonstrates a laudable, even exemplary enthusiasm and passion;" therefore, the errors of her heroine must be identified as more than the mere "offspring of sensibility" (2000: 36). Sensibility, even fostered by literature, which in Hays's discourse can be beneficial if properly educated and controlled, is in Emma's case excessively nurtured and undisciplined. As Hays stated in her prologue, she offers Emma more as warning than as example, therefore, her unbalanced reading conveys the didactic message that "to read actively and critically, without excessive emphasis on the self, yet with a proper degree of feeling and introspection" is the ideal to which her young readers should aspire (Bray, 2009: 81); that "kind of reading that her heroine [...] tries, but fails to achieve; sympathetic, without putting herself into the text, and ardent, without allowing her own feelings to dominate" (2009: 82). Writing to her adopted son, Emma introduces herself as a banner which announces the dangers of that failure, she consciously presents herself as that "scarecrow" Pawl identified female quixotes with, not to frighten readers away from fiction, but from a selfabsorbed perusal of it that may lead to extreme unhappiness and alienation. Emma's fraught approach to reading and her need to acquire detachment and control, her quixotic over-sympathetic reaction to fiction and adoption of literary principles, will then constitute the core of the novel. In this regard, for 
the rest of the novel, Emma must struggle to interpret the world laying aside the expectations raised by her readings and to avoid becoming a victim of her distempered fancy.

For once, she is a quixote aware of her distorted perception of self and world mediated by literature, mindful of how reality contradicts her expectations, and conscious of the accommodation she struggles to achieve between her romantic desires and the truth of her experience. In her correspondence with Mr Francis, Emma passionately writes:

Everything I see and hear is a disappointment to me: - brought up in retirement - conversing only with books - dwelling with ardour on the great characters, and heroic actions, of antiquity, all my ideas of honour and distinction were associated with those of virtue and talents. I conceived, that the pursuit of truth, and the advancement of reason, were the grand objects of universal attention $[\ldots]$.

Is virtue, then, a chimera - does it exist only in the regions of romance? [...]

Ah! tell me not - that the gay expectations of youth have been the meteors of fancy, the visions of a romantic and distempered imagination! If I must not realize them, I would not live at all. (2000: 79-81)

As happened in Lennox's novel, romance, with its grand actions and sentiments, is presented as a paragon of virtue, but also as an obsolete system of reference, which reflects negatively on a society that has abandoned such values. Emma perceives that the ideals of romance are unattainable; she considers them above the degraded principles of contemporary society. Hence the disappointment she expresses in the aforecited quotation, and her final intimation that she would rather not live in a world that does not and cannot live up to those romantic tenets. Mr Francis, much as the Countess or the Doctor of Divinity, must require her to control her "excessive sensibility" and not believe that because every man "is not a hero" she should distrust the existence of virtue (2000: 81). As the mentor-figure of the novel, he attempts to cure Emma of her romantic approach to reality, hoping she will adopt a more conventional set of principles which will enable her successful interaction in society. However, Emma, while rejecting the role of passive heroine of romance, will still assume the idealism of virtue and love from her readings and will labour to create an ideal image of a hero. Consequently, it is her play 
with the image of Augustus in her mind even before she has met him (2000: 86), which will trigger her later "insanity" and "moon-struck madness" (2000: 168,169) as Mr Francis would term her passionate obsession, as well as her subsequent tragic circumstances. Emma is once more a conscious -and original- quixote who can at one time see the impossibility of employing the principles of romance to guide her life, and at the same time still find ways to insist on that idealistic and unattainable reading. She calls herself a "reasoning maniac," "the most dangerous species of insanity" (2000: 172), for she can dissect and rationalize her monomaniac behaviour, criticising it and fuelling it alike through her self-explanatory narrative. By never allowing herself enough emotional distance from the object of her desire and by actively employing her readings to mediate her experience, adapting them to what she wishes, Emma prolongs her quixotism and the possibility of defying conventions it allows her.

As can be ascertained, then, Emma Courtney is a novel mainly about reading. However, it does not revolve only around the interpretation of texts, but also of people. In the first place, following Hays tenets on reading, Emma learns to understand herself, and in the first chapter of the novel she claims that her intention is to look for the self-examination of her own mind (2000: 44). In that sense, her sympathetic reading has allowed her to know herself better. As evinced in Emma's abovementioned exaltation of the principles of romance and in her response to Rousseau's work, reading not only awakes in her a yearn for romance and heroism in her youth, it also open her eyes to her own sexual desire, therefore revealing to the young quixote those feelings and desires which usually awaken her from her delusion into the domestic plot of marriage, but which here only serve to reassert Emma in her stance and reinforce her alienation as a feeling and sexually active woman. ${ }^{170}$ Emma will admit that the effect her readings had on her, their emotional awakening, determined the whole course of her life: in Hays's conception, reading mirrors the self by its reflection in the stories of others, but it also shapes the self with the models

${ }^{170}$ In a letter to Godwin, which she will later partially reproduce in the novel, Hays states "what are passions, but another name for powers?" (2000: 229). Consequently, in her novel passion is not a cure to quixotism, but its impulse, what moves Emma into action. For Emma, as for Hays, "reason was the auxiliary of [her] passion, or rather [her] passion the generate principle of [her] reason" (2000: 172), a statement that later Hamilton would parody in one of Bridgetina's speeches. 
found in it. Emma's readings provide sense for what she experiences, but they also trigger her sentimental story: she then reads herself in the texts, but also reads her world $b y$ them. If, according to a Helvétian belief, feeling and passion have an immense formative influence, if, as Emma states echoing Helvétius and Godwin, we are all "creatures of sensation and circumstance" (2000: 171), then her "'character' is formed by her passion for Augustus, but this is in turn produced by her unregulated and excessive passion for reading" (Bray, 2009: 69), and her extremely sympathetic response to it. Later in life, once fully awaken from her romantic dreams, Emma will have to make sense of what she has felt immersed in the texts and in her own sentimental narrative. In that regard, the epistolary novel is a particularly suited genre for this process of self-awareness and, more importantly, self-creation: letters demand that Emma reworks and reiterates meaning both for the reader and herself as writer (Wallace, 2001: 245). Therefore, Emma epitomises Hays's ideal heroines or "female philosophers" who are "thinking, rational beings whose highly developed sensibility exists in dynamic tension with reason as they struggle to understand and control their circumstances, choices and actions" (Wallace, 2001: 238). The epistolary biography Emma is writing serves then as a "mode of philosophical control for the raw material of sensibility" echoing Hays's model of "sensibility as a first response which through the mediation of rational reflection develops into true philosophy" (Wallace, 2001: 249). Early in the novel, Emma makes this need for rational mediation explicit in order not only to continue her narrative, but to do so with control of her material; she states that she must "check this train of overwhelming reflection, that is every moment on the point of breaking the thread of my narration, and obtruding itself to my pen" (2000: 62). While in her youth she had not achieved this mediation, the older Emma, who is editing her own self, gains distance and offers those remarks on her own sentimental response to reality and even on her own writing.

Together with her construction of a self, Emma's main epistemological effort throughout her narrative is the need to be able to decipher and rework the object of her affection, Augustus Harley. In a letter to Godwin, Hays explicitly asserted this should be so, and that their relationship had to be "equivocal," not 
"clear \& unambiguous" (qtd. in Brooks, 2000: 18), so as to develop Emma's obsessive passion and her self-exploration (Brooks, 2000: 21). Therefore, Emma's foremost desire is to be able to read Augustus's mind (2000: 122), and throughout the novel he is the "perfect enigma," the "inflexible, impenetrable, man" that remains to be deciphered (2000: 134, 138). This epistemological obscurity leads her to exclaim: "I can read any mind with greater facility that I can read your's (sic); and, yet, what other have I so attentively studied? This is a problem I know not how to solve" (2000: 138). To highlight this need for interpretation, their relationship is mainly textual, conducted through letters, therefore emphasising the act of critical reading Emma aims to fulfil in trying to understand his vague, obscure, enigmatical writing and behaviour, or even his prolonged silences. However, in the same manner that her extreme passion and sensibility interfered with her reading of texts, Emma's unrestrained passion for Augustus and her own desire for sexual fulfilment filter her epistemology. In other words, it is precisely that passion which transforms an otherwise unromantic man into the hero of the sentimental story that Emma is writing for and about herself. As Ty has asserted, the Augustus of Emma's letters is a hero created by the heroine's imagination (1993: 54), very different from the unresponsive man he is outside Emma's reconstruction of him through her romantic colouring. It is only Emma's imagination which can transform him into a hero worthy of Rousseau, into the "St Preux, the Emilius, of [her] sleeping and waking reveries" before they even meet (2000: 91). Don Quixote had transformed Aldonza Lorenzo into an ideal object of his affections, into the Dulcinea of his dreams, by means of his distempered imagination; Arabella and other female quixotes had also built perfect representations of romantic heroes to fulfil their desires. Emma inherits this transformation based on desire and universalises the quixotic experience by displaying how love itself distorts perception, how the lover projects his or her imagination on the beloved object to convert him or her in an ideal.

Emma herself is aware of her delusion. She states that "cut off from the society of mankind, and unable to expound my sensations, all the strong affections of my soul seemed concentrated to a single point:" her love for Augustus (2000: 91). In addition, she avows that, after a course of self-examination, she had to 
acknowledge that it was "solitude, the absence of other impressions, the previous impressions that had operated on my character" which had combined to "awaken all the exquisite, though dormant" sensibilities of her nature (2000: 92). As a result, "however romantic it might appear to others, and did appear even to [herself]," she confesses that she "loved an ideal object (for such was Augustus Harley to [her]) with a tender and fervent excess" (2000: 92). Differently to Arabella and her quixotic daughters, Emma is aware of her romantic delusion and the fact that Augustus is only a creature of her pygmalionic imagination. What is more, she even analyses the reasons that have led her to such a distempered fancy focused on an object of affection. She then serves at once as illustration and as exegetic critic of the female quixote. In addition, Emma will diverge from her quixotic sisters as well in the process of seduction which in her case is triggered from within her own imagination and not by the manipulation of appearance performed by other characters. Emma tries to combat her quixotic illusion, but in vain: her "reason was but an auxiliary to [her] passion" and it persuaded her that she was "only doing justice to high an uncommon worth;" her imagination "lent her aid, and an importunate sensibility, panting after good unalloyed, completed the seduction" (emphasis added, 2000: 93). In an interesting turn of events, it is not the lover who aims to seduce the heroine by his impersonation of the romantic hero, as Sir George or Hamilton's Vallaton do. Emma requires no external aid to read Augustus as the ideal hero and it is her imagination alone which conspires to seduce her. She recurrently asserts that it is she who misconstrues otherwise natural emotions with her sentimental veil (2000: 99) and who greedily absorbs the "delicious poison" of hope (2000: 101, 103). In addition, Augustus's role as her intellectual mentor, as a guide through the fields of language, philosophy, criticism, grammar and composition, as a companion in music, drawing and reading (2000: 103), reinforces Emma's interpretation of him as the hero of the sentimental narrative she is constructing about herself.

This active misconstruction on Emma's behalf has other important interpretations. In accordance with other quixotic heroines who saw courtship as the only realm in which their story could ever occur, Emma seems to fall in love with him because she has no other channel for her energies and aspirations 
in the midst of her solitude and confined possibilities (Ty, 1993: 54). Her passion for him and the aspiration to a conventional romantic plot offers Emma the possibility for her philosophical, epistemological and sentimental divagations as well as for the writing of her own story. ${ }^{171}$ In the requisite of balancing her position between her need to conform to the feminine ideals and her desire to participate in the "male" realm of public discussion (Ty, 1993: 47), Emma then employs the female experience of love to condone her writing of other topics. ${ }^{172}$ In the process, she reverses the usual roles in courtship and she objectifies Augustus, transforming him in the object of her adoration, in her own idealised dulcinea, to which she acknowledges her feelings against society's "pernicious system of morals" which teaches hypocrisy and concealment in women (2000: 109). What is more, she even proposes the possibility of matrimony, insisting in knowing if there is a prior engagement. ${ }^{173}$ Going even one step further, she not only appropriates the prerogatives of the knight, but also of the rake; when her request for marriage goes unreciprocated, she offers herself as Augustus mistress. In the most criticised episode in the novel, she writes her willingness to enter into this outcast role, concluding: "My friend - I would give myself to you - the gift is not worthless" (2000: 155). ${ }^{174}$ Therefore, he becomes the sexual impulse in her quixotic quest and the excuse for her positioning as controlling subject of both the narrative and the

${ }^{171}$ In this regard, Binhammer states that "If moralists were concerned that young female readers would read a copy as the original and become the original themselves - that is, would read a fictional representation as reality and copy the text - here the reader reads the copy as a copy, for there has never been a correspondence between Emma's text and her world. All Hays gives us is a representation of the representation of a romantic hero, and the reader's distance from the inaccessible original makes her see the impossibility of female desire in the world outside the text" (2003: 10). Tompkins's early assessment of the novel also distinguishes between two readings of Augustus. She asserts that he is presented as more of a Werther than the Unitarian mathematician he is supposed to be, stating that Hays provides no sign in any of her novels of ever having studied or understood a man, for he is merely the "Object of her Sensibilities," being "far more aware of them than of him" (1938: 162). While Tompkins's evaluation of Hays's personal and literary achievements is, in general, excessively jaundiced, Augustus does indeed appear as a type, a model, rather than a real man, and an excuse for Emma's self-reflection and exploration of her own sensibility in the shape of a novel.

${ }^{172}$ According to Brooks, Hays learnt this from Helvétius; for this philosopher, as long as it was 'in society's interest for women to elevate love into a 'primary pursuit', they would be educated for little else and they should exploit this," something Hays tried to convince Godwin of (2000: 23).

173 Brooks perceives the correlation once more between Hays's and Emma's objectification of the man they love: she states that Hays was in love not only with the real-life William Frend but with her idea of him, and that she transformed Frend into that "object" of love (2000: 9); an objectification both men reacted to in similar ways.

${ }^{174}$ Here some critics saw a veiled message to Frend, Hays's object of affection who inspired Augustus, and amply attacked and satirized Hays for her forwardness. 
love affair, longing for the two sources of male power, knowledge and sex (Ty, 1999: 55), and raising the accusations of unsexedness that were to follow against both heroine and author. In that sense, Emma is very different to other female quixotes: she is not in the liminal position between object and subject that Arabella was as a heroine of romance being courted by the hero or as a romantic character framed in other people's narrative. Hays's heroine is the only subject in her passionate first-person narrative. As Hays stated in her preface, it was not the hero's memoirs that she professed to write (2000: 37); he is now rendered the footnote in the heroine's story.

And it is because of this position as subject that Hays's assertion that she is writing a cautionary tale becomes problematic. Not only does she, as author, proclaim the didactic intention with which she has written the novel, but the heroine herself recurrently states that she has taken the pen for the instruction of her young readers so they can learn from her life "a more striking and affecting lesson than abstract philosophy can ever afford" (2000: 43). Writing for the benefit of her adopted son, Augustus Hartley Jr., she believes her story can help educate both men and women readers. Nevertheless, Hays's portrayal of Emma as a didactic instrument is ambiguous; in this sense, as Binhammer has asserted, the main "interpretative problem of Emma Courtney for the female reader is whether to read Emma as a warning or an example, as misguided or justified in her desires," with the novel itself foregrounding the "question of how to read Emma Courtney through the text's obsession with how Emma reads," therefore allowing the embedded reader in the text to reflect "Hays' critical position on how to read Emma" (2003: 6).

First of all, Emma is far from being a Richardsonian exemplary female model. Whereas in 1793 Hays praised Clarissa as an ideal model which could inspire her readers into imitation, by 1797, in an essay entitled "On Novel-Writing" published in the Monthly Magazine, Hays had changed her ideas, as she had changed the genre that was her focus. She stated that Richardson's heroine was "far removed from common life and human feeling" (qtd. in Brooks, 2000: 285). In Hays's opinion, then, “fiction should represent reality as it is and not gloss over the ugly and difficult," instead, "it should delineate the conditions of actual female experience," even if in this extreme application of Godwin's 
"perfect sincerity" one could take the narrative "beyond existing limits of female propriety" (Walker, 2006a: 172). Emma, her female philosopher, is then conceived "as fallible, and as a working model, not a fixed ideal like the heroines of other sentimental or Jacobin novels" (Wallace, 2001: 244). In Hays's own words,

It has commonly been the business of fiction to pourtray (sic) characters, not as they really exist, but, as, we are told, they ought to be -a sort of ideal perfection, in which the nature and passion are melted away, and jarring attributes wonderfully combined.

In delineating the character of Emma Courtney, I had not in view these fantastical models: I meant to represent her, as a human being, loving virtue while enslaved by passion, liable to the mistakes and weaknesses of our fragile nature. - Let those readers, who feel inclined to judge with severity the extravagance and eccentricity of her conduct, look into their own hearts; [...] yet, let them bear in mind, that the errors of my heroine were the offspring of sensibility; and that the result of her hazardous experiment is calculated to operate as a warning, rather than as an example. (2000: 36)

Her realistic, although subversive and extremely sentimental, heroine is then a questionable role model and, probably to avoid this particular censure, Hays identified her as a warning rather than a model in the preface. Despite this assertion, her first-person narrative does not allow the necessary distance from the heroine's discourse to become a warning either; the omnipresence of Emma is absolute and, with few exceptions, her voice is the only one the reader hears. Moreover, Hays's employment of the usual devices of the sentimental novel -the tragic scenes, the swoons, the raving fevers, the tears, the passionate exclamations and broken syntax, even the impossibility of writing due to emotion- all aim to manipulate the reader and to seduce him or her into Emma's point of view and her self-absorbed text. The implied reader, one of "the thinking and the feeling few" to which Hays addresses her novel (2000: 38), will then need to struggle to maintain a balance between distance and sympathy, reproducing the same fraught approach to sentimental literature that Emma is experiencing. In a sense, Hays, who placed more faith on the educational power of sensibility than Wollstonecraft did and who employed it with less ambiguity in her narratives, ${ }^{175}$ educates the reader through

${ }^{175}$ Wallace has identified the struggle between sensibility and rationality which takes places in Wollstonecraft's and Hays's novels, and the differences between them. She concludes 
immersion: her ideal reader is also a quixotic one, one that can fully sympathise with the heroine, but who can awaken at the end by the pain caused by the example of her sufferings. At the very beginning of the novel, Emma exhorts her reader to "exercise [his] understanding, think freely, investigate every opinion, disdain the rust of antiquity, raise systems, invent hypotheses, and, by the absurdities they involve, seize on the clue of truth;" she pleads: "rouse the nobler energies of your mind; be not the slave of your passions, neither dream of eradicating them" (2000: 42), for passions are powers. The result will be to "arrive at truth through many painful mistakes and consequent sufferings," which is man's unavoidable constitution (2000: 43). However, the boundaries between engaged and detached reading are blurred, and the dangers are the same as for her self-absorbed and passionate heroine.

In this regard, Hays's gender concerns also stand in the way of her didactic intentions, a fact which is highlighted by the lack of cure or repentance at the end. Emma does not follow other quixotes' pattern of awakening. Although she begs Mr Francis to become her surrogate "conscience" (2000: 70) and to "save [her] from [her]self" (2000: 175) -in the same manner Arabella asked the Doctor to discover her to herself-, it is to her own conscience she must respond and it is her own exercise of self-examination, resolution and perseverance she must develop in order to overcome her prejudices (2000: 70). While a "friend and counsellor" (2000: 72), Emma sometimes doubts Mr Francis's role as confident precisely because he cannot sympathize with her feelings of oppression (2000: 73) and because he claims for her an independence she cannot truly obtain as a woman (2000: 173). In addition, in both an echo and a reversal of Lennox's Countess, it is the wise Mr Francis who abruptly disappears from the narrative and leaves Emma once more to her own self. Another common place of the cure of the female quixote, marriage, is rendered difficult owing to her ideal aspirations, for she rejects marriage "for an establishment" or the "permanent obligation" under which it would put her, especially if her affections were not engaged (2000: 88-9). Nevertheless, at one point Emma believes that she is cured from her "morbid excess of a 
distempered imagination" and her romantic and frenzied visions of life in her unromantic marriage to Mr Montague (2000: 197). However, her quixotism does not disappear with marriage and motherhood, and her reunion with Augustus attests that her passions are as enthusiastic as ever.

As she approaches the end of her narrative, she states "there is no cure for me" (2000: 177), and her half-spirited final recantation does not provide the rotund closure of other quixotic novels. This again points at the Jacobin and Romantic exaltation of the quixote as a superior creature placed in a hostile and undeserving world, transferring the author's satire towards that debased society. ${ }^{176}$ Throughout the whole novel, the focus has been on Emma's wish to escape the confinement placed on her because of her gender, and her literary and philosophical quixotism is very much an expression of that desire for freedom. In one of the best-known quotations from the novel, Emma states this gendered constraint in the following terms:

Cruel prejudices! - [...] - hapless woman! Why was I not educated for commerce, for a profession, for labour? Why have I been rendered feeble and delicate by bodily constraint, and fastidious by artificial refinement? Why are we bound, by the habits of society, as with an adamantine chain? Why do we suffer ourselves to be confined within a magic circle, without daring, by a magnanimous effort, to dissolve the barbarous spell? (2000: 65-6)

Over and again does Emma echo Hays's position in the debate on female understanding and education; she recurrently states that if character is modified by circumstances, then it is "the customs of society" which have "enslaved, enervated, and degraded women" (2000: 73), in opposition to the freedom granted to men. Resuming the image of the magic circle, Emma complains of the limiting female habits acquired by precept and example from an early age, and regrets her immobility and the frivolous and trifle activities afforded for women:

I perceive, indignantly perceive, the magic circle, without knowing how to dissolve the powerful spell. While men pursue interest, honour, pleasure, as accords with their several dispositions, women, who have too much delicacy,

${ }^{176}$ As Ty phrases it, "her half-hearted repentance and her romantic narrative do not actually condemn pure passion as much as the conventions of society which do not tolerate its expression" (1993: 58). She also exposes how sensibility, representative of the female power of disruption, remains unchecked at the end (1993: 58-9). 
sense, and spirit, to degrade themselves by the vilest of all interchanges, remain insulated beings, and must be content tamely to look on, without taking any part in the great, though often absurd and tragical (sic), drama of life. Hence the eccentricities of conduct, with which women of superior minds have been accused - the struggles, [...] of an ardent spirit, denied a scope for its exertions! The strong feelings, and strong energies, which properly directed, in a field sufficiently wide, might - ah! what might they not have aided? forced back, and pent up, ravage and destroy the mind which gave them birth! (emphasis added, 2000: 116)

The isolation and lack of freedom is presented as the source of Emma's eccentricities; therefore, Hays voices the idea that had been implicitly conveyed in previous quixotic fictions: that the young female quixote's imagination is a consequence of that restraint and that quixotism is what grants her the moment of freedom and action she has longed for. This repression, which is expressed at several levels -linguistic, professional and sexual- in the novel (Ty, 1993: 46), is reinforced by the asphyxiating "circular and repetitive structure of the narrative" (1993: 56) and by Emma's constant exclamations that she will never be society's "slave" (2000: 78). ${ }^{177}$ Time after time, Emma implores to break the magic circle, to advance her plot, to become married, to become Augustus's mistress, to continue with her philosophical, scientific and sexual education; and, even when Augustus is finally out of her reach, it is Emma herself who chooses marriage in order to achieve change and to fulfil her destiny as a woman. Therefore, while Emma becomes the subject of her narrative and takes the initiative in her romantic and sexual plot, she is nevertheless bound by the conventions of society and her story can only advance in the accustomed manner. Her recurrent frustration at her father, at Augustus, at Mr Francis, springs from the limited possibilities they offer her: they instruct her beyond the limits of conservative conventions, they open the gates of knowledge and independent thought, but provide no possibilities for her to put her knowledge into practice, except as a dutiful daughter, wife and mother. She angrily exclaims: "Why call woman, miserable, oppressed, and impotent, woman - crushed, and then insulted - why call her to independence

${ }^{177}$ To reinforce her satire against society and its constriction of women, Hays allows another ridiculous male character, Mr Melmoth, to draw a comparison between servants, women and slaves, all of which should be debarred from thinking (2000: 144). Emma's satirical answer to this remark, to another man's attack against female wits, and even to the defence of slavery and colonization (2000: 142-45), voices Hays's Jacobin concerns. 
- which not nature, but the barbarous and accursed laws of society, have denied her. This is mockery! [...] [you] mock the child of slavery and sorrow!" (2000: 173). In this sense, "Hays' critique of the social restraints placed upon Emma's active mind constitutes [...] less a warning against the excesses of the female imagination than an indictment of prejudice and the constraints women must operate under in attempting to communicate their desire" (Binhammer, 2003: 11).

Returning to the matter of her reading, while "the scenes of intimate reading unleash an unrealizable desire in Emma," Hays still critiques "the cultural conditions surrounding Emma's reading" when, "rather than being a passive receptacle of what she reads, Emma actively refuses the confines of the world because of the knowledge she has gained from reading" (Binhammer, 2003: 11). Reading and its subsequent quixotism is then an act of subversion and, whereas for other female quixotes it is a state they overcome by the end of the narrative, in Hays's novel it defines her heroine for life and points at the impossibility of a, for Hays, acceptable situation for Emma in contemporary society. Hays is again original in this respect: neither killing her heroine, nor granting her the accustomed happy ending, she leaves her in the liminal space between freedom and constraint quixotism provides, suggesting to her female readers that, unfortunately, the "only way to be a free and desiring woman is by living in a novel" (Binhammer, 2003: 12). Emma's quixotic intellectual and sexual aspirations then clash with and expose the Enlightened hypocrisy on gendered matters (Walker, 2006a: 144-6; 2006b: 18). In addition, while at times testing the patience of her audience, Emma's recurrent complaints together with her "inactivity and confinement" are designed to "instigate revolt and reaction in the reader" (Ty, 1993: 57). Therefore, as happens in all female quixotic narratives, the private story of her quixote is an instrument in Hays's hands in order to invest private female matters with public meaning (Wallace, 2001: 244), inscribing it in the context of the increasing social and political significance of private experience, and, in particular, of women's private experience.

This delicate equilibrium between propriety and impropriety, between constraint and freedom, between private and public, female and male spheres, 
is also reflected in the form which Hays chose for her novel: the hybridization between a philosophical tract and an epistolary novel, between a political novel and a sentimental one. According to Wallace (2001: 238), Hays, as other women writers, negotiates her public image by means of her generic experimentation. In this sense, her complex and subtle negotiations between sensibility and reason, between Hays's and Emma's position as emotional and intellectual beings, between their role as philosophers and as sentimental writers, between their locus as private and public people, are mirrored in the novel's hybrid nature. By employing the feminine epistolary and sentimental novel, but tincturing it with her political and philosophical concerns, by transforming her private experience into a means to deal with public concerns, Hays positioned both herself and her heroine in a dangerously unsexed territory. ${ }^{178}$ This unsexedness, in the sense that they reject the condoned behaviour for women, is achieved, ironically, for being too sexual. Emma explains her liminal position in the following terms:

I feel, that I am neither philosopher, nor a heroine - but a woman to whom education has given a sexual character. It is true, I have risen superior to the generality of my oppressed sex; yet, I have neither the talents for a legislator; nor for a reformer, of the world. I have still many female foibles, and shrinking delicacies, that unfit me for rising to arduous heights. (2000: 149)

In the form in which her narrative is presented, Emma cannot fit into neat established roles, such as the "philosopher" or the sentimental delicate "heroine," with all they imply: she is a woman, in all its realistic complexities. This fact is emphasised at the end of the novel. Emma studies "physic, anatomy, and surgery, and the various branches of science connected with them" (2000: 196), to help her husband, who is a doctor. Having to take care of the injured Augustus, she "neither trembled, nor shed a tear - [she] banished the woman from [her] heart" and acted like a skilled surgeon, "vanquishing every shrinking sensibility" and exclaiming that "affection had converted [her]

${ }^{178}$ She had done this from her early correspondence with her fiancé, John Eccles, in which, as Kelly has asserted, she reconciled the secular culture of Sensibility with her Dissenting background (2001: 80), emphasizing sensibility's foregrounding of the "feminine" in "social practice, culture, and discourse," with Dissent's stress on intellectual cultivation and ethical freedom (2001: 80-1). 
into a heroine!" (2000: 203), in this case the unsexed, hybrid, liminal heroine of Hays's equally hybrid narrative. ${ }^{179}$

Hays termed Emma Courtney a "philosophical romance" in a letter to Godwin (qtd. in Kelly, 2001: 94), highlighting this hybridization and the blending of the female experience of love with the masculine realm of philosophy, and taking Jacobin fiction beyond what it had been until that moment. ${ }^{180}$ In this sense, from the point of view of genre, Hays is not writing a romance: her psychological realism, her exploration of the processes of the mind and of her heroine's sexuality and yearning point towards a different species of writing, a philosophical psychological novel or, as psychology in Hays's is determined by feeling, a philosophical sentimental novel that "enacts the conjugation of sensibility and rational control as philosophical exploration through the conscious recontainment of narrative form" (Wallace, 2001: 249), which is true as much for Emma as for Hays. Moreover, in her preface Hays overtly links her work to the new species of writing being developed in the eighteenth century, when she states the following:

Whether the incidents, or the characters, are copied from life, is of little importance -The only question is, if the circumstances, and situations, are altogether improbable? If not -whether the consequences might not have followed from the circumstances? -This is a grand question, applicable to all the purposes of education, morals, and legislation. [...]

Every possible incident, in works of this nature, might, perhaps, be rendered probable, were a sufficient regard paid to the more minute, delicate, and connecting links of the chain. Under this impression, I chose, [...] a simple story -and even in that, the fear of repetition, of prolixity, [...] made me, in some parts, neglectful of this rule: -yet, in tracing the character of my heroine from her birth, I had it in view. (2000: 37)

${ }^{179}$ One of the strongest marks of this unsexed state is Emma's oblivion of her duties as wife and mother. Although she states she does not indeed forget them (2000: 204), twice is the reader told that she actually abandons her nursing duties towards her daughter (2000: 202, 204). This abandonment is reproduced in Mrs Bullock's anti-radical Dorothea, in which the child actually dies, and constituted one of the strongest arguments against Emma's selfabsorbed nature.

180 Interestingly, Kelly asserts that Hays "feminizes Godwin's novel form and masculinizes Holcroft's to construct her own, Revolutionary feminist version of the English Jacobin novel, or "philosophical romance';" in this regard, her depiction of a female philosopher is already more daring and scandalous in relation to "the gendering of discourse and culture" (2001: 105). 
In this sense, Hays was again contributing to the generic debate of her time, aligning with the formally and morally plausible novel, filling her novel with the kind of minute detail that later Hamilton would parody, while at the same time acknowledging the limitations this form of realism posed for the novelist. However, in another turn of the generic screw, Hays includes in her narrative both fictional and real letters. As all Hays scholars are aware of, the author used her letters to Godwin or Frend and partially rewrote them to thinly veil the authentic nature of some of her novelistic material, intentionally and strategically blurring the boundaries between fiction and biography (Wallace, 2001: 245). Hays, hence, gained distance and control over her material by transferring her life experience to her heroine, so she could consequently achieve greater rational control in order to philosophically shape her personal emotional experience. By so doing, she created a complex novel that at times loses its artistic coherence in the process of self-exploration, but which nevertheless gains validity in this self-division of heroine and author because of its reinforcement of the message of the "irreconciliabity of the feminine and the philosophical in unrrevolutionized society" (Kelly, 2001: 107), and the need for the female subject to negotiate her position in it. Emma revealingly states that hers is a "solitary madness in the eighteenth century" (2000: 173), that she is a "romantic enthusiast" who is exhorted to "become more like an inhabitant of the world" (2000: 146). She is recurrently described as a "solitary enthusiast," an innocent "child in the drama of the world" ${ }^{181}$ who must learn that those "who have the courage to act upon advanced principles, must be content to suffer moral martyrdom" (2000: 163); she calls herself an "alien," alone in the universe (2000: 190), a "solitary outcast from society" (2000: 191), all Romantic images of the quixote as a solitary wanderer, as an outcast from a flawed society. As Hays did in real life, Emma will end her days in retirement, neither capable of accepting the limitations of society, nor of rejecting her enthusiastic persona. This failure, or unwillingness, to negotiate her position thwarts Emma's integration in society and the happy conclusion for the quixotic novel of development and, therefore, subverts the conservative plot of reinforcement of the status quo by means of the female quixote's cure.

181 This last expression is copied verbatim from Mackenzie's Man of Feeling, in which the sentimental quixotic hero, Harley, describes himself as such. 
The closeness that is perceived throughout the novel between author and heroine, of course, triggered much of the subsequent censure at her own personal exposure, as the gendered and generic challenges Hays posed also did with regard to the condemnation of her radical ideology and her transformation into the embodiment of the dangers that ideology had for women. However, it also transformed Hays into one of the boldest, most innovative female authors of her time, as she advanced the psychological exploration that would characterise the nineteenth- and twentieth-century novel. As her quixotic heroine, Hays aspirations of intellectual and sexual freedom were not to be granted in her time and she would have to remain an alien, awkward being, until rescued by later readers and critics.

\subsection{Good and Bad Reading: Quixotic Readers and the Proper Female Model in Hamilton's Novels}

A novelist and essayist, Elisabeth Hamilton (1756?-1816) is another of those striking examples of women writers who made use of their increasingly influential voices to partake in the political, moral and cultural debates of her time. Educated by her uncle and aunt, she had a childhood devoted to helping neighbouring families and reading avidly, from which she derived a certain passion for heroes such as William Wallace or even those belonging to Classical literature. She studied science and regretted her deficiency in receiving a Classical education; however, her aunt's vision of female improvement seems to have been much more limited than her niece's, and she instilled in the latter the idea that learned women were to become the objects of ridicule and criticism. In one of the letters her friend Elizabeth Benger included in Hamilton's Memoir she stated this sense of shame in her passion for learning in the following terms: "Do I not well remember hiding Kaims's Elements of Criticism, under the cover of an easy chair, whenever I heard the approach of a footstep, well knowing the ridicule to which I should have been exposed, had I been detected in the act of looking into such a book?" (1818: II, 31). This assertion, which reminds of Austen's similar statement about her writing, manifests Hamilton's ambiguous approach to her own career as an 
educationalist and writer. This fact is evidenced in her reluctance to publish her first novel under her name, a disinclination which arose from the belief that the "woman, who has once been brought before the public, can never be restored to the security of a private station" (Benger, 1818: I, 128).

Despite her initial embarrassment, Hamilton started her literary career as an essayist, with the publication of an anonymous article in Henry Mackenzie's periodical The Lounger in 1785. Deeply influenced by her religious beliefs, Hamilton developed her own theories of the "science of mind" as a hybrid of both empirical and rationalist science and evangelical religion (Warburton, 2001: 270), and applied it to her main field of interest: education, a subject she recurrently and ambitiously explored in fiction and non-fiction alike. For example, her Letters on Education (1801), republished in a second edition as Letters on the Elementary Principles of Education (1801), "offers detailed theoretical explorations of how children learn, and owes at least as much to the philosophical theories of John Locke as it does to the era's standard conductbook advice on girls' education" (Perkins, 2004: n.p.), which again proves the richness and variety of her sources. This interest in education is also manifest in her works of fiction. The Memoirs of the Life of Agrippina, Wife of Germanicus (1804) was intended to be read as philosophy, for it "attempts to use the techniques of fiction to interest young women readers in questions of ethics and morality raised by historical studies" (Perkins, 2004: n.p.), and Hamilton was obviously upset when instead it was "preposterously classed with novels" and read as "a sort of biographical romance" (1818: I, 160). Later came Letters, Addressed to the Daughter of a Nobleman, on the Formation of Religious and Moral Principle (1806), which attempted "to explain ethical principles in terms comprehensible to a young child" (Perkins, 2004: n.p.), and one of Hamilton's greatest literary successes The Cottagers of Glenburnie: A Tale for the Farmer's Ingle-nook (1808), which features the reformation of a highland community by the commonsensical instruction of a visiting relative. In an article believed to be written by Maria Edgeworth for the Gentleman's Magazine, this novel was highly praised for its "faithful representation of human nature in general, as well as of local manners and customs," together with its mixture of pathos and humour which appeals to all readers, and its 
benevolent satire which seeks to improve and not to wound (Edgeworth, 1816: 623). According to Edgeworth, nations as well as individuals benefited from Hamilton's drawing of their flaws (1816: 623).

Besides her role as a novelist, Edgeworth praises above all Hamilton's educational purposes, especially her interest in educating women so they in turn could educate their children appropriately. Edgeworth highlights the fact that Hamilton was also educated in philosophy and that she made metaphysics practical by its application to the field of education, as well as accessible and intelligible for less learned readers, in particular, women. However, Edgeworth states, she did so without incurring in the abandonment of any form of femininity and emphasises that Hamilton was a model both of a domestic woman and a literary one (1816: 624). ${ }^{182}$ In this sense, as Goodman (1999) or Grogan (2000: 11-12) have asserted, Hamilton was a liberal, rather than a radical educationalist, who did not shy away from public debate, but who nevertheless still remained a defender of a conservative position about the visibility of women in the public sphere. This engagement with current issues, and its focus on the feminocentric realm of education, is also evidenced in her later works: Exercises in Religious Knowledge; for the Instruction of Young Persons (1809); A Series of Popular Essays, Illustrative of Principles Essentially Connected with the Improvement of the Understanding, the Imagination, and the Heart (1813); and Hints Addressed to the Patrons and Directors of Schools (1815).

${ }^{182}$ Edgeworth's early assessment already pointed out at Hamilton's liminal position in the "vain debate" on women's intellectual capabilities, and their access to certain studies such as metaphysics. She wrote: "In recommending to her own sex the study of metaphysicks (sic), as far as it relates to education, Mrs. Hamilton has been judiciously careful to avoid all that can lead to that species of 'vain debate' of which there is no end. She, knowing the limits of human understanding, does not attempt to go beyond them, into that which can be at best but a dispute about terms; she does not aim at making women expert in the "wordy war," nor does she teach them to astonish the unlearned by their acquaintance with the various vocabulary of metaphysical system makers - such jugglers' tricks she despised: but she has not, on the other hand, been deceived or overawed by those who would represent the study of the human mind as one that bends to no practical purpose, and that is unfit and unsafe for her sex. Had Mrs. Hamilton set ladies on metaphysic ground merely to shew their paces, she would have made herself and them ridiculous and troublesome; but she has shewn how they may, by slow and certain steps, advance to an useful object. The dark, intricate, and dangerous labyrinth she has converted into a clear, straight, practicable road - a road not only practicable, but pleasant; and not only pleasant, but what is of far more consequence to women, safe" (1816: 624). 
Despite her prolific essay-writing, where Hamilton's engagement with public issues is at its best is in her satirical novels. Her first published fiction, Translation of the Letters of a Hindoo Rajah; Written Previous to, and During the Period of His Residence in England; To Which is Prefixed a Preliminary Dissertation on the History, Religion, and Manners of the Hindoos (1796), joins a satire "on courtly society and empire to a satire on courtly-revolutionary politics in England," which raised Hamilton's fears on how such an "unsuitable," that is, unfeminine novel, would be received as the work of a woman (Kelly, 2001: 129). A tribute to her recently deceased brother Charles, a well-known orientalist, in her first novel Hamilton displays an ample knowledge of her sibling's work and a skilled management of it within a fictional frame. According to Kelly, Hamilton aims "to blend discourses conventionally differentiated hierarchically by gender" (2001: 132). On the one hand, Hamilton employs the novel and the translation of learned foreign works, even if a mock one, which traditionally appeared associated to women, while, on the other hand, instead of the sentimental travel narrative, Hamilton develops the satirical travel narrative, which authors such as Swift, Montesquieu, or Johnson had made popular at the time. ${ }^{183}$ Therefore, Hamilton employs a genre suited to her ideological purposes and, by so doing, "reclaims her novel from the 'merely' feminine by appropriating discourses conventionally gendered masculine," including "the Enlightened learned disciplines practised by her brother and his colleagues- in her 'Preliminary Dissertation', glossary, and notes" to create an instance of the "footnote novel" women writers would employ to "practice learned discourses and engage in political issues conventionally closed to them" (2001: 132-33). These footnote novels would then present a more conventionally feminocentric narrative in the main text, while they would qualify its ideological or intellectual context by the construction of a complex and detailed paratext, shifting the unconventional discourses to the margins of the novel. In this sense, Hamilton proves her anti-

183 Once again, the culture of sensibility was associated with women and many women writers chose a subjective, first-person epistolary narrative in order to portray their experiences abroad and to offer a comment of their times and their own personal experience. These women would often unite a radical ideology and a Romantic focus on the self; therefore, Hamilton's detachment from their chosen genre is significant of her ideological and aesthetical positioning. The best example of this form sentimental travel writing would be published the same year as Hamilton's novel: Wollstonecraft's Letters Written During A Short Residence in Sweden, Norway and Denmark (1796). 
radical stance and her distance from Hays's philosophical novel, by displacing her political discourse from the novel to its paratext, transforming it into a footnote to her fiction and pointing at the marginal nature of the possibility of female involvement in political matters. That is, while Hays introduced philosophical discussions in Emma's letters, placing them at the core of her novel, Hamilton's narrator glosses texts or ideas in the preface or in footnotes to her main text. Hamilton's narrative then dialogues with the masculine discourse, but the latter has now become the subtext and hers the dominant voice and discourse. In addition, Hamilton's strategy of employing translation as an excuse for her writing and her use of a borrowed male voice, as is the Rajah's, again displaces the centrality of her female voice and allows a double reading: she is the medium for a male's voice, therefore validated by it, but she is also its editor, appropriating and controlling it. Moreover, the fact that the Rajah is a figure of authority, but a foreign and displaced one in British culture, adds complexity to Hamilton's game of voices and authority. This interplay of voices and discourses anticipates some of her techniques in her subsequent novel, more focused on a debate on genre.

More relevantly for her later employment of the quixotic plot, in its ample social comment on British society, Letters anticipates many of the central topics of Hamilton's second novel. Her first work of fiction already includes a satirical portrait of British radicals and Hamilton's use of symbolic names to highlight the traits that her characters' embody. For instance, Lord and Lady Caprice represent the corrupted nobility, the court rake and coquette, while Dr Sceptic, Puzzledorf, Axiom and Vapour embody the creeds of Godwinian theory. More importantly, Hamilton already portrays a young woman deluded by her novel-reading and her philosophical uncritical consumption: Miss Ardent, a radical feminist. When he meets this representative of the society he is exploring, the Rajah, despite his taste for the fabulous, still finds novels "too extravagant and fantastic, with especially bad effects on women readers" (Kelly, 2001: 138). Employing thus the Rajah's vision of British society to "defamiliarize the taken-for-granted" through the perspective of an alien to that culture, Hamilton not only distinguishes her fiction from "most examples of the genre in which it participates," but also proposes to reform "novel reading as 
the main exercise in critical thought for women, who are the basis of domestic and thus public life" (Kelly, 2001: 138) in the family-politic trope developed by radical and anti-radical novelists alike. In this regard, in contrast to Miss Ardent, more proper models of domestic women will be proposed. These exemplary women will be rewarded in the conventional courtship and marriage plot of anti-Jacobin fiction: they will marry in a "union of minds" that includes "a similarity of taste and sentiment" (1796: II, 306). Nevertheless, one woman in particular, a very exceptional one, will be granted a different fate: Charlotte Percy, identified as a self-portrait of the author, will overcome her grief at her brother's death by employing her "powers of mind" to become a writer, in spite of her fear at being hated or ridiculed owing to her condition as author (1796: II, 329).

Letters was reviewed by Mary Hays, and her critique to Hamilton's attack on philosophy, metaphysics and radical discourse, evinces the different positions of women who otherwise moved in similar intellectual circles and defended similar positions on women's education and even authorship. ${ }^{184}$ Nevertheless, it is from this non-radical stance that Hamilton engaged in the war of ideas about the "science of the mind" and, in particular, women's minds, in the press and in her novels alike. In this respect, her dialectical battle with the radicals' discourse, in general, and with Mary Hays, in particular, through the means she dominated best, the satirical novel, was and is amply known. From this dialogue and, more specifically, from Hamilton's response to Hays's own novel, as well as from her own concerns on women education, did her masterpiece, Memoirs of Modern Philosophers (1800) spring.

In its role as a didactic novel, Memoirs employs the recurrent opposition of pernicious and exemplary female models, in this case, of female reading models. In this regard, Hamilton draws two different quixotic readers, Bridgetina and Julia, and a role model in the shape of a detached female reader, Harriet. The main quixotic character that Hamilton portrays is her mock-

184 Actually, Hays entertained Hamilton at a gathering in which Godwin and Wollstonecraft were also present, and both authors commenced a friendly epistolary communication until the publication of Hays's review. For a detailed description of Hays's review and Hamilton's private and public response to it, in the context of the war of ideas and of both women's anxieties as aspiring authors, see Walker (2006a), pp. 173-76. 
heroine, Bridgetina Botherim, ironically termed the "true and proper heroine of this our story" (2000: 136) and an obvious caricature of Mary Hays. Hamilton mockingly reproduces in her heroine not only Hays's appearance, but also her fame as an uncritical radical and an overtly sexual woman. ${ }^{185}$ Bridgetina's name is in itself already revealing of her author's satirical intent and didactic message: her surname refers to her character as a "bother-him," a caricature of Mary Hays as a "pestering 'female philosopher' and man-chaser," while her name again highlights her open sexual nature with a reference to "Bridget" or "Bride," diminutives which relate to Bridewell, the house for prostitutes and fallen women (Kelly, 2001: 149). Small, deformed, half bald and with a squint, all physical qualities attributed to Hays, Bridget Botherim is the epitome of the anti-heroine, and Hamilton seems to enjoy buoying up her satirical attack on her heroine's romantic and intellectual aspirations by emphasising how far the self-called "Bridgetina" is from the literary models she peruses. From the very beginning, Bridgetina is represented as self-centred and prone to that selfaggrandizement that London identified as a recurrent critique to Jacobin quixotism by conservative writers. Her undiscerning and well-meant mother introduces her as a "great scholar" who is "far too learned to trouble herself about doing any thing useful," but who has "read every book in the circulating library" (2000: 38). However, her mother soon stands corrected by the haughty heroine: Bridgetina does not read "all the dry stuff" of its collections, such as "history and travels, sermons and matters of fact," she only reads "novels and metaphysics" (2000: 38). Hamilton's critique then becomes bi-directional and exposes what Bridgetina reads and, more importantly, how she reads.

Bridgetina is a literary quixote who reads novels of the worst kind: she rejects Cervantes, Moliere and Fielding, for their wit and knowledge of the human heart cannot compare to the new philosophical "works of imagination" which are "generated by system" and which reflect their authors' energies "expanded in gloomy masses of tenebrific shade" (2000: 172-3). Instead of these works of fiction, Bridgetina ludicrously mimics Emma Courtney's education in fiction and adopts the same course of reading. She obsessively peruses the "wild

185 This caricature was evident to contemporary readers, and one wonders at the seemingly inappropriate reading of Hamilton's work as a "satire upon a system" which yet "avoids all satire of individuals" done by Edgeworth (1816: 623). 
extatic wanderings of imagination" and the "solemn sorrows of suffocating sensibility" (2000: 173). Her passion for literature daily increases, and she continuously expands her imagination by novels, strengthens her energies by romances and invigorates her powers with metaphysics (emphasis added, 2000: 176). As did Emma, Bridgetina employs her exegetical powers to accommodate her readings to her own desire. A relevant example would be the moment in which Bridget states: "as I read each sweet, delicious tale, I reasoned, I investigated, I moralized. What! said I to myself, shall every heroine of all these numerous volumes have a lover and shall $I$ remain 'a comfortless, solitary, shivering wanderer in the dreary wilderness of human society?"' (2000: 176). Having read Rousseau's Helöse, she once again echoes Emma and perceives the hero of the novel, Henry Sidney, as the "St. Preuse (sic) of [her] heart" (2000: 173), while her perusal of Hays's novel provides her with new material to sanction the self-centred reading of her own story and the extraordinary lengths to which her persecution of the hero goes. Bridget's selfabsorption and relentless will to gratify her desire then parodically surpass Emma's and expose the self-centred nature of both heroines' narratives. This egotistical reading is precisely what characterises Bridgetina's quixotism. According to Binhammer, Bridget "understands novels through her self" and, consequently, her quixotism or "diseased reading emerges from an overactive sense of self" (2003: 15). In this sense, "her delusion has nothing to do with being unable to distinguish herself from a heroine $[\ldots]$; rather, it emerges from her belief that heroines correspond to her own sense of self" (2003: 15). In this regard, her soliloquies are very revealing. There are numerous moments in which Bridgetina "soliloquising in the manner of all heroines" (2000: 119), appropriates and monopolizes discourse, aiming to support her will with arguments borrowed from fiction and philosophy alike.

In this reliance on philosophy Bridgetina is also an ideological quixote that parodies not only Emma's education, but also her radical language. This radical discourse she has learnt from the same source as Emma: Godwin's Political Justice, which Bridget first encounters as wrapping paper for her mother's snuff. She "greedily devours" Godwin's quartos, among fits of sneezing, until "the germ of philosophy" fructified in her soul and, as a 
consequence, she became a "philosopher," although she later returns to novels to nurture the needs of her "ardent sensibility" (2000: 176). The jocular account of Bridgetina's conversion not only mocks Emma's serious and minute analysis of her transformation into a philosopher, but also highlights the indiscriminating nature of Bridget's reading: from the circulating library, to the refuse used in shop-wrapping (Binhammer, 2003: 15). This uncritical nature of her reading is again emphasised by the fact that she repeats what she has read as "neat as imported" (2000: 166); that is, although she displays a great "capacity to retain," she does not combine it with the "power to digest and combine," which renders her reading of "very little advantage" (2000: 166). Bridget's verbatim quotations of Godwin, and even of Hays herself, expose her lack of critical thought because she is not aware of the incongruities of the philosophical discourse she employs, and hence becomes an unwitting parodist of these authors' language and a satirist of their ideology. For instance, having read Emma Courtney, she unknowingly mocks Emma's language when she commences her story with an unintelligible speech on "sensations, passions, powers" which generate associations, habits, ideas and sensibilities (2000: 174), an echo of Hays's complex use of such terms to build her sentimental philosophy. She also implicitly parodies once more Emma's self-centred narrative stating how the "history of [her] sensations" is interesting and instructive (2000: 174). Again directly borrowing from Hays's novel, Bridget's avows to the object of her affections: "I shall talk, I shall write, I shall argue, I shall pursue you; and if I have the glory of becoming a moral martyr, I shall rejoice that it is in the cause of general utility" (2000: 309).

This self-absorbed reading and acting not only renders the otherwise unattractive and ridiculous Bridgetina an easy target for satire, but it also serves as the means of an attack on the philosophy she embodies. The search for general utility and female freedom are divested by Bridgetina's inappropriate use of them from the idealism of radical discourse, and are presented in the context of Hamilton's narrative as synonyms for selfish greed and female ruin. In this regard, Bridget's desire is prior to her reading, and literature and philosophy are only means by which she can echo and reinforce her own discourse. As Julia states, Bridgetina can only remember her own 
discourse, but ignores or forgets all others in the debate (2000: 166), and it is this failure to perceive the dialogical nature of truth, the abovementioned soliloquizing, the "living in a world in which only her own voice exists," which "figures the problem of the way she reads" (Binhammer, 2003: 15-6). Her selfcentred reading renders her blind to the feelings of others and to the world around her. Her squint is in this sense a metaphor of her distorted or limited perception: she actively seeks to impose her desires, her will, on others and on social interactions, forcing Henry to love her with the sole force of her own passion as reason, while she wishes to live in society according to the principles of philosophy even if some of its principles prove against the very laws of nature or decency that most members of society accept. ${ }^{186}$ In the construction of her anti-radical discourse, Hamilton must establish a certain "group consciousness" (Grogan, 2006: 308) and build an "Imagined community," into which self-serving radicals bring sexual, intellectual and political disruption, which has consequences for the individual and the nation alike (Grogan, 2006: 309-10). This disruption and the alienation from the ideal national community Hamilton portrays is what make Bridgetina not just a literary but an ideological quixote, and not merely a parodic but also a satirical instrument for the hidden subtext in radical discourse, in particular the sexual nature of their aspirations and their reading of women in mere sexual terms (Grogan, 2006: 324). ${ }^{187}$

In relation to the sexual dangers of her philosophical and sentimental quixotism, Bridgetina has a tragic "sister pupil in philosophy" (2000: 119), Julia Delmond, who also follows Emma's course of reading, from an early enthusiasm for fiction, to a passion for philosophical reading. As Bridgetina or Emma, Julia is brought up in literary enthusiasm by the errors of judgment of her parents. Her mother is an almost illiterate beauty who pays little attention to Julia's education, while her father, Captain Delmond, an ardent admirer of

${ }^{186}$ In Binhammer's words: "Bridgetina aggressively desires a man and decries the social position of women. Unlike Emma's desire, however, Bridgetina's is ridiculous and repulsive because she is grotesquely hideous. Hamilton satirizes Hays and her Emma through the scenes of Bridgetina's novel-reading and translates Hays' fraught relation of self to text and world as simply dangerous narcissism" (2003: 13).

${ }^{187}$ This reading of radical discourse is, of course, emphasized by its employment by the villainous Jacobin Vallaton to seduce Julia; in particular, his use of the argument of general utility to sustain his wish for an elopement (2000: 234). Vallaton then responds to the stereotype of the vaurien, and will find its echo in Bullock's Williams, for instance. 
romance in his youth (2000: 78), places such a high value on Julia's understanding as to encourage her "insatiable appetite for knowledge with a free command of all the books which either the private collections of his friends or the circulating library could afford" (2000: 85). He therefore puts no restraint on her choice, echoing the mistake of the uneducated Mrs Botherim. In the midst of this freedom, Julia starts two different courses of reading, and while she reads "with pleasure books of philosophy, history, and travels to her father," a "pleasure still more poignant" comes from "devouring the pages of a novel or romance in her own apartment" (2000: 85-6). ${ }^{188}$ Hamilton's heroine thus embodies the obsessive and self-gratifying consumption of fiction which moralists had warned against, and her isolated and intimate reading triggers a pleasure that intoxicates her imagination and inflames her passion. Hamilton builds on this sensuous discourse, employing all the common places of sentimental quixotism:

[Julia's] feelings were alive to all the joys and all the sorrows of the heroes and heroines, whose adventures she had the delight of perusing. The agitation they excited was so animated, so intoxicating, that she felt a void in her breast when not under the influence of strong emotions. In vain did her reason revolt at the absurdities which abounded in these motley tales; in the kindling passions of her youthful bosom they found a never-failing incentive to their perusal. (2000: 86)

Her self and the world disappear, and Julia lives through her readings: she has become an addict of feeling and only in her readings does she find a gratification real life cannot provide. The narrator states that from the "inebriating quality" of her unrefined imagination she acquires a "disrelish for the common enjoyment of life;" consequently, she pursues the "flattering dream of fancy" and keeps her "mind's eye so fixt upon its airy visions, that she at length believed in their reality," to the point that "what appeared at first the mere suggestion of imagination, seemed in the sequel the certain dictates of truth" (2000: 75). Julia's quixotism is then different to Bridget's; in Bray's words, "while Bridgetina contrasts her reading with her own situation, relating

${ }^{188}$ Binhammner also reflects these two modes of reading: "the scene, not the content, produces Julia's delusions that the world is a novel. Julia reads philosophy, history, and travel narratives; yet because those books are read out of duty (she reads them aloud to her sick father) the how of reading overrides the what, and she does not learn from them the lessons that she should" (2003: 13). 
everything back to her own real-life dilemmas, Julia puts herself into her reading, imagining herself a heroine in the romances she reads" (2009: 74). In the same manner, she imagines the scheming Vallaton, the deceiving villain who finally seduces her, the hero of a typical romantic plot of obscure births and suddenly-discovered nobility, which she has learnt from her favourite novels and which she tries to act out in real life, attempting to effect such a discovery in the most striking and pathetic way possible (2000: 75), with comic results owing to the contrast between her imaginative heroic reconstruction of Vallaton and his nature as a fashionable hairdresser. As the novel advances, her mimetic interpretation of herself through the novels she reads loses its comicality and progresses towards the tragic consequences that Julia's name has forewarned.

Placed in the recurrent situation of having a suitor chosen for her, Julia reads herself as a heroine who must suffer the "cruel persecutions with which so many heroines have been tormented" (2000: 231). However, she fortunately reflects, though her fate "was cruel, it was not unexampled" (2000: 231), and she recurs to her readings in order to find guidance for such a trial. In particular, she reads herself as a new Clarissa accosted by a "hateful Solmes" and under the tyranny of a father who behaves with "all the cruelty of all the Harlowes" (2000: 231). Indeed, her fate will be similar to Clarissa's: she abandons her home and ends the narrative ruined, possibly pregnant and dying. Therefore, in the same manner Emma did not benefit from the moral warning of Rousseau's Héloïse, Julia does not read the novel critically and fails to see the dangers of attempting to re-enact the novel. Julia's lack of critical reading is moreover emphasised by her praise of Cervantes and his disciples, Fielding and Moliere. While she exalts these authors for their wit and their depiction of human nature, Julia has failed to read herself in the mirror their texts provide for absorbed readers. Ironically, in that case she had not read herself enough in those novels and had therefore not benefitted from their attention call to the dangerously deluding nature of certain forms of fiction. Once again, not allowing a dialogue to take place, but blindly and uncritically accepting the discourse of philosophy and sentimental fiction, Julia is incapable of awaking to the truth of her distorted perception and flawed system of morals until it is 
too late. Julia is thereby another, less obvious, reference to Hays's Emma. According to Bray,

By offering different kinds of reading process then, and suggesting that for any text a variety of readings are possible, Hamilton is putting under scrutiny the single-minded, obsessive reading of Emma Courtney. Both the thirdperson form of Memoirs of Modern Philosophers, and its representation of the distinctive reading practices of three heroines, call into question the insistent monologism of Hays's text, and especially the heroine's dependence on reading the world through Rousseau's La Nouvelle Héloïse. Emma's unswerving passion for Rousseau's text causes her both to foreground her own feelings, and to misread other people and the world. She thus combines the worst qualities of Hamilton's two 'sister pupils in philosophy' [...] Hamilton expertly draws out through her two heroines two dangerous and damaging aspects of reading embodied in Emma Courtney, at the same time she is offering a more exemplary model through the restrained, rational reading of Harriet Orwell. (2009: 77)

Harriet is indeed the exemplary heroine and reader of the novel. Brought up in the principles of religion and the "love of virtue" as "ruling passion" (2000: 187), she embodies Hamilton's ideal of female education which seeks selfimprovement rather than pedantic erudition (Grogan, 2000: 20). Warned by her wise aunt against the dangers of imagination and its tendency to confuse passion with virtue (2000: 187), Harriet is nevertheless presented by her relative as above the common deficiencies of female education, a course of instruction which would usually render her prone to the mistakes of fancy, by giving additional force "to the power of imagination" and by weakening the "influence of judgement" (2000: 188). Harriet, on the contrary, has learnt to submit the "passions to the authority of reason," to "control the throbbing tumult of the heart," to direct her attentions to the "real sufferings of others" and therefore to estimate her own, "not by the exaggerated representations of self-love, but by the eternal rules of impartial truth and justice;" in addition, her mind "has not been suffered to run wild in the fairy field of fiction" but has been turned to "subjects of real and permanent utility" (2000: 188). Hamilton's recurrently expressed opinion that sensibility without action is useless (Warburton, 2001: 268) takes shape in Harriet's active feeling which finds expression in her continuous exertion throughout the novel to fulfil her domestic duties and to take care of all ill or unhappy characters, in particular Julia. Harriet also approaches the sentimental and the philosophical discourse 
of the quixotes with critical distance and judgement, echoing the implied author's notions of the usefulness of Christian principles to counteract the dangers of moral and intellectual corruption this discourse implies. Moreover, she creates her own discourse, asking Julia not to use words that are not her own, and to avoid "plagiarism" in their parley (2000: 165). The conventional sentimental plot with which Hamilton rewards her is enough evidence of the author's reinforcement of the moral and educational discourse she represents, while this marriage, prevented for most of the narrative by adverse circumstances, could only have taken place in those same "fairy fields of fiction" which Harriet, contrary to Emma, has not escaped to. ${ }^{189}$

However, while presenting this exemplary heroine and reader as opposed to the traditionally seduced and ruined warning, Hamilton's text has already questioned the value of introducing a moral exempla or even warning when the reader is not critical enough to benefit from it, as Emma or Julia are incapable of learning from other heroines' mistakes or even from other quixotic narratives. In this sense, Hamilton is not completely ironic when she terms Bridgetina the "ostensible heroine of these memoirs" (2000: 378) just before she effects her cure: Bridget reads Julia's story, awakens and becomes the model of domestic daughter and altruistic social being that she was intended to be, something Julia was incapable of achieving. While Julia can read Bridgetina's quixotism as absurd, she fails to apply the lesson to herself and, hence, is not saved in time. ${ }^{190}$ Therefore, in Hamilton's novel the tragic quixote cures the comic one, and the latter embedded deluded reader mirrors the awakening to fiction the implied one may achieve. It is from Bridgetina's parodic and satirical plot, then, that the implied readers learn to become selfaware ones, not only because she is the quixote who finally achieves cure and

189 Binhammer states that "the sentimental plot undermines Hamilton's explicit theories about Harriet's reading, as her world ultimately mimics fiction. She gets her love and fortune in the same way that any fashionable heroine would. If you, dear young female reader, do not read novels, Harriet's embedded reading suggests, you will end up living in them" (2003: 17).

${ }^{190}$ Several are the examples of Julia's failure to read herself in Bridgetina's story and her lack of cure. For instance, "when Bridgetina spoke of Henry, Julia perceived nothing in her discourse but the ravings of a distempered fancy. She pitied the imbecility of her judgment, and deplored the weakness of her perception; but when she uttered the praises of Vallaton, how sensible, how judicious, how just were her remarks! She appeared endowed with uncommon penetration, and was the friend whose congenial mind was most worthy of her confidence" (2000: 182). 
closure, but because she allows Hamilton's own self-referential and selfconscious comment on fiction.

This is so because Bridgetina's parody of Hays's novel and of Godwin's philosophical texts explicitly directs both the embedded and the implied reader to Emma Courtney and Political Justice, as both readers peruse the imbedded quotations that permeate Hamilton's novel. The inclusion of these texts, as well as of a critical discussion on the merits and demerits of Wollstonecraft's Vindication of the Rights of Women, in which only "superficial readers" could think she intended to "unsex" women (2000: 101), evinces that Hamilton did not agree with the more radical anti-Jacobin stance that reading, and reading philosophy, metaphysics or novels, should be prohibited. Rather, her use of parody and her numerous other quotations point at the fact that since certain texts "will not go away and cannot be controlled it is imperative to teach the young how to read them circumspectly" (Grogan, 2000: 24). Therefore, Hamilton does not ban the reading of the abovementioned works, but highlights the need to promote their "informed reading with what Bridgetina does not have -distance from one's self" (Binhammer, 2003: 16). ${ }^{191}$ In this sense, her narrator's address to the "knowing reader" who "will think" and the "learned reader" who "will undoubtedly suppose" $(2000: 81,82)$ the same as the narrator, that is, that will agree with what the narrator's exegesis of the situation is, emphasises the critical stance that the implied author is requiring from her readers. Hamilton then builds a metanarrative and self-reflective apparatus to engage her female readers at an active level of interpretation, to dispel the illusion of reality and to evidence that her novel is indeed a novel. Hamilton achieves this by a series of methods.

191 Ty ascribes this to Hamilton's mid-position between the radical and anti-radical stances of the dialectical battle and claims that "the use of parody might suggest, not so much the inadequacy of its predecessor, as a desire to re-function the form to its own needs," and that Hamilton's text "which replaces the seriousness and ardour of Godwin's and Hays's proposals with buffoonery and pathos, can be read as a reworking rather than a condemnation of 'modern philosophy"," owing moreover to the fact that "the novel does reveal that there are many social ills that need to be changed" (1993: 27). Consequently, for Ty, Hamilton's conservative discourse is subverted by this use of quotation and parody, and its subsequent instance of heteroglossia, reaching the conclusion that Hamilton's novel "perches precariously between dependence and independence, between mockery and admiration of the parent texts and their philosophies" (1993: 28). 
First of all, Hamilton employs the resource of the found manuscript. Written by an unknown gentleman who died in poverty and bought by a Geoffry Jarvis, the latter decides to publish it even if its lacks its first fifty pages. ${ }^{192}$ The unknown origin of the manuscript, the impossibility for the author to claim as many others did that his didactic work of fiction was based on true events or not inspired by life, already forewarns the impossibility of trusting the text. In addition, Jarvis had expressed his desire to become an author, but also his lack of inspiration. Appropriating somebody else's text points at the play of quotations Hamilton will develop in her narrative, and reveals that the author's intentions can be questioned, manipulated or obviated in the use others' do of his or her text. In this sense, in Hamilton's novel the author is, quite literally, dead, even erased from the prefatory pages, and what remains of him are his echoes in the implied one. Echoes the reader cannot be sure have not been manipulated by the editor.

This editor, Jarvis, moreover submits the text to several critics and includes the review of one of them in the preface as a justification for his search for publishing; the reviewer makes explicit the author's intentions of providing quotations of Godwin to highlight only "its dangerous tendency" in the hands of bad men (2000: 36), as well as of using Bridgetina as an "antidote to the poison" of uncritical perusal of philosophical novels (2000: 37). In addition, the reviewer disclaims any possible personal attack on individuals and asserts that the author satirises only systems. The obvious caricatures of Godwin and Hays in the blind Mr Myope and Bridgetina proves otherwise and undermines the trust the reader can place on the reviewer and on any of his assertions. In the same manner Letters was, Memoirs is then presented as an "oblique text," an incomplete one, which requires greater caution in its perusal; moreover, its presentation highlights the "accidental, highly mediated process" by which a book comes to the public, therefore also representing the "accidental, social and contingent nature of authorship and publishing" as opposed to the

${ }^{192}$ Given Hamilton's recurrent ascription of meaning to the names of her characters, one wonders if this name is a veiled reference to two works related to Don Quixote: Jarvis's translation of Cervantes' novel and Richard Graves' The Spiritual Quixote: or, the Summer's Ramble of Mr Geoffrey Wildgoose (1773). Both are owners or editors of a poor, witty, deceased gentleman's text -Don Quixote- and mediators between the original novel and the readers that will approach it through their texts. 
inexorable spreading of truth that modern philosophers predicated (Kelly, 2001: 156).

In addition, this framing allows Hamilton to masculinise her discourse: the author, the editor, the reviewer, and the narrator are men. Consequently, their defence of women's education or of fiction becomes greatly legitimised by the use of these authorial, editorial and narratorial male masks, although, at the same time, it subverts patriarchal discourse by transforming them in a woman's instruments. Moreover, Hamilton also employs generic hybridization to achieve the same ambiguous purpose; she uses elements conventionally associated with "men's genres," including "satire, burlesque, the learned quasinovel, the social survey, the quixote tradition, the roman-à-clef, and the philosophical dialogue, historically used to satirize 'false' ideologies" (Kelly, 2001: 144). While most of these genres had already been appropriated by women writers, Hamilton's blending of them emphasises her authorial command over all forms of gendered genres and how even returning to a male discourse means going back to a genre already in the hands of women. This generic experimentation and authorial control is also expressed by her use of interpolated stories, in order to provide a sketch of the flawed characters of the story in third-person narratives which oppose the radical and Romantic confessional first-person narrative and, therefore, offer a critical comment on their reconstructed story (Grogan, 2000: 22). In addition to these, she only allows a first-person epistolary narrative from a reliable voice: the letter the moral role model Dr Sydney writes to his son, containing the also moral tale of his youthful and virtuous love for the equally exemplary Mrs Fielding. Controlling her readers distance, then, Hamilton again emphasises those texts or textual bodies that require more critical reading, and relates once more to Hays's self-centred confessional novel. In addition, these stories create in the reader the impression of a complex and interconnected pattern of stories, which subverts the desire of the quixotes for neat narratives which follow romantic or novelistic conventions.

In addition to these techniques, Hamilton develops metafictional methods in the train of Cervantean emulators such as Fielding or even Sterne. In the paratext of the novel, for example, Hamilton employs epigraphs and notes to 
the text to anticipate the content of the chapter and to comment on the fictitiousness of the narrative. Hamilton's epigraphs not only evidence her extensive knowledge, and once again play with the idea that such knowledge belongs to a male author, but also at times satirically comment on the contents of the chapter they introduce and even allow the novel a greater intertextual reading. For example, one of them refers to another quixotic text, Butler's Hudibras, and, as a consequence, it depicts the nature of Jacobins as descendants from Puritan rebels (Kelly, 2001: 158). As for the notes, employing Kelly's term, Memoirs is also a "footnote novel" which includes glosses on the quotations the quixotes' employ and even mock assertions that some scenes are taken from real life. What is more, they are sometimes utilised to draw the reader away from the narrative to reflect on its fictitious nature. A relevant instance would be the narrator's note on Bridgetina's index of sentimental terms, entitled "note, for the benefit of Novel-writers:"

We here generously present the fair manufacturers in this line with a set of phrases, which, if carefully mixed up with a handful of story, a pretty quantity of moonshine, an old house of any kind, so that it be in sufficient decay, and well tenanted with bats and owls, and two or three ghosts, will make a couple of very neat volumes. Or should the sentimental be preferred to the descriptive, it is only leaving out the ghosts, bats, owls, and moonlight, and the above phrases will season any tender tale to taste. (2000: 308)

Mocking the language and conventions of sentimental or Gothic fiction, Hamilton also exposes the formulaic nature of fiction and assumes the reader will share this knowledge of the formulas of contemporary novels and will, therefore, be able to identify that her own fiction is both exposing and subverting them. Not only does Hamilton call for the readers' attention from the margins of her text, but also from within the narrative itself, with her use of an omniscient intrusive narrator who comments on the action and who recurrently addresses the readers to call attention to the novel's own discourse. For instance, the narrator addresses his audience and states that he would recommend reading against boredom, did he not apprehend that "to recommend books, through the medium of a book, to those who never look into one, would not probably be attended with any great effect" (2000: 78). In another turn of the screw, Hamilton actually included her readers in her 
narrative, as Cervantes' imbedded the readers of the first part of his novel in the second and transformed them in critics. At one point, she includes an interpolated reader in the story, a young fashionable woman whom she satirises because "with a yawn she throws down" Hamilton's book, as she is fatigued of the non-romantic episodes in it (2000: 297). In another instance, the narrator addresses the readers and reconstructs a conversation with them, asking them if they were ever in love and requesting that, were they to answer in the negative, they "may go on to the next chapter" (2000: 377). Finally, the conclusive chapter includes a dialogue between the narrator and several female readers of the novel, on the matter of their opinions on the novel and their suggestions for a more conventional conclusion: Bridgetina's marriage to either a reformed Vallaton or a suddenly rich Mr Myope; Mrs Fielding's marriage to Dr Sydney; or Harriet and Henry's marriage leading to more romantic circumstances, such as living in a poor cottage (2000: 385). These embedded readers express their disappointment at the unromantic conclusion the novel offers, to which the narrator answers by deconstructing the plausibility of each of the possible endings according to the conventions of romantic fiction. Hamilton's narrator then opposes a more realistic fiction to these readers' romantic expectations, and highlights the fact that the whole narrative has suppported: that the embedded female readers can mirror the real ones and their varied romantically-biased responses, and that the former are consequently portrayed for the instruction of the latter. The embedded readers introduced at the end are the Julias and Emmas who have not learnt to read themselves in Bridgetina's quixotic narrative or in Hamilton's Cervantean novel, and are still in need for a cure in order to become the model of detached decoder the implied author proposes as her ideal (woman) reader.

Finally, by concluding with two unmarried women who nevertheless are presented as examples, Mrs Fielding and the reformed Bridgetina, Hamilton reinforces but also subverts the traditional courtship plot and domestic woman enthroned by sentimental fiction. Hamilton is proposing not only a different social standard for women as something more than marriageable goods, she is also establishing a more realistic and less romantic conception of the novel which would reflect that social reality and female characterization. Women in 
Hamilton's novels are more than mere reading misses or sentimental heroines: they must be modest but active, religious but critical, intellectually challenged but not presumptuous, reflective but not self-absorbed, and, above all, they must read actively and critically in order to become such a model. Hamilton then challenges many of the established radical and anti-radical conventions about women, in general, and about young female readers, in particular, and calls for a different model of women writers and women readers who actively engage in the issues of their time as expressed in fiction, and who instruct and respond to each other, creating that sympathy with the author and that intellectual expansion which enclosed women find it difficult to achieve.

Consequently, one could conclude that, despite her attack on Hays's novel, Hamilton's position with regard to the intellectual potential and critical power of women readers is similar to her opponent's. Hays and Hamilton both evince the multiple reading processes and fraught approaches to even the same text -as is the case with Rousseau's Heloïse- and subvert the neat categorisations of women readers performed by coeval tracts or novels. In addition, they develop fictions which go beyond the conventional plots of seduction by fiction and which focus on the process of quixotization and de-quixotization for most of their narrative, even subordinating the sentimental and political plots to their analysis of quixotism. As a consequence, Hays and Hamilton detach themselves from the more overtly political war of ideas and shift towards a feminocentric narrative which explores the "sentient female mind" in all its complexities, foretelling the quixotic bildungsromane of Edgeworth or Austen. 
5. A New Century, a Different War: Literary Satire in the Late EIGHTEENTH CENTURY

[T] he most useful [books] are novels and romances. Such as I am, these, these alone have made me.

The Heroine, 177

Following the classification offered in the introduction to this chapter, this last section will focus on the gradual displacement that takes place in the early nineteenth century from overtly ideological satires to works of fiction that more emphatically parody literary genres and mock elements of the literary world, whether authors, trends or the reading audience itself. Two authors will be placed under this light, Eaton Stannard Barrett and Sarah Green, both writing at the turn of century and until the 1820s. Both pen quixotic narratives that, although still tinged with political allusions, move beyond the ideological wars to serve the purpose of awakening their audience to a critical approach to any form of reading, whether ancient romances or contemporary novels. In order to do so, while still adopting common places of anti-Jacobin fiction, they will return to Cervantes or Lennox looking for inspiration to develop their parodies by means of a quixotic figure. With this return to fiction prior to the peak of the literary war, they serve as an important link in the tradition of female quixotism between the abovementioned authors and other coeval novelists to be studied in subsequent chapters.

\subsection{Eaton S. Barrett's The Heroine, or, The Best Cure is Always Laughter}

Eaton Stannard Barrett (1786-1820) was an Irish lawyer and man of letters who wrote several well-known political and social satirical poems. Among his better known works are Woman and other Poems (1810), and particularly a piece written in the manner of Pope, "Woman, a poem," which run into several editions until as late as 1841. His political satires included The Rising Sun: a Serio-Comic Satiric Romance by Cervantes Hogg, and The Second Titan War 
Against Heaven, both published in 1807. Most successful was All the Talents: a Satirical Poem in Three Dialogues by Polypus (1807; at least nineteen editions) ridiculing the Whig ministry of the day. Further satires followed in quick succession and Barrett achieved great recognition, as proved by Byron's allusion to this work in English Bards and Scotch Reviewers (Haigh, 2004: n.p.). Barrett's admiration for classic authors such as Cervantes and Pope, obvious in his choice of pseudonym, "Cervantes' Hogg," and in his satirical approach to contemporary topics, is reflected in his greatest success, his female quixotic narrative The Heroine, or, Adventures of a Fair Female Reader (1813), an epistolary novel which was a best-seller at the time. That Barrett's purpose was to remain connected to Cervantes and this satirical tradition in its consideration of the quixote as the epitome of fiction and its power of disrupting the mind of some of its readers, is made clear by the fact that Don Quixote himself appears in the introduction to the novel as one of the fictional characters that the heroine encounters on the Moon -a metaphor of the world of the unreal, full of fictional characters, many of them quixotic, such as Barrett's heroine herself or Captain Shandy and Tristram (1909: 7). This preface, entitled "The Heroine to the Reader," also announces the male reappropriation of narrative fiction that Barrett's novel will claim, by defining the initial voice of its heroine mainly through authoritative male intertexts, such as works by Pope, Cervantes, Milton or Sterne, with only a reference to Maria Edgeworth (Pearson, 1999: 206). In accordance with the extended view that women had taken over the novel quantitative and qualitatively, as seen in chapter two, Barrett's narrative sets out to transfer literary authority to where it allegedly belonged. From his introductory tale, then, Barrett sets the tone for his literary parody and political satire and, in particular, for his position as to where women should stand in those two fields, as Cherry's quixotic delusion will afford Barrett the opportunity to develop a dual attack: firstly, against the form and content of certain literary genres, and, secondly, against the social disruption caused by the principles preached in certain readings. 
5.1.1. The Literary Dimension: Parody and the Return to a Romantic Female Quixote

In Barrett's novel, Cherry Wilkinson, a farmer's daughter with no experience in the world, tries to live according to the example acquired from the romances she has read, which have been her sole source of knowledge and entertainment. Her reading of French novels and Gothic romances shapes her mind, as chivalric romances did with Don Quixote. Considering herself a heroine and rejecting her father's choice of suitor, Robert Stuart, she changes her name for Cherubina de Willoughby and leaves her home in order to live incredible adventures, as well as to find her noble ancestors. Along the way, she creates many upheavals, while being abused by many unscrupulous characters. She is taken first under the protection of the unprincipled Mr Betterton, whom she quickly escapes, only to be fooled by an actor, Abraham Grundy, who impersonates a nobleman, Montmorenci, to achieve her hand and fortune. At the appearance of farmer Wilkinson in London to recover his daughter, Grundy even convinces Cherry to imprison her father in a mental asylum. Besides these base characters, Cherry also encounters honest but gullible ones, such as Jerry Sullivan, an Irishman who will follow her in her subsequent adventures. After Betterton and Grundy kidnap Cherry and Stuart comes to her rescue, she becomes aware of the gross manner in which they have taken advantage of her delusion. After the necessary period of seclusion following the recurrent fever, Cherry finally abandons her heroic aspirations and becomes a devoted wife of the very man she tried to escape from, Stuart.

The literary delusion of Barrett's quixote is overtly emphasised. Early in the novel, Cherry, echoing the dichotomy between history and fiction that was made apparent in Mock-Clelia or The Female Quixote, will align herself with the latter, setting the basis for her later heroic behaviour:

'At least,' said I, 'novels must be much more true than histories, because historians often contradict each other, but novelists never do.'

'Yet do not novelists contradict themselves?' said he. 
'Certainly,' replied I, 'and there lies the surest proof of their veracity. For as human actions are always contradicting themselves, so those books which faithfully relate them must do the same.'

'Admirable!' exclaimed he. 'And yet what proof have we that such personages as Schedoni, Vivaldi, Camilla, or Cecilia ever existed?’

'And what proof have we,' cried I, 'that such personages as Alfred the Great, Henry the Fifth, Elfrida, or Mary Queen of Scots, ever existed? I wonder at a man of sense like you. Why, sir, at this rate you might just as well question the truth of Guy Faux's attempt to blow up the Parliament-House, or of my having blown up as house last night.' (1909: 28-29)

By undermining the authority of history, Cherry validates the one of fiction. First of all, Cherry's syllogism works within a certain quixotic logic. Cherry assumes that if life is sometimes full of contradictions, so must its faithful representation be. With that argument she can defend the veracity of novels against the over-planned historical accounts which sound too artificial to her. Then she likens characters of fiction to those considered "historically true." She attributes to authors of historical accounts a prejudiced view that leads them to "contradict each other" over events that should prove irrefutable, tincturing history with a hallo of invention because of this amount of subjectivity usually associated with novelists. Finally, in another turn of the screw, Cherry equates a famous story of popular English folklore, that of Guy Fawkes, with her own story, once again connecting those implausible stories which belong to historical annals to her own fiction. Cherry writes herself as Cherubina, a heroine of romance, and, if romance is plausible, so is her existence, hence the importance of ratifying romance as truthful and relevant. In Barrett's novel, Cherry openly justifies the reading of fiction as it is useful because of how it has shaped her mind and identity:

To you, then, my fair auditory, I would enjoin a diligent cultivation of learning. But oh! Beware what books you peruse; for, trust me, some are as injurious as others are salutary. I cannot point out to you the mischievous class, because I have never read them; but indubitably, the most useful are novels and romances. Such as I am, these, these alone have made me. (1909: 177) 
Once again, education is viewed as shaped through extensive reading, however, only of those "good" books, which, in Cherry's opinion, are romances and novels. Her criterion is based on their usefulness, and no other books are so efficient in providing women with the tools to become heroines of their own story, as Cherry is at the moment of speaking. Narrative fiction, once more, is defended by the quixote as of use in the shaping of the female reader's world and self and will consequently become the object of Barrett's parody. Returning to Cervantes as source, Barrett will employ Cherry's quixotism to highlight the lack of verisimilitude and plausibility, the shortcomings in both form and content, of romantically-embedded genres such as French novels and Gothic narrative fictions, in a highly comic burlesque narrative. These two genres are conspicuously identified as Cherry's source of delusion. On the one hand, characters pinpoint the cause of Cherry's quixotism in pernicious French novels, while, on the other hand, many of the elements of Barrett's burlesque resemble the most famous Gothic novels of the time: Cherry refurnishes Monkton castle -a possible reference to Lewis's The Monk and the French word "ton" or fashion, referring to the fashion for the Gothic represented by Lewis (Kelly, 1990: 234)-, and her mention of Italy, horrors, tapestries, recall in a parodic style Radcliffe's The Italian or The Mysteries of Udolpho, both set abroad.

As happens in most quixotic narratives, parody will be employed by Barrett to frame these genres within his own narrative, highlighting the fact that fiction is not going to be condemned per se, but only those expressions of fiction considered inappropriate epistemological instruments in the hands of inexperienced female readers who cannot perceive their implausibility and hence employ them as valid behavioural guides. Barrett, for instance, explains their effect in the following paragraph, through the words of Stuart, one of the voices of reason in the novel:

[...] unfortunately so seductive are the latter class of composition [romances], that one is apt to neglect more useful books for them; besides, when indulged in extreme, they tend to incapacitate us from encountering the turmoils of active life. They present us with incidents and characters which we can never meet in the world; and act upon the mind like intoxicating stimulants; first elevate, and at last enervate it. (1909: 293) 
In the same way that the later sensible austenite hero, Henry Tilney, will not only acknowledge his reading of novels, but his fondness for them, Barrett's hero is also a reader of fiction. However, the reading of the same novels has different responses for men and women. Following Lennox's novel closely, Barrett's narrative will focus on his young heroine's reading and response to it as a generalization of the dangers of women's reading. Due to the fact that women, as opposed to what happens with men, cannot experience life outside their limited circle, they take what they read as a representation from the real world. From these romances they extract values and models of behaviour they consider true and established social codes, but which, even in their idealism, prove deficient as a system of reference in contemporary society. Stuart states it thus:

[...] your principles, which have hitherto been formed upon such books alone, appear, at times a little perverted by their influence [...] as your ideas of real life are drawn from novels; and as even your manners and language are vitiated by them, I would recommend you to mix in the world, to copy living instead of imaginary beings, and to study the customs of actual, not ideal society. (emphasis added, 1909: 294)

Their isolation, their lack of experience, of a proper and, most importantly being women, guided education, make them become romantic quixotes, directed by the tenets of ideal literary models. Their system of reference is then inadequate and will require to be tested against experience. Nevertheless, this empirical awakening will prove fraught, for no matter how often throughout the novel her examples are quoted only to be flagrantly contradicted by the reality she is experiencing, how recurrently Cherry's senses and imagination are in permanent conflict, the authority allowed to her readings is so great that she barely dares to question those very antecedents which are her guide in the passing from adolescence to adulthood, and her entrance in the world.

These precedent heroic examples are followed in every aspect of her life, from her understanding of herself to her interpretation of others or the world itself. In the same manner Arabella did, Cherry also possesses some archetypal heroic attributes, while she uses her powers of accommodation to read in herself those she does not. Firstly, she has grown up in an idyllic country, wondering 
"through painted meadows, and by purling rivulets" (1909: 9). Secondly, following the conventions both of romances and of quixotic narratives, she is deprived of female guidance at an early age. She is under the sole care of a male guardian, her father, and bitterly exclaims: "Motherless, am I to be bereft of my more than mother, at the sensitive age of fifteen?"(1909: 9). Cherry, having no mother and her governess being dismissed at the beginning of the novel, searches for female models of conduct and must recall past heroines to exemplify her rite of passage into adulthood. In this sense, it is relevant that Cherry peruses mainly Gothic novels, for that genre teaches her "a dangerously inflated idea of the feminine, especially the maternal" (Pearson, 1999: 206), while its plots emphasise the meanings of the "presence of the absent mother" (1999: 207), a mother Cherry will devote her narrative to seek and for whose absence she compensates with previous female role models in the shape of romantic heroines. Her youthfulness is another quality she shares not only with prior heroines of romances, but also with quixotic antecedents such as Arabella. Last, but not least, Cherry admits to her own beauty as endowing her with the most important requisite in order to be a heroine:

That I am not deficient in the qualities requisite for a heroine, is indisputable. All the world says I am handsome, and it would be melancholy were all the world in error. My form is tall and aërial, my face Grecian, my tresses flaxen, my eyes blue and sleepy. But the great point is, that I have a remarkable mole just over my left temple. Then, not only peaches, roses, and Aurora, but snow, lilies, and alabaster, may, with perfect propriety, be adopted in a description of my skin. I confess I differ from other heroines in one point. They, you may remark, are always unconscious of their charms; whereas, I am, I fear, convinced of mine, beyond all hope of retraction. (1909: 11)

Cherry's mode of description, and even her vanity, is clearly copied from literary examples, as the account of her graces is full of clichés concerning heroines, such as their white skin and rosy cheeks, or the Grecian face, which seems highly out of place in a plump and healthy-looking daughter of a farmer. Moreover, Barrett's irony is blatantly present in her mentioning of that "remarkable mole," which probably does not contribute to her beauty at all, and her admission of how aware she is of her praised good looks. Funnily enough, that "all the world" is reduced to "nobody but a farmer or the Parson" (1909: 10), the only people, in Cherry's own account, who ever visit her home. 
Although called "sweet girl" or "fair" by Stuart (1909: 23) and being lustily admired by Betterton, there are no raptures at beholding her beauty, as was the case with Arabella; neither does the reader encounter a charming description from the author, as with Lennox. Barrett offers Cherry's relation of her own charms to stress the shortcomings of her heroine and her quixotic reading of her own attractiveness.

Nevertheless, despite all the abovementioned heroic qualities Cherry sees in herself, one thing is lacking for her claim to heroism: nobility. As Cherry states: "There is but one serious flaw in my title to Heroine -the mediocrity of my lineage" (1909: 11). Or, more explicitly: "Is it possible, that I, who was born to be a heroine, and who must therefore have sprung from an idle and illustrious family, should be the daughter of a farmer, a thrifty, substantial, honest farmer? The thing is absurd on the face of it, and never will I tamely submit to such an indignity" (1909: 13). She needs to believe that she is more than a mere landowner's daughter, because none of her admired predecessors were such. In romances, even if the heroines seemed to be of low origin, in the end they would turn out to be the long lost daughter of a Marquis, a Duke, a King. Hence, all Cherry is doing with these exclamations is following the romantic patterns of "blood will tell" (Frye, 1976: 161), and forging an aristocratic identity for herself, which Arabella, for instance, already possessed and needed not add to her already romanticised status. Therefore, Cherry's quixotic reading goes beyond that of Arabella and resembles Don Quixote's rise to knighthood. Cherry, in this case, is consciously creating or writing a new identity for herself, mainly because her present situation in life is hostile to her quixotic emplotment. When her father dismisses her beloved governess and burns all her novels, Cherry determinately reaches the conclusion that such a cruel man cannot, and will not, be her father:

It was not till this morning, that a thought of the most interesting nature flashed across my mind. Pondering on the cruel conduct of my reputed father, in having burnt my novels, and discharged you, without even allowing us to take a hysterical farewell, I was struck with the sudden notion that the man was not my father at all. In short, I began with wishing this the case, and have ended with believing it. (emphasis added, 1909: 12) 
That is, Cherry employs a quixotic dialectic accommodation to adapt reality to the possibilities romance presents in front of her. Cherry's syllogisms work in much the same way as Arabella's, confounding real and fictitious terms: if in books, people who are hard-hearted towards the heroine, especially their guardians (A), are identified as villains (C), and Mr Wilkinson (B) is a guardian who has acted cruelly towards Cherry, the heroine (A), then $\mathrm{Mr}$ Wilkinson (B) is obviously a villain (C) in disguise. This works under quixotic logic, which moves backwards and forwards from literature to life, applying the principles of the former to the latter. Moreover, it is a conscious effort made by Cherry to emulate the examples found in her novels: she wants to believe Wilkinson is not her real father but a terrible villain, and ends believing him to be so. Since her claim to heroism would be undermined if she were a farmer's daughter, she desperately holds on to the illusion of her noble origin throughout the novel.

For that reason she also changes her name from Cherry Wilkinson to Cherubina de Willoughby, as she needs to christen her new being with a name in accordance to her new rank. The quixotic transformation of her name, as that of Alonso Quijano to Don Quixote, symbolises her renunciation to her old self and the creation of her quixotic persona:

[...] what a name -Cherry! It reminds one so much of plumpness and ruddy health. Cherry- better be called Pine-apple at once. There is a green and yellow melancholy in Pineapple that is infinitely preferable. I wonder whether Cherry could possibly be an abbreviation of CHERUBINA. 'Tis only changing $y$ into ubina, and the name becomes quite classic. Celestina, Angelina, Seraphina, are all of the same family. But Cherubina sounds so empyrean, so something or other beyond mortality; and besides I have just a face for it. Yes, Cherubina I am resolved to be called, now and forever. (1909: 11)

In his particularly humorous style, Barrett describes once again how Cherry equals herself with previous heroines, in this case with a new name which follows the fashion of romance of exotic-sounding names and adds reminiscences of Italian or French. Moreover, the fact that her correspondent is named "Biddy," a probable allusion to Steele's and Hamilton's quixotes, who also changed such a common name for a more heroic one, allows the 
intertextual references to highlight Cherry's malady as part of a tradition of female quixotes and to indicate the persistence of literary delusions in female readers. In addition to her change of name, Barrett contrives a particularly parodic scene in which Cherry discovers a piece of old parchment in which the name "Willoughby" is written. From this she derives that she must be the lost daughter of a noblewoman, reinforcing her claim to nobility and to the absent mother.

However, a mere name or title is not enough. Cherry desires to act as heroines did and, moreover, to have her deeds recorded. Cherry writes her letters in the same fashion as other heroines do, in order to preserve written record of all her adventures. This first-person narrative not only serves to parody the conventions of sentimental epistolary fiction, which allow for that immediate and unmediated experience, but also becomes an instrument to satirise the selfcentred narratives of radical fiction, such as Hays's Memoirs of Emma Courtney. At one point, Cherry holds a very witty conversation with a man, at the end of which she writes: "the best of this is, that every word he said will one day appear in print" and "men who converse with a heroine ought to talk for the press, or they will make but a silly figure in her memoirs" (1909: 173). This again refers back to Emma's pre-eminence of her own personal experience as material for a book. In another similarity to Hays's heroine, Emma's youthful enactment of her readings, Cherry decides to live out her romances. In Cherry's conception her intimate thoughts are not enough to fill a narrative and, so, in order to become a read heroine, she must search for a plot outside the conventional domestic one, in which as a woman she would become invisible. Therefore, when her father introduces the notion of an arranged marriage to Robert Stuart, this final attempt of the "villain" to impose his will on her gives Cherry her excuse to elope and start a series of adventures in order to find whom she believes to be her real ancestors. As old Don Quixote did not want to accept that the end of his life was near and hoped to lead an active existence as a knight, Cherry cannot willingly accept that her end as the sole governing force of her life was approaching in the way of submission and the acceptance of an arranged marriage. According to Horner and Zlosnik, quixotism offers her an opportunity to create this "benign 
doppelganger $[\ldots]$ which allows the heroine a freedom and power undreamt of" (2001: n.p.); that is, through her quixotic persona she can become mistress of her destiny even if for a moment and become the visible heroine of her own story. In this line, Cherry states that "a mere home is my horror" (1909: 98) and decides to "roam through the wide world" (1909: 17) as a true heroine would do. She leaves her secure place at home, and defies all social rules as she elopes. She justifies her actions thus:

I see plainly, that if adventure does not come to me, I must go to adventure. And indeed, I am authorized in doing so by the example of my sister heroines; who, with a noble disinterestedness, are ever the chief artificers of their own misfortunes; for, in nine cases out of ten, were they to manage matters like mere common mortals, they would avoid all those charming mischiefs which adorn their memoirs. (1909: 26)

Once more, Cherry tries to accommodate to the model set by fictitious heroines by rejecting to "manage matters like mere common mortals," that is, refusing to behave as any woman would be expected to do in her circumstances: accepting her father's choice of husband and becoming an invisible and dutiful wife for the rest of her life. By doing so, she would certainly avoid those "mischiefs" which later threaten to ruin her reputation: Cherry breaks all propriety as she elopes, lives under the roof of an unmarried man such as Betterton, allows the fortune-hunter actor Grundy to speak love to her, blows up a house, storms another and conquers a castle, remains a whole night in prison and claims to be who she is not. As she sets out for adventure, Cherry imitates Don Quixote as a much more rambling heroine than decorously domestic quixotes, such as Arabella, and, by so doing, also comes closer to Bullock's Dorothea, equally menacing to disrupt her social order. She definitively reads herself as a social being, with more visibility and power than, as a woman, she had been granted; a being capable of fighting banditti, of becoming a political leader and of achieving ownership and independence. In this sense, Cherry is much closer to the model of Cervantes than to the one established by Lennox's Arabella. Cherry, in her disruptiveness, becomes a greater threat -and a greater fool. She becomes the butt of ridiculous plots and 
of the physical humour developed by Barrett in the manner of Cervantes, as well a banner for the social and personal dangers that lie in her disruptiveness.

The most important of these dangers, in Barrett's discourse, is the threat women's romancing implies for their honour. With this consideration, Barrett returns to the origins of the tradition of female quixotism, its focus on the plot of courtship and the importance of not failing to interpret men appropriately. Most of the female quixotes' misreadings are related to the men around them, whether parents, lovers or even servants, and Barrett resumes this common place in his fiction. From the very beginning, Cherry's reading of herself as a heroine implies a rejection of her origins as a mere farmer's daughter and, thereby, demands a complete rereading and rewriting of the character of her socalled father. Even when finally reconciled to the idea of Wilkinson being her real father, she temporarily holds on to her only hope of noble origins and exclaims: "that honest squire [...] may yet come out to be a marquis" (1909: 289), in the recurrent cognition scene of romance (Frye, 1973: 170). In the happy end of romance, maybe Cherry could unveil hidden truths about her birth. If Wilkinson is her real father, Cherry then can only hold on to his rewriting as an unknown nobleman to sustain her claim to heroism. As for the interpretation she does of the rest of her male acquaintance, Cherry is, even more than Arabella, constantly surrounded by men and it is their character which she persistently mistakes. Betterton is described at first as "the best of men" and a "benevolent guardian" who praises her for being "so penetrating" that it would be "impossible to deceive" her (1909: 30). However, in their first encounter, Betterton invents the story of a heroine named Angelica Angela Angelina, who "was hanged at the Old Bailey for stealing a broken lute out of a haunted chamber" (1909: 30), in order to fright Cherry into remaining at his house so that he can propose. He is finally discovered to be an unprincipled man with "infamous designs" to ruin Cherry's virtue (1909: 282). His character is however made known to the reader, and even to Cherubina, when he tries to marry her and she flees his house calling him "monster" and "ruffian" and attributing to him some "vile design" (1909: 31). Later in the novel Cherry discovers the landlady "is plotting with Mr Betterton to betray me into his hands at the masquerade" (1909: 96), and, as his plot has been discovered, he 
tries to manipulate her at that same masquerade using romantic conventions and disguised as old Eftsoones, an assumed servant of the Willoughbys, who allegedly informs her about her ancestors (1909: 113-116). Nevertheless, she insists on seeing him as a mere character in her plot, and not as the real dangerous man he is. Despite being made aware of his plans of abduction by Higginson, a poet who is in love with her, and his mother, all she has to reply is: "you have destroyed half the interest of this intrigue against me, by forewarning me of it" (1909: 92). Cherry's experience in the world is too limited to allow her to perceive the real danger in her acquaintance with such a man; she only interprets him in the terms of romance, where heroines' virtue is always preserved by some fortunate turn of event. In this sense, she resembles Biddy or Arabella in that her innocence and romantic colouring prevents her from reading reality in the sexualised terms of contemporary interpretation.

The character about whom she is most mistaken is the false hero, Abraham Grundy, the actor who becomes the noble Lord Altamont Mortimer Montmorenci. It is with him that Cherry must exercise her exegetical power of reconciling the reality she perceives with the notions acquired from literature, her power of making windmills become giants. It is with Grundy that the constant dialectic between reality and idealism and the authority of literature over life, both so present in Cervantes' quixote and Lennox's Arabella, seem clearer. From the very start of their acquaintance Cherry takes him to be her hero, deluded by his words and looks, so in accordance with those of a knight. Once more, as happens with most female quixotes, appearances are the main artifice of delusion. Due to the fact that he falls into the description made of heroes in the novels she has read, she fancies him a nobleman and fancies it her duty to fall instantly in love with him (1909: 47). However, she will constantly see signs which contradict her heroic expectations; for instance, his use of inappropriate and base language, his promises of love to the landlady or his alliance with the villainous Betterton. Or, moreover, recalling once again the importance of appearances in relation to heroism, the fact that he has lost his two front teeth in his fight with Jerry:

'My Lord,' said I, 'of this you must be conscious, that a complete set of teeth are absolutely indispensable to a hero.' 
'Well?' cried he, starting.

'Well,' said I, 'having lost two of your's (sic), you must be conscious that you are no longer a hero.'(1909: 242)

This extremely amusing passage, resembling Don Quixote's loss of his teeth at his fight with the shepherds whose sheep he had thought to be armies and his pain at such an unheroic injury, proves that the reading she makes of other characters is never fixed, but that it rather evolves depending on the circumstances. In instances such as the aforementioned, it is Grundy who must recall his knowledge of romance to adjust his circumstances to heroic examples which may be accepted by Cherubina, therefore inventing vows which forced him to speak as an uneducated man (1909: 80-81) and excusing himself for bespeaking love to his hostess by accusing her of forging the letter (1909: 99). However, to his alliance with Betterton, and especially to his unheroic lack of teeth, Cherubina can never be reconciled.

As happened with The Female Quixote, The Heroine also offers a true hero, $\mathrm{Mr}$ Robert Stuart. He saves Cherry from many dangerous or compromising situations and Cherry's reading of him, as that of Glanville, also changes as the novel advances. At first he is read as an inadequate suitor, in Cherry's words, a "man whose legitimacy is unimpeached [...] his name Robert too: -master Bobby [...] a fellow that mewed like a cat when he was whipt. O my Bob! What a pretty monosyllable for a girl like me to pronounce!" (1909: 17). He has nothing of the heroic in him: neither the name, nor the dark past; he is just "a husband of decent birth, parentage and education" (1909: 17). As Cherry falls in love with him, he becomes the hero both of the romance she is writing and of the sentimental plot in which she is the heroine, especially as Stuart opposes the fake hero Grundy and their true feelings contrast with the false love experienced between Cherubina and Montmorenci. The latter love is as illusory as the characters' epithets and embodies the romance Cherry aims to write, while Stuart and Cherry are as real and as plausible as their names, proving again this dichotomy between Cherry's romantic quixotic narrative and the anti-romantic narrative frame in which it is embedded, while also highlighting their similarities. Despite his detachment from the world of 
romance, his common and non-romantic name which does not end in $o$ or $i$, the fact that he is in no way the humble servant of his lady and that his main ambition is to cure Cherry from her nonsensical heroic behaviour, Robert Stuart still makes possible the most important circumstance in romances: the final wedding. Even Cherry makes this circumstance obvious when she tells Stuart: "You see [...] after all your pains to prevent me from imitating romances, you have made me terminate my adventures like a true romance- in a wedding" (1909: 297-8). Recalling Lennox's romanticising of her quixotic heroine, Barrett also transforms Cherry into a true heroine of the domestic plot of the sentimental novel.

In all the abovementioned readings of her male acquaintance Cherry develops a great capacity for accommodation; she constantly reconciles those elements which contradict her expectations with other examples from her romances. Detaching his description of quixotism from Cervantes and moving closer to Lennox, Barrett also portrays female quixotism as a youthful delusion or romantic colouring that does not pervert the intellect (Welsh, 1981: 149). Cherry is well aware of her sensorial perception and does not transform Grundy's lack of teeth or the terrible conditions of the prison in which she awaits trial for robbery. At her father's office she finds an old parchment she believes to be her claim to a title; when she is kidnapped by Grundy and his friends and held prisoner in a false cell, she sees a stain on the floor she thinks to be blood. The paper and the stain are real, and under the conventions of romance the interpretation as a title and blood, respectively, is plausible, and does not defy the perception of her senses. Furthermore, Cherry herself sometimes comments on the difficulties of reconciling what her senses perceive with what her imagination, inflamed with romances, expects:

I too rose, and having now recovered my wardrobe, enjoyed the luxury of changing my dress; for I had worn the same cloaths several days, and consequently was become a perfect slattern. How other heroines manage, I cannot imagine; for I have read of some of them who were thrown among mountains, or into cells, and desolate chambers, and caverns; full of slime, mud, vermin, dust, and cobwebs, where they remained whole months without clean linen, soap, brush, towel, or comb; and, at last, when rescued from captivity, forth they walked, glittering like the morning star, as fragrant as a lily, and as fresh as an oyster. (1909: 235-236) 
With passages such as this, Barrett highlights the implausible adventures of romances, in particular the ways in which they contradict empirical evidence, and lays the foundations for his parodic approach. His burlesque indeed permeates the whole novel. For instance, his use of the conventions used in romance in matter of rivers, downpours and violent fevers is once again highly ironic. Instead of diving into a river like Clelia or Arabella, Cherry ridiculously falls into a stream as she is wandering along a very idyllic countryside and decides to wait in the water to be rescued by her lover. The episode is described as follows:

[...] leaning too much over, I lost my balance, and rolled headlong into the middle of the rivulet. As it was shallow, I did not fear being drowned, but as I was a heroine, I hoped to be rescued. Therefore, instead of rising, as I might have easily done, there I lay, shrieking and listening, and now and then lifting up my head, in hopes to see Stuart come flying towards me on the wings of the wind. Oh no! my gentleman thought proper to make himself scarce; so dripping, shivering, and indignant, I scrambled out, and bent my steps towards the cottage. (1909: 137)

Neither is she rescued by Stuart, nor does she feel unwell. What is more, she must present herself in front of him with in her wet clothes, making a very foolish sight. Furthermore, when she does finally fall ill, at Lady Gwyn's house, it is not due to her ladyship's intention to poison her, but to "a violent rheumatism" (1909: 150) contracted by the aforementioned fall into the water most probably by her insistence in waiting for her rescuer. If there was anything unromantic, that would be the idea of rheum and what it entails: old age and "flannel waistcoats," as the also romantic Marianne Dashwood complains about in Austen's Sense and Sensibility. There is nothing romantic in rheum, no heroine was ever said to experience such a degrading condition, and, if she could choose, Cherry would "fall ill of a scald from a lover's tear, or a classic scratch from the thorn of a rose" (1909: 151). She even believes that "this horse's constitution of mine is a terrible disadvantage to me," as it will not allow her to possess "that languid delicacy of illness" (1909: 151); a stoutness that Austen's mock-sentimental heroines will also display. Cherry, therefore, in both episodes is doubly ridiculed as her romantic assumptions contrast with a more realist and somewhat humorous explanation. 
Barrett's recurrent portrait of Cherry as the butt of his ridicule and as the means of his attack on certain forms of fiction lasts until the very moment of the traditional epiphany and awakening to her quixotic delusion. Although half way through the novel, Cherry suffers a fever and starts to consider the moral dangers of her behaviour, she is soon recovered, forgets her promises of amendment, and continues in her obstinate quixotic delusion. Her definite cure will need more than words and reflection. If women are not the rational creatures that Wollstonecraft claimed, but the sentimental ones Barrett envisages, the cure will be brought on an emotional level by the extreme vexation to see herself ashamed. Therefore, Cherry is finally placed in the middle of the most extravagantly implausible tableaux: kidnapped, taken to the castle of a "Baron Hildbrand," held prisoner in a horrible cell visited by Grundy's actor friends as famous characters of fiction or ghosts, and forced to marry Montmoreci if she wants to avoid horrible torment, the greater of which is "waking some morning with a face like a pumpkin" by the dampness of her cell (1909: 272). At this moment, Cherry is presented at the height of her ridiculous quixotic delusion, but she is also more conspicuously faced with the fictional nature of her models: as the heroes and heroines of her favourite readings are introduced, she perceives the ravages reality has had on them, how they have aged and how their ideal love stories have ended in tragedy or even in an uneventful domestic life. Not only Gothic characters, but even those from realistic fiction, such as Sir Charles Grandison, Pamela, Evelina, Cecilia, Corporal Trim, prove that their narrative, despite its apparent verisimilitude and plausibility, is not real, but limited and mediated. Moreover, the ghost that torments her commits such a mundane action as to sneeze, and Cherry finally manages to perceive that the horrors of Gothic fiction are mere tricks, delusions, in the same manner the actor who is impersonating that ghost is playing one on her. In addition, the aforementioned characters aim to convince her that the romantic happy endings of novels are ironic, for after the wedding all romanticism ends. Therefore, they support the anti-romantic circumstances of marrying a man even if she does not love him, although in this case it is the romantically-construed Montmorenci. 
However, even if questioning her romantic interpretation of the world, Cherry rejects renouncing to the epitome of romance in the shape of a wedding for love. Therefore, to conclude her awakening, she escapes from her cell, only to discover Abraham Grundy, Betterton and all the other plotters together laughing at her, boasting of their plan and torturing Higginson, the poor poet who had tried to help Cherry. Her emotions at this moment trigger the beginning of her path to self-awareness; Cherry exclaims: "just fancy my revulsion of soul, my dismay, my disgust, my bitter indignation -oh! how shall I describe to you half what I felt [...] My heart died at the sight" (1909: 278). More intense is her reaction to the mockery Grundy performs on her romantic confession of love, upon which, furiously ashamed and invoking her "sacred honour" (1909: 278), she discovers herself and the action quickly advances to her rescue by Stuart and the first opportunities to face the terrible consequences of her acts: the pain inflicted to the people who have come in contact with her, to her father and to Higginson, her own stupidity and ridicule, and the true danger she had been exposed to by the dealings of Grundy and Betterton. In this sense, Barrett explicitly addresses the sexual danger of his quixote, when he describes the arrangement between the actor and the nobleman: the former having agreed to marry Cherry and, "for a stipulated sum, to give Betterton the opportunities of prosecuting his infamous designs" (1909: 282). Following West, Bullock or Lucas in his anti-Jacobin message on the frailty of women's honour, Barrett allows a greater exposure to danger for his heroine to stress the absolute need for the abandonment of such aspirations and the total cure from her heroic delusions.

Barrett does at last follow the previous tradition of female quixotism inaugurated by Lennox in the process of cure, as Cherry falls extremely ill with "a violent fever of a nervous nature" (1909: 291) caused by the impression of the consequences of her foolishness. A clergyman is requested and again he acts as the representative of male authority, as well as that of the Church. Echoing Lennox's novel, several days of rational talk follow in which it is the religious precepts that operate the greatest change on Cherry's attitude, restoring her to humbleness and to the "duty" towards her father, Stuart, herself and God, which she had sacrificed to her "inordinate gratification of a 
particular caprice" (1909: 292). The recovery of passiveness once more becomes fundamental for the quixote's restoration and Cherry claims that "I have risen from my bed, an altered being; and now I look back on my past delusions with abhorrence and disgust" (1909: 292). Finally, one last touch is added to Cherry's cure. If ridicule and rational conversation were in themselves enough to cure young women's minds from their delusions, then works such as Barrett's The Heroine would be rendered unnecessary. Hence, Cherry is guided to an absolute restoration of propriety by her male mentor, Stuart, through a series of didactic and rational conversations and the reading of appropriate books, sanctioned by the male reader: Burney's Cecilia, Edgeworth's Fashionable Tales or More's Coelebs are accepted because of their presentation of "man as he is" not as "he cannot be, superhuman," and even Radcliffe's romances are praised because of their appeal "to the imagination alone" (1909: 293). However, the female reader must still always take care the perusal of such seductive fiction does not become compulsive and again intoxicate her (1909: 293). The most important of these proposed readings, nevertheless, is Don Quixote of La Mancha, from which Cherry derives great benefit (1909: 292). Subsequent to this restoration to a patriarchal context, emphasised by this reinstatement of male cultural authority by a male speaker recommending a male text (Pearson, 1999: 208), Cherry confesses "I am no longer a heroine" (1909: 296) and can proudly say "I am a wife" (1909: 297). In the end, the language of confinement is made more evident by her previous unlimited freedom. However, this return to a mode of imprisonment is closely related to her cure of quixotism, her return to the condoned status quo and her transformation into the epitome of the domestic woman, which is hailed as the appropriate example for Barrett's female readers to imitate.

Cherry's transformation into a domestic heroine, as happened with Arabella, signals the change of genre, as she steps out of the romance she is writing about herself and assumes her role in the novel that is being written about her, the frame of her own story. With this step out of the boundaries of the romance, Cherry is also allowed a fuller entity before she immediately disappears. As the narrative unfolds, little is known about her psychology or personality beside those qualities exposed through her folly. Cherry's thoughts 
are so extremely romanticised that it is difficult to apprehend her character as plausible and complete; her sole interest seems to be that of marriage and heroism. Moreover, once and again Cherry assesses her smallest actions through the precedents of romance even if her own words express how questionable her quixotic experience is. That is, she does not refute the precedent examples of heroines even if they contradict her experience, as when she is covered in dirt or when she exclaims, after walking for more than an hour, that she found herself "unable to proceed a step farther," which was "the more provoking, because heroines often perform journeys on foot that wound founder fifty horses" (1909: 25). Her statements are so obvious in their ironical condemnation of romances that there is little psychological depth to be found; and the implausible mode of narration, the first-person epistolary narrative, parallels her implausibility as a credible character. Cherry is nothing else but the embodiment of the author's judgement throughout the novel, the fooled character on which he bases his ironic narrative. Only at the end, after Cherry's moment of shameful awareness, and during her process of cure and repentance, is the reader allowed to perceive a more important development of the author's powers to approach the complex nature of his creature's mind: it is in her abandonment of her delusion when the rational thinking which had only briefly appeared throughout her heroic wandering finally appears. Even if with less detail than in the case of Arabella's conversations with the Doctor of Divinity, Cherry describes her rational conversion from a heroine to a housewife with more credibility, assuming she is not to be transformed instantly, but that the new correct precepts must become "rooted and methodized" in her mind (1909: 292). However, he does not grant her sentimental heroine full agency either, but rather resumes an authoritative male voice at the end to mediate her experience -with Stuart acting as surrogate for a third-person, moral narrator. Barrett then concludes the novel appropriating the accustomed conclusion of the sentimental novel, another genre dominated by women writers, an ending he has already questioned with his parodic use of the great characters of the sentimental and domestic novel. 


\subsubsection{The Political Dimension: an Anti-Jacobin Comic Fiction}

As implied in the abovementioned description of Cherry's quixotism and punishment, while returning in his novel to a more literary quixotism than most anti-Jacobin authors developed, Barrett still places The Heroine at the margins of the aforementioned ideological quixotism and of anti-radical fiction. In Barrett's transitional narrative, Cherry's return to her place in the domestic sphere and the loss of her voice has more implications than those regarding generic transformations; it provides a comment on her virtue or her duties as a daughter or a wife and the need to return to a more acceptable social frame, which also parallels the generic one. In the typical anti-Jacobin train, Barrett equates the domestic with the public, the household with the nation, and portrays the social dangers of Cherry's literary delusion. As Pearson has stated, in Barrett's anti-Jacobin discourse:

The stability of the state depends on that of private life, which itself relies on women relinquishing their desire to be the heroines of their own stories and accepting their place within domestic ideology; and this is figured especially in their subordination as writers and readers. Novel-reading is a feminised, feminising, female-empowering act in this novel, and consequently must be strictly disciplined. The uncontrolled female reader is identified not only with class, gender and sexual transgression, she also transgresses against "national virtue' and is implicated in the politics of revolution. (1999: 209)

As stated, Cherry is a much more adventurous quixote than many of her predecessors, and her romantic adventures therefore have a greater political resonance in Barrett's employment of the "family-politic" trope. While Arabella hoped to be abducted and forced to travel, Cherry exclaims:

Yes, I will roam through the wide world in search of my parents; I will ransack all the sliding panels and tapestries in Italy; I will explore Il Castello Di Udolpho, and will then enter the convent of Ursulines, or Carmelites, or Santa della Pieta, or the Abbey of La Trappe. Here I meet with nothing better than smiling faces and honest hearts; or at best, with but sneaking villains. No precious scoundrels are here, no horrors, no atrocities, worth mentioning. But abroad I shall encounter banditti, monks, daggers, racks - $\mathrm{O}$ ye celebrated terrors, when shall I taste of you? (1909: 18) 
Cherry reads her world as uneventful and socially constrained, therefore she rewrites it after the fashion of her romances as a place full of literary situations of danger and love which await someone bound to be a heroine, as she thinks herself to be. In all her naivety, she is never aware of the real danger those circumstances would pose; however, it is the unconsciousness and innocence in the ways of the world which allows for her escape from conventions. Her quixotic notions, even if dangerous because of exposing her to scandalous situations, are the means through which she can attain for once social visibility and the chance of being more than a housewife; also the reason why, in Barrett's discourse, she must be disciplined and reinstated in a more appropriate domestic narrative.

Her quixotic delusion also enables her to read the world as a dreamt place in which she can act very much as well as she pleases, because the laws of romance will condone her heroic behaviour. If prior heroes and heroines could blow up a house, take over a mansion, steal, or blackmail, then she can follow their examples. Very early in the novel, when she has just begun her journey, she states that she "despises the common law of England" (1909: 29), if it condemns a heroine for detonating powder and making a house full of banditti explode. Later in the novel she once again echoes Arabella when she states:

Besides, the code of moral law that heroines acknowledge is often quite opposite from those maxims which govern other conditions of life [...]; but the mere Miss has no business to attempt any mode of conduct beyond modesty, decorum and filial obedience. In a word, as different classes have distinct privileges, it appears to me, from what I've read of the law national, and the law romantic, that the heroine's prerogative is similar to the King's, and that she, like him, can do no wrong. (emphasis added, 1909: 112)

Counterpoising the "law national" and the "law romantic" again indicates the political or social disruption that the adherence to romantic principles may imply. In fact, Cherry commits several transgressions, among which destroying private property, larceny, breaking into houses, or disruption of public order could be enumerated. Nevertheless, again equating the domestic with the public, her greatest crime seems to be her anomie when it comes to certain areas of her relationship with men, when she rejects that mode of conduct of 
"the mere Miss" based on "modesty, decorum and filial obedience." Following other heroine's examples, she accepts Betterton's mendacious protection and is willing to remain at his house, as she actually did with Grundy; or travels alone with Stuart and Betterton. She even laughs at the loss of virtue so achingly important for a woman in her position:

[...] 'but such is always the fate of us poor heroines. No, never can we get through an innocent adventure in peace and quietness, without having our virtue called into question. 'Tis always our virtue, our virtue. If we are caught coming out of a young man's bed-room,-'tis our virtue. If we remain a whole night in the streets,-'tis our virtue. If we make a nocturnal assignation,- $\mathrm{Oh}$ ! 'tis our virtue, our virtue. (1909: 79)

She does not accept that her virtue must always be questioned due to her quixotic life, even in such scandalous situations as the one she mentions. While Arabella remains exceedingly prudent, as far as her delusion allows her to, Cherubina follows the most rebellious and pernicious examples in literature. Not until her virtue is about to be publicly compromised by sleeping in the same castle as her little army, is Cherry unable to recount any previous heroic example which would condone such a scandalous behaviour (1909: 255). For once, it is the consideration for her honour and her shame which puts a stop to her quixotic pretensions as she surrenders her dominion over the ruins of the castle.

Her virtue being compromised is however only a symbol of the social disruption Cherry causes. Women's virtue, as stated in the introduction to this chapter, was the standard by which anti-Jacobin authors measured the corruption of national morals. The threat of her marriage to a fortune-hunter and the loss of her dowry, estate and honour announce the dangers which radicalism hides for wealth and status, both bases of the conservative discourse. This discourse on the importance of virtue associated with wealth is reinforced in a lengthy episode in which Cherry escapes from Betterton's house after his lascivious advances and finds a girl crying in the street, named Maria, which she takes for "a sister in misfortune" (1909: 31) and who is in reality a street prostitute. Cherry offers her some money from her purse in order to help her out of her distress, and Maria adds to it her own sixpence to 
become partners. However, at Maria's suggestion of spending the money at a pothouse, Cherry runs away and Maria accuses Cherry of stealing her purse. That is, Maria projects her dishonest nature on Cherry, at the same time she tries to take advantage of her, and the heroine is accused of stealing her own purse and the very same money with which she was trying to help. Both girls are taken to court after a stay at the watch-house, "a room filled with smoke and culprits; where we stayed all night, in the midst of swearing, snoring, laughing and crying" (1909: 33), a place where no respectable woman should ever find herself in. Both Cherry and Maria claim and describe the content of the purse. After some nonsensical romantic talk which almost has her committed, Cherry sensibly proves her innocence and recovers her money. While she is finally cleared from the charges, Cherry has risked losing her money and her honour for her foolishness and her search for adventures.

Moreover, detaching the narrative from a mere domestic plot of courtship and from Cherry's virginity as symbol for the preservation of the state, Barrett develops a more overtly political plot in which, once more, the Irish rebellion finds its comic echo in the Irish peasants' rise to ransack Lady Gwyn's house or to conquer Monkton castle under Cherry's orders, with more ridiculous than serious consequences. This humorous treatment of the rebellion is particularly embodied by one of the casualties of Cherry's disruptive ideas, Jerry Sullivan, an Irishman who Cherry helps to defend at court and who becomes her faithful companion, clearly echoing Don Quixote's very own Sancho. He represents, in Gary Kelly's words: "the gullible common people, too easily led by their 'betters" (1990: 237), the kind of trusting but uninformed people willing to follow who they consider a worthy leader. In words of Sullivan, a former revolutionary, he was convinced to rebel by "gentlemen with rusty superfine on their backs" who pronounced "the longest words in the world" and who persuaded him "that old Ireland was going to ruin; I forget how now, but I know I had the whole story pat at that time, and the end of it was, that I became a United Irishman" (1909: 217). As it becomes detached from its more extremist ideological antecedents, the novel reverts to Cervantes' original parodic intent and abandons the flagrant satire of Lucas or Bullock. While the latter fictionalised the Irish Revolution in all its cruelty, Barrett, with the 
distance given by time, decides to undermine it by ridiculing the reasons behind the peasants' uprising. From Jerry's speech it then must be derived that the danger in 1798 , as it is in 1813 , lies in the power of "the longest words in the world," in political rhetoric and, of course, in literature.

In the frame of this political context and its literary implications, it is again significant that it will be in French and Gothic novels where Barrett places the origin of Cherry's quixotism. According to Kelly (1990), the Gothic and its association with un-Britishness was a genre linked to political danger, and, once more, in Barrett's anti-Jacobin discourse, characters become recurrently connected to dangerous or sanctioned genres. In this line, Betterton and Grundy make use of the conventions of French and Gothic novels to fool Cherry, and are therefore associated with this un-British threat which becomes obvious in their desire to physically and financial ruin the heroine. Recalling Sir George's history of his life in Lennox's novel, Grundy must construct a story in a burlesque of Gothic fiction; in addition, he mentions a connection with France and Napoleon himself (1909: 61). On his part, Betterton represents the republican corrupted man who embodies radical philosophy and morals. According to Kelly, this is signalled in his name, a compound of "better," an allusion to radicals' ideas on man's perfectibility, and again “ton" (1990: 235). At one point, Stuart, the representative of Britishness, says to him "your wines are as foreign as your sentiments" (1909: 98), making this association perfectly explicit. In contrast with such characters, well-informed English middle-class men defend the rejection of such ideals, as Stuart does, and become associated with the kind of fiction that Barrett's hero provides at the end of the novel as Cherry's cure: moral narratives and Don Quixote itself. Stuart, as this embodiment of the ideal British citizen and critical reader, renders obvious where the danger of corruption finds its source, when he asserts:

In a country where morals are on the decline, novels always fall several degrees below the standard of national virtue: and the contrary holds in an opposite state of things. For as these works are an exaggerated picture of the times, they represent the prevalent opinions and manners with a gigantic pencil. Thus, since France became depraved, her novels have become dissolute; and since her social system arrived at its extreme of vicious refinement, they too have adopted that last master-stroke of refined vice, 
which wins the heart by the chastest aphorisms, and then corrupts it by the most alluring pictures of villainy. (emphasis added, 1909: 293)

Therefore, novels and their perversion, including the ever-present fiction by Rousseau (1909: 294), are identified with France and its social system, which threatens to contaminate Britain with their ideas. A little later, Stuart affirms that "though we seldom see such publications in this country, yet there is a strain of well-meaning, but false morality prevalent in some" (1909: 294), what is to say, that the trend of Francophile narrative fiction had spread to Britain, teaching the same false ideas and morals and posing the same danger those dissolute French romances had for Cherry. Moreover, the political ideas and social system adopted in France had an echo in Britain through the essays of many philosophers and writers. In this sense, Barrett does conform to the antiJacobin view of British radicals as dupes and fools, and even more so as he chooses those two groups that were believed to be the more susceptible readers, identified by Grenby (2001) as the lower orders and women. The latter is especially relevant, as, by placing a woman deluded by fiction as the main character of his novel, Barrett gives new life to the conservatives' "negative associations of gender, genre, and the novel" (Kelly 1990: 226), present at the core of anti-Jacobin female quixotism.

The consequences of this politicised delusion are many, and presented at many different levels. Cherry and Jerry commit several transgressions of the law in his decision of assuming Cherubina's claims to be possible, proving how quixotism may pose a threat to the established order. In a moment in which the Napoleonic wars had brought back the echoes of the French revolution and its consequences in England, and had, therefore, become the most important political issue, Cherry embodies that image of revolution and disruption which was seen as a menace by the more conservative sectors of society. In this regard, it is significant that she compares herself to Guy Fawkes, equalling herself with that revolutionary character. As a case in point of her connection with social disturbance, at one stage she is left under the protection of a noblewoman she believes connected to her ancestors, Lady Gwyn, and starts a riot in order to gain possession of what she considers her inheritance. Later she 
will even claim an abandoned castle as her fortress and will start a battle, followed by her faithful Jerry and some of his Irish friends. The situation of upheaval against the monarchy and the privileges of the noblemen which occurred in France is somewhat reflected in Cherry's desire to become a noblewoman and the owner of Lady Gwyn's castle, as well as by the disruption of order caused by her followers when storming the noblewoman's house or defending the castle. The idea of property is subverted, together with the notion of rights based on high birth or wealth. Moreover, Cherry addresses certain matters as the property of the land and the majesty of the people, which are at the core of the abovementioned revolution. At one point, when addressing her small army of poor Irishmen, Cherry describes herself as "adorned with all the terrible graces of beauty belligerent" (1909: 248). A moment later she delivers the following speech to her "soldiers:"

I promise to them all such laws and institutions as shall secure their happiness. I will acknowledge the majesty of the people. (Applause) I will give to them a full, fair, and free representation. (Applause) And I will grant them a radical reform; or in other words, a revival of the feudal system. (Shouts of applause) I will assume no monarchical prerogatives that are unjust; if I should, do not forget that people have always the power and the right to depose a tyrant.

I promise that there shall be no dilapidated hopes and resources; no army of mercenaries, no army of spies, no inquisition or private property, no degraded aristocracy, no oppressed people, no confiding parliament, no irresponsible minister. (Acclamation) In short, I promise every thing. (Thunders of acclamation)

Each man shall have an acre of ground, a cottage, and an annual salary. (Long life to you! cried the troops. That is the best thing you have said!) Such is the constitution, such are the privileges that I propound to you. (1909: 248)

This speech proves that Cherry's political ideals are full of contradictory notions, such as calling a return to the feudal system and acknowledging the majesty of the people. However, this uncritical approach is not to literature, but to the news and speeches she has read in contemporary papers. The aforecited address to her army of Irishmen is said to be founded on those she had read "in the daily prints" (1909: 248). Therefore, her wild political notions are based not only on romances, but rather on the actual situation her country is experiencing 
which makes her absurd claims a more direct attack to radical ideology. Several times does Cherry acknowledge her desire to bring a "revival of the feudal system" which is "all so favourable to heroines" (1909: 208), and she considers herself the "restorer of that chivalric age, when neighbouring barons were deadly foes" (1909: 247). The critique to the revolutionary ideals is implicit in Cherry's inconsistencies. On another level, it also proves that Cherry believes that utopia is possible, as she pictures an ideal state with her as an ideal leader. In that sense, she comes close to Don Quixote's aspirations to what he considered a political and social utopia, as he imagined a return to a feudal system, to a time and place where knight-errantry and honour had meaning, in order to escape from the harrowing reality of seventeenth-century Spain. Cherry's companions in her most revolutionary adventure are the poor and the destitute, and their desire to own a piece of land and to receive an annuity parallel Cherry's ascension to nobility by her quixotic delusion. Her social and political claims are mere dreams, impossible to fulfil in eighteenthcentury England, as the aforementioned speech proves. In a way, then, Don Quixote and Cherry can be seen as embodiments of an ideal, which in the latter's case is dangerous because of its implications and its proximity to the Revolution in time and space. In this sense, Cherry is in clear contrast with Arabella, who cannot aspire to a higher social stratum than the one she already belongs to. Her claim is to her choice of a spouse and the time of her marriage, which were choices a woman could rarely make. So, while Arabella's aspirations were more overtly domestic than political, as her actions were almost completely limited to her immediate circle, Cherry's actions, following Don Quixote's example, pose more danger because of the political implications they offered.

In addition, due to these implications and according to anti-Jacobin standards, Cherry becomes less intrinsically feminine and therefore even more dangerous for her subversion of established gender roles, coming once again full circle to the idea of women as representatives of the status quo and its need to be preserved. Cherry is an example of what Polwhele termed an "unsexed female." Focusing particularly on Wollstonecraft, Polwhele attacked her "gender politics" (Moskal, 2000: 31), her involvement in the male sphere of 
politics and her "Gallic frenzy" (Polwhele, 1798: n.p.). All these criticisms could be applied to Cherry as well. First, she claims a visible place in society which does not correspond to a "mere Miss;" secondly, though humorously, she is nevertheless involved in politics and moreover states that "the same qualities which have made me so good a heroine, would, if I were a man, have made me just an illustrious patriot" (1909: 249); and, finally, her "frenzy" has indeed a Gallic origin. As Moskal has insightfully explained, Barrett then equates the realm of female heroism or quixotism with the political territory forbidden to women and presents Cherry as this unfeminine creature "raised by the spectre of Wollstonecraft" (2000: 32). At one point, this unsexedness is even made evident by Cherry appearance: having run away and hiding at a milliner's house, she is described as "a mad woman [...]; dressed half like a man, half like a woman, and with hair down to the ground!" (1909: 107). Her manly appearance and her disruptive behaviour are then explicitly associated in Barrett's anti-radical discourse.

To complete the negative portrayal of his power-seeking heroine, Barrett describes the ways in which Cherry consciously uses the influence she has over the male characters involved in her romantic plot. Her nature is much closer to the coquettish and, hence, the morally dubious: she plays several love scenes with Montmorenci, she manipulates Higginson and even toys with Stuart's concern over her. When she finds the latter at the theatre, she approaches him with the intention to "extract a most interesting scene from him, besides laying a foundation for future incident" (1909: 77), for which she recounts a story insinuating her ruin, to which Stuart replies with the passion of his concern: "Is this fact? [...] or are you merely sporting with my feelings?” (1909: 78). In the end, Cherry manipulates the male characters as to have even the treacherous Grundy and Betterton playing by the rules of romance and becoming as ridiculous as herself in their disguises; she manages to upraise an army and to transform Higginson and Jerry in accomplices of her disruptive acts; and, finally, she converts Stuart into a true hero when he is forced to rescue her from her captors. Barrett thus focuses his discourse on the search for female power and its consequences. While Lennox tried to escape from the negative stereotype of women who aimed for control by offering a coquettish Other in 
the form of Miss Glanville, Barrett emphasises this reading of Cherry as a scheming woman as long as she is under her delusion.

However, probably in order to engage his readers in his heroine's narrative, Cherry is nevertheless also an innocent and deluded fool who is subject to the same kind of injustice as her sister quixotes. She is also deceived by those who employ her same code of romance to take advantage of her, such as Grundy, Betterton or Lady Gwyn. Lady Gwyn strongly resembles the Cervantean characters of the Duke and Duchess. She has the means to prepare a fabulous setting for the absurdities of her quixotic guest. She humours Cherry's fantasies and then exposes her to her guests to amuse them. She prepares a crowning ceremony and one of her relatives dresses up as Cherry's old, ugly antiromantic mother. In the end, Lady Gwyn confesses and Cherry must "suffer new mortifications" (1909: 284) when she discovers how she has been fooled:

[...] at the instance of Stuart, she began to relate all the pranks which she had practised upon me while I was with her. She confessed that the crowning ceremony was merely to amuse her guests at my expence; and that my great mother was her own nephew! [...] She said that Stuart, who had known her for some years, begged of her when I paid her my first visit to let me remain under her care, till his return from Town; and to humour my pretty caprices, as she called them. But he did not desire her to go so far with the jest. (emphasis added, 1909: 284)

In this case, injustice comes from the fact that, instead of taking care of the young girl, her ladyship employs literary conventions for a base purpose, such as laughing at Cherry's delusion. In this paragraph, her ladyship has accomplished what are considered jokes; however, these pranks have egotistical and cruel intentions which bring them closer to the unjust abuse of the quixote's innocence.

Barrett then portrays both the fool and the hero in his quixote, although still with a clear emphasis on the former. His heroine's idealism and naivety results in her suffering of injustice, and, consequently, there could be a deeper pathos in the portrayal of Cherry's character and a higher degree of identification and pity from the readers. Barrett lessens this possible empathy by means of the innumerable examples of spreading disturbances caused by his quixote. The 
feeling of empathy due to the absence of negative consequences may increase the satire against the world outside the quixote; however, it would lessen the critique directed towards the foolishness of the quixotic character, reducing the parodic and didactic purpose of Barrett's anti-Jacobin work. ${ }^{193}$ Therefore, depending on the amount of censure the author desires to direct towards his quixote, this pathos is cleverly reduced by also turning her into an object of ridicule and laughter, in the way Cervantes had done with his knight. Barrett then adopts Cervantes' dualism and develops both sides of his quixotic character, complementing each other, following previous quixotes such as Adams or Arabella, whose "foolishness saves them from being pitiful, and their heroism from being entirely comic" (Welsh, 1981: 182), but combining the two elements in different proportions to those employed by his predecessors. In this sense, Cherry's wild and radically foolish behaviour triggers Barrett's more mirthful treatment of her misadventures. The way in which she is slapped at a shop, chased through the city, covered with dirt, laughed at because of her appearance, are such jokes as to ridicule her without posing an excessive emotional concern and involvement from the readers.

Moreover, this is achieved through the use of a first-person point of view, instead of an intrusive narrator that can explain or comment on the ridiculous behaviour of the character and the reactions it triggers in other characters. Barrett chooses a fallible narrator to relate his story; it is as if the ideas of the Revolution were so absurd in themselves that they needed no filter in order to be considered so by the reader. Cherry is, at the same time, butt of the satire and unconscious instrument of a satire against those political notions Barrett sees embodied in her quixotic idealism, which is expressed verbally through characters such as Jerry or Stuart. What is more, the fact that the authorial voice is absent from the narration, while in most quixotic novels there is a third-person intrusive narrator, stresses the difference of Barrett's status as writer and the different aim with which he wrote his quixotic narrative. While

${ }^{193}$ On this matter, Amy Pawl writes: "As parody and satire collide, the reader may be forgiven for being confused. Which is the work's primary goal: the debunking of a particular literary form, or the deflation of wordly pretenses and practices?" (2000: 148). Her conclusion is very similar to that of Staves or Welsh: "the result in both cases is the ambiguity for which Don Quixote has long been famous: a central character who is either a lunatic, a hero, or both" (2000: 148); something which could also be applied to Barrett's quixotic narrative. 
Lennox's narrator, for instance, praises Arabella and somehow conditions the readers' positive attitude towards her, Barrett's irony is better expressed by leaving romantic absurdities expose themselves. In the same manner Grundy employs the conventions of romances to articulate his absurd speech, so does the whole narrative reflect the author's parody by means of Cherry's discourse, leading scholars to state that Barrett's work is more a burlesque than a novel (Butler, 1987: 288). In this regard, in those novels written by women writers, where the third-person narrator allows more comments on narrative or genre, romance, in all its forms, is better integrated and allows a more developed dialogic structure.

Barrett's worth in the tradition of quixotism is then based on a return to the emphasis on the parodic dimension of quixotism and his development of a successful burlesque, as Edgar Allan Poe insightfully and somewhat ironically perceived. ${ }^{194}$ His political message, that whether novels or ideas, all import from France is dangerous for England, proved still relevant enough in 1813 to justify another anti-Jacobin quixotic novel. However, besides the mere political reading of his work, Barrett is of importance to understand the changes taking place in the tradition of female quixotism at the beginning of a new century. The humorous treatment of that danger and of his quixote's rather diluted and fantastical political aspirations detach him from the anti-Jacobin reading of the quixote as political agent and render him closer to that interpretation of quixotism as a romantic colouring of the world found in the tradition of female quixotism established by Lennox. Moreover, as time and the political events in Britain allow a certain detachment from the early anti-Jacobin reaction, Barrett returns to a much more comic and parodic plot, as he chooses, once again, a romance reader as his quixote, rather than an ideological enthusiast. In this

194 Poe wrote: "Everybody has read Cherubina. There is no one so superlatively unhappy as not to have done this thing. But if such there be --if by any possibility such person should exist, we have only a few words to say to him. Go, silly man, and purchase forthwith 'The Heroine: or Adventures of Cherubina' [...]. There are few books written with more tact, spirit, näiveté, or grace, [...] and none more fairly entitled to rank among the classics of English literature than the Heroine of Eaton Stannard Barrett. When we say all this of a book possessing not even the remotest claim to originality, either in conception or execution, it may reasonably be supposed, that we have discovered in its matter, or manner, some rare qualities [...]. This is actually the case." He concludes: "Yet the Heroine must be considered a mere burlesque; and, being a copy from Don Quixotte, is to that immortal work of Cervantes what The School for Scandal is to The Merry Wives of Windsor" (1835: 41). 
sense, though Barrett preserves the satirical plot borrowed from Graves and adapted to the current political situation of the Napoleonic wars, it is still subordinated to his parodic intentions.

This parody of Gothic romance is particularly relevant in the relation of Barrett with the epitome of the change in the conception of female quixotism that will take place at this time, Jane Austen. It is important to note that Barrett was read and enjoyed by Austen, as one of her letters, dated 2 March 1814, bespeaks:

I finished the 'Heroine' last night, and was very much amused by it. I wonder James did not like it better. It diverted me exceedingly [...] I have torn through the third vol. of the 'Heroine'. I do not think it falls off. It is a delightful burlesque particularly on the Radcliffe style. (qtd. in Chapman, 1985: 154-55)

Austen not only enjoyed the novel, but was probably encouraged by it to pursue the publication of her own quixotic narrative. In her essential book on Jane Austen, Mary Lascelles propounded the idea that Barrett's success was a reason to strive for publication, as "it must have shown her that the time for mocking false romance was not yet past" (1995: 36). His influence on her and his position as a link in the chain that develops from Lennox to Austen, together with his intelligent comic use of the plot of the quixote, render Barrett's importance in the tradition of female quixotism unquestionable.

\subsection{Sarah Green and the Dangers of Literary Quackery}

Sarah Green (1790-1825) was a prolific Irish novelist who, over a span of more than thirty years, produced a number of varied works, most of which could be said to be characterized by their conservatism and their satirical character. ${ }^{195}$ Among these satirical pieces, she wrote several quixotic narratives

${ }^{195}$ Still little is known about her, although her origin seems to have been Irish. In his entry for the Oxford Dictionary of National Biography, the most thorough account of Green's career so far, Paul Baines lists the following novel as hers: Charles Henly, or, The Fugitive Restored, published by the Minerva Press in 1790, and ascribed to her on the evidence of a Minerva Library catalogue of 1814; although the first work of fiction that can be attributed to her with any certainty is Court Intrigue, or, The Victim of Constancy (1799). At least sixteen more novels followed: the quixotic narratives at the core of the present chapter; a historical romance, The Carthusian Friar (1814), which is a successful imitation of Radcliffean Gothic; a 
in which her attack was directed against literature and ideology alike. It is interesting to note, for instance, the conspicuous The Reformist!!! A SerioComic-Political Novel (1810), published, as many of her other works, in the Minerva Press, and which was a satire on Methodism. In the anti-Jacobin atmosphere of the age, to which Green fervently contributed, there were constant attempts to "demonstrate the affinity of new philosophy and religious 'enthusiasm', a catch-all phrase that could mean anything from Calvinism to Methodism to Evangelicalism, anything that was not the conservative Arminianism of the Church of England" (Grenby, 2001: 83). These attempts, as Grenby has insightfully asserted, reached their apogee with Green's attack on Methodism, which provides a more thorough development of the equation of the language of radical philosophy and Methodism that Lucas had previously portrayed in a section of his antiradical The Infernal Quixote (1801).

Green's novel follows the progress of a "Methodist picaresque hero, censuring at first his religion and then, once the folly of that has been shown, and he switches enthusiasms, the campaign for political reform he takes up in London" (Grenby, 2001: 84). Percival Ellingford is a young handsome man who "possessed a warmth of heart that readily swelled into enthusiasm;" with a "natural abhorrence of vice, a high sense of decorum, and 'unpolished by l'usage du monde,' he was gay and volatile" (Critical Review, 1811: XXI, 284) and who, at the age of twenty-three, was converted into Methodism, starting his quest to make new believers. He therefore fulfils many of the tenets of quixotism understood as a benevolent and idealistic delusion, and of the quixote as a romantic hero fooled by his good intentions and his little knowledge of the world -which denies the epithet of "picaresque" Grenby has attributed to him. In his quest, he travels to London with his honest and Sancho-like servant, Humphrey, in order to perform the important task to

number of tales of marriage in contemporary settings; scandalous fiction such as The Private History of the Court of England (1808), which retold the prince of Wales's amours in a fifteenth-century setting; leading to her final work, allegedly Parents and Wives, or, Inconsistency and Mistakes (1825). Green also published a moral book for young ladies and a public letter in defence of the sanity of the visionary Richard Brothers (1757-1824) in A Letter to the Publisher of Brothers's Prophecies (1795). According to Baines, "the glimpses of somewhat fervent spiritual life afforded there seem at odds with the conservatism of her other work" (2004: n.p.), evincing that still much is to be done in order to understand Green's prolific and complex body of work. 
"reform the world." His aspirations have ludicrous consequences, rather than the high ones he expected. Moreover, Percival's common sense has difficulties reconciling the "pride, the superfluity of ornament and dress, the exposed bosom, and the transparent clothing, with the prodigal expenditure of every thing around him to the faith that teaches us modesty, humility, and self-denial of every kind" (1811: XXI, 284). Disgusted with the hypocrisy of the elected, he changes enthusiasms and becomes a "staunch patriot and a free thinker, till he plunges into a vortex of errors and delusions" (1811: XXI, 285), of which he is saved by the sensible heroine of the novel, Charlotte Tyler, whom he marries and with whom he regains his possession and status.

As a true quixote, Green's protagonist has a head brimming with Utopian schemes for the future welfare and virtue of mankind, which, as in Lucas's portrait of the religious Harrety and the deluded radicals, is a description that “applies equally to both of his foolish fixations" (Grenby, 2001: 84). Green's similarities with Lucas would be enough to connect her with a longer tradition of conservative quixotic fiction; in addition, her links can be traced to other authors in the ideological and satirical quixotic tradition. The most obvious reference would be Graves'Spiritual Quixote (1773) or even Butler's earlier Hudibras. Moreover, the identification of this particular work of fiction as a " $A$ Serio-Comic-Political Novel" refers to another author of Irish origin relevant for the tradition of female quixotism, Eaton Stannard Barrett, whose The Rising Sun: a Serio-Comic Satiric Romance (1807) is mentioned in Green's later quixotic Romance Readers and Romance Writers (1810), of which echoes can be traced in Barrett's own 1813 version of a female quixote. Moreover, her sentimental conclusion and cure for her quixote again point towards the tradition of quixotism inaugurated by Lennox. In addition, the fact that her heroine saves her quixotic hero refers as well to Maria Edgeworth's quixotic novels, evidencing the continuous intertextual dialogue among quixotic novels themselves.

Despite the abovementioned political quixotic narrative, Green's mastery is at her best in those novels in which the ideological targets fade into the background, and she aims her satirical powers at the morals of her society in relation to women and, more relevantly, at the "issues of her profession" as a 
novelist (Baines, 2004: n.p.). These satirical and metaliterary novels are two, Romance Readers and Romance Writers. A Satirical Novel (1810) and Scotch Novel Reading, or, Modern Quackery (1824), both with a female quixotic protagonist who serves as butt and instrument of Green's social satire and literary parody. The former novel, published the same year as her anti-Jacobin The Reformist!!!, provides the more obvious conservative approach to the trope of female quixotism and is teeming with many of the common places of the tradition. It tells the story of two sisters, Mary and Margaret, who have been brought up in the country and whose innocence and goodness will ultimately suffer from their contact with a degraded society. However, following the conservative dual plot of the good and bad sister, their respective fates will depend on their appropriate choices as women, not only of suitors, but of readings and ways of life. While Mary is the epitome of the domestic woman, Margaret is absorbed by her readings of romances. As a consequence, Mary concludes the narrative married and relatively happy in her present state, whereas Margaret is reduced to the isolated state of a seduced and abandoned single mother.

The construction of Margaret as a deluded female reader follows many of the patterns established by previous authors. First of all, the death of her mother as consequence of her birth and her education in a prominently male environment resemble Arabella's own childhood. In Margaret's case the patriarchal establishment becomes more noticeable, because she lives with her father and two uncles, whom she perceives as "barbarous inhuman" men who burn her novels (2010: 24), and with whose rough and open manners her languishing or soft romantic behaviour, language and aspirations even more conspicuously clash in a highly ridiculous mode. Secondly, she changes her name from the vulgar Margaret or Peggy to the more romantic "Margaritta" (2010: 22) and she aims to adapt her plain and dishevelled appearance to the descriptions of the heroines of her romances. In spite of her aspirations to heroic beauty and amorous fate, Margaret resembles Don Quixote in that her appearance does not run parallel to her gallant delusions. Recurrently described as ugly, Margaret also shares with the Spanish Knight or with other ludicrous female quixotes, such as Tenney's Dorcasina, an unattractive lack of front teeth, which comes as 
a consequence of having mistakenly masticated the claw of a fine rock lobster instead of its meat in the midst of "a romantic reverie" (2010: 25). In addition, in common with Hamilton's Bridgetina, she has a slight squint and is becoming increasingly short-sighted (2010: 39), which points at her distorted perception or at her lack of clear vision. The incongruence between her appearance and her aspirations to romantic conquests and adventures renders Green's satirical portrait of her quixote highly comical and detaches her from Lennox, while it approximates her to the Cervantean humour of Tenney or Hamilton. Finally, and more relevantly, Margaret's reading matter once more connects her with previous female quixotes. It is said she reads romances from the fourteenth century, which "deal with the marvellous" and are full of incredible events (2010: 18), and whose implausibility will be recurrently parodied throughout the novel. Although Green never specifies the exact nature of her quixote's readings, over and again they are qualified as implausible, but moral romances. The fact that they are as old as the fourteenth century suggests chivalric romances, while several events that are comically reproduced indicate that Green has her parodic sights on genres much closer in time, such as heroic romances or even Gothic fiction. This seeming inconsistence could be explained by the narrator's comparison of old and contemporary romances performed in the introduction, of which more will be said later. In this comparison, contemporary authors are termed "vampers" of ancient romances (2010: 2), imitating them without the aesthetic worth of the originals, and in the case of Gothic fiction, without their moral value either. Consequently, Green's lack of commitment to a particular subgenre of romance indicates that it had all come to be the same, in generic terms, in the chaotic literary panorama of the age and in the uncritical reader's eyes. Hence, despite the fact that she proves an insightful literary critic elsewhere, Green still parodies the general qualities of romance as if it was an undetermined whole.

In this parody not only Margaret's characterization, then, but the manifestations of her romantic delusion are developed in accordance with many of the common places of the attack on romance and of the quixotic tradition. In this sense, they serve as basis for some episodes of truly Cervantean humour. Having read of "her favourite heroines despising fear, and 
investigating minutely all that bore the appearance of mystery, she resolved, some day, when her father and uncles would not be likely to interrupt her, she would begin her search, and address the immaterial and awful being" she believes to exist in her house (2010: 61). In addition, she believes she might be able to find "in some hitherto concealed recess, the papers which contained the elucidation of her birth" (2010: 61), which, in a heroine, is supposed to be noble. Decided thus to search for these adventures befitting her status as heroine, Margaret explores her uncle's farm dressed in white muslin and with white flowers in her hair, in true romantic fashion. Ascending an old staircase, she believes to have found a hunted apple-chamber; in it, her active imagination transforms the call of a servant for patience, "anan," for the voice of a spirit which she names "Lady Anannia" (2010: 63). Before she can contact the spirit again, she is interrupted by the servant and decides to descend a ruined flight of stairs which he has advised her not to use; she then finds a locked door and believes a suitor is trapped behind by some "spells of magic or the influence of evil spirits" (2010: 64). "Breathless with the ideas of adventure and romantic peril, heated with the phantoms of her imagination" (2010: 63), she exerts all her might to break the door open, and "the heroine of romance was precipitated into a noisome and offensive dungeon" (2010: 64), although, in reality, she falls into a dark stye, landing on a litter of pigs, badly injuring her body and greatly damaging her already pitiable face. Her dirty and bloody appearance, and her later swollen and bruised face, provides a source for ridicule and pity to cruel and benevolent characters respectively.

Despite Margaret's anti-heroic essence and the physical nature of some of the jokes played on her, her delusion is, once again, mainly circumscribed to courtship, and, as Arabella, she reads lovers in every man who approaches her with kindness or civility. At one point, she perceives three lovers which conform to different stereotypes found in her readings. One of them is Sir Edward Harrington, who advices her "with the gentleness of a parent" not to give way to her romantic character, and whom she reads under her romantic colouring. The narrator states that "though neither his fine manly person, nor his ideas were at all to her taste, yet she plumed herself on a new conquest, and dreaded the persecutions of this tyrannical old lover" (2010: 77). Another and 
more persistent suitor she creates in her mind is her servant Phelim O'Gurphy, a jolly Irishman whom Margaret reads as a nobleman in disguise. The whiteness of his skin convinces the quixote of his noble origins, whereas his amiability and disposition to help her she interprets as a sign of devotion to his lady. While her conviction wanes at times, new readings reinforce her interpretation of him. After discovering in "the excellent novel" Gil Blas, "in the interesting romance" Zaide, ${ }^{196}$ and in similar readings, the plot of the disguised nobleman who passes for a servant to be close to his beloved lady (2010: 135), Margaret applies this reading to her reality and Phelim becomes not only a nobleman, but a prince, for she also misreads his Irish proud exclamations of ancient noble blood as a confession of his lineage. In addition, his Irish dialect, comically and minutely reproduced, confuses her even more and renders their communication impossible: their respective Irish and romantic slang isolate Phelim and Margaret in their own discourse. In the end, she acknowledges his low birth and Phelim, who, contrary to the servants in Barker's or Tenney's stories, remains unaware of the romantic plot he was involved in, lives happily ever after as a tradesman. Finally, Margaret's last and most dangerous misreading is Sir Charles Shefton, an unprincipled libertine who will accomplish her ruin. From the beginning of their acquaintance, Margaret mistakenly reads him in the terms of her romances inspired in the middle ages. Seeing him dressed in green, she tells her sister that she can look at no one but the "knight in green, who I am certain, from his complexion, is some foreign prince: they remind me, dear Mary, of the green knight and his lady" (2010: 34). Her confounded perception is evident in her sister's answer:

[...] I am sure no one need envy [the lady] being seated by the side of such a yellow, unhealthy looking being as the one you have been pleased to dub a prince: what a fortunate event, my dear girl, it would have been for many a needy adventurer, had you been an absolute monarch! How many princes and nobles would have owed their origin to the prepossession you might have received in their favour, from their personal appearance only! (2010:34)

Mary's more accurate perception also highlights the danger of Margaret's delusion: that she will be fooled by men which aim to gain something from her.

${ }^{196}$ Work by the French dramatist Jean de la Chapelle, published in 1700. 
In her case, as she has no fortune to tempt those needy adventurers, it will be her honour which will be at stake. This speech echoes Green's didactic supersystem on the dangers to be found in the delusion of romance, and accompanies a subsequent mise-en-abyme moment in which Mrs Kennedy, a novelist, reads the cards for the sisters and foretells how the plot of their respective stories will unfold:

She told the astonished, convinced, though trembling and horror-struck Margaret, that she loved a very fair man, short of stature; but that she was deceived in him, for if she believed him to be a gentleman, she would find herself very much mistaken, for he was the very lowest of the low-born: that a very rich and great man, much older than herself, would fall in love with her; but she must take care of him, for he had evil designs against her. (2010: 82)

With this metanarrative comment on her own plot, Green evidences how the quixotic plot of a deluded female reader who is subject to the ridicule, first, and the dangers, secondly, of her epistemological confusion has become a recurrent storyline and how her novel is then playing with well-known conventions that are written in the cards that the novelist shuffles. She will then continue to develop both plots, finally unmasking Phelim and Sir Charles as what has been announced they truly are. In the ultimate metanarrative mirror, Green also includes the conventional scene at a masquerade in which characters are hidden and finally revealed. In this context, Mary is indisposed and Margaret is called to take off the mask in which she was impersonating Lady Isabella and reveal her true good self in attending her. She must also attempt to unmask the characters around her and to discover their real intentions, especially those of her beau and her friend, Sir Charles and Lady Isabella, hidden under more elaborate disguises than actual masks. Whereas other characters achieve that reading, Margaret's persistent failure to do so precipitates her fall.

In order to unfold the plot of seduction carried out by the evil Sir Charles, Green once more resorts to the common places of conservative quixotic fiction, placing the blame on Margaret's readings and way of reading, and on the use unprincipled characters make of the conventions found in literature. At the beginning, Margaret is said to read romances "the morals of which, however 
absurd their incidents and events, were unexceptionable;" her father, thus, decides not to prohibit her reading of those kinds of books. He reasons that:

[...] it would be only to teach the gaining of [these books] by stealth; and then, works of a more dangerous tendency might corrupt the heart and undermine the principles of this girl: while the works she now perused, only ensnared the imagination for a time; and as her years increased, he hoped she would be able to see the folly of giving credit to them, and only draw from them those sentiments and feelings which they were intended by their authors to inspire; -an admiration of their ingenuity, and the grandeur and sublimity of their language; with an abhorrence of vice, and a sincere love and veneration for virtue. (2010: 66)

Margaret's uncritical and undiscriminating romance reading is perceived as a youthful foible, as a romantic colouring of reality attached to her inexperience, which will be overcome and which, in the meantime, will preserve her virtue by means of the highly moral tenets of old romances. In this sense, Green's approach to romance reading resembles Lennox's. However, more pernicious genres are likewise available for the perusal of young readers and the change in Margaret's readings correspondingly foretells her ultimate ruin.

A "tool" and a "fool" in the hands of the conniving Lady Isabella (2010: 96), Margaret is re-educated by her through the perusal of the novels that have corrupted the former into becoming a "pretty female atheist" (2010:31) and a "female sophist" (2010: 217). Isabella's course of reading includes modern publications which all consist of "false systems" (2010: 30):

[...] the deluding sophistry of some free-thinking German authors, with whose language she was well acquainted, and whose dangerous and delusive principles she imbibed; from whose fascinating descriptions she found vice stripped of its hideous appearance, and wearing an angel's form; while for her lighter reading she perused the loose sentiments contained in the French novels of Faublas; Le Fils naturel, and all the dangerous works of Diderot, and other revolutionary writers. The effects of such studies on a mind like that of Lady Isabella's may well be conceived; marriage she held in utter contempt, openly expiated on the folly of all the outward ceremonies of religion, and was a very pretty female atheist. (2010: 30-31)

The narrator readily informs the reader that for these last sentiments Isabella was indebted to "our modern female reformist, Mary Woolstonecraft (sic), and her husband;" from them she learnt that these sentiments are "so uncongenial 
with our 'national prejudices', as she chose to call them" (2010: 31). Resuming the anti-Jacobin discourse against Wollstonecraft and Godwin as the source of dangerous philosophical delusion, Isabella becomes in the conservative discourse of the novel a deluded and deluding Jacobin figure, as much a fool as the innocent Margaret, but with the intellectual power to become a pernicious influence on her and to accomplish her literary and moral seduction of the naïve quixote. With regard to her readings, Isabella tells her devoted Margaret that:

I never go beyond probability; and the romances I peruse, shew me, if not the exact picture of human life, at least what it ought to be: I'll send you some of my books; they will not stuff your brains with ideas of ghosts, magic and witchcraft; but will ennoble your ideas, enlarge your understanding, and teach you how to charm, and not so like one of the antiquated sybils you are so fond of reading about. (2010: 96)

Her aim is "to delude her mind with those seductive novels, whose chief subject is love" and which did not always make "marriage the finale of the piece, but rather taught the young mind to lean to love unrestrained and unlimited' (2010: 98). Echoing the anti-Jacobin discourse on seduction through reading, the narrator describes how Isabella trains Margaret with a packet of novels which "consisted of such as would delude the weak and unwary mind" into immorality (2010: 98) and which included the infamous Delphine by Madame de Staël and Rousseau's omnipresent Heloïse (2010: 99). From these novels, Margaret learns new moral principles and a new code of coquettish behaviour, transforming her quixotism and herself. In this sense, Green blends in one quixote Arabella, Bridgetina and Julia and provides a critique to the genres they respectively represent: the implausibility but virtuousness of romance, and the verisimilitude but immorality of French treatises and novels. The latter Jacobin course of reading, reinforced by the Francophile and corrupted atmosphere Margaret's later protectors, the Davenports, live in and the radical speeches proclaimed by Sir Charles and Isabella, provide the context for the ruin of an otherwise highly virtuous and innocent young girl. Margaret's innocent foolishness, which is emphasised throughout the whole novel, especially in contrast with the scheming Isabella, the depraved Sir Charles and the cruel and jealous Mrs Davenport, transforms her into the dupe 
and the victim of these aristocratic characters, thus calling attention to their own dubious moral standards.

In this sense, Green's satire moves beyond the sphere of literature and reflects on the values of the society it portrays. Several chapters in her novel are devoted to depicting the debauchery of the high clergy and the privileged classes; and, while her conservative message is that "it is impossible that all men can be born equal" (2010: 131), this only serves to emphasise the responsibility of the ruling classes in the example they provide. The aristocratic Isabella, Sir Charles and the Davenports debase the innocent middle-class Margaret, whereas the highborn Frederic Harrington, with his corrupted manners, is only saved by his repentance and his return to his marriage with the virtuous, but unsophisticated, lower-class and poor, Mary. In this sense, two other females besides Margaret evidence this attack on the moral corruption of society and its consequences on women's lives. The first is the unprincipled Isabella: beautiful, intelligent and worthy, the narrator repeatedly assures the reader that it was the combination of "the pernicious works she perused, the ill example of her nearest relatives, and a naturally mischievous disposition" which corrupted her heart (2010: 97). This, together with the prevalence of fashion and the lack of a sound education, conspire to ruin her. The importance education would have had in her disposition is recurrently emphasised, and the narrator concludes that "had she been differently educated, [...] she would, with her native energies, have been as conspicuous for her virtue, as for her contempt of that ornament to the female character, and her mind would have become as excellent as it was great" (2010: 219). An adulteress and almost a suicide victim -following her radical and atheist principles which reject as "prejudice" the condemnation of taking one's life (2010: 223)-, she is literally and metaphorically saved by the sisters' father and curate, Edward, who guides her in her reformation and saves her from "the worst of all her enemies herself!" (2010: 226), also a common place in plots of female quixotic delusion (Gordon, 2005). Finally isolated from society and dissipation, she lives a life of retired virtuousness, reading and enjoying the society of more honourable people than the ones she had been used to knowing. As the characters are classified by their ending, the fact that Isabella and Margaret share a similar 
fate reinforces the conservative message that both were deluded victims of the new philosophy and both are, consequently, barred from regaining their place into society due to their loss of virtue, the basis of the nation. Despite their awakening, the happy conclusion of their development cannot be granted. ${ }^{197}$

Nevertheless, the more obvious instrument of satire against a corrupted society is the exemplary heroine of the novel, Mary. Beautiful, virtuous, charitable and a good house manager, she is the epitome of the domestic and philanthropic woman praised by anti-Jacobin writers: she cooks and sews for her family and for the poor in their parish. Mary becomes the truly sentimental heroine of Green's plot, as announced by Mrs Kennedy in her card-reading scene:

To Mary, she told, that [...] a young gentleman loved her beyond all the girls he had ever seen; and that at last they would certainly be united; but they would meet with a great many troubles and obstacles at first: that she would find, or had already found this gentleman rather too free in his moral principles; but that he was only led astray by fashion, and rather an extravagant turn of mind; he would soon love her, and her good conduct and prudence would restore him to himself, and entirely eradicate all his former errors. (2010: 82)

Indeed, she marries the former libertine Frederic Harrington, much to the disappointment of his proud and noble uncle. However, returning to his old scenes of dissipation and to his former admiration for the newly-married Isabella, Frederic abandons his wife, commits adultery with Isabella and is subject to immense scandal when her husband, who had agreed to their sexual liaison, claims compensation. In the end, Mary must forgive him and welcome him back with no reproaches in order to grant his complete restoration. This plot, similar to Edgeworth's earlier Leonora, once again portrays the consequences even virtuous women experience in a society with a double moral standard for the sexes; Mary, as Leonora, becomes the ultimate suffering sentimental heroine who overcomes all trials by force of their virtue. Both are assailed by other debauched suitors, in Mary's case the married Rector Mr

197 It is relevant how the moral conclusion emphasizes this final alienation. The benevolent Sir Edward invites Margaret to join his household together with her father, sister, and brother-in-law. However, this suggestion is rejected by Edward Marsham as inappropriate, and Margaret must remain close, but isolated (2010: 230). 
Leslie, and must experience the hardships of preserving their honour in their single state and even when married to a weak husband. ${ }^{198}$

This feminocentric reading of the hardships of women within a patriarchal context and their role as preservers of virtue and the middle-class values of work and charity is moreover reinforced by Mary's education and her nature as a reader. Her education is always in the hands of male mentors, first, her father and her uncles, who believe she should not learn foreign languages or accomplishments above her station; then, by her husband, who is embarrassed by her lack of fashionable knowledge and who, nevertheless, prevents her from learning; and, finally, by Sir Edward, who instructs her in cards, music, dancing and Italian in order to transform her into a lady of fashion who could win her husband back. However, the narrator highlights the error of this latter train of female education when she claims that Sir Edward "was weak enough to think those accomplishments essential in the education of a lady, which are merely ornamental" (2010: 131), even stating that there are "mental accomplishments, which are peculiarly adapted to [the female] sex, and in which the masculine understanding, however great its superiority, sometimes finds itself, in brilliancy and quickness of idea, outdone" (2010: 154). Echoing Wollstonecraft's words on the dangers of shallow accomplishments and the need for a more rational instruction, in Green's narrative Mary shines as an exemplary heroine also in the manner in which she was firstly educated: as a Christian, rational and useful being. Only by means of that sound instruction can she resist and conquer the corrupting forces which surround her and even finally accomplish the well-known "reform of the rake."

In addition, Mary is presented as the model of a proper female reader. While her uncles may sometimes wish that their nieces did not read romances at all

198 For the analysis of Leonora, see chapter six. This dystopic plot and the unfulfillment of the happy integration of the reformed quixotic heroine challenge the conventions of Green's admired Burney or other female authors of proper courtship plots. The depiction of the hardships of single or married women resembles Wollstonecraft's own questioning of the utopic storyline of the happy progression towards marriage and the happy acceptance of the role of wife and mother (Goulding, 2010: xviii), and evince that Green does not unquestioningly accept the tenets of conservative didactic fiction. Green's qualification of women's education, which echoes many of Wollstonecraft's concerns, again displays the similarities among radical and anti-radical positions and their ambiguity when developed by women praising a conservative stance from the public area. 
(2010: 23), Mary proves that a balanced reading is not only possible, but beneficial in a female readership. She avows to sometimes reading romances, but not to making herself, like her sister, "a slave to them" (2010: 23). She then adds,

[...] since our kind uncle Ralph indulged us with subscribing to the library, I very seldom get a novel I like; for Margaret sends for such incredible, such marvellous kind of works, that I shut the works with disgust, and seldom have patience to read them through: but, indeed my dear girl, [...] your health would be better if you did not sit so closely over your favourite studies, which disturb your dreams, and make you unable some nights to close your eyes: would you, like me, enjoy the fresh morning air, which you lose in broken slumbers, after your restless nights, you would soon have done with such idle fancies, which you describe by the title of nervous affections and hypochondriac malady! (2010: 23)

Mary thus correctly ascribes Margaret's malady not only to her choice of study, but to her obsessive perusal of it. The difference between them is reinstated when, both forlorn because of love, the former "applied herself to her needle" and the latter to her fourteenth-century romances (2010: 93); their malady is described as "in the heart and the imagination" respectively (2010: 93) and the cure for both is activity rather than nurturing it with the same poison that caused it. Didacticism, the main objective in anti-Jacobin fiction, permeates Green's novel and is directed towards those idle female readers who may be in danger of obsessing with literature and forgetting their duty towards their families and their selves.

However, as happens in other anti-Jacobin works of fiction, reading is not totally condemned and, in the context of her activity, Mary still sends for poems and those novels from the circulating library "whose subject was the softer passion; but then it was always virtuous love and its reward which they described" (2010: 99). In that way, Green's highly moral novel can be recommended as one of those virtuous sentimental novels that young ladies can peruse without danger. In addition to the commendation of female reading she offers at an intradiegetical level, Green frames it within an extradigetical context of literary criticism in which appropriate and inappropriate works of fiction are distinguished. Green's female narrator starts her narrative with a "literary retrospective," a thorough invective aimed at a series of works of 
fiction and of authors of romance, subtitled "rudus indigestaque" (2010:1) due to the chaotic literary scene that the narrator describes. In this introduction, as stated before, she starts by contrasting the "good old romances of our ancestors, and those of the eighteenth and nineteenth centuries" (2010: 1), and distinguishes between Amadis of Gaul, Palmerin of England, Merlin and The Romaunt of the Rose, and contemporary romances such as The Libertine, The Sable Mask, The Minstrels of the Acre or Thalaba the Destroyer. Echoing Cervantes and his defence of Amadís and Palmerín -two of the romances saved from the fire by the barber and the curate in the Spaniard's novel-, the narrator also positions herself as critic of the tradition of the romance in British literature and wishes all the "vampers of romance, who merit annihilation" were in her presence to be beaten (2010: 2). These poor imitations of ancient romances are, in the narrator's opinion, "the vermin of literature" (2010: 2); they have, moreover, invaded the homes of every family, being found in "the bed-chambers of our daughters" or frequently "placed beneath their pillows, to occupy their minds at day-break, or to beguile a sleepless night" (2010: 2). These romances, in the anti-Jacobin rhetoric of conquest and seduction, then occupy the British home and threaten the minds of their female inhabitants.

These vampers or patchers the narrator criticises particularly because of three things: the poor quality of their productions, the dubious moral of their works and their pernicious confusion of history and fiction. The narrator criticises what she terms the "ludicrous sublime" in these works of fiction (2010: 5), as well as their use of the "same ingredients" or formulas, including the employment of "sentimental passion" which is a drug that disarms criticism by "wrapping the passive and unconscious mind in the elysium of a sound nap" (2010: 7). In addition to the little aesthetic quality of these modern romances, many are also found wanting in morals and the narrator agrees with Thomas Mathias's statement in his famous anti-Jacobin stance, The Pursuits of Literature, that Lewis's The Monk should be condemned for its obscenity (2010: 9). Lewis, moreover, is criticised for the pernicious trend he started with his Gothic romances; resorting once more to the rhetoric of light and obscurity so characteristic of the ideological literary war, the narrator states that Lewis is "the moon that rules the present night of romance reading: but as the moon and 
planets are eclipsed by the blaze of day, so are the works of these nocturnals unnoticed by enlightened readers" (2010: 3). Many of his "nocturnal" imitators are also harshly -and wittily- satirised in this literary retrospective.

However, not only male authors become the butt of the narrator's sharp wit. She also condemns "the most licentious writers of romance," two women, Sydney Owenson and Rosa Matilda (Charlotte Dacre), whom she terms the "Scylla and Charybdis of Romance" (2010: 9). Finally, a "celebrated French Historical Romance Writer," Madame de Genlis, is also her target. The narrator states that she is very anxious "that the reader should not do what she herself has done, that is, confound historical with fictitious incidents" (2010: 9). Moreover, Green parodies Genlis's use of the footnote "historique" to grant authenticity to her material by ludicrously using it in her own narrative. The narrator's final diatribe is against her use of "selection" rather than "invention" in order to publish her historical novels -a flaw she shares with Scott himself (2010: 9). This leads to a criticism of the editorial world in which "historical romances are manufactured weekly -French novels and tales of romance translated and published as originals -and old novels republished, without being acknowledged as such" (2010: 10). Furthermore, Green attacks the vogue of novel writing, and, in particular, the myriads of women writers who take the pen to establish "the reign of dullness and of folly" (2010: 10). This is not to say that Green adopts the strategy of detaching herself from a tradition of female authors in order to establish her own valid authority as a novelist, since she later praises Mrs Fielding (2010: 47-8) and Fanny Burney (2010: 133), who seems to be her favourite author and the only one she warmly encouraged young girls to read. ${ }^{199}$

Once introduced the novel in this literary frame, the intrusive narrator continues to provide the reader with her satirical or moral comments on fiction throughout the novel. In other instances, Green resorts to an intradiegetic comment on readings to reinforce her role as critic with the opinion of one of the characters invested with the necessary authority to act as support of her

${ }^{199}$ She published a treatise entitled Mental Improvement for a Young Lady (1793), 'addressed to a favourite niece', in which she praised Burney's writing as the only "of that kind you may peruse with safety" (qtd. in Goulding, 2010: xvii). 
literary supersystem. For example, the honourable Edward Marsham voices what appear to be echoes of the opinions the implied author has presented in her introduction. He praises Hannah More's "moral and excellent works" and her theological instruction, while he criticises that "for a work of fiction" her Coelebs "is too religious," forgetting that a "religious book is one thing - a modern novel is another" (2010: 46-7). Therefore, escaping the too palpable moral of anti-Jacobin novels which hinders the aesthetic quality of narrative fiction, Green's alter ego in this literary discussion praises other models:

Let the writers of the modern novels, [...] like the excellent Richardson, Fielding, and Smollett, hold up a faithful picture of the times they live in; lash vice, in whatever shape it may appear, and applaud virtue in every-one, while they make up their heroes not demi-gods, but mere erring men; and let them, like those incomparable authors, intersperse their works with only those few religious sentiments, which may serve to shew the orthodoxy of their own principles, and prove to their readers, that there is no trust to be placed on mere moral rectitude and philosophy, without the aid of Omnipotence: these serious interspersions $[\ldots]$ are quite sufficient for a work which is only meant to unbend and recreate the mind; and make those read who are not fond, naturally, of study; and who, if they find these works too serious, will close the book, not read at all, or else fly to the dangerous rubbish of licentious publications. In devotion's closet let me read the immortal works of a Tillotson, a Sherlock, and a Young; but let not such divine breathings as theirs find their way into a tale composed from fancy, or the fertility of imagination. (2010: 46-7)

Detaching her narrative from the dry moral of anti-Jacobin fiction, Green aligns herself as an author with Richardson or Fielding in offering reflection in the pleasing form of her novel, with digressions that the narrator explicitly wishes to remain short and scarce in order not to bore and to leave the reader to her own judgement (2010: 98). In her introduction, she moreover avows her intention of uniting morality and amusement, for her readers' sake (2010: 11), while her picture of men and manners, from the dissipated Rector to the fashionable and corrupted aristocrats, from the low-class Phelim to the prejudiced Ralph or Charles Marsham, provides as wide a field for a "faithful picture of the times they live in" as Fielding's novels. In this line, Green returns later to her praise of the entertainment to be found in "the domestic novels of a RICHARDSON or a MISS BURNEY" (2010: 133), whose works Margaret cannot enjoy due to her vitiated taste. 
The fact that a conspicuous female author clearly positions herself as critic of works by Lewis or Scott and as imitator of the satirical tradition that included Fielding is already significant of the self-assurance that Green, as a novelist, had. On the other hand, the circumstance that reviewers still found it difficult to gender the author of her previous satirical works, or that her overt style and language was criticised (Baines, 2004; Goulding, 2010: xi), also proves that there still existed a certain biased approach with respect to genres, subject matter, language or tones that were considered appropriate for female authors; boundaries which Green most explicitly breaks throughout her extensive body of work. That Green moreover defies this opinion of the critics is clear in the fact that she identifies herself as the author of the scandalous "The Private History of the Court of England" and affixes the "REAL initials" of her name to the advertisement (2010: 11), an anomalous fact in works of a satirical kind, even among male authors, which singles her out (Wilson, 2007: 31). Moreover, in response to those critics who perceive her satire as unwomanly, she openly and proudly defends her position as satirist. Besides her didactic intention to show the "effects of romance-reading on the weak and ductile mind of the youth" in Romance Readers, Green wishes to emphasise her satirical intent when she claims that she will use "authentic allusion" marked by the use of the word "historique" in imitation of the reputed French authoress (2010: 11). While she introduces echoes of real contemporary events, such as Wellington's 1809 Peninsular Campaigns (2010: 20), without any authorial comment, a number of supposedly fictional scandals referred to are ironically footnoted "historique," although "it would have been apparent to her readers that a number of them closely resemble actual events involving real people" (Goulding, 2010: xiv). In that way, she "mischievously layers satire upon satire and blurs the boundaries between her fictional narrative and historical actuality" (Goulding, 2010: xiv). Finally, she even attacks the abovementioned critics when she writes: "it is an adventurous task to oppose satire to satire: before true criticism, tempered with that politeness and gentleness due to her sex, the Author humbly bends; the pseudo critics she defies and laughs at" (2010: 11). Her own blunt satire against her peers and against genres she herself had cultivated, such as the scandalous history or the Gothic romance, imbibes Romance Readers with all the complexities of those sometimes 
"contradictory methods women novelists developed in order to insert themselves into discourses of satire" (Wilson, 2007: 29), at times alerting the reader to be prepared to decipher the implications of her satire, and at others leaving him or her suspicious of self-deprecating irony on the author's part (Goulding, 2010: xiv). In this sense, Green's narratives are nothing but challenging in their interpretation.

This self-confidence and her satirical powers towards social and literary flaws alike become even more apparent in another quixotic work in which the main target of Green's satire are not old-fashioned romances, French or Gothic novellas, but Britain's most beloved author: Sir Walter Scott, and the rave for Scottish novels which his cult started in other regions of the United Kingdom, particularly England. In her introduction to Romance Readers, Green included a footnote in which she criticised Scott thus:

The delight I have felt on reading "THE LAY OF THE LAST MINSTREL," and "MARMION," has made me full sensible of the transcendent powers of Scott's genius: why has he made use of the magic of a name, but to delude us? Does he imagine that his name alone can attach importance to a book, and, like the touch of Midas, that it can make every thing gold to which it is attached? Some people may be blinded by their prejudices in his favour, but he will do well to remember that we are not all [...] ignorant barbarians. (2010: 10)

Green resumes the criticism to Scott in Scotch Novel Reading, or Modern Quackery. A Novel Really Founded on Facts. By a cockney (1824), and develops it into three volumes which revolve around a quixote blinded by her prejudice in favour of Scott and his historical and Scottish romances.

Green's second to last novel follows the development of the pretty Alice Fennel from a romantically deluded admirer of Scott, and of Scottish novels and historical romances, to, ultimately, a truly sentimental heroine. As a quixote, Alice shares several important characteristics with Margaret and other female quixotes: her motherless state, her education in a patriarchal environment, her opposition to a more positive sisterly model and the interspersed nature of her madness, which only dwells on one aspect: her passion for Scott and his many imitators, including Hogg (1824: I, 10), Burns (1824: I, 44) or Galt (1824: II, 109). Despite the circumscribed field of her 
delusion, it is expressed in a particularly forceful and picturesque manner. The narrator states that Alice Fennel, in true quixotic fashion, effected to read "what she could not understand one half of - to be half in love with every Scotch author - to fancy herself the Scotch heroine of every Scotch tale - to affect a queer kind of jargon and pronunciation, which she thought was true Scotch dialect, and, like a persecuted heroine, to endure the laughter of her sister and of her brother-in-law, and the frequent and severe reprimands of her father" (1824: I, 37). Alice's quixotism also manifests itself in that she reads other characters as heroines of Scottish novels; and, "while the fit was on her," she styled her sister Elizabeth Howard "lady Jane Howard" (1824: II, 112) and changed the servants names to those found in Scott's novels. More relevantly, she dresses like the Scottish heroines of her romances and she attempts to speak like them, jocularly parodying the unintelligible Scottish dialect which characterises the national heroes and heroines of these fictions and which renders Alice incomprehensible as well for the surrounding Londoners or "cockneys" (1824: I, 12) and even causes the hero of the novel, Robert, at first to believe she has some impediment of speech or even that she was born dumb (1824: I, 47). While her Scottish dress is very becoming and even after her restoration to common sense it is said to enhance her beauty, Alice's speech is her most characteristic and attacked trait. For example, Miss Southgate, a scheming coquette, impersonates Alice and forges a letter in her own Scottish style to turn a gentleman's opinion against her. Alice's peculiar jargon makes her easy to imitate: she is as artificial as the romances she is mimicking, and her own romantic silliness transforms her into a possible dupe of these jokes (1824: III, 65). The representatives of patriarchal England, her father and suitor, constantly mock or angrily object to her use of it, and, moreover, associate it with a misunderstood Scottish nationalism that is threatening to infect or conquer England (1824: I, 48). This uncritical and even unpatriotic imitation is the most negative mannerism in her quixotism; heteroglossia once again provides a political reading in which the different speeches hide varied social and national discourses, and in which the adoption of the foreign dialect is perceived as a renunciation of a more throughout Englishness. This is particularly obvious in the comparison between Alice and a truly Scottish heroine, Margaret: both are romantic readers and both wish to speak and 
behave according to the conventions of the Scottish and English reading they have respectively perused. Margaret tames her Scottish accent and is ashamed of her step-mother's thick dialect and unpolished manners, while Alice desires to become a Scottish heroine in speech, costume and behaviour. In the same manner that previous quixotes had proved themselves ridiculous with their imitation of sentimental or philosophical language and manners, which contradicted their own nature as anti-heroic quixotes or even their own common-sense, and were transformed not only into the butt of the author's satire but also into the instrument of her parodic and satirical intent, so does Alice in her Scottish quixotism.

As a consequence, as a true quixote, Alice will have to learn how to read her romances and her acquaintance in a more discerning way. Alice is said to "skim" through the long volumes of Scottish writings, without truly understanding what she is reading and perusing only the "romantic parts" in them (1824: I, 4; II, 87). Moreover, she rejects other works of fiction because they "were too much like the real events of life, and they were not Scotch" (1824: I, 37). A votary of the fashion of Scottish romances and novels, she is then a victim of a lack of discerned and detached reading. Part of her development is then to learn to read critically, which she does under the tuition of a proper female reader, Mrs Hannah Meredith -a probable allusion to Hannah More-, an old maid who devotes more time to "doing much good" than to reading (1824: II, 183), but who, nonetheless, has a good library and taste, including Scott's poetry (1824: II, 184). She is, more importantly, a very critical reader and she states that Scott must be read "with profound attention, or not at all" (1824: II, 187). Therefore, under her tutelage, Alice reads Scott, though, this time, carefully and critically, expected to provide an informed opinion on his works, without allowing "all the finer qualities of her mind to be absorbed in mere Scotch novel reading" (emphasis added, 1824: II, 188). This previous form of uncritical absorbed reading leads to what Mrs Meredith openly condemns as Alice's greatest foolishness: her "insulting mimicry" (1824: II, 194), or quixotic imitation, which is an absurdity that renders any imitator "ridiculous" (1824: II, 195). Finally, she lectures Alice on the dangers of historical romances, including those by Scott, for they "give a false notion of 
history" (1824: II, 186). However, in a similar pattern to the one undergone by Arabella, these lectures by a wise female reader do Alice no good, for the confusion of fiction and history continues to delude her (1824: II, 195-6). She will need a more powerful awakening, such as the direct confrontation with the reality that hides beneath her romantic colouring of everything Scotch. Similarly to Barrett's Cherry in her encounter with a gross impersonation of her long lost mother, Alice will have to face the portrait of a Scottish woman: Lady Macbane. Dirty, vulgar and loud, she shatters Alice's expectations because she is "very different from the heroines of her favourite novel-writer" and, moreover, because she can "neither read nor write" (1824: I, 173, 175), which for Alice is unthinkable in a woman. ${ }^{200}$

Furthermore, her father and her husband-to-be employ deceit to awaken her to the impossibility of her romantic dream of marrying a Scottish hero. Early in the novel, her sister had stated that Alice "is already so firmly wedded to her favourite study" that she would not listen to any proposal of marriage, "unless it was with some Scotchman, that could not speak English so as to be understood at all by us poor Londoners" and, moreover, unless he was "one who has written as many novels as the author of Waverley" (1824: I, 76). In addition, Alice is described as a "romantic female Prometheus," who had, "like all other romance readers, formed a hero from her own ideas, and had not yet met with him in real life, because he must be Scotch" (1824: II, 140). In order to effectively accomplish her cure, then, the three representatives of patriarchy employ Alice's promethean visions to create for her a hero who answers to her literary patterns. Impersonating a parody of Rob Roy, Duncan McGregor, a Scott who has been seriously injured in the war, Robert comically challenges her illusions and finally achieves her awakening to reality. Ironically, by renouncing to her promethean dream, Alice is nevertheless granted her wish: the Scottish hero and her beloved Robert, who are the same person.

${ }^{200}$ Commenting on examples of burlesque quixotic novels published before Austen's own Northanger Abbey, Mary Lascelles is one of the first scholars to perceive the similarities between Barrett and Green in their "brutal" treatment of their heroines: in their narratives the quixotic girl "can only be convinced of her folly by violent calamity or ponderous argument" (1995: 57), and both authors display impatience with the "fools whom they have created and undertaken to reform" (1995: 57). This impatience is obvious in Barrett's novel and in Green's, in the latter expressed by the outbursts of Alice's father. However, there are differences and Green's benevolent description of Margaret and Alice as innocent and domestic women, saves them from causing as much havoc as Cherry and from receiving as strong a censure. 
Furthermore, Alice falls in love with Robert when he rescues her from a fire, discovering that "singular heroism" (1824: III, 216) exists outside her Scottish romances, after which "Scotch novel reading, as well as the dialect, began to lose its charms" (1824: III, 217). As is the case with many female quixotes, the awakening to love and desire is the first step in the path to recovering her senses. This recovery is only complete after the disguised Robert has offered Alice the opportunity for "just reasoning," which has more effect on her mind than "all the sarcasms of the Butlers, my brother's incessant laughter, or my father's violence against what he calls quackery" (1824: III, 121). Following Lennox's pattern, Alice awakens to her heart and then to her mind, uniting sentiment and reason in the quixote's cure.

Despite this emphasis on Alice's quixotism and subsequent awakening to her own heart and to her capacity for critical understanding, her delusion is yet only one of many elements in Green's novel that advises critical reading and rational expectations in its readers. Although the most important instrument in Green's metaliterary novel, Alice is inscribed in a more comprehensive attack on literary and social "quackery" alike, a supersystem that is supported by more than the parody developed through Alice's foolish quixotism. This literary supersystem is evident throughout the whole novel with the presence of Green's highly intrusive and critical narrator and with the use of the chorus's repetition of what are the implied author's opinions. This time a man and identified as a "cockney" (1824: I, 36), like his characters, the narrator usually addresses the readers with a "we" that provides a touch of objectivity in otherwise very subjective digressions, and that calls to English community. ${ }^{201}$

${ }^{201}$ Once again, Green's intentions are difficult to read. The fact that she advertises the novel as written "By a cockney" certainly emphasises its importance in the nationalistic interpretation of Alice's Scotchmania and the country's quackery; however, given her Irish origin, her use of this epithet applied to her narrator is ambiguous. As an Irish, does she impersonate a cockney to make that "we" inclusive with her readers and gain the favour of her reading public? This claim could be supported by the inclusive "us poor cocknies (sic)" (1824: II, 110) which she employs in the context of their lack of understating of the Scottish accent. Or is it an ironic device to highlight the English obsession with literary vogues that she explicitly mentions later in her text and hence to detach the implied author from her narrator, a fact emphasised by the change in gender? The narrator exclaims: "It is a wonderful -at least, it appears so to me, who am a poor matter-of-fact cockney- how any bookseller would publish a work that bore so heterogeneous a title, or that any mere London novel-reader would think of looking into its pages" (1824: II, 111). This apparently criticises the English taste for poor literature. Given Green's complex use of satire, the second possibility gains weight under the light of her recurrent attack to deluded English readers. 
Together with the narrator, Mr Fennel is the most informed and recurrent literary critic, who very often echoes the implied author's ideas. In Green's novel, Scott is duly praised for the "chasteness," "elegance" and "morality" of his work (1824: I, 58), in which not a "single impropriety" is to be found (1824: III, 6). As happened with Margaret's reading of romances, the ideal morality they display once again contrasts with those more pernicious works of fiction which Alice would be in danger of perusing if she were banned from reading Scott by her father (1824: I, 58). Scott's poetry is moreover highly exalted, while his novels centre all the negative comment: he is accused of excessive prolixity, coping poetry, narrative fiction and drama alike (1824: II, 115); of a lack of variety (1824: I, 48); of improbabilities (1824: II, 186) and of blurring fact and fiction (1824: II, 186-87, 196); of a rapid composition which consequently produces some carelessness in the style and accuracy of his works (1824: II, 87); and of becoming merely an author in search for gain (1824: I, 35) or whose worth is granted only by his being in fashion, for such torrent of works from the fertile pen of "some poor unknown author, perhaps of almost equal genius, would be deemed careless scribbling" (1824: I, 35). This last attack is placed in the context of a more general censure on one of the forms of "modern quackery" the novel satirises: while including quack medical practice, preaching or acting as butts of her satire, Green's main target is the quackery of authors or "mere book-makers" (1824: I, 22). Mr Fennel, the greatest champion against literary quackery, deplores the present state of literature, for "when he read, he loved to be amused with diversity, and could not endure the beaten track, which an unaccountable mania in Englishmen caused those who catered for their vitiated taste to tread over and over again, for a long period, till real taste and discrimination turned away in disgust" (1824: I, 23-4). Quackery is then presented as a national mania which, in turn, forces certain forms of literary obsession or quixotism in the reading audience as they are unable to read what is not in vogue. The narrator states that $\mathrm{Mr}$ Fennel, "when he wanted to unbend his mind, with light reading, for about two or three hours in the course of a month, [...] was fond of perusing well-written works of fiction" (1824: I, 24); however, he must endure the effects of the different literary fashions: 
At one time, he found nothing but Miss Burney's novel thrust upon him; then Mrs Radcliffe's romances, with all their moonlight descriptions and midnight horrors: next came, in rapid succession, those of Miss Owenson; and Rosa Matilda trod in the steps of Monk Lewis. Wearied with the trash of more insignificant bards, who dealt in fictitious lore, he seriously resolved on real domestic happiness, by taking a wife. (1824: I, 24)

Moreover, as a parent, he gave his daughters a taste not only for the domestic, but for the "works of deserved celebrity" so as to "turn away in disgust from those common-place novels and romances, which even so late as thirty, or even five-and-twenty years ago, swarmed like insects, and like them expired" (1824: I, 35). ${ }^{202}$ However, his literary education backfires when Alice develops her mania for Scotch novels, bards and even reviewers who "puff off the writing of their own countrymen" (1824: I, 36), all of which develop this literary quackery aimed at gaining money by "picking the pockets of an infatuated public" (1824: I, 35-6). Green's novel, as later Austen's Northanger Abbey, aims to awaken not only her deluded heroine, but her infatuated readership, with her own satirical comment on the poor aesthetic quality of these works of fiction and on the dangers of undeveloped critical discernment in the perusal of novels which are recommended only by fashion. ${ }^{203}$ Green then mockingly addresses literary critics and readers when she has her narrator state, after Robert Butler's diatribe against the lack of variety in novels and of discernment in readers, the following:

[...] recollect, dear reader - for all my readers are very dear to me - that we are not to be supposed as giving our own individual opinion, but only committing to the press the opinion of Mr. Robert Butler; [...]. Not but that we must say, we find nothing in his ideas or remarks on the above celebrated works at all absurd, not in anywise approaching to the ridiculous; we wish we could say as much for the enthusiastic adoration expressed by the sublime admirers of this most sublime northern bard. (1824: II, 100-1)

${ }^{202}$ The period the narrator evokes, between 1794 and 1799, is the peak of the literary war and, therefore, of literary production of radical romances and novels, and the counterfictions that followed. Green's attack at the poor aesthetic quality of both Jacobin and antiJacobin productions in her quixotic novels is unique and, again, qualifies her work as a relevant example of literary criticism by a woman.

203 Lascelles again perceives the similarities between Edgeworth's "Angelina," Barrett's Heroine and Green's Romance Readers as belonging to the "crop of burlesques of current fiction" that appeared between the date when Northanger Abbey was drafted and the date when it was published (1995: 55), making it possible to claim an influence of them in Austen's work. Scotch Novel Reading undoubtedly belongs to this tradition, enhanced by Austen's supreme talent for the burlesque and her famous defence of the novel as a genre that can be morally and aesthetically outstanding. 
The narrator does indeed benevolently laugh at those readers who are deluded by the "ludicrous sublime" that can be found in the northern bard.

Green's stance as a critic and her wish to cover as wide a range of literary quackery as she can, is highlighted by the presence of yet another female literary quixote in her novel: Alice's sister, Elizabeth, a quixote who experiences an acute case of "Byronomania," among "other romantic follies" (1824: I, 43). Her quixotism manifests itself in much the same manner as later will Alice's: she changes the name of her servants to Byronical epithets (1824: I, 2) and she reads herself as a heroine, asking on the day of her wedding if she does not look "like the Bride of Abydos" (1824: I, 4). However, in the very first page of the novel, her father states that she has been "cured" from her madness by her husband (1824: I, 1). He later expounds that, due to her beauty and good sense, her lover "took her, with all her imperfections: and being a shrewd, sensible man, who had read a great deal, he attacked her on her weak side; then pointed out to her, her romantic folly, till he made her laugh at herself" (1824: I, 4). While still with occasional relapses into her romantic quixotism, such as the above quoted exclamation at her wedding, married life has effected a desired and absolute cure on Elizabeth, who forgets "in the affections of an excellent husband, and in the delight of becoming the mother of a beautiful boy" all her past romantic follies (1824: I, 42-3). Consequently, Elizabeth and her husband, who openly and playfully refer to her past follies and subsequent cure, support the need for Alice to overcome her romantic delusion by love and, of course, marriage (1824: I, 75-6). Despite this conservative process of cure, Green's awakening from quixotism does not imply a renunciation to fiction, but rather a varied, moderate and critical approach to reading. To Alice's accusation that Elizabeth does not read, besides the copy of "Domestic Cookery" she has on her toilet (1824: II, 102), her husband offers evidence of her role as exemplary wife and reader:

Elizabeth is right to study what every lady ought to know; but she reads other works, $[\ldots]$ several of those she peruses are by the best and most approved writers of fiction, and other light reading; but, [...], she does not make herself a slave to novel-reading: nor does she neglect other authors of ingenious works, to give herself up merely to the study of those produced by one. Neither [...] does she spoil her own native language, to talk a jargon that no 
one can understand, because she might chance greatly to admire a Scotch writer. (1824: II, 102-3)

As she did with Mary Marsham, Green provides exemplary female readers who combine their domestic and intellectual characteristics. Elizabeth is only one of them; another one is the wise Hannah Meredith, whose extensive library includes works of fiction and, as stated above, many of Scott's poetical works. In addition, once Alice is cured she does not quit her taste for literature: she concludes singing some lines by Scott which Robert taught her to sing (1824: III, 243). Her spirit, as a woman and a reader, is not broken by the conventional fever or near-to-death experience. Neither is she required to renounce fiction: as with the later Catherine Morland, "the real lesson is not to stop reading romance, but to stop judging by appearances" (Pearson, 1999: 217), that is, to read critically. In the same manner Alice can at times distinguish between Scott and his imitators, and even laugh at the latter (1824: II, 109), so must she learn in the end to read reality for what it is, distinguishing fact and fiction, truthfulness and deceit.

Furthermore, the author's own wide-ranging reading serves as another commendation for female perusal of literature. As evidenced in her previous quixotic novel, Green possesses an extensive knowledge of contemporary fiction, as well as an acute satirical stance as a literary critic. The introduction of Elizabeth as a female quixote whose delusion has a different source to Scotch novels widens the scope of her parody and presents quixotism as a much more universal experience, which can be triggered by the uncritical or imitative approach to any form of fiction, author, or literary vogue. Despite this focus on literary quixotism, Green's novel abounds with more displaced quixotes, and she describes several male and female enthusiasts who are, at times, as deluded as the main quixotic character. In particular, Green portrays three older characters whose experience and age nevertheless do not protect them from varied manifestations of sentimental enthusiasm. A character who openly disclaims the statement that age cures folly is Alice's maiden godmother who, in her fifty-ninth year of life, has a fit of romantically-induced enthusiasm and is duped by her young and attractive servant into marrying 
him. Her letter announcing the wedding is employed by Mr Fennel as a warning for his daughter; he wishes the aunt's "silly letter" would be a means of turning Alice "from all romantic folly, by setting it in its true and ridiculous light" (1824: I, 139), a ridicule in her old godmother which the young Alice is sensible of. At her reading the former's letter, Alice "laughed heartily," though the "young girl blushed at the conduct of the old girl" (1824: I, 148). Echoing young Alice's own change of dress, language and behaviour, her godmother transforms her appearance, way of life and manners to become those of a young girl in love, becoming as ridiculous or embarrassing for her relatives as her young niece is with her Scottish mania. While introduced with benevolence -as a "kind-hearted excellent creature" who was pitifully made the "dupe of others' art and of her own weakness" (1824: I, 157)-, Alice's godmother dies without awakening from her romantic dream, whereas the young quixote has hope for reformation and can overcome her youthful colouring of reality. The fact that both women are named "Alice" reinforces this parallelism, as well as old Alice's girlish exclamation to young Alice that they were both of them "always two such romantic things!" and that "romance comes far short of the happy reality of being united to the object of one's love" (1824: II, 81), which, for young Alice will be true when she finally marries, while old Alice will die in her delusion. A conclusion seems to be that female quixotism, or any form of enthusiasm, is less condemnable at a young age in which a cure can still be accomplished: Mr Fennel repeatedly asserts that his daughter's delusion "will all wear off in time" (1824: II, 33; III, 6) and Elizabeth's cure is empirical evidence that it will.

In addition to this inclusion of older female quixotes, Green also portrays more experienced, male ones. The otherwise anti-romantic Mr Fennel is described as having a great share of enthusiasm in his nature and his sentimental exaltation of friendship, cultivated from an early age in which it were more understandable, still reaches quixotic heights in his older age. An epitome of the patriarchal establishment, Mr Fennel readily assumes that romantic folly is a female trait; however, he remains oblivious to his own quixotic disposition. When reflecting on the romantic heritage of his daughters, he decides to teach them "good housewifery" to transform them into "better wives," but also 
because he thinks that it would be "the most effectual method of destroying that romantic disposition which they inherited from their mother, and which very early evinced itself in her two girls" (1824: I, 32-33). Nonetheless, the narrator qualifies his assertions thus:

$[\ldots]$ indeed, $[\ldots]$ we none of us know ourselves, Mr Fennel himself was not without a strong portion of the romantic in his own temperament, however he might laugh at the enthusiastic flights of fancy in many a "romance writer and romance reader". He was singularly benevolent, and all his feelings strongly tinctured with an enthusiasm very different from what is felt by ordinary mortals. (1824: I, 33)

This, added to his "many peculiarities" (1824: I, 33), among which is an opposition to any form of quackery so strong that it almost becomes an obsession as persistent as his daughters' literary manias, transform him into a quixote. Furthermore, he is an instance of a benevolent quixote, "often cruelly duped" (1824: I, 39); that is, at times little more discerning than his daughters. This form of benevolent enthusiasm for friendship links him with other examples of the "amiable" quixote (Tave, 1960), such as the hero of the anonymous The Amicable Quixote; or, The Enthusiasm of Friendship (1788), the Purbecks' eponymous character in William Thornborough, the Benevolent Quixote (1791) or even Sarah Fielding's David Simple in the novel of the same name. His best friend from youth, Mr Butler, shares his sentimental conception of friendship. Mrs Meredith states that one of them "could not exist without the other" and she believes they are as inseparable in old age as they were when "two young students, full of all the romantic enthusiasm of early friendship" (1824: II, 177), an enthusiasm Butler's son Robert is said to have inherited (1824: III, 14). In addition, Mr Butler displays a rather obsessive fondness for money, which is recurrently described as his hobby-horse. Both enthusiastic friends, moreover, embark in a quixotic project: to make their children fall in love with each other. Butler, in particular, becomes obsessed with the idea, and the narrator pitifully exclaims that he has an enterprise in his head which "even the renowned knight of La Mancha, with all his fancied prowess, would have trembled at undertaking" (1824: I, 50), clearly identifying him as a quixote. ${ }^{204}$

${ }^{204}$ This is one of the two explicit references to Cervantes' work that can be found in the novel; the other is the word "Rosinantes" to refer to Lady Macbane's old horses (1824: I, 
Later, Butler is described as having his head "full of the romantic idea of uniting two of the greatest opposites in nature," scheming a "plot as intricate, and as much beset with difficulties, as could possibly be conceived in the fertile and wonder-working brain of any fabricator of the most highly varnished and improbable tale of the century" (1824: I, 64-5). This improbable romantic plot echoes the author's own last implausible homage to the traditional plots of romance to reunite her hero and heroine.

Quixotism is then not absolutely gender-biased, nor circumscribed to literary manias, in Green's work. This message is also emphasised by means of the young male quixote that the novel introduces: the anti-romantic, novel-hater Robert Butler. ${ }^{205}$ Robert is said to be "styled anything but romantic," for, while "he had taste in literature" and "had written himself some sweet little MSS. songs and poems, and he admired true genius wherever he found it," he abhorred fashionable literature and mere "book-making" (1824: I, 46). In particular, he dislikes the long volumes of Scottish novels, the dialect they inflict on their readers, and the nationality they display, which he perceives as narrow-mindedness, much to the agreement of the narrator (1824: I, 48). In contrast, he prefers "the writer of fiction, who has more variety, as well in change of scene as of character" (1824: I, 48). His literary perception is most emphatically opposed to Alice's and progressively becomes as biased as hers. In the matter of love and fiction, he scoffs at all the nonsense found in romances, "till, like all others who indulge in giving way to extremes, he carried it so far as to take a rooted aversion to all fictitious tales -till at last he would not read any novel whatever, however good, however instructive, or how truly soever it might depict the real scenes of life, or ably satirize the manners of the fashionable world" (1824: I, 118). As a consequence, he "even preferred the romances of the late Mrs Radcliffe, because he said they plainly shewed themselves to be a tissue of the most abominable lies that ever a flighty imagination could devise" (1824: I, 118), again recalling Barrett's quixotic

169). Both expressions were too well-known at the time to allow for conjecture on Green's reading of Cervantes or her knowledge of his novel rather by second-hand references.

205 One wonders if Green is attempting a veiled reference to Barrett's own hero, Robert Stuart. The game between the Scottish form of the surname "stewart" and "butler," both referring to the profession of steward and the fact that they share their given name could signal a subtle dialogue with Barrett's work with which, as stated above, she seemed to be indeed familiar. 
novel. Echoing some of the remarks by the Marsham brothers or Barrett's comic parody in his heroine, Robert then continues to wittily expostulate on the impossibility of preserving the beauty and purity of the "beauteous females" confined in "caverns or towers," for "what [...] did the poor girl do for a change of linen?" (1824: I, 118-9). In those circumstances, rather than admire the "resplendent beauty" of the fair one, Robert "would not touch her with a pair of tongs" (1824: I, 119). The ludicrous and anti-romantic image that the reality of the heroine's situation would create is then a recurrent presence in the critique to the quixotic romantic delusion of the young female reader; in this sense, Robert's discerning reading of romances apparently condones their perusal, as long as their fictitious nature is acknowledged. In this regard, as many other male mentors in female quixotic fictions, he stands for the more plausible form of fiction that the author is developing. ${ }^{206}$ His contribution to Alice's cure and his role in making the sentimental plot of courtship possible legitimises the novel in which the quixotic romantic delusion is inscribed, as well as the conservative scheme of reform and marriage as a subversive woman's destiny.

However, Robert is an ambiguous epitome both of patriarchy and the novel, because he is also a deluded youth in need for an awakening. He is under an even more blatant romantic delusion than Alice's, for he is the "victim of the most romantic passion that ever could assail the heart and fancy of man since the days of the famed Pygmalion" (1824: I, 120). If Alice is a promethean figure, creating a hero from the fabric of her own imagination, Robert is called a "second Pygmalion" (1824: I, 115) in the title of this chapter, because he falls in love with a woman in a painting. In addition, he is clearly identified as a quixote -which Alice is not- when the narrator states that "he was now on the quixotic search to discover the charming original" of the image that had triggered his "visionary passion" (1824: I, 120), much in the same style as Edgeworth's Virginia. This passion transforms him into a true romantic quixote, who even adopts the hyperbolic language of those romances he despises when he states that he "would encompass sea and land [...] sail to the

206 The narrator, for example, supports his views on the "wretched sameness" to be found in those romances so in vogue (1824: II, 100), as well as his sarcastic laugh at the public that reads them (1824: II, 99). 
artic regions [...] climb Mount Vesuvius at its most fearful explosion, could [he] but behold the original" (1824: I, 123). In addition, in clear parallel with Alice's own vow not to marry without finding the hero of her dreams, Robert insists on pursuing his "quixotic expedition" (1824: I, 133) until he finds his fancied beauty or to "lead a single life if his search was unsuccessful" (1824: I, 134). Over and again does the narrator emphasise that Robert "was not much behindhand in enthusiasm with the romantic Alice" (1824: II, 105), or even that his fancy is more profoundly deluded than Alice's, condemning his lack of self-criticism for rejecting with disgust Alice's scotchmania or any form of romantic enthusiasm when he is a victim of the strongest form of it (1824: I, 228). Furthermore, Robert has equal trouble reading Alice as the innocent girl has reading the coquettish female characters around her or even MacGregor, and his reflections in front of Alice's portrait prove the fraught process of awakening he will undergo (1824: III, 51-2). In this sense, Alice must read through her own inexperience and through metaphorical and literal disguises created to delude her, while Robert is blind to her true self behind her romantic nonsense, which acts as a mask or veil that requires a more critical reading. Consequently, he is as bad a reader of true character as she is and doubly deluded by the veil of romance: first, not to see Alice, and then not to perceive the madness of pursuing a painting.

The fact that the three more important representatives of patriarchy with regard to the deluded female reader -her father, father-in-law and lover- are as romantic in their behaviour as she is -or even more, for the Butlers are the only characters overtly identified with Don Quixote- undermines the taming of the subversive female reader by male mentors, first, because it evinces that "excessively 'romantic' behaviour is not gender-specific" (Pearson, 1999: 217), as many moralists and novelists claimed, and, secondly, because the heroine contributes to the cure of her husband to be: as his own darling dulcinea she will teach him not only the beauty of fiction, but the supremacy of reality over the fanciful pictures of an inflamed imagination. What is more, only after Robert is cured from his fanciful quest for his artistic ideal by discovering that it is Alice and by falling in love with her real self, can he proceed to complete her reformation, which she had started long before due to 
her love for him (1824: III, 217). Therefore, Green subverts the traditional plot of female quixotism in that the hero is "less self-evidently superior," and that, rather than the hero accomplishing the quixote's awakening, they both must “cure each other" (Pearson, 1999: 216).

Finally, Green also seems to play with her readers' own absorbed reading, for she contrives the most implausibly romantic plot in order to bring Alice and Robert to a happy conclusion. Reproducing the chanceful discoveries and twists of plot found in romances and sentimental novels, Green's narrator states that:

We meant to have devoted an entire chapter to elucidations, but we are assured it is unnecessary; the reader must already have guessed that Alice Fennel was the original of the Cherub and the Sleeping Beauty that had led captive the heart and senses of young Butler, and that Mr Fennel and his daughter were the persons whom this enthusiastic young man had snatched from the peril of fire, and saved their lives. (1824: III, 214-5)

This deus ex machina advancement of the plot resorting to well-known romantic conventions echoes Robert's assertion that appropriate fiction enables the reader to see through its implausible excesses, never aiming to mislead him or her, a fact which is emphasised by the direct address of the narrator. It also recalls Austen's metanarrative comment at the end of Northanger Abbey when she assumes the reduced number of pages left have given a clue to the readers about the happy conclusion of her novel, and also echoes her intention to awake her own quixotic readers.

Moreover, in Green's novel, while the front page includes the ubiquitous statement "a novel really founded on facts," the italics and her narratorial advice to authors either to "write novels, good fabrications of fiction, or write history, as you please; but let your volumes contain one thing or the other" (1824: II, 196), reveals this ironic claim to truthfulness in her highly implausible work of fiction, which obviously parodies that same claim in less self-conscious narrations. In addition, to reinforce the intertextuality of her aforecited deus ex machina conclusion with the clumsy conventions of momentous scenes of romance, the narrator discovers to the reader that the fire from which Robert rescues Alice and her father "owed its origin to novel 
reading; but not Scotch novel reading; no, it was owing to a maid-servant, who was as fond of the marvellous as the young lady-lodger" (1824: III, 215). Having fallen asleep reading one of these supernatural novels, she sets the house on fire, in another image of the inflammatory effects of reading on females. That is, the serendipitous event that brings Robert and Alice to realise their love for each other is linked to a very different form of fiction, as "the maid, loved to read all about ghostessess, and them kind of things, or an account of what was right arnest, a dreadful murder, for the moderate charge of a penny" (1824: III, 215). These horrid romances, which recall some of Margaret's initial readings, were extremely popular among the lower classes for their reduced price and gruesome content. They were also recurrently linked to women readers and criticised by moralists and novelists alike for the pernicious effects they had, and, in Green's work, they once more emphasise the degradation of certain forms of romance.

In this regard, as Pearson has pointed out, despite the inflaming nature of romance, in this case it works ultimately to the benefit of the heroine and her lover (1999: 217) and evidences once again the persistence of romance in the plot of courtship that novels had at their core. The fact that romance contributes to the triumph of the epitome of the domestic plot, the final marriage, highlights Green's message in both her quixotic novels that romance has not hindered the domestic nature of the female characters that perused them: not only Mary Marsham, but also the quixotic Alice Fennel are exemplary in their household duties (1824: II, 200). Not even in the "height of her adoration of Walter Scott, or whatever other Scot he may be" did Alice neglect "those household concerns, which every female ought to be well acquainted with;" what is more, she is described as being "naturally of a very domestic turn of mind" (1824: III, 128). In Green's work, then, Margaret is the exception, only because she drifts away from romance as her model. Green's later novel is atypical then because her quixote does not intrinsically change: she is always a good domestic woman, always a potential good wife. Moreover, her passion for romance will not disappear with her marriage with the equally romantic Robert. Once her Scottish accent has disappeared, and the political and national implications have been erased, she can remain a romantic heroine and can 
retain a "strong tincture of romantic enthusiasm" even after her Scotch novel mania has started to disappear (1824: III, 143). Romance therefore permeates Green's novel and, again, is ultimately validated as a form of fiction that provides sound morals and entertainment as long as it is perused with discernment. That is, according to Pearson, "even when reading is figured out as cultural or national transgression or conflagration, Green allows high levels of gender equality and legitimises the activity of her readers by demonstrating that its final results are positive" (1999: 217).

Furthermore, she legitimises fiction written by women and for women, and her novel is full of praise for working women (1824: I, 31), for respectable old maids (1824: II, 177, 183), for female authors and even for female rulers, such as Elisabeth I (1824: III, 27-8). What is more, the most condemnatory attack to women writers is voiced by the pedantic Mr Hartfield, who considers himself the "arbiter and censor of all literary merit or demerit" (1824: I, 89). This connoisseur of literary worth has so poor an opinion on the talents of female authors as to think them "incapable of penning ant thing good;" moreover, "to the more dryest (sic) prose writer, and vilest poetaster of his own sex, he would, at all times, give the preference, against the most sprightly or witty productions, if they came from the hands of that sex generally denominated the fair" (1824: I, 89-90). To conclude his approach to women, the reader is told that he "secretly wished woman to be entirely like another pretty animal of the domestic kind" which would "stay at home, and make herself useful" (1824: I, 90). Not only does Green undermine his authority by his biased approach to literature, but, in an ironic twist, she inscribes him in the plot of a female author, More's Coelebs. Mr Hartfield was in search "of this somewhat superior domestic animal, a wife" (1824: I, 90) and was therefore engaged in a "Coelebs-like search" (1824: I, 91). Finally, his critical attacks on Byron and Scott are silenced by two women, Elizabeth and Alice, respectively (1824: I, $103 ; 110)$, while he is also exposed by Alice when he must change his opinions concerning Scott to gain the favour of Margaret. Consequently, despite her conservative message, Green does not cast aside women writers or their production. 
In addition, in her quixotic novels, with their comprehensive analysis of what is being published in her time, Green establishes critical criteria based on merit rather than gender. Similarly to how she employed satire to defy gender-biased critical approaches to her previous quixotic novel, Green appropriates in Scotch Novel Reading a man's voice by her use of a male narrator. Similarly to Lennox in her creation of the Doctor of Divinity, Green performs a ventriloquist trick in which she evinces how she can masterfully imitate and manipulate discourses invested with male authority. Although it could be contended that she did so in order to sanction her novel with canonical authority and, hence, to avoid censure, Green's enlightening manifesto in the introduction to Romance Readers suggests a different answer. Green's open challenge to criticism based on her condition as woman and her attack on fiction penned by men and women alike make it difficult to claim that she perceived fiction as belonging to one gender or another. In Green's later novel both male and female critics are at times silenced, contended, ridiculed, or proved biased, while others, such as Mr Fennel or Mrs Meredith are portrayed as exemplary critical readers. Ultimately, reading or writing appropriately does not depend so much on gender as on judgment and it is more to Green's authority as a critic than as a woman that the reader must yield to in the trenchant analysis of contemporary literature performed in her quixotic novels.

Progressively abandoning the ideological anti-Jacobin agenda of her earlier quixotic novels, Green's narratives thus offer rich and compelling approaches to quixotism, literary parody and satire, and the role women readers and writers have as literary critics. Despite this abandonment and her claim to gender equality, however, Green's recurrent portrait of exemplary domestic heroines still provides a moral discourse on the appropriateness of certain feminine roles. This conventional female exemplarity undermines her subversive message on female independence and allows her to stand next to less radical female authors who, notwithstanding their defence of women's intellectual powers and their presence in the public sphere, still combined the freedom granted by literature with the constrain demanded by decorum in order to become successful and morally praised authors on their own right. Her novels then possess all the complexity of conservative quixotic narratives about and 
by women, which dwell, as the female quixotes, in that liminal space between subversion and convention. And, as mirrored by Green's quixotic fictions, this intricacy will become increasingly independent of ideological messages as the new century advances and will focus only on the young woman reader's process of maturation and critical awareness. 



\title{
6. FEMALE BILDUNGSROMAN OR THE DEVELOPMENT OF THE YOUNG FEMALE QUIXOTE
}

\begin{abstract}
But you yourselves, I think, will allow that war, commerce, politics, exercises of strength and dexterity, abstract philosophy, and all the abstruser sciences, are most properly, the province of men. I am sure those masculine women, that would plead for your sharing any part of this province equally with us, do not understand your true interests. [...] Your business chiefly is to read Men, in order to make yourselves agreeable and useful. It is not the argumentative but the sentimental powers, which give you that insight and those openings into the human heart, that lead to your principal ends as Women. Nevertheless, in this study you may derive great assistance from books.
\end{abstract}

James Fordyce, Sermons to Young Women, 1766

\section{INTRODUCTION: DEFINING THE FEMALE BILDUNGSROMAN}

In Lorna Ellis's insightful analysis of the novel of female development, or female bildungsroman, in eighteenth-century British literature, she points out some of its recurrent characteristics, which are particularly relevant for the present study. ${ }^{207}$ First, the alienation that the protagonist of the traditional bildungsroman must overcome in order to negotiate his or her place within society is particularly striking. In the female variation of the genre, alienation is "based on the material disempowerment of women and the repressive social expectations placed on women, and it is manifested through the disjunction between the heroine's appearance and her sense of her motivations" (1999: 23). Hence, female bildungsromane expose the "rift between the self as initially

${ }^{207}$ Terminology has proved ambiguous and scholars continue to discuss if there exists what one could term female bildungsroman. Susan Fraiman (1993) analyses the origin of the term bildungsroman and its history in England, only to conclude that the novel of female development does not partake in the most striking characteristics of the apprenticeship novel and is, hence, generally speaking, something different. She bases her conclusions on the fact that the pillars of the young man's experience are travel (1993: 6), sexual adventures (1993: 7), the exaltation of genius (1993: 8) and of individuality (1993: 10), areas which are especially fraught in the female realm of experience in the eighteenth century and which must receive a different treatment in fiction. Lorna Ellis (1999), while acknowledging the existing difference, still considers it a genre in its own right. Both scholars, nevertheless, agree on the particularities of the novel of female development. The present work with employ the term "female bildungsroman," although always keeping in mind the genre's own original traits in contrast with the tradition of the male apprenticeship novel. 
perceived by the heroine and the self that is reflected back by other people's expectations," a rift in which there will be a particular emphasis on appearances and on "sight" and "seeing" (1999: 23). The heroine's maturation then "involves learning to see herself as others see her, learning how to experience herself as the object of other people's gaze" (1999: 30). This gap in perception is to be overcome in order to avoid the initial alienation, and any bildungsroman plot usually displays three elements necessary for the abovementioned happy integration: the heroine's agency over her life and beliefs, her cogitation on her own sense of self, and an attempt to become reintegrated with society (Ellis, 1999: 26-27). In the female bildungsroman, then, there is space for a plot of female development that "provided women with a sophisticated understanding of their constricted place in society while encouraging them to manipulate societal expectation in order to promote their own welfare" (1999: 23). In this sense, by acknowledging that they are subject to other people's point of view, they can also learn how to manipulate them for their own gain (1999: 30). That is, female bildungsromane developed an intricately paradoxical nature in which women were taught to negotiate with their need to diminish their visibility and agency in order to successfully achieve integration and acceptance, by fulfilling their more constrained role as wives and mothers. These paradoxes allowed to offer a "limited possibility for female autonomy while simultaneously critiquing the societal expectations that constrict women" (1999: 29).

In this regard, the novel portraying a plot of female development, having sprung from the popular conduct books written by and for women, inherited the intrinsic ambiguity in the message of female visibility and authorship. As Fraiman has demonstrated in her analysis of eighteenth-century conduct literature written by women, these texts present "two major nodes of conflict, two areas of dense ambivalence about how to plot a girl's life" (1993: 16); "one area concerns what we could loosely call affiliation: the desire for dyalic, familial, and also wider communal ties" and it usually relies on "the trajectory of courtship, marriage, and motherhood" (1993: 16), while "the other area has to do with ambition, especially the ambition to study, to gain intellectual authority, and perhaps to write" (1993: 16). Both areas will prove particularly 
troubled. On the one hand, with their warnings against seductions or their call to patience in unhappy marriages, the romantic plot will be contrasted to an anti-romantic one; in Fraiman's words,

[...] the reader is alerted in conduct book and novel alike to a rift in the romantic plot: a split between one narrative that continues pleasurably along a gentle rise and another that slopes down or spins round into pain. [...] the second, dysphoric narrative is not associated solely with the rejected suitors or with the possibility of seduction; it also runs darkly along the road to marriage with an Orville, Darcy, Rochester, or Stephen Guest. Even in the ostensibly comic novels [...], both stories of female development, which we might loosely call the romantic and antiromantic, recur. (1993: 19)

On the other hand, the path to learning or even writing is not an easy one. Conduct book after conduct book, from Fordyce to Chapone, moralists warn of the dangers of excessive learning or reading, or of the desire to become a woman of letters. Women novelists themselves will assume part of this conservative patriarchal discourse in their own works. However, such discourse will be challenged in several ways. As Fraiman has explained in the context of didactic literature, "the mother/mentor's example directly undercuts her lesson, for all of these female-authored texts are founded [...] upon the contradiction between 'proper lady' and 'woman writer'” (1993: 29-30). Despite this apparent contradiction, women novelists present themselves as both proper women and writers. In addition, while female moralists claimed that publication reduces a woman's spirit to an article of sale and bargain, "the extraordinary fame and popularity of $[\ldots]$ these writers, the high visibility and wide circulation of their works, tell a different story" (1993: 30). Hence, the biographical details surrounding the novel itself is one of the manners in which these texts subvert the patriarchal discourse. Nevertheless, the challenging subtext is not only provided by the context, it sometimes permeates the novel itself, for example, by "staging a woman in the act of writing" in the epistolary novel, hence, implicitly posing "its own production history" and defending the "fact of female authorship" (Fraiman, 1993: 30).

The novel of development written by and for women served then the purpose of presenting this duality of female visibility and invisibility, excusing the women novelists' attempt at authorship because of their need to employ the 
form available to them and their female readers to enhance rather than hinder their education and moral instruction. This instruction aimed to provide young women readers with illustrations of mistaken women who achieved a euphoric or dysphoric ending according to the overcoming or not of her youthful foibles. What were considered foibles were usually those beliefs or codes of behaviour which defied the conventional rules of society and, consequently, which frustrated the young woman's integration and success in it as she entered the world as an adult. In this regard, the tutoring for social success that these fictions offered covered a wide range of topics: fashion, courtship, marriage, aspirations to knowledge or fame, and, in an especially relevant and recurrent way, the dangers of uncontrolled reading. This last matter, which is recurrently introduced as of paramount importance in the instruction of young women in their road to social integration, indicates that quixotic fictions will become a perfect vehicle to convey in a pleasing form these tales of female development.

In this sense, many of the traits of the female bildungsroman identified by Ellis are traceable in those quixotic fictions with a heroine at their core. First of all, there is a chasm between the quixote's perception and that of the surrounding characters. In quixotic narratives, the rift created by the heroine's usual inexperienced, innocent and idealistic view of the world is widened by the quixote's literary expectations. More than in any narrative, as made evident in Cervantes' novel itself, the interplay between appearances and truth becomes essential, and the semantic field of seeing of key importance to understand the process of awakening from the veiled vision of the quixote. Secondly and closely related to the literary nature of the quixote's delusion, the abovementioned opposition between the romantic vision of the traditional courtship and marriage plot, and the anti-romantic reality of women's renunciation or suffering in marriage is also relevantly embodied in the figure of the female quixote. She is the best example of a romantic or idealistic young woman that will awaken to the anti-romantic circumstances in which she lives, a recurrent topos since Steele or Barker, fully explored in Lennox's pivotal novel and reaching its epitome in Edgeworth's and Austen's fictions. The accommodation of the learnt or acquired anti-romantic vision will be the cornerstone of the young quixote's growth into maturity, as well as the pillar 
on which the author's critique to the axiologically inferior society will be based. Thirdly, this process of awakening and final integration, as hinted in the analysis of Lennox's novel, follows the tenets of agency, self-awareness and a final desire to become accepted members of society which Ellis highlights as indispensable in a female bildungsroman. Finally, in narratives which portray a female quixote, the subversive female agency is very often acted out and not left at the level of potential, as other narratives identified by Ellis do (1999: 33), although it is also limited to a circumscribed area or period of time before the heroine's return to reality and duty. Nevertheless, it is still effective in its double aim of offering a space for female autonomy and of subtly highlighting the limiting rules of society towards women, for, more than in its male counterpart, female development or women's "personal destiny" evolves "in dialectal relationship to historical events, social structures and other people" (Fraiman, 1993: 10). Female quixotism, with its female readers and writers, will provide a space for the aforementioned struggle for authorial agency to take place in an even more relevant and conspicuous way. In the end, one could conclude that:

[...] all these writers, by dramatizing female development in contradictory ways, pointed to the "feminine" as a site of ideological confusion, struggle and possibility, thereby opening up still more debate around this term. Unable to represent a girl's entrance into the world as a simple, graceful passage, attending in diverse ways to its dangers and insisting on its deprivations, they managed collectively to question the routines of growing up female and male and at moments to imagine they could be otherwise. (Fraiman, 1993: 31)

Those novels dealing with female quixotes will then inherit all the ambiguities of conduct books and those novels describing the rites of passage of a young girl into adulthood and would add to them all the complexities inherent to quixotism. Therefore, in order to illustrate the transition towards quixotic bildungsromane and to provide a context for subsequent novels, this chapter commences with an analysis of two relevant examples of antecedents to the quixotic heroines of a bildungsroman, More's reading and writing quixotes and Burney's pivotal heroine, the idealistic Evelina. More's work, halfway between narrative fiction and a conduct book, will exemplify the development towards Burney's more compelling novels of the coming of age of a young woman. 
In the train of Burney, subsequent authors such as Maria Edgeworth, Mary Brunton, and later Jane Austen, would depict similar young female characters in the process of maturation and discovery of themselves and society. In addition, enrooting with Lennox and the prior tradition of female quixotes, they would employ the topos of the deluded female reader to emphasise the overcoming of a romantic or idealistic interpretation of the world and themselves and the need to renounce to them in order to gain that ambiguous happy acceptance in society. Together with the abovementioned novelists, other authors, such as Elisabeth Sophia Tomlins, would ascribe to the tradition of female quixotism so as to evidence the difficulties of finding a space in patriarchal society for literary women, hence creating a more dystopian female bildungsroman and developing in greater depth the genre's "rewriting of the heroine's rise to happy maturity as a history of obstruction, imposition, and loss" (Fraiman, 1993: 10); a matter later masterfully explored by George Eliot in The Mill on the Floss. These eighteenth-century women writers would then establish a link with the nineteenth-century Victorian novel and construct a continuum from More to Eliot. ${ }^{208}$ This chapter will therefore explore these didactic novels which focus on the process of awakening and maturity of a young heroine, serving as acknowledged precedents for Jane Austen's mastery in the construction of the novel of manners or of the quixotic female bildungsroman.

${ }^{208}$ See Myers, 1986: 267. 


\section{BRIDGES TOWARDS THE QUIXOTIC BILDUNGSROMAN}

2.1. Didactic Precedents of the Young Reader's Coming of Age: Hannah More's Life Lessons for Women

A particularly illustrative example of a didactic work of fiction which overtly aims to provide a comment on the abovementioned issues and to serve as an educational instrument for the benefit of young readers would be Hannah More's popular Stories for the Young, or, Cheap Repository Tracts: Entertaining, Moral and Religious, written in the late 1790s. Moreover, she is also an example of an author who wrote works specifically destined to be perused by young female readers, such as the early The Search after Happiness: a Pastoral Drama (1762), which includes a deluded novel reader in need for correction who will find a happy acceptance into society once she matures and renounces her quixotic aspirations. Probably no author epitomises the success of the woman writer in the development of didactic prose fiction, or the need to appear self-effacing while doing so, better than More. Early in her production -she wrote this drama in verse when she was only eighteen-, she already created a strikingly feminocentric work, confessedly written "by a lady," addressed to female readers and portraying eight characters, all young women. In her pastoral drama More depicts four ladies in search for happiness, Euphelia, Cleora, Pastorella, and Laurinda, who seek the counsel of a wise woman, Urania, who lives with her daughters Sylvia and Eliza in pastoral retirement, and is attended by a young shepherdess, Florella. Each of the four ladies embodies one of the dangers to which women are exposed, and Urania presses each one of them to declare "her ruling passion" with truth (1773: 14): Euphelia is obsessed with fashion, Cleora with fame, Pastorella with novels, while Laurinda's misfortunes flow from ignorance. In order to achieve happiness, mostly in the shape of marriage, they are encouraged to "reap the council of the truly wife" (1773: 5), a woman in whom "united worth and wisdom dwell" (1773: 6). Urania, a name closely intertwined with the history 
of women's writing in Britain, ${ }^{209}$ offers advice to these young women to instruct them in the path of true Christian and womanly happiness. Together with her daughters and Florella, who also comment on the ladies' foibles, she hence establishes a feminocentric community of experience and learning in which wisdom is transmitted from woman to woman. In the depiction of this female community, Urania is recurrently identified as a mother who dotes on her literal and figurative daughters, and all are encouraged to attend the counsel of this "fond, maternal friend" (1773: 12) in whom an "ample heart" and "wisdom's noblest treasures" are united (1773: 6). This motherly figure who recalls the long tradition of women writers in Britain and who teaches with intelligence and feeling becomes More's alter ego and reasserts the author's stance that women writers should be the literary mothers who appeal to mind and heart in their works in order to educate their male and female readers. ${ }^{210}$ In More's life and fiction, the "female teacher" stands "as surrogate mother, regulating and redeeming her microcosmic world" (Myers, 1986: 276). ${ }^{211}$

This didactic purpose and the intention to create a literary feminocentric community is restated in the work's advertisement and introductory address. As the latter deals with many of the common places of women's self-effacing stance when facing authorship, it is worth perusing in full:

With trembling diffidence, with modest fear,

Before this gentle audience we appear.

Ladies! survey us with a tender eye,

Put on good-nature and lay judgement by.

No deep-laid plot adorns our humble page,

But scenes adapted to our sex and age.

Simplicity is all our author's aim,

She does not write, nor do we speak for fame.

To make amusement and instruction friends,

A lesson in the guise of play she sends;

She claims no merit but her love of truth,

No plea to favour, but her sex and youth:

${ }^{209}$ Mary Wroth's The Countess of Montgomery's Urania (1621) was the first romance written by a woman to be published in Britain and enjoyed an enormous success; it is also a pastoral romance whose main character is named Urania. See chapter three.

${ }^{210}$ More wrote works destined to be read by lower classes of both sexes for their instruction, such as the abovementioned Tracts, and even her most successful conduct book, Coelebs in Search of a Wife (1808), has as main character a young man. Therefore, her potential or implied audience was not only female.

${ }^{211}$ On the figure of the mother as instructor of the real or surrogate reading daughter in eighteenth-century literature, see Jane Spencer's “'Of Use to her Daughter': Maternal Authority and Early Women Novelists," in Spender (1992), pp. 201-11. 
With these alone to boast, she sends me here,

To beg your kind, indulgent, partial ear.

Of critic man she could not stand the test,

But you with softer, gentler hearts are bless'd,

With him she dares not rest her feeble cause,

A mark too low for satire, or applause.

Ladies, protect her --- do not be satiric.

Spare censure, she expects not panegyric. (1773: B1)

More's address to the reading ladies is evident; not only is her work conceived with an implied female reader in mind, it is also dedicated to a woman praised by her domestic and educational virtues. Instead of appealing to a well-known public figure, More writes to a Mrs Gwatkin: "I know not to whom I can, with more propriety, dedicate it, than to you, as the subject it inculcates [education] has been one of the principal objects of your attention in your own family" (emphasis added, 1773: vii). The proper addressee would then be a woman, and, moreover, one who develops her educational skills in order to strengthen her own family core. Her virtue is next restated by More: "Let not the name of dedication alarm you: I am not going to offend you by making your eulogium. Panegyric is only necessary to suspicious, or common characters. Virtue will not accept it. Modesty will not offer it" (1773: vii). This dedication emphasises the model of addressee More may expect: virtuous and drawn to didacticism, while rejecting the idea of fame.

This image of the female educationalist who shuns public notice is consciously developed by More in her own presentation to the reader. Already in her advertisement, More apologises for the publication of her youthful composition, but claims that, though it may have many defects, "if it may be happily instrumental in promoting a regard to Virtue and Religion in the minds of young persons, the end for which it was originally composed, and her utmost wish in its publication will be fully asnwer'd" (1773: vi). This selfeffacing introduction reveals what will become More's compulsive need to justify her abandonment of invisibility and her attempt at becoming a published author. This claim to promote "Virtue and Religion" will become a recurrent topos not only in women's own works, but also in the critic's analysis of them, placing the novel's moral worth above its aesthetic merits to the point of 
condoning errors in style because of the obvious didacticism of the work. In addition to her advertisement, in the subsequent dedication More emphasises her didactic purpose, stating that "the following little poem turns chiefly on the danger of delay, or error, in the important article of Education" (1773: vii). The almost derogatory epithet "little" joins the later more elaborated selfdeprecating description of her work in the introductory address. In it expressions such as "diffidence," "modest fear," "humble page," "a mark too low for satire or applause," "to beg your kind, indulgent, partial ear," once again highlight the self-effacing strategy developed by More, together with her appeal to her audience to set judgement aside and read with good nature, always remembering the author's gender and age. Moreover, she disclaims any desire for fame and states she writes only to join amusement and instruction, to present a lesson in the appealing dress of a play. More then nurtures the patriarchal discourse on female authorship which proclaimed a double-standard in the reception and assessment of fiction written by men and women. However, this conservative gender-centred critical discourse is also most strategically employed to appeal, not to men, but to a female readership, a female community of readers and critics who, according to the discourse of the age, was the most influential audience as far as literary success was concerned. This dual relationship with fiction -its dismissal and praise- and to female authorship and readership -its regulation and defence- will be more thoroughly developed in the drama itself by More's treatment of female quixotism, of literary aspirations or delusions, as one of the topics in which women need to be instructed, in contrast with her own fulfilled authorial status and her defence of female reading.

In her gallery of deluded young heroines, More portrays a woman writer and a woman reader. Cleora's ruling passion is a search for fame which leads her to exclaim: “I sigh'd for fame, I languish'd for renown,/ I wou'd be prais'd, caress'd, admir'd, and known./ [...] I long'd to burst these female bonds, which held/ My sex in awe, (by thirst of fame impell'd;)/ To boast each various faculty of mind" (1773: 16). Cleora later aims to be ranked together with a large list of acclaimed male writers: Pope's graces, Johnson's learning, Swift's satire, Burke's sublimity, Mason's numbers, Colman's wit, Melmoth's talents, 
Hume's polished page, Hammond's softness, Dryden's rage, Otway's and Goldsmith's passion, sentiment and style, Sterne's poignancy and humour, Gray's call of the muse of elegy and Langhorne's fancy's fairy walks (1773: 16), are all praised and longed for. Cleora proves an informed and critical reader whose only delusion is an aspiration to fame than will be conducted a step further when she abandons her passion for fiction and substitutes it with a passion for science. As she states: "Abstruser (sic) studies soon my fancy caught,/ The poet in th' astronomer forgot;/ The schoolmen's systems now my mind employ'd,/ Their chrystal Spheres, their Atoms, and their Void" (1773: 17). It is now Newton and Halley who her "soul inspire;" her admiration for Descartes and Euclid leads to "plans and problems" all her soul to possess (emphasis added, 1773: 17). Finally, her studies take a new course and she asserts: "I now with LOCKE trod metaphysic soil,/ Now chas'd coy nature thro' the tracks of BOYLE; Sigh'd for their fame, but fear'd to share their toil" (1773: 17). In this new course for her intellectual monomania she becomes one of those learned ladies that Aragon (2004) identified as recurrently mocked women readers. Moreover, she precedes the hero of The Philosophical Quixote (1782), David Wilkins, in her obsession with metaphysics and science, as well as in her wish to become a renowned scholar. In Cleora's case, as it was in Wilkins's, it is not her literary taste that is condemned, but rather her hope to achieve fame and, being a woman, to "break the bonds" of taste or custom with regards to the appropriate female sphere. It is this scientific mania which hinders her chances for happiness and thus causes Urania's correction: science was not made for female minds, nor was the male spheres in which scientific fame is achieved. The "milder graces" of the intellect -which include goodnature, patience or sweetness- are to be cultivated by young ladies who wish to shine in their "proper sphere" (1773: 34). This criticism to women's desire for fame was already present in Lennox's novel, in Arabella's wish to have her deeds recorded and to become as well-known and admired as Clelia. Similarly to what Lennox did with her quixote's cure, Urania continues to exhort in Cleora the exertion of "accomplishments" to achieve virtue as their end (1773: 35). The young enthusiast of erudition finally learns "Humility with reading to unite,/ The finish'd character must both combine,/ the perfect Woman must in 
either shine" (1773: 35). Leaving her quixotic monomania behind, Cleora can become the perfect model of an accomplished and virtuous woman.

The same could be said of the most strikingly quixotic character, the passionate novel-reading Pastorella. Having no "prudent parent" to form her "ductile youth," Pastorella has been left to cultivate her own mind and, consequently, her "ruling passion" is caused by "pernicious novels" she choses to read, by considering fiction her "guide" and romance her "law," and by allowing Fancy to reign over Reason, hence becoming a "victim to imagination's sway" (1773: 18-9). The "poisonous influence" of these readings "led [her] mind astray" and she commenced to fancy things she had never seen and heroes that had never existed, finding "adventures in each common tale" and loathing the real world in comparison (1773: 18). In addition, she started to speak and act as a true heroine. She "talk'd and sigh'd to ev'ry passing gale;/ Convers'd with echoes, woods and shades and bow'rs,/ Cascades and grottos, fields and streams, and flow'rs," and, more relevantly in the tradition of female quixotism, she received professions void of meaning and "Imagin'd all who courted me, approv'd,/ Who prais'd, esteem'd me, and who flatter'd, lov'd./ Fondly I hop'd, (now vain those hopes appear,)/ Each man was faithful and each maid sincere" (1773: 18). Despite her recurrent disappointment, her wishes still kept her "soul in play," living without being truly alive to the world around her (1773: 18-9). Pastorella's exposure of her literary mania comprises all the common places of eighteenth-century female quixotism, already present in Steele or Lennox: the lack of prior education, the literary fancy or language which converts winds into zephyrs, or the perception of every faltering man as an appropriate suitor. Female quixotism, here introduced as one of the accustomed delusions of young women that More's readers would be familiar with, is understood as flights of fancy and images of what never existed, as the rewriting of the world under the guide of fiction, or the law of romance. The consequence of such obsession with fiction is also the familiar corruption of the young woman's mind and, hence, the hindering of her chances to marry, for she expects a hero or a love story that can never exist. Urania's address to Pastorella makes these dangers explicit, as she deplores the latter's state and the fact that fiction has almost ruined a young woman naturally inclined to 
virtue: "I pity PASTORELLA's hapless fate,/ By nature gentle, generous, mild, yet great;/ One false propension all her pow'rs confin'd,/ And chain'd her finer faculties of mind,/ Yet ev'ry virtue might have flourish'd there/ With early culture, and maternal care" (1773: 32). The emphasis is More's and highlights the educational role that both Urania and the author are fulfilling by pointing at a better employment for her intellectual faculties, a role that is identified as eminently female. This instruction aims to substitute the seeds of novel reading for those of Christian morals, to substitute fiction for truth. As Urania claims, "[i]f Good we plant not, Vice will fill the mind/ [...] Those very passions that our peace invade,/ If rightly pointed, blessings may be made;/ Then rise, my friend, above terrestrial aims,/ Direct the ardour which your breast inflames,/ To that pure region of eternal joys" (1773: 32-33). To this speech, Pastorella replies: "I mourn the errors of my thoughtless youth,/ And long, with thee, to tread the paths of truth" (1773: 33). Female quixotism, or the obsession with novel reading, is once again dealt with as a mistake committed only due to inexperience, and an error that may be overcome with education and maturity. Nevertheless, it is still a dangerous delusion that may lead to the unfulfilment of women's Christian duties, whether marriage or the performance of pious deeds. Urania's conclusions are summarised in her closing speech: women must flourish unseen, "give domestic life it's sweetest charm," be "fearful of Fame," correct and subdue their passions, and develop one sole ambition, to be virtuous and good (1773: 38-9). As a consequence of the double-standard in the measurement for male and female fiction, More has detached herself from her deluded characters who seek fame or pleasure in the perusal of fiction, and has made evident that she sees writing prose as a mere instrument for instruction, which in any case also implies a statement of self-confidence. ${ }^{212}$ As Urania asserts "life's chief happiness and woe,/ from good or evil Education flow" (1773: 29), and her drama has been amply identified as an educational instrument, as well as a call for the need to instruct young female minds. In this regard, Euphelia's shallow obsession with fashion and Laurinda's ignorance

${ }^{212}$ Myers quotes More when she states that "it furnishes little proof of the modesty of the woman to fancy that she can instruct;" however circumscribed her topic to domestic affairs or to an audience identified as children or young women, in More's production "virtue and usefulness justify assertion, activity, responsibility; ultimately, doing good even confers power" (1986: 268). 
are condemned as evils of women's condition. Urania states that "flattery, dress, and show,/ the too, too common source of female woe!" (1773: 30), while 'Laurinda's dark, untutor'd mind may shew/ what ills from want of Education flow" (1773: 31). In particular, the latter's ignorance has hindered her chances of becoming a wife; Laurinda, who describes herself as "in size a woman, but in soul a child" (1773: 20), states "unfit for converse, and to books unus'd;/ the wife avoided me, they cou'd not hear/ my senseless prattle with a patient ear" (1773: 21). While joining Wollstonecraft in her criticism of women's infantilization, More nevertheless advances a less radical stance towards the intellectual and professional development of women. ${ }^{213}$

Restating her belonging to a recognised tradition of female authors and, moreover, stressing a didactic purpose which will enhance the opportunities to fulfil the appropriate duties of women's station in life, More justifies not only the act of writing in itself, but the moral worth of her production. Her work then avoids becoming one of the dangerous literary productions that moralists condemned, ans is instead a didactic essential for the education of her young female readers. Therefore, she at once disclaims visibility and authorship for her characters, while effectively claiming them for herself in the name of didacticism. Other women writers will resume this highly and overtly didactic purpose, uniting a comment on young ladies' need for education and a defence of their role as legitimate educators by means of their own prose fiction destined to be read by a female audience. In fact, the plot of the development of a young girl into adulthood and her acceptance in and of society, what would be termed the coming-of-age or development novel, became predominant in the later part of the century and well into the following one, enrooting with the rising novel of manners and the Victorian taste for female bildungsromane. Taking fictions like More's as stating point, later authors such as Mrs Baker, writing in the 1820 s, still developed short moral tales with a quixotic heroine destined for the instruction of her young women readers. In them they would sketch all the common places of the tradition of female

${ }^{213}$ Her Cheap Repository would prove much more radical in its challenge to the customary bases of traditional society, portraying a host of ineffectual men and hard-working, capable women, and claiming the need for a "bourgeois renovations of manners and morals," which would mark the transition from the eighteenth to the nineteenth century (Myers, 1986: 269). 
quixotism to entertain and educate alike. Other writers, however, progressively abandoned archetypal characters to create complex heroines and plots with which to contribute to the debate on women's education and their literary aspirations. This progression also involved a greater attention to the figure of the female quixote, which enabled a more compelling debate on gender and genre, and on the limited social sphere allowed for women. In addition to the influence of didactic fictions and prior quixotic narratives, in this evolution of the novels of female development another author will be essential to understand the adoption of certain common places by later quixotic authors: Frances Burney and her tales of a young lady's entrance into the world.

\subsection{Frances Burney and the Young Reader's Entrance in the World}

The cornerstone of the tradition of dramatizing female development would probably be Frances Burney (1752-1840) and her acclaimed novel Evelina or The History of a Young Lady's Entrance into the World (1778). Considered one of the first British female bildungsromane, it positions itself as such in its preface:

[...] a young female, educated in the most secluded retirement, makes, at the age of seventeen, her first appearance upon the great and busy stage of life; with a virtuous mind, a cultivated understanding, and a feeling heart, her ignorance of the forms, and inexperience in the manners of the world, occasion all the little incidents which these volumes record, and which form the natural progression of the life of a young woman of obscure birth, but conspicuous beauty, for the first six months after her Entrance into the world. (1829: I, vi)

The novel follows the entrance into society of the young Evelina Anville and how she must learn to negotiate her position in the world as a woman and a lady of unknown origins until she finds her place in it as the daughter of Sir Belmont and the wife of Lord Orville. Evelina's story commences a generation earlier, when the aristocrat Sir John Belmont secretly marries her mother and later disclaims her and their daughter. Her mother dies and Evelina is left under the tutelage of her mother's mentor, Mr Villars. As she abandons her retired life in the country and enters genteel society, Evelina will be required to 
contrast her romantic assumptions and ideal visions with the anti-romantic and debased reality of the world. In her journey to adulthood, she will encounter a series of characters that embody the different instances of "men and manners" to be found in eighteenth-century British society, which Burney minutely portrays in all the splendour of their particular speech and idiosyncrasies with a subtle satire that has much of Fielding and Smollett in it, and that Edgeworth and Austen will later admire and equally reproduce. ${ }^{214}$ As a heroine of a bildungsroman, Evelina will be required to learn how to read each one of them, from her embarrassingly spirited grandmother to her own father. More relevantly, she will have to learn how to read the villainous Sir Clement Willoughby or her beloved Lord Orville, the bad and good suitor in the inevitable courtship plot at the core of the novel.

With echoes of Haywood's and Lennox's life stories of adolescent heroines, Burney's novel introduces and builds on the characteristics that will become common places of the narratives of female development in general, and those portraying a female quixote, in particular. The most important one is that there is an obvious chasm between Evelina's perception, and the one shared by other characters. Brought up in isolation, Evelina displays a very innocent vision of reality which will be recurrently challenged by her experience in fashionable society. Similarly to Arabella's experience in Bath or London, Burney's heroine will encounter many social types characterised by dress, speech and behaviour. Burney's mastery in reproducing the ridiculous and vapid speeches of the fops, or the uneducated discourse of the middle classes that rose to money, and in presenting the ridiculous fashions of the day or the cruelty and selfishness of shallow elites, for example, enables readers to humorously identify well-known mannerisms and foibles as they accompany Evelina in her discovery of the world and her instruction in its ways. As an inexperienced viewer, Evelina becomes the best possible judge and commentator of these

214 David Lodge, placing Burney's employment of humour side by side with Edgeworth's, characterized it as leavening the "sentimental novel with comedy" in the form "of "comic relief' from the main story" which "often takes a rather robust, farcical form reminiscent of the comic fiction of Fielding, Sterne and Smollett, which itself derived ultimately from Rabelais, Cervantes and the picaresque tradition" (1990: 120). Burney's sense of humour reaches extremes of cruelty towards its female characters, with the episodes in which Mrs Duval is tied to a tree, or two elderly ladies are forced to run in a race to amuse the gentlemen, and points out at the threats of society towards women and the ridicule to which they are subject even in their old age. 
shortcomings, while her innocence and moral righteousness places her above the shallow society she is describing, much in the train of Adams or Arabella in their own interaction with the world. Moreover, the interpretation other characters make of the heroine, as a naïve, gullible or scheming woman also prove that Evelina is a true heroine of a bildungsroman, forced to become aware of her image and then to learn to negotiate it in society. In this negotiation, in the struggle to avoid being misread by others and to build an adequate self-image, the heroine's simplicity, innocence and goodness will shine in comparison with other characters, in the common axiological superiority of the heroine of the female bildungsroman.

This fraught negotiation is exemplified for instance in Evelina's interaction with her mentor and surrogate-father, Mr Villars, the man who educated her in retirement and who must guide her through her rite of passage. Mr Villars, more than any other character, emphasises the importance seeing and reading, that is, active interpretation, has for Evelina. In a scene that opens with $\mathrm{Mr}$ Villars and Evelina in a reading position, Villars parts with his book to become wholly engrossed in observing her. Evelina asks him if he has been reading, to which her mentor responds that he has been studying "a book that both afflicts and perplexes me" (1829: II, 94). Evelina immediately and explicitly identifies this book as herself and provides no answer; Villars then seeks interpretation asking her to read that text together, so she can assist him with its obscurity (1829: II, 94). Villars, as a sympathetic reader, identifies her sorrow with his and insists in Evelina opening to him her whole heart (1829: II, 95), the part of herself she has yet to know. At his persistence in guessing her pain at her separation from Orville and her own stubbornness in hiding it from him, Evelina asks whether she should fetch him another book or whether he will have the same one again, after which she seeks a literal text to divert Villars' scrutiny (1829: II, 96). As Bray has asserted, Evelina proves herself a "stubborn and perplexing text" (2009: 34), and this play of literal and embodied texts reflect the epistemological core of Burney's novel: Evelina's need to read critically and actively, as well as to manage wisely her own selfimage and reading. The same could be said of later heroines, such as Edgeworth's Belinda, often described in a reading position, often the subject as 
well as the object of scrutiny and analysis, and often having to develop an exegesis of her own conduct to be properly understood and portrayed.

Although Evelina's need to read and be read by people around her -friends, foes and family alike- will be resumed in Tomlins's, Edgeworth's and Austen's novels, for example, once more Burney develops the epitome of the feminocentric narrative, the courtship plot, to emphasise her heroine's veiled perceptions and the dangers it implies for her honour. It is in this plot that the relevance of the semantic field of seeing, associated with the novel of female development, becomes more conspicuous, an importance that already existed in previous quixotic fictions were appearances proved misleading, but which increases its presence and significance in later novels by Brunton, Edgeworth and Austen. Evelina's need to appropriately see the male characters in the novel is again particularly relevant for her position as a marriageable woman searching for her social niche and, more importantly, as a vulnerable young and innocent girl in a threatening society.

In a revealing example, Sir Clement manipulates events so as to have Evelina in his power twice; both times the heroine will need to interpret the scene accurately to save her virtue. Once, she is riding in his carriage and he intentionally diverts their way to be able to prey on her. At his approach, Evelina starts to suspect the truth and reacts attempting to jump out of the carriage. When asked what the matter is, she can only exclaim that she does not know (1829: 115), although her behaviour provides the opposite meaning. She finally exclaims that, if he is not to murder her, he should "for mercy's, for pity's sake, let her out" (1829: 116), a language that indicates the possibility of rape, the sexual threat that Evelina, in her innocence, cannot fully comprehend at first or even give expression to. In a second episode involving Sir Clement, Evelina is molested by a group of riotous men who take her for "the prettiest little actress" (1829: II, 6); however, Sir Clement intervenes and asks to leave the lady to him. Then, instead of releasing her, he takes her into another "dark alley" in which to be "least observed" so as to obtain her favours himself (1829: II, 7). Evelina then awakes to his intentions and runs for where "lights and company" seem to be (1829: II, 7). The metaphor of darkness and light, of not seeing and then recovering her sight plays an important role in the novel of 
female development and stresses the importance of the young lady's epistemological process of understanding the world around her. Adequate perception in Burney's novel is then always difficult, especially for the naïve heroine, even when it concerns the interpretation of her own self. For example, Evelina's sexual innocence prevents her from perceiving in what terms she is being interpreted by Clement until it is almost too late. Following the previous scene at the alley, the ensuing conversation takes place:

"By Heaven," cried he, with warmth, "you distract me; - why, tell me, - why do I see you here? - Is this a place for Miss Anville? - these dark walks! - no party! no companion! - by all that's good I can scarce believe my senses!"[...]

“So you will not explain to me your situation?" said he, at length.

"No, Sir," answered I, disdainfully.

"Nor yet - suffer me to make my own interpretation? -"

I could not bear this strange manner of speaking; it made my very soul shudder, - and I burst into tears. (1829: II, 8)

Sir Clement employs the conventional reading of Evelina as a beautiful, unprotected girl who was wandering alone in the dark, and, therefore, inviting seducers such as himself to approach her. Evelina's acknowledgement of the dangerous reading she has unsuspectingly allowed is what triggers the shudder at her exposure and its consequences. Once again, the heroine is under the gaze of the suitor and her moral character will depend on his interpretation. In addition, Evelina learns that her claim to Sir Clement for protection has actually made her vulnerable once more, for the knights in shining armour now aim to take advantage of the defenceless ladies. As Fraiman has asserted, Burney's plot and subplots are "a sadistic and satirical rewriting of the fairy tale, so that the very man who saves the heroine from distress takes advantage of her trust and gratitude to assault her in turn;" therefore, "as prince turns repeatedly into dragon, rescue into recapture, and relief into trepidation, Evelina begins to doubt not only the world but also her own ability to interpret it" (1993: 36). In this rewriting of the fairy tale, the heroine, as the implied reader, will discover that, far from being in dungeons, danger lies in the “domestic settings of the realist novel" (1993: 36). 
This same fraught interpretation must be developed in relation to the hero of the novel, Lord Orville. Orville somehow responds to Evelina's need of him as an object of her affections in order to, first, reject his uninvited advances and, secondly, to fulfil her social expectations. As the hero who can grant her happy integration in society, Evelina will require interpreting Orville more carefully, and Burney develops around him many references to actual reading, as a metaphor of the epistemological process Evelina must undertake in order to properly understand him. This fact is evidenced by a passage in which literal reading symbolises the interpretation of embodied texts the young heroine should do. At one point, she receives a highly offensive letter under Orville's name, and her approach to this missive mirrors that to the writer:

The moment the letter was delivered to me, I retired to my own room to read it; and so eager was my first perusal, that, - I am ashamed to own, - it gave me no sensation but of delight. Unsuspicious of any impropriety from Lord Orville, I perceived not immediately the impertinence it implied, - I only marked the expressions of his own regard; and I was so much surprised, that I was unable for some time to compose myself, or read it again: - I could only walk up and down the room, repeating to myself, "Good God, is it possible? am I then loved by Lord Orville?"

But this dream was soon over, and I awoke to far different feelings. Upon a second reading I thought every word changed, - it did not seem the same letter, - I could not find one sentence that I could look at without blushing: my astonishment was extreme, and it was succeeded by the utmost indignation. (1829: II, 87)

Evelina's broken syntax once more reflects the emotion with which she reads and responds as a reader. It also proves the difficulty of composing herself, of constructing a coherent discourse to make sense of what she reads under the weight of her emotions. She must read the letter twice to understand the inappropriate contents, which her first, idealistically romantic reading had obviated in the possibility that Orville might love her. Not knowing how to interpret this letter in the context of her experience, she recurs to Villars for an explanation on how the same man could talk and write so differently (1829: II, 99). However, Villars also requires several readings, in fact, he "read it three times before he spoke," becoming "so much astonished" that he knew not what he read, and hence required yet another perusal and a time of consideration 
before proposing some conjecture (1829: II, 99). In the end, she will discover it was forged by Sir Clement.

Not only Evelina's reading of the hero is paramount for the euphoric conclusion to take place, but Orville's reading of her becomes also of incredible importance in order to fulfil her happy ending. In this sense, Evelina constantly employs the language of seeing, observing, and reading to describe her relationship with him. She states, for example, that "seeing [...] Lord Orville,[...] [he] not only read my sentiments, but, by his countenance, communicated to me his own" (1829: II, 123); in another occasion she "turned to Lord Orville, and saw, with concern, the gravity of his countenance," after which she was rendered speechless though she believed, however, that "he read [her] thoughts" (1829: II, 161); and Orville, after offending her, at one point exclaims that "if I may be my own interpreter, Miss Anville's countenance pronounces my pardon" (1829: II, 144). The importance of reading in relation to Orville is emphasised when Evelina includes reading together as one of the activities that allows them to know each other; in her own words: "when we read, he marks the passages most worthy to be noticed, draws out my sentiments, and favours me with his own" (1829: II, 133).

It does not seem a coincidence that reading, literal and metaphorical, should be associated with Orville more than with any other character, for it is in relation to him that Evelina's romantic imagination will be more actively employed. With the development of the courtship plot based on the reading of textual bodies, on the fraught interpretation of appearances and discourses, Burney inherits many characteristics of Lennox's plot and advances them in full. In this sense, it is important to note that Evelina is indeed identified as a romantic quixote, once more highlighting the importance of Burney's novel as a link between Lennox and later authors. This romantic quixotism is evident in Evelina's pygmalionic nature. Early in the novel, not willing to dance with Sir Clement, Evelina states she is pre-engaged, to which Sir Clement responds that he will leave her, unless the alleged man is nothing but a "partner of her own creating" (1829: 39). Evelina is finally forced to name Orville, who indeed dances with her and who becomes, in a sense, her partner for the rest of the novel. However, the question remains if Orville is indeed an ideal figure of the 
heroine's creating, a "convenient fiction" made up by the heroine "in her effort to resolve the difficulties of courtship and useful to that narrative strain satisfied with marriage as the capstone of female development" (Fraiman, 1993: 46-7). Evelina's interaction with him stresses her enhancement of this chivalric, protective role, when she describes herself to him as a "young creature" who "greatly wants" and "earnestly wishes" for his advice and help (1829: II, 146). If this self-conscious construction of their respective roles as damsel in distress and knightly hero was not enough to evidence Evelina's romantic colouring of her reality, Mr Villars' words to awaken Evelina to her romantic delusion emphasise her quixotic approach to Orville. Villars emphasises, first, her inexperience, the fact that she has grown up "free from all other impressions." He continues stating that "[y]oung, animated, entirely off your guard, and thoughtless of consequences, Imagination took the reins; and Reason, slow-paced, though sure-footed, was unequal to the race of so eccentric and flighty a companion" (1829: II, 148-9). Evelina's quixotic progression is then fast and conventional:

How rapid was then my Evelina's progress through those regions of fancy and passion whither her new guide conducted her! - She saw Lord Orville at a ball, - and he was the most amiable of men! - She met him again at another, and he had every virtue under Heaven! I mean not to depreciate the merit of Lord Orville, [...]; but it was not time, it was not the knowledge of his worth, obtained your regard: your new comrade had not patience to wait any trial; her glowing pencil, dipt in the vivid colours of her creative ideas, painted to you, at the moment of your first acquaintance, all the excellencies, all the good and rare qualities, which a great length of time and intimacy could alone have really discovered. (1829: II, 148-9)

In what will become a common place of the novels of female development, such as Brunton's or Edgeworth's, Villars employs the common language of fancy as an artist, painting in vivid colours ideal images in the young girl's mind. These metaphors had already been employed not only by More in her portrait of a female quixote, but also by prior novelists such as Hays, once more strengthening the associations between quixotic fictions and the concept of female bildungsroman.

If this was not enough to link Evelina to other quixotic heroines, Mrs Selwyn moreover identifies Evelina as a romantic quixote and marriage with Orville as 
her dulcinea when, pressing Evelina to marry Orville as soon as possible, she states "luckily you have an excellent subject for Quixotism; - otherwise this delay might prove your ruin; but Lord Orville is almost as romantic as if he had been born and bred at Berry Hill” (1829: II, 226). Berry Hill being Evelina's home and where she acquired her secluded and naïve education, this assertion equals Orville's romantic imagination to her own. Orville has, however, little of the quixotic in him, besides the fact that he falls in love with a woman of unknown origin against his better judgement. The same could be said of Sir Clement, who concludes the narrative "half mad" (1829: II, 211), acting out in a "touch of the heroics" his jealousy (1829: II, 213). Nevertheless, Orville and Clement are at all times aware of the social and moral system of reference which rule their interactions with other characters, as they are also conscious of the role they are to play and the image they are to project. Evelina is the only one that expects the world to live up to her romantic expectations and who will be not only disappointed, but awakened by the anti-romantic reality she encounters.

In this sense, Evelina must become aware of her own feelings and learn to give them their proper expression in the recurrent pattern of female quixotic awakening. Approaching the end of the novel, she receives a letter from Villars in which he expounds to her "the perils of her situation," his hopes that "the same inexperience which occasioned [her] mistake, with the assistance of time and absence, would effect a cure," and his unwillingness "to destroy [her] illusion" in case it made her attachment stronger (1829: II, 149-50). However, the possibility of fulfilling the attachment to Orville leads Villars to exhort Evelina to "awake" as the "deluded child" she is, to the dangers and evils that threaten her (1829: II, 150). After this letter, Evelina answers in the following manner:

I have just received your letter, - and it has almost broken my heart! - Oh, Sir! the illusion is over, indeed! how vainly have I flattered, how miserably deceived myself! Long since, doubtful of the situation of my heart, I dreaded a scrutiny; - but now, now that I have so long escaped, I began, indeed, to think my safety insured, to hope that my fears were causeless, and to believe that my good opinion and esteem of Lord Orville might be owned without suspicion, and felt without danger; - miserably deceived, indeed! (1829: II, 169) 
Apparently, Evelina follows the course of awakening from her romantic delusion of her sister quixotes. However, Burney's cure for her heroine is deceiving, for Evelina's letters had already presented a self-conscious awareness of her feelings for Orville. Dreadful of scrutiny, her exposure is not so much to herself but to others: Villars can read her heart and her belief that she could love Orville without suspicion and without danger proves impracticable. Her romantic illusion is indeed shattered, although her quixotic quest for her father's name and Orville's hand will nevertheless be granted in the end.

In opposition to more knowing characters, one of Evelina's main lessons will be that she is subject to the reading of appearances, which have an immense weight on a woman's reputation; therefore, her education as a heroine of a novel of development very much revolves around how to wear or manipulate the masks that society requires (Ellis, 1999: 94) and how to build an image or identity that will be conventionally acceptable. In this sense, Evelina is indeed a heroine who must learn to negotiate her individual principles so as to integrate in society, and to renounce to certain ideals of transparency, fairness and equality in a patriarchal world. That is, she must renounce her "fiction of self-making" (Fraiman, 1993: 53), her romantic quixotic and unique self, in order to become deinvidualized and conventionalized. The fact that this integration involves an abandonment of her own unique identity is emphasised by her change of name: from being Evelina Anville, she becomes first a Belmont and then an Orville, transitioning from the different subordinate positions of protégée, daughter and wife. At one point, there is no name she can claim, in the transitional period between the moment she is acknowledged as Sir John's daughter and when she expects at some point to become Orville's wife. Having to write a letter, she states that "not knowing by what name to sign" she was forced to send it without any (1829: II, 251). Evelina's coming of age includes a period of liminality between being nobody and becoming somebody, moving on the margins between being an outsider and achieving social integration, the peak of success in any bildungsgroman. In the end, she marries as a Belmont and is transformed into Lady Orville, claiming her place as daughter and wife, finally achieving her deserved space in society. 
Evelina's liminal position in the sphere of what is considered conventionally acceptable is expressed in another of the common places that Burney adopts in her transitional narrative: her heroine is a woman reader and writer. In fact, she is the main reader and writer in the novel and, moreover, a sanctioned one by the implied author. Mrs Selwyn exclaims that Evelina is indeed rare, because she is a reading lady. Asked if she will attend the assembly, Evelina answers in the negative and to the question of how she will spend her evening, Mrs Selwyn replies: "In a manner which your Lordship will think very extraordinary [...] for the young lady reads" (1829: II, 105). Voiced by Mrs Selwyn, the epitome of the learned lady who continuously exposes the deficiencies in the men around her, this is not a critique against Evelina but against his Lordship. Evelina also opposes other uninformed characters, such as $\mathrm{Mr}$ Lovel, who do not read the play-bills or even listen to the actors when attending the theatre, and she can discuss the merits of British theatre with delicacy and taste. Very relevantly, Evelina also poses as writer by means of the epistolary form. The writing of letters has a double aim: on the one hand, to make sense of herself and her experience, understanding better the "dialectic between self and society" (Ellis, 1999: 90); on the other hand, to become the subject of the story and to be able to present it to her addressees in her own terms. That is, she gains agency and control over her self-construction, with all the potential subversion such a creation implies (Ellis, 1999: 91-2), much in the same manner as Hays's heroine did. Several are the examples throughout the narrative that indicate that Evelina is extremely aware that she is writing for an audience and that she is a very conscientious writer. For example, she writes:

Indeed, notwithstanding the attempts I so frequently make of writing some of the Captain's conversation, I can only give you a faint idea of his language; for almost every other word he utters is accompanied by an oath, which, I am sure, would be as unpleasant for you to read, as for me to write: and, besides, he makes use of a thousand sea-terms, which are to me quite unintelligible. (1829: I, 166)

Here Evelina disclaims responsibility for her lack of mimeticism owing to two limitations: what is not proper, such as foul language, and what she does not or cannot know, such as sea-terms. The heroine's intention of portraying a vivid image of society must thereby be checked by her position as woman, an echo 
of Burney's own concerns. However, her narrative also evinces the power of women's narrative. For example, it will only be after reading her late wife's letter that Sir Belmont will be moved into acknowledging Evelina as his daughter (1829: II, 217). Her own writing, which ends abruptly with her wedding, has given her an unprecedented agency and control, for even male texts, their letters, appear framed in her own narrative and interpretation. ${ }^{215}$

As a writer and surrogate author, Evelina is also concerned about how her readers will interpret her, transforming the matter of appearances and selfimage of the female bildungsroman into a reflection of the woman novelist's own issues. She writes to Lord Orville to apologise for the use of his carriage; the moment the epistle is sent, Evelina regrets writing it and unsuccessfully tries to recover it (1829: II, 76-7). She is aware that she has put herself in the position of being scrutinised and judged, mirroring Burney's own concerns as an author, expressed in her preface. Employing a similar language to her heroine's, Burney addresses the authors of the Monthly and the Critical Reviews in her original prefatory dedication thus: "Without name, without recommendation, and unknown alike to success and disgrace, to whom can I so properly apply for patronage, as to those who publicly profess themselves Inspectors of all literary performances?" (1965: n.p.). She then devotes her dedication to encouraging her critics to protect her, to have mercy on her, to take her youth into account, the same arguments Evelina had utilised to gain and preserve her mentors' protection and avoid their negative reading of her. She moreover continues to seek male mentors, this time the great names that have saved the novel from "contempt" and "depravity," and continues her selfeffacing discourse in her preface with the following assertion:

To avoid what is common, without adopting what is unnatural, must limit the ambition of the vulgar herd of authors: however zealous, therefore, my veneration of the great writers I have mentioned, however I may feel myself enlightened by the knowledge of Johnson, charmed with the eloquence of Rousseau, softened by the pathetic powers of Richardson, and exhiliarated by the wit of Fielding and humour of Smollett, I yet presume not to attempt

${ }^{215}$ According to Fraiman, "Words have been Evelina's best defense against assaultive experience. As the novel's preeminent narrator, she wields more power than she herself knows. To a large extent, her meanings, both conscious and unconscious, have prevailed. [...] Clearly letters give Evelina a kind of control that, away from her writing desk, she rarely has" (1993: 57-8). 
pursuing the same ground which they have tracked; whence, though they may have cleared the weeds, they have also culled the flowers; and, though they have rendered the path plain, they have left it barren. (1829: I, viii)

However, Burney adopts the same liminal position between visibility and selfeffacement which her heroine and authorial alter ego adopts. In her preface Burney states that "the following letters are presented to the Public [...] with a very singular mixture of timidity and confidence, resulting from the peculiar situation of the editor;" an editor who, "though trembling for their success from a consciousness of their imperfections, yet fears not being involved in their disgrace, while happily wrapped up in a mantle of impenetrable obscurity" (1965: n.p.). Presenting herself as editor of the letters and wrapped in the veil of anonymity, Burney finds confidence to seek publication and, despite her disclaim, to rank her production among the new species of writing which the abovementioned authors had raised to fame. ${ }^{216}$ She moreover detaches her narrative from the pernicious train of reading of the romance and ranks her own production among those salutary for her young readers, stating that her novel aims to add "to the number of those which may be read, if not with advantage, at least without injury," and concludes asserting that:

Let me, therefore, prepare for disappointment those who, in the perusal of these sheets, entertain the gentle expectation of being transported to the fantastic regions of Romance, where Fiction is coloured by all the gay tints of luxurious Imagination, where Reason is an outcast, and where the sublimity of the Marvellous rejects all aid from sober Probability. The heroine of these memoirs, young, artless, and inexperienced, is

No faultless Monster that the world ne'er saw;

but the offspring of Nature, and of Nature in her simplest attire. (1829: I, vivii)

Rather than running away to the fertile fields of romance, Burney then writes to "draw characters from nature, though not from life, and to mark the manners of the times" (1829: I, v-vi). In that way, by a concoction of modesty and

${ }^{216}$ For an analysis of Burney's self-effacement as an author and her use of the female “nobody,” see Gallagher (1994). 
assertion, Burney justifies her stance as author and recommends her narrative fiction as beneficial.

In that manner, both Evelina's and Burney's narratives are imbedded with the double-voice that characterises fiction written by women, as well as of the dissident meanings that hide in their plot of female fulfilment: its defence of female invisibility while granting both heroine and author presence and agency, a characteristic that Ellis and Fraiman had both identified as intrinsic to the novel of female development. Employing the plot of female development, Burney depicts the tensions that arise between the two main concerns of the bildungsroman: "an emphasis on individual agency, shown through Evelina's attempts to control her own destiny, and a final integration with society" (Ellis, 1999: 105). As Mrs Selwyn states, "young ladies [...] are nowhere" (1829: II, 105), and while her narrative has placed her in a significant position, Evelina must return to that nowhere, which is the female somewhere, as her inclusion in the domestic plot of courtship reaches its closure. This ending to the young heroine's story has once more the undertones of the rehabilitation of the female quixote to society through marriage: disappearance or a metaphorical death. While Burney concludes her bildungsroman granting Evelina her happy ending and her place in society, such an ending proves far from unambiguous. Evelina's narrative ends with her marriage, after that she will no longer write. The final address by Villars and her own response to it, on her wedding day, present a conspicuous choice of words: "ALL is over, my dearest Sir; and the fate of your Evelina is decided! This morning, with fearful joy and trembling gratitude, she united herself for ever with the object of her dearest, her eternal affection" (emphasis added, 1829: II, 272). Her narrative then ends in a eulogic tone which seems out of place in the context of a euphoric conclusion to the young heroine's story. The romantic and idealist female quixote once again dies to be replaced by the homely wife, and the author of the letters becomes silent, as she had been rendered speechless before by the mere presence of Orville.

In conclusion, Evelina is a novel that stands as an important link between More's advice for young girls and a more thorough and psychologically compelling story of a woman's coming of age and of her negotiation to achieve 
social acceptance. Burney would resume many of the topics of her first novel in her subsequent works of fiction, all of which revolve around a young heroine struggling to find her place in the world. What is more important, in all of them the importance of reading as a female site for freedom and the threats society poses for women are recurrently emphasised. These portraits of reading heroines who must awake from their romantic imagining by gaining experience in an often disappointing world also places Burney as an important bridge between Lennox and subsequent authors who penned what could be considered quixotic bildungsromane. 


\title{
3. The Female Quixote of Sensibility: Elisabeth Sophia Tomlins's REVISION OF THE SENTIMENTAL BILDUNGSROMAN
}

\begin{abstract}
Like an eagle confined by a chain, who wishes in vain to soar to the gates of the morning, and behold the fountain of light, I am bound in the trammels of custom.
\end{abstract}

The Victim of Fancy, 31

Much has been written on the topic of sensibility and its significance for the history of British culture and literature. A complex and ambiguous concept which became part of the discourse of several schools of thought in the first half of the eighteenth century, it was ingrained in the mental landscape of the British nation, which experienced a true "revolution in sensibility" in the 1740s, radically changing the cultural panorama of the age. Scholars have associated this revolution with a "gendered transformation of manners $[\ldots]$ in a wide range of cultural practices which cumulatively describe and proscribe the way women lived and were regarded, both at macro-cultural levels [...] and at micro-cultural levels [...]” (Ellis, 1996: 27). Sensibility was thought of as a "distinctly feminine field of knowledge, which, although available both to men and women, was particularly associated with behaviour and experience of women and often apostrophised as a feminine figure" (Ellis, 1996: 24). The cult of sensibility emphasized what were considered natural female attributes such as "intuitive sympathy, susceptibility, emotionalism and passivity" (Todd, 1986: 110), for instance, as opposed to "rationality and objectivity," seen as more masculine traits (Turner, 1992: 43). Therefore, though two new models appear, the man and woman of sensibility, they are markedly different. Todd identifies these sentimental archetypes as "the chaste suffering woman, happily rewarded in marriage or elevated into redemptive death, and the sensitive, benevolent man whose feelings are too exquisite for the acquisitiveness, vulgarity and selfishness of his world" (1986: 4). This image of female sensibility, this chaste and suffering woman relegated to the role of wife, was essential in the construction of the new domestic ideology and in the shaping of the debate on it which permeated the eighteenth century. 
Sensibility was used both as an argument for and against the immurement of women in a limited domestic role. On the one hand, there were the considerations about women's physical limitations. As Todd asserts, at this time, "the female body [...] became an organism particularly susceptible to influence" and such a susceptible organism was thought to "easily become erratic and deranged" (1986: 19). A disease such as hysteria was then considered especially female, for instance. This effect of women's particular sensibility on their bodies was used to prove the impossibility of them taking responsibilities in the more public sphere; for example, in the before mentioned portrait by Stevens in which the liberation of women may bring such disgraces as an "admiral in histerics (sic)" or a Prime Minister "brought to bed" (1799: 34). On the other hand, it was the nature of women as epitomes of sensibility which allowed female critics to emphasize the important role they could develop in society. In line with the ideas on sympathy, benevolence or the growth in philanthropy which this century witnessed, female sensibility was avowed to transform women into the perfect representatives of the increasing importance of charity and the concern about social matters. This was the argument of otherwise antagonistic writers, such as Hannah More and Mary Wollstonecraft, who both criticized the role of a passive domestic woman and vindicated the social role of women.

More praised a kind of Christian sensibility she saw as a positive female characteristic; however, she "defined sensibility as an active rather than passive sympathy for the sufferings of others, one that immediately attempts to relieve the misery it perceives" (Mellor 2000: 28). Therefore, she deplored the immobility and passiveness of the model of female sensibility that authors such as Richardson, for instance, had made so influential at the time. In her view, women's sensibility could be an excuse to open new fields of action to them if it was not allowed to become crippling and if their education was properly oriented. Wollstonecraft focused her criticism on much the same passivity, and demanded not only action springing from feeling, but also from thought. She asserted that women's education had debilitated their minds and made them mere "creatures of sensation," prisoners of their physical and emotional responses to extreme feeling. In her famous Vindication of the Rights of 
Women she claimed that "novels, music, poetry, and gallantry, all tend to make women the creatures of sensation. [...] This overstretched sensibility naturally relaxes the other powers of the mind, and prevents intellect from attaining that sovereignty which it ought to attain" (1975: 61). Wollstonecraft then attributed the "limited intellectual development of most women to the social pressures forcing the female to feel rather than think" (Spacks, 1994: 506) and condemned this "debilitating" education (Richardson, 1994: 174). Wollstonecraft aimed at a kind of education and fiction that would arouse its readers from lethargy and appeal to the "feeling mind" (Analytical Review 1973; qtd. in Mellor, 2000: 93). While she asserted that the natural characteristics of women may lead to the fulfilment of their duties as female citizens, warnings were raised against women's capacity of increased feelings or their vulnerability to "soft love," which would ruin their chances of felicity in this world or the next, by the corruption of female virtue (Todd, 1986: 137) or by its defence of suicide or abandonment to death (1986: 138).

In this debate on the sentimental and domestic construction of women one can perceive the complexities of the message of sensibility. This ambiguity is somehow stressed by the greatest paradox of sensibility, the fact that, although considered to be a natural attribute, a "proper, sincere and virtuous sensibility" could be taught by means of reading (Ellis, 1996: 27). Literature as cultural product and producer of cultural models was considered the best vehicle for the reinforcement of the construction of female sensibility. Conduct books, and especially novels, reflected the inherent ambiguities of the cult of sensibility, at once praising natural feelings and condemning fake displays of emotions, while at the same time participating in this instruction and clearly pointing out the role of literature in the education of the readers' minds and principles. In these narratives, as Wollstonecraft argued, "sensibility must be joined with correct perception," so that "literature must record not flights of fancy or escapist desire but empirical truth" and "not any feeling, but the right feeling must be aroused by good literature" (original emphasis, Mellor, 2000: 94). In this sense the sentimental novel has an extraordinary self-reflective capacity, as in almost all sentimental novels there is some discussion on novels and 
reading, of course differentiating those pernicious books from the beneficial ones, including the very same book the reader has in her hands.

Quixotism thus became a perfect vehicle for such an intention: a young girl's excess of sensibility, fostered by her readings, was identified as quixotism, as a delusion that could be cured and used as an exemplary banner for the implied female readers. It moreover allowed this extreme sensibility to be detached from the author herself, who could offer a framework narrative that would display the limitations, contradictions and dangers of the quixote's discourse of sentiment. Novels of sensation by women, then, very often adopted the perspective defended by More and Wollstonecraft and "led in the movement to establish the active sensibility of the heroine as the model for a new kind of engagement with public issues," while "they remade the novel into a feminized public space in which contemporary political issues could be discussed" (emphasis added, Richetti, 1996: 227). Sensibility became an open space because of those very same ambiguities, and women could use it to defend their status as moral writers or to argue for a change in women's education and social roles.

A quixotic novel that particularly illustrates all the complexity of the debate on sensibility and which serves to reflect on the ambiguous role of sentimental women writers is Elisabeth Sophia Tomlins's The Victim of Fancy. A Novel (1787). Tomlins (1763-1828) is still not a very well-known author, as is the case with many other women writers who were popular in the eighteenth century. Little is known about her life, and not much more about her literary career. Her first novel was The Conquests of the Heart. A Novel. By a Young Lady (1785), and was a highly romanticized biography of a Jamaican friend, also the subject of two of her poems. It enjoyed some praise: The Critical Review stated she pled "the cause of morality and virtue" with success, while The Monthly Review recommended it "for it pleads the cause of virtue" (qtd. in Garside, 2000: 364-65). Both journals, however, agree that it has little or no originality. The critic in the Monthly, identified as Charles Burney the Younger, even compared it to Frances Burney's best-sellers Evelina (1778) and Cecilia (1782) - a comparison that would not have displeased the admiring new author. Charles Burney bestowed an interesting assessment on Tomlins's first 
work, as an example of that new species of writing, the "novel:" he considered the author "possessed some knowledge of nature, and, perhaps, more of modern life," although some passages verged on the "improbable" (qtd. in Garside, 2000: 365).

Tomlins's first novel was popular enough to be used as advertisement for the second one. This subsequent work of fiction, mainly in epistolary form, was The Victim of Fancy. A Novel (1787), which her later obituary would mention as the most popular of her performances. ${ }^{217}$ Later in life, she would publish two more novels: Memoirs of a Baroness (1792) and Rosalind de Tracey (1798), which manifest that “as a novelist Tomlins's style shifted from early sentimentalism and didacticism to a post-1797 realism about deprivations of economics and personal freedom" faced by the working woman (Stevens, 2004: n.p.). A very educated woman and in touch with the intellectual circles of her time, besides these novels, Tomlins wrote poems, translations and contributions to several periodicals. She became well known for political poems which supported the anti-slavery movement, some co-authored with her brother, with whom she published a poetical collection, Tributes of Affection: with a Slave and other Poems, by 'A Lady and her Brother' (Stevens, 2004: n.p.). ${ }^{218}$

The Victim of Fancy is an obvious product of the cult of sensibility. The protagonist is a beautiful and virtuous young girl, Theresa Morven, who is estranged from her father and sent to a nunnery by her cruel stepmother. Released into the world at the beginning of the novel, under the care of an aunt, Deborah Carlton, and awaiting the return of her soldier brother from Gibraltar, she is allowed many leisure hours which she fills with those very same

${ }^{217}$ As Schneider has recorded, it was even translated into the French as La Victime de l'Imagination ou L'Enthousiaste de Werther by A.G. Griffet de Labeaume and F. Notaris (1987: 305). The date of this translation is given by Garside et al. as 1795 (2000: 414).

${ }^{218}$ The biographical and literary data are still scarce. Schneider, in her entry for the Dictionary of British and American Women Writers 1660-1800 (1987), does not provide the titles of all her works. Dale Spender (1986) includes Tomlins in her list of a hundred women writers before Jane Austen, although the data are incomplete as she seems to list both novels, Conquests and The Victim, as being only one work. Cook provides in his introduction relevant data on her personal and professional life; however, the most detailed documents remain Polly Stevens's entry for the Oxford Dictionary of National Biography, which has been used as source for all biographical information provided here, and her obituary in the Gentleman's Magazine, amply quoted by Stevens and Cook. 
accomplishments which Wollstonecraft had signalled as dangerous for women's strength of mind. Theresa becomes an enthusiast of general improvement, in the shape of music or art, and, more particularly, fiction. Among her favourite novels is The Sorrows of Young Werther (1774; translated into English in 1779), with which she becomes so obsessed as to start a quest to meet its author. Instead of Goethe, she meets another highly sentimental creature, Vincent Burrell, and they fall in love at first sight. At the same time, she becomes an enthusiast of knowledge and a philanthropist, who has high aims with regard to her intellectual and artistic aspirations. However, her interaction with the world is limited because her excessive sensibility will transform her into a "creature of sensation," suffering in excess at the sorrows of others as well as her own, and physically incapacitating her several times throughout the novel by means of nervous breakdowns. At one point, her brother hears of Theresa's distresses and abandons the woman he loves, sails through the Channel under a storm, falls ill and arrives in time to see his sister before he dies. Theresa reacts by acting distracted and becoming ill again; her aunt dies because of her delicate condition after nursing her, and Theresa can do nothing but conclude her suffering and the narrative by dying as well.

With its nature as a straightforward construction of a dystopic quixotic plot, with an enthusiast who seemingly dies as consequence of her delusion, the novel raises questions on the associations between sensibility and women, on the impact sensibility has on female development, on the (im)possibility for women of fulfilling their intellectual and authorial aspirations, and on the way in which these aspirations hinder their euphoric integration. Throughout the novel, Tomlins builds a complex discourse in which the patriarchal threat of immurement is exposed and challenged, while the culture of sensibility is described as the main instrument for female enclosure instead of a liberating tool. As a result, the difficulties of employing sensibility as an argument to advance women's independence, and moreover, their authorship, will be also amply displayed in Tomlins's work. The author then seems to shift between notions of active and passive sensibility, of female duty and female freedom, creating a highly ambiguous work of fiction which develops all the 
aforementioned paradoxes of sensibility, in general, and of moral sentimental prose written by women, in particular.

\subsection{Sentiment, Knowledge and Literature: a Different Female Quixotism}

A perceptive critic of The Monthly Review defined Tomlins's second novel as "a new kind of Female Quixote," but rather insightfully saw in it "no resemblance to any former work of the sort" (qtd. in Garside, 2000: 415), distinguishing it from the rest of Lennox's literary heritage. In several ways, Theresa is undoubtedly Arabella's daughter and Lennox's trace is clearly perceptible in Tomlins's novel. For instance, Theresa's story also starts in an overtly fairy-tale fashion: her mother has died as a consequence of her birth and she is left with only one brother, who goes to war, while she is entrapped in a nunnery by her stepmother with the compliance of her "dear, though, deluded parent" (2009: 19). ${ }^{219}$ Finally rescued by her brother and sent to live with her aunt, almost immediately she meets the man who will become the knightly figure in the novel, Frederick Burrell, a suitor also sanctioned by her kinswoman. In the same manner Arabella had some native charms and circumstances which could add plausibility to her transformation into a romantic heroine, Theresa's nature is also described as particularly fit for a sentimental heroine, and, moreover, a quixotic one. First of all, Theresa is young and rich, and throughout the novel she is recurrently praised by her extraordinary beauty. Beauty is required in a sentimental heroine for, under the notions of eighteenth-century physiognomy, the "tie made by Shaftesbury of ethics and aesthetics in popular thought, together with the emphasis on communication through the female body," almost ensured "that female beauty would denote moral worth" (Todd, 1986: 118-9). Moral worth is, of course, a necessary attribute for a virtuous and sympathetic heroine, whom, despite her delusion, will still be required to be exemplary. Finally, Arabella's enclosed

${ }^{219}$ Interestingly, nothing more is said about Theresa's father, of whom she just writes to her brother that she will not remove "the veil you have so tenderly endeavoured to throw over his foibles" (2009: 19). The epithet "deluded" also contrasts with Theresa's description of her mother as "dear and amiable" (2009: 19). This dichotomy may reflect Tomlins's own family situation or emphasise the reinforcement of a matriarchal society or fictional tradition in the face of ineffectual men, as will be later expounded. 
childhood preserved her in a state of innocence from the ways of the world and granted her quixotic naivety. Theresa's confinement has similar consequences: her innocence and virtuousness are identified as her most prominent characteristics and they, once more, link her not only to prior and subsequent female quixotes, but also to the model of sensitive heroine of the time.

Despite the preservation from the corruption of the world it grants the quixotic heroines, this immurement also closes the doors to the wider learning and experience society offers. This exclusion will trigger in Theresa a desire to access all forms of knowledge and fiction, in order to recover the time she has lost with no instruction in science, art and fiction, and will account for many of the mistakes she commits. The greatest is to ignore the impropriety which accompanies excessive female knowledge or to slight the rules of contemporary genteel courtship. These faux pas were also committed by Lennox's Arabella, for instance, once more emphasising what quixotic fictions have of stories of female development within a social context. In addition to these resemblances to other female quixotes, Theresa is said to have an enthusiastic disposition (2009: 9), her frame is recurrently described as delicate (2009: 40-41), her mind as possessing fantastical earnestness (2009: 39), her soul as ardorous (2009: 31). The choice of words seems far from accidental: her enthusiasm - a trait recurrently associated with quixotism in the eighteenth century- and her ardour - a term that relates to the simile of sensibility, and by analogy the sentimental novel, as inflaming- highlight her quixotic disposition, while her delicateness emphasises the fragile nature of her female body and renders her the epitome of the particularly feminine weakness attributed to the heroines of sensibility.

However, Theresa's sensibility is not merely a product of nature: the quixote of sensibility is also the child of culture and society. ${ }^{220}$ Tomlins's heroine is a girl educated in a religious environment who has somehow been taught to have an

${ }^{220}$ In this sense, Tomlins's novel contradicts the traditional portrayal of the heroine of sensibility, summarised in Spacks's famous statement that, in the general discourse of eighteenth-century sensibility and its representative novels, "the hero of sensibility allows himself to feel" while "his female counterpart can't help herself" (1994: 506), and that "the heroine of sensibility, then, only plays out the instinctual nature of her sex, fostering the culture of female victimization" (1994: 507). Tomlins will emphasize in what degree this natural sensibility is brought by women's constraint and how female victimization is to be exposed and challenged even within the form of the sentimental novel. 
exalted spirituality expressed through music which awakens the "fervor of devotion" in her heart (2009: 71) or ecstatic "sacred and rapturous reflections" in her mind as the novel unfolds (2009: 22, 92-93). More importantly, as later West's or Austen's sentimental Marianne will do, throughout the novel Theresa reads those authors considered to foster young readers' sensibility: Ossian, Shakespeare, Homer, Milton, the Countess of Genlis, Sophia Lee, and Fanny Burney are among her favourite writers, with a special place, of course, for the translation of Goethe's extremely sentimental Werther. From the very first letter the reader learns of Theresa's literary enthusiasm and quixotic passion for reading and learning, which leads her to weep over her inability to "read Homer in the original" (2009: 11) and to shed "enthusiastic tears of admiration" over Milton's grave (2009: 12). ${ }^{221}$ As a consequence, it is particularly this literary obsession with fiction which will set the foundation for her sentimental excesses and will also trigger her quixotic quest. The passion Werther inspires in Theresa impulses her to scheme a "project of enthusiasm and fancy" (2009: 75): she decides to start a journey to meet and converse with its author, deriving in what will be called her "foibles" (2009: 30), her “extravagance" (2009: 31), or even her "Werteromania" (2009: 97).

In this sense, Theresa becomes a quixote not only of exalted sensibility, but also of intellectual enthusiasm, for her passion for learning will overcome every other aspect of her life. In a way, hers is a dual quixotism which corresponds to the dichotomy of heart and mind, which Tomlins will recurrently emphasise: a sentimental reactive one, which determines how she responds to the sensorial world, and an intellectual productive one, which triggers her actions and her thirst for knowledge. The first answers to the general construction of the sentimental hero or heroine of the age, so excessively awake to the sorrows of the world that they cannot interact properly in it. As Deborah, Theresa's aunt, asserts, “if your heart flies out thus to every stranger $[\ldots]$ what, my dear niece, will your existence be? If you feel so much in leaving an acquaintance of a week or two, how do you think the great misfortunes of life are to be borne?" (2009: 29). The answer, of course, is

${ }^{221}$ Pearson mentions Milton's Paradise Lost as a milestone for female taste and virtue in eighteenth-century fiction (1999: 58-59), while Shakespeare and Homer share this category as sign of taste. 
that they are not to be borne, for dying of grief is possible for a heroine of sensibility. In this sense, Tomlins's narrative enroots with other novels published in the later years of the century which warned of the dangers of quixotic sensibility. ${ }^{222}$ As for the second, Frederick Burrell most clearly identifies her intellectual obsession, and he exclaims against the warmth of her heart being "wholly expended on works, though noble, inanimate" (2009: 11). Both interact and battle, the delicate frame prone to weakness, and the strong mind willing to learn. Deborah, Theresa's aunt, describes her condition in the following terms:

The unremitting eagerness with which she has perused after knowledge from the time of her being with me, has, I fear, impaired a constitution naturally delicate. In the first earnestness of enquiry she wished to comprehend every thing at once, and, all her talents being in their full perfection, the rapidity of their own progress, which surprized every tutor she employed, encouraged her, perhaps too much inclined, to persevere. Rest, food, pleasure, with her, all gave way to study. She must perceive an alteration in herself; yet her temper retains all its sweetness, and her mind all its gentleness as well as its force. (emphasis added, 2009: 41)

In addition to this obsession or mania with learning, by means of her readings she becomes a paradigm of the literary quixotism that was sweeping through Europe in the shape of that Wertherian enthusiasm which so concerned moralists and authors alike, especially in the case of the more susceptible female readers. $^{223}$ In this sense, Theresa replicates not only Werther's susceptibility to the impressions of the senses, but his own monomaniac nature. In their respective obsessions both idealise the object of their adoration: in Werther's case, an object of love, Charlotte; in Theresa's, one of admiration

${ }^{222}$ Some examples would be Anna Thompson's Excessive Sensibility; or, the History of Lady St. Laurence. A Novel (1787) or the anonymous Arulia; or, the Victim of Sensibility: A Novel, by a Young Lady (1790), in which the heroine also dies from excess of feeling. Walter Scott himself, in the review of Mackenzie's own sentimental Julia de Roubigné, states that "the calamities of the catastrophe should arise [...] from the excess of and over-indulgence of passions and feelings, in themselves blameless, nay, praiseworthy, but which, encouraged to a morbid excess [...] lead to the most disastrous consequences" (qtd. in Todd, 1986: 122).

${ }^{223}$ As an example, in 1792 appeared a novel translated from the French called The Female Werter, written in imitation of Goethe by a Mr Perrin. The critic from the Monthly Review described it as "sentimental trash; fit only to convert our boarding-school misses, first into melting Julias, [...], and then into frantic Elizas, [...]." While in the Critical Review we read in relation to the novel that "the pernicious poison of the "Sorrows of Werter [sic]" wanted not a more general dissemination (qtd. in Garside, 2000: 572). The association of Tomlins's novel with this trend is explicitly acknowledged in the aforementioned translation into French. 
and esteem, her favourite authors and the writer of Werther, an ideal man and author she has created in her head. Once again, her aunt describes her obsession thus:

[...] mild and gentle as she is in other things, when once some object for her impetuosity interposes, she is not to be withstood; she fixes her mind with a fantastical earnestness on one point, and then sees nothing with complacency, but what tends toward it. Who but herself ever thought of setting out in search of an author, because she is persuaded, she knows not why, that he is an Englishman, and fancies herself the only person in the world who does him justice. (2009: 39)

In an interesting turn of events, Theresa is not deluded by fiction: although she displays an intensively sentimental response to her reading, she does not take the discourse of the novel for reality. She acknowledges fiction as such, but is so inspired by it as to hope to debate its merits with the author she so admires. Hers is an obsession of a critical kind, a desire to engage in an intellectual dialogue with her favourite writer and even to become a critic herself: a quixotic one that believes she is the only one who understands and can do justice to Goethe's work -ironically, the perfect foundation to become a critical scholar of any kind. Throughout the novel she cleverly analyses Werther's characterization, plot and moral message in articulated speeches that evince that she is a rational reader that has taken her passion too far. This sentimental response to literature and the subsequent critical mania is later transmitted to her reading of Frances Burney and Sophia Lee. On Burney she states that no other author can be ranked with her, while she states of Cecilia: "[t]here is a strength of mind and nobleness of sentiment pervading that whole work, which has often forced tears from my eyes, and has warmed and enraptured my heart" (2009: 36). At one point, Theresa hears Sophia Lee is in the Pump Room at Bath. Lee, at the peak of her success after the publication of the popular Gothic novel, The Recess (1783-85), attracts "universal attention" and draws a crowd towards her while her name is whispered through the room (2009: 36). Theresa's thoughts at this moment are very revealing:

$[\ldots]$ the intelligent countenance of a lady, who stood near, interested me at the first glance. [...] And this then, though I, is the Temeraire, whose name has been publicly joined with that of one of the first female writers of our age!

[...] I wished, however, to address this celebrated author; [...] 
I will read this Recess, of which she is the author, if I shall be able to procure it; [...] (2009: 36-7)

Lee, compared with the inimitable Burney, attracts Theresa's attention as an author, in the same manner Goethe did. However, the appeal is triggered in this case first by Lee's person: her intelligence and her success are an enticement for the reading of her famous novel to ascertain its worth and for Theresa's interest in her as a novelist. Theresa's reaction to The Recess is described in detail in her own recommendation of it to her brother:

[...] that elegant work, in which is united all that is most charming to the heart and the imagination! Its language, with all the fire and all the softness of poetry, conveys images the most enchanting to the fancy, and scenes the most interesting to the heart. [...] As I read, I felt the pains of suspence (sic) at my heart, and I know not a term which can convey to you an idea how infinitely I felt myself interested through the whole: I was frequently affected even beyond the power of weeping,[...] I had all the luxury of weeping over it by myself. I concluded it some hours before I attempted to rest, and then I started from my dreams, impressed with all the sensations I had felt so strongly in perusing it. (2009: 56)

Theresa once more reacts sentimentally to her reading of Lee, but she also becomes a rational critic of her fiction, who can articulate her opinion on its merits, as well as on the effects it has on her. Her suspension of disbelief, her absorbed reading, lasts only while she reads: after the book is closed, Theresa aims to become as capable of expounding on it as any other male character in Tomlins's novel does.

As was the case with prior quixotes, Theresa's quixotism, whether expressed in her exalted sensibility, her aspiration to knowledge or her quest for Goethe, allows a double message of freedom and constraint which enroots with the same dichotomy already present in previous female quixotes. On the one hand, Theresa's quixotic quest allows her to abandon her limited domestic circle and travel around the country, arriving, as well as Arabella or later Catherine Morland, to Bath, the better stage in which to contemplate all rituals and characters from genteel society and to shine in comparison. In Theresa's interaction in society her moral and intellectual superiority once again provides the axiological comment so intrinsic to female quixotism; in several instances 
the shallowness of other people is stressed by means of their conversation on "reigning fashions" and "crapes" and "blondes," even expressing the opinion that Theresa's judgement "in those important affairs" might in time be expected to improve (2009: 12). A very striking example occurs when she visits a museum. In truly sentimental fashion, Theresa is a confessed admirer of painting, "that more than speaking sister of poetry" (2009: 13), and spends an hour contemplating a painting that particularly speaks to her fancy. Her enraptured and admired attention contrasts with that of another lady who directs Theresa's attention to the frame, which she assures "cost 150 guineas," to which Theresa exclaims: "the frame, my dear brother, of a picture, and such a picture! - For my part, I had not even seen that it had one" (2009: 14). While her enthusiasm for painting may be seen as extreme, the lady's ignorance and shallowness renders Theresa's passion less condemnable. In contrast with her superficial peers, her fervour for Werther, and reading in general, also provides an opportunity to make evident her rational thinking and impress the reader with a sense of her intelligence. She is capable of discussing the merits of Werther with another learned man, Doctor C--, and to aptly express herself in written form, not only on the description of her experience, but also on literary or artistic criticism. In those instances, Theresa becomes the subject of her own story, shaping its plot and its discourse. She even openly avows her quixotic desire to search for fame (2009: 105), as the old Spanish knight or even Arabella intended to do against all social impediments.

On the other hand, her mania, as would happen for other female quixotes of this age, will be dangerous for her virtue, and Deborah writes to her nephew that she trembles "lest some designing person should get scent of that peculiar turn of mind of hers, which might lay her open to arts of which she would be the last person in the world to imagine herself the object" (2009: 41). Indeed, her turn of mind makes her a “dupe, not only of another's artifice, but of [her] own weakness" (2009: 75), when a man in love with her assumes the identity of the author of Werther and she agrees to meet him alone in a retired house. In addition, Frederick Burrell, his brother and Theresa's aunt agree to deceive her so as to cure her mania by pretending Vincent Burrell is Goethe himself. Despite the fact that others adjust to her Wertherian quixotism, that others play 
along to fulfil her quest, Theresa is not aware of it as Arabella was of Glanville's adoption of romantic conventions for her sake. It is unwillingly that she imposes her vision on others and she remains without control of it. Therefore, in this situation Theresa also becomes the object of others' plots and is relegated to the role of responder rather than agent, once more emphasising the liminal space which quixotic heroines inhabit. ${ }^{224}$

As stated above, the ambiguity inherent to female quixotism, this dichotomy between power and submission, freedom and constraint, is reinforced by the presentation of sensibility at the core of Theresa's nature, with all the implications of the liberating or entrapping effects it could have on women. In this regard, the surrounding characters interpret her epistemological confusion as founded not on how she romantically interprets people or reality, but on how she sentimentally answers to her sensorial reading of the world sanctioned by the examples found in the novels she reads, especially Werther. This sentimental response, this filter or veil that clouds her judgement and conditions her interaction in society, works both on a physical and an intellectual level. As a perfect sentimental heroine, she possesses their most striking characteristic: a superlative and virtuous sensibility that she communicates through a meaningful body and that evinces its authenticity in a series of conventional physical reactions, such as tears, blushes, palpitations and fainting fits. As the novel unfolds, Theresa's body constantly reacts to her phenomenological experiences, to her sensorial perceptions. She reacts to sight and hearing, which trigger most of her extreme reactions: she is moved by the sight of a sickly man, or by the sound of a flute, for example. While these responses grant her the possibility of greater expression, they also limit her because of the physical weakening and immobility they imply. Even so, the discourse of sensibility does not remain merely on the physical level; despite its nature as a discourse of the body, this phenomenological experience is translated into philosophical or moral principles that will rule Theresa's actions and thoughts, a fact emphasised by her highly mystical living of religion. Her

\footnotetext{
${ }^{224}$ Parenthetically, Theresa offers a lengthy digression on the embarrassment women must suffer as objects under the gaze of men, when their confusion and their blushes are misunderstood for vanity (2009: 21), highlighting their role as object. Though another piece of evidence of the social comment that Tomlins provides in her novel, it is also a perfect metaphor for the exposure of Tomlins and her sentimental heroine to the gaze of male readers.
} 
exalted sensibility therefore finds expression in the way in which she interacts with others, highlighting the discourse of active Christian sensibility that women were developing at the time. Theresa's sentimental quixotism is thus the construction of what others perceive as flawed axioms -for instance, her extreme pity or generosity. However, once more, these axioms or values have a double reading depending on the conception of sensibility as an active or passive practice, as a social instrument or a mere physical reaction, and, as a consequence, on the role of subject or object, of active agent or passive responder that Theresa adopts.

In Theresa's own words, sensibility understood as sympathy for others should lead to active compassion. In a discourse similar to More's, Theresa's opinion is that sensibility should be associated to the practice of philanthropy. She then not only sympathetically responds to the suffering of others, but she also actively seeks to perform charitable acts:

I thought $[\ldots]$ of the numbers who fall and are lost in the devouring gulph of perdition. I looked towards heaven -children of error as we all are, my eyes filled with tears, when I thought of the severity which some of them experience. [...] 'Be it mine, Father of Mercy!' said I, 'never to transgress thy laws; be it mine also to pity those who do!'- When we stretch forth the hand of compassion to the feeble, when we raise them from the gulph which should open to receive them, does it return to us sullied by their guilt, or does the tincture of their crimes overspread it? Let us fly their contagion; but, in doing so, let us not suffer it to extend to others; let us not, careful of our own security alone, suffer it to destroy for ever those who are already infected. (2009: 72)

In accordance to these beliefs, Theresa relieves a very sick man and his sister from penury, and she acknowledges she raised "from the dust a daughter of imprudence and misfortune," removing her from scenes of infamy to "honest industry" (2009: 72), in an echo of what More and other female reformers sought by housing and educating former prostitutes or single mothers. In spite of the fact that her aunt, "who is rather severe in her morality," blamed her for her philanthropic vision, Theresa states that a year has elapsed since she helped the fallen woman and that she hopes her expectations and not her aunt's "will be fulfilled" (2009: 72). While her aunt defends a more restrained conception of sensibility and philanthropy, Theresa's sensibility then also fuels an 
idealistic project of social and moral reform which preaches the need for women to become involved in the reality of their time and attempt to actively relieve the suffering of others. In her aunt's conservative discourse, Theresa's excessive sensibility leads her to become, first, a fool in the hands of that fallen woman and, secondly, a woman who leaves her proper sphere. Theresa's quixotic adherence to her own ideals and her wish to do good place her in the position of those male philanthropic quixotes at the turn of the century: morally superior, but at odds with their less idealistic contemporaries.

This alienation from her sanctioned place is moreover emphasised throughout the novel in the manner in which Theresa expresses her sympathetic responses as a capable woman of action who, in a very heroic manner, runs to the rescue of her fellow creatures. For example, she breaks her arm trying to prevent her aunt from falling out of their carriage when it is overturned (2009: 18); she puts herself in danger aiming to save some children from being injured by the fall of a may-pole (2009: 27); she revives a sick soldier by applying restoratives when all other people present had been "overcome with terror" and had appeared "incapable" of helping (2009: 50); and, more relevantly, she prevents her undeserving lover, Frank, from committing suicide. After deceiving her by means of an impersonation of Goethe, Frank, the suitor of Theresa's closest friend, decides to shoot himself. At his attempt, Theresa reacts as a true heroine:

[...] I saw his eye glance to the dangerous engine [a pistol] which yet lay on the table. The hint was enough. Swift as thought I darted across the room, and happily secured the pistol, and summoning all my resolution, with one hand, as he wildly seized the other, discharged it. The window being down, it made a violent crash; [...]. Defeated of his intention, Frank flung himself on the floor, whilst Ruth, no longer able to sustain herself, sunk on the spot where I had left her. I returned to support her [...] (2009: 79)

Theresa is moved to action by the necessity to help others and, in particular, in order to prevent an even more wertherian act than any of her own. In this regard, she is a more active quixote than Arabella and she becomes closer to the Spanish knight in his desire to do good deeds for the more unfortunate. As a consequence, she is involved in actual adventures such as the above described and also approaches other contemporary heroines who more actively 
interact with society than the isolated female quixote, such as Burney's successful and influential Evelina. ${ }^{225}$

However, despite her active and heroic nature, as happens with other sentimental female quixotes, throughout the novel Theresa is also forced to immobility and uselessness by her fainting fits and general weakness, which are triggered by her extreme emotional responses and by her incapacity to deal with extreme physical or intellectual challenges. In her exaltation in conversing with Doctor C-- her own exertion of energy stops her (2009: 42). At the moment of saving her aunt from falling from the carriage, Theresa breaks her arm and, as a consequence, she is taken ill and must remain immobile; on another occasion, after taking care of her during an illness, Theresa herself falls ill with a fever which seriously undermines her health (2009: 41). What is more important, she is constantly forced into immobility by the surrounding characters. Burrell prevents her saving the children, and several characters aim to thwart her quest in search for Goethe, always employing her delicate health and her childlike innocence as excuse. Subsequent to the episode with the carriage, Theresa writes: "[a surgeon] insists on confining me some days longer" (2009: 19). Another example of Theresa's rendering as controlled object appears after she has prevented Frank's suicide, when Burrell immediately enters the room and takes charge of the action, once again thwarting Theresa's absolute command over the situation and leaving the heroine little option of agency but fainting. Tomlins then contributes to Wollstonecraft's criticism of the childish state in which women were asked to remain in order to become more controllable and invisible within society, most often with their sensitive nature provided as an argument for their need for restraint.

In addition, the novel's conclusion reinforces the dangerous passivity triggered by women's lack of agency. Though capable of preventing the above mentioned scene of death worthy of Werther himself, Theresa dies in a very

${ }^{225}$ Cook has pointed out how this passage resembles Evelina's hold of Macartney's arms to prevent what she assumes is his intention to commit suicide, causing him to drop his pistols. Cook concludes that "both Evelina and Theresa have to grapple with the weaknesses of masculine sentimentalism in order to validate their own strength" (2009: xix), a matter that will be later resumed. 
similar way to her literary hero. Even if not committing suicide, she abandons herself to death in the peak of passivity when faced with extreme feeling. Theresa finally seems to display that selfish emotionalism which had been amply condemned in Goethe's novel and her sensibility, ironically, leads not only to physical but emotional insensibility. This is especially obvious in the scene in which Major Morven dies. As she embraces her dead brother she "appeared totally insensible," for days later "the rays of her eyes would be quenched in insensibility," and "she would remain for hours resting on her harp only $[\ldots]$; her look cast with a wild and melancholy earnestness towards heaven, $[\ldots]$ whilst only the deep sights which at intervals escaped her bosom, shewed (sic) any recollection" (2009: 103). Her insensibility is highlighted by the effect her state has on others. The narrator then explains that "all hopes of restoring her were lost, and her aunt, whose health, was at all times but indifferent, affected beyond recovery by the double shock, quickly followed young Morven to the grave" (2009: 103). ${ }^{226}$ Vincent is described as "half distracted;" and even Ruth, Theresa's close friend, has her health injured "by her attendance of her friend" (2009: 104). In her last days, Theresa becomes more than ever a child, a doll to be taken care of by others, and, finally, a silent creature that cannot even write by her own hand any more.

This final silence and immobility emphasises what have been the most relevant questions concerning women's nature and social status throughout the novel. Theresa's final renunciation seems to answer to the impossibility of negotiating with the demands the culture of sensibility has on women, as well as to the difficulty in overcoming the obstacles in her quixotic quest. Hence she gives in to her highly feminine sentimental and passive death, thwarting her integration into society and providing a dystopic plot of female development. This tragic ending in Theresa's story of development reflects the dangers of sensibility for the happy conclusion of the female bildungsroman. These dangers threat, on the one hand, the domestic sphere and the conventional courtship plot, in which she is hindered from fulfilling her aspirations to becoming Vincent's wife. On

${ }^{226}$ It is interesting to note that Deborah Carlton, one of the greatest advocate of conventional and patriarchal rules, and a strong critique of Theresa's sensibility dies, in a similar way to her niece. Her death, together with the decease of Major Morven, reassert the frailty of patriarchy itself, as will be subsequently expounded. 
the other hand, they also affect a more intellectual and even professional realm of a woman's story of development, expressed by Theresa's wish to become a learned woman and an acclaimed author. This focus on professionalization is an interesting addition that brings the novel of female development closer to the more conventional bildungsroman understood as the apprenticeship of a young character. The fate of the woman of letters therefore runs parallel to that of the woman of sensibility in Tomlins's novel, as will be subsequently asserted, and their respective negotiation of their place in society provides two answers to the plot of female development.

\subsection{Not a Wife, but a Writer: an Alternative Ending for a Sentimental Female}

\section{Bildungsroman}

As was the case with other narrative fictions which focused on a young heroine's story -More's didactic works or anti-Jacobin quixotic novels, for example- Tomlins is employing an antidote that shares the form with the poison it hopes to counteract: she is writing a sentimental novel that expects to teach the value of regulating excessive sensibility in the public, and in women readers in particular. The didactic intent of the novel is highlighted by Theresa herself when she writes in her last letter to Ruth:

[...] when capable of her mother's sensibility, tell my little Sophy the short story of your Theresa's life; from that let her learn to regulate her passions, even the most innocent of her heart: it is the impetuosity of mine, I am persuaded, which has done much in destroying me. [...] If we would live, we must regulate, we must even subdue the tenderest feelings of the human soul. (2009: 107)

Hence, as happens with most works in the present study, the didactic purpose of the quixotic narrative of cured enthusiasm restates the value of the novel itself. $^{227}$ As the critics had asserted of her previous novel, it is Tomlins's defence of virtue and morality which renders her work worth reading. At one

${ }^{227}$ It is also significant that she addresses a child. Theresa also offers a digression on children's education, defending an early attention to their "power of comprehension" and "susceptibility of impression" in order to abridge childhood and gain more maturity (2009: 84). By addressing her story to a girl, Theresa states the didactic utility of moral novels in the education of young girls. 
point, Theresa explains to Doctor C-- that Werther's intellectual powers are weak at the moment of attempting to end with his life, he is then not to be blamed but pitied, and his story to be used as an example for the readers. In addition, in the advertisement of the novel Tomlins herself describes her intention as presenting the moral of Goethe's novel under a more favourable light; moreover, she hopes that "whilst endeavouring to render justice to acknowledged genius, and to regulate the principles of the heart, she may have been able to engage its affections, and to point out to it, as the most desirable of all blessings, Religion and Virtue" (emphasis added, 2009: 6). Therefore, Tomlins parallels her extremely sentimental heroine with Goethe's in the sense that she aims not to foster imitation of her heroine, but to create sympathy in her readers -to engage their affection, as she proclaimed in her advertisementand to use Theresa as a banner to avoid that distraction, the Wertherian madness of excessive sensibility. Not only is this excessive sensibility learnt from a novel to be counteracted by another one, as coeval works of fiction had aimed to do, but apparently Theresa's own Werteromania or literary enthusiasm, Tomlins's original addition to the heroine of morose sensibility, is also destined to be exposed by means of her tragic exemplary story. The fact that she identifies Theresa's enthusiasm as a mania allows this association with delusion and can hence be more easily forgiven and counteracted with the same instrument that brought the poison: a novel.

During part of the narrative Tomlins in fact gives the impression of preparing a conventional happy ending, with Theresa's cure of her wertheromania and her quixotic literary aspirations, and her reward through a marriage to her beloved Vincent to highlight this return to patriarchy as the desired end for the heroine. In this sense, Tomlins seemingly follows Lennox's creation of a model of a romantic quixotic heroine who achieves her fairy-tale conclusion. Theresa states "this Werteromania is cured" because her "heart and imagination are at present so much otherwise engaged" by her love for Vincent Burrell (2009: 97); even the Doctor states that the object of her admiration "is perhaps less visionary at present, and something more easy to be pointed out and procured" (emphasis added, 2009: 97). Theresa's obsession with literature will be overcome by a focus on a more appropriate female experience: love. The 
epigraph chosen by Tomlins, taken from The Progress of Fashion (1786), a popular work on women's education, stresses the idea that one passion could be subdued by a more proper one: "with frames and constitutions weaker than Men have, the passions of Women are warmer; and the rays of their genius concentrate to the object on which they engage themselves more strongly -it absorbs all other considerations" (2009: 3). As Arabella substituted one form of fiction for another, and became the compliant heroine of the domestic didactic novel, Theresa is asked to do the same: to renounce to the plot of her literary quest and her desire for learning which has given her voice and to become an invisible -and unnarratable- wife. This is particularly clear when one reads the text from the Progress of Fashion which Tomlins summarized, as provided by Cook:

The great end of a human being relatively to his fellow-creatures is social happiness. In the union between man and wife, this is almost the sole object. And how shall we expect to attain this end, with a woman given entirely to any one pursuit of science or of pleasure? If of science, there is surely little prospect of finding, combined with it, a steady attention to the duties of a wife, a mother, or a friend. The reason is obvious. With frames and constitutions weaker than we have, their passions are warmer, and the rays of their genius concentrate to the object on which they engage themselves more strongly than ours. It absorbs all other considerations. (2009: 109)

Therefore, the passion for science, or intellectual improvement, must be abandoned in order to achieve the traditional happy ending in the shape of marriage, which is also perceived as the great end of women in the conventional bildungsroman plot. Yet Tomlins remains unresolved: she hints at the romantic plot and the opportunity for happiness, but it is not a cure, it rather fuels a sentimental obsession that can completely engage her heroine's heart and imagination instead of her intellectual and literary enthusiasm. As the novel unfolds, the characters that represent the patriarchal discourse actively aim to restrain Theresa from any intellectual activity or any unladylike physical exertion, hence trapping her in the discourse of sensibility and female duty. The cure cannot be then complete because love only renders Theresa still a creature of sensation as much as she was thought to be in her excessive sentimentalism; Burrell, Vincent or Deborah, then aim not to cure Theresa's sentimental response to life and literature, but to direct it at a more acceptable 
and appropriate obsession, love and marriage. That is, of all her enthusiasms, the traditional conclusion of the courtship plot would reinforce Theresa's passive sentimentality, while curing or erasing her more intellectual aspirations, her wertheromania or her desire to read and write. Her family and friends then seek for the conventional closure of the quixotic plot, recurrently emphasising the need to focus on the more acceptable female experience of love and courtship than science or literature. Theresa's aunt complains that she "paid a thousand times more attention to the entrance of a young lady [Lee], who has lately distinguished herself as a writer, than to all the compliments of this new and elegant lover [Mr. S]" (2009: 41). In this scene at the Pump Room, her suitors prevent her access to Lee, while later her aunt hinders her reading of her novel, emphasising how the patriarchal plot stands in the way of Theresa's aspirations and hopes she will direct them towards a more conventional feminocentric experience. Frederick Burrell states in the first letter of the novel that "the desire of knowledge in her [Theresa] [...] almost becomes a passion; but a man who loved her, would know there is another much stronger than that in the world, and would hope too, that such a mind as hers was destined some day or other to experience it" (2009: 8). He recurrently complains about the one idea that so wholly possesses Theresa's "intelligent mind, that no other can find entrance in it" (2009: 11). To this Theresa firmly answers, "You mistake me, Burrell, [...] one idea does not yet possess me wholly, to the exclusion of all others. You mistake me, I am not yet absolutely mad" (emphasis added, 2009: 11). In Theresa's opinion, her philanthropic, literary and artistic interests remain diverse enough to avoid the charge of a maddening monomania, and contrast with the idea other characters share that the sole interest of women should be love and marriage.

Love, in Tomlins's novel, is then neither cure nor closure, because Theresa is incapable of renouncing to all other aspirations to concentrate on love and marriage, as other quixotes did. While, in general, in these quixotic female bildungsromane the acknowledgement of love is usually the first step to selfawareness, it is not complete without a rational and moral conversion as well; nevertheless, the latter cannot exist when it is precisely the denial of any intellectual activity which is being advocated by Theresa's alleged mentors. 
Therefore, instead of portraying as Lennox the possibility of intellectual instruction and, hence, of a rational process of awareness, Tomlins emphasises the reality of women's limited education and the absence of training for their "powers of the mind," as well as the patriarchal desire that female ignorance should remain unchecked. ${ }^{228}$ This element is emphasised by the condemnation of knowledge in women, reinforced by the representatives of the patriarchal model of the family. At the beginning, Theresa's aunt has allowed her to spend all her spare time reading, without advice or guide. Theresa's mentor and first suitor, Mr Burrell, states in a letter to her brother that he is afraid their aunt reads little herself but "leaves the world of books open" to Theresa (2009: 9), and he adds that he "cannot but fear lest her lively imagination should mislead her; since whatever she peruses, she enters into with a warmth of disposition" (2009: 9). Opposed to this general improvement, or these accomplishments, intellectual education is not encouraged by her family. Theresa's moral worth and her delicate sensibility are praised above her intellect; however, she places her worth elsewhere when she exclaims: "why should I blush to avow to that world my passionate admiration of the sublime effusions of science or sensibility?"(2009: 10). The reason seems to hide in her aunt's speech on female education:

[...] when women talk of their love of learning, half of the men charge it to affectation only; and, what is worse, when they believe it real, by a paradox I cannot solve, they at once envy and despise us for it. To own the truth, learning is a qualification seldom necessary in our sex; and, without extraordinary humility in its possessor, only disgusting -besides that there are a thousand others more conductive to happiness. (2009: 12)

Theresa warmly asserts that "this turn of reasoning is not very consonant" with her own ideas (2009: 12) and she continues to expose her aunt's "complaint of the diligence I am as incapable of abating as she perhaps of approving" (2009: 12). Moreover, she states that were she capable of believing that women were condemned owing to their knowledge, she would not write it, for "the heart formed by nature not ungenerous, remains long shut to those severe dictates which age so often dignifies with the name of prudence" (2009: 12). Another

\footnotetext{
${ }^{228}$ As Todd has phrased it, "the sentimental heroine is exemplary in accomplishments, [...] while not compromising, with formal education, her status as victim" (emphasis added, 1986: 118).
} 
of those dictates proclaimed under the name of prudence concerns the reading matter considered proper for women. Echoing the words of many moralists, Deborah recommends history to her niece. However, as did Arabella and will do later heroines such as Barrett's Cherubina or Austen's Catherine, history is found wanting in the eyes of female readers. In Theresa's words,

I have read history, and what, my dear brother, is it? A picture of the crimes of mankind from generation to generation - too often a false mirror of persons, such as they never existed; while those characters alone worthy of imitation, are frequently lost in the multitude, without even a memorial of their virtues remaining. (emphasis added, 2009: 16)

Fiction, on the other hand, allows not only to delineate characters worthy of imitation and, hence, to serve a clearly didactic purpose, but also to offer a memorial for those minor characters who are lost in the traditional narration of historical events. The novel, as opposed to historical accounts, can then recover not only History, but what Unamuno termed intrahistory; it can provide space not only for the great events of mankind, but also for the uneventful construction of the domestic core of the British nation which is the silent background against which the famous happenings are played. In this regard, those exemplary and often-forgotten characters whose virtue is praised in fiction, of course, could include more women than are usually portrayed in history.

In opposition to the patriarchal defence of the reading of history, Theresa continues to claim an aspiration to more artistic and creative tasks, in particular writing. She expresses her wish to adequately express herself in writing: "how often have I lamented, how often hereafter I shall lament, the impossibility of adequately explaining the sensations which arise in my soul! I take the pen in hand; I put my thoughts on paper, and they are nothing" (2009: 13). Her continuous comment on her writing and her appeal to her reader's benevolence or understanding is evidence of her concern with authorship as something more than a lady's pastime in the shape of letter-writing. ${ }^{229}$ Moreover, her raptures in

${ }^{229}$ Constantly appealing to her brother's understanding of her character or feelings, Theresa writes: "I am surprized at the length of my last letters, and you perhaps may never receive them, or, should they reach your hands, they may but little interest you. -But, no, I will not believe it. The narrative of those sentiments and emotions which arise in the heart -and, 
front of Milton's tomb, or a painting, or while playing, give voice to the liberating effects that art has for women. While the discourse of sensibility has been recurrently analysed as a subtle means by which women could give expression to their feelings and desires, Theresa's exalted sensibility is in this case ineludibly intertwined with her artistic aspirations. She continuously describes her heart as susceptible to "genius and sensibility," art and rapture go hand in hand and offer freedom in the face of the recurrent patriarchal discourse of control, with which it starkly contrasts.

This opposition between constraint and freedom, as asserted above, provides one of the cruxes of the novel, also in relation with her intellectual and authorial aspirations. The language of immurement and control which the representatives of patriarchy employ or act out as the novel unfolds, is presented in opposition to Theresa's impatience "of control" (2009: 31) and her desire to press her aspirations further. Theresa herself counterpoises the language of confinement and freedom, both in terms of physical and mental states. Liberated from the nunnery, she exclaims: "For twenty years immured from all that the heart pants after, from knowledge [...] awakened from the darkness of ignorance, [...] I now first feel that I exist; [...] I rejoice in this happier birth-day, I look on the first moment of being as infinitely less dear: my mind is no longer benighted" (2009: 9-10). Her physical confinement is made wearier owing to her mental limitation; once she escapes the nunnery she is born again, her intellectual rebirth becoming her most important beginning, her intellectually quixotic aspirations becoming the dearest part of herself. Nevertheless, even out of the walls of the nunnery, Theresa will battle for control over her intellectual responses. Confined by the surgeon, she states: "writing I will not be denied. I have a thousand things more to add; but my aunt, dear woman! too watchful over me, insists on my deferring them for the present. [...] My heart labours with a thousand emotions, and I am forbidden to express them" (2009: 19). What seems natural care will at times be described by Theresa as asphyxiating control; she states "my aunt, who would never

conscious of it as I am, why should I not say it? -the sensible heart of your sister, you are incapable of perusing with indifference; you will take part in every sensation of her soul, and, if you cannot be blind to its errors, you will, at least, behold them with the unreproaching pity of sympathy, and the tender partiality of affection" (2009: 90-91). 
leave me alone, $[\ldots]$ prevented me from sitting down to write to you till night" (2009: 54), or that she will "always find some method of drawing me from my writing" (2009: 55). In addition, despite her rejection of love as sole pursuit, she will struggle for control over the decision which proves essential for all female quixotes and heroines of bildungsromane: whom to love or marry. Continually pressed by her aunt and Burrell to accept the latter as an appropriate husband, Theresa struggles to maintain her ideal love first for the author of Werther, and then for the mysterious man which is discovered to be Vincent Burrell, once more uniting the intellectual and the sentimental as sites of rebellion. As the novel unfolds, and she persists on both her rejection of Burrell as a suitor and her quest for the author of Werther, Theresa protests of the coldness and disapproval she receives from her aunt, stating that "she seems to think that there may be another way of controlling me besides tenderness" (2009: 30), while her raillery and severity, thought to "subdue" Theresa's feelings, only teaches her to "conceal" them (2009: 54). Accused of impropriety in her stubbornness not to accept a conventional destiny, she revealingly complains: "If my ideas and my affections are to be confined, I will quit them, I will quit England, and fly from their [Deborah and Burrell] persecutions. The ardour of my soul is not, I cannot wish it to be subdued. They attempt to stop its torrent; but they mistake, they only increase its rapidity" (emphasis added, 2009: 31). Her desire for escape in the face to opposition to her quixotic quest for unlimited freedom will only be granted through death; she has no place in her society, as Don Quixote did not find one in seventeenth-century Spain, and they both disappear.

Theresa is then an exemplary quixotic heroine who moreover faces many trials which heighten the empathy of the reader. Nevertheless, she is not awarded her intellectual satisfaction. What is more relevant, neither is she awarded the conventional ending her family and friends try to force on her. While in the case of other female quixotes this failure to fulfil the conventional happy ending of the sentimental plot is presented as a punishment for their subversive aspirations, as will be the case with West's heroines, the challenge to conventional discourses has been made too evident to interpret Tomlins's ending as anything else than a comment on the impossibility of fulfilling 
female aspirations to a creative profession within a society that is found wanting. The failure of the patriarchal establishments and plots is evidenced, at least, in three facts: the ineffectual male guidance of the doctor or the curate, the death of Major Morven and Theresa's failure to marry.

The Victim of Fancy widely addresses, in the first place, the matter of ineffectual patriarchal models. In particular, there are three failed fatherly characters: Theresa's deluded father, Doctor C-- and Mr Manville, a curate. Theresa's father is erased from the narrative from the beginning. Doctor C-stands as a surrogate father figure in the novel, looking after Theresa physically and intellectually, and his "fatherly manners" towards her are explicitly acknowledged (2009: 71). First of all, Tomlins evidences how the discourse of Doctor C-- can be not only refuted, but how it can be merely an echo of Theresa's own considerations. That is, in much the same subtle manner in which Lennox had Arabella appropriate the Doctor's own argumentative power, Theresa convinces the Doctor of Werther's madness, or Charlotte's blame. Moreover, at one point she accepts his advice as that of a "father" (2009: 73), even though his words are merely a reproduction of what she had written to her brother before. Thus, when the Doctor warms her against those novels that portray the possibility of love at first sight as "both improbable and unnatural," and as guiding their readers by "fancy and imagination" only (2009: 72), Theresa's own reflections on the irrationality of her partiality for Vincent after one meeting prove a more effective didactic instrument than his lecture. In addition, the Doctor's authoritative speech is imbedded in her own first-person narrative, granting Theresa editorial powers over his discourse and superposing her voice over his.

A more overt criticism to the patriarchal establishment is Tomlins's satirical portrayal of one of the epitomes of the patriarchal establishment, a curate $\mathrm{Mr}$ Manville, whose name is even significant of his status as representative of male authority. Less subtly than Lennox's questioning of the Doctor's authority, she has Theresa openly criticise the curate's hypocrisy and, hence, undermine both his discourse and his position as a valid source of moral authority. Mr Manville at first impresses Theresa with his eloquence and his sublime reading, perceiving him as a man of true sensibility, as she is herself; but, once she 
opens her eyes to the true nature of the divine, Theresa acknowledges her mistake in the following terms: "The enthusiasm I boast of deceives me. [...] The torrent of eloquence and energy which I had heard, flung a mist before my eyes: he who had enchanted me with it, seemed struck with the sensibility I could not repress, and I was blinded completely" (2009: 23). Invited to his house, she is finally able to read him as the hypocrite he is, interpreting man and discourse accurately and awakening from her enthusiastic delusion. The curate is then another ineffectual father figure and mentor.

Secondly, Tomlins's novel also highlights the failure of men to remain impervious to the dangers of sentimentality themselves in order to fulfil their role as husbands, guardians or mentors. In this sense, the men in the novel prove to be at least as Wertherian as Theresa is. The abovementioned example of Frank's attempt to shoot himself is the most obvious example. Even before the failed suicide scene, Frank consciously identifies himself with Werther, when he is deeply moved by the events described in Goethe's book and compares them to his own situation with Ruth and Theresa (2009: 26). Prevented from committing suicide, he can live up to his promise of love and marriage to Ruth and become the husband and father that men of honour are intended to become. However, there are other less noticeable examples of men of feeling and the dangers they pose to society. Mr S--'s reaction to Theresa's rejection -his rambling speech or his rash leave of Bath-, are once more consistent with the idea of a Werther at fault for his excess of passion and his lack of control when faced with romantic disappointment. Major Morven is identified as a similar enthusiast to Theresa. Theresa writes to him: "You accuse me of enthusiasm! - you my brother who yet wander with the ardour of a soldier on the rock of Gibraltar, and have dedicated your life to the hero who defended it" (2009: 9). Moreover, Deborah advices her nephew: "Do not suffer yourself to be carried away in the same manner as [Theresa], nor, through a romantic admiration of the general you have so well distinguished yourself under, suffer your sister to want that protection which her peculiar turn of mind, her inexperience, and her very attractive person, put her so much in need of" (2009: 41). In addition, he fulfils a sentimental destiny and dies as consequence of his excessive feeling for his sister and his sense of duty 
towards her, which leads him to defy the storm and fall ill. By doing so, he is also prevented from fulfilling his duty as soldier and from marrying his own fiancée; that is, his story is also a thwarted novel of development. More relevantly, he is unable to exert the power he has over Theresa (2009: 40) or to claim the "obligations" which she acknowledges in relation to her brother (2009: 8), being one of them her possible marriage to Burrell. Sensibility then also undermines patriarchal authority when it provides an escape from female obligations of marriage by its effeminising effect on men. ${ }^{230}$

Tomlins, as woman and writer, appropriates the discourse of sensibility and employs it to create a gallery of sentimental, powerless and ineffectual men, hence evidencing that extreme sensibility possess an unnaturalness common to men and women, for it incapacitates both from fulfilling their natural potential and/or their social duties. Of course, these duties are different to that of women, for while "men pursued the practical business of commerce, women became preservers of the religious values of charity and compassion" (Todd, 1986: 18). Theresa is incapacitated to continue her charitable actions or to become a wife and mother, while Morven is prevented from becoming the epitome of the British middle class: a successful professional and married man. This incapacity is once more inherited from other instances of sentimental men of feeling, including Werther or Henry Mackenzie's Harley. Werther is described as "incapable either of any sustained effort or of acting decisively, except to end his life" (Salm, 1973: 47), while Harley is repeatedly shown as unable to adapt to a world in which commerce is the main business. ${ }^{231}$ Mackenzie also claims the sentimental novel may divert attention from easing real sorrow in the face of a fictitious one and can lead to what he terms the

${ }^{230}$ Another example of this escape from obligations would be Burrell's rejection of Theresa's offering to marry him out of gratitude and a sense of duty. His true delicacy, recurrently expressed by sighs, tears and even a temporary sense of weakness (2009: 86-87), avoids his acceptance of her sacrifice.

${ }^{231}$ Harkin quotes Burns's remarks on Mackenzie's novel which state that "there may be a purity, a tenderness, a dignity [...] which are of no use, nay in some degree, [are] absolutely disqualifying, for the truly important business of making a man's way into life" (1994: 321). Harkin then expounds this matter further: "These comments about the specific unfitness of sentimentalism as system of virtue for a practical, commercial age and its male heirs (though Burns's characterization of the novel's 'purity' and 'tenderness' suggests there may be a place for it in the feminine, domestic sphere) indicate that the story of Harley was understood by its earliest as well as its most recent critics as a model for the conduct of the reader," hence highlighting the need to point out that "a sentimental turn generally unfits its male devotee -author or reader- for business" (1994: 321). 
enthusiasm of sentiment, as seen in chapter one. This enthusiasm, again associated with quixotism, prevents men, as well as women, from appropriately interacting in the world, ${ }^{232}$ and hence hinders the fulfilment of their duties within the Christian framework so relevant in the construction of didactic fiction. Sensibility, in Tomlins's hands, is then employed as a critique to an imperfectly termed effeminate society that has allowed the Christian standards of duty and morality to be weakened. Her novel sets to prove that this flawed society is the contrary of what a female society would be.

As the novel unfolds, female characters remain in a predominant position both as agents and epitomes of Christian charity. Theresa, Deborah, Ruth, and Joannah, the sick soldier's sister, all perform charitable deeds, take care of each other, and even look after the men in the novel. In moderation, the cult of sensibility becomes a tool in women's hands to follow More's or Wollstonecraft's advice and to be active citizens in society. In addition, women in the novel long for a sense of an effective female community, and the relationship between Ruth and Theresa has important relevance in the novel. Both are deceived in Frank, Ruth's suitor, who, as seen above, abandons her to pursue Theresa and finally threatens to kill himself in front of them. Literally and figuratively, they must support each other to face this situation created by a weak man: the threat is once more against their virtue -in Theresa's case- and their appropriate survival in society -Ruth's possibility to marry again. What is more, it is Frank's wertherian attitude, his over-sentimental fantasies, which stand in the way of correspondence between Theresa and Ruth, highlighting the threat not only to the romantic solution of marriage, but also to female friendship. ${ }^{233}$ Once again, fortitude and survival comes not because of male mentorship but despite men's plots against the female protagonist.

${ }^{232}$ For Harley's social mistakes, his failed interpretative practice and lack of decoding skills, see Harkin (1994, pp. 330-1). Some of his mistakes concerning class closely resemble Dorinda's or Arabella's own confusion of servants for noblemen, connecting Mackenzie's text with the tradition of female quixotism. The implications are the same: the threat to social and financial stability by interacting with them; women, by their marriage and the bestowing of money, land and title on lower-class suitors, men, by their more literal commercial transactions with them.

233 This latter plot of sentimental female friendship against hardship becomes increasingly significant in the last half of the century, sometimes being preferred over marriage as the epitome of a sympathetic and understanding community, far from the dangers society, in general, and men, in particular, hold for women. In Tomlins's own work it will gain more 
Not only are women portrayed as the best examples of a proper sensibility expressed in philanthropy and friendship, but they also become the models of a literary and intellectual community. At Ruth's house, Theresa portrays a picture of a female reading community which very closely resembles those in Barker's works, for instance. Theresa describes it to her brother thus:

I have made up a little library here, in a closet which joins to the rooms I am now in, and when I go I shall even leave my Werter with this Ruth, who has already attached me: and to the dear girl, whom she has taught already to read, I have given the works of the charming Countess of Genlis, those works so formed to open the heart, and awaken it to all the finer sensations. You will scarce believe how much I envy to France the birth of that benevolent writer. I find with pleasure Sophy already comprehend something of her story of Pamela. (2009: 22)

This stereotypical picture of a private female library in the closet, full of sentimental novels by Goethe or Genlis, reinforce the image of novel reading by women as private and awakening to the "finer sensations." In this closet, novels written by women about women will pass on from woman to woman in a kind of literary motherhood; as Arabella inherited her romances from her deceased mother, so will Ruth and Sophy inherit not only the sentimental novels, but the sentimental and moral story of the deceased Theresa. This feminocentric space and literary activity once more establish a site for freedom in the patriarchal context provided by the rest of characters in the novel.

Finally, Tomlins questions the established patriarchal codes framing the quixotic plot of female development when she rejects the final redemption of her character in the shape of marriage to a deserving hero. Not only the overtly sentimental Vincent Burrell, but his likewise sentimental brother Frederick, together with Frank and Lord S. are discarded throughout the novel as suitors and cure to Theresa's obsession. All of them offer only one alternative, love and marriage; while Theresa pursues her literary and charitable quests to find Goethe and to help people along the way, it is men who hinder her story with the conventional plot of courtship. In addition, Tomlins has introduced a

weigh in later novels; in Rosalind de Tracey (1798) she features "the lone female character who ventures haplessly into public commercialized space" and who is subject to male plots of abduction and violence, being Tomlins's acknowledged purpose to promote "fortitude in affliction" (1798: vi; qtd. in Stevens, 2004: n.p.) and "female friendship" (Stevens, 2004: n.p.). 
female other to highlight the nothingness the conventional characterization and plot imposes on women. Similarly to Lennox's Charlotte Glanville, Tomlins presents Miss C---. A lady of fashion, she is depicted in the novel by Theresa as "a genteel woman" who "may have sense perhaps," but who "by her silence concerning every thing but cards and fashions" does not allow others to perceive if it may indeed be so (2009: 42). Miss C-- is then reduced to silence in all important matters by her ignorance; she may be praised as a lady of fashion but her position remains unfulfilling in Theresa's opinion. Moreover, Miss C-- not only cannot discuss The Recess in anything but superficial terms, but she is also not moved by it, evidencing both a lack in judgement and in feeling. A novel that appeals to mind and heart alike, that claims its intention is to "engage the heart," cannot condone such shallow reading and, while advocating a more regulated sentimental approach to novels than Theresa's, Miss C-- remains in Tomlins's novel a bad model of female reader who does not or cannot be improved by what she peruses. In addition, the reader is told that Miss C-- marries, which signals her complete disappearance from the text, while Theresa's plot still advances. In fact, the mention of her marriage is slight -“[Doctor C--'s] daughter is married; I paid her my compliments” (2009: 97) - and it becomes only a brief echo in the main narration. By assigning the more conventional happy ending to the shallow though socially acceptable female character, but by so doing erasing her from the narration, Tomlins seems to make a statement on her own position as woman and intellectual: shallow female models or wives are impossibly narratable heroines, and even less so possible narrators. The story belongs to the quixotic reader, a character that can claim the right not to remain invisible or silent even if because of her delusion.

What is more significant, differently to Hamilton's Julia or West's Geraldine, Theresa does not die as punishment for her loss of virtue: she dies because she is incapable of finding her place within such a constraining patriarchal society, she is erased because she has not learnt to negotiate her position or her image as other heroines of bildungsromane had. Theresa does not renounce her quixotic aspirations, nor does she accept her conventional role as wife, and there is nothing left for her to do but completely disappear from the narrative. 
She is transformed more radically than Arabella into the unnarratable heroine. It is also noteworthy that it is precisely at this point in the plot where the firstperson narrative gives way to a third-person narration, highlighting that Theresa increasingly becomes insensible, that is, incapable not only of feeling, but of thinking and even writing, and, consequently, she also becomes invisible, a nobody. As has been stated in the case of Mary Hays's narrative, the epistolary form was amply and aptly employed by women writers to provide a space for the creation of a "self" (Spender, 1992: 5). By editing her speech and her experience, Theresa had become the author of her life, for most of what the reader knows was mediated by her. Moreover, she had become a perfectly capable narrator addressing and even manipulating her implied reader. However, Theresa finally loses control over her life and, hence, her narration. Consequently, by shifting to a third-person narrative, Tomlins recovers control over the narrative before Theresa's final descent into silence, in order both to build the final moral and to comment on Theresa's authorship. Tomlins abandons the wertherian letter-writing and shifts to a more controlled form of prose. In this sense, Tomlins, as other women novelists of fictions of sensibility, seeks to re-establish order in the act of narration by contrast with the excessive sensibility that has disrupted her heroine's plot (Ballaster, 2000: 211), as well as to gain distance for a final reflexion in relation to Theresa's end. In this regard, Tomlins choice of a final third-person narrator can be interpreted as implying a desire to highlight the author's detachment from the flaws of her heroine -and her heroes- as well as to grant a more objective account of the pathetically sentimental tableau of suffering and death. Instead of having the other characters involved recount what has happened, Tomlins introduces a third-person narrator who "gathered from the lips of Mrs. Aylesby" (2009: 98) every transaction of those days, and retells them for the benefit of her readers. In this way, Tomlins does not reach the total immersion in the heroine's self that later Hays would employ in her quixotic narrative, Memoirs of Emma Courtney (1796), although her conclusions are similar. Tomlins builds a powerful didactic fiction presented as the only plausible cure for a female reader's incapacitating excess of sensibility: it calls for a union of feeling and reason, appealing to the heart and the mind alike, as Hays would subsequently do. However, her narratorial detachment allows this instruction 
not to be fully mediated by her heroine, and therefore to lessen the lack of critical judgement with regard to the reasons that are behind Theresa's death. In addition, Tomlins also provides a more radical conclusion than Emma Courtney. Emma attempts to marry and live according to society's rules, but her story still ends in tragedy and in her own personal misery. Tomlins equally rejects marriage as a satisfactory closure, but the only alternative she offers is death. Both authors, Tomlins and Hays, will then emphasise the impossibility of integration in a patriarchal society unless the female quixote absolutely renounces her aspirations, which is the same as killing the self both heroines had constructed throughout the narrative and negotiating a different, more conventional one.

Differently to her heroine, the implied female author does achieve a voice, a moral and literary authority, in the feminocentric community of writers and readers her novel has envisioned. Tomlins did, in fact, attain recognition and success as an author, while she did renounce the conventional life of a wife and mother. Her quixote then stands as the surrogate figure of the author, a learned and writing woman who is sacrificed to convention and who embodies the difficulties of achieving the euphoric ending of the bildungsroman within the constraint possibilities offered to women. The quixotic aim to become a successful learned and published lady only becomes possible for the author; however, they both illustrate that it is achieved at the price of the more conventional and desirable ending for women: marriage. 


\section{To See and to Be Seen: the Female Quixote's Discovery of Her Place IN THE WORLD IN MARY BRUNTON'S NOVELS}

Reading, reflection, and advice do much to form the character of women.

Mary Brunton, Letter to Mrs Balfour, January $7^{\text {th }} 1818$

Mary Brunton's life (1778-1818), despite being atypical in many ways, is an excellent example of Christian practice and didacticism as main impulse to start a literary career. ${ }^{234}$ Born in a relatively accommodated family, she was under the education of her mother, who made her a master of French, Italian and music; according to her husband, accomplishments more fit for court than active life that had to be complemented by her brief schooling in Edinburgh. She is known to have barely written during her childhood, just some "vile rhymes," as she would later term them (Letter to Joanna Baillie, March 1810, 1819: xlii), and which her husband thought not fit to publish after her death. Given the choice between a splendid life in London and a marriage to Alexander Brunton, a young minister of the Church of Scotland, she chose the latter, orchestrating a quick and almost secret marriage. ${ }^{235}$ With her husband, first in a quiet parish and later in Edinburgh, she devoted her life to her belief that Christianity should be an active principle and to increasing her learning under the encouragement of her husband. This improvement also took place by means of her literary discussions with her female friends, in particular her closer acquaintance Mrs Izett, with whom she started to write as a form of

\footnotetext{
${ }^{234}$ Unless otherwise stated, all biographical details have been drawn from Alexander Brunton's enlightening and fascinating "Memoir" (1819). The only full biography I am aware of is Mary McKerrow's book Mary Brunton. The Forgotten Scottish Novelist (Kirkwall: Orcadian, 2001), which also builds on Mr Brunton's account for its conjectures. For a more concise biography, see Isabelle Bour's entry for the Oxford Dictionary of National Biography (2004) or Ruth Facer's biographical and literary account for the biographical list of Chawton House Library (2009). Dale Spender's reassessment of Mary Brunton as an early woman writer was of infinite value to call my attention to this novelist (1986, pp. 325-38).

${ }^{235}$ This is one of the instances in which Mary Brunton's life accounts prove still controversial. McKerrow includes in her book a romanticized story of her elopement: Mary was sent to stay with some friends in the island of Gairsay so as to be kept far from her suitor. Alexander is then said to have rowed there and have taken her away to be married (2001: 58). Although this romantic account would well suit the Bruntons' love story, as Facer has stated, "in reality Mary walked out of a house in Edinburgh and married Brunton on the 4th or 5th December, 1798" (2009). More romantic adventures would then have to wait for Mary's novels.
} 
amusement. As her husband records, the greater part of the first novel had been completed before he knew about his wife's activity. Mary's description of the scene to the Scottish playwright and critic Joanna Baillie asserts this idea: "I cannot help laughing, when I recollect the glowing face and oppressed breathing with which I read the first chapters to my husband; making, in order to please him, a strong effort against my reluctance to the task. Indeed, the book was far advanced before even he saw it" (March 1810, 1819: xlii). This first novel, Self-Control (1810-11), almost accidentally found its way into press by means of a publisher who had first been interested in her husband's work. She worked minutely on the manuscript and transformed a pastime into her profession, setting herself a number of pages to be written a day. Notwithstanding the authorial pride that her letters exude, it was her choice to publish anonymously, not to risk staining her husband's reputation. Moreover, while displaying an extraordinary assurance on her didactic achievement and a great share of insightful self-criticism, ${ }^{236}$ Mary also expressed a fear of the reviewers' influence on her novel's reception, which again demonstrates that her attitude was not of a mere amateur. She claimed that she was "one of the republic of letters" and that the thought of "failure" made her "flesh creep" (Letter to Mrs Izett, October $4^{\text {th }} 1810$, 1819: xxxviii-xxxix). Despite Brunton's fears and anxiety, her novel was an instant success: it immediately went into a second edition and, as she recurrently records in her correspondence, it was sold at such a rate that not a copy was to be found in either Edinburgh or London. ${ }^{237}$ Her second novel, Discipline (1814), was also a success. Even more thoroughly planned and laboriously developed, it was the work of a fully professional author. It is interesting to note that at this stage Mary was not so worried about the fact of writing in itself, but rather about the possible similarities with a novel of recent publication, Waverley (1814), in which there was a romanticised portrait of the Highlands which she feared surpassed her own. Her husband states that she was reluctantly persuaded to preserve her

${ }^{236}$ Her letter to the already successful Baillie is a surprising example of her selfconfidence as a writer, responding to Baillie's suggestions and rejecting some of the proposed changes for the second edition. This attitude is maintained throughout her correspondence, in which she states that she will only accept those suggestions with which she agrees and will only follow advice if she likes it. Even her husband states that "she felt herself at liberty to avail herself of few of these" pieces of advice (1819: xliv).

${ }^{237}$ This assertion is supported by Jane Austen's frustration at having tried "to get SelfControl but in vain" in a letter to Cassandra dated April $30^{\text {th }} 1811$. 
heroine's Highland episodes, and her letters brim with enthusiastic praises for Scott's novel and its "matchless, for nature, character, originality, and pathos," Scottish scenes (Letter to Mrs Izett, August $4^{\text {th }} 1814$, 1819: 1xxiv). Moreover, Alexander writes: "her standard for estimating skill in the delineation of character had been raised by the appearance of Waverley; and she felt -more perhaps than she ought to have done- how poorly her own sketches appeared beside those of that masterly work" (1819: 1xix). In a letter to her sister-in-law, she states on her novel:

It is very unfortunate in coming after Waverley, by far the most splendid exhibition of talent in the novel way, which has appeared since the days of Fielding and Smollett. There seems little doubt that it comes from the pen of Scott. What a competitor for poor little me! The worst of all is, that I have ventured unconsciously on Waverley's own ground, by carrying my heroine to the Highlands! (December 1814, 1819: lxxvi)

These assertions confirm that Mary's concerns were those of a fully professional and conscious artist, anxious of the influence of precursors and worried about her legacy to posterity, expressed in her disappointment at the silence of reviewers on her second novel (1819: 1xix). Despite these concerns, Mary's self-confidence on her own style and subject matter persisted. After rejecting a change of subject matter in a proposed series of essays on her admired Cowper, she started her third novel, Emmeline, although never completed it, for she died of childbed fever after giving birth to a stillborn child in 1818. The five chapters she did complete appeared in 1819 , with a memoir of her life and literary career written by her admiring husband. His "Memoir" remains one of the most enlightening documents on what it meant to be a successful and professional woman writer, as well as a most fascinating portrait of a witty, intelligent, spirited, and pious woman.

Brunton's three novels feature a young heroine and all of them present her in her road to self-awareness and social integration. All of her heroines must learn difficult lessons on what it means to be a woman in eighteenth-century Britain. Her didactic purpose is evident in all three novels; however, the hardships her heroines must endure in their path to maturity and felicity increase in every work. Laura, the main character of Self-Control and her more conspicuously 
virtuous heroine, in spite of her adherence to the moral quality announced in the title, must still suffer privations, attempted abductions, a kidnapping, or an adventurous escape from Indians before reaching a happy conclusion. In her second novel, Ellen Percy experiences a frustrated elopement, financial penury and even enclosure in a madhouse before finding happiness in the Highlands with the worthy hero, who, in the recurrent plot of the female bildungsroman, has also acted as her mentor. Ellen's story is a prolongation of Laura's, although her nature as a flirtatious and superficial woman renders her errors deeper than the latter's. As a consequence, in Mr Brunton's words, the novel revolves around "the means through which, when self-control has been neglected, the mind must be trained by suffering ere it can hope for usefulness or for true enjoyment" (1819: liv-lv). Emmeline, the eponymous heroine of her unfinished novel, seems condemned to a life of misery with no chances for happiness, as "the scope of this was to shew, how little chance there is of happiness when the divorced wife marries her seducer" (1819: 1xxxiii), which she does in the first pages of the novel, only to be forfeited of reputation, friends and even her husband at the end. Her novels then, in the tradition of the female bildungsroman, foreground "a young woman's consciousness," and, as a consequence, "the heroine's moral concerns and spiritual development provide the major interest of the plot" (Wood, 2003: 129).

While Brunton's complete body of work is an interesting exploration into the novel of female development and its Christian discourse on virtue and fortitude, it is her first novel, featuring a literary and sentimental young female quixote and, moreover, a virtuous and idealist heroine who must face the antiromantic reality of the world concerning love and women's claim to authorship, which develops the topos of the female quixote within a bildungsroman and which provides a more complex comment on the role of the female artist within the constraints of eighteenth-century British society. Brunton then divides her parodic and satiric approach to quixotism in two characters: Julia, the deluded reader, and Laura, the heroine who is clearly superior to the society in which she dwells. Her second novel will resume the topic of the young and uneducated sentimental heroine, and will advance more thoroughly the story of development of a young inexperienced and fallible girl 
into maturity and happiness, contrasting her romantic vision with the surrounding anti-romantic world. In this sense, the sentimentally-deluded Julia and the romantically-fooled Laura respond to the tenets of the tradition of female quixotism established by Lennox.

In addition to this well-known tradition of the female novel of growth, the fact that the heroine of her first novel is an artist, hence a professional woman, will allow Brunton to develop a plot of female development closer to what Lorna Ellis (1999) describes as the male tradition of British bildungsroman that enroots with Goethe and his seminal Wilhelm Meisters Lehrjahre, uniting then both the feminocentric and androcentric Bildung tradition -both the influence of the courtship and apprenticeship novels- in one single work of narrative fiction. Instead of focusing on the plot of courtship as merely a parallel to the plot of professional success that is at the core of the bildungsromane featuring a male protagonist, Brunton also depicts Laura as a working woman who must struggle to find critical and financial success as an artist. Consequently, the professional and public sphere in which men's story of integration takes place is also granted to Laura, and her process of social acceptance will hence be dual: she will live the traditionally feminocentric and androcentric plots of sentimental and professional development, respectively. Therefore, both aspects, the personal and professional maturation of her quixotic Laura will be subsequently expounded, highlighting the tensions the courtship and apprenticeship aspects of the bildungsroman create in the young quixote's story.

\subsection{Julia, or, the Dangers of Literary Quixotism}

Relatively early in Self-Control, the reader and the heroine are introduced to a young woman, July or Julia Dawkins, the sentimentally-educated daughter of Laura's landlady. From her very literary and sentimentally charged name, to her mode of behaviour and her language, Julia could be said to recall Lennox's Arabella and, for some critics, to somehow anticipate Austen's Catherine Morland (Sobba Green, 1991: 121). In the tradition of other quixotic heroines, such as West's Marianne or Green's Alice, Julia has been educated by a 
wealthy but nonsensically romantic aunt, who, after raising her in grandeur, elopes and hence deprives Julia of all her privileges. Mrs Dawkins complains to Laura that "indeed it's very hard as I should have all them there things to do myself, when I have a grown up daughter in the house. But, poor thing, it a'n't her fault after all, for she never was larnt (sic) to do nothing of use" (1811: I, 103-4). In Brunton's characteristically humoristic style, she subsequently explains the whole affair to the heroine:

Yes, but it might'nt (sic) have been so misfortunate neither, only, you see, I'll tell you how it was. My sister, Mrs Smith, had a matter of L. 10,000 left her by her husband, and so she took a fancy when July was born as she'd have her called a grand name; and I'm sure an unlucky name it was for her; for many a fine freak it has put into her head. Well, and so as I was saying she took July home to herself, and had her larnt (sic) to paint, and to make fillagree (sic), and play on the piano, and what not; and to be sure we thought she would never do no less than provide for her. But what do you think, why, two years ago, she ran away with a young ensign, as had nothing in the varsal (sic) world but his pay; and so July came home just as she went; and what was worst of all, she could'nt (sic) do no more in the shop nor the day she was born. (1811: I, 104)

Mrs Dawkins also provides some other common places of female quixotism: the identification with a romantic identity because of a particular name and instruction; the lack of an education according to the young woman's station in life; and the unfitness of the quixote to be a useful member of society, either as a member of her household or of the middle-class trade. ${ }^{238}$

Despite the existence of this description of the heroine's education, recurrent in all novels of female development, in Self-Control, a novel more concerned with women as producers of art and culture, Brunton emphasises the literary sources of her heroine's distorted perception and, therefore, moves back once again to a more literary quixotism and to Lennox as a source. From the beginning, Julia's reading is presented as quixotic, as her interpretation of herself and the world contrasts starkly with how others perceive her or with the anti-romantic world in which she is placed. Brunton introduces her character

${ }^{238}$ In Discipline Brunton would resume this critique to inadequate female instruction when Ellen reports the (mis)education of her friend Juliet Arnold, who is sent to boarding school only as the means through which to gain a husband. Her education is described as shallow and her purpose in life as useless, and Juliet grows up to believe that her only role in society is to become the passive and decorative wife of a nobleman. 
thus: "Her figure was short, inclining to embonpoint -her face, though rather pretty, round and rosy, -and her whole appearance seemed the antipodes of sentiment. She had, however, a book in her hand, on which, after exchanging compliments with Laura, she cast a languishing look, and said, 'I have been paying a watery tribute to the sorrows of my fair name-sake"” (1811: I, 105). Julia is reading a Romantic work, The Minister: a Tragedy. In Five Acts, a translation of Friedrich Schiller's original play Kabale und Liebe (1784) by M. G. Lewis, published in 1797. In contrast with Julia, Laura is not acquainted with The Minister. After an argument with Mrs Dawkins about the merits of the book's language, Julia attempts to read one of its speeches so Laura may decide on the matter:

She had, therefore, recourse to her book, and with great variety of grimace, read aloud one of Casimir's impassioned, or, as Laura thought, frantic speeches. The curious contrast of the reader's manner, with her appearance, of the affected sentimentality of her air, with the robust vulgarity of her figure, struck Laura as so irresistibly ludicrous, that, though of all young ladies, she was the least addicted to tittering, her politeness would have been fairly defeated in the struggle, had it not been reinforced by the entrance of $\mathrm{Mr}$ and Mrs Jones. (1811: I, 106-7)

This passage, another evidence of Brunton's taste for the comical, emphasises Julia's quixotic distorted perception of herself as a sentimental lady and enroots with Cervantes' creation of an abysmal chasm between his character's aspirations and his true nature, together with the ludicrous effect it triggers on the sane people around him. This description also aligns Brunton with Austen more than with Lennox; while the latter portrayed a quixotic character that inspires too much awe to be laughed at, the former will develop this farcical contrast between sentimental appearance and unromantic reality even further in her famous description of Catherine Morland as the epitome of the antiheroine.

Brunton also provides a comment on language and its power to construct different realities, the romantic and the anti-romantic, or, as Julia's case will evidence, the sentimental and the emotionally balanced, the amoral and the moral. First, the overtly sentimental language is ridiculed by the contrast of matter and manner exposed in the quixotic lady's speech and its comparison 
with that of the surrounding characters. Brunton parodies it when she has Julia very highly ask her sister, Mrs Jones: "have you an accurate idea of what constitutes a castle? of the keeps, the turrets, the winding staircases, and the portcullis?," only to be answered by a description of the "very decent sort of an inn" in which her sister stayed, though they could not be served hot rolls even if they were as "hungry as hounds" (1811: I, 109). Impervious to this unromantic answer, Julia continues in a style resembling Biddy Tipkin's talk on fanning gales or Arabella's romantic linguistic raptures:

"What would I have given," cried Miss Julia, turning up the whites of her eyes, "to have been permitted to mingle my sighs with the mountain breezes!" Mrs Jones was accustomed to her sister's nonsense, and she only shrugged her shoulders. But Mrs Dawkins, provoked that her daughter should be so much more than usually ridiculous before a stranger, said, "Why, child, how can you be so silly,-what in the world should you do sighing o'top of a Scotch hill? I dares (sic) to say, if you were there you might sigh long enough before you'd find such a comfortable cup of tea, as what you have in your hand." (1811: I, 110)

Julia refuses to dignify such remark with an answer, and, instead, "turning to our heroine, she addressed her in a tone so amusingly sentimental, that Laura feared to listen to the purport of her speech, lest the manner and the matter united should prove too much for her gravity; and rising, she apologized for retiring, by saying, that she heard her father stir, and that she must attend him" (1811: I, 111). By means of this mirthful portrait of her quixotic character and by giving pre-eminence to Laura's point of view on Julia's foibles, the implied reader is expected to partake not only in Laura's laughter at Julia's unconscious mock-sentimentality, but also in the heroine's more realistic perception of reality. The reader's and Laura's approach to reality then seems the same in opposition to Julia's sentimental reading of the world.

Later in the novel this difference between fiction and reality is again emphasised in a conversation between both women. Julia asks to see one of Laura's paintings which depicts Leonidas's farewell to his family. Julia instantly identifies him with Tom Jones, an association which triggers first Laura's amazement and then her laughter. A conversation follows in which it is made evident that Julia and Laura possess a different system of reference. When Laura mentions Leonidas, Julia replies: 
"Leonce, you mean, in Delphine," said Julia; "Oh, he is a delightful creature too."

"Delphine!" repeated Laura, to whom the name was as new as that of the Spartan was to her companion. "No, I mean this for the Greek general taking his last leave of his wife."

[...]Miss Julia again declared, that the picture was charming, and that Leontine, as she was pleased to call him, was divinely handsome; but having newly replenished her otherwise empty head with Fielding's novel, she could talk of nothing else; [...] (1811: I, 132-3) ${ }^{239}$

Laura's ignorance of the heroes of German or French Romantic works of fiction is a positive contrast to Julia's illiteracy in the matter of classical heroes. Moreover, Julia's impostured sensibility is contrasted to Laura's true one also in the matter of art. When they both attend a play in which Mrs Siddons acts, Julia's comment "I think nothing is so delightful as a play," stands as shallow opposition to Laura's absorbed attention, in which she intensely feels and reacts together with the main character (1811: I, 227). More importantly in Brunton's Evangelical novel, Julia's sentimental ethics will also be pointed out as empty of any moral truth or lesson. In this sense, Brunton aligns herself with the critique to outlandish fictions which teach lax morals to young female readers. Following the example of West or others critics of the selfish discourse of sentiment expressed in these Romantic works, Brunton, for example, offers a reflection on the emptiness of the sentimental language of generosity when the narrator states that Julia's "ideas of generosity, culled from her favourite romances, were on that gigantic kind of scale that makes it unfit for common occasions, and therefore in danger of total extinction" (1811: I, 136). In contrast, Laura defends "the quiet domestic generosity which is of daily use" and "thousand little acts of self-denial" instead (1811: I, 135). Brunton's Evangelical notions on sympathy and active charity are echoed in her heroine's implied rejection of the grandiloquent rhetoric of the sentimental discourse, and Brunton's heroines hence enroot with West's Laura and Marianne, as well as anticipate the distinction between Elinor's true self-

${ }^{239}$ Delphine (1802) is a novel by Madame de Staël which defends romantic choice over conventions. Her style and subject matter, united to her connections with the German Romantics, would inscribe her as part of the Romantic Movement and would then be ranked with Schiller's work or Lewis's translation as morally dangerous by the conservative and Methodist Brunton. 
denying generosity and Marianne's self-centred sentimental principles in Austen's Sense and Sensibility. ${ }^{240}$

In addition, the exalted sentimental language of the novels has other more obvious dangers. When The Minister is discussed, the following conversation ensues:

"Oh," cried Mrs Dawkins, "that's the young woman as swears so horridly. No, I dares (sic) to say, Miss Montreville never read no such thing. If it an't a shame to be seen in a Christian woman hands, it is. And if she would read it by herself, it would be nothing; but there she goes, ranting about the house like an actress, cursing all aloud, worser nor (sic) the drunken apple-woman at the corner of the street."

"Pray Mamma, forbear," said Miss Julia Dawkins, in a plaintive tone; "it wounds my feelings to hear you. I am sure, if Miss Montreville would read this play, she would own that the expressions which you austerely denominate curses, give irresistible energy to the language."

"This kind of energy," said Laura, with a smile, "has at least the merit of being very generally attainable." This remark was not in Miss Julia's line. (1811: I, 106)

Mrs Dawkins and Laura perceive the exalted language of the play in its impropriety and immorality; furthermore, Laura deprives it even of aesthetic value by her comment on both the recurrence of such expressions in the flow of sentimental novels and the truly mundane nature of the terms employed in the play. More relevantly for the identification of Julia as a female quixote, as seen in the abovementioned example, Laura also considers the "impassioned speech" of the play as "frantic," connecting Julia's sentimental reading with the idea of madness or delusion: her intellect or senses are in frenzy, a fact that her mother reinforces when she claims her daughter impersonates her favourite heroines and reads out like an actress. This impersonation, or, in Bray's terminology, this "actor/spectator" model of over-identification (2009: 57), and, as a consequence, the rewriting of her behaviour and language to act in

${ }^{240}$ Amusingly enough, after Laura's speech against Tom Jones' lack of true generosity and virtuousness, the narrator states that "Miss Dawkins, by this time more than half-suspected her companion of being a Methodist" (1811: I, 136). Brunton also joked in her letters about the negative perception of herself by some of her acquaintance because of her Methodism, proving that her religiousness is far from the serious uprightness of some of More's discourse and closer to the comic morality of Austen's novels. 
accordance with the model of sister heroines, determines Julia's nature as a female quixote.

Julia's "preposterous affectation," though it "sometimes provoked the smiles," more often caused Laura's pity, as the narrator tells the reader that her good nature allowed not to see people make themselves ridiculous in such a manner. As a consequence, "she applied to the cure of Miss Dawkins's foibles, the ingenuity which many would have employed to extract amusement from them" (1811: I, 130). Once again, Brunton cleverly conducts the reader through Laura's perception to pity the young woman's state, notwithstanding her comicality. However, despite her good intentions, Laura finds Julia's delusion too ingrained in her literary mind:

[...] she was combating a sort of Hydra, from which, if she succeeded in loping off one excrescence, another was instantly ready to sprout. Having no character of her own, Julia was always, as nearly as she was able, the heroine whom the last read novel inclined her to personate. But as those who forsake the guidance of nature are in imminent danger of absurdity, her copies were always caricatures. After reading Evelina, she sat with her mouth extended in a perpetual smile, and was so very timid, that she would not for the world have looked at a stranger. When Camilla was the model for the day, she became insufferably rattling, infantine, and thoughtless. After perusing the Gossip's Story, she, in imitation of the rational Louisa, suddenly waxed very wise -spoke in sentences-despised romance-sewed shifts-and read sermons. But, in the midst of this fit, she, in an evil hour, opened a volume of the Nouvelle Eloise, which had before disturbed many wiser heads. The shifts were left unfinished, the sermons thrown aside, and Miss Julia returned with renewed impetus to the sentimental. (1811: I, 131)

What is particularly interesting in this passage is that its critique is not aimed at one specific genre or author; it is only the uneducated and undiscerning mind of Julia, her lack of personality, which makes these books dangerous and which transforms even the quixotic narrative of West in a useless fiction of awakening. In fact, in contrast with the previous Romantic works of fiction Julia has mentioned, Brunton has chosen here three novels usually considered the epitomes of didacticism. Burney's Evelina and Camilla, and West's A Gossip's Story all portray exemplarily virtuous heroines who are nonetheless imperfectly, and hence comically, reproduced by Julia: Evelina's gentleness and modesty, Camilla's childishness, and Luisa's gravity are mocked by the quixote's caricature. Nevertheless, although the characteristics of the heroines 
are taken to the extreme, Brunton's censure also seems ambiguously directed towards these novels: if Julia had possessed a better training in critical reading and had not forsaken "the guidance of nature," she would have perceived the unnaturalness of such perfect heroines and would have recognised their function as role models; however, as absolute role models, such exemplarity can be transformed into absurdity by its very same unnaturalness. That is, if readers were to literally imitate these ideal models, they would make a character as ridiculous and as unfit for society as Brunton's quixote. Moreover, their most striking characteristics, highlighted by the quixote's imitation, emphasise those traits of femininity which Brunton seems intent on avoiding in her own heroines: passivity, infantilism and pedantry, all absent in Laura's or Ellen's character. In addition, Brunton mirrors her own concern as an author, her will to create morally impeccable heroines who would nevertheless be as natural as they could as characters, a tension that will be made particularly evident in her portrayal of the virtuous Laura and the later more flawed Ellen. Her heroines are not perfect or ideal models, and, in this regard, their errors not only illustrate the books' lessons but also contribute to psychological realism (Wood, 2003: 129). Brunton would then aim at a more plausible construction of character, learnt from Fielding or Scott, than at a description of manners, such as the abovementioned novels provide. ${ }^{241}$

Nevertheless, this ambiguity concerning these three English novels is dropped with a reference to the (in)famous Julie or the Nouvelle Heloise. With its high sentimentality and its amoral message, it appears worse than any other, for it is capable of disturbing "even wiser heads" than Julia's. The mention of this novel connects Brunton with other writers which developed the fiction of a female reader deluded by Rousseau's work, such as Hays or Hamilton, and it may be an implied reference to the previous tradition of female quixotism which, in Brunton's extensive reading, she might have come across. In

${ }^{241}$ Writing to Mrs Izett on her opinion on a new "historical romance" by a lady, Brunton concludes with her assessment of the poor delineation of character that women writers have achieved in the novels of manners, a genre of which Burney in particular is said to be a founder: "Now -and all other Misses, must pardon me, if I think that ladies are more likely to make their works interesting by well imagined incident, than by masterly delineation of character. Ladies have, indeed, succeeded in delineating real life; a very few of them have done so; but it has been rather in pictures of manners than of character" (April $10^{\text {th }} 1810,1819$ : xxxii-iii). 
addition, it brings to the reader's mind the example of previous heroines inspired by Rousseau's and it triggers the association with her usually tragic ending as consequence of her delusion. Throughout the eighteenth century, even after the peak of the political and literary war of ideas, if the name of the deluded heroine was the highly sentimental "Julia," in all probability her ending would be even more tragic than mere spinsterhood. ${ }^{242}$ In fact, in her second novel, Brunton introduces another sentimentally-deluded character, Juliet, who is granted the closure many didactic conservative novels saw fit for their sentimental immoral heroines: she becomes the mistress of a nobleman, gives birth to an illegitimate child, is then abandoned and dies in poverty and sickness, only supported in her last days by Ellen's humble industry. Brunton's narratives then enroot with the tradition of conservative quixotic fictions in their warning against pernicious readings, in particular Rousseau's, as an example of a foreign dangerous aesthetic and moral influence.

Despite the abovementioned similarities, Brunton nevertheless devises an original conclusion for her quixotic plot in Self-Control. Although in the novel Brunton apparently anticipates a tragic ending for Julia with her explicit reference to Rousseau's novel, she offers an innovative variation to the conventional ending for the sentimentally deluded young woman: the learning of a profession. Once more, Mrs Dawkins tells of her daughter's destiny:

She informed Laura, that Miss Julia, having lately read the life of a heroine who in the capacity of a governess captivated the heart of a great lord, had been seized with a desire to seek adventures under a similar character; but finding that recommendations for experience were necessary to her admission into any family of rank, she had condescended to serve her apprenticeship in the tuition of the daughters of an eminent cowfeeder. The good woman expressed great compassion for the pupils of so incompetent a teacher, from whom they could learn nothing useful. "But that was," she observed, "their father's look out, and in the mean time (sic), it was so far well that July was doing something towards her keeping." (1811: II, 73)

Pamela, the servant who achieves the heart and, of course, the fortune of a great lord is substituted by a governess, signalling a change that was taking

${ }^{242}$ It is present in Brunton's novel and in Edgeworth's essays on female education, for example, in "Letter from a Gentleman to his Friend upon the Birth of a Daughter, with an Answer" (in the 1799 edition), where Edgeworth resumes the matter of Rousseau's work, and in her story "Letters of Julia and Caroline," which portrays the abandoned, single mother Julia dying in remorse. 
place in fiction and society alike. Brunton parodies what seems a new form of Richardsonian romantic fiction, one featuring a young governess that must undergo many troubles in order to achieve her successful happy ending, while also becoming an exemplary character. The novels which flourished at the beginning of the new century, and which anticipated the Bröntes' focus on a working woman who finds love and her place in the world after gaining financial and social independence as a governess, romanticised the increasingly common figure of the young lady who must partake in work outside the household. With new times, came new fictions, and what could be termed the governess novel gained popularity among educated female readers who were left with little labour options besides taking a position with a family to educate its children. Fiction featuring an exemplary governess had been popular long before, with Sarah Fielding's The Governess, or the Little Female Academy (1749), Mary Wollstonecraft's Original Stories from Real Life (1788), H.S.'s Anecdotes of Mary; or, the Good Governess (1795), Maria Edgeworth's "The Good French Governess" (1801), and Mrs. C. Matthews' Ellinor: The Young Governess: A Moral Tale Interspersed with Historical Anecdotes (1809), as relevant examples. In the later Victorian period, however, the governess became a truly central fictional figure, presented prominently in works such as Jane Eyre, Agnes Grey, Shirley, Villette, or Vanity Fair. Brunton parodies the early form of these novels, but also satirises the still aristocratic aspirations of her character, with the incompetent Julia hoping to find a "great lord" and working instead for an "eminent cowfeeder." Once again, her quixote's grand aspirations are contrasted with a middle-class reality of hard work, of personal value and success based not on birth and beauty, but on effort and education, also a consequence of Brunton's own Methodist beliefs. However, despite her persistent delusion, Julia's new form of quixotism has placed her in a more advantageous position than she was before: she is now an independent woman taking care of her keeping. Brunton, as Steele, does not cure her quixote, but she goes even further and substitutes Julia's sentimental immobilising delusion with an active and useful form of quixotism that highlights both the blooming Victorian governess novel and the increasing numbers of middle-class women 
who took up a position as a private tutor. Brunton is then not satirising Julia's work, only her use of it as a means for her quixotic grand aspirations. ${ }^{243}$

With this change Julia, although still quixotic, moves closer to the proper models Brunton has depicted in the working women of the novel. In order to emphasise the incapacitating danger of female sentimental quixotism, Brunton had developed before this final transformation another of the recurrent techniques of didactic fiction, the opposition of two sisters (Spacks, 1986), already seen in West and later to be brilliantly developed by Austen. Julia is from the start contrasted to her sister, Kate or Mrs Jones, not only in the possession of a less literary name, but in the conduction of her education. As their mother asserts,

[...] one comfort was, I had Kate brought up in another guess-way; for I larnt (sic) her plain work and writing, and how to cast accounts; and never let her touch a book, except the prayer-book a-Sundays; and see what's the upshot on't (sic). Why, though July's all to nothing the prettiest, nobody has never made an offer for she, and Kate's got married to a warm man as any in his line hereabouts, and a man as has a house not ten doors off; and besides, as snug a box in the country as ever you seed,--so convenient you've no idea. Why, I dare say, there's a matter of ten stage-coaches pass by the door every day. (1811: I, 104-5)

The destiny of the sentimental daughter is never to marry, while the sensible one finds conjugal bliss in her middle-class, hard-working marriage. Although not cured from her literary delusion, and although she will be incapable of teaching the children anything useful, at least the fictional model chosen for Julia's behaviour, as her mother states, has led her to "doing something towards her keeping," which will be a consolation if she never marries. This dichotomy also pervades Discipline, in which Juliet is contrasted to the heroine, Ellen: both shared a similar shallow nature, however Ellen matures by means of hard work and personal discipline, while Juliet remains sentimentally deluded, passive and indulged until her death. In this regard, Brunton's anti-

${ }^{243}$ For relevant texts featuring a governess see The Governess. An Anthology. Ed. Trev Broughton and Ruth Symes. New York: St Martin's Press, 1997. Much has been said about the figure of the governess in nineteenth-century fiction. A most enlightening study is Katherine L. West's Chapter of Governesses: a Study of the Governess in English Fiction, 1800-1949. Michigan: Cohen \& West, 1949, on which later work build. One of these would be Kathryn Hughes' The Victorian Governess Novel. London and New york: Hambledon and London, 2001, which provides a relevant analysis of both social context and literature. 
romantic emphasis on money and work in her dealing with the female realm of experience, highlighted by critics such as Smith (1986: 41), will be intrinsically intertwined with her own form of romance: the story of female self-fulfilment, the story of the development of her young female artist, the displaced quixote and heroine, Laura.

\subsection{Laura, or, the Dangers of Romantic and Professional Aspirations}

Laura Montreville is introduced from the start of the novel as an ideal model for any young woman: beautiful, educated and virtuous, she is also an active and strong character. Laura, very much like West's, Hamilton's or Austen's sensible ladies, is so perfect a heroine that, as the admiring maid Fanny asserts, she must have been made to be a queen, "for the more one likes her, the more she frightens one" (1811: II, 161); and, as a queen, she stands in her role as "Matriarchal heroine" who inspires awe in her older and wealthier aunt and who must act as a ruling parent with her own father (Bannet, 2000: 87). Indeed, Laura proves to be a formidable heroine: not only does she reject the advances of the libertine Hargrave despite her deep love for him or support her father with her own work, but she escapes without any help, first from the carriage of a man who had abducted her, and, then, from an Indian village to which the rake of the story had taken her, after which she rows down an American river on her own. This last episode, amply criticised by her contemporaries as improbable and unnatural, ${ }^{244}$ also caused Austen's famous comments on her otherwise praised novel:

I am looking at Self-Control again, and my opinion is confirmed of its being an excellently-meant, elegantly-written Work, without anything of Nature or Probability in it. I declare I do not know whether Laura's passage down the American River, is not the most natural, possible everyday thing she does. (Letter to Cassandra, October $11^{\text {th }} 1813$ )

${ }^{244}$ Brunton transcribed and analysed many of the censures to her first novel in her letters; on this particular and controversial passage, she wrote: "The American expedition, too, -though, in the author's opinion, the best written part of the book,-is more conspicuously a patch, than any thing else which it contains. Though I do not see the outrageous improbability with which it has been charged, I confess that it does not harmonize with the sober colouring of the rest. We have all heard of a 'peacock with a fiery tail;' but my American jaunt is this same monstrous appendage tacked to a poor little grey linnet" (Letter to Mrs Izett, April $19^{\text {th }} 1811$, 1819: xlviii). 
[I intend] writing in close imitation of Self-Control [...] I will improve upon it, my Heroine shall not merely be wafted down an American river in a boat by herself, she shall cross the Atlantic in the same way, and never stop still she reaches Gravesend. (Letter to Anna Lefroy, 1814)

Brunton herself complained about the difficulty of sustaining the narration of her heroine's life and righteousness. In a letter to Mrs Izett, she asserted: "If ever I undertake another lady, I will manage her in a very different manner. Laura is so decently kerchiefed, like our grandmothers, that to dress her is a work of time and pains. Her younger sister, if she ever have one, shall wear loose, floating, easy robes, that will slip on in a minute" (emphasis added, April 10 $0^{\text {th }}$ 1810, 1819: xxxi-ii.). As she had implied about Burney's or West's heroines, Brunton's own exemplary main character runs the risk of being too impressively -or frighteningly - irreproachable to be a plausible, or even an attractive, model of behaviour. Even within the novel itself, Brunton allows some humorous comments on Laura's perfection, as in the abovementioned conversation on the merits of Fielding's Tom Jones:

\footnotetext{
"You have such strict notions," said [Julia], "that I see Tom Jones would never have done for you."

"No," said Captain Montreville, "Sir Charles Grandison would have suited Laura infinitely better."

"Oh no, papa," said Laura, laughing; "if two such formal personages as Sir Charles and I had met, I am afraid we should never have had the honour of each other's acquaintance.” (1811: I, 136)
}

Laura's last exclamation provides a self-reflective comment on one of the problems of the didactic domestic novel: if one were to portray an absolute model of domestic values, with its message of modesty and passiveness, there would be nothing to narrate. Therefore, Laura will have to prove different from Sir Charles and Richardson's discourse on domesticity for the action to take place. Certainly, Laura is a heroine who not only blatantly taunts the conventions of a domestic heroine with her American adventure, but who also commits several errors of judgement which lead to that very same abduction and travel. These errors will then not only enable the action to take place, as they did in Betsy's or Harriot's life stories, but they will also constitute Laura's 
quixotism and hence trigger the process of awakening and development at the core of the novel. As the narrator asserts: "in the chaste propriety of Laura's character" there was "something to command respect; and in her gentleness and warmth of heart, something to engage affection; while, in her ideas, which solitude had slightly tinged with romance, though strong sense had preserved them from absurdity, and in her language, which sometimes rose to the very verge of poetry," there could be "found constantly somewhat to interest and amuse" (1811: I, 205). This quotation mirrors the desire to engage the reader in a moral and amusing story, by both the heroine's virtue and her romantic flaws, which make possible the advancement -or even existence- of the feminocentric plot of development and its progression towards a proper conclusion. In this regard, Brunton's heroine is a naïve girl who, as Evelina, has built a romanticised and idealistic vision of the world that she will require to contrast with her experience. Laura, despite her virtues, is not impervious to the effect of romance. She is a reader whose early solitude and limited exposure to the ways of the world have drawn a veil over her perception, especially concerning her suitors, Hargrave and De Courcy. As the following pages will expound, Laura draws an ideal picture of Hargrave based on her readings and her natural romantic turn, while her idealistic thought that a reformed Hargrave will become her husband renders her blind to Courcy's status as the true hero of the novel. In addition, her lack of knowledge and her artistic enthusiasm enable her to believe that she can live outside her proper sphere as a woman, and she will need to be reinstated in a role acceptable to society. A young woman discovering love and the world, Laura will misread men and her own financial and professional chances in society; she will face reality with the eyes of romance and idealism, and will have to discover herself, both with regard to the state of her heart and to her place in the world as a woman and an artist. With her romantic and youthfully idealistic colouring of reality, somehow ingrained in her nature and not only fostered by her readings, Laura is then a displaced quixote, in the furthest ripple from the quixotic centre, but at the core of a female bildungsroman of awakening to an anti-romantic reality. 
Laura's most important misreading and re-education concerns the cornerstone of the eighteenth-century female bildungsroman, courtship and marriage. In this sense, Brunton situates her heroine at the recurrent position of being courted by a good and a bad suitor and her choice of husband will determine her personal growth. The novel opens with the address of the handsome Colonel Hargrave, whom Laura loves and from whom she expects an honourable proposal of marriage. However, Hargrave instead wishes her as his mistress, after which Laura banishes him from her presence for two years. In this period of time, Laura retains her feelings for Hargrave, as she proves when he becomes the model which springs to her mind when she draws. Moreover, Julia's mention of Tom Jones allows perceiving the parallelism Laura draws between literature and life:

"But why were you so offended, that I compared your Leontine to Tom Jones?-Is he not a favourite of yours?"

"Not particularly so," said Laura.

"Oh why not?-I am sure he is a delightful fellow-so generous-so ardent. Come, confess-should you not like of all things to have such a lover?"

"No, indeed," said Laura, with most unusual energy; for her thoughts almost unconsciously turned to one whose character she found no pleasure in associating with that of Fielding's hero.

“And why not?” asked Miss Julia.

"Because," answered Laura, "I could not admire in a lover qualities which would be odious in a husband." (1811: I, 133-34)

The identification of Leonidas, whose model was Hargrave, with Jones emphasises the similarities between them. A resembling appearance to the literary hero is important in female quixotism since Lennox: if a man seems a hero the quixotic heroine may more plausibly take him to be one. In addition, Jones and Hargrave share many qualities, among them, their generosity and ardour. With these parallelisms, the reader could expect their fate to be the same: Hargrave could abandon his amoral behaviour and marry the heroine in the same manner that Jones did with Sophia. As the novel unfolds, this outcome seems possible because both hero and heroine's feelings appear fixed and because Laura's virtuousness may be hoped to produce a reformation in 
Hargrave. However, Brunton had a very different plot in mind; in her first letter to Baillie she stated "I merely intended to shew the power of the religious principle in bestowing self-command; and to bear testimony against a maxim as immoral as indelicate, that a reformed rake makes the best husband" (March 1810, 1819: xlii). The Colonel, "the spoiled child of a weak mother" (1811: II, 83) who is used to having his idleness and desires gratified, develops the "conviction that, however obtained, the possession of Laura was necessary to his peace" (1811: II, 86), and after several scenes of vigilance, persuasion and jealousy in which Laura remains constant to her resolution, he abducts her and takes her to America. Although he clears Laura's name in the end, he is still granted the conclusion of a villain: he commits suicide. In Wood's opinion, with the implausible American adventures, narrow escapes, and high villains, Brunton "places this self-reflecting heroine in the context of a more typical romance plot (as opposed to [...] domestic plot) that teaches the value of 'selfcontrol' even as it provides incidents to 'interest' a more secular reader" (2003: 129). Therefore, Brunton achieves more than entertainment: she employs romance to reinforce her moral stance. Consequently, in opposition to Fielding's quoted Tom Jones, in which romance triumphed within an antiromantic reality, even despite the sexual amorality of its hero, in Brunton's novel the epitome of the romantic rake dies and a more moral narrative imposes itself, providing an anti-romantic conclusion to the story. ${ }^{245}$ This is evidence that, while Brunton's dialogue of genres and her parodic and ironic nature as a writer was expressed in both her completed novels, her didactic intent did not allow her to develop its full possibilities in the shape of a comic romance in the line of Fielding himself. That kind of comic romance will have to wait for Austen's more perfect mastery of narrative and genre, in a great measure probably influenced by Brunton's own experimentation with romance and the didactic novel. In Brunton's narrative, the former is at once overcome and employed to convey a Manichean didactic intent. As the novel unfolds, this didactic purpose supersedes the romantic plot of the reformed rake, and

${ }^{245}$ In the novel, Captain Montreville and Laura lament that Tom Jones failed to provide a better constructed moral by the popular appeal of its main character and they more explicitly criticize the fact that he finally married Sophia (1811: I, 134). It is obvious then that Brunton disapproved of Fielding's comic resolution for his romantic plot and decided to contrive a different one for her own rake and heroine. 
Brunton clearly aims to teach her otherwise rational heroine that to expect such a reformation is just as foolishly romantic a notion as any of Julia's sentimental readings of reality. Answering to criticism towards Laura's resilient feelings for the Colonel, Brunton writes: "It is alleged, that no virtuous woman could continue to love a man who makes such a debut as Hargrave. All I say is, that I wish all the affections of virtuous persons were so very obedient to reason" (Letter to Mrs Izett, April 19 ${ }^{\text {th }} 1811,1819$ : xlix). At the same time that she chastises her heroine's unruly desire for an unworthy object, Brunton, as did the American novelists of the late eighteenth century, with her reversal of the romantic plot of the reformed rake, plays with the acquired literary expectations of her implied female readers and exposes them as romanticallydeluded as Laura.

In the dichotomy that Brunton constructs between the romantic and the rational choice of a husband, Hargrave is then the embodiment of the dangerous romantic delusion that Laura harbours. This fact is emphasised because, in addition to the traditional seductive, but profligate and amoral, nature of the villain of romance, Brunton offers an interesting analysis of Hargrave's character under the light of his connection to literature:

[...] a tedious illness confined [Hargrave] to recreations in which mind had some share, however small. During the interdiction of bats and balls, he, by accident, stumbled on a volume of Peregrine Pickle, which he devoured with great eagerness; and his mother, delighted with what she was pleased to call a turn for reading, took care that this new appetite should not, any more than the old ones, pine for want of gratification. To direct it to food wholesome and invigorating, would have required unremitting though gentle labour: and to labour of all kinds Mrs Hargrave had a practical antipathy. But it was very easy to supply the young man with romances, poetry, and plays; and it was pleasing to mistake their intoxicating effect for the bursts of mental vigour. A taste for works of fiction, once firmly established, never afterwards yielded to the attractions of sober truth; and, though his knowledge of history was neither accurate nor extensive, Hargrave could boast an intimate acquaintance with all the plays, with almost all the poetry, and, as far as it is attainable by human diligence, with all the myriads of romances in his mother tongue. (1811: I, 856)

In a reverse of the usual female quixote plot, it is Hargrave who has been spoiled by an early deficient education and a misapplication of his natural abilities to reading unprofitable works. In order to emphasise this idea, Brunton 
reproduces the rhetoric of so many didactic -and quixotic- novels before her: the metaphor of the inordinate appetite for fiction, for intellectual food not of the wholesome kind, but of an intoxicating or poisonous one, connects this passage with the warnings of moralists to young readers, and, ironically, especially to female ones. Hargrave's connection with romances only emphasises his own enactment of the role of romantic suitor and villain and the dangers hiding in Laura's constant interpretation of him as a hero of romance. In yet another turn of the common places regarding didactic literature written by and for women featuring a young heroine, it is not the female figure that will be the object of scrutiny by a male gaze, but it is rather Hargrave who becomes an object in Laura's eyes, chosen as a model for Leonidas only because of his heroic appearance. Defending her artistic election, Laura states that "being the handsomest man I had seen, I saw no harm in making use of [Hargrave's] beauty in my picture" (1811: I, 208). The Colonel is then not only the object of Laura's gaze, but his beauty is what she uses for her art; in this case, it is the beau who has become an artistic commodity in the hands of the female artist. This also has implications for the romantic plot. As Mrs Douglas, Laura's friend and mentor, states:

All male writers on the subject of love, so far as my little knowledge extends, represent possession as the infallible cure of passion. A very unattractive picture, it must be confessed, of the love of that lordly sex! but they themselves being the painters, the deformity is a pledge of the resemblance, and I own my small experience furnishes no instance to contradict their testimony. (1811: II, 78)

Rejecting Hargrave in spite of his power over her feelings and inscribing him in her own artistic composition, she frames or writes him in the domestic sentimental story she has envisioned. In the painting, Leonidas is leaving his wife; the characters in the picture reflect the ones in the novel, with Laura positioning as the hero's wife. The fact that the female figure stands in this picture as his wife again reveals what Laura's seems not to acknowledge to herself: that she wishes to inscribe the romantic hero/villain within a domestic plot. 
The reading of her suitors in terms of the heroes of different genres is also developed with the third vertex of the love triangle. The second suitor, Montague De Courcy, is a well-educated gentleman who tactfully and generously supports Laura and her father during their financial distress, and whose association with romance is more positive than Hargrave's. The narrator advances that "between Laura and De Courcy, almost from the first hour of their acquaintance, there seemed (to use the language of romance) a sympathy of souls; - an expression which, if it has any meaning, must mean the facility with which simple, upright, undesigning minds become intelligible to each other" (1811: I, 205). Brunton's exegesis of the terms of romance in her own down-to-earth language already signals the different discourse in which De Courcy will be inscribed. This fact is emphasised in that De Courcy is identified with a book he lends Laura, The Pleasures of Hope, ${ }^{246}$ and hence with a different form of narrative to the romantic plot that Hargrave embodies. In opposition to Hargrave's association with outward beauty, the above quoted passage also employs the words "souls" and "minds" as a positive contrast and as a way to unite him to Laura's more rational and congenial choice of husband. Moreover, Hargrave, at one point impulsed by a desire of emulation, is induced "to try whether he could not draw as well as his play-fellow, De Courcy" (1811: I, 85-6), stating another realm in which Laura and De Courcy share their skills and which will be essential for the development of their own love story: the professional sphere of the artist. Finally, De Courcy is associated with a new model of masculine domesticity, a model of masculinity which incorporates "Evangelical values -nurturing, piety, and domesticitywhich were most often figured as feminine" (Wood, 2003: 132). It will be to the value of this model of the domestic man, whose ambitions are to become "a husband and a father" (1811: I, 264), that Laura will need to awake to, by her "shifting desire" and her "slow realization of the desirability of the domestic man" (Wood, 2003: 132).

Despite her initial disinterest, De Courcy is also an object to Laura's gaze, but, because of the abovementioned qualities, he is the model of a very different

\footnotetext{
${ }^{246}$ A well-reviewed work by Scottish poet Thomas Campbell, The Pleasures of Hope: with other poems (1799) combines sentimentalism with an exalted spiritual tone to discuss the matter of the triumph of hope over misery.
} 
picture: he becomes the central figure of "Hercules at the Crossroads Hesitating between Virtue (Duty) and Vice (Pleasure)," very popular in eighteenth-century iconography (Burlin, 1986: 60). This identification with Hercules, the semi-god of ancient Mythology, is relevant under the light of the previous conversation with Julia on literary heroes. Julia, "repeating what sounded like a page of the catalogue of a circulating library," provides an extensive list of gentlemen "mentioned in novels," including Lord Orville, Valancourt or Peregrine Pickle, and asks Laura to choose her "favourite" (1811: I, 136). Favourite of course also relates to her privileged or elected suitor, and heroes such as Orville or Pickle bring to mind Hargrave's character or readings. Laura rejects these "accomplished persons" on the basis of her limited acquaintance with them, and elects very different literary models: the moral Thaddeus of Warsaw, Miss Porter's hero. She describes him in terms that would suit a didactic novel: "[t]ruly generous, and inflexibly upright, his very tenderness has in it something manly and respectable; and the whole combination has an air of nature that interests one as for a real friend" (1811: I, 137). Her choice of such a perfect hero leads Laura's father to echo Brunton on her complains about her heroine, and to assert that Laura's "favourite has the same resemblance to a human character which the Belvidere Apollo has to a human form. It is so like man that one cannot absolutely call it divine, yet so perfect, that it is difficult to believe it human" (1811: I, 137). De Courcy, portrayed as the semi-god Hercules, is then this mixture of the ideal and the human that Brunton associated her moral romance and characters with, and is contrasted to the usual heroes of novels, including Hargrave's favourite Peregrine Pickle, by his true generosity and manly tenderness, which are traits that Brunton develops in her hero throughout the novel: he supports Laura's art with delicate generosity and he becomes the model of a new form of sensitive manliness opposite to Hargrave's more violent expression of manhood. Mrs Douglas, a surrogate motherly adviser who echoes Brunton, praises De Courcy as providing a "friendship so honourable and advantageous to you, as that of a man of letters and a Christian; whose conversation may improve your mind, and whose experience may supply that knowledge of the world which is rarely attainable by women in the more private walks of life" (1811: II, 81), and exhorts Laura to consider the transient nature of passion, to awake to the 
qualities of her more deserving suitor, and to explore her heart to find the changes brought by esteem, respect and gratitude. Laura's obstinacy and slowness in awakening despairs characters and narrator alike; the narrator's voice becomes particularly intrusive to mockingly complain about her "extraordinary stupidity" in not being able to observe his true heroic qualities (1811: I, 162). The playful levity of the narrator's comments, which strongly resembles Austen's own in her Juvenilia and in Northanger Abbey, emphasises how blind Laura is, how unobservant of the qualities and love of De Courcy owing to the romantic veil created by her love for Hargrave. This focus on seeing, as previously stated, is essential to understand female bildungsroman and its focus on the heroine's correct perception of herself and others, as well as to comprehend the play that Brunton develops between her heroine's perception and that of the other characters or the narrator. Similarly to the interplay between internal and zero focalization that Austen would later master in her novels, Brunton shifts from Laura's consciousness to the narrator's insightful comments to contrast the limited and the thorough knowledge they respectively hold; that is, this authoritative and at times very intrusive narrator is used to "indicate the appropriate readerly response" and to emphasise the ideological supersystem that reassesses the systems represented by the characters (Wood, 2003: 66). In addition, by the employment of a still tentative free indirect discourse Brunton gains control of distance, as Wayne Booth would later state of Emma (1961), allowing Laura's intelligence and wit to engage esteem, while still detaching both the implied reader's and author's perception from her heroine's to evince how deluded the intrinsically romantic and inexperienced Laura still is. What Laura sees or perceives, then, is filtered and exposed to the informed scrutiny of the reader, who shares the omniscient narrator's complete vision of the characters' motives and desires.

This is particularly important in Laura's relationship to Hargrave and De Courcy through her painting. The emphasis on seeing is fundamental in the conception of Laura as woman and artist, because in the act of gazing at her male objects and presenting them in her pictures, Laura is also exposing herself to the gaze of an audience and of the very same lovers she has portrayed. This fact connects her with other female quixotes, such as Dorinda or Arabella, 
because their desire to become subjects in another realm of power and control, courtship, also more obviously exposes them as objects, creating that liminal space in which the, at one time, powerful and powerless quixote stands. This liminal space is also created in relation to Laura's authorial aspirations. First, though "she had hoped the resemblance would be apparent to no eye but her own" (1811: I, 120), her portrait of Leonidas is clearly identified by Laura's father as Hargrave, and he assumes it is because he has made an impression on Laura's heart, therefore her secret is openly exposed to everybody's look. When Harriet identifies her old beau Hargrave as the model for Leonidas, she teases Laura on her feelings for the model and De Courcy falls into a fit of jealousy, which again indicates that other characters have been able to read into Laura's art and feelings better than herself. Secondly, Leonidas is portrayed in the moment of leaving his wife to fulfil his duty. Captain Montreville states that "the suppressed anguish of the matron is admirably expressed, and contrasts well with the scarcely relenting ardour of the hero" (1811: I, 133); suppressed anguish and ardour are adjectives which describe Laura and Hargrave at their parting, when he is banished from her presence to reform. After discussing Colonel Hargrave, Captain Montreville reads into his daughter's thoughts and the narrator explains that "[t]hough Laura had little of romance in her composition, her father now began to imagine, that she allowed herself to cherish the romantic dream, that sympathy of souls, and exactly concordant tastes and propensities, were necessary to the happiness of wedded life" (1811: I, 45), to which Laura answers that she does not wish to marry but to devote to him and her art. Despite the fraught nature of reading even for representatives of patriarchy and in spite of her claims to a single life of artistry, her painting is revealing of her true feelings in spite of herself: Laura feels inclined to the romantic plot of marriage to the reformed rake rather than to the (Romantic) interpretation of the artist as isolated individual, in this case, a single woman.

Even more conspicuous is the example of Laura's representation of De Courcy. Electing a well-known eighteenth-century subject for painting, the choice of Hercules between Virtue and Vice, Duty and Pleasure, Laura unwillingly reveals more than she intends, especially when she portrays herself 
unconsciously as Virtue and makes Vice problematically similar to the former. Laura's choice is significant on a number of levels. First, from the point of view of the artist it makes a statement on what kind of art she is creating. As Katrin R. Burlin has stated, Sir Joshua Reynolds, maybe the greatest artistic influence of the day, painted this topos as "Garrick between Tragedy and Comedy," hence dramatizing the "central moral choice as between genres, with Tragedy as Duty and Comedy as Pleasure" (1986: 60), a moral choice that later Edgeworth or Austen would also dramatize in Belinda or Mansfield Park as a comment on their own genre transgressions. The temptation of comedy towards pleasure and the call of tragedy to one's duty is also an observation on Laura's art, which aligns itself with the dutiful and the moral. Leonidas leaves his wife to go to war; Hercules twists his body towards duty rather than pleasure. Laura signals her identification with sacrifice and responsibility, and rewards De Courcy's aid in her path as an artist paying homage to her duty as daughter and as a proper lady. However, comedy or pleasure, of which she knows not the improper or base kind, mirrors tragedy or duty, and her works are both aesthetically pleasing and morally impeccable. In the same manner Belinda is a novel which combines humour and didacticism, Brunton aims to follow in the path of her admired Edgeworth, whose "genius" she somewhere else praises for her inculcation of "worldly wisdom," "her shrewd observation, and exquisite painting of character" (Letter to her brother, October $27^{\text {th }} 1815$, 1819: 1xxxii). Brunton then covers both her virtue and her pleasure with agreeable draperies, with a heroine that can teach and entertain, that can literally embody the utile et dulce without losing any propriety in the conveying of humour and amusement. Moreover, with the depiction of the warrior/rake in a domestic scene, and of the domestic man at the crossroads of the romantic struggle between duty and pleasure, Brunton reflects though Laura's art on her own cross-gendered novel in which romance and a more verisimilar plot and characterization aim to coexist. Although maybe not still perfectly integrating the different genres, her experimentation with form and plot then "improves More's didactic project by establishing the means of 'interesting' a reader" (Wood, 2003: 135), in the same manner the spectator of the painting is engaged by the virtuous figure of Pleasure. 
Secondly, despite the fact that Laura intends the painting as a gift of her gratitude for his heroic support of her art, it receives a different reading from its male viewers. De Courcy is shown into Laura's painting room and uncovers the hidden picture to his great emotion. Her identification with Virtue, to which Hercules is naturally inclined, allows a comment on Laura's propriety, but the similarities of the chaste female form with Pleasure, who wears the same draperies and is represented with the same decency, would also allow Courcy to interpret the painting as a display of Laura's own passion for him. A scene ensues in which a play with the words "see," "show," "look" and "uncover" signal De Courcy's interpretation of the painting as Laura's secret and even unconscious love for him; half distracted by his passion he flees the house and Brunton provides the reader with one of the insights into her troubled hero's mind:

He shut himself up in his chamber to consider of his situation, if that can be called consideration, which was but a conflict of tumultuous feeling. That Laura should have painted his portrait in a groupe where it held such a relation to her own; that she should keep it concealed in an apartment exclusively appropriated to herself; her alarm lest he should examine it; her confusion, which had at last risen to the most distressing height, from the idea of what De Courcy might infer, should he discover that his own portrait was the cause of so many blushes; the confiding affectionate manner in which she treated him;-all conspired to mislead De Courcy. He felt a conviction that he was beloved, and, in spite of himself, the thought was rapture. (1811: I, 270)

De Courcy's immediate impulse then is to "read the iconography as a kind of proposal, rather than as a learned compliment" (Burlin, 1986: 66), and his thorough analysis of what appearances speak of her intentions also display the difficulties heroes encounter to read and comprehend the heroine. Even the virtuous hero's thoughts reveal that, although Laura has become the subject who controls even her own objectification, she cannot avoid the sexual reading that her figure in the picture raises, nor the interpretation of her private painting-room as a space in which to give expression to her innermost thoughts and desires. This lesson is important for all heroines of bildungsromane, who, as Ellis has asserted, are required to become aware of how they are read by others in sexual terms, how important virtue is for their image in society, and how they can control or negotiate this image to achieve their happy ending. 
While Evelina or Emma constructed their image and their story through writing, Laura does the same through painting: the closet is substituted by her painting studio as a space for women.

The space of the painting-room is also important to understand Laura's relationship with her two suitors, and their association with her art. The painting-room, "a small room, or rather closet, which Laura immediately appropriated" (1811: I, 102), is described in the novel as a feminine site which can be violently or subtlety invaded by the male figure, in the same way other quixotes' closets were ransacked to find books. In fact, for Laura's father, who does not approve of her professional aspirations and who believes marriage as the only "respectable business" in which she should be concerned, her painting room is "a place for potential amorous intrigue rather than of artistic performance" (Burlin, 1986: 66). In De Courcy's case, his entrance is not only sanctioned by the father figure as a proper suitor for his daughter, but he makes it possible himself by providing the room for Laura to take possession over:

[Courcy] looked round with delight on the marks of her recent presence. There lay her book open as she had quitted it, and the pencil with which she had marked the margin. It was one which he himself had recommended, and he thought it should ever be dear to him. On a table lay her port-folio and drawing materials: in a corner stood her easel with the picture, over which was thrown a shawl which he had seen her wear. (1811: I, 266-67)

This feminised private space is brimming with references to Laura's reading and professional painting, her two sites of creative agency, the two instruments through which to interpret and frame her suitors. This space belonging to Laura, however, is not only sanctioned by both mentor figures, but has already been figuratively furnished and occupied with luxuries and a book recommended by De Courcy. Despite this intrusion, this suitor's entrance is very different to the violent trespassing of Hargrave, who, in a fit of jealousy at finding De Courcy's portrait and book in her painting-room, madly seeks Laura and "rudely seizing her he forced her into the painting-room, and bolted the door" (1811: II, 47). In a scene that Richardson could have proudly acknowledged as his own, Laura must defend her dignity and her art from the attacks of Hargrave, who finally repents and calms his passionate rage. 
Nevertheless, Laura's personal and professional space has been inspected and violated by the male gaze, despite the fact that her virtue and honesty finally prevail.

This danger has been forewarned by her father when she decides to become a professional painter in order to relieve Captain Montreville's poor financial and physical situation. Laura's difficult story of apprenticeship as a professional woman artist not only mirrors Brunton's own, but also provides an insightful comment on the difficulties and disillusionment of the female artist in eighteenth-century Britain. From the very start, even as a self-taught amateur, Laura is an object of study under male eyes. A critic visiting Mrs Douglas is encouraged to offer his informed opinion on a painting which is Laura's; the critic concludes that it must be the work of a young artist whom he would not be surprised to see "one day rise both to fame and fortune" (1811: I, 60). However, Laura wishes to remain anonymous:

Mrs Douglas was about to direct his praise to its rightful owner, but Laura silenced her by a look. The stranger's last expression had excited an interest which no other earthly subject could have awakened. Her labours might, it appeared, relieve the wants or increase the comforts of her father's age; and, with a face that glowed with enthusiasm, and eyes that sparkled with renovated hope, she eagerly advanced to question the critic as to the value of her work. In reply, he named a price so far exceeding her expectations, that her resolution was formed in a moment. She would accompany her father to London, and there try what pecuniary advantage was to be derived from her talent. (emphasis added, 1811: I, 60)

Art then becomes Laura's project of enthusiasm, and her desire to become a successful artist takes over other considerations, rendering her blind to De Courcy's passion, for instance, and hence contributing to her misreading of the reality around her and to a displacement of the romantic plot by the apprenticeship one. Interestingly, Laura is not interested in fame, as was Lennox's Arabella or Tomlins's Theresa, but she is in fortune, signalling a change in subject matter and an approach to the Victorian novel which described the concerns of the working classes. The whole conversation with the critic revolves around the material value of her work and it is the pecuniary advantage she expects to find which impulses her decision. Money is a relevant and recurrent topic when Laura considers her choice of profession: she chooses 
to perform sketches in chalk because the "lowness of the price might invite purchasers" and, consequently, she would have a greater chance of success and of obtaining "a subsistence for her father" (1811: I, 289-90). As previously advanced, Laura is portrayed as a professional also hoping to find her place in the world. She labours hard and prides herself in her work, "for it brings her strength through discipline," or the self-control of the title, which also allows her "while painting, a measure of control over her life" (Burlin, 1986: 67). Brunton would later resume this topic with Ellen, who also learns control by means of hard work; in addition, Brunton's own detailed account of the minute process of documenting and writing her novel evinces that her own conception of art as work is reflected in Laura's and that she conceived her writing as a profession in which she could excel.

However useful, and despite her skills and her pride in the fruits of her secret artistic labour, Laura's art is also impaired by her need for concealment from her father and from the dangerous gazes that she would attract because of her sex, age and beauty. When her father dies, she realises that she needs men to protect her from the gaze of other men and from the dangers of a woman living "alone and unprotected" (1811: II, 121). Her professional aspirations cannot be fulfilled because she is trapped, "overwhelmed by power which she could neither resist nor escape" (1811: II, 122). Unable to sustain herself without male protection to screen her from this exposure, Laura reflects with regret that "even if she could again produce a Leonidas, she might never again find a De Courcy" (1811: I, 286). However, even De Courcy in his role as an admiring artistic mentor does not expose her paintings to the public view, which forewarns the fact that her marriage will not provide the desired space to become an artist in a more protected environment than the single state. In fact, in the same manner her father is embarrassed by her work, a husband might be so as well. In spite of her mentorship by her husband and her publishers, Brunton herself wrote under the cover of anonymity, in her own words, to preserve her husband's name. She aimed to avoid the immodesty of an artistic notoriety that would equal her to a "rope-dancer," making the connection between impropriety and fame explicit. 
In the face of this situation, Laura's only recourse is to become a governess, but to this the narrator answers by thoroughly expounding on her lack of skills in the more shallow accomplishments needed for such a position. Laura herself realises "her deficiency in these fashionable arts, on seeing them exhibited by young ladies, who, to use their own expression, had returned from finishing themselves at a boarding-school" (1811: II, 125). Even the shallowly educated Julia is better fit to become a private tutor, which enables Brunton to continue developing her criticism to young ladies' unguided education. In the end, she becomes a companion to her aunt, Lady Pelham, who is a tyrannical woman that nonetheless at one point wishes to make Laura her heiress. Despite her talent and education, the bildungsroman of apprenticeship provides then a disillusioned ending: Laura's place in the world will have to be found by means of the plot of female bildungsroman developed thought courtship. Laura's idealistic dream of professional and financial independence disappears as she realises her dependence on relatives or suitors, as she awakes to her limitations as a lady, even one that has become the gazing subject in art. What is more, the plot stresses this idea with her abduction and defiling: although she resumes her role as controlling subject by preserving her virtue and by escaping her prosecutors, her name still needs to be cleared by Hargrave. In the end, restored to respectability, she does not return to art, but to the unnarratable state of wife:

Laura has now been for some years a wife; and the same qualities which made her youth respectable, endear her to the happy partner of her maturer (sic) life. She still finds daily exercise for her characteristic virtue; since even amidst the purest worldly bliss selfdenial is necessary. But the tranquil current of domestic happiness affords no materials for narrative. The joys that spring from chastened affection, tempered desires, useful employment, and devout meditation, must be felt -they cannot be described. (emphasis added, 1811: II, 296-97)

Having concluded her toils and adventures, having learnt the value of her truly worthy lover, her narrative concludes in the accustomed way: in marriage and invisibility. Moreover, it ends in the habitual manner for quixotic plots of female development, with an overcoming of romance and the inscription within a different form of narrative. Hargrave, from his early association with romance and his embodiment of the implausible plot of the reformed rake, 
represents the form of fictional illusions that the young quixote must reject. On the other hand, De Courcy, with his connection to sentimental moral poems such as The Pleasures of Hope, his role as Laura's mentor and protector, or his portrayal as a truly sentimental, domestic and moral hero, epitomises the didactic fiction that Brunton is herself developing. Moreover, he represents the type of novel that Brunton defends against criticism: a narrative fiction that combines noble sentiments, lively descriptions, natural characters, unity of action and an irresistible moral; a probable story that conducts to "a useful and impressive moral lesson" (Letter to Mrs Izett, August 15 ${ }^{\text {th }} 1814$, 1819: 1xxiv). De Courcy represents all the good qualities Brunton hopes to find in a novel. Therefore, although Brunton's novel has much of the fable construction of Tom Jones, with her villains and heroes and her American adventures, and of the Richardsonian story of virtue miraculously preserved and rewarded, she achieves to use it to convey moral but full characters "like Miss Edgeworth's" (1819: lxxiv). However, the tension between didacticism and naturalness is not completely resolved in this first novel, and Brunton's genius shines more distinguishably in her next work of fiction, which also conveys the dichotomy between virtue and pleasure, the domestic and the romantic, in an engaging bildungsroman heroine and plot.

In conclusion, Brunton's value in the history of the quixotic novel comes, first of all, from her experimentation with plot and form. Searching for the pleasing form of Fielding's comic romances, but uniting it with "her own Methodist concerns on the development of character and of the value of work and selfworth," Brunton developed what came to be termed the "Evangelical romance" (Wood, 2003: 28): a useful moral in the pleasing draperies of a romantic plot. Moreover, Brunton's benevolent didactic intent provided the vision of a romantic reading of the world as a youthful mistake that could be overcome by a development towards maturity; a conception that she shared with other creators of female quixotes, as well as with another Scottish writer, Walter Scott, in his later Waverley, as Welsh has famously attested. In Brunton's novels it will only be characters such as the idle Hargrave or the passive Juliet who will be punished without a final happy integration within society; her active and hard-working heroines achieve the rewards of a happy marriage and 
the chances to continue performing good deeds in their own family or community. Brunton then becomes a meeting point of the conception of quixotism as a youthful romantic vision, of the tradition of female sentimental bildungsroman and of the novel of apprenticeship, and hence anticipates the popular Victorian novel of hardship and development with an idealist female character at its core.

In this construction of an idealist and active heroine who saves herself from danger and who supports others with her own work, in this reversal of the stereotypical sentimental heroine, lies another of Brunton's landmarks: the creation of independent women (Facer, 2009) and her development of a new conception of femininity (Bour, 2004). This innovative practice enables then "a fuller exploration of female subjectivity, and a reconceptualization of the relationship of both women and men to the domestic circle" (Wood, 2003: 13536), which derives in a portrayal of courtship and marriage as more than a power or a love relationship, rather as a space for social unity (Smith, 1986: 55). Brunton's conception of the domestic woman as the core of the family and her community proves not only possible for herself and for both Laura and Ellen, but also a realistic plot for all women. On the other hand, her quixotic artist, which stands as surrogate for her own career as woman writer, experiences the problems of the woman artist and must renounce to her profession, signalling the difficulties of the plot of apprenticeship for women. Nevertheless, Brunton's fiction, for the most part, supports Laura's talent and aspirations, and reveals that the dangers of a female artist's claim to professionalization lie not in the gazing artist, but only in the eyes of the male beholder. 
5. ReAding to Become Oneself not a Quixotic Other: MARIA EdGEWORTH AND THE PROBLEMS OF SELF-PERCEPTION

But I read that I may think for myself

Belinda, 227

Maria Edgeworth (1768-1849) is currently one of the better acknowledged mothers of the novel in British fiction, and the importance of her influence on didactic literature for children, teenagers or women, on Scott and the development of the historical novel throughout Europe, or on the novel of manners, is too exceptional to be contained in these pages. Educated by her father in mathematics, science and philosophy, and encouraged by her aunt to read more literary works, Edgeworth's oeuvre proves extensive and varied: from treatises, to moral tales, epistolary novels or even plays, from education manuals to political works of fiction, from a lively wit to a stern didacticism, she became one of the most prolific and influential novelists of her time. While her novels of national manners, or her children's stories, are immensely relevant for any scholar interested in understanding the literary and political panorama of the age, or the contemporary Enlightened theories on education, it will be only to the works in which she constructs a system of literary education aimed at women, and, more particularly, to her moral tales and novels of manners, that this chapter will be devoted. More specifically, it will focus on how she became a mistress of "her day's [...] multiple possibilities for selfconstitution through writing" (Myers, 1992: 139), not only of her own self as a successful and influential novelist, but of her female characters' as critical and intellectually independent women who always become subject of their own story.

Highly concerned with education, her works entitled Practical Education (1798), written with her father, and, more relevantly, Letters to Literary Ladies (1795), offer a particularly insightful comment on women's education and reading. The former book, as Bray has attested, "represents education as an active enquiry after knowledge, rather than passive absorption, foregrounding 
the process of learning, rather than the mechanical recitation of facts," while it evidences that it is "the manner, rather than the content, of reading that is the Edgeworths' primary concern, as they emphasise the importance of reflection and self-observation in a girl's education" (2009: 118). This process of learning will be made evident in Edgeworth's bildungsromane, her adolescent moral tales of awakening and maturation or in her later novels of manners. As for the matter of reading and its effects, the Edgeworths write, for instance:

With respect to sentimental stories, and books of mere entertainment, [...] they should be sparingly used, especially in the education of girls. [...] We know, from common experience, the effects of which are produced upon the female mind by immoderate novel-reading. To those who acquire this taste, every object becomes disgusting which is not in an attitude for poetic painting; a species of moral picturesque is sought for every scene of life, and this is not always compatible with sound sense, or with simple reality. [...] A tragedy heroine, weeping, swooning, dying, is a moral-picturesque object; but the frantic passions, which have the best effect upon the stage, might, when exhibited in domestic life, appear to be drawn upon too large a scale to please. The difference between reality and fiction is so great, that those who copy from any thing but nature are continually disposed to make mistakes in their conduct, which appear ludicrous to the impartial spectator. Pathos depends on such nice circumstances, that domestic, sentimental distresses are in a perilous situation; the sympathy of their audience is not always in the power of the fair performers. Frenzy itself may be turned to farce. (1815: 426-27)

In the first place, the Edgeworths indeed circumscribe a number of genres which may be a dangerous recreation for their young readers; dangerous not only because it becomes a source for immoderate leisure, but also because it leads to that rebirth of the reader into a quixote which opposes her romantic or picturesque interpretation to sound sense or reality itself. In a fictional reproduction of reality, these quixotes replicate their reading in too grand a scale, they forget to follow natural models, and hence become mere objects to be gazed at -a picturesque object, literally- and, furthermore, to be exposed and ridiculed. As will become evident in Edgeworth's works, as in those by her contemporary Mary Brunton, the metaphor of art, painting or the scenic, as something to be created and also to be envisioned and interpreted, and the topoi of contemplating subjects and objects, will be a recurrent presence in latecentury female bildungsromane and novels of manners to refer to the young female quixote's veiled perception or romantic colouring of reality, and her fraught interpretation of men and manners. Secondly, this separation between 
fiction and reality, between artistic recreation and nature, once more highlights the dangers literature may have for its readers: it can foster a fake notion of sensibility. The writers assert that "[b]esides the danger of creating a romantic taste," romantic imagery may diminish instead of increase the readers' sensibility. Readers' only know elegant distress, and, consequently, their imagination becomes "accustomed to this delicacy in fictitious narrations," and "revolts from the disgusting circumstances which attend real poverty, disease, and misery," hindering the subjects' practice of true benevolence (1815: 428). The Edgeworths then join contemporary criticism on the effect of fake sentimentality learnt from the myriads of novels which appeared at this time. Moreover, they echo other women writers' denunciation of passive sentimentality rather than active well-doing which truly relieves misery.

Letters resumes these issues and includes a practical application in literature of the principles expressed in her treatises. The book opens with "Letter from a Gentleman to his Friend upon the Birth of a Daughter, with an Answer," in which Edgeworth echoes contemporary opinions on what and how women should be taught, and, more importantly, what and how should they read. Edgeworth's defence of a comprehensive education and programme of reading for young ladies contrasts with the more restrictive views of Fordyce or Gregory; however, she is also aware of the dangers that an uncritical train of reading may entail for a young female reader. On the one hand, the gentleman of the title echoes the abovementioned moralists by rejecting the "literary and philosophical education of women" (1795: 21). He states that women's power of knowledge will never be equal to that of men, for the latter have the capacity to "mix in the world without restraint, to converse freely with all classes of people" (1795: 6), plus all the advantages of education. While he admits female education has improved, he questions not the genius of women to benefit from that instruction, but the "utility" of teaching women what they will not employ in life (1795: 8). In addition, he criticises women writers for excelling only at "poetry, plays or romances;" that is, at the "art of imposing upon the understanding by means of the imagination" (1795: 9) -even referring to the scandalous chronicles or stories written by women, in an obvious reference to the fair triumvirate of female wits, Behn, Manley and Haywood (1795: 11). 
Finally, for many pages, he enumerates the "evils" and ridicules the "foibles" of literary ladies (1795: 22), a group he wishes his friend's daughter never to join. He avows "romance, poetry, and all the lighter parts of literature" corrupt young women and, worse still, literary and worldly knowledge deviate the attention of these Femme Savantes from the "duties of domestic life" (1795: 36). The answer conveys Maria's own conception of female education and reading: women should not be preserved in the "bliss of ignorance" (1795: 44), while the addresser should not be considered a radical, "a champion of the rights of women" (1795: 45). Rather than radicalising her discourse, as Richard de Ritter has stated (2010), Maria Edgeworth stands in a liminal position which again questions the notions of public and private spheres. Defending women's "leisure to be wise" in this epistolary exchange, Maria defends the sound and comprehensive education of women, not to fulfil a role outside the domestic sphere, but to be able to develop a wider and more thorough train of knowledge. As stated by the enlightened father in these letters, in female education he would aim more to "cultivate the general powers of the mind than any particular faculty," and to develop "the love of knowledge" (1795: 73). Therefore, “women's reading is described as the basis of expansive knowledge, which provides them with the intellectual capital necessary to participate in rational discussion" (Ritter, 2010: 318); a rational discussion described in her novels as conducted in private circles such as the family or an assembly of friends. Moreover, this love of knowledge would never lead to female subversion or her conquest of public domain, for, as Edgeworth's character asserts, "the common fault of ignorant and ill-educated women is a love of dominion" (1795: 53). Regarding women's role as writers, owing to this exclusion from politics or an active life or education in society, women can devote themselves to literature while men have to diversify their knowledge and occupation to the branch or field in which they will find their profession (1795: 50), and hence women are transformed into influential writers which can set a cultural or moral tendency in the growing reading public. In this sense, the female subject can be "elevated by her learning to a position outside the division of labour and the partial interests it brings into being" (Ritter, 2010: 318). As a consequence, reading becomes equated with female intellectual labour, and the worth of reading becomes in Edgeworth's work a 
metaphor of a form of "material property and the ownership of professional skills" (Ritter, 2010: 330).

In relation to the danger of reading, she writes: "women have not erred from having knowledge, but from not having had experience" (1795: 56). In the 1799 edition of Letters Edgeworth more deeply explores this matter. First, answering to the Francophobic political and literary atmosphere of the age, she highlights the dangers of Rousseau, his inculcation of false morality and his message on the need in women for "coquetry to attract, and dissimulation to preserve the heart of men" (1799: 103), after which she expounds:

I would not, however, proscribe an author, because I believe some of his opinions to be false; I would have my daughter read and compare various books, and correct her judgement of books by listening to the conversation of persons of sense and experience. Women may learn [...] from the unprejudiced testimony of a father or brother [...]; they may learn to distinguish the pictures of real life, from paintings of imaginary manners and passions which never had, which never can, have any existence. (emphasis added, 1799: 103-4)

Once again employing the metaphor of painting, which she will resume in Belinda in connection with the quixotic Virginia, Edgeworth claims that it is only uncritical reading which may pose danger for the ignorant or ill-educated female reader and which may impulse her to create imaginary pictures that do not exist in reality. Furthermore, this critical judgement can be acquired through reading guided later by means of conversation. While claiming here the importance of the discourse and representatives of patriarchy, in her later tales and novels, in which her creative freedom seems less constrained than in the instances of shared authorship, Edgeworth will rather portray a female community of learning that will encourage and help its members to develop their judgement and to make sense of their reading of books, men and manners, on the one hand criticising ineffectual models of surrogate "mother-daughter" relationships, and, on the other hand, establishing exemplary ones that epitomise her concept of a successful female instruction and of women as perfect moral educators.

This epistolary exchange between gentlemen sets the tone for Edgeworth's whole work. While condemning what she perceives as particularly pernicious 
or immoral works of fiction, throughout her career she created innumerable reading heroines, some deluded and some not, emphasising with particular force that the danger lay not so much in what they read, but on how they approached fiction. That is, applying the abovementioned ideas on reflective reading and education, Edgeworth will portray reading as an activity that must lead to self-creation, to self-identification, to an awareness of oneself and one's role in life, rather than the mere imitation of literary models which forsake the guidance of nature, as stated above. In this sense, she develops a dichotomy between her "fictional practice" and her "antifictional" discourse (Gallagher, 1994: 275), which would link her to other Cervantean authors, such as Fielding, who emphasised the need to become aware of the fictionality of their novels to awake the naïve deluded reader. Responding to her context, Edgeworth will embody this blurring of the boundaries between reality and fiction mainly in sentimental heroines who cannot actively and judiciously read, who cannot interrupt their sympathy for the characters once they close the book, and who then become unproductive members of society, and even ineffectual educators of their children.

This is made evident in "Letters of Julia and Caroline," the second narrative in the early Letters, this time a feminocentric epistolary narrative in which the enhancement or the hindering potential of reading over women is displayed. In this early didactic work, the reader is presented with two young female readers. On the one hand, Caroline is a sensible and moderate consumer of literature, who defends the "proper sort of reading" which "fortifies the rational faculties and imparts information about the world, allowing women to practice selfcontrol and prepare for their pedagogical role," leading to a "shaper selfdefinition" (Gallagher, 1994: 275). On the other hand, Julia epitomises the dangers of sentimental reading. Building on the recurrent common places of sentimental literature and of its criticism, Edgeworth creates an overtly sentimental reader who confesses she feels rather than thinks, who defends her literary sensibility adducing it enhances real compassion, who equals sympathy for fictional characters with pity for real people, and who becomes a model of the passiveness of sensibility, a woman only valid to be gazed at and to please the gazer. Her sentimental enthusiasm, the manner in which it renders her blind 
to actual suffering, and the ways in which her sentimentality is a mere replica of that found in her readings, make her a quixote, although still embryonic and only a sketch of the author's later female quixotism. In addition, Edgeworth also contrives a cure for her character's delusion and a moral warning for her female readers. She ascribes to a long tradition in the didactic fiction of her time and employs the name Julia to connect her enthusiastically sentimental character with Rousseau's Julie or the Nouvelle Heloise. In the same manner as the French heroine, Julia's real life becomes tedious to her; as a consequence she abandons her husband, she is finally disgraced and ignominiously dies, leaving her daughter in Caroline's care. It will be Caroline who, at Julia's request, will later tell the young girl her mother's story as a pedagogical warning, fulfilling the educational role she has learnt from her prudent reading and transforming Julia's story into a "Fieldingesque mirror that her daughter (as well as the reader who stands in her place) will use to reflect philosophically on her own literary habits" (Gallagher, 1994: 286). Therefore, the reader is asked to imagine herself as two potential readers: "she can either read reflectively, like Carolyn (sic), and thereby become more and more herself, or she can read hysterically, like Julia, and become more and more fragmented" (1994: 286).

In this line, as Gallagher has insightfully asserted, Letters allows Edegworth to exercise the skills of "emotional involvement and extrication," therefore, "putting fiction to work to teach nonsentimental reading habits and to train reasonable, resilient, and agile personalities" (1994: 280). While mid-century writers, following Johnson's exaltation of example, "implied that the universal expropriation of nobody's sentiments would be offset by their provisional and temporary quality" and that normal readers would stop their identification once they closed their book (Gallagher, 1994: 278), with her critique to the rage of sensibility which followed these writers, Edgeworth depicts how the sentimental reader came to be thought of not as "an affective speculator, capable of entering and abandoning emotions," but as "an emotional addict, craving fictional identification and powerless to disengage from it" (1994: 279). In this sense, Letters, as will her later novels, describes "sentimental reading as pathological in order to recommend a different kind of fiction" 
(1994: 279), a form of fiction much as her own moral tales or didactic novels. In the works subsequently explored, sensibility learnt from literature will be the blinding enthusiasm that will render women -and some men- fragmented and incomplete quixotes in need for self-perception and self-realization. Together with these literary quixotes, Edgeworth will develop the story of displaced quixotes: women, such as Mrs Fangle, Belinda or Leonora, whose perception is not distorted directly by literature but who still evidence that the reading or seeing of characters and motives is nevertheless fraught for any young idealistic woman trying to make sense of herself and the world she inhabits. Quixotism remains then but a vague reminiscence and the heroines become the protagonists of a story of development where reading is transformed in an aid and not a danger. Both types of female protagonist will be at the core of a story of discovery and self-fulfilment in the midst of a complex social milieu, therefore contributing to strengthen the foundations for the nineteenth-century female bildungsroman.

5.1. Quixotic Precedents: the Universality of Hobby-Horses in Whim for Whim

Maria Edgeworth and her family were in their Irish home, Edgeworthstown, when the 1798 Irish insurrection took place. The family's surviving papers offer vivid records of the experience, and it can be ascertained that it had an impact on Maria's attitude and writing. Although the family was suspected for their Francophile attitude, which surfaces for instance in the benevolent treatment of French refuges in "Angelina," Edgeworth would always associate in her works a certain lack of morals with pernicious philosophical and literary influences imported from France or Germany. An example would be her almost unknown play, Whim for Whim (1798), written and performed closely after the rebellion. Apparently, she had been working on the manuscript and was one of the things she carried with her when they returned to England. According to the Memoirs, it was acted twice in January 1799, "with great applause," although it was nonetheless rejected as "not comic enough" or "perhaps as too controversial for the stage managed by Sheridan, himself 
tainted with Irish rebel politics" (Myers, 1998: 78). In addition to the Irish matter, it was a satirical piece on spies and spy-mania which moreover drew "on the diamond necklace scandal involving Marie-Antoinette and the socalled Countess Jeanne de la Motte in 1785, and the swindles of the adventurer, the so-called Count Cagliostro" (Manly, 2004: n.p.).

With a protagonist identified as a "quixotic reformer and quasi-hero" (Myers, 1998: 77), who moreover has a Sancho-like companion in his black servant Quaco, the play advances many of the recurrent elements of Edgeworth's subsequent and more developed quixotic fictions. The protagonist is young Opal, an enthusiast of Illuminatism and a lover of everything new, which will put him at odds with his uncle, Sir Mordent, an elderly gentleman and defender of everything old. Opal will be recurrently deluded by the philosophical villains of the story, the Illuminatists, who are portrayed as egotist manipulators of the young quixotic philosopher. These are Count Babelhausen, a German illuminatus; his spy, Felix, who acts as Sir Mordent's valet and who contrives throughout the play to cheat everybody and steal off Mrs Fangle's diamonds; and, finally, the villainess, Mademoiselle Fanfarlouche. The latter is the greatest deceiver in the play: as she states, she "plays all [...] roles" (2003: 303); she assumes the personality of a German princess and illuminée, Aspasia, to delude Opal into marrying her; she also pretends to be a virtuous governess for Mrs Fangle's children, though her teaching is deficient; and, finally, she is the Count's mistress and partner in the fraud by which he intends to marry either Mrs Fangle or Caroline, and also Felix's accomplice in the robbery.

In this regard, the play already expounds Edgeworth concept of quixotism as a mania, an obsession or hobby-horse, in this particular case identified as a whim, which may affect people from all ages and conditions, emphasising how a truthful reading of others and oneself is a fraught process. The most obviously deluded character is Opal, described as an exemplary man who, despite his many virtues, has even more whims; who, despite never being a knave, has something of the dupe in him (2003: 327). Echoing Sir George Warrington and anticipating Peacock's Scythrop, Opal becomes an enthusiast of the new philosophies imported from Germany and France. Deluded by the typical vauriens, he will attempt to live by the moral code of the Illuminati, 
which proves both impractical and immoral. Opal's conflict raises thus from the difficulties of reconciling theory and practice, fiction and reality, and in so doing it allows a reflection on the application of certain forms of philosophy, which include once again well-known ideas extracted from William Godwin and Thomas Holcroft. Opal's ideas of general good lead him to build castles in the air, and to aim to achieve the "reformation of the world" (2003: 309). As any ideological enthusiast, Opal undergoes a process of awakening from misunderstood philosophy that involves, on the one hand, acknowledging the interests behind the apparently idealistic principles of the reformers and, on the other hand, an awareness of one's feelings and an acceptance of more conventional sets of beliefs or code of behaviour. Opal will awake to both the intriguers' deceit and his true love for the heroine in the play's climactic scene. When he is about to marry Aspasia, the fake princess, the veil that covers her face lifts and Caroline appears. Everything is explained and he is finally united to the wise heroine. This scene represents Opal's unveiled mind; at this point, he can confidently assert "now instead of pure reason I will follow commonsense" (2003: 384), which closely resembles other quixotic cures and which provides the opportunity to substitute the system of reference at fault for a more sensible one. Opal overcomes his youthful quixotism and can be happily rehabilitated in his uncle's opinion, gaining status, wealth and a bride at the same time. Edgeworth has abandoned the flagrant condemnation of ideological quixotism, and introduces it as a youthful idealistic colouring of reality that can be corrected by means of a more commonsensical approach to experience. In addition, it can still be presented in a positive light as the motor to change old customs.

In this sense, Opal will not be the only character in need for correction. A clear precursor of Lady Delacour in Belinda, the play portrays the rich and whimsical widow, Mrs Fangle, described as a "charming bewitching whimsical creature" who has the "learning of a batchelor of arts, the enthusiasm of a girl of fifteen, and the airs of a woman of fashion," and "wit and beauty enough to drive a man mad" (2003: 324). Subject to fashionable follies, nevertheless, "she is not a passive fashion victim, for her rampant consumerism is as much about ideas as objects" (Myers, 1998: 79), including new educational 
experiments which enable Edgeworth to mock her otherwise admired Madame de Genlis in Mrs Fangle's system of education. Her passion for everything new will contrast with Sir Mordent's obsession with everything traditional, and, as a consequence, both characters engage in highly comical dialogues -or rather, in battles of monologues, in which their individual and monomaniac discourses clash with each other. In the end, Mrs Fangle's awakening arrives with the loss of her fortune, the discovery of the treachery of her suitor the Count and the falseness of the Illuminati, and with her final admission to Caroline: "forget my follies-I will be worthy of your friendship" (2003: 384). Anticipating Lady Delacour, Caroline can perceive that Mrs Frangle pretends to be worse than she is (2003: 317), which allows the latter to state that Caroline will be able one day to "laugh [her] out of [her] whims" (2003: 316), something she finally does.

Finally, the third character to display this whimsical nature is Sir Mordent Idem. His obsession with the past, which leads him to dress following Sir Charles Grandison's fashion for a masquerade, and his pettishness about certain parts of ancestral traditions, displayed in his obsession with his wig, an ancestral "Beresford Bob"he always wears (2003: 357), and a "full bottomed periwig" (2003: 363) he chooses for his impersonation of Richardson's character, conform his character. His whims are also humoured and subtlety controlled by Caroline, who also highlights the opposition of uncle's and nephew's similar manias. When Opal exasperatedly complains to Caroline about his uncle's whim to wear a wig, she laughs and answers: "Oh Whim for Whim" (2003: 363). In this sense, "as much a victim of the idée fixe and abstract rationality as his uncle is of the idée reçue and the material past, the changeable Opal and the stick-in-the-mud Sir Mordent alike must learn the arts of accommodation and embodied rationality as represented in Whim for Whim's real reformer" (Myers, 1998: 79).

And this ideal reformer is the sprightly, witty and virtuous Caroline. Teasing and later curing her lover's, Sir Mordent's or Mrs Fangle's hobby-horses she evinces that she is the only character with a sound judgement. In addition, by so doing, she becomes the author-surrogate, unmasking the hidden personalities and plots, and making sense of the former and the latter alike. 
Opal and Mrs Frangle both beg "Oh speak Caroline! [...] Can you explain this my story?" (2003: 382); and the young heroine, "Edgeworth's symbolic expression of intellectual woman as mediatrix and cultural reformer" can and does (Myers, 1998: 80). Caroline moreover epitomises the individual and critical discourse that Edgeworth aims to inculcate in her heroines and her implied readers alike. In a play full of monological discourses that represent each character's monomania, Caroline is the only character who can truly read every one of them and reconcile the seemingly contradictory visions of the world. Later heroines echo Caroline in their exegetical effort to make sense of people and their discourses, as well as to cure those same characters from their own limited perception. Edgeworth resumes the gallery of deluded characters in her mature novels to provide a comment, first, on the need for a young woman to read adequately not only texts, but, more importantly, people, and, secondly, on the role wise women perform as insightful mentors. The process towards this awareness and critical reading will hence also be at the core of Edgeworth's subsequent works of narrative fiction with a young heroine as main character.

\subsection{The Problem of Reading and Being Read: "Angelina; or L'Amie Inconnue"}

Maria Edgeworth became extremely popular owing to her moral tales. Among them one stands out: the multi-volume Moral Tales for Young People (1801), which contains several stories aimed at the improvement of its readers and which once more exemplifies the principles of her essays. One of these tales focuses on the matter of women's reading and features a literary quixote. "Angelina" is the story of Anne Warwick, a sixteen-year-old orphan under the care of the fashionable Lady Diana Chillingworth, who, after experiencing an absolute lack of attention from her guardian, finds refuge in reading novels. Consequently, she creates a more literary persona under the name "Angelina," and starts correspondence with Araminta, an author of sentimental novels who befriends her and convinces her to elope and live with her in a Welsh cottage. After arriving at the cottage and finding Araminta gone, Angelina travels to 
Bristol with Araminta's ludicrous Welsh maid. In her quest for her unknown friend, Angelina will come across many different characters and will experience humiliating adventures until she is reunited with her beloved author, only to discover that she is a drunk and profligate woman by the name of Rachel Hodges. This discovery, united to her embarrassing adventures, trigger Angelina's awakening, and her cure is completed with the advice of the effective maternal figure of the novel, Lady Diana's sister, Lady Frances Somerset, and the reading of Lennox's The Female Quixote.

Anne's transformation into Angelina and her return to Miss Warwick exemplifies Edgeworth's claim that literature without guidance may confuse young readers in their quest for their own self, rather than enhance their selfidentification. As many other female quixotes, Anne is an orphan, even though she is the protégée of Lady Di, a woman only concerned with fashion and the opinion of the world, who ignores Anne in favour of the sycophantic Miss Burrage, and who overlooks her flights of fancy until they are due to cause scandal. Anne is then twice an orphan, isolated among a group of individual and egotistical females. Disgusted with the shallowness of the company and of society in general, intelligent and good-natured, Anne finds refuge in fiction. As Myers has stated, "fiction offers the orphaned protagonist a language, a place, a dream of her own," and even if fiction is the reason she errs, at least it offers her "possibilities for resisting the trivialities of the culture that surrounds her," it provides her with the means to "define her emotions and to articulate the youthful idealism that the tale values" (1989: 29). That is, despite the errors of judgement in which Angelina incurs throughout the novel, from the beginning Edgeworth is ascribing them not only to literature, but also to her youth and her lack of guidance; as Lady Frances concludes, women of Anne's "superiour (sic) abilities require something more than common sense, to direct them properly" (1806: 152), as opposed to mere women of fashion. In this sense, as happened with Fielding's Adams or Lennox's Arabella, Angelina's delusion is treated with benevolence and employed to criticise the shallowness of society and the improper education of women. That the satire is aimed more at the surrounding flawed characters than at the quixote herself is stated when 
Lady Frances asserts of Angelina and Lady Di: "a simpleton of sixteen is more an object of mercy, than a simpleton of sixty" (1806: 243).

Confronted with such an ineffectual surrogate mother, Angelina must find in fiction the guidance she cannot find in the real but shallow Lady Di. As a consequence, Angelina sets out to find her literary godmother, a motherly figure that can guide her in the process of coming of age and of constructing her true self. In this sense, Angelina anticipates Barrett's wandering heroine and shares Mrs Bullock's coeval portrait of a rambling quixote, highlighting how Edgeworth subverts the conventions of the eighteenth-century heroine. Rather than following Lennox's virtuously immobile quixote, Edgeworth depicts a heroine that does not just sentimentally react to reality, but who also shows initiative and creates her own opportunities for adventure. In addition, Edgeworth departs from Lennox's narrative and the tradition she instituted in one other matter: Anne does not follow romantically-imbibed tenets when she elopes, for she does not escape to meet a suitor. What had been the recurrent plot in Arabella's romances, or Dorcasina's sentimental novels, does not trigger Angelina's quixotic quest. It is sentimental female friendship that she quixotically seeks for, and her search proves an original one. Lady Frances, for instance, finds it "incredible" that there is no romantic object with or for whom Angelina has eloped, for she is sure there must be some admirer or lover involved (1806: 150); aware of the common places of sentimental fiction she cannot conceive any other reason for a young girl to take such a step. Therefore, not only the quest itself challenges the conventions of traditional structural patterns for young heroines, but the object of the quest is different to what could be expected from a female quixote deluded by fiction. In this regard, Edgeworth plays with the readers' expectations and subverts the tradition of female quixotism itself, negating the two possible endings for her quixotic heroine, happy marriage or ignominious death, because the motives of her quixote negate the heterosexual plots of cure through marriage or of seduction and abandonment. Connecting with prior works of fiction such as Sarah Scott's narrative of a utopian female community in Millenium Hall (1762), which is presented as a better option than marriage, Edgeworth constructs a novel that advances a new conception of female bildungsroman, a 
story of development understood as more than a sexual or emotional awakening prior to becoming a wife. She will hence anticipate the stories of female self-construction and independence of the nineteenth or even twentieth century.

Despite this rejection of the traditional heterosexual plot, as in any story of development, there exists the same process of delusion and awakening that all female quixotes undergo. Angelina expects adventures to befall her during her rambles throughout the Welsh rough landscape, in the inns or the mountain walks, but her experience will contradict her romantic expectations. Neither the people, nor the dwellings or the situations are what she had learnt to look forward from her novels; instead, in a pattern clearly adopted from Cervantes, reality will prove jocularly different from fiction: rather than idyllic mountaineers, shepherds or innkeepers, she encounters gossips and rude Welshmen and women in resemblance of the human landscape Don Quixote finds at the inn he mistakes for a castle. However, in the tradition of female quixotism, Angelina's senses are in perfect order, and she is capable of balancing illusion against reality and to awake to her mistakes. The greatest awakening of course regards every aspect related to her cherished unknown friend, Araminta.

First, it is Araminta's cottage, very sentimentally named "Angelina bower," which disillusions her. After a comic arrival in the middle of the night in which the maids take her for a ghost, she finds the cottage excessively sentimental for her taste: too small, too isolated. It is moreover too "low for so lofty a head" (1806: 173). When she is about to enter "Angelina bower" she bumps her head with the ceiling, an image of how reality will recurrently hit her with its harshness. Then, the romantic maids of her novels are transformed into the extremely farcical Betty Williams. Closer to Sancho than to Arabella's Lucy, Betty is characterised by her clumsiness, her regional accent and sayings, her immoderate appetite, her superstition, her picaresque, and her ability to involve her mistress in many ridiculous situations. Exasperated, the romantic Angelina thinks: "She's actually a female Sancho Panza!," to which the narrator aptly adds: "her own more striking resemblance to the female Quixote never occurred to our heroine -so blind are we to our own failings" (1806: 220). 
Together they perfectly echo the dichotomy already found in Don Quixote and Sancho between lofty ideals and physical needs, between romantic idealism and the spirit of the worldly picaro. However, Betty lacks Sancho's wisdom and remains a plain comic relief.

Finally, it is in the person and character of Araminta that Anne is more evidently mistaken. After finding in the circulating library a novel entitled The Woman of Genius, Anne is charmed with the character of its heroine, Araminta. Told by the preface that the novel is founded on real facts from the authoress life, Anne writes to the publishing house addressing the "woman of genius" and hence her correspondence starts. In the poor intellectual context in which Anne lives, illustrated, for example, by Miss Burrage's taste for ridiculing what is not "sanctioned by fashion" and her "total want of any taste for literature" (1806: 158), Araminta becomes a positive model, who in addition reads and writes. However, the true Araminta/Rachel, the unknown friend of the title, remains hidden from view most of the narrative, not only physically, but also by means of the linguistic and literary screen she has created for herself. Having thoroughly read Rousseau's Heloïse and a few German plays -the worn-out books Angelina finds in her cottage (1806: 174)-, Rachel has constructed an effective fictional persona that conceals her true nature by the use of all the conventions of sentimental language and feeling: her professions of unalterable friendship (1806: 155); the broken syntax to convey emotion (154); the hyperbolic structures such as "sublime confidante" or "supreme felicity" (1806: 155); the lexicon of sensibility and radical freedom, such as "sympathizing," "agonizing," "heart-broken," "system of social slavery," "oppressed, degraded, enslaved, must our unfortunate sex for ever submit to sacrifice their rights, their pleasures, their will, at the altar of public opinion" (1806: 155). Her discourse in her letter, and in her novel The Woman of Genius, and her literary persona bluntly contrast with the woman Angelina founds at the end of her quest through the streets of Bristol, the most unromantic setting she could imagine. Angelina's first impressions at seeing her friend shock her, especially when she discovers her name to be Miss Hodges, or that the man she takes for the footman is the famed lover "Orlando" of Araminta's letters, in reality Mr Nat Gazabo, the soon-to-be husband of the 
authoress. Nothing matches her literary expectations, not even Miss Hodges' cutting of the bread and butter, "which she did not do with the celebrated grace of Charlotte, in the Sorrows of Werter" (1806: 227). ${ }^{247}$ Angelina's thoughts in the midst of this anti-romantic and ridiculous tableau reveal that her awakening is in process:

[...] whilst [Miss Hodges] was declaiming on her favourite topic, her Angelina was revolving in her altered mind the strange things which she had seen and heard in the course of the last half-hour; everything appeared to her in a new light; when she compared the conversation and conduct of Miss Hodges with the sentimental letters of her Araminta; when she compared Orlando in description to Orlando in reality, she could scarcely believe her senses: accustomed as she had been to elegance of manners, the vulgarity and awkwardness of Miss Hodges shocked and disgusted her beyond measure. -The disorder, \&c-for the words must be said-slatternly dirty appearance of her Araminta's dress, and of every thing in her apartment, were such as would have made a Hell of Heaven; and the idea of spending her life in a cottage with Mrs Hodges-Gazabo and Nat overwhelmed our heroine with the double fear of wretchedness and ridicule. (emphasis added, 1806: 229-30)

This scene increases in absurdity, with Miss Hodges falling into drunken fits of anger and tears, and Angelina suffering under the weight of sustaining her delicate friend's head on her shoulder to relieve her tears. The narrator underscores the comic effect with burlesque comments on the "mixed problem of physics and metaphysics" concerning how long Angelina's shoulder could cope with such weight (1806: 232), exhibiting Edgeworth's witty sarcasm within her didactic purpose. The problem remains unsolved, for Betty, the Constable and many of the characters Angelina has encountered appear to accuse her and her maid of theft. The Constable has already arrested her when Lady Di, Miss Burrage and Lady Frances enter with some more characters involved in the story. Ridicule escalates, and Lady Di repudiates her protégée.

After this scene, Angelina is completely restored to her senses. Her liberation is signalled by her literal escape from Miss Hodges grip and her farewell to her with a "my unknown friend, indeed!" (1806: 239). Her newly gained self-

${ }^{247}$ Edgeworth's choice of this mundane action to be compared in reality and fiction adds to the comic effect and to the critique of sentimental fiction as deforming even the most everyday events. In an echo of her critique in Practical Education, it demonstrates how sentimental people expect everything to be as picturesque as it is in fiction, especially in the epitome of sentimentality which is Goethe's novel. It is interesting to note that Edgeworth will mention this particular passage again in Leonora (1806), a novel that, as will be stated, also condemns sentimentality learnt from novels, especially foreign, as false and dangerous. 
awareness is expressed by her regret at what she has exposed herself to and by her opening "her whole mind to Lady Frances, with the frankness of a young person conscious of her own folly, not desirous to apologize or extenuate, but anxious to regain the esteem of a friend" (1806: 240). Angelina expresses herself "fully sensible of her folly" and of the fact that she had been misled by Araminta's descriptions of friendship and felicity, by the commonly shared mistake that "those best can paint them who can feel them most" (1806: 242). The final touch is Lady Frances' suggestion to read the romance "Arabella, or the female Quixote" so that Angelina can tell her who of their acquaintance "the heroine resembles most" (1806: 242), once again pointing out at the role of fiction as a mirror for the implied reader. Finally, it is also Lady Frances who reflects on the need to control the greatest danger, the amount of scandal which Angelina's escape has created.

Lady Frances is satisfied with the impression this last comment makes on Angelina's mind and assures her "she did not intend to torment her with useless lectures and reproaches" (1806: 243). In this she proves that, as the narrator states, she "understood the art of giving advice rather better than Lady Diana Chillingworth" (1806: 243); and, indeed, better than other advisors in quixotic fictions. Compared to Lennox's Doctor of Divinity, Lady Frances contrives a less serious manner to cure her pupil for ever, and it is her mercy, more than any "severe reproaches," which touches Angelina (1806: 244). More relevantly, Edgeworth adopts the plot that Lennox seemed to have dropped when she eliminated the Countess from her novel: she creates a surrogatemother figure who gently but firmly conducts the young quixote in her path to a final complete self-awareness and critical judgement. The final paragraph concludes:

As for our heroine, under the friendly and judicious care of Lady Frances Somerset, she acquired that which is more useful to the possessor than genius -good sense. - Instead of rambling over the world in search of an unknown friend, she attached herself to those whose worth she received proofs more convincing than a letter of three folio sheets, stuffed with sentimental nonsense. In short, we have now, in the name of Angelina Warwick, the pleasure to assure all those whom it may concern, that it is possible for a young lady of sixteen to cure herself of the affectation of sensibility, or the folly of romance. (1806: 255) 
This ending, in which the moralistic and humorous narrator once more addresses her readers directly, advances the comic morals that close Austen's novels, in particular Northanger Abbey or Persuasion, and their parody of the stern moralistic voice so characteristic of the genre of didactic fiction. Moreover, it confirms Edgeworth's interpretation of quixotism in this particular work as an error of youth that may be overcome. In the end, because of this interpretation of quixotism, in the place of Angelina's expected punishment, the character emerges relatively unsullied and wise, and her final name, Angelina Warwick, seems to foretell the construction of a unique personality, uniting the best of her idealism and her experience. In addition to this positive approach to quixotism, the fact that her final cure is presented after the discovery of Miss Burrage's low birth and deceiving conduct, highlights that Angelina's mistake and cure is more to be condoned than Lady Di's. At the latter's discovery of her favourite's origin and her concern on what the world will say at such imposture, Lady Frances again emphasises that her sister has been as deluded as Angelina, stating "it is very imprudent to have unknown friends, my dear," advising her not to condemn Angelina too harshly for "if you talk of her unknown friends, the world will certainly talk of yours" (1806: 253), as much a piece of advice for narratees and implied readers.

Edgeworth's tale makes clear that the possibility of delusion does not belong only to a young inexperienced girl, and that the search for truth may be equally fraught for all characters. In fact, nobody except Lady Frances fully interprets Angelina: Lady Di only reads Angelina as a disgrace for her reputation; Miss Burrage, as a deluded woman and a danger to her position of privilege which she assumes Angelina may want; the Welsh people, as an indecent runaway; and in Bristol she is read as a mad woman. Furthermore, it exposes the fact that, as Smollett or Sterne had already made clear, each person possesses or constructs his or her personal discourse and with it marks his or her personality; consequently, there exist difficulties for reading other people whether a quixote or not. This is signalled in Edgeworth's mastery of regional dialects which impedes fluid communication between the Welsh Betty and the Irish coachman, creating some of the most jocular scenes of the novel by their misunderstanding and their mutual attack on their origin. Moreover, there is 
little Clara Hope, Lady Frances' Scottish protégée, or a little French refugee boy, whose speech, perfectly reproduced, signals them as foreign to the main characters. Even the good and wise Dinah and John Barker are characterised by their Quaker form of speech. Again, language moulds identity. All the abovementioned linguistic patterns demonstrate how "one arrives at selfhood through language and how misunderstanding another's way of construing the world means trouble, no less in the tale's continual playing with dialects than in its heroine's misreadings of romance and reality;" therefore, "you can become what you read; you are what you speak, not a prior essence, but a self defined through language" (Myers, 1989: 28). In this sense, dialects which expose national identity coexist in the tale with different styles of speaking, different ways in which the female characters have fashioned themselves, from Lady Frances wise wit to Lady Di's shallow and fashionable talk, from Angelina's sentimentality and radical pseudo-feminism, to Nat's simple and vulgar language. In this regard, Edgeworth proves how Angelina's true voice can only develop in society, in dialogue with all the discourses that constitute it. As Evelina or any other bildungsroman heroine, Angelina then requires this entrance into society to mature and become her own self. Moreover, Edgeworth adopts another convention from the female story of development and expounds how discourse can be manipulated to hide the truth -as in the newspaper that publishes a scandalous version of Angelina's escape-, and to hide oneself -as performed by Araminta/Rachel-, or how it can be a series of clichés that do not allow the individual's own unique personality to be developed, exemplified by Angelina's construction of a sentimental self.

In fact, the greatest part of Angelina's lesson will be to learn how to analyse discourse beyond the surface, and how to distinguish authenticity from mere cliché. Of course, the best example is Araminta's pseudo-sentimentality and Wollstonecraftian discourse. Both her sentimental speech in writing and in person brim with common places which wise Lady Frances at once recognises as artificial. As Angelina listens to Miss Hodges, this artificiality is made ostensible, not only by its contrast with the appearance of the speaker and the context in which they are spoken, but especially when it is placed parallel to 
Angelina's true feeling. When the Constable is about to arrest Angelina, the following scene ensues:

"Villain! unfeeling villain! oh, unhand my Angelina, or I shall die! I shall die!" exclaimed Araminta, falling into the arms of Nat Gazabo, who immediately held the replenished glass of brandy to her lips -"Oh, my Angelina, my Angelina!"

Struck with horror at her situation, Miss Warwick shrunk from the grasp of the constable, and leaned motionless on the back of a chair.

"Come, my angel, as they call you, I think -the lady there has brandy enough, if you wants spirits -all the fits and faintings in Christendom won't serve you now. I'm used to the tricks o' the trade." (1806: 234)

In this brief passage Edgeworth not only contrasts fake with true feeling, but she also identifies the extreme form of sentimentality with the recurrent image in anti-sensibility discourse of an intoxication, stressed by the constable's play with the word "spirits," and with a mere "trick of the trade," that is, a mere convention employed by novelists to achieve an effect on the audience. The discourse of sensibility in the shape it presents in literature is foreign to Miss Hodges's true self and to Angelina's alike; it is learnt, not the expression of natural feeling. In this line, the narrator emphasises the fact that Angelina has not yet acquired all the sentimental assets required from a heroine when she bursts into tears at her folly and the reader is told that "though a sentimental lady, she had not yet acquired the art of bursting into tears upon every trifling occasion," rather "hers were tears of real feeling" (1806: 243). In another powerful image, Angelina removes from her neck the gold locket in which a lock of Araminta's hair is kept, and gives it to the poor refugee boy; with this act, she moves from passive literary sensibility to active and charitable one, evidence of her true self. Both the heroine and the reader have then been exposed to the artfulness behind sentimental speech, the ways in which it can mask a reality very different from what it portrays, and the need to create a different self through a more proper discourse, such as that of compassion. Heroine and readers alike need to become aware of the ways in which literature can enhance or hinder their self-development, and choose to read critically and resistingly. The same could be said of Miss Hodges speeches on female freedom, or liberation from aristocratic oppression: her grand radical rhetoric 
only hides her dishonourable arrangement with Nat. Discourse modelled on Wollstonecraftian views is then discarded as false and amoral, a recurrent critique in Edgeworth's novels. ${ }^{248}$

In the end, Angelina learns good sense, which will enhance her chances of avoiding further misreadings in the future. After all, she concludes the narration still sixteen and unmarried, therefore her story is still open according to traditional romantic plots. More realistically than her contemporaries, Edgeworth highlights that the creation of a young girl's personality or subjectivity does not aim to achieve marriage, not does it conclude on the wedding day. On the contrary, "the tale demonstrates that the protagonist achieves the heroism of mature female subjectivity [...] in an ongoing process that is not complete by story's end -and cannot be complete in life. Experience, like reading, is an interactive process, not an achieved state" (Myers, 1989: 29). The idea that women continue to develop their own subjectivity after marriage will be at the centre of novels such as Belinda or Leonora, and will assert Edgeworth's defence of a comprehensive education that does not find closure in the married state. Together with this vision of female development, the topic of the "unknown friend" and of the screen that different discourses create will be thoroughly developed again in Belinda and Leonora, a recurrence that evidences the importance of the theme of reading or discovering people in Edgeworth's work, and the richness with which the author treats it.

\subsection{Perception and Self-Development in Belinda}

Belinda (1801) legitimately stands as one of Edgeworth's masterpieces and as a perfect example of the problems of female self-awareness and perception which serves as foundation for the female bildungsroman, as well as for the novel of manners featuring a young heroine: Edgeworth impeccably integrates

${ }^{248}$ It is interesting to note, though, that the French refugee boy is a positive figure in the tale, and that he allows Angelina to practice active sensibility for the first time. The number of refugees who escaped the Reign of Terror was high, and many writers joined in claiming the need to support those anti-radical French emigrants who arrived in Britain. Edgeworth's attack on Francophile discourse, as that of many anti-radical authors, including such extremist ones as Charles Lucas, is directed only at Jacobin fractions and not at the French victims of their government. On this matter, see Kirsty Carpenter, Refugees of the French Revolution. Émigrés in London, 1789-1802 (Basingstoke: Palgrave Macmillan, 1999). 
the story of a heroine that must become integrated in society with a comprehensive re-creation of the social world that mocks the flaws of the different strata. Not as experimental or fragmented as the later Leonora (1806), it concentrates on fewer characters and provides the comprehensive and reliable comment of an omniscient narrator. Belinda Portman is a "handsome, graceful, sprightly, and highly accomplished" young woman, "educated chiefly in the country" and "inspired with a taste for domestic pleasures," who is "fond of reading" and "disposed to conduct herself with prudence and integrity," though her character is described as "yet to be developed by circumstances" (2008: 7). Her only relative is an aunt, Mrs Stanhope, a well-known matchmaker who prides herself in having "established half a dozen nieces most happily," which is to say, she had them married "to men of fortunes far superior to their own" (2008: 7). Although she has tried to educate Belinda in the notion that "a young lady's chief business is to please in society, that all her charms and accomplishments should be invariably subservient to one grand object -the establishing herself in the world" (2008: 7), Belinda proves difficult to educate in these axioms. In order to achieve her purpose, Mrs Stanhope fastens Belinda upon the fashionable Lady Delacour so that she can improve her chances of meeting eligible suitors. This visit will mean her entrance into the world, and the start of her development process to know others as well as herself. Belinda will need to learn to decipher friends and suitors alike, in particular the man she is in love with, Clarence Harvey, and her friend, the seemingly shallow and amoral Lady Delacour; these characters will also need to decode Belinda, so as to conclude with a happy ending, with Belinda choosing the right husband and reuniting Lady Delacour with her estranged husband and daughter.

In Belinda, undoubtedly one of her most achieved novels, Edgeworth advances the subject matter of the need to develop critical judgment to literally or figuratively read texts or characters which she had already introduced in "Angelina." Belinda, as was "Angelina" and will be Leonora, is thus the fictional enactment of Edgeworth's motto in "Letter from a Gentleman:" a young girl will be required to "read and compare various books, and correct her judgement of books by listening to the conversation of persons of sense and 
experience," she will need to learn how to distinguish "the pictures of real life, from paintings of imaginary manners and passions which never had, which never can, have any existence" (1799: 103-4). Assuming reading and books in their literal and figurative sense, the novel that Edgeworth develops revolves around this fraught process of perception and interpretation, which is, after all, at the core of a genre, the novel of manners, that offers a "perspective on the nature of the self as shaped but not entirely determined by social forces; as expressing itself in relation to, but not necessarily in accord with, the values of a society embodied in outward conventions" (Bowers and Brothers, 1990: 4), and which, therefore, places a great emphasis on interpretation as a crucial concern for "characters in as well as readers of" the novel (1990: 13), that is, for diegetical and implied readers alike. To highlight the complexities of critically seeing or reading others, as well as oneself, Edgeworth once more depicts two literal quixotes, Virginia and Clarence, deluded by romances and by French novels respectively, and a group of characters who cannot interpret one another: Lady Delacour is a mystery for Belinda, for her husband or her child, and she cannot interpret them either; Clarence misreads Virginia and Belinda, and they both misread him; and the unsex'd virago in this novel is Harriet Freke, who also tries to discover what hides under Belinda's or Lady Delacour's surface. In this sense, the novel resumes the difficulties of reading and interpretation already present in Burney's Evelina and focuses on Belinda's discovery that "the reading of $[\ldots]$ characters in general, is frequently problematic and dependent on subjective interpretation" (Bray, 2009: 111).

Belinda is a fond reader and observer. Her country education involved much reading, but this changes as she enters polite society. The narrator explains that "her taste for literature declined in proportion to her intercourse with the fashionable world, as she did not in this society, perceive the least use in the knowledge that she had acquired" (2008: 10). Moreover, her reading until that moment had been passive and subordinated, for "her mind had never been roused to much reflection; she had in general acted but as a puppet in the hands of others" (2008: 10). As she enters the world, however, she will become aware of the need to adopt a model of active and stimulating reading in order to make 
sense of herself, manners and men. In addition, experience will develop the moral principles she had only acquired in an abstract manner and will allow her to apply them to making rational decisions. Despite this emphasis on experience, once she faces the difficulties of deciphering her friends, or the intellectual and moral dangers of a superficial society which does not encourage thinking for oneself, Belinda resumes her course of reading to strengthen her mind. It will be her reading, united to rational conversation, which will distinguish her from other characters that do not or cannot develop their understanding by means of critically approaching literature. After misquoting Milton and being corrected by Belinda, the radical Mrs Freke initiates an essential passage to understand Edgeworth's approach to reading:

"You read I see! I did not know you were a reading girl. So did I once! but I never read now. Books only spoil the originality of genius. Very well for those who can't think for themselves -but when one has made up one's opinions, there is no use in reading."

"But to make them up," replied Belinda, "may it not be useful?"

"Of no use upon earth to minds of a certain class. You, who can think for yourself, should never read."

"But I read that I may think for myself."

"Only ruin your understanding, trust me. Books are full of trash -nonsense. Conversation is worth all the books in the world."

"And is there never any nonsense in conversation?"

[...] Mrs Freke [...] did not choose to attend to this question [...] (2008: 227)

Differently to most authors in this study, Edgeworth directly and unabashedly praises the role books have in her heroine's independent thinking. Whereas most authors imply the benefits of regulated or critical reading, and seek to substitute the teachings of other novels with the principles of their own, Edgeworth advocates freedom to read and to think for oneself, even if, or precisely because, one is a young woman. In Edgeworth's novel, for example, only bad or stupid characters, such as the men of the world Rochfort or St. George, do not read or despise those who do (2008: 93). In this sense, as Ritter has pointed out, Belinda constructs her identity through "intellectual labour" and an "industrially cultivated sense of ethics" (2010: 326), as opposed to 
Harriet Freke's or even Lady Delacour's shallowness and exteriority. For instance, Mrs Freke -whom Juba, Mr Vincent's black servant, calls the "manwoman" (2008: 219) - with the unsexed qualities of a radical woman, such as her fondness for wearing men's clothes, or for daring actions such as fighting a duel, has been rather spoilt by her lack of reading. Moreover, her discourse is full of radical clichés which demonstrate that it is her who cannot think for herself. In addition, she is the epitome of the corruption the pleasures of society or radicalism hide for women: she badly influences a young woman, whose reputation she ruins, in the same manner she exerted a bad influence over Lady Delacour. As the latter detaches herself from Freke and attaches her friendship to Belinda, the difference between the principles of both become even more obvious as Lady Delacour commences to think without consideration to the opinion of society. This difference has been foretold when, at one point, Belinda renounces the pleasures of social events in order to spend hours alone reading in the library. As she reflects,

Is it possible [...] that I have spent three hours by myself in a library, without being tired of my existence? How different are my feelings now, to what they would have been in the same circumstances six months ago! I should then have thought the loss of a birthnight ball a mighty trial of temper. It is singular, that my having spent a winter with one of the most dissipated women in England should have sobered my mind so completely. If I had never seen the utmost extent of the pleasures of the world, as they are called, my imagination might have misled me to the end of my life; but now I can judge from my own experience, and I am convinced that the life of a fine lady would never make me happy. (emphasis added, 2008: 126)

Therefore, Belinda embodies Edgeworth's message that literature and experience should be joined in women's education so that they can critically judge society and their own desires and aspirations. Literature and life then nurture and balance each other: if Belinda had only literature as guide, idealism would never be overcome; if she had not literature, the shallowness of polite society would corrupt her higher ideals. Only uniting both elements, then, can Belinda accurately "think for herself," and not be deluded by her perusal of written works. This model is emphasised by the exemplary wife and mother that Edgeworth portrays in Lady Anne Percival, a woman who had "without any pedantry or ostentation, much accurate knowledge, and a taste for 
literature, which made her the chosen companion of her husband's understanding, as well as of his heart" (2008: 216). She is a woman with whom her husband converses as if she were a man, with whom he can pursuit "any branch of knowledge," and who properly educates her children and impulses her husband to "happy social energy" (2008: 216). ${ }^{249}$ Both Lady Anne and, more particularly, Belinda are therefore model readers and the opposite of the literary quixotes which Edgeworth creates in Virginia and even in Clarence.

Similarly to Cervantes' interspersed stories, the story of Virginia stands as an independent narrative from the main one. Chapter XXVI is entitled "Virginia" and it displays the contents of Clarence's first-person account of his connection to her. The narrator, however, appropriates it and, to save the hero "from the charge of egotism," decides to relate the "principal circumstances in the third person" (2008: 362). With this metanarrative effect, the story will gain objectivity and the delusion of both Virginia and Clarence can be commented upon. Identified by Bray as the true deluded and quixotic reader of the novel, and compared to Lennox's Arabella (2009: 111-12), Virginia's story as a quixote commences as a consequence of Clarence's own quixotic romantic delusion. Having spent some time in Paris and becoming disillusioned with women's artifice and perversion, in the midst of his disenchantment the reader is told that:

[...] he read the works of Rousseau: this eloquent writer's sense made its full impression upon Clarence's understanding, and his declamations produced more than their just effect upon an imagination naturally ardent. He was charmed with the picture of Sophia, when contrasted with the characters of the women of the world, with whom he had been disgusted, and he formed the romantic project of educating a wife for himself. (2008: 362)

This project of fancy, similar to Theresa Morven's wertheromania or Alice Fennel's pygmalionic aspirations, aims to project imagination onto reality and to literally emulate the model of female education found in Rousseau's novel. With this scheme in mind, he returns to England and tries to find "a proper object for his purpose" which will match his "high expectations" (2008: 362). He finally finds such an object in Rachel, the natural daughter of an unknown

${ }^{249}$ See Ritter (2010) for an analysis of how this model responds to Edgeworth's notions on the domestic circle as the space to exert women's essential intellectual labour. 
gentleman, bred up "in innocence" away from boarding-schools and only taught to read and not to write (2008: 366-8). Clarence is moved by her simplicity, sensibility, and, above all, her beauty, and his romantic project takes the following shape: "the idea of attaching a perfectly pure, disinterested, unpractised heart, was delightful to his imagination: the cultivation of her understanding, he thought, would be easy and a pleasing task; all difficulties vanished before his sanguine hopes" (2008: 367). He consequently embarks in a quixotic project to transform her into his ideal heroine. The first step is to alter the only element that stopped the current of his imagination, her name: he consequently changes it and, as he was struck with her resemblance to the description of Virginia in M. de St. Pierre's "celebrated Romance," he chooses her new name accordingly (2008: 369). The second is to preserve her from the world by making sure she lives in the same isolated state of her childhood. He forces her to remain unseen, with the only company of her governess. In this context, Rachel/Virginia enchants Harvey with her innocence, artlessness and lack of vanity; however, this enchantment is also a product of his imagination. After she charms him by rejecting a pair of diamond earrings, the narrator comments:

Isolated from the world, [Virginia] had no excitements to the love of finery, no competition, no means of comparison, or opportunities of display; diamonds were consequently as useless to her, as guineas were to Robinson Crusoe, on his desert island. It could not justly be said [...] that she was free from vanity, because she rejected the diamonds. These reflections could not possibly have escaped a man of Clarence Harvey's abilities; had he not been engaged in a defence of a favourite system of education, or if his pupil had not been quite so handsome. (2008: 372 )

Isolation enables Virginia's perpetual state of innocence, as it did with Arabella. Nevertheless, it also results in the same consequences it had for Lennox's heroine. Possessing "exquisite sensibility and ardent imagination" and "without any real objects to occupy her senses and understanding," Virginia's "mind was either perfectly indolent, or exalted by romantic views and visionary ideas of happiness" (2008: 379). Secluded from society and with the only company of her governess, Mrs Ormond, "all her notions were drawn from books" (2008: 379-80), highlighting how Clarence's scheme results in the creation of another quixotic figure. In this regard, following eighteenth-century 
conventions on female reading, Virginia's becomes an "insatiable" appetite for books, especially after the "severe restrictions" that had been imposed on her by her grandmother in her childhood; it also becomes "almost her only pleasure" (2008: 380), again connecting immoderate consumption and desire with reading. This literary feasting is both restricted and encouraged by Clarence, for, while "Hervey had cautioned Mrs Ormond against putting common novels into her hands, [...] he made no objection to romances;" he thought that these "breathed a spirit favourable to female virtue, exalted the respect for chastity, and inspired enthusiastic admiration of honour, generosity, truth, and all the noble qualities which dignify human nature" (2008: 380). Virginia's appetite does not diminish, and she "devoured these romances with the greatest eagerness" (2008: 380). These readings create in her mind images of what does not exist. She confesses to her governess that she has "only confused ideas, floating in [her] imagination, from the books [she has] been reading" to the point that she no longer distinctively knows her own feelings (2008: 381). Virginia's dreams, whether during the day or at night, evidence the intoxication of her romances: she thinks or dreams about the charming heroes of her books, who speak to her in the language of romance (2008: 383). Furthermore, she reads St. Pierre's Paul and Virginia. As a consequence, she commences to try to "realize the illusion, and to be the Virginia of whom she had been reading" (2008: 381). To complicate matters further, Hervey has her picture taken in this character, which transports illusion into a real representation, blurring the limits between fiction and reality. In addition, Virginia becomes obsessed with a portrait of a man depicted in the character of Paul, who in her imagination starts to appear as Paul himself.

At one point, Virginia describes one of her dreams to Mrs Ormond. This dream appears as a narrative within the narrative and as the best example of the romantic illusion she is creating. Rachel/Virginia dreams that she is not herself, but "the Virginia that [they] were reading of" and she is in the Isle of France, which she recognises from the prints in the book (2008: 387). The unknown Paul confesses his love for her, interrupted by Hervey, who accuses her of ungratefulness, after which she consents to give him her hand. When she is about to marry Hervey in her dream, the setting changes and two knights, one 
in black and one in white, are engaged in combat in a tournament described in the fashion of romances. She elects the white as her champion, only to discover it is not Hervey, but the unknown man. This man kills the black knight, Hervey, who dies reproaching Virginia for her ungratefulness and fall. In this dream, the effect of romances is conspicuously depicted: it substitutes the real with ideal images that render reality unsatisfactory in comparison. When he discovers her dreams, Hervey fears for her sanity, though he finally realises she in possession of her understanding, despite the fact that "her imagination, exalted by solitude and romance, embodied and became enamoured of a phantom" (2008: 469).

Edgeworth here explicitly acknowledges the tradition of female quixotism founded by Lennox, in which romances, although considered morally superior to novels, are still dangerous for exalted imaginations because they create unsatisfied women incapable of interacting in the real world. In the same manner Arabella expected a knight in shining armour and is disappointed in Glanville's anti-romantic nature, so is Virginia disappointed in Hervey, incapable of distinguishing between dream and reality, and in need to awaken to the anti-romantic world. The moral of Virginia's story has been foretold by the wise Mr Percival, whose wife, Lady Anne, is the female role model of the novel. He states that "from poetry or romance, young people usually form their ideas of love, before they have actually felt the passion; and the image which they have in their own minds of the beau ideal is cast upon the first objects they afterward behold" (2008: 255). He adds that, while "there are ingenious minds which will never be enslaved by fashion or interest," there are also those that "may be exposed to be deceived by romance or by the delicacy of their own imaginations" (2008: 256), as the innocent and unassuming Virginia has been deluded by her reading. This deluded state leads to misery for, "the struggles between duty and passion may be the charm of romance, but must be the misery of real life" (2008: 256). In this sense, as Percival asserts:

[...] the woman who marries one man, and loves another, who [...] nourishes in secret a fatal prepossession for her first love, may perhaps, by the eloquence of a fine writer, be made an interesting heroine; but would any man of sense or feeling choose to be troubled with such a wife? [...] Now could a husband who has any delicacy be content, to possess the person without the mind? - the duty without the love? (2008: 256) 
In this regard, Virginia has been transformed into the appropriate heroine of a romance, while being rendered incapable of becoming a true wife, for she loves another and would marry Hervey only out of gratitude or duty. In the end, she is rather ironically granted her wish and the model of the portrait in the character of Paul, Captain Sunderland, appears. He is also in love with her after seeing her through a telescope, another metaphor of distorted perception that frames an ideal portrait of Virginia and that tells of this suitor's romantic enthusiasm (2008: 475).

In Virginia's story, criticism is aimed at Clarence, who intended to be such a husband as the one above described, and at the literary Rousseaunian model he elected for the choice and education of his future wife. By implication, it is also aimed at patriarchal models of female education which promote seclusion, a lack of worldly experience or of wider knowledge. In this regard, Clarence is as mistaken in his notions as Virginia. He believes he can artificially create an ideal wife by means of seclusion and the reading of romances which portray elevated models of female virtue. While Virginia certainly ignores the pleasures of the world, her imagination and the models of literature are Clarence's greater enemies, for an ideal model cannot be fought against, as her dream has attested. Clarence's delusion by Rousseau's model of female education also evidences a shallow reading of his work: the education of Rousseau's Sophia leads her to fall in love with the fictional character of Telemachus and, as a consequence, to find that reality falls short of her expectations. Sophia indeed does not confuse real and fictional worlds, she is aware that her ideal man is fictional, but her love does not become less real to her because of it (Bray, 2009: 114). In the same manner Virginia loves a flight of fancy, so does Clarence create in her a fictional object that responds to his own distempered romantic imagination. It is when he meets Belinda and he can contrast the romantic illusion embodied in Virginia with the real woman that Belinda is, that he awakens to his true feelings for the latter and to his folly, to what is termed the "intoxication" of his mind (2008: 374).

This awakening is not easy. Clarence is at first incapable of reading Belinda appropriately. His perception is prejudiced by the character of her matchmaking aunt; otherwise he would have though her "an undesigning, unaffected 
girl," though "now he suspected her of artifice in every word, look and motion; and even when he felt himself most charmed by her powers of pleasing, he was most inclined to despise her for what he thought such premature proficiency in scientific coquetry" (2008: 15). Applying his own standards to his reading of her character, Clarence remains deluded, until he compares Belinda with Virginia. After conquering his first prejudices against a niece of Mrs Stanhope, he reflects:

In comparison with Belinda, Virginia appeared to him but an insipid, tough innocent child, the one he found was his equal, the other his inferiour; the one he saw could be a companion, a friend to him for life; the other would merely be his pupil, or his plaything. Belinda had cultivated tastes, an active understanding, a knowledge of literature, the power and the habit of conducting herself. Virginia was ignorant and indolent, she had few ideas, and no wish to extend her knowledge. She was so entirely unacquainted with the world, that it was absolutely impossible she could conduct herself with that discretion, which must be the combined result of reasoning and experience. Mr Hervey had felt gratuitous confidence in Virginia's innocence; but on Belinda's prudence, which he had opportunities of seeing tried, he gradually learned to feel a different, and a higher species of reliance, which is neither in our power to bestow nor to refuse. The virtues of Virginia sprang from sentiment; those of Belinda, from reason. (2008: 378-9)

Love will be the first step to self-awareness, and Clarence becomes inscribed in the tradition of quixotism perceived as youthful romantic colouring of reality which finds its cure in the heterosexual plot of marriage to the partner which has enlightened him. In this sense, the traditional roles of female quixotism are reversed: Belinda has been the rational mentor, Clarence the deluded youth who will be cured by love and the example of his wife-to-be. Edgeworth returns to the plot and characterization of Whim for Whim, creating the same interplay between the quixotic hero and the wise heroine. As happened with Opal and Caroline, it is Clarence's character that cannot stand the comparison with Belinda's. The narrator describes him as "smitten with the desire of being thought superiour (sic) in everything and of being the most admired person in all companies," a quality that makes him become a "chameleon character" who varied in the "different lights" and "according to the different situations" he happened to be placed in (2008: 14). As an example, Clarence sometimes hides his literary talents or even disdains "every species of knowledge" not to be considered a pedant (2008: 14). Once more, Edgeworth turns the charges 
usually associated with women -vanity or the desire to seem less learned in company-, against her hero instead of her heroine and thus transforms him into the object of critique. The belief in his superior intellect leads him to his literary delusion; his chameleonic character, his lack of personality, in Edegworth's fictional world stands for a threat of non-existence: being everything to everybody is the most certain way of becoming nobody. And Clarence almost loses Belinda and himself in the process. One could state that Clarence is an early and masculine version of Elisabeth Bennet: he must overcome his prejudices and his romantic expectations of who seems a perfect partner, to learn a lesson of perception and self-awareness and to be rewarded by true happiness with the worthiest woman.

In this sense, parallel to Belinda's self-development, Clarence will also need to become a more mature man who will deserve her and his happy place in society at her side. From a man who at the beginning of the novel is described as this "chameleon character" (2008: 14), a man too concerned with public opinion to want to appear pedantic and who is identified as an "actor" (2008: 13), a man who adopts literature as unquestioned guide, a man who engages with the "gay world" and diverts himself with coquettes such as Lady Delacour (2008: 378-9), he will become a self-aware man who appears before Belinda in his true nature. Edgeworth in a way constructs a dual bildungsroman, male and female, in which both hero and heroine complement and teach each other, in which reading the Other in the traditional heterosexual romantic plot at the core of the bildungsroman becomes essential to understand one's desires and character. Throughout the whole novel, the semantic fields of reading and seeing are employed by Clarence and Belinda to state the difficulties in interpreting each other, as well as in their own relationship to their other love interest, Virginia or Mr Vincent, respectively.

As demonstrated by her previous works and further developed in Leonora, character, and with it the discourse in which it is expressed, must stand the test of comparison within society. In Edgeworth's novel, Belinda also learns from experience and from contrasting the behaviour of others to her own moral standards. She soon perceives Clarence's ambiguous attitude towards her; the narrator records that "his manner towards her was so variable and inconsistent, 
that she knew not how to interpret its language," for sometimes she reads in the "eloquence of his eyes" that he adores her, and others she imagines he is warning her of his previous attachment to Lady Delacour (2008: 15). This first pang of jealousy is humorously identified by the narrator as the start of her moral education:

[...] it excited, in the most edifying manner, her indignation against coquetry in general, and against her ladyship's in particular; she became wonderfully clear sighted to all the improprieties of her lady's conduct. Belinda's newly acquired moral sense was so much shocked, that she actually wrote a full statement of her observations, and her scruples, to her aunt Stanhope [...] (2008: 15)

Her jealousy not only triggers her first more serious moral considerations, but it concludes with the first instance in which Belinda admits to "an errour of [her] judgment, and not of [her] heart" (2008: 17), when she commits the impropriety of speaking ill of Lady Delacour while appearing her friend, but repents and defends her. The scene closes with Belinda imploring Lady Delacour to read her letters and hence have disclosure of her true feelings for her (2008: 18). From that moment, Belinda becomes more prudent in her judgment and action, having learnt from experience.

Despite this minor instance of impropriety, as a true heroine in need for an awakening the main error of both judgement and heart is still her inability to read her suitors, first, Clarence, and then whom she believes a more congenial suitor, Mr Vincent. The latter, described as having "a frank ardent temper, incapable of art or dissimulation, and [...] unsuspicious of mankind," a man with aristocratic notions of virtue, an enthusiast of everything and everybody, and deficient in the "habit of reasoning" (2008: 217-18), stands as a mild attack on men without character and of epicurean tastes. His enthusiasm is directed towards his love for Belinda, and expressed in romantic terms as an “enthusiasm, which sustains the blast of adversity" (2008: 440). Belinda proves once again a positive and anti-romantic influence when she rejects the clichés of courtship found in literature: she declares herself "not so romantic" as to think they could be happy in absolute poverty; she believes that without displaying "that species of enthusiasm" described in fiction, without "being in 
love like Clelia or Cleopatra," she can still deserve affection (2008: 441). However, Mr Vincent's enthusiasm will also be unfortunately directed towards gambling, and, once his mania is discovered, Belinda does not attempt to exert her positive influence on him to achieve his reform, but recedes from attaching herself to a man of his character, uniting judgement and heart in her decision. She does at this stage know her heart and her mind, and, when Clarence is finally disengaged from his promise to marry Virginia, she can at last read in his expression everything that he feels, for his "glance" finally "expressed his heart" (2008: 471).

Clarence's or Vincent's reading of Belinda is equally problematic. As stated above, Clarence at first reads her as a coquette trained by her aunt. At a masquerade in which Belinda dresses as tragic muse, and Lady Delacour as the comic one, he mistakes one for another and speaks ill of her and her cousins. When Belinda takes off her mask, his error is revealed: the true coquette is Lady Delacour and Belinda's authentic nature will start to develop before Clarence. Lady Delacour highlights this fact when she exclaims: "your mask must come off $[\ldots]$ This is not the first time Clarence Hervey has ever seen your face without a mask, is it?" (2008: 27), which ironically it is. With the visually powerful images of masks and the references to art, to the stage, and to the implications tragedy and comedy have of virtue and pleasure, Edgeworth's emphasises the distorted reading Clarence has of character as well as of literature. The enthusiastic $\mathrm{Mr}$ Vincent is not less unreliable in his interpretation of her character. Differently to the scheming Mrs Luttridge and her sentimental daughter Anabella, who attempts to win Mr Vincent with her "delicate sensibility" (2008: 427), Belinda does not offer excessive displays of sensibility, which leads Vincent to misread her character as "insensible," a charge she shares with the later Leonora. Belinda's absolute control of her countenance and emotions render it difficult for others to interpret her, but once her feelings are unveiled, they prove stronger than any shallow excess of emotion. Mr Vincent discovers that her "coldness of manners, which he had attributed to want of sensibility, arose probably from its excess" (2008: 426). Lady Delacour, also misreading her as insensible, finally concludes: 
[...] we have all of us seen Pamela married -let us know see Belinda in love, if that be possible. If! [...] in spite of all my raillery, I do believe, that the prudent Belinda is more capable of feeling real permanent passion, than any of the dear sentimental young ladies, whose motto is 'All for love, or the world well lost' [...]. (2008: 472)

Lady Delacour is also the character who, in general, more insightfully perceives Clarence's and Belinda's feelings and who prompts their reflections and ultimate happiness. In this discovery of the heroine's feelings, language again screens and influences the character's intentions and perceptions. Teasing Belinda into a confession of her feelings for Clarence, Lady Delacour and the heroine engage in a playful game of words, in which what is said is as important as what remains unsaid, with Delacour concluding "I mean what I say, which very few people do" (2008: 453), referring to Belinda's language of prudence. Determined to "move Heav'n and Earth to break off this absurd match" with the sentimental doll she perceives in Virginia (2008: 453), Lady Delacour also liberates Clarence from his engagement and allows the declaration of his love and the confession of his folly which follow one another: he declares "that from the moment he had discovered her real character [...] his whole soul had been hers;" subsequently, he states that his folly arouse from his "presumption and imprudence," and that "nothing could be more absurd than [his] scheme of educating a woman in solitude, to make her fit for society" (2008: 472). ${ }^{250}$ Therefore, the acknowledgement of true feelings will be not only essential in Clarence's awakening from literary delusion, but also in Belinda's gaining of knowledge and moral authority, a process which involves more aspects of her realm of experience than courtship or marriage, for instance, friendship, motherhood, or even colonialism. ${ }^{251} \mathrm{By}$ the acknowledgement of her moral worth and her true sensibility, her opinion

${ }^{250}$ Ironically, this disclosure of her character takes place at a masquerade (2008: 471). In another turn of the screw in the tradition of female didactic novels, in Edgeworth's work the masquerade is a moment of disclosure: masks reveal what those masks approved of by society hide every day.

${ }^{251}$ Once again displaying her involvement with contemporary issues, such as the abovementioned French and Irish insurrection, Edgeworth reflects in her novel on the financial and social problems of colonialism. See Andrew McCann's "Conjugal Love and the Enlightenment Subject: The Colonial Context of Non-Identity in Maria Edgeworth's 'Belinda."' NOVEL: A Forum on Fiction 30:1 (1996): 56-77. 
on all those matters becomes sanctioned and presented as the echoes of the implied author's stance.

Friendship is the recurrent field in which Belinda more pressingly needs to unveil what is hidden. In Clarence's and, specially, in Belinda's process of self-awareness, Lady Delacour plays an important role. Clarence perceives through her that there may be more than meets the eye in women: approaching Lady Delacour as a mere coquette, he discovers in her "talents [...] far superiour (sic) to what are necessary for playing the part of a fine lady" (2008: 378). As Belinda had also discovered, Lady Delacour makes herself appear worse than she really is (2008: 121). This is represented in the novel by the cancer Lady Delacour feels she experiences, in reality a consequence of an injury caused by her foolishness, and which she hides until it almost kills her. In a chapter entitled "Masks," Edgeworth develops this idea of the hidden identity with the recurrent theme of the masquerade, following it by two chapters under the title of "Lady Delacour's History" in which her secret past and present pain are disclosed. In Belinda's case, Lady Delacour will teach her the lesson Angelina and Leonora will also need to learn: friends can be unknown and require as much deciphering as any other character. Moreover, to what Angelina learnt with Rachel/Araminta is added what Lady Di learnt from Miss Burrage: that appearances in a fashionable society can hide innumerable truths. Early in the novel, Lady Delacour is compared to a "spoiled actress of the stage," and Belinda soon begins "to see through the thin veil, with which politeness covers domestic misery" (2008: 10). As the novel unfolds, Edgeworth develops the comparison of Lady Delacour with an actress, even in her appearance at a masquerade -the recurrent scene in eighteenth-century fiction in which identity is hidden or subverted- she struggles between the costumes of Tragedy and Comedy, choosing the latter and, as she confesses, emphasising the disgrace under her humour and nonchalance (2008: 29). ${ }^{252}$ Stating that her only real friend is Harriet Freke (2008: 29), after her betrayal and her awakening to Belinda's positive influence, Lady Delacour will have to

252 At one point, Lady Delacour states of her maid Marriot that she stands as "in distress like Garrick, between tragedy and comedy" (2008: 19). This image, also employed in Brunton's quixotic narrative Self-Control has been placed in context with these female authors' comment on art and on their own authorship. Once again, see Katrin. R Burlin enlightening analysis of the use of this image in both novels (1986). 
face the truth of her follies concerning her attitude in society and her concept of friendship, as well as her failure regarding her marriage and her role as mother. Ironically, a Lady whose name relates to the heart and who is particularly penetrating concerning everybody else's feelings, remains very much oblivious to her own and will be in need of the due awakening before adopting a more privileged and authoritative stance as wiser woman. Resuming the role of the young and wise female friend as mentor which Edgeworth had already presented in Whim for Whim, Belinda will then become the insightful reforming agent of the lady of fashion. Women thus influence women, while the paternal mentors, such as Doctor X or Mr Percival, are relegated to become secondary characters.

In addition to being one of the actors of the play, once cured of her folly, the reformed Lady Delacour claims her authority as a wiser woman and becomes the adequate mentor to enable Belinda's happy integration in society as Clarence's wife. With engaging wit and sense, Lady Delacour forces Clarence and Belinda to acknowledge their feelings, and contributes to the advancement of the plot by providing Virginia with her romantic hero, Captain Sunderland. The last pages are again a metanarrative comment on novel writing and on how to end one, and Lady Delacour guides the characters in a witty comment on the clichés of novelistic happy endings. Arranging all characters in a living sentimental tableau, Lady Delacour ends claiming the authority of "the rule of the stage" (2008: 478). In the end she "stands in for the author, unravelling the intricate events and stage-managing everybody for the final scene; she is the novelist's surrogate who unmasks others and makes things happen" (Myers, 1998: 80). In her role as surrogate narrative authority, she addresses the diegetic and implied readers who have to make sense of living and artistic portraits, stating in third person "now, lady Delacour, to show that she is reformed, comes forward to address the audience with a moral -a moral!- yes: 'our tale contains a moral, and, no doubt,/ you all have wit enough to find it out" (2008: 478). Character and narrator blur, and they address the implied readers to emphasise that they, in the same manner as the diegetic ones, must make sense of the novel they have just concluded. 
Once again, complete disclosure is difficult to obtain; absolute truth belongs to no single character and illumination is only granted after a fraught process of perception and interpretation. This same comparison is required from the implied readers: to judge the portrait presented to them in the novel, and, in the end, to judge themselves by means of their position in relation to it. Referring to another perfect tableau described before, the Percival's exemplary family, the narrator states:

Those who unfortunately have never enjoyed domestic happiness, such as we have just described, will perhaps suppose the picture to be visionary and romantic; there are others -it is hoped many others-who will feel that it is drawn from truth and real life. Tastes that have been vitiated by the stimulus of dissipation might, perhaps, think these simple pleasures insipid. Every body must ultimately judge of what makes them happy, from their comparison of their own feelings in different situations. (2008: 216-17)

In the same way Belinda is convinced by "this comparison" between the Percivals' and the Delacours' households "that domestic life was that which could alone make her really and permanently happy" (2008: 217), so can the reader share her comparison, and by her example disclose what lies under the surface and reach the same conclusion in a final act of self-awareness.

A deluded perception is then a more universal experience than one circumscribed to young and innocent women; in fact, these young heroines prove ideal mentors for friends and lovers alike, not to mention the readers who peruse their story. The idea that epistemological interpretation is always fraught is developed in greater depth in a subsequent novel, Leonora (1806), which again conceives one's individual perception as an epistemology that needs to be tested and corrected against others' interpretations in order for the character to achieve the final objective of any novel of development: personal growth and a happy place in society. This increasing emphasis on the topic of the flaws of perception developed through the distorted interpretation of the characters echoes Cervantes, and signals Edegworth's use of the quixote as the perfect instrument to explore this matter, as well as her progressive abandonment of quixotism towards cervantism in her later novel. 
5.4. Things are not Always as They Seem: Perceiving Others and Oneself in Leonora

Written some years later, Leonora (1806) resumes many of the subject matters found in "Angelina" and thoroughly develops them into a richer, deeper and more mature novel. Leonora tells the story of a love triangle involving the eponymous heroine, her husband, Mr L, and her friend Olivia. The novel opens with Olivia as a guest in Leonora's house, writing to her friend Gabrielle in Paris her minute impressions and actions. Having married young and divorced her husband out of ennui, Olivia has returned to her native Britain from France with new radical notions on marriage and echoes of scandal attached to her. Leonora, decided to change the public opinion that she perceives as unjust, invites Olivia to her castle to dispel attacks to her reputation, while she also attempts to convince her mother, a formidable Duchess, that Olivia is a falsely accused woman. As the novel advances, the Duchess's fears are justified: Olivia and Mr L engage in a seduction and power game that will conclude with their elopement and Leonora's abandonment. Almost dying in childbirth and then losing their long-awaited male heir, Leonora remains faithful to her husband despite the courting of a Prince. In the meantime, Mr L starts to regret his decision, but Olivia attempts to commit suicide to retain him and to force him to keep his promise to take her with him in his new position as an Embassador in Russia, where she already has been instructed by the conniving Gabrielle to attempt to seduce the Czar. About to embark, forced by his promise to Olivia, Mr L falls extremely ill. Leonora runs to be by his side, risking her own heath. Still bound by his promise, Mr L is finally liberated by the chance discovery of Olivia's letters to Gabrielle, in which her scheming seduction is displayed. With husband and wife happily reunited, the novel concludes.

Written in epistolary form, the novel consists of the correspondence of several people, mainly that between Olivia and Gabrielle, and Leonora and her mother. However, it also records the letters between $\mathrm{Mr} \mathrm{L}$ and his friend General B; Olivia and Mr L; Helen, Leonora's friend and frequent visitor, and Margaret, her most trustworthy female confident; and occasional letters from the General or Helen to the Duchess, from Olivia's servant to another French maid or from 
Leonora's maid to Mr L's valet. Letters record the innermost thoughts and principles of the characters, as well as their impressions on the motives of those around them, and therefore allow perceiving the difference between the characters' perception of one another and what they are in reality. In this sense, the topic of the unknown friend applies to all characters in the novel: Leonora believes in Olivia's goodness, Olivia in Leonora's unfeeling nature; Leonora believes her husband a better man, he believes her a colder woman than she is; Mr L reads Olivia's love and sensibility as true, Olivia reads $\mathrm{Mr}$ L as a sentimental hero; Helen complains she cannot read Leonora and she believes $\mathrm{Mr} \mathrm{L}$ is only playing with Olivia; General B trusts his friend is only acting the coquet and could never leave his wife, while Mr L believes his friend will support his decision. Constantly employing the semantic field of seeing, Edgeworth depicts how none of the characters possesses a perfect or clear vision of others or of how others perceive them. Even when they pride themselves in seeing better than others, the whole truth remains veiled. For example, Helen cannot understand how Leonora does not see Olivia's true intentions; however, in the same letter in which she insightfully discloses Olivia, she mistakes $\mathrm{Mr} \mathrm{L}$ as acting a coquettish play that does not involve real feelings (1815: 129). Leonora has been mistaken about Olivia, and yet she can perceive that Helen cannot see "things in their true light" concerning her husband as she can (1815: 146), again evincing, as would later Austen in Emma, that total disclosure, that absolute truth, is seldom achieved.

The main characters, the participants in the triangle, are the most misinterpreted and misinterpreting in the novel, and the letters progressively expose how the conception the characters have of one another gradually change as they are confronted with facts. All characters remain in the dark until a moment of disclosure arrives, usually by the reading of those very same letters which the characters send to one another as proof of ultimate sincerity. For instance, Leonora sends Olivia's letters to her mother to vindicate her character, although they rather serve as basis for the Duchess's condemnation; the Duchess sends Leonora's letters to her husband to convince him of her worth, her love and her awareness of his infidelity; Leonora sends a letter to Olivia stating her knowledge of her betrayal and exposing her more than 
feeling reaction to it; Leonora leaves a letter expressing her feelings to her husband which he does not read and is therefore still deluded; in addition, the final disclosure of Olivia's true colours comes in the shape of her private letters. The epistolary form is then the ideal vehicle by means of which Edgeworth can explore the complexities of perception and self-awareness, depicting literary or idealistic deluded characters that need to know others as well as themselves. With the already mentioned interplay between fact and fiction that letters provide, with their position in the liminal space between public and private spheres, letters embody the ways in which truth can be hidden and manipulated, and how complete disclosure is either impossible, or only achievable after a fraught intellectual and emotional process.

In this process, the implied reader will be required to accompany Edgeworth's own textual readers. The novel's constant shift of internal focalization and the lack of a coherent external one that can holistically make sense of the totality of the characters' experience mirror the difficulty of piecing together the nature of people and events for diegetic and implied readers alike. In the same manner that in "Angelina" the different discourses had to be placed against one another to be tested and validated as the means to construct a sound self, Edgeworth develops the possibilities of heteroglossia even further in Leonora: the discourse of morbid sensibility and French radicalism will stand against British common sense, moral stance and true sensibility, each of them expressed with an infinity of shades depending on the characters' personality and beliefs. Gabrielle, Olivia and Mr L display different degrees of adherence to the axioms of the cult of sensibility or of Francophile ideas on the slavery of custom. Helen or General B, for instance, express a more practical common sense than Leonora, whose strict principles and desire to remain faithful to herself even trigger her disregard for her friends' or mother's counsel at times. Edgeworth again demonstrates that each person is a complete different universe that is expressed and moulded by language, that develops in relation to other discourses and that is more complex than a mere set of moral or sentimental clichés. Moreover, as there is no narratorial discourse, there is no obvious sanctioning or condemning of a character's discourse either. All there exists is the trace that the reader may perceive of the implied Edgeworth in the 
Duchess's comments on Olivia, French manners and the effects of pernicious literature as clues of what will finally be the outcome of the story of seduction. In this regard, the Duchess stands at times as surrogate narrator, for her knowledge and experience is more complete, her comments on the actions of characters' are more insightful and somehow outside the main plot owing to her physical and emotional distance from the main events, and by her advice or intrusion the plot is sometimes made to advance. However, not validated or judged by a conspicuous narratorial stance, the different discourses will still then interilluminate each other, without the safer guidance of the omniscient narrator of "Angelina" or Belinda, and the implied reader will have to participate in them, becoming aware of their unreliability and aiming to make sense of the whole.

In this context, Olivia is another example of the way in which Edgeworth employs a quixote to expound her concern with psychological processes and how they echo the consequences of a faulty education or reading. Olivia is a clear instance of a deluded character, in this case a mixture of both sentimental and ideological quixote. From the beginning of the novel she confesses herself a passionate reader of French and German sentimental fiction; her writing is full of quotations by Voltaire or La Fontaine which support her liberal views; and in her early presentation to Leonora she confesses that readings were “opiates" which settled her soul into a state of melancholia (1815: 9) in the midst of her sorrows after her separation. As she develops in full:

Sometimes I had recourse to books; but how few were in unison with my feelings, or touched the trembling chords of my disordered mind! Commonplace morality I could not endure. History presented nothing but a mass of crimes. Metaphysics promised some relief, and I bewildered myself in their not inelegant labyrinth. But to the bold genius and exquisite pathos of some German novelists I hold myself indebted for my largest portion of ideal bliss; for those rapt moments, when sympathy with kindred souls transported me into better worlds, and consigned vulgar realities to oblivion.

I am well aware, my Leonora, that you approve not of these my favourite writers: [...] But would you forbid those to taste felicity in dreams who feel only misery when awake? Would you dash the cup of Lethe from lips to which no other beverage is salubrious or sweet? (1815: 7-8) 
Olivia's choice of readings is already significant: metaphysics and German novels substitute history or didactic fiction. However, it is how she reads which makes her a quixote: she reads with no distance, she is absorbed by her reading into the world of fiction to escape reality. Moreover, she reads aiming to find congeniality with her own feelings and thoughts, she does not read to improve her mind, but to feel and to be enraptured in a fictional sympathy. The Duchess, in her role as surrogate narrator, dialogues with Olivia's discourse and expounds the nature of her delusion, providing the main moral of her story. Quoting parts of Olivia's original letter, the Duchess concludes that the "course of reading which her ladyship followed was the certain preparation for her subsequent conduct" and that the pleasure promised in her readings has, like a "mirage in the desert," bewildered her "feverish imagination" (1815: 35-6). In addition, she expounds on the manner in which these readings create a morbid sensibility in their women readers, so they cannot interact properly -or virtuously- in society:

I always suspected the imagination of these women of feeling to be more susceptible than their hearts. They want excitation for their morbid sensibility, and they care not at what expense it is procured. [...] To their vitiated taste the simple pathos, which o'ersteps not the modesty of nature, appears cold, tame, and insipid; they must have scènes and a coup de théâtre; and ranting, and raving, and stabbing, and drowning, and poisoning; for with them there is no love without murder. Love, in their representations, is indeed a distorted, ridiculous, horrid monster, from whom common sense, taste, decency, and nature recoil. (1815: 35-7)

Assimilating and responding to Olivia's text within her own, the Duchess's discourse is once again identified with Edgeworth's response to sentimental fiction in her own text and her warning to her implied readers about the former's dangers.

In addition to becoming lost in fiction, Olivia adopts all the conventions learnt from novels and acts them out in reality. Throughout the novel, Helen, the Duchess or the General will highlight the artificiality of Olivia's alleged sensibility and will compare her conduct to those of novel heroines. Her language will be accused of the "perversion of terms" characteristic of foreign sentimental novels in which prudence becomes "coldness; fortitude, insensibility; and regard to the rights of others, prejudice" (1815: 33-4), in 
which sentimental "sacrifices and generosity" becomes egotism (1815: 35), emphasising the construction of a different discourse through which reality is moulded and the dangers this discourse has for morality. ${ }^{253}$ Her eloquence will be equalled with that of bad novels which any boarding-miss may write (1815: 31) and her letters will be described as written in "true heroine style" (1815: 32). Once and again, Olivia will be accused of acting out her sensibility. Helen, the sensible and practical friend, with her British humour, terms her the heroine of "The Sentimental Coquette, or, The Heroine unmasked" (1815: 135), and recurrently contrasts her theatricality with Leonora's behaviour. While the latter avoids attention, Olivia will often seek the gaze of the men around her, almost as an actress on stage playing her sentimental part. Olivia's conspicuousness is avowed in her own words:

The starers enjoyed their pleasure, and I mine: I moved and talked, I smiled or was pensive, as though I saw them not; nevertheless the homage of their gaze was not lost upon me. [...] one likes to observe the sensation one produces amongst new people. The incense that I perceived in the surrounding atmosphere was just powerful enough to affect my nerves agreeably: that languor which you have so often reproached me for indulging in the company of what we call indifferents gradually dissipated. (1815: 157-8)

This sensation and the search for the male gaze will be played by Olivia to achieve Mr L-. By acting what he considers true sentiment, Olivia becomes his ideal female model: "Mr L-made me comprehend, that languor indicating sensibility of heart was to him the most touching of female charms; I sighed-" (1815: 238).

${ }^{253}$ The Duchess elaborates on this matter: "By this perversion of terms they would laugh or sneer virtue out of countenance; and, by robbing her of all praise, they would deprive her of all immediate motive. Conscious of their own degradation, they would lower every thing, and every body, to their own standard: they would make you believe, that those who have not yielded to their passions are destitute of sensibility; that the love which is not blazoned forth in glaring colours is not entitled to our sympathy. The sacrifice of the strongest feelings of the human heart to a sense of duty is to be called mean, or absurd; but the shameless frenzy of passion, exposing itself to public gaze, is to be an object of admiration. These heroines talk of strength of mind; but they forget that strength of mind is to be shown in resisting their passions, not in yielding to them. Without being absolutely of an opinion, which I have heard maintained, that all virtue is sacrifice, I am convinced that the essential characteristic of virtue is to bear and forbear. These sentimentalists can do neither. They talk of sacrifices and generosity; but they are the veriest egotists-the most selfish creatures alive" (1815: 34-5). 
However, although she employs the language of sentiment to delude men, she has also deluded herself. As the more practical and scheming Gabrielle warns her "dear romantic Olivia," she should not be "the dupe of those fine phrases that we are obliged to employ to deceive others" (1815: 225). Nevertheless, she is indeed a victim of her own literary imagination. Her language, her behaviour, her expectations are modelled on those of literary heroines and $\mathrm{Mr}$ L-will soon find that even he falls short of the literary ideal: 254

Rousseau, it has been said, never really loved any woman but his own Julie; I have lately been tempted to think that Olivia never really loved any man but St. Preux. Werter, perhaps, and some other German heroes, might dispute her heart even with St. Preux; but as for me, I begin to be aware that I am loved only as a feeble resemblance of those divine originals (to whom, however, my character bears not the slightest similarity), and I am often indirectly, and sometimes directly, reproached with my inferiority to imaginary models. But how can a plain Englishman hope to reach

"The high sublime of deep absurd?"

I am continually reviled for not using a romantic language, which I have never learned; and which, as far as I can judge, is foreign to all natural feeling. (1815: II, 147-8)

The summit of her sentimental enactment arrives at the suicide scene, in which she revealingly copies the setting and the actions of Rousseau's Julia. Mr Lrecounts his impressions:

At this instant [...] a confused recollection of Rousseau's Heloise, the dying scene, and her room ornamented with flowers, came into my imagination, and destroying the idea of reality, changed suddenly the whole course of my feelings.

In a tone of raillery I represented to Olivia her resemblance to Julie, and observed that it was a pity she had not a lover whose temper was more similar than mine to that of the divine St. Preux. Stung to the heart by my ill-timed raillery, Olivia started up from the sofa, broke from my arms with sudden force, snatched from the table a penknife, and plunged it into her side. (1815: II, 190-1)

${ }^{254}$ As for her relationship with $\mathrm{Mr} \mathrm{L}$ - , even in her correspondence with him she expects his literary discourse to equal hers: "Ask me no more to explain to you the cause of my melancholy. Too plainly, alas! I feel it is beyond my utmost power to endure it. Amiable Werter-divine St. Preux-you would sympathize in my feelings! Sublime Goethe-all-eloquent Rousseau-you alone could feel as I do, and you alone could paint my anguish" (1815: II, 146). 
While $\mathrm{Mr}$ L — has mistakenly read Olivia and Leonora and has allowed his principles to change, he distinguishes between fiction and reality and does not enact a sentimental hero, while Olivia does so to its ultimate consequences.

In addition to her attempted suicide, which signals her lack of any Christian principles, her Francophile education in revolutionary principles concerning love, marriage and divorce, transform her into a more disruptive quixote than other sentimental heroines are, for instance, Tomlins's Theresa or West's Marianne. Her opening letter in the novel complains about the slavery of women (1815: 1-2), and rails against bounding custom and against marriage as a form of "legal prostitution" (1815: 7). Moreover, she rejects any form of social convention or duty, whether those of daughter, wife or mother (1815: 30). Olivia compares the French and the English approach to maternity, and, in opposition to her sentimental talk on the "sentiment of maternity," Olivia rejects Leonora, whom she describes as having the quality of having more of "a matron than of a heroine" (1815: 60), and the English ladies who become "des bonnes mères de famille, not from the impulse of sentiment, but merely from an early instilled sense of duty," and who, instead of abandoning her child as she did, "devote their lives to their children" (1815: 62). Resembling her use of the same passage in "Angelina," Edgeworth employs one of the sentimentalized everyday episodes in Werther to oppose Olivia's literary expectations with reality:

Upon recollection, in my favourite "Sorrows of Werter," the heroine is represented cutting bread and butter for a group of children: I admire this simplicity in Goethe; 'tis one of the secrets by which he touches the heart. Simplicity is delightful by way of variety, but always simplicity is worse than toujours perdrix. Children in a novel or a drama are charming little creatures: but in real life they are often insufferable plagues. (1815: 63-4)

Olivia thus becomes the epitome of the "unsex'd female" which Polwhele associated with Francophile radical thought and with Wollstonecraft in particular. In Olivia's own words, she possesses a "fatal mixture of masculine independence of spirit, and of female tenderness of heart" (1815: 11). This 
alleged tenderness is expressed in romance, not maternity. ${ }^{255}$ Her unsexedness, or her position in a liminal space between masculinity and femininity, is also developed in the political implications of her powers of seduction: not only does she aim to become tyrant in her relationship with $\mathrm{Mr} \mathrm{L}-$, and as a consequence rules over his principles and his duty, but if she were to follow Gabrielle's plan for the Czar's seduction she would become mistress in both sexual and political terms, controlling the man and the country together. Because of this radical danger, the Duchess's and the General's criticism of Olivia go beyond the private sphere of the British home and use it rather as a metaphor of the whole nation. The Duchess, in her final letter to her daughter, avows:

I am told that Lady Olivia -- is going to the continent, and that she declares it to be her resolution never to return to England. She is in the right. England is not the place for women of her character.

Happy the climate in which no venomous creature can exist! More happy the country under whose salutary laws and opinions no exotic vice can flourish. (1815: II, 259-60)

These are also the concluding words of the novel and the Duchess, again echoing the implied Edegworth, leaves the reader with the anti-radical moral of the text. Parallel to the more obvious political didacticism of the novel, the conclusion that Edgeworth seems to offer is that awakening and correct vision can only be arrived at after a process of self-awareness which unveils the flaws or biases of individual perception and, hence, accepts that others possess different systems of intellectual, emotional or moral reference. These different systems not only contrast with, but may also complement, the individual's perception of him or herself and the world. The only character who does not learn this lesson is Olivia, who remains trapped in her sentimental obsession, abandoned and erased from the novel's conclusion and happy ending. Other characters fare better in their path to awakening.

In this line, Leonora proves as unreliable as any other character and closely resembles Austen's later Elisabeth Bennet's status as a heroine that is

${ }^{255}$ The Duchess expresses what seemed to be Edgeworth's views on the fortitude and capability of women when she writes to Leonora that "the ladies who wish to be men are usually those who have not sufficient strength of mind to be women" (1815: 33). 
completely mistaken about the people who surround her and even about her own feelings. An exemplary heroine both in beauty and behaviour, Leonora is nevertheless also an idealistic character who assumes the idea of her friend's benevolence. Leonora is a displaced quixote: her mistaken reading is more concerned with human nature than with novels, which she can critically approach much better than Olivia. ${ }^{256}$ Consequently, as it departs from the core of the quixotic delusion based on literary principles, her quixotism fades away and its only trace remains in the idealistic system of reference with which she interprets the world around her. Fighting against the windmills of public opinion and even of her own friends' judgement, Leonora quixotically defends, first, her friend and, then, her husband. She states that she is determined to support Olivia's "cause" (1815: 13), that she rather be "imprudent than unjust" in her defence of her friend from "unmerited censure" (1815: 48), and that she "may do Lady Olivia some good" while the latter can do her no harm (1815: 49). However, she is very soon reproached by her mother for her imperfect vision. The Duchess, having "seen Vice and Folly dressed in so many different fashions" can "find not difficulty in detecting them under any disguise," while Leonora's "unpractised eyes are almost as easily deceived as when [she] was five" (1815: 16). Emphasising both Leonora's innocence and her inexperience, she is recurrently termed "blinded" to Olivia's artfulness and culpability (1815: $37)$, or deluded by a "visual orb" that is "cleared with charity and love" (1815: 75), which veils what is obvious to other characters. As Helen exclaims,

Lady Olivia takes it for granted that I am as short-sighted: but I can assure her Ladyship that my sphere of vision is not quite so contracted. I can see perhaps further than she wishes, even to the ultimate object of all her manoeuvres: and farther still, I can see, Lady Olivia, what you cannot see, that you will be completely duped, and make yourself thoroughly ridiculous. To all which I have not the slightest objection; for by your operations Leonora's eyes will be opened at last, and she will see that I was right in neither loving nor pitying you for your exquisite and unfortunate sensibility. (emphasis added, 1815: 126-7)

${ }^{256}$ Both Leonora and her mother are models of good readers who read critically and resistingly, not becoming absorbed by their readings, not learning their sentiment from them. Leonora even defends novel-reading as part of women's education, as long as is it not performed in secret (1815: 43-46), while her mother expresses her admiration for "good German writers" (1815: II, 259), as opposed to the ones Olivia reads. 
While still mistaking the amount of her power over Mr L, Helen can see through Olivia's fake sensibility, which Leonora could not. Edgeworth's heroine will be fully awakened to reality by her husband's elopement, but, before that, her process of awakening has already started. Similarly to Arabella, jealousy and desire are the first symptoms of her arousal. Quite atypically, Leonora is a woman who expresses her passion for her husband and her need to experience the fervent love of her early marriage for its happy continuation. The loss of his affection in favour of Olivia arises her first suspicions, but she remains stubbornly fixed in her idealistic idea that Olivia is good, "that she is perfectly innocent of all design to injure" her, and that "she is not aware of the impression she has made" (1815: 152). Rather than accusing her, Leonora blames her own jealous "distempered imagination" (1815: 147). When facts are too obvious to ignore, Leonora fully awakens and, ignoring her mother's advice for prudence and silent contempt, she proves not to be a dissembler by making her feelings known to Olivia in the following manner:

It is possible that $\mathrm{Mr} \mathrm{L}-$ - may taste some pleasure with you whilst his delusion lasts, whilst his imagination paints you, as mine once did, in false colours, possessed of generous virtues, and the victim of excessive sensibility: but when he sees you such as you are, he will recoil from you with aversion, he will reject you with contempt. (emphasis added, 1815: II, 42-3)

Building on the discourse of deceit and blindness, Leonora not only signals her unveiled perception but her husband's nature as the now deluded character. Moreover, Leonora displays absolute notions on what she considers good and bad, proper and improper, and even in moments in which she may do something against her principles to regain her husband, she remains true to herself. Instead of following others' advice and coquetting with the Prince to make her husband jealous, or showing him Olivia's newly-found letters to open his eyes, Leonora adheres to what her own self tells her: she cannot lose her husband's esteem to gain her love, and, more importantly, she cannot lose her self-esteem in the pursuit of happiness. In this sense, Leonora resembles Don Quixote in the strict following of what seems an obsolete code of behaviour which others cannot understand, but which becomes an intrinsic part of themselves, of whom they are. This trait in her exasperates and admires Helen or the General for its impracticality and its heroism, respectively, a common 
response to quixotic idealistic principles which prove axiologically superior to their environment. In the end, her husband's admiration and esteem for her also wins back his unconditional love.

As stated by Leonora in the abovementioned quote, together with Olivia, $\mathrm{Mr}$ $\mathrm{L}$ - is the character that is more thoroughly confounded. Similarly to Clarence, Mr L_'s notion of sensibility, learnt from novels, leads him to erroneously interpret two women: his wife and Olivia. The former he considers too cold to feel, and the latter he believes the ideal of a sentimental woman. As happened with young female quixotes, appearances and his own expectations distort his perception, while the French morals he practices endanger his position in society. After a series of tragic events, he will learn to read both women and himself appropriately, and to reject foreign values. One of the innovations of Edegworth's novel with respect to other works of fiction which provide an anti-radical political message, is that $\mathrm{Mr} \mathrm{L}-$ 's literal and metaphorical seduction by Olivia and by Francophile customs takes over most of the plot and is not merely explained to provide the inception for the action. In antiJacobin fictions by the Purbecks or Lucas, for instance, the seduction carried out by texts or radicals is sketchily described employing certain conventions of anti-radical quixotism, such as enclosure, innocence, idealism, appeal to vanity, etc. However, no other novel offers such detailed insight into the mind both of the deluded object and the deluding subject, nor of the subtle process by which the venom is implanted or counteracted in their minds. Despite these differences, Edgeworth's text resembles previous fictions in that it does follow a pattern of sentimental and ideological delusion, as well as of a fraught awakening and a restoration to family, status and rationality.

In this regard, $\mathrm{Mr} \mathrm{L}^{-}-$also resembles Lady Delacour: he becomes the dupe of a shallow and amoral code of behaviour in need for correction and, in addition, he is also the most difficult character to read. At first even the shrewd Helen and the Duchess are deceived by his reputation as a "man of superior abilities" who knows "women too well to become a dupe" (1815: 169), as his mother-inlaw states. In the end, Helen's accusations of blindness must shift from Leonora to her husband (1815: II, 35). However, as his correspondence with the General unfolds, the reader is allowed to see what Helen or the Duchess 
cannot at the time: how his interest for Olivia and her French philosophy increase to the point of becoming a "madman" capable of abandoning such a wife for such a mistress (1815: 247). In this sense, the General is his most insightful reader and the one who can see $\mathrm{Mr} \mathrm{L}$ - before anybody else, even before himself, as a deluded man. When Mr L- questions him about the French laws of divorce, the General forewarns the dangers. At one point, the General writes in answer to his friend that, although $\mathrm{Mr} \mathrm{L}$ - considers himself "proof against French coquetry and German sentiment," his vanity disguised as pride may cause his fall (1815: 196). Mr L — becomes then not only a deceiver, an artist of "male coquetry" (1815: 212), but more conspicuously the "dupe of a frenchified coquette" (1815: II, 2), a foolish man in love (1815: II, 17), and "nearly stark mad" (1815: II, 169). He starts by excusing "foreign-born, or foreign-bred" coquettes because, doing what they have learnt from the example of their mothers or ladies of fashion, they break "no restraints of custom or education" (1815: II, 2); then he excuses his own advancing breach of decorum by stating that "nothing can [...] make amends for any offence against propriety, except it be sensibility -genuine, generous sensibility" (1815: II, 3). This genuine sensibility he opposes to the "coldness" of female virtue (1815: II, 3), and, more particularly, to his wife's behaviour. In his misreading of his wife, he claims that she is "calm, serene, perfectly sweet-tempered, without jealousy and without suspicion; in one word, without love" (1815: II, 8), later adding that her conduct "argues great insensibility of soul" (1815: II, 10). Also a fond reader of fiction and a confessed defender of sensibility in women, he is incapable of perceiving Olivia's learnt sensibility as false and extreme, and his wife's quiet feeling as true, until the negative and the positive consequences of both are made evident. Other characters are aware of his faults before his own awakening: the General satirically expounds on the dangers of certain forms of sensibility in women which transforms them in wantons and prostitutes (1815: II, 21) ${ }^{257}$ while together with Helen he accuses $\mathrm{Mr} \mathrm{L}$ - of being blind to his wife's obvious feeling (1815: II, 14, 24). Finally, it is the General who better

257 Another indication of Mr L-loss of sensible moral ground is the General's assurance that he will not accept to be challenged by $\mathrm{Mr} \mathrm{L}$ - for his insinuations about Olivia. Displaying a more sensible concept of honour than the one portrayed in sentimental novels, where dueling became a commonplace, the General very graphically asserts that he has "reputation enough to be able to dispense with the glory of blowing out [Mr.L's] brains" (1815: II, 26). 
describes his deluded state: he is a man in a dream, a somnambulist who must be awakened (1815: II, 65), who must recover his senses (1815: II, 89).

This awakening has not only consequences at a personal level; it is once more a reflection on the state of the whole nation. Deluded as well by Olivia's discourse on the true nature of love and on the condemnation of the slavery of custom, he learns from his "heroine" the "sentimental logic" which transforms "virtues into vices, and vices into virtues, till at last [he does] not know them asunder" (1815: II, 175-6). In this deceived state Mr L- abandons all emblems of his own identity as a Briton and a gentleman: his estate, his family, his honour and his principles. In addition, he also loses his heir, the greater symbol of continuity and stability, and the preserver of his name. He therefore becomes an Other, a foreign version of himself, and, worse still, he will soon be a Nobody in his deluded persona, erased from his country and family. In the same process that female quixotes experience, a fever and the proximity of death work as a rebirth to whom he really is. After her recovers from his fever, he can tell Leonora that she has his "undivided love" (1815: II, 224), his deluded persona embodied in his love for Olivia is no more. In the same manner Opal literally lifts the veil to discover real Enlightenment in Caroline and not in Aspasia, so does $\mathrm{Mr} \mathrm{L}$ - metaphorically unveil real sensibility and virtue in Leonora rather than in Olivia. Only after this awakening and his return to his family, house and duties, does he become the epitome of the British gentleman he used to be.

Not as technically perfected as Belinda, this novel is still one of Edgeworth's most interesting experiments with focalization and heteroglossia in order to ascertain the problem of perception and self-awareness, a conflict which will later serve as basis for the novel of female self-knowledge and development masterfully written by Jane Austen. Edgeworth's novels then provide an insightful analysis on the dangers of uncritical reading of texts, manners and character, creating a gallery of both wise and deluded characters who present the reader with two models in which to reflect him or herself and through which to develop his or her discourse on literature, knowledge, society or even oneself. 


\section{Jane Austen AND the Pre-Victorian Female QuiXote}

As an inducement to subscribe Mrs Martin tells us that her Collection is not to consist only of Novels, but of every kind of Literature, \&c, \&c. - She might have spared this pretension to our family, who are great Novel-readers and not ashamed of being so; but it was necessary, I suppose, to the self-consequence of half her subscribers.

Letter to Cassandra, December $18^{\text {th }} 1798$

Seldom, very seldom, does complete truth belong to any human disclosure; seldom can it happen that something is not a little disguised, or a little mistaken; but where, as in this case, though the conduct is mistaken, the feelings are not, it may not be very material.

Emma, 347

It is hard to find something that has not already been said about Jane Austen's life (1775-1817) or body of work. Few authors have received such (deserved) unfailing and minute attention in recent years, and the circumstances and characteristics of her writing still provide material for immeasurable research. However, the present study aims at introducing Austen as part of the tradition of Cervantes' sons and daughters in Britain, and her novels as the result of the assimilation and overcoming of previous examples of narrative fiction dealing with female quixotism. An avid reader, and not ashamed of being one, from her early productions to her mature works, Austen displayed a particularly insightful approach to fiction. In her letters, one finds abundant references to literary works, as well as her personal critical comments on them. For instance, of Sarah Burney's Clementine (1798), a popular and moral novel, she asserted that "[i]t is full of unnatural conduct and forced difficulties, without striking merit of any kind" (emphasis added, October 1807), while she claimed that she did not like "a Lover's speaking in the 3rd person; -it is too much like the formal part of Lord Orville, and I think it is not natural" (emphasis added, July 1814, Le Faye, 1997:267). And, as stated before, she found even Brunton's otherwise praised Self-Control, unnatural and improbable.

As both her correspondence and her fictional work attest, throughout her life she was a critical reader who could identify, and then mock, the patterns and 
conventions of the most popular genres of her time, highlighting in her characteristic sense of humour their incongruities and shortcomings and calling attention to their nature as mere formulas. In this regard, Austen dissected and deconstructed fiction and exposed its intricate workings for her readers, while she later pieced it together to create something entirely new. With this moving in and out of fiction, with this control over narrative and metanarrative material, Austen became the epitome of an author concerned not only with the diegetic figure of a female reader, but also with the implied one that was at that moment perusing her novel, establishing the foundation for the claim of her belonging to the quixotic tradition in Britain in the train of Fielding or Edgeworth. In this sense, as critics such as Bray (2009) or Richardson (2005) have attested, reading plays an essential role throughout Austen's body of work, and her representation of readers and reading practices also mirrors her implied readers' choice of literary material and of an attached or detached approach to reading. What is more, in all her novels reading is associated with "education in the broadest sense, that is, with intellectual and moral development" (Richardson, 2005: 402), therefore linking her use of quixotic fiction with the novel of female development that she would perfect and for which she would come to be known and admired. In this regard, her knowledge and employment of the techniques and topoi learnt from Lennox, Barrett, Burney, Brunton or Edgeworth, among other prior quixotic novelists, allowed her to expose in her novels the transition the quixotic heroine underwent at the turn of the century. From a literal and literary quixote, to a displaced one in the shape of the biased protagonist of a tale of female development, Austen's heroines signal the definite evolution to the nineteenth-century heroines of George Eliot and her contemporaries, which had also been announced in the abovementioned female authors. Therefore, her novels will be approached in the context of the importance of Cervantes' reception for the development of British narrative fiction and of the tradition of female quixotism as a reflection on the changes of genre. That is, while her contribution to the novel is unquestionable, the understanding of this impact could not be achieved without paying special attention to her masterful use of the topos of the female quixote; a comprehensive examination of which this chapter hopes to achieve. 
In this context, it is relevant to approach her Juvenilia as the announcement of what was to come in her later complete novels. Kathryn Sutherland asserts that what links her "anarchic, often violently energetic comic pieces is a pronounced thread of critical comment on contemporary fiction," and that "from the immense fertility of their intertextual parody" one must conclude that "Austen was by her early teens widely and deeply read in eighteenthcentury English fiction" (2004: 249). In particular, what these early pieces show is "how extensively the activity of critical reading disciplines her function as a writer" (2004: 249). Her adolescent pieces of narrative fiction certainly provide a fascinating insight into her approach to contemporary fiction and to novel-writing as an overcoming of a generic formula. As Mary Waldron has asserted, Austen became interested "in the form and language of the novel, and in its relationship with its readers," and, consequently, attempted to refashion fiction to isolate elements that were "at best formulaic, at worst perfunctory" (1999: 16). She employed her early burlesques to expose popular narrative forms as "hypnotic and thought-denying," making fun of the wilder examples of the novel of sensibility, of the French philosophes and even of conduct-literature, and placing fashionable fictional stereotypes "into a frame which renders them ludicrous and, more importantly, shows them to be repetitious and stultifying" (1999: 16). By so doing, from her earliest narrative fictions "she set out to put forms and theories to the test of the everyday, without which they were, as she saw it, merely substitutes for coherent and rational deliberation" (1999: 16).

Austen's early writings, dated from the 1790s and intended for family reading, indeed brim with burlesque rewritings of romance, of sentimental or Gothic narrative fiction, and even of history itself. Examples would include her reductio ad absurdum of the cognitio scene of romance in "Henry and Eliza" or in "Love and Freindship" (sic), in which, respectively, a lady suddenly recollects having had a baby and that baby being the heroine, or an old lord identifies every young person entering the room as his lost granddaughter or grandson. ${ }^{258}$ Another parodic example would be her "History of England,"

${ }^{258}$ On the matter of her comic approach to romance, well-known is her response to the Reverend James S. Clarke, Librarian to the Prince Regent, when he suggested possible choices 
which highlights the prejudices, unreliability and formulaic nature of even historical accounts, by taking to extremes Oliver Goldsmith's deficiencies as a History writer. ${ }^{259}$ However, more than any other genre, Austen most recurrently exposes and comically subverts the conventions of the sentimental novel, from its stock titles to its whole apparatus of empty language and formulaic plots. "Love and Freindship" and "Lesley Castle" are examples of this form of sentimental burlesque. In the former, for example, Butler has identified an "unequivocal relationship with the sentimental novel both in form and content" (1987: 271). Described as a "novel in a series of Letters," Austen's tale includes parodies of conventions already subverted by previous quixotes' use of them, for instance, a resistance to parents' choice of spouse. In her story, the hero is accused of having studied novels by his father (1998: 79) when he exclaims:

My Father, seduced by the false glare of Fortune and the deluding Pomp of Title, insisted on my giving my hand to Lady Dorothea. No never exclaimed I. Lady Dorothea is lovely and Engaging; I prefer no woman to her; but know Sir, that I scorn to marry her in compliance with your Wishes. No! Never shall it be said that I obliged my Father. (1998: 79)

Moreover, he expects his beloved Laura to live in romantic and exalted poverty, subsisting on love rather than on mundane elements such as "Victuals and Drink" (1998: 82), a sentimental lack of which kills several characters in Austen's early narratives. This, for example, is an unnatural convention of novels which Barrett would later parody as well, and which had already found its comic imitation in Sir George's romantic narrative in Lennox's novel, linking Austen with her predecessor. Austen, as did prior novelists, will expose the implausibility of these narratives by means of her parody. That is, throughout her Juvenilia, Austen's employment of burlesque permits her to

of genre or subject matter for her next work of fiction: "I am fully sensible that an historical romance, founded on the House of Saxe Cobourg, might be much more to the purpose of profit or popularity than such pictures of domestic life in country villages as I deal in. But I could no more write a romance than an epic poem. I could not sit down to write a serious romance under any other motive than to save my life: and if it were indispensable for me to keep it up and never relax into laughing at myself or other people, I am sure I should be hung before I had finished the first chapter. No, I must keep to my own style and go in my own way" (Letter to Rev. James S. Clarke, March, 1816).

${ }^{259}$ For a revealing study of this piece as parody, see Annette Upfal's "Introduction." The History of England (Sydney: Juvenilia Press, 2009), pp. xiv-li. 
maintain "an awareness of both the normal reactions and literary reactions to the various situations," allowing the reader to "have two views of the characters and their behaviour in terms of fictional and social situations" (Kauvar, 1970: 215). Her early fiction then sets the context for subsequent quixotes, in particular, for their literary interpretation of reality and its contrast with the epistemology of the surrounding characters.

In addition to this critique to plausibility, Austen equally attacks the improper model that the novel of sensibility offers for its readers. Anticipating her critique to sentimentality in her mature novels, throughout "Love and Freindship" and the following "Lesley Castle" Austen parodies the excesses of sentimentality, the swoons, raving episodes and, above all, the self-centred insensibility of heroes and heroines modelled on some well-known examples of the fiction of her time. In this sense, her characterization of her sentimental heroes and heroines is also ludicrously inadequate, paving the way for the later flawed heroes and heroines of her mature novels, as well as for the more elaborate and subtle questioning of the tenets of sensibility to be found in Sense and Sensibility (1811). From the drunken Alice of "Jack and Alice," to the squinty, greasy and ugly hunchbacked Rebecca from "Frederic and Elfrida," the heroines of her Juvenilia are far from the perfect models of sentimental fiction. In addition, exposing what Claudia Johnson has termed "the politics of female sensibility" (1989), Austen contends the image of the dying woman of sensibility as an ideal heroine by her image of sturdy heroines such as Laura, who are incapable of dying despite hunger or distress and therefore miss the opportunity to achieve the "glorious death" of a true sentimental heroine (1989: 164). In fact, Austen mocks the immobility of passive heroines by having Laura revive due to her frenzy fits and her friend die because her fainting made her catch cold while lying insensible on the floor, leading to the well-known jocular moral for young ladies: "Run mad as often as you chuse; but do not faint-" (1998: 99). Neither are her heroes what the reader would expect: for instance, Jack dies almost unmentioned, and most other heroes also die; or, as Frederic, after a period of courtship extended throughout the many accustomed years of romance, they threaten to abandon the heroine for a younger and more beautiful girl. Austen thus recurrently and unashamedly mocks the alleged 
exemplarity of the sentimental male and female model. In her overt parody of Sir Charles Grandison, she allows her own Charles to describe himself in the following manner to a man who has had the presumption of disclosing his daughter's partiality for him:

I look upon myself to be Sir a perfect Beauty -where would you see a finer figure or a more charming face. Then, sir I imagine my Manners and Address to be of the most polished kind; there is a certain elegance a peculiar sweetness in them that I never saw equalled and cannot describe- ${ }^{-}$. Partiality aside, I am certainly more accomplished in every Language, every Science, every Art and every thing than any other person in Europe. My temper is even, my virtues innumerable, my self unparalleled. Since such, Sir, is my character, what do you mean by wishing me to marry your Daughter? (1998: 23)

In the manner of Grandison, Charles must decide between several female suitors, all dazzled by his beauty and wit, two qualities unrelentingly mocked by Austen in her hyperbolic description of his radiance, which only Eagles can stand (1998: 11), or in her narrator's implied satire on his actual lack of any intellectual worth. Besides this shallowness, the above displayed selfcentredness will be Austen's most common critique against the culture of sensibility. Her sentimental heroine, Laura, after expounding on her own merits very much as Charles had done, exclaims that "a sensibility too tremblingly alive to every affliction of my Freinds, my Acquaintance and particularly to every affliction of my own, was my only fault, if a fault it could be called" (1998: 76). This heroine, together with the later characters of "Lesley Castle," exposes the truth that hides in the fictional construction of sensibility: egotism, vanity and a lack of true compassion for the well-being of others. ${ }^{260}$ This recurrent, "original, formalistic challenge to the solipsism of sentimental narrative" in her Juvenilia will also find more sophisticated expression in her later works (Mandal, 2007: 48), and in subsequent quixotes of sensibility, such as Marianne Dashwood.

Therefore, as can be inferred from these examples, in her early works, by deconstructing and challenging the creation of a sentimental narrative, and emphasising not only its implausibility but its, at times, lack of morality,

${ }^{260}$ For a more thorough comment on some of these passages in relation to Austen's approach to the culture of sensibility, see Brodey (1999), pp. 112-4. 
Austen displays the dangers of assuming fictional principles as a sole guiding system of reference for life, for these tenets do not and cannot stand the test of the everyday alluded to by Waldron. From the beginning of her career as an author, Austen is then fascinated by the "formal qualities of fiction itself, and by the fictionality of fiction" (Doody, 1998: xxxii). By her subversive and humorous dissection of fictional conventions and her use of them to write in a completely different style, she evinced that fiction worked as a series of clichés through which the reader can make sense of the narrative, but she also exposed the lies that hide under them and the impossibility of neatly employing them to make reality absolutely comprehensible. Consequently, she presented her readers with the need to recognise these formulas as what they are: fictional patterns that cannot be taken at face value. While in her juvenilia she did so in a Rabelaisian or Fieldingesque style, in a highly violent and comic style that exposed the threats of real life as opposed to the order of fiction, her awareness of the difficulties her prose would encounter if she aimed for publication -as happened with her first, unpublished manuscripts- apparently led her to change her style and to employ the courtship novel as a cover story for her untamed, subversive approach to fiction (Doody, 1998: xxxi). In a more commercially successful formula than her early parodic ones, she adopted the Richardsonian plot of virtue rewarded, of a fair and orderly ending for the deserving and undeserving characters, nevertheless still allowing her narrators to provide some satirical comments on her bittersweet plots and closures. As a consequence, in her mature novels she enabled her narratorial voices to warn their readers that what they peruse, even if closer to reality than the implausible characterization or plots of previous genres, is only fiction. That is, throughout her whole body of work, Austen displays a "complex concern with the disparity between illusion and reality" (Kauvar, 1970: 215); this disparity will not only relate to the difference between literature and reality, but will also encompass idealistic or naïve imaginings, integrating, as did Lennox, both the quixotic formula and the coming-of-age theme in her own fiction (1970: 214). Becoming then part of the tradition of female quixotic bildungsromane, Austen aims to cure readers from their quixotic reading of novels and life alike, uncovering the unromantic nature of both, and the failure of the and plot formulas that readers had inadvertently assimilated as instruments to 
understand the more complex and threatening world in which they lived, if not complemented with sound reasoning and a thorough knowledge of human nature. These generic and metanarrative games with deluded diegetic and implied readers alike and her progressive displacement of the quixotic plot towards the epitome of the nineteenth-century novel of female development, will be some of her trademarks and what characterises her contribution to the tradition of female quixotism.

\subsection{Northanger Abbey, or Cervantean Games on Quixotic Heroines and Readers}

Kathryn Sutherland, in her essential study on Jane Austen's contribution to the modern novel, states that the activity of critical reading which permeates her early production as a writer becomes an endemic habit of her composition. As a consequence, all Austen's "full-length novels imply a critical perspective on fiction which drives through their narratives the contemporary debate over the status of the genre and the dangers and profits of its reading;" consequently, in her novels "the novel itself is assumed as the common ground or shared locus of illusion on which all readers can draw" (2004: 249). Nowhere is this better seen than in her first written, though last published, complete novel, Northanger Abbey (1818). This novel, published posthumously, developed from an early manuscript entitled Susan, written around 1798 and thoroughly revised for later publication. As Austen herself states in her advertisement, her novel was finished in 1803 but, owing to the bookseller's failure to find it "worth while" to publish (1998: n.p.), it did not find its way to the press until fifteen years later. This chronology explains why this late novel is closer to her early work than the rest of her mature production. Indeed, Northanger Abbey relates much more obviously to her juvenilia and remains her most metaliterary novel. This assertion is sustained by the fact that it includes Austen's most direct address in defence of the novel as a genre, therefore calling attention to her role as novelist and to the narrative fiction she is writing as matter for debate. The well-known digression is worth quoting: 
Yes, novels; - for I will not adopt that ungenerous and impolitic custom so common with novel writers, of degrading by their contemptuous censure the very performances, to the number of which they are themselves addingjoining with their greatest enemies in bestowing the harshest epithets on such works, and scarcely ever permitting them to be read by their own heroine [...] Alas! If the heroine of one novel is not to be patronized by the heroine of another, from whom can she expect protection and regard? I cannot approve of it. (1998: 21)

Rather than rejecting as unworthy the work of novelists, Austen asserts the need to belong to a tradition of writers who would support each other in their right to create novels, as well as to defend their art as valid and important, in the same fashion one heroine is supported by previous ones. ${ }^{261}$ With this statement, she also defends her choice of a reading heroine as her main character and her own metaliterary comments. She begs: "let us not desert one another; we are an injured body" (1998: 21), and sets example by praising novels written by women:

"It is only Cecilia, or Camilla, or Belinda;" or, in short, only some work in which the greatest powers of the mind are displayed, in which the most thorough knowledge of human nature, the happiest delineation of its varieties, the liveliest effusions of wit and humour are conveyed to the world in the best chosen language. (1998: 22)

By mentioning these works by Frances Burney and Maria Edgeworth she inscribes herself in a tradition of women writers and of their highly natural, entertaining, and well-written novels. Therefore, to reinforce the kind of author she is meant to be, Austen seeks the support of a tradition of female novelists on which to base her claims to authorship as the writer of a novel of female development that aims to possess all those qualities she perceives in the works of others. Aligning herself with women writers of female bildungsromane, who even depicted obvious portraits of female quixotes, instead of with Radcliffe and other representatives of the female Gothic or of the stock sentimental

${ }^{261}$ According to Gilbert and Gaubar, Austen is here also criticising the assumed need of the women writer to "present her job in self-deprecation," not to be "ignored or criticized" (1979: 61). These scholars assert that Austen does not conform to the convention, as other female authors did, of feeling compelled to "apologize for their literary efforts" (1979: 63), and the bold style of her early writing or the intrusive first person narrator indeed support this claim. 
novel, Austen carefully chooses her literary heritage. All things considered, Austen's quixotic narrative certainly inherits many of the qualities of Edgeworth's, for, although it indeed parodies the conventions of Gothic romance or the sentimental novel, the implied author's supersystem does not reject fiction, but rather criticises the limited education and experience which makes a young girl like Catherine prone to believe what she reads is an accurate description of reality. ${ }^{262}$ At the same time, Austen also proposes a genre that moves away from the unnatural depictions of romance, a generic detachment expressed in her more subtle and mature form of burlesque and her praise of the novel as the adequate form for the thorough or natural depiction of human nature. As Levine has stated, it is significant that in the only direct parody of any of her major narratives Austen still includes such an explicit praise of novels as the one quoted above: Austen introduces herself as "a novelist writing a novel" (1975: 337), and, as such, creates a fictional form that is at the core of all great novels. Levine identifies this form as linked to Don Quixote and calls it the form of "disenchantment," a "form recognizable as central to the tradition of the novel: the story of hero or heroine who must learn to recognize and reject youthful illusions in order to accept a less romantic, a more tediously quotidian reality" (1975: 337). That is, a hero or a heroine that must learn to read illusion and reality for what they are, distinguishing both. For this scholar, then, Northanger Abbey becomes the "slight and girlish cousin" of Madame Bovary, Great Expectations, Sense and Sensibility, Pride and Prejudice and Emma (1975: 337). Although Levine displays a poor choice of epithets for such a complex and intrinsically dark work, Northanger Abbey stands indeed as an Emma-to-be. In it one perceives what Austen's later novels of female development will be, once she decides to leave her parodic intents in the background and to increasingly focus on the story of female disenchantment with reality rather than with literature. However, probably none of her later novels would have possessed such marked narrative mastery

${ }^{262}$ Pearson agrees with this vision that Austen is not radically condemning fiction, as previous quixotic authors had done, but rather employing a quixotic fiction to offer more profound reflections of women's education, reading and writing. In particular, Pearson places Austen's novel in contrast with Barrett's and states that it "revises Barrett's attack on women writers by using the female quixote plot as a smokescreen behind which to launch a vigorous defence of the novel in general, and women writers in particular" (1999: 210). 
if it had not been for Austen's early experimentation with form in her first burlesque pieces or novels.

In this sense, owing to its quixotic inheritance, parody will indeed play an essential role in Austen's generic experimentation in Northanger Abbey, as she aims to balance the forces of romance and anti-romance, of previous genres and their parody, so that her fiction emerges as something new. In the line of her early writings, Austen indeed does not abandon her role as parodist of such popular genres as Gothic or sentimental narrative fiction; a parody which, once more, invites those same genres to dwell in, and at times subvert, her own narrative, enriching it with several textual layers. In the train of Don Quixote or Joseph Andrews, Northanger Abbey evinces the contradictions latent in parody, especially in the form of comic romance that Austen is borrowing from Fielding, in which a happy ending is called for, so that in being true to the content of the novel, Austen is somehow untrue to its parodic form. This comic or positive ending is just one more sign that Austen is writing something different, "a new literary tradition" that emerges from this "contest between enchantment and disenchantment," from the creation of a reality that allows satisfactory resolutions not from the "large passions" of romance, but from "rational understanding of the self and the social order" (Levine, 1975: 339). Still, Austen's narrative, in her comic resolution, once more proves that the energies of romance lurk behind her more realistic form, something that is also made evident throughout the novel, in the tensions created between the literary quixotic narrative and the novel of female development that she constructs around Catherine's naivety.

Catherine and Austen's implied reader, then, travel together the road of awareness to detached reading and critical thinking in that dual narrative. Those two elements of the narrative merge for most of the novel, while at times one of them will supersede the other: the bildungsroman at Bath and back at Fullerton, and the literary quixotic narrative at the Abbey. None of them disappears and both complement each other in Austen's intention to awake her readers, contradicting most scholars' claims that the novel is clumsy in its 
accomplishment of the integration of both narratives. ${ }^{263}$ According to Claudia Johnson, this is the great achievement of Northanger Abbey: to "put the gothic novel and the novel of manners into conjunction with each other, to unite the horrid with the familiar, [...] in part by cultivating [a] sagacious readership" (2001: 175). In order to cultivate this sagacious reader of and within the novel, employing Lascelles' words, Austen develops two types of burlesque in her work: one, modelled on Lennox and other quixotic fictions, in which the "contrast between false and true is reflected in the career of a character whose expectations, derived from fiction, are challenged and found false by experience" (1995: 56); and another in which "some fictitious situation or course of action is translated into terms of actual life" (1995: 57). In the first kind, it "is necessary that this character, in suffering the birth-pangs of common sense and apprehension of reality, should cooperate with the author in pointing the contrast between false and true" (1995: 59), which will be the case of Catherine's quixotic awakening at Northanger. In the other kind, "when a situation is developed in deliberate opposition to the rules of fiction, it is not necessary that any of the characters involved should become aware of the contrast" (1995: 59), as happens when the readers' expectations of heroic adventures are translated into Catherine's experience as an ordinary eighteenthcentury young woman. While Catherine remains unaware of any heroic readings of her own life, it will be the implied reader who will be required to become aware of the contrast. Consequently, Austen's novel introduces two different, though parallel, stories of awakening and critical instruction: the heroine's and the implied reader's. Both will entail a call of attention to the danger of applying literary formulas and living by literary expectations, as well as to the difficulties of interpretation that are to be found outside the neat conventions of fiction.

${ }^{263}$ Kauvar is fundamental in stating that Austen emphasises the theme of education and employs the burlesque to reinforce it (1970: 215), and placing the episodes of literary burlesque at Northanger Abbey in context within the main action (1970: 216). However, most scholarly work has perceived them as two different narratives, two plots in one novel. For comments on the integration, or lack of it, of both narratives see Lascelles (1995), p. 64, and Loveridge (1991), pp. 2-3. 
6.1.1. A Journey to Quixotism and Back: the Literary and Social Instruction of a Young Heroine

In the context of Austen's development as a writer, Northanger Abbey soon anticipates the changes that will take place with regards to her adolescent pieces. As Catherine's story takes off in Bath, Austen abandons her early style for a more subtle irony directed not only towards literary expectation, but also the social panorama Catherine encounters at Bath, signalling the transition towards her novels of female development and towards a more natural narrative. Northanger Abbey can be labelled as Austen's first novel to follow her recurrent plot of the awakening of a young girl. In this sense, it resumes the common places of prior narratives of female development, from Burney to Edgeworth, and foretells the later more mature novels of her own production. In this story of self-awareness and critical maturation, Catherine starts the narrative as any heroine of a novel of female development: as an innocent and good girl who is unaware of the workings of society, owing to the fact that she has grown up in a small rural community. She then resembles Evelina or Belinda in that her story commences as she enters society and must make sense of her experience, as well as to accurately read those around her. Bath, once again, becomes the perfect scenario in which to study social interactions and to develop a more realistic portrayal of her heroine. Catherine, attending her first ball, goes almost unnoticed. Despite this displacement towards a narrative of social awareness, the narrator continues to tease her readers, stating it was now the time for her "heroine" to be admired (1998: 10). However, instead of rapturous wonder, whispers of eager enquiry or being called a divinity (1998: 10), Catherine is pronounced to be a "pretty girl," a compliment for which she felt more obliged than "a true quality heroine would have been for fifteen sonnets in celebrations of her charms" (1998: 11). Austen tones down the impact of her heroine's debut in society and once again contrasts the hyperbolic rhetoric of sentimental fiction with her record of natural speech and events. Austen's natural story of female development, divested of all remaining traces of romance, takes over the sentimental narrative. For the whole of the episodes at Bath this will be constant feature of Austen's narrative and it is particularly evident in her contrast between the usually sleep-deprived and 
anguished sentimental heroines, and Catherine, who, even while falling in love, sleeps, eats and drinks as any healthy young girl. Over and again the narrator highlights the differences between the circumstances of her heroine and those of romances, and emphasises that her experience relates much closer to that of an eighteenth-century young girl. For instance, when Catherine hopes that Thorpe will not ask her to dance and Tilney will do so again, the narrator asserts:

Every young lady may feel for my heroine in this critical moment, for every young lady has at some time or other known the same agitation. All have been, or at least all have believed themselves to be, in danger from the pursuit of some on whom they wished to avoid; and all have been anxious for the attentions of some whom they wished to please. (1998: 54-5)

Reducing the usual Gothic triangle of persecution and seduction to a lady and her dancing partners -something later stressed by Tilney's comparison of dancing with marriage (1998: 57)- reveals that Austen's employment of such literary material is parodic. What is more important, it highlights that the true adventures of a heroine of this new form of narrative inherits the intrinsic qualities of prior genres, but without the need to translate the natural into the unnatural in order to prove fascinating reading for an audience, nor the need to construct elaborated metaphors of female seduction or her pursuit of marriage, when reality already provided more mundane examples. In line with this displacement of her heroine and her narrative from the reading of reality portrayed in previous genres, Austen manifests that Catherine is not yet a quixote and that she has yet not adopted literary tenets as a means to interpret reality. ${ }^{264}$ Catherine remains impervious to the bias of romance, when, for instance, instead of assuming the woman standing next to Mr Tilney is his wife, Austen has Catherine rationally conclude from the evidence she has that this woman is indeed his sister. The narrator states that she was "guided only

${ }^{264}$ Although, as Bray has recorded, most scholarship agrees on terming Catherine a female quixote (2009: 144-5), this assertion has also been recurrently qualified. I believe this disagreement is born from the failure to recognize that there are two Catherines, so to speak: the quixote and the naïve heroine of a non-quixotic bildungsroman. Consequently, I would contend a middle ground: she is not a quixote at the beginning of her journey in Bath; however, she progressively becomes one, reaching the summit of her delusion at the Abbey, where her quixotic nature becomes evident. 
by what was simple and probable," therefore "unthinkingly throwing away a fair opportunity of considering him lost forever" and not having a chance to turn pale and fall in a fit on Mrs Allen's bosom (1998: 36). Throughout these scenes at Bath, it is then not Catherine but Austen who is imitating books, translating heroism into another language (Levine, 1975: 347-8), into a different narrative. Consequently, all the references to heroic conduct and their contrast with Catherine's circumstances and behaviour are intended for the implied reader.

In addition to this initial highlighting of Catherine as an inexperienced yet sensible heroine of a bildungsroman, at Bath the rest of traditionally relevant characters to be read appear on stage: the hero, Henry Tilney; the bad suitor, John Thorpe; the sentimental friend, Isabella; the suffering chaste woman, Eleanor Tilney; and the villain, General Tilney. Although all could be said to respond to certain characterization formulas, to certain literary types that Austen had recurrently mocked, the author detaches her narrative from stereotypical or merely parodic depictions and creates more complex characters for Catherine to decipher in order to prove that common life may and can still be interpreted with the simplified formulas of fiction that replicates reality, but that it will always require a deeper knowledge and reading to be fully comprehensible. In this regard, Austen places special emphasis on Catherine's reading or interpretation of the surrounding characters; an interpretation that runs parallel to references to more literal reading. Austen's novel, then, moves beyond a gallery of social types, but also gives a "more complex picture of contemporary reading practices than simply the impressionable Miss avidly reading away in the privacy of her bedroom or "closet"' (Richardson, 2005: 400). In the context of Austen's novel, reading is then more than an "escapist or self-deluding pursuit," it "promotes friendship, contributes to social distinction, forms a common topic and pursuit for men and women" (Richardson, 2005: 400), as subsequent examples will attest. Reading practices, literary genres and social behaviour remain thus intertwined throughout the whole novel, transforming it into a very particular quixotic female bildungsroman. 
John Thorpe, for example, is a character that signals Austen's detachment from the stereotypes of romance and her more ironical approach to social -and literary- types. He is a coarse character whose conversation turns around horses, dogs and his own imaginary consequence. He moreover embodies what seems Austen's principle that stupidity relates to how (little) characters read and immorality to what they do actually peruse. In Thorpe's case, he only enjoys Tom Jones and The Monk, and rejects most other novels as "full of nonsense and stuff" and the "stupidest things in creation" (1998: 31-2). In addition, he criticises Udolpho, but praises novels penned by Radcliffe, having to stand corrected by Catherine on the authorship of the former. Finally, to add insult to injury, he harshly condemns Camilla and Madame D'Arblay. This opinion, so contrary to the one expressed by the narrator in her famous defence of novels, among them Camilla, obviously places Thorpe as an anti-hero, entirely against the novel's supersystem. Although thus positioned as the antihero in the courtship plot, Thorpe does not provide the usual obscure interpretation of a Gothic seductive villain. Catherine highly disapproves of his manners and behaviour. The omniscient narrator offers the reader a description of Catherine's annoyed feelings at every occasion in which John Thorpe approaches her, and it is in his character that her powers of discernment are first exerted with absolute authority and good judgement, despite all external influence:

Little as Catherine was in the habit of judging for herself, and unfixed as were her general notions of what men ought to be, she could not entirely repress a doubt, while she bore with the effusions of his endless conceit, of his being altogether completely agreeable. It was a bold surmise, for he was Isabella's brother; and she had been assured by James that his manners would recommend him to all her sex; but in spite of this, the extreme weariness of his company, which crept over her before they had been out an hour, and which continued unceasingly to increase till they stopped in Pulteney-street again, induced her, in some small degree, to resist such high authority, and to distrust his powers of giving universal pleasure. (emphasis added, 1998: 48)

Contrary to the interpretation of scholars who assert that it is only at the Abbey when Catherine starts exerting her deductive powers, ${ }^{265}$ Austen's heroine is

${ }^{265}$ Malina, for example, sees Catherine at the Abbey as coming "out of the safety of her own room in search of some action, constructing herself as figure of movement rather than 
never taken in by his words or his claim of feelings towards her, and he is read as only an obstacle for her aim to spend more time with Tilney. Thorpe ruins her chances of dancing with Tilney at the ball by engaging her first dance and then abandoning her, he also lies to her and makes her incur in displeasing Henry and his sister by not keeping her appointment for a walk with them. In Austen's ironic world, John Thorpe is the parodic counterpart to the suitor in search for a wealthy conquest who will employ all kinds of stratagems in order to obtain the heroine for himself. However, far from his Gothic or sentimental models, far from the Montonis or the Sir Clements, he lacks the charm or the obscurity of a true Gothic villain. Nevertheless, it is his slander of Catherine's situation to the General which brings her subsequent expulsion from the Abbey and creates the greater distress for her. John Thorpe may not be read as a villain, but he is definitely not considered a gentleman either, which was accusation enough in Austen's narratives.

Other characters are more subtly tinctured with literary undertones and will prove more difficult to decipher than Thorpe. Where Catherine is highly deluded and where she will have to exert all her deciphering powers, is in the character of Isabella. Catherine, as Arabella, has never known the ways of the world and is totally unaware of how an unfeeling coquette may act. Her innocence and good disposition towards congenial friendship, so necessary for any heroine, prevent her from noticing the incongruities in Isabella's behaviour and the double meaning hidden behind her words. In addition, Catherine displays that axiological superiority that Pardo identified as a recurrent characteristic of female quixotes (2005c: $357-8)$, which consequently increases her biased reading of Isabella. As Henry states, Catherine reads others through her own moral prism, her own standards of behaviour (1998: 103), and this leads to a very positive and naïve vision of reality. For instance, Henry claims that by attributing to Captain Tilney good nature as a motive in his dealings with Isabella, Catherine has convinced him of "being superior in good nature

as a passive figure of closure" (1996: 286). In addition, she "must become a detective to discover the truth behind the "common life' mysteries," that is, in order to interpret the General's, to her, mysterious behaviour (Malina, 1996: 286). However, while scholars' emphasis on the importance of the Northanger episodes for the focus on Catherine's powers of interpretation is justified, Austen's heroine is never a completely passive reader of reality or characters and her development as a critical reader begins much earlier, at Bath. 
[...] to all the rest of the world" (1998: 104). Over and over again, if Catherine is perplexed by her friend's behaviour, as when she decides to follow two young men she vows not to care about (1998: 27), she never doubts of her friend having an ulterior motive and considers that Isabella has a deeper knowledge of the ways of the world. Nevertheless, her playfulness with Captain Tilney does affect her, as Catherine is always on the side of what is morally right, and suspicions do arise in her. It is at this point when she becomes aware of the pressing need to be able to read others in a social context and when the fact that Catherine is a heroine who engages in deep processes of interpretation becomes evident. At first, she attributes ignorance to Isabella and the Captain: she must not be aware of the latter's infatuation, he must not be aware of her engagement. Catherine's perception of the situation of course tells more about Catherine as a reader than about the objects of her interpretation: she reads them according to her moral code, to what should be, morally speaking. Nevertheless, of course, in this case, what must be is not and Catherine becomes aware of Isabella's incongruous behaviour in private and in public. She starts to read her more actively than before, she struggles for meaning: "[w]hat could be meant by such unsteady conduct, what her friend could be at, was beyond her comprehension. Isabella could not be aware of the pain she was inflicting; but it was a degree of wilful thoughtlessness which Catherine could not but resent" (1998: 117). In the same manner, when she learns through Henry that the Captain knows about her engagement she naively expects Henry to answer her rather indiscreet questions and the following conversation ensues:

\footnotetext{
"But what can your brother mean? If he knows her engagement, what can he mean by his behaviour?"

"You are a very close questioner." [...]

"[...] you must know your brother's heart."

"My brother's heart, as you term it, on the present occasion, I assure you I can only guess at. [...] if it is to be guesswork, let us all guess for ourselves. To be guided by second-hand conjecture is pitiful. The premises are before you. $[\ldots] "$
} 
"Well," said Catherine, after some moments' consideration, "you may be able to guess at your brother's intentions from all this; but I am sure I cannot. [...]." (1998: 119)

However, Henry tries to appease her worries and Catherine finally censures herself, because she undermines her own opinions and capacity for observation and analysis in order to submit to Henry's allegedly more balanced and informed perceptions. In the narrator's words, "Henry Tilney must know best. She blamed herself for the extent of her fears, and resolved never to think so seriously on the subject again" (1998: 120). Relying on whom seems a better source of authority hinders Catherine's own epistemological process something no diegetic or implied reader should do in Austen's narrative world. This invalidation is particularly blatant as Catherine proves not to have been completely mistaken when Isabella's engagement to her brother James is broken due to her infatuation with Captain Tilney. At that moment, Catherine completely opens her eyes to the real Isabella, the one that she had only suspected and had not wanted to fully discover. Catherine finally awakes from her delusion relating her so-called friend, through a moment of epiphany and recognition. In this sense, Pardo has interpreted Catherine's misrepresentation of Isabella and her subsequent moment of anagnorisis as the essential awakening in the novel. Catherine's error is not quixotic, it has not literary origins, but it is linked to it, on the one hand, because it is a manifestation of the difficulties of reading reality appropriately, and, on the other hand, because it also springs from Catherine's inexperience (2005c: 362). Both types of mistakes, the quixotic and the non-quixotic, are therefore framed in the narrative of a young girl's maturation and self-awareness (2005c: 362) and are a perfect example of the type of anagnorisis found in female quixotic narratives, where these young girls' delusion is characterised by errors of judgement about the nature of people (Pardo, 2004: 1632-33). As Catherine herself states, she "never was so deceived in anyone's character in [her] life before," to which Henry's insightful and ironic answer is "among all the great variety that you have known and studied" (1998: 166), precisely the subject matter of a novel of female development: knowing a variety of characters and discovering what hides behind appearances. Although usually employed to highlight an awakening to an undeserving lover, Austen utilises the language of 
shame and love to state Catherine's cure of her delusional friendship with Isabella: Catherine is ashamed of her, and "ashamed of having ever loved her" (1998: 175-6). In addition, Catherine states that her character is now fully known to her and she recognises her as a "vain coquette" whose tricks have not answered (1998: 176). She concludes by wishing she had never known her and by vanishing her from her heart and mind. This final awakening signals Catherine's higher point of critical social reading and also an important landmark in the process of knowing herself: she does not suffer from sentimental distress at the loss of her friend. Once more, she proves not a sentimental imitator, but a natural girl. Henry highlights this fact when he presents to Catherine some of the clichés that would be expected from a heroine at this trying time:

"[...] You feel, I suppose, that in losing Isabella, you lose half yourself: you feel a void in your heart which nothing else can occupy. Society is becoming irksome; and as for the amusements in which you were wont to share at Bath, the very idea of them without her is abhorrent. You would not, for instance, now go to a ball for the world. You feel that you have no longer any friend to whom you can speak with unreserve, on whose regard you can place dependence, or whose counsel, in any difficulty, you could rely on. You feel all this?" (1998: 166)

After a moment's reflection Catherine states that she does not, and naively asks if she ought to feel that way. She asserts that she does not feel as afflicted as "one would have thought" (1998: 167), once more highlighting what is expected from a sentimental heroine, what she ought to do in these circumstances. To this Henry wisely replies "[y]ou feel, as you always do, what is most to the credit of human nature" and adds an essential idea in any story of development: "[s]uch feelings ought to be investigated, that they may know themselves" (1998: 167). By awakening to Isabella, Catherine may also awaken further to her true self, disregarding literary common places and fake emotions learnt from a culture of sensibility.

However, in Austen's highly metaliterary novel, this event is also closely linked to a literary awakening as well, once again highlighting how both elements of the narrative work within Austen's novel. Isabella, with her beauty, 
her Italian name so naturally romantic and her excessive love for Gothic romances, embodies the deceiving world of appearances which is so closely related to that of romance, as had been articulated in the case of Arabella or Cherry's conclusions based on them, for instance. Although Austen's narrator has told her audience that Catherine was a reader from her early childhood and that she collected those useful quotations for a heroine's eventful life from Pope, Gray, Thompson or Shakespeare (1998: 3-4), it is actually Isabella who introduces Catherine to Gothic novels, the source of Catherine's later quixotism. She is the one who provides Catherine with the list of "horrid" readings -the Castle of Wolfenbach, Clermont, Mysterious Warnings, Necromancer of the Black Forest, Midnight Bell, Orphan of the Rhine, and Horrid Mysteries-, who fosters her obsession with The Mysteries of Udolpho, and who suggests reading The Italian together (1998: 23-4). In addition, as well as her brother, she has no real critical discernment, for she equals Radcliffe's novels with the other "ten or twelve of the same kind" she suggests and which are, mostly, low-quality imitations (1998: 23). ${ }^{266}$ She moreover terms Sir Charles Grandison "an amazing horrid book," although she has never read it herself (1998: 25), misusing horrid and therefore equating both forms of fiction. In another turn of the screw, Isabella, and not Catherine, is the true sentimental heroine of Austen's novel, and, what is more important, the true sentimental imitator or enactor (Glock, 1978: 37; Grogan, 2002: 21; Nardin, 1973: 67). She is the one who employs language and sentiment learnt from her readings, the one who aims to apply what she has found in novels to reality and who is finally ruined by the sentimental plot she constructs around Captain Tilney. ${ }^{267}$ Her conscious manipulation of literary clichés, of literary hyperboles

${ }^{266}$ For a throughout description on the plot and style of these largely unknown novels, see Michael Sadlier's germinal article "The Northanger Novels: a footnote to Jane Austen." The English Association Pamphlet 68 (Oxford: Oxford University Press, 1927); in which he also compares Catherine's carefully selected list of readings to that of another female quixote, Lydia, in Sheridan's The Rivals (1927: 9).

${ }^{267}$ Isabella's nature as a would-be sentimental heroine is also highlighted by the fact that, as Tilney later states, it is her who would be after a "baronet" if he happened to come in her way (1998: 166), the same case that Austen's burlesque narrator had mentioned as part of Catherine's mock-heroic description (1998: 4). In the frame of Austen's narrative, Catherine has the true heroic feelings of unselfish love, while Isabella embodies the recurrent plot of romance which requires nobility and a title for a hero to achieve the hand of the heroine. Or, in Schaub's words, "Catherine's instinctive sympathy is heroic" for "it embodies the good qualities of sentimental heroines, while Isabella's arch reading and speaking does not" (2000: n.p.). 
and feelings, prevents her from becoming a quixote, but she is nevertheless a coquette in the line of Miss Glanville, employing Catherine's naivety and embodying an amatory fiction of seduction and betrayal. By awakening to her falseness, Catherine also rejects the unnatural narrative her so-called friend embodies. However, this interpretation of Isabella in terms of her readings or the narrative she seems to represent is implicit and intended once more as a message for the discerning implied reader.

Catherine only once in the novel literally interprets a character in terms of her Gothic readings: General Tilney, and, in that sense, her most interesting reading is undeniably that of the General character. Catherine is intimidated by him from the first moment she sees him at a ball. He is described at that moment as "a very handsome man, of a commanding aspect, past the bloom, but not past the vigour of life" (1998: 59). Catherine is also greatly overwhelmed by his civilities towards her. On the occasion of Catherine's sudden appearance at his house he "attended her himself to the street-door, saying everything gallant as they went down stairs, $[\ldots]$ and making her one of the most graceful bows she had ever beheld" (1998: 79). His attitude greatly contrasts with that shown on the previous paragraph, where he was unreasonably angry with a servant and "if Catherine had not most warmly asserted his innocence, it seemed likely that William would lose the favour of his master for ever, if not his place" (1998: 79). That is, in the General's character the author describes a duplicity which is even more poignantly expressed at the Abbey, where the General's bad temper and his concern about Catherine alternate, drawing her to confusion with regard to his character. He is difficult for Catherine to read accurately and there is always a sense of awe in her when confronted with the General: even when he tries to be as polite as possible, there is a remnant of fear. She is aware of a repressive attitude towards his children and herself, which she translates into making him the villain of her story. Influenced by his character and the atmosphere of the Abbey, she constructs a reality in which the General is the murderer or jailer of his suffering wife. After listening to Eleanor's story of her mother's short and sudden illness and death, Catherine develops the following plot: 
Catherine's blood ran cold with the horrid suggestions which naturally sprang from these words. Could it be possible? Could Henry's father-? And yet how many were the examples to justify even the blackest suspicions! And, when she saw him in the evening, while she worked with her friend, slowly pacing the drawing-room for an hour together in silent thoughtfulness, with downcast eyes and contracted brow, she felt secure from all possibility of wronging him. It was the air and attitude of a Montoni! What could more plainly speak the gloomy workings of a mind not wholly dead to every sense of humanity, in its fearful review of past scenes of guilt? Unhappy man! (1998: 149-50)

Her use of the word "horrid" triggers the recollection of her Gothic readings at Bath and indicates the source of her interpretation, which the comparison with Montoni ratifies. The inexperienced Catherine makes use once again of the conventions of romance, as other female quixotes did, in order to interpret a reality -in this case the General's character and a threat that she can perceive but not identify- that escapes her comprehension and that she needs to place in the neat conventions of fiction. First of all, his appearance corresponds to those attractive but dark characters which are the villains of Gothic narratives and, as a quixote, Catherine reads these appearances in accordance to the stereotypical characterization of fiction. Secondly, his obsessive control over his household is reminiscent of the tyrannical figure of the Gothic father or guardian who shows an unfailing tendency to lock up his wife or his daughter. In this sense, his control over Eleanor, imposing on her the need to lie about her being at home and causing her to be uncivil, his demand that she be his constant companion or the constant silence to which she is forced by his speeches are seen by Catherine as the equivalent of the Gothic imprisonments in castles. Catherine has an insight into the General's personality despite his civility, and she shapes her suspicions in the form of the literary conventions which she has learnt through her readings, rewriting the General as the murderer of his wife. Her terrible reimagining of the General is immediately corrected and scolded by Henry as resulting from her imagination running wild and contradicting all logic.

However, the narrator, in her ironic view, tells the readers that Catherine is not totally mistaken in her reading of the General, for when Henry explains the reasons which drove his father to behaving towards her as he did, the narrator states that: "Catherine, at any rate, heard enough to feel, that in suspecting 
General Tilney of either murdering or shutting up his wife, she had scarcely sinned against his character, or magnified his cruelty" (1998: 201). The farfetched comparison between murder and the General's actual crimes are a sign not only of Catherine's still excessive immaturity in her employment of literary formulas, but also of Austen's intention, once more, to tame the Gothic and bring it to a more domestic setting. Although the General may not have murdered his wife, his behaviour towards her renders him, in society's contemporary standards, an oppressive husband. Even Henry and Eleanor admit that their mother was not a happy wife. Moreover, as any Gothic villain, the General is an unprincipled character, only interested in gratifying his vanity or greed, focused on material luxuriousness and an extraordinary appetite, which again relates to the immense sensuousness of previous anti-heroes. In addition, he is a modern villain for whom his children are worth the good or bad match they make in marriage and for whom people are classified according to what they possess. As long as he thought Catherine was a worthy match for Henry he behaved towards her with utmost civility. When he discovered she did no longer serve his purpose, he immediately reacted evicting her from Northanger, without any consideration or offer of help. Catherine is left to travel alone and to the disgrace of being expelled in such a manner, turned out of doors and exposed to the dangers of the road that Austen had foretold in her juvenile parodies of the Gothic plot and villains. General Tilney is, therefore, a villain; if not a Gothic murderer or persecutor, definitely an eighteenth-century achingly unconsidered and rude man. Catherine learns to make sense of his cruelty through literary tenets, only to put them aside as her greater experience in the world proves a better guide to judging the General's motives. As revealed by Austen's narrative, a Gothic villain is merely a General Tilney reduced to a formula, but that formula has served its purpose and needs to be overcome in the narrative of social and personal awakening. ${ }^{268}$

268 Although almost parenthetically, Austen does the same with Captain Tilney. Parodying the possibility of his performance as the full Gothic seducer and abductor, the narrator states: "[Catherine] looked at [Captain Tilney] with great admiration, and even supposed it possible that some people might think him handsomer than his brother, though, in her eyes, his air was more assuming, and his countenance less prepossessing. His taste and manners were beyond a doubt decidedly inferior; for, within her hearing, he not only protested against every thought of dancing himself, but even laughed openly at Henry for finding it possible. From the latter circumstance it may be presumed that, whatever might be our 
Finally, as for the hero of the story, from the very beginning Henry Tilney is read as such, although his description, as that of Catherine, does not suit his role as a heroine's match and defies the mere fictional formula: in striking contrast with Glanville, Stuart, and the heroes of romance, Tilney's attractiveness is not founded merely on appearances, which are not very dashing. His wit, his conversation and his "gentlemanlike" manners are praised above his looks. What is more, he is a clergyman, that is, a hero with a profession and a representative of a new kind of bourgeoisie main character that would take over the Victorian novel, a transition between the noble and the working class hero. Tilney is neither rich nor noble; he does not possess a large state as Glanville or Stuart do. But Catherine still falls in love with him and recurrently considers him "handsome," fitting him into a heroic design. Furthermore, despite her obvious liking of him, their relationship does not follow the ordinary patterns of romance. She is not the one in power at the process of courtship, she is never haughty nor does she exert any influence over his wishes, rather the opposite: Tilney mocks her and his humour is what concerns Catherine and determines her course of action. In Austen's antiromantic narrative, the conditions of marriageable young women are never idyllic, but rather portray the pressing need they experienced of finding a suitable husband. Therefore, Austen's heroines are never in control and they prove their dependence on the eventful chance of a proposal of marriage, as Henry has implied in his metaphor of dancing as marriage: men can propose, women's only power is to refuse (1998: 57). Nevertheless, as in all Austen's mature novels, romance is allowed to overcome a more sober narrative in the end, and Henry performs his role as hero, because, even if he never saves her life nor goes to extremes to fulfil her slightest wishes, he gives her a heroine's truly deserved happy ending. Catherine is raised to heroism by attaining what heroines did: the love, and hand, of the hero. What is more, he defies his father

heroine's opinion of him, his admiration of her was not of a very dangerous kind; not likely to produce animosities between the brothers, nor persecutions to the lady. He cannot be the instigator of the three villains in horsemen's greatcoats, by whom she will hereafter be forced into a traveling-chaise and four, which will drive off with incredible speed. Catherine, meanwhile, undisturbed by presentiments of such an evil, or of any evil at all, except that of having but a short set to dance down, enjoyed her usual happiness with Henry Tilney, listening with sparkling eyes to everything he said; and, in finding him irresistible, becoming so herself" (1998: 102). The italics in the use of that "he" somehow create the illusion that the foretold event will actually take place, once more teasing the reader for his or her expectations. 
and, in a true heroic style, rides to Fullerton to make his love and his honourable intentions known.

In addition to his role as romantic enabler, Henry is also the object of Catherine's scrutinizing gaze as heroine of a bildungsroman. As the object of her affections and the hero of her story of awakening, Henry Tilney is most often the object of Catherine's analysis from the beginning of their acquaintance. At first she hardly understands his archness (1998: 11), but she soon comprehends his humour and realises that he "indulged himself a little too much with the foibles of others" (1998: 15), that is, even allowing herself to question his character. However, her general attitude is one of reverence to his knowledge and criteria. On the matter of the picturesque or even of the qualities of women, Catherine has no problem believing that "Henry Tilney could never be wrong;" the narrator continues: "his manner might sometimes surprize, but his meaning must always be just: -and what she did not understand, she was almost as ready to admire, as what she did" (1998: 89). Tilney could be said to stand for Austen's narrative, for her blending of mild satire, of plausibility and naturalness, and of a certain romance that has survived in the final love story of her novel. He could be said to represent Austen's supersystem and his role as Catherine's mentor would certainly indicate that, as in prior female quixotic or development narratives, the hero/mentor stands for the moral of the novel. Indeed, Tilney is usually Catherine's interlocutor on matters of education, language, literature or, more importantly, perception. The most relevant conversation on reading, novels, history and perception takes place, in fact, during a walk with the Tilney siblings, throughout chapter XIV of part one. For the first time, Catherine interprets her surroundings according to the picture she has drawn from her readings. As they walk through the scenery that surrounds Bath, the following conversation takes place:

\footnotetext{
"I never look at it," said Catherine, as they walked along the side of the river, "without thinking of the south of France."

"You have been abroad then?" said Henry, a little surprized.
} 
"Oh! no, I only mean what I have read about. It always puts me in mind of the country that Emily and her father travelled through, in the "Mysteries of Udolpho.' [...].” (1998: 82)

In the same manner Catherine later aims at making sense of the General through literary tenets, so she starts at this point to interpret what she does not know by means of the experience gained by reading. One would expect Henry's instant rebuke for this, rather innocent, translation of literature to life; however, the conversation continues very differently when Catherine assumes that he never reads novels because "they are not clever enough" for him, as "gentlemen read better books." Henry's reply undermines this opinion and supports the narrator's defence of fiction:

The person, be it gentleman or lady, who has not pleasure in a good novel, must be intolerably stupid. I have read all Mrs. Radcliffe's works, and most of them with great pleasure. The Mysteries of Udolpho, when I had once begun it, I could not lay down again; I remember finishing it in two days -my hair standing on end the whole time. (1998: 82)

Rather humorously, Henry proves an even more voracious novel reader than his sister, and appropriates a novel that was "her own, particularly her own" (1998: 83). Furthermore, Henry considers himself a greater reader than even Catherine herself when he playfully answers her next remark, that she thought "young men despised novels amazingly," thus:

It is amazingly; it may well suggest amazement if they do-for they read nearly as many as women. I myself have read hundreds and hundreds. Do not imagine that you can cope with me in a knowledge of Julias and Louisas. If we proceed to particulars, and engage in the never-ceasing inquiry of 'Have you read this?' and 'Have you read that?' I shall soon leave you as far behind me as -what shall I say? - I want an appropriate simile; -as far as your friend Emily herself left poor Valancourt when she went with her aunt into Italy. (1998: 83)

Henry's speech not only serves as reinforcing chorus of the narrator's defence of the novel, but, in Catherine's unassuming opinion, his taste for novels also justifies her own. Once again, he must know best. And he does when he 
teasingly parodies the excessive novel-reading of young ladies like Catherine, or when he later mocks her inaccurate use of language when he states that when she calls Udolpho "the nicest book in the world" she means "the neatest," which must depend upon the binding (1998: 83). Henry's slightly pedantic concern over language, supported by the male authority of Johnson and Blair (1998: 83) and expressed in his subsequent diatribe on the use of the word "nice," emphasises the need for a critical approach not only to language itself, but to reading. This is overtly stressed with Catherine's next assertion that she reads little more than novels. She can read "poetry and plays, and things of that sort" and she does not dislike travels (1998: 84). Nevertheless, as most other female quixotes, she struggles with one particular genre, history:

History, real solemn history, I cannot be interested in. [...] I read it a little as a duty; but it tells me nothing that does not either vex or weary me. The quarrels of popes and kings, with wars and pestilences in every page; the men all so good for nothing, and hardly any women at all -it is very tiresome: and yet I often think it odd that it should be so dull, for a great deal of it must be invention. The speeches that are put into the heroes' mouths, their thoughts and designs - the chief of this must be invention, and invention is what delights me in other books. (1998: 84)

Echoing Austen's own earlier parody on history, for Catherine, torment and instruction can mean the same when forced to study such dull subject (1998: 85), which also provides little help for a young girl in her understanding of a world that, according to historians, offers scarcely anything for women to do. Nevertheless, the reading of history proves once again to distinguish educated and critical readers from mere fiction seekers. Not only Mr Allen, Catherine's father or Henry like history, but also Eleanor is "fond of history" and can distinguish facts from embellishments, and enjoy both of them for what they are (1998: 85), transforming her into one of the model readers of the novel (Grogan, 2002: 22). Catherine has not been taught to relish its perusal; in her own words: "if people like to read [historians'] books, it is all very well, but to be at so much trouble in filling great volumes, which [...] nobody would willingly ever look into, to be labouring only for the torment of little boys and girls, always struck me as a hard fate; and though I know it is all very right and necessary, I have often wondered at the person's courage that could sit down 
on purpose to do it" (1998: 85). Instruction and pleasure are very different things, and the childish Catherine has not yet been taught to labour for meaning or critical thought.

In the same way, the following course of instruction which Henry undertakes to educate Catherine has to do with her inability to discern, or see, certain realities. On the matter of the picturesque, Catherine is completely at a loss. While Henry and Eleanor are "viewing the country with the eyes of persons accustomed to drawing" and deciding "on its capability of being formed into pictures, with all the eagerness of real taste" (1998: 86), Catherine needs to be instructed in the art of viewing. Consequently, the semantic field of seeing or gazing remains connected to female instruction in Austen's novel of development. However, the greater lesson on interpretation, this time linked to Catherine's readings, is the confusion between Eleanor and Catherine in which real and fictional matters collide. When Catherine exclaims "something very shocking indeed, will soon come out in London," something "more horrible than any thing we have ever met with yet," something "uncommonly dreadful" with "murder and every thing of the kind" (1998: 87), Eleanor assumes she is referring to real events, more specifically, a riot. Henry, as author-surrogate in this case, with a full knowledge of the discourse of fiction and non-fiction, can perceive both and explain them to each other:

My dear Eleanor, the riot is only in your own brain. The confusion there is scandalous. Miss Morland has been talking of nothing more dreadful than a new publication which is shortly to come out, in three duodecimo volumes, two hundred and seventy-six pages in each, with a frontispiece to the first, of two tombstones and a lantern-do you understand? And you, Miss Morland -my stupid sister has mistaken all your clearest expressions. You talked of expected horrors in London - and instead of instantly conceiving, as any rational creature would have done, that such words could relate only to a circulating library, she immediately pictured to herself a mob of three thousand men assembling in St. George's Fields, the Bank attacked, the Tower threatened, the streets of London flowing with blood, a detachment of the Twelfth Light Dragoons (the hopes of the nation) called up from Northampton to quell the insurgents, and the gallant Captain Frederick Tilney, in the moment of charging at the head of his troop, knocked off his horse by a brickbat from an upper window. (1998: 88) 
Henry's jocular speech enables readers to contrast once more the literary and the non-literary reactions of the characters, highlighting what their own system of reference to interpret reality is. Despite the humorous treatment of this passage, as happened in her juvenilia, Austen's use of comicality can hide a threat: in this case an allusion to the terrible Gordon riots of the 1780s. Austen is playing, and so is her character, not only with the confusion of real and literary referents, but also with the fearsome apprehensions of her times and with the disconnection from real life infantilized women such as Catherine display.

Throughout this chapter, and most of the novel, Henry thus stands as correction for Catherine's literary or, more often, uninformed perception. However, his stereotypical role as mentor of a novel of development is mocked with Austen's famous ironic comments on female ignorance. Catherine is ashamed of her ignorance, yet the narrator terms it a "misplaced shame" for where people "wish to attach, they should always be ignorant," and claims that "[t]o come with a well-informed mind is to come with an inability of administering to the vanity of others, which a sensible person would always wish to avoid. A woman especially, if she have the misfortune of knowing anything, should conceal it as well as she can" (1998: 86). In addition, the narrator highlights how the plot of the young women in need for correction has already become a recurrent topos in literature. It is said that "the advantages of natural folly in a beautiful girl" have been set forth by the "capital pen of a sister author;",269 however, the inexperienced Catherine does "not know her own advantages" as a heroine, she is not aware that "a good-looking girl, with an affectionate heart and a very ignorant mind, cannot fail of attracting a clever young man, unless circumstances are particularly untoward" (1998: 86). Austen, in a style close to her playful juvenilia, criticises the plot of female education in which a young girl that has been deprived of all the advantages of education is rendered attractive precisely because she is a blank slate on which the male mentor can inscribe his teachings. That is, as made evident by Waldron, not even more

${ }^{269}$ The sister author she alludes to is most probably Frances Burney, and the character, the beautiful and shallow Indiana, who, opposed to Camilla, relies mainly on her beauty rather than on her intellectual endowments. Burney exposes the inconveniences of such shallow attraction to a woman, a lesson Austen resumes. 
sanctioned genres, such as conduct-literature, escape Austen's inquisitive analysis. What is more, this comment stands as a veiled hint at the readership of female bildungsromane: the appeal of a story of development and selfawakening is that the reader must know more, know better, than the heroine. Therefore, Catherine's ignorance not only flatters Henry, but also those readers who are aware of her failings in education and, of course, in perception, as they share the narrator's omniscient perspective and even Henry's discourse. However, as this hint may testify, both Henry and the readers will later be subtly challenged and their vanity mildly chastised.

In addition to this satire on the assumed need for male guidance as a young girl enters society to undermine Tilney's sanctioned role as mentor, as happens with all seemingly perfect characters in Austen's novels, Henry is also presented as flawed himself: neither is his own vision independent or fully reliable, nor does he promote full self-determining thought in Catherine. For instance, his lecture on the picturesque is a lesson on how to see or perceive the world around her according to a set of principles and, consequently, she does not acquire a taste of her own, for she later complains at the Abbey that without him "she should not know what was picturesque when she saw it" (1998: 141). According to Fergus, it is difficult to claim that he educated Catherine in "anything but a greater consciousness of convention," for he does not even supply a moral standard that the heroine must "learn to accept or move toward" (1983: 14), as Catherine is already morally flawless. What is more, his own vision of the world is tinctured with his own idea of the probable, for example, in his rebuke of Eleanor's interpretation of Catherine's words as relating to an actual riot or his absolute rebuttal of the latter's suspicions of his mother's murder. Although his perception is usually sanctioned, his vision also stands subtly corrected, first of all, because sometimes Catherine makes him doubt, as in the case of the probability of Captain Tilney having proposed to Isabella. When he worries about this possibility, the reader is reminded that previously he thought it absolutely impossible. Secondly, because the threats expressed by Eleanor and Catherine are more plausible than Henry seems keen to admit: the Gordon riots of the 1780s, the echoes of the French revolution in Britain, the suspension of the habeas corpus and the Treason trials of the 1790s, Pitt's 
famous net of spies, and women's well-known subjection to even unfeeling husbands, all frame Austen's narrative and allow the true threats of an otherwise idyllic reality to permeate her novel. ${ }^{270}$ Once again, the reader or the heroine need not escape to France, Italy or the pages of a Gothic romance to encounter certain dangers. Once more, these threats can be included in the narrative with naturalness, plausibility and humour, avoiding the Manichean characterization and implausible plots of Gothic or sentimental fiction and requiring a more perceptive effort of interpretation from the readers.

Although he indeed qualifies Catherine's literary vision and he exposes literary clichés, Henry is also an ambivalent mentor owing to the fact that he has fun at the expense of her Gothic expectations by his own employment of its conventions to create a narrative fiction for her. Catherine's imagination is excited by the sole mention of the Abbey, nevertheless, it reaches its highest pitch by means of Henry's construction of a Gothic plot set in the Abbey in which Catherine is the heroine. Henry perceives Catherine's favourable ideas on the abbey, and she confirms that she expects it to be "just like what one reads about" (1998: 124). On these premises, Henry pictures for her a burlesque story in which all the common places of Gothic romances are included: mysterious paintings, vaults, murders, haunted rooms, an old domestic named Dorothy, storms, cabinets, parchments, and a heroine, Catherine herself. In the same manner she was so engrossed by Udolpho in Bath as to be late for her appointments, Catherine once more becomes an absorbed reader and suspends her disbelief, not perceiving Henry's parodic intentions. Midway through his tale, Catherine exclaims: “Oh! Mr. Tilney, how frightful! -This is just like a book!- But it cannot really happen to me. I am sure your housekeeper is not really Dorothy.-- Well, what then?" (1998: 125). She is eager to continue listening and she once again loses herself in the

${ }^{270}$ Warren Roberts asserts that in Northanger Abbey Austen employed burlesque as a "device for reaching behind the world of illusion and showing the real world" (1995: 22); and this "real world" in his opinion is the England that had definitely been affected by the French Revolution. Roberts analyses from a historical point of view two passages from the novel: the misunderstanding which occurs between Eleanor and Catherine when the latter mentions a horror expected in London, talking about a novel, and the former interprets it as the suspicion of a real riot; and the well-known passage of Catherine's suspicions of General Tilney and Henry's famous rebuke concerning a "neighbourhood of voluntary spies" (1998: 159). He relates these episodes to historical accounts and concludes that these passages reflect how England had been perturbed by the revolution in France. 
narrative, becoming "immersed" in the fiction though still being able to recognise it as fiction, as something that may happen in a book but not to herself in real life (Bray, 2009: 146). Henry's tale increases its intensity and he starts to employ even the broken syntax of the genre he is imitating as he reaches the climax of his story. When his laughter at her eagerness does not allow him to conclude the tale of the unfortunate Matilda, which his heroine had found in an old parchment, Catherine finally "recollecting herself, grew ashamed of her eagerness, and began earnestly to assure him that her attention had been fixed without the smallest apprehension of really meeting with what he related" (1998: 126-7). Catherine is awakened from her immersion by Henry's laughter, and if the implied reader has experienced the danger of becoming as engrossed, he or she must have been stirred as well by Austen's reversion to the techniques of her juvenilia. Not only does Henry's parodic reproduction of all the clichés of Gothic literature together expose their implausibility, but his jocular comments on this same lack of plausibility highlight once again Austen's emphasis on naturalness and probability. For example, he asserts that in one room "perhaps there may be a dagger, in another a few drops of blood, and in a third the remains of some instrument of torture; but there being nothing in all this out of the common way, and your lamp being nearly exhausted, you will return towards your own apartment" (emphasis added, 1998: 126), or that she will for some time not discover anything of importance in the mysterious drawers of the cabinet, "perhaps nothing but a considerable hoard of diamonds" (1998: 126). In addition to this emphasis on the absurdity of claiming such events can and do happen when young girls are placed in strange dwellings, Austen again frames the Gothic narrative in a more common and less threatening context: first, during a ride in a sunny day, with no unexpected dangers awaiting on the road, and then as Catherine enters the Abbey and is disappointed by its modernity. Contrary to Don Quixote, she does not transform reality to accommodate to her readings, but rather relates reality back to her only source of knowledge, books, and is aware of the (disappointing) difference. As Bray has stated, not even approaching the Abbey does Catherine lose her hold on reality, on her immediate situation (2009: 148). As she approaches the house, Catherine's thoughts are revealing of the literary expectations she had been harbouring: 
She knew not that she had any right to be surprised, but there was a something in this mode of approach which she certainly had not expected. To pass between lodges of a modern appearance, to find herself with such ease in the very precincts of the abbey, and driven so rapidly along a smooth, level road of fine gravel, without obstacle, alarm, or solemnity of any kind, struck her as odd and inconsistent. (emphasis added, 1998: 127).

Of course, reality is only inconsistent with her literary expectations, heightened by Henry's story.

This inconsistency, this clash between fact and fiction, will become more apparent as Henry's tale seems to become true. After her first disappointment at the appearance of the Gothic Abbey, Catherine discovers many similitudes in her apartment with the rooms described in Henry's narrative. Her attention is first attracted to an old chest and she decides to explore its contents right away to prevent having her candle go out in the evening, as foretold by Henry (1998: 129). Once more, she becomes so absorbed by his tale, as to forget "everything else" (1998: 129), in particular her duties as a guest, and to incur in the General's anger at being late for dinner. In addition, she is found by Eleanor in the ridiculous scene of opening the chest still half dressed. Her friend's simple explanation of the origin and position of the chest, once more shame her and make her form "wise resolutions with the most violent dispatch" (1998: 131). Despite her good resolutions, however, her imagination will get the best of her in the well-known mock Gothic scene that follows. That very same night, Catherine seems placed in a typical Gothic tableau: a horrible storm, the extinguished fire and lamp, footsteps, etc. Throughout these highly mockGothic episodes, as Catherine tries at first to reason with herself that despite the promising Gothic context, nothing can truly happen to her, the use of free indirect speech increases and highlights the sway from the world of romance to the world of the novel, from Catherine's imagination to the reality in which she is placed, and how she moves between both (Bray, 2009: 149). However, as everything answers to Henry's story, Catherine acknowledges the "very remarkable coincidence" (1998: 133) of finding a cabinet she had not perceived before, exactly as he had foretold, and her absorption increases. She suspends her critical questioning and becomes fully immersed in her role as a 
heroine of a Gothic narrative. Being "well read in the art of concealing a treasure" (1998: 134), Catherine follows in the steps of prior heroines, opening the drawers with difficulty, feeling for false linings, and, finally, encountering a manuscript which she is prevented from reading by the sudden extinction of her lamp and her own terror, which forces her to hide in bed until morning. When she then peruses her precious manuscript, she discovers it to be a washing-bill. Her thoughts at her discovery are once again illuminating of the process of disenchantment that she is expected to follow after such quixotic adventures:

She felt humbled to the dust. Could not the adventure of the chest have taught her wisdom? [...] Nothing could now be clearer than the absurdity of her recent fancies. To suppose that a manuscript of many generations back could have remained undiscovered in a room such as that, so modern, so habitable! $[\ldots]$

How could she have so imposed on herself? Heaven forbid that Henry Tilney should ever know her folly! And it was in a great measure his own doing, for had not the cabinet appeared so exactly to agree with his description of her adventures, she should never have felt the smallest curiosity about it. This was the only comfort that occurred. (emphasis added, 1998: 137)

Similarly to Subligny's mock Clelia, if the real frame in which she is set had not resembled fiction so closely, her delusion might not have reached such heights. Once more, the correlation between fact and fiction, the search for verisimilitude and detail, can confuse young readers even more than the more obviously implausible plots of romance.

Catherine's awareness of the dangers of this correlation and her chastisement seem to promise her cure, although not long after this she builds her most elaborate Gothic plot: the General's murder or entrapment of his wife. As she constructs this plot, the references to her nature as a reader and as a quixote increase. The narrator states that "she had often read of such characters, characters which Mr. Allen had been used to call unnatural and overdrawn; but here was proof positive of the contrary" (1998: 144); that the General could not fool the "well-read Catherine" (1998: 145); that she wished to dismiss her suspicions, but that "appearances," the similarity with the characters and plots 
she is so familiar with, made such dismissal "impossible" (1998: 151); that she "had read too much not to be perfectly aware of the ease with which a waxen figure might be introduced, and a supposititious funeral carried on" (1998: 153). As when guided by Isabella's opinions, or by Henry's lectures on the picturesque, Catherine is once more relying on an authority not her own to make sense of what she does not understand and this leads to more, and deeper, mistakes. In this case, she is dependent on "mother Radcliffe" and her Gothic narratives (Castle, 1998: xxi). This absolute reliance on fiction to guide her will once more require correction, this time of the strongest sort, in the shape of Henry's widely known speech:

[...] Dear Miss Morland, consider the dreadful nature of the suspicions you have entertained. What have you been judging from? Remember the country and the age in which we live. Remember that we are English, that we are Christians. Consult your own understanding, your own sense of the probable, your own observation of what is passing around you. Does our education prepare us for such atrocities? Do our laws connive at them? Could they be perpetrated without being known, in a country like this, where social and literary intercourse is on such a footing, where every man is surrounded by a neighbourhood of voluntary spies, and where roads and newspapers lay everything open? Dearest Miss Morland, what ideas have you been admitting? (1998: 159)

In the recurrent pattern of female quixotism, after a moment of shame and time for reflection, Catherine's cure as a quixote is completed: "[ $\mathrm{t}]$ he visions of romance were over. Catherine was completely awakened. Henry's address, short as it had been, had more thoroughly opened her eyes to the extravagance of her late fancies than all their several disappointments had done" (1998: 159). She acknowledges that it was all a "voluntary, self-created delusion, each trifling circumstance receiving importance from an imagination" that had been prepared to become inflamed (1998: 160). Her train of thought reveals the awakening from fiction and her discovery of the true nature of reality. She acknowledges she had created the "infatuation" before quitting Bath and she traces it to "that sort of reading which she had there indulged." She compares her literary expectations with her experience and she concludes that “[c]harming as were all Mrs. Radcliffe's works, and charming even as were the works of all her imitators, it was not in them perhaps that human nature, at 
least in the Midland counties of England, was to be looked for" (1998: 160). Continental Europe may be faithfully represented in all its vices and horrors, but the reality of the novels does not correspond to England. In England, she has learnt to distinguish the truth of human nature:

[...] among the English, she believed, in their hearts and habits, there was a general though unequal mixture of good and bad. Upon this conviction, she would not be surprised if even in Henry and Eleanor Tilney, some slight imperfection might hereafter appear; and upon this conviction she need not fear to acknowledge some actual specks in the character of their father, who, though cleared from the grossly injurious suspicions which she must ever blush to have entertained, she did believe, upon serious consideration, to be not perfectly amiable. (1998: 160-61)

Although her awakening is still ludicrously naïve -as Catherine, who now relies only on experience, does not trust her ingenuousness when it comes to territories and people beyond the midlands--, her cure from quixotism brings a new maturity, one that allows her to acknowledge that everybody requires greater interpretation, that nobody is either extremely good nor extremely bad, not even Henry or the General. As Catherine herself acknowledges, that "occasional memento of folly, however painful, might not be without use" (1998: 161) as the "anxieties of common life began soon to succeed to the alarms of romance" (1998: 161). The return of Catherine from a quixote deluded by romance to the heroine of a bildungsroman, deluded merely by her own innocence and inexperience with appearances and social practices, is completed with this transference of anxieties to James's subsequent letter and the exposure of Isabella's character, the second and final awakening, as Pardo has stated.

Catherine's story as a literary quixote is central to the novel; nevertheless, it is still a short tale imbedded in a longer and much more comprehensive tale of female development within society. Austen then already announces the shift from a purely quixotic fiction to a female bildungsroman, and the displacement in emphasis from literary delusion to an idealism caused by inexperience. In addition, she displays a more Cervantean manner of dealing with the matters of literary expectation and deluded perception by subverting certain clichés in her 
own narrative for the benefit of her implied readers and, hence, by highlighting how Catherine and the reader must go down the same path of awareness together.

\subsubsection{The Awakening of the Readers}

Despite being written in the late 1790s, when Gothic and sentimental fiction were at their peak, Austen's parody of readers' literary expectations with regard to those genres was as relevant in the 1810 s as it was when her novel was first conceived. As Lascelles has famously asserted, the trend of burlesque fiction had not diminished, and the success of narratives such as Barrett's may have encouraged Austen to pursue the publication of her early novel with its original parodic elements, as she realised that the "time for mocking false romance was not yet past" (1995: 36). ${ }^{271}$ In fact, the beginning of her novel reminds of the forceful denial of the clichés of contemporary genres of her juvenilia, as well as her claim that her narrative has been conceived as something entirely different. Catherine's early introduction as the epitome of an anti-heroine effectively conveys this message:

No one who had ever seen Catherine Morland in her infancy, would have supposed her born to be a heroine. Her situation in life, the character of her father and mother, her own person and disposition, were all equally against her. Her father $[\ldots]$ was not in the least addicted to locking up his daughters. Her mother [...] had three sons before Catherine was born; and instead of dying in bringing the latter into the world, as any body might expect, she still lived on [...]. (emphasis added, 1998: 1)

Of course, the "no one" or the "any body" Austen refers to is any reader who is aware of the common places of Gothic or sentimental fiction and who "might expect" a certain characterization or plot. Therefore, from the very start, as stated above, the novel itself certainly becomes that "common ground or shared

${ }^{271}$ Lascelles also mentions Green's Romance Readers and Edgeworth's “Angelina” as examples of this burlesque quixotic vogue. Grogan supports the claim that Barrett's novel proves the relevance of this genre, together with the fact that Peacock's Nightmare Abbey appeared in the same year as Austen's posthumous novel (2002: 10). 
locus of illusion on which all readers can draw" (Sutherland, 2004: 249). It is for that informed audience that Austen continues her deflation of the generic and heroic conventions with Catherine's appearance, stating that it was as "unpropitious for heroism" as her mind (1998: 2). Fond of boys' plays rather than the "more heroic enjoyments of infancy," and described as "occasionally stupid," Catherine is an anti-heroine for whom to be called "almost pretty" is a higher delight "than a beauty from her cradle can ever receive" (1998: 3). Similarly to her earlier subversion of the perfect heroic portraits of sentimental gentlemen and ladies, echoing heroines such as Laura, Austen presents a main character that possesses mundane rather than stereotypical heroic attributes, plus almost masculine heroic attributes -strong features, fondness for outdoor activities that require exercise- rather than the delicate ones of a heroine. In addition to her parodic characterization, Austen will also expose her innovation with regard to plot, mocking, for instance, the chanceful discovery of noble birth. In this sense, she also stresses ironically what the fate of Catherine, as a heroine, should be:

\begin{abstract}
She had reached the age of seventeen, without having seen one amiable youth who could call forth her sensibility; without having inspired one real passion, and without having excited even any admiration but what was very moderate and very transient. This was strange indeed! But strange things may be generally accounted for if their cause be fairly searched out. There was not one lord in the neighbourhood; no -not even a baronet. There was not one family among their acquaintance who had reared and supported a boy accidentally found at their door - not one young man whose origin was unknown. Her father had no ward, and the squire of the parish no children.

But when a young lady is to be a heroine, the perverseness of forty surrounding families cannot prevent her. Something must and will happen to throw a hero in her way. (emphasis added, 1998: 4-5)
\end{abstract}

As a heroine, Catherine is bound to attract the attention of a worthy gentleman whom she will eventually marry, because a heroine needs a hero to make her story complete. The heroine is the object of desire of the hero, such is her role. Of course, no unworthy -or poor- men can be considered heroes. At least a baronet is required. And it is at this point where Austen's irony becomes blatant: according to Catherine's situation in life, her options of becoming a wife to a noble and rich man are rather scarce, when not almost impossible. 
Therefore, when the narrator states that Catherine's lack of a worthy lover is strange and sets off to attempt to give a plausible explanation for the absence of a hero, the result is the opposite: to highlight once again the implausibility of the plot of romance or sentimental fiction and to point at the novelists' technique of aiming to provide a halo of credibility by searching out for conceivable causes. Austen here criticises the fact that, although authors seem to have moved from the casuality of romance to the causality of more realistic fiction, this causality is still applied to events that contradict human experience and to characters that do not resemble human nature. That Catherine is not a true heroine and that she does not have a beau is then only strange in the context of certain fiction, but not when framed in Austen's more natural one, which aims to reflect more closely the reality she shares with her readers. Nevertheless, readers have been taught to expect such romantic twists of fate in their readings. Consequently, Austen exposes the quixotism that may derive from assimilating the implausible romantic plots that dwell in fiction.

However, there is an essential difference with prior quixotic novels: in these initial passages Austen is not exposing her heroine's quixotic expectations, but those of her implied readers - the reading anybody, the mass of consumers of literature- as she did in her prior short fictions. It is that mass of readers that expects Catherine to be a heroine and to fulfil the conventional destiny of such a character. Consequently, while prior quixotic fictions employed the quixotic heroine as mirror of the implied reader, at the beginning of her novel Austen addresses her implied audience directly. In this sense, Austen somehow reverses Lennox's strategy. Announcing the quixotic nature of her narrative in her title, Lennox's readers expected the parody of certain literary genres, in particular, the romances Arabella is so fond of. Nevertheless, Lennox in the end provides her readers with a similar romance, a fact that Barrett highlighted in his own burlesque when Cherry exclaims that her marriage to Robert has granted her the romance she expected (1909: 297-8). On the contrary, Austen's title relates to the Gothic fictions so in vogue at the turn of the century and the beginning of her narrative is intended to disappoint and awaken those readers who approached her novel with certain generic expectations. Still, in order to provide this critical awakening, romance will again find its way into the 
narrative, in more subtle or ambiguous manners than in Lennox's novel. In this line, for the rest of her narrative Austen will play both with her heroine's and her readers' quixotic expectations, hinting at romantic and mysterious possibilities, only to subsequently deny them. In the same manner Catherine will be required to become a reader in the broadest sense, both of books and people, so will Austen's implied readers always be required to do the same critical effort as her heroine and to be educated by the author's masterful use of irony and indirectness (Schaub, 2000: n.p.). As Grogan has insightfully asserted, Austen's novel is also "an exercise in reading” for the implied reader, because the author "demands a sophisticated level of reading on the reader's part to untangle the novel's complex intertextual web and interpret the authorial comments about genres and writers" (2002: 7). In this sense, Austen's "continual play with social and fictional conventions in her novel" means that the work of the implied reader parallels that of the heroine herself, for "as Catherine reads herself in relation to other people, other texts, and other situations so the modern reader must situate herself in relation to other works, other genres, and other critics' readings" (2002: 8).

This need for critical awareness owing to the integration of the parodic quixotic narrative and the serious novel of development is obvious from the very commencement of the novel. After the inauspicious introduction of her heroine, Austen continues to direct the reader towards the narrative she is indeed writing. She mockingly claims that Catherine is "in training for a heroine" (1998: 3) and that, as such, she had "read all such works as heroines must read to supply their memories with those quotations which are so serviceable and so soothing in the vicissitudes of their eventful lives" (1998: 3). In order for her heroine to experience those difficulties which would provide the chance to employ her literary knowledge, Austen states that she is about to launch her heroine to "all the difficulties and dangers of a six weeks" residence in Bath" (1998: 5). However, later she mocks each one of the usual fictional conventions at such a time of separation: Catherine's mother is not worried about dangers or seducers, her sister will neither miss nor write to her, her father does not provide large sums of money, and on her journey, "neither 
robbers nor tempests befriended them, nor one lucky overturn to introduce them to the hero" (1998: 6). As the narrator states,

Every thing indeed relative to this important journey was done, on the part of the Morlands, with a degree of moderation and composure, which seemed rather consistent with the common feelings of common life, than with the refined susceptibilities, the tender emotions which the first separation of a heroine from her family ought always to excite. (1998: 6)

In addition, she asserts that the only alarming event that happened on the road to Bath was Mrs Allen's fear that she had "left her clogs behind her at the inn" (1998: 6). From the beginning of her narrative Austen thus places the tenets of fiction side by side with the dealings of more "common life," so they stand in ludicrous contrast and they trigger the reader's critical awareness. The latter is derived from the fact that Austen, with this contrast, exposes the fictional formulas that are repeated ad nauseam, therefore proving that novels imitate each other, rather than life (Fergus, 1983: 11). This is moreover stressed when she hints at what Mrs Morland's attitude should be as the mother of a heroine. The narrator states that "the maternal anxiety of Mrs Morland will be naturally supposed to be most severe" and, furthermore, asks "Who would not think so?" (emphasis added, 1998: 5). Of course, "who" again relates to her reading audience, which is about, once more, to be mocked by the anti-sentimental farewell scene that ensues, a scene that is indeed natural or commonsensical, in opposition to an anxiety that cannot be natural, as it is founded only on fictitious grounds. Austen is therefore forewarning what will be a constant in her work: that she is to move away from romance, and even from mere burlesque, and aim at a more faithful portrayal of nature or common life, that she is to write narratives that "rely more directly on the illusions fostered by the techniques of probability and naturalism" (Loveridge, 1991: 12). An example would be the characterization of $\mathrm{Mr}$ and Mrs Allen, Catherine's guardians in her trip to Bath. They are not the villainous hosts that usually appear in novels, who may "contribute to reduce poor Catherine to all the desperate wretchedness of which a last volume is capable [...] whether by intercepting her letters, ruining her character, or turning her out of doors" (1998: 7). In particular, the narrator, without much subtlety, offers an ironic 
description of Mrs Allen so the reader may judge "in what manner her actions will hereafter tend to promote the general distress of the work" and contribute to the aforesaid wretchedness. Mrs Allen hardly responds to any of the descriptions of the Gothic female stereotypes:

Mrs. Allen [...] had neither beauty, genius, accomplishment, nor manner. The air of a gentlewoman, a great deal of quiet, inactive good temper, and a trifling turn of mind, were all that could account for her being the choice of a sensible, intelligent man like Mr. Allen. In one respect she was admirably fitted to introduce a young lady into public, being as fond of going every where and seeing every thing herself as any young girl could be. (emphasis added, 1998: 7)

Mrs Allen is therefore neither the intelligent and artful noblewoman, nor the cruel temptress, for instance, one could find in Gothic fiction; on the contrary, she is neither beautiful nor clever, but she does have a good temper, while her husband is no tormenter, but a "sensible, intelligent man." In contrast with what her role would have been in a conventional Gothic narrative, Austen presents Mrs Allen in her role of social chaperone, the guide any young woman should have in her entrée into society, the core of any female novel of development. In addition, very much in the fashion of the tradition of female bildungsromane, Mrs Allen will also prove an ineffectual mentor, who fails to point to Catherine what is socially "improper" (1998: 81) and, consequently, seeds the ground for her young protegée's social faux pas or adventures.

Recurrently throughout the novel, then, the readers' expectations have been challenged and mocked. Even at the peak of Catherine's quixotic perceptions, the readers are reminded that they should not absorb themselves as much as she does. A reader who has believed Austen's forewarnings of the dangers that awaited Catherine and who expected a more thrilling narrative at the promising Northanger Abbey, will be equally disappointed and chastised. In the same manner Henry has buoyed up Catherine's expectations at her arrival at the Abbey, so has Austen increased the immersion of the implied reader into a mock-Gothic narrative only to completely and finally deflate all pretensions to be writing a conventional Gothic or even sentimental novel. From the obvious contrast presented between the heroic pretensions of her readers and 
Catherine's unheroic, in conventional terms, reality, Austen imbeds her character in a more plausible Gothic setting and correlates her own textual reality with that of the romances her diegetic and implied reader have perused. Both in Catherine's and the readers' experience the reality of Gothic romances will prove implausible and ridiculous, and it is so in part because Austen seeks to portray a textual world that is as close as possible to the one she shares with her implied readers. Once more, creating a natural and plausible narrative avoids the flaws of the genres she has mocked since her early writings. This does not mean that the reader is not meant to use his or her powers of interpretation; on the contrary, as stated above, a more realistic narrative does not sustain as easy formulas of characterization or plot. In this line, Austen returns to one of the important topics of her juvenilia: the threats that lurk behind everyday life events, which have been oversimplified in literary formulas, but which prove equally dangerous if not interpreted correctly. As has been previously stated, the most important one is the danger of those principles embodied by the General. In the same manner that the greatest danger in her juvenile stories was to conclude the narrative single, dependent and/or impoverished, the same could be said of Northanger Abbey and all of Austen's finished and unfinished novels. All Austenite heroines require employing great powers of perception and interpretation in order to avoid that danger and to achieve their deserved happy ending, by accurately reading not only the heroes of their stories, but also the characters that stand as impediment, and, more importantly, their own selves in the process. Northanger Abbey, therefore, truly sets the foundation for Austen's more mature novels and her well-deserved fame as a writer of coming-of-age or development novels.

In order to emphasise that this new form of fiction demands careful interpretation, although the transformation of her novel into a female bildungsroman has been almost complete after Catherine's cure from quixotism and her awakening to Isabella, Austen has not yet done playing with her readers and their romantic readings. Approaching the end of the novel, in the midst of the General's anger at his son's engagement to Catherine, her narrator assumes greater presence and commences to forewarn her readers of 
the expected romantic ending which lies ahead: "The anxiety, which in this state of their attachment must be the portion of Henry and Catherine, and of all who loved either, as to its final event, can hardly extend, I fear, to the bosom of my readers, who will see in the tell-tale compression of the pages before them, that we are all hastening together to perfect felicity" (1998: 203). This selfreferential comment to the book the readers are holding in their hands is enough to warn them that Austen is once more playing with their own awareness as readers. In another turn of the screw, General Tilney's tyrannical paternal authority unknowingly results in the real romantic story of the novel, that of Eleanor Tilney, which nobody was cognizant of and of which Austen has only given subtle hints throughout her narrative. ${ }^{272}$ This story partakes of many of the conventions found in the romances Catherine is so fond of: a devoted daughter, forbidden to marry the man she loves due to his lack of fortune and suffering her love in silence, a suitor so in love as to overcome all vicissitudes and earn her father's consent by acquiring money and status, and a cruel parent who finally consents on sufferance to the marriage he had prohibited. Eleanor's is rewritten in the end as a truly romantic character, something which Catherine, and the reader, could not have foreseen. This fact is brought to knowledge by the novel's omniscient narrator; a very ironic narrator, who displaces the role of heroine to a secondary character, while seemingly guiding the reader to focus on the unheroic, unromantic protagonist. As she presents this story, Austen's narrator becomes increasingly intrusive and the parodic humour she employs, more obvious. For example, she writes that:

Her husband was really deserving of her; independent of his peerage, his wealth, and his attachment, being to a precision the most charming young man in the world. Any further definition of his merits must be unnecessary; the most charming young man in the world is instantly before the imagination of us all. Concerning the one in question, therefore, I have only to add -(aware that the rules of composition forbid the introduction of a character not connected with my fable) - that this was the very gentleman whose negligent servant left behind him that collection of washing-bills, resulting from a long

272 The most significant one when Henry and Eleanor exchange a meaningful glance at Catherine's definition of the General as "liberal" and her reproduction of his claim that he "only valued money as it allowed him to promote the happiness of his children" (1998: 165). There is also a brief pause in the conversation: gazing and silence are always meaningful in female bildungsromane and Austen seems aware of this convention as well. 
visit at Northanger, by which my heroine was involved in one of her most alarming adventures. (1998: 204)

Austen once more mocks the unexpected turn of events in romances, which require some farfetched explanation to be able to connect them to the narrative and justify their inclusion in it. As Levine has asserted, this washing-bill is indeed a "romantic laundry list," which represents the permeability of romance in the novel (1975: 336). In addition, the happy ending and the story of parental tyranny are commented on in the ironic narrator's final address to the reader:

To begin perfect happiness at the respective ages of twenty-six and eighteen is to do pretty well; and professing myself moreover convinced that the general's unjust interference, so far from being really injurious to their felicity, was perhaps rather conducive to it, by improving their knowledge of each other, and adding strength to their attachment, I leave it to be settled, by whomsoever it may concern, whether the tendency of this work be altogether to recommend parental tyranny, or reward filial disobedience. (1998: 205)

Even in her concluding remarks, Austen leaves interpretation open to her reader with her subversion of the traditional moral summary. As she has done throughout the whole novel, she encourages a personal effort of elucidation with her romantic anti-romance, her natural mock-Gothic narrative, and her ironic sentimental ending. Northanger Abbey is then "a novel about reading, reading novels, reading people and reading situations directed at the heroine and the reader" (Grogan, 2002: 23), in which Austen's mixing of genres and destabilizing games force her audience to develop a critical approach to literature and life alike. Later novels will then progressively lose their focus on a literary interpretation of reality and highlight what is already in Austen's first novel: a young lady must learn to critically interpret the world and herself in order to achieve her happy ending. 


\subsection{Moving Towards the Victorian Novel: Other Austenite Heroines}

Kauvar's article exploring the influence of Lennox's The Female Quixote on Jane Austen's body of work undoubtedly remains the starting point for any scholar interested in how the quixotic formula contributes to enhance the coming-of-age theme so characteristic of her mature novels. Analysing the relationship of Austen's heroines to reading and perception from her juvenilia to her masterpiece, Emma, Kauvar exposes the importance of the burlesque techniques learnt from Lennox as "reinforcement" of Austen's "more important theme" (1970: 220). In addition, this scholar insightfully explains the progressive refining of the integration of burlesque in her narrative, the increasing displacement of the trope of the reading female quixote, "until human delusions spring from personal quirks instead of fictional ones," until she creates "a final product uniquely her own" (1970: 220). Levine reinforces this idea when he states that the new tradition that Austen inaugurates with her quixotic parody develops throughout her work, from the burlesque Northanger Abbey to the more mature Emma (1975: 340-1), still equalling the latter's eponymous heroine with Don Quixote in her process of disenchantment and disappearance (1975: 343). Later scholars, such as Pardo (2005b; 2005c), will resume this idea and also emphasise the transition towards a more fully developed coming-of-age novel, based on Austen's masterful use of the quixotic formula as developed by Lennox and her writing daughters. Austen's work then somehow mirrors the progression the female quixote as trope had experienced throughout the long eighteenth-century, from mere burlesque device to complex heroine of a novel of development, and resumes many of the elements of her quixotic predecessors, leaving the novel of female quixotism at the doors of the celebrated Victorian novel.

Sense and Sensibility (1811) is very often quoted as an example of the more mature and masterful integration of the burlesque elements of Austen's early writings into a novel which focuses on the process of self-awareness and awakening to the world of two young girls. According to Fergus, "the joke on the relation between literature and life" that the narrator in Northanger Abbey "never stops playing on the reader and on Catherine Morland" is in this novel 
"assimilated to character" and exploited through Austen's "technique of contrast" (1983: 7). Well-known is the plot of the novel, as well as the identification of Elinor and Marianne with the sense and sensibility of the title: faced with several difficulties in life and love, both sisters react according to the rules of strict propriety or extreme sensibility, respectively. While they achieve happiness, and a husband, in the end, both suffer the consequences of their choice of behavioural principles. This dichotomy, inherited from West's sisters plot, allows Austen to construct "among the feelings, judgements, predicaments and conduct of all her characters parallels and contrasts so elaborate and insistent that the reader cannot escape comparing, weighing and evaluating," while she further assists the implied reader's critical judgement by allowing the "characters themselves to weigh and evaluate their own conduct, feelings and judgements" (Fergus, 1983: 7). Adopting the dialectic strategies of Edgeworth in Leonora, for instance, and avoiding the more explicit demands on the reader's attention to be found in Fielding or Sterne, Austen refines her critical and moral instruction and leads the reader to infer and decide for him or herself on the central issue of her novel: "what kind of judgement and what degree of sympathy to accord Elinor and Marianne" (Fergus, 1983: 7).

Marianne is the quixote of the novel. By her attempt to enact all the tenets of the culture of sensibility, she is indeed a quixote of sensibility in the train of Mackenzie's man of feeling or Tomlins's woman of sensation: her expectations about life and love are modelled on her readings, while her morose sentimentalism incapacitates her to life appropriately in society. Like her predecessors, Marianne also demands from the reader/listener the same sympathy that she displays when she sentimentally approaches her reading. In addition, Marianne is even a Romantic quixote, entrapped in Romantic literature and a Romantic approach to nature and society, who foreshadows later parodies of Romanticism, such as Peacock's caricature of Shelley, and whose willingness to be independent of social constraint makes her particularly sympathetic to modern readers. Nevertheless, as in most quixotic narratives, her biased perception of the world will need to be overcome to achieve the happy integration into society that concludes her story of development. 
Early in the novel, Marianne is described as aiming to fulfil the stereotypes found in a sentimental novel. On the matter of love, she early exclaims that she "could not be happy with a man whose taste did not in every point coincide with [her] own," for, in the conventional image of sentimental soul-mates, her ideal hero "must enter into all [her] feelings; the same books, the same music must charm [them] both" (1984: 14). In addition, he must be able to express the same sensibility when reading "those beautiful lines which have frequently almost driven [her] wild," (1984: 14) something Elinor's choice, Edward, cannot do in his reading of Cowper. Marianne's comments are very revealing of her own rapturous approach to this pre-Romantic author's poetry and to love:

[...] if he is not to be animated by Cowper! — but we must allow for difference of taste. Elinor has not my feelings, and therefore she may overlook it, and be happy with him. But it would have broken my heart, had I loved him, to hear him read with so little sensibility. Mama, the more I know of the world, the more am I convinced that I shall never see a man whom I can really love. I require so much! He must have all Edward's virtues, and his person and manners must ornament his goodness with every possible charm. (1984: 14-5)

These raptures, which recall those of West's or Hays's sentimental quixotes, highlight in Austen's parody the unnatural or conventional response of an overtly sentimental reader and the fact that, although Marianne believes she is different to her more conventional sister, she is merely following a different set of tenets. Marianne's natural taste for wild scenery is moreover borrowed from the Romantic creed, in the same manner Catherine's delight in the picturesque had to follow pre-established rules. Marianne's taste for twisted tress and rough landscape will be recurrently commented throughout the novel. On the possibility of the sisters ever having money to spend, Edward states:

[...] and as for Marianne, I know her greatness of soul, there would not be music enough in London to content her. And books!-Thomson, Cowper, Scott - she would buy them all over and over again: she would buy up every copy, I believe, to prevent their falling into unworthy hands; and she would have every book that tells her how to admire an old twisted tree. (emphasis added, 1984: 79) 
The exaltation of her soul through music and literature, her passion for Romantic writing and her allowing literature to teach her how to admire the epitome of the Romantic depiction of picturesque nature all point at the core of her quixotic enthusiasm and of her distorted perspective. Early in the novel, taking a sentimental farewell from her home, Norland, she addresses the "wellknown trees" that "will continue the same; unconscious of the pleasure or the regret [they] occasion, and insensible of any change in those who walk under [their] shade! -But who will remain to enjoy [them]?" (1984: 23). Her discourse is full of the clichés of sentimental language, as well as of that solitary exaltation of nature of a Romantic taste. This passage displays a fixation on the observance of nature and the emotions it triggers in the viewer, together with the fact that Marianne believes no one will see or feel what she does in the company of her trees, and already proves what will be her greatest flaw: her self-centredness, her belief that her sensorial and emotional reaction to the world around her are the only uniquely natural and valid ones, when in fact they are brimming with conventions learnt from her readings. Over and again as the novel unfolds, Marianne will reproach Elinor for her lack of vision and emotion and will establish her own approach to literature and life as the only adequate perspective, while she flouts society's conventions in a very Romantic claim for individuality, although this independence, once more, is based on an extreme imitation of literary clichés: the image of the outcast, unfit for society, is a well-known Romantic type, found in Cowper's poetry or Charlotte Smith's novels. Elinor teases Marianne about her disregard for convention, about her freedom with Willoughby in their first interview, and about their accordance in essential topics to Romantic minds, asking: "how is your acquaintance to be long supported, under such extraordinary despatch of every subject for discourse? You will soon have exhausted each favourite topic. Another meeting will suffice to explain his sentiments on picturesque beauty, and second marriages, and then you can have nothing farther to ask" (1984: 40). Exposing another literary convention, the forming immediate and inflamed attachments or the existence of a first and only love, Elinor's mockery aims to call Marianne's attention to the artificiality of this, as well as her inappropriate behaviour. However, Marianne's answer evinces how she believes it to be a prerogative of a spirit free from the conventions of society: 
I see what you mean. I have been too much at my ease, too happy, too frank. I have erred against every common-place notion of decorum; I have been open and sincere where I ought to have been reserved, spiritless, dull, and deceitful:- had I talked only of the weather and the roads, and had I spoken only once in ten minutes, this reproach would have been spared. (1984: 40-1)

This disregard for politeness is a constant in Marianne's behaviour, as it was in West's eponymous heroine, and it is justified as an impossibility not to react naturally, not to move beyond convention or decorum, leading to the highly inappropriate interaction with Willoughby and Marianne's subsequent exposure to gossip and censure owing to her artless reaction to seeing him with another woman.

As usually occurs in the stories of female development, quixotic or not, the greatest mistake and lesson of the heroine concerns her reading of her suitors, the good and the bad one. Marianne's reading of Willoughby is tinctured with her literary quixotism, not only because she believes he answers to her early description of an ideal hero, but also because much of their relationship is based on their common admiration and even enactment of the same works of fiction:

[...] she proceeded to question him on the subject of books; her favourite authors were brought forward and dwelt upon with so rapturous a delight, that any young man of five and twenty must have been insensible indeed, not to become an immediate convert to the excellence of such works, however disregarded before. Their taste was strikingly alike. The same books, the same passages were idolized by each; or if any difference appeared, any objection arose, it lasted no longer than till the force of her arguments and the brightness of her eyes could be displayed. He acquiesced in all her decisions, caught all her enthusiasm; [...]. (1984: 40)

Books bring them together and the scenes borrowed directly from romances Willoughby's carrying her home after she twists her ankle, his cutting a lock of her hair, for instance- establish the tone of what seems a conventional courtship according to the tenets of sentimental novels. As happens with her sister quixotes, Willoughby's appearance and character, so naturally romantic and sentimental, deceive her into believing he embodies her dreams come true. Nevertheless, he is not the hero of romance: he is the villain. His story as the 
seducer of a young girl, whom he after abandons ruined and pregnant, equates him with the Vallatons of fiction. Despite his initial villainous nature, Willoughby is one of Austen's mixed characters who defy the neat categorization of romance. While he is still not a hero in his abandonment of Marianne for a rich heiress, his love for Marianne certainly transforms him in a character worthy of a sentimental novel: after she falls extremely ill, he irrupts in the house where she stays, wild and incoherent, to explain his uncountable behaviour to Elinor. Half a knave, and half a fool, as he himself confesses, he anticipates Henry Crawford, a mixed character that could have developed to be the hero or the villain of a sentimental novel, but who remains in the more natural though less unambiguous role of a bad suitor in Austen's narrative.

Austen's anti-romantic narrative thus does not allow the transformation of the rake into the husband, although she will allow the anti-romantic older suitor to become the groom. Reading Brandon with the expectations of romance, it is no wonder he does not cut a very striking figure in Marianne's imagination: she thinks of him as advanced in years, as in a "forlorn condition as an old bachelor" (1984: 31). Moreover, he embodies the epitome of an anti-hero by his use of flannel waistcoats. ${ }^{273}$ When she changes her mind and decides to marry him, after all his kindness and protection, Marianne is acting under a different model: the model of the realistic novel Austen is writing, a model that reflects the harsh reality of the marriage market for eighteenth-century women. This is signalled by the change in tone as the narrator half-mockingly describes the courtship and marriage of the former quixote and her older guardian: with the confederacy of her family and friends against her, with her knowledge of his sufferings and goodness, what else could she do but marry him, wonders the narrator (1984: 333). In addition, Marianne is transformed once more into a different type of heroine, the protagonist of Austen's narrative of self-

${ }^{273}$ Austen's knowledge of the sentimental conventions and her parodic treatment of them is proved once again in the conversation held by the Dashwood sisters on Colonel Brandon's rheumatism: "But he (Colonel Brandon) talked of flannel waistcoats," said Marianne; "and with me a flannel waistcoat is invariably connected with aches, cramps, rheumatisms, and every species of ailment that can afflict the old and the feeble," to which Elinor answered: "Had he been only in a violent fever, you would not have despised him half so much. Confess, Marianne, is not there something interesting to you in the flushed cheek, hollow eye, and quick pulse of a fever?" (1984: 32-3). The similarity between the romanticism of Marianne and Cherry again seems to suggest the influence of her thorough reading of The Heroine. 
awareness. The narrator explains that Marianne was born to "an extraordinary fate," "to discover the falsehood of her own opinions, and to counteract, by her conduct, her most favourite maxims;" she was bound to overcome her youthful and fanciful attachment formed "with no sentiment superior to strong esteem and lively friendship," and to voluntarily to give her hand to another, an antiromantic other "whom, two years before, she had considered too old to be married, -and who still sought the constitutional safeguard of a flannel waistcoat!" (1984: 333). With this ending, Marianne signals the transformation from quixote to the heroine of the domestic novel that Lennox anticipated in her heroine's cure:

\begin{abstract}
Instead of falling a sacrifice to an irresistible passion, as once [Marianne] had fondly flattered herself with expecting,- -instead of remaining even for ever with her mother, and finding her only pleasures in retirement and study, as afterwards in her more calm and sober judgment she had determined on,- - she found herself at nineteen, submitting to new attachments, entering on new duties, placed in a new home, a wife, the mistress of a family, and the patroness of a village. (1984: 333)
\end{abstract}

Romantic and sentimental envisions are abandoned, dutiful behaviour restored, and the cure of the quixote completed, while the courtship plot at the core of the female bildungsroman achieves its happy conclusion.

Once more, then, Austen parodies formulaic genres and proposes something different. Resuming the criticism of pieces such as "Love and Freindship" and of Northanger Abbey, Austen attacks what is unnatural, what has become a mere code or formula, or, in Brodey's words, she attacks "the sensibility which has become insensible to others, to nature, and even to oneself through excessive codification, elitism, or narcissism" (emphasis added, 1999: 114). Once again, this unnatural or formulaic behaviour will be chastised. This correction will be expressed at the level of narrative with the abovementioned editing or qualifying both the narrator and Elinor do of Marianne's vision and behaviour. At the level of plot, one encounters Marianne's close-to-death experience as result of her own immoderate grief and her awakening to her own insensibility and her sister's pain. Marianne's cure takes the shape of the conventional awakening of a female quixote established by Lennox: a fever as 
a consequence of her own folly and a process of deep and critical reasoning over her past behaviour. Austen challenges the culture of sensibility expressed in the body of the dying heroine in distress (Johnson, 1989: 165), and allows Marianne to live and to mature, although the quixotic heroine indeed dies and a more subdued woman emerges. As a result of her distress, then, her eyes are open once again to the reality that surrounds her and she better judges others and herself, as well as the possibilities she holds of that independence of thought and action she had defended throughout the novel. Marianne renounces her romantic dreams and marries an old man and a second attachment. Despite the fact that she achieves the epitome of the romantic plot of a heroine, an advantageous marriage for love, Austen transforms it into an anti-romantic one. The reader is then reminded that, for a happy ending to take place, the quixote of sensibility, however sympathetic and however sanctioned at times, must return to the frame of social convention in order to be able to interact properly in society. More relevantly, she must return to moderation or the natural expression of sensibility, as well as to a commonsensical or realistic perception of a young girl's possibilities in eighteenth-century society.

In relation to the readers' perception, according to Brodey, “Austen wants us to see that Marianne does not suffer from an excess of sensibility, but rather from the wrong kind. Marianne's selfish sensibility paradoxically leads to the dulling of her senses, whereas [...] Elinor's more social sensibility enables [her] to perceive more of [her] surroundings" (emphasis added, 1999: 119). Stressing the importance of both diegetic and implied readers' critical approach to texts and reality alike, Austen will also require the participation of the latter in order not only to perceive the flaws of Marianne's vision, but to understand Elinor's more complex point of view and how at once it corrects and enhances sensibility. As the novel unfolds, in contrast with the increasingly insensible and self-absorbed Marianne, "the reader begins to see that, somewhat ironically, Elinor has greater powers of observation, more poignant feelings than Marianne, and [...] is also capable of greater humanity, generosity, and virtue" even if at times it remains unappreciated (Brodey, 1999: 119). Although readers have gained insight into Elinor's thoughts and feelings, which predominate in the novel, her final disclosure of her feelings enables 
Marianne and the audience, the diegetic and implied readers, to fully read her. Even then, the mode of narrating and of reading highlights the proper and improper sensibility. In this sense, while Elinor's "narration was clear and simple; and though it could not be given without emotion, it was not accompanied by violent agitation, nor impetuous grief;" this grief "belonged rather to the hearer, for Marianne listened with horror, and cried excessively," again displaying the reaction of a quixotic sentimental reader and forcing Elinor to become "the conforter of others in her own distress, no less than in theirs" (1984: 227). Despite Elinor's confession of her love for Edward and her suffering, her sister is still reluctant to believe her. Therefore, Elinor continues her narrative with the statement: "I understand you. -You do not suppose that I have ever felt much" (1984: 229). She then discloses her suffering and emphasises through the semantic field of freedom and constraint that she was bound to silence and decorous appearances by duty and her concern for others (1984: 229). ${ }^{274}$ Recalling West's own Laura and Marianne, duty, reason, and exertion allow Elinor to control the absorbed excesses of emotion that almost kill Austen's Marianne. Austen's sentimental heroine cannot but exclaim: “Oh! Elinor [...] you have made me hate myself for ever. How barbarous have I been to you!-you, who have been my only comfort, who have borne with me in all my misery, who have seemed to be only suffering for me!” (1984: 230). As a true Austenite heroine, Marianne will come to terms with her quixotism by means of her own critical self-awareness after she learns from experience how to truly read people and situations, for instance, her sister and her secret suffering. And that initial you, as the no one that opens Northanger Abbey, could also be directed at the implied reader, warning him or her that their

${ }^{274}$ Elinor's full speech highlights this: "For four months, Marianne, I have had all this hanging on my mind, without being at liberty to speak of it to a single creature; knowing that it would make you and my mother most unhappy whenever it were explained to you, yet unable to prepare you for it in the least. It was told me,- - it was in a manner forced on me by the very person herself, whose prior engagement ruined all my prospects; and told me, as I thought, with triumph. This person's suspicions, therefore, I have had to oppose, by endeavouring to appear indifferent where I have been most deeply interested;- - and it has not been only once;- $[\ldots]$ If you can think me capable of ever feeling, surely you may suppose that I have suffered now. The composure of mind with which I have brought myself at present to consider the matter, the consolation that I have been willing to admit, have been the effect of constant and painful exertion; they did not spring up of themselves; they did not occur to relieve my spirits at first. No, Marianne. Then, if I had not been bound to silence, perhaps nothing could have kept me entirely_not even what I owed to my dearest friends-from openly showing that I was very unhappy" (emphasis added, 1984: 229). 
engagement with Marianne's distress should not have rendered them blind to Elinor's suffering.

In this sense, Elinor has been the true condoned sentimental heroine and the lack of appreciation will be solved by Austen in another of her deus ex machina inherited from romance, in which Edward is almost miraculously liberated from his engagement to Lucy and can propose to Elinor, reaching her final expression of feeling and her deserved happy ending as the heroine of the euphoric romantic plot of the novel. The need for this authorial intervention is explained by the excessive control Edward and Elinor have over their feelings and their submission to conventions, which also goes against their natural inclinations and which is expressed throughout the novel with words such as "exertion," "forced," "bound," etc. Austen then stands in the middle ground between excessive freedom and excessive control of emotions, and again vindicates a natural reaction not only to literature but also to life, expressed in her literary burlesque and her double coming-of-age plot. In addition, she dwells on the matter of perception, on the complexity of judgement and sympathy as response to literature and life (Fergus, 1983: 8), which will be at the core of her next novels, Pride and Prejudice (1813) and Emma (1816).

The title of Austen's next published novel is already a statement about her intentions: taken from a quotation of Cecilia, it points to its nature as a narrative of development. After the lovers in Burney's novel are finally and happily reunited, a character states that "the whole of this unfortunate business [...] has been the result of PRIDE and PREJUDICE" (1784: 303). Austen is set to develop other unfortunate businesses that are the result of these blinding qualities and for most of her novel her hero and heroine must learn to read themselves and each other until they are happily married. Following Burney and Edgeworth, Austen's novel conforms to the characteristics of a female bildungsroman: Elisabeth's misjudged impressions cause all kinds of trouble for herself and for others, she will require experience and disenchantment to correct her vision, and, finally, she will achieve happy integration with a marriage that places her in an advantageous position, both financially and socially. In addition, as Lorna Ellis has indicated, Pride and Prejudice explores 
in depth the "importance of the visual realm as an arena of internal growth" (1999: 130). After all, it is her eyes that are praised above every other feature by Darcy, and mocked by the shallow and unobservant Miss Bingley. Elisabeth is from the start a rebellious object of gaze and an active gazer, especially in her own plot of double courtship. At the ball where Darcy first observes and judges her, she decides to defy his impressions of her, while keenly and partially gazing and judging him herself. She also judges Wickham by his appearance, manners and story favourably: he is framed in the narrative by her impression of him. When she receives Darcy's explanatory letter on the story of Wickham's seduction of Georgiana Darcy, her seeing his story and his character develops as she reads and re-reads with the closest attention (1966: 141), much in the same fashion as Evelina, although this time the author devotes an entire chapter to the manner in which her heroine's reading and her perception of both suitors changes. Increasing in attention and judgment, Elisabeth ultimately reaches the necessary moment of epiphany, of selfrevelation in which she acknowledges she is ashamed of herself for having been "blind, partial, prejudiced, absurd" with respect to Wickham and Darcy (1966: 143). In a process of enlightenment and humiliation, she concludes that she had prided too much on her own discernment, that she had been blinded by vanity, and that until that moment of humbleness and error she had never known herself (1966: 144). They way in which she intently fixes her eyes upon Darcy's picture at Pemberley emphasises this change in opinion, but also that Elisabeth is still an agent when it comes to judging. In addition, she learns how she has been regarded by others, more importantly Darcy, and learns to accept and manipulate male gaze in order to regain what she believes his lost esteem (Ellis, 1999: 132). Therefore, as happens in most female bildungsromane, Elisabeth must reach a compromise, she must understand that she cannot only see, but must be "fit to be seen," she must regulate her wit, her sarcasm and her appearance, to achieve her happy ending, but she is not required to stop looking and judging for herself (Ellis, 1999: 134). The sympathetic, though flawed, heroine is rewarded with the best possible marriage and the best possible influence in society given her circumstances as a woman with little prospects. Once more, romance permeates Austen's novel, but it cannot erase her commonsensical and anti-romantic ending, which details all the difficulties 
even the perfectly romantic Elisabeth and Darcy encounter in their roles as husband and wife.

Once again, then, Austen aims at educating judgement and sympathy, perception and emotion, both in her characters and her readers, and her first draft of the novel, provisionally entitled First Impressions, overtly emphasises this educational intention and the need heroine and reader share of overcoming those first impressions of character. Austen does so employing not only the technique of parallels and contrasts she used in her previous novel, but also the characters' own debate on perception of others and of themselves. In anticipation of her later novels, in Pride and Prejudice "the difficulty of judgement and of response is treated by the characters themselves as a central issue" (Fergus, 1983: 83), as Elisabeth and Jane's constant conversations on Bingley and Darcy attest. If this were not enough to encourage her implied audience to critically approach her novel and the characters in it, Austen will continue playing with their sympathies and critical approach with the use of an overall structural principle in which the action is organized "so as to reverse or undercut the main characters' expectations of judgements and the reader's as well” (Fergus, 1983: 8). Throughout her narrative, Austen violates or plays with the reader's conventional novelistic expectations, returning once more to her games with the reader of her previous, more metaliterary works. In this sense, the unconventional development of the Bennet sisters' courtship, the reversal of villain and hero that happens with Willoughby and Darcy, all keep the reader at one time engaged in the story and aware of the challenge to his or her expectations. This call of attention demands then an engaged judgment to be effective, and Austen certainly develops themes and techniques that create a certain intimacy with the characters and an absorption in the world of the novel that grants the adequate reader's response and his or her later chastisement together with Elisabeth, reminding both the need for critical judgement even when engaged sympathetically. ${ }^{275}$

${ }^{275}$ Nardin terms this form of structural irony "detached rhetorical irony" (1973: 6) which encourages the reader into forming a habit of "reading with suspended judgment," and is used by Austen to teach the reader to think for him or herself $(1973: 7,9)$. 
Whereas her instruction of her flawed heroines and implied readers continues, Austen's earlier burlesque is almost abandoned in this novel, and, while Elisabeth is known and admired for her reading in opposition to the shallow Miss Bingley, it is her sister Mary and her father who on this occasion embody the flawed readers. Mr Bennet employs literature as escapism, while Mary Bennet reads much but understands little: she merely repeats quotations and is not intellectually or morally improved by her readings. However, they are merely secondary characters; therefore, the shift in the novel's focus is apparent. Austen's “concentration on Elisabeth and what she learns, and her lack of attention to Mary, suggests her movement away from the interest in books as a cause of mistaken notions towards the more fully human mistakes and illusions we find in Emma" (Kauvar, 1970: 218). The literary female quixote is thus definitely abandoned and substituted by the heroine of the bildungsroman. Pride and Prejudice then reinforces a development that had started with Catherine, and that will culminate with Austen's matchless story of female development in Emma.

In Austen's masterpiece, as in Pride and Prejudice, literature is no longer the source of the heroine's illusions. Emma is not a compulsive reader. Although she reads books with Harriet and can quote Genlis's novels (2000: 371), Knightley specifies that she never reads any of the volumes in the long list of books she continuously writes. He claims that she only read half of what Mrs Weston wished she would, and concludes that he does not expect "any course of steady reading from Emma" or any course than demands "a subjection of the fancy to the understanding" (2000: 27). From his words one may infer that Emma does read and is a fanciful reader of reality. However, the emphasis on pernicious reading in not on her, as her readings are not revealed. On the contrary, it is Harriet who reads Gothic romances such as The Romance of the Forest and The Children of the Abbey, and whose future husband, Robert Martin, is characterised by reading better books, in this case, Elegant Extracts or The Vicar of Wakefield (2000: 20). Moreover, she is the one more often characterised by her gullibility, and her ignorance renders her a perfect piece in Emma's romantic plots. Even if she reads with the better educated Emma, she still expects her life to conform to literary plots. At one point, rescued by Frank 
Churchill from the gipsies and by $\mathrm{Mr}$ Knightley from being slighted by $\mathrm{Mr}$ Elton at a dance, Harriet speaks of an extreme gentlemanlike behaviour. Emma believes she must have fallen in love with Frank, but Harriet speaks of Knightley. Much in the same fashion the Gothic triangle had become a choice between dancing partners in Northanger Abbey, Harriet has started to expect the same turn of events. In the end, she will marry Martin. After all, she is not the heroine for whom Austen always has something better in store.

The fact that this gullible reading young woman is not the heroine is one of the elements that points at the definite break from earlier burlesques and a conscious shift to a more complex psychological creation in the shape of a bildungsroman heroine, as had been the case in Austen's previous Pride and Prejudice with the emphasis on Elisabeth and not Mary. While still with many elements traceable to Lennox and her founding female quixote, in Emma, the "notion of fiction as the prime cause of illusions has been replaced by human illusions" for she misjudges situations because of "her lack of information not because of her reading" (Kauvar, 1970: 218). The transition is then complete and, as Lorna Ellis (1999) has asserted, Emma becomes the epitome of a heroine of a narrative of female development: she is inexperienced in the ways of the world outside her very limited circle, she desires autonomy and consequence, but she must learn to work within society, within society's rules, to achieve it, finally learning how to read and be read, to see and be seen. Emma, then, connects with Catherine's innocence or Marianne's naïve aspirations, while she is further deluded than Elisabeth. Whereas both Elisabeth and Emma are fooled by what they perceive as their own cleverness and independence, Elisabeth only errs when it comes to her suitors. Emma's mistakes are more wide-ranging: they include love, consequence, or friendship, and are therefore, a summa of previous Austenite heroines' errors of judgement. As Levine avowed, Emma is indeed the quintessence of a heroine in a novel of disenchantment that anticipates nineteenth-century ones, even if she does not read romances or novels herself as other heroines of this form of narrative do. In this sense, she is a displaced quixote who has abandoned her literary musings for a naïve reading of reality; she is placed in the furthest ripple from the quixotic core, from the example of Don Quixote, but one can 
nevertheless trace the origins of her illusion to that same centre. This is so because the heroine of such a novel of disenchantment "must begin by not understanding what the real world is like" (Levine, 1975: 340); a comprehension the isolated and inexperienced Emma certainly does not possess. Then, her "illusions consort with an ambition to get beyond the limits of the social world into a more intense and richer sort of experience," which Levine calls "the dream and the form of romance" (1975: 340), romance here understood as a form of idealism. In addition, the heroine "must cast off the illusions and settle for much less; and this is the dream and form of realism" (1975: 340). While he sets as example Emma Bovary, a reading heroine, Austen's heroine still fulfils these tenets even if she is not a quixotic reader: she holds an illusion of autonomy and power in her status as the social prime of her village and as a single woman meddling with the lives of her neighbours; however, she must come to realize that her fulfilment lies in her love and marriage to Knightley.

Part of this illusion indeed implies a deluded reading of reality, only this time Emma does not acquire it from literature but from some naïve perception of love, marriage, status and control: the idea that she can be independent and influential even as a single woman. This fact is emphasised throughout the novel, for example, when Emma must relinquish her role as main lady for the married Mrs Elton. More importantly, it is stressed by the fact that, unlike female quixotes, she does not perceive herself as the heroine, but as the author of romantic texts, in this case, her matchmaking stories. What Mandal terms "romantic mythmaking" (2007: 157) aims to give Emma certain control over the world around her, just as romance provided Arabella and other female quixotes with power in courtship. The difference is that, instead of inscribing herself into this kind of plot, Emma aims to evade it and, in its place, writes romantic narratives for the people around her, especially for whom she intends as a "putative heroine," Harriet Smith (Mandal, 2007: 154). For example, Emma rewrites Harriet as the natural daughter of somebody of high birth and plots for her several love stories. Assumedly, this writing of others' romances and of herself as author, would help Emma acquire more power and control than previous heroines had. However, most of her romantic mythmaking 
backfires and inevitably entraps her in the text: while Emma tries to become a matchmaker to Mr Elton and Harriet, she becomes Mr Elton's object of affection and ambition; Emma cleverly gossips about Jane's alleged lovers to amuse herself, but she unknowingly becomes a pawn in Frank's concealment of his relationship with Jane. She is transformed into a heroine, an object of gaze, rather than an author. What is more, she remains oblivious to the romantic plots developing around her: Jane Fairfax's life of hardships, her secret engagement and Emma's own role as the rival of the true heroine; or, more conspicuously, Harriet's love for Knightley. Finally, Emma must awaken to the romantic plot concerning Knightley and herself, triggering the awaited moment of epiphany. The realisation that she is the heroine, not the writer, of her own romance, the awakening to her own feelings and to her desire to become wife to her mentor, to the representative of the community and the status quo, cure Emma of her illusions and bring her to terms with her reality.

Imaginative over ambition is checked and must adjust to a reality that is assumedly more desirable than the illusions or dreams of romance; nevertheless, the dreamer is also portrayed with certain sympathy, for reality is not as benevolent as it may be required for the ideal happy conclusions of most novels. In this regard, following in Cervantes' train, Austen's energies as a novelist are better perceived in her portrayal of people who question the disenchanted world than in those who acquiesce to it (Levine, 1975: 341), transforming Emma into the complex character that she is. Ambition and illusion are sometimes desirable, not the less so because they allow the heroine to exist, as they allowed Alonso Quijano to become Don Quixote: disenchantment and death come together in Cervantes' novel, disenchantment and marriage go hand in hand in Austen's novel, and both conclude the characters imaginative energies, and, thus, the novels (Levine, 1975: 343). In addition, marriage in Emma, as it did in Northanger Abbey, Sense and Sensibility and Pride and Prejudice, is not an ideal state that proclaims the fairy-tale motto of happily ever after: it is expected to be full of trials for both heroine and hero. Despite her conventional endings, in all of Austen's closures the dream of ideal romance is over and the dream of reality takes over. 
Her heroine's awakening once more serves the purpose of addressing an implied audience which deals with similar issues of absorbed or critical interpretation. Intertwining romantic and anti-romantic materials, the stories Emma writes and the reality that contradicts her, and masterfully using linguistic screens and even silence, is how Austen plays with her implied readers. At the level of plot, for example, Jane Fairfax, as Eleanor Tilney, is the final joke Austen inflicts on her romantic -and unaware- readers: the heroine they were expecting was elsewhere, while a less perfect, less exemplary woman took her place as a more interesting main character. At a narrative level, as Wayne Booth (1961) has seminally explained, Austen continues to play with the concepts of judgment and sympathy, entering and leaving Emma's point of view or, in Booth's terms, controlling distance so that the reader is off balance, sympathetic but able to detach his or her perspective from Emma's predominant consciousness. By seeing what Emma sees and also by being able to pierce through the veil of appearances that last until the very closing line of the novel, the reader should perceive the famous quotation that opens this chapter as the epigraph of the novel: seldom does full disclosure belong to any human interaction, especially if one does not read actively and critically. $^{276}$

In conclusion, one could assert that the quixotic novel has then been steadily and skilfully transformed in Austen's hands. While reading will continue to be a major issue in her remaining novels -with Fanny's absorbed attention in reading in Mansfield Park (1814), Anne's reliance on literature for comfort or Captain Benwick's morose relish for Romantic poetry in Persuasion (1818), or Sanditon's own unfinished version of what promised to be the first fully developed male quixote of Austen's production-, Austen abandons her early burlesque or straightforward quixotic narratives and develops something uniquely her own. As Sutherland has insightfully suggested, Austen's narratives contribute to shape the novel as a serious modern literary form, with her games on perception and her lack of absolute disclosure; with the

${ }^{276}$ An interesting analysis of the importance of appearances, and the meaning of language and silence in Emma is Andre Brink's "Charades. Jane Austen's Emma," in The Novel. Language and Narrative from Cervantes to Calvino (Basingstoke: Macmillan Press, 1998), pp. 104-25. 
confrontation between previous genres -which her novels digest and critiqueand everyday life -which in the form of the novel she reproduces and enlarges-; with the development of the inwardness of her heroines, the conversation of the self with itself, and, consequently, with the use of a narrative method inflected by the personal subjectivity of a self-conversing heroine (2004: 253-4). And, in line with the quixotic tradition, she did so as well with the dual inclusion and questioning of romance that previous Cervantean authors used in their own generic experimentations. All elements which develop from a quixotic narrative into a soft or comic novel of disenchantment, which anticipates the harsher awakenings of Eliot's or Wharton's innocent and naïve heroines, and even paves the way for the intricate narrative games, the free incursions into characters' consciousness, of later novelists. 


\section{EIGHTEENTH-CENTURY QUIXOTIC AFTERWORD}

The aim to cover the long eighteenth century is now almost at an end. With Brunton, Edgeworth or Austen the transition towards the quixotic fictions of the following century is complete. Later novelists will receive their baton and continue to enlarge and improve the quixotic tradition in British narrative fiction, in particular in the shape of the novel of female development. However, the rich perception of the female quixote is not lost in the first decades of the new century. Despite the predominant displacement away from literature and towards an idealistic heroine, this does not mean that literary quixotes disappear, or that the parodic intention of quixotism is lost. As the nineteenth century progresses, the eighteenth-century inheritance of the rich interpretations of the quixotes survives and, with it, warning tales for reading misses can still be found in the libraries. ${ }^{277}$

An example hitherto unacknowledged that resumes the common traits of the works previously analysed would be Mrs Baker's tale "The Romance Reader," in one of her volumes of the Drawing-Room Tales (1820). In her entertaining didactic tale, Baker resumes all the common places of female quixotism and employs them, as did More, in the context of moral lessons for young readers. In the same manner that Overbury's character of a reading chambermaid or More's depiction of a deluded reader within their respective summas of stereotypes allowed to infer that the female quixote was a well-known type in the collective consciousness, Baker's story of a female quixote, in the frame of a collection of entertaining and moral short tales, allows to reach the same conclusion. The cautionary tale of the deluded female reader had definitely become a popular one. In addition, Baker's story displays its nature as the heir of a long tradition of quixotism. It tells the story of a young girl, Amanda Sempleton, defined as a "romance-reading" girl (1820: 56) who loves nothing

${ }^{277}$ On the rich quixotic tradition beyond the eighteenth century see Pardo's "El mito de Don Quijote en la novela victoriana: The Newcomes, de William Thackeray, y The Ordeal of Richard Feverel, de George Meredith." Reescrituras de los mitos en la literatura. Estudios de mitocrítica y de literatura comparada (Cuenca: Ediciones de la Universidad de Castilla-La Mancha, 2008), pp. 361-74; or his forthcoming article "El Quijote filantrópico victoriano: Donna Quixote, de Justin McCarthy." (Anales Cervantinos, 2013b). 
better than reading "novels, romances, and plays" (1820: 55), even above eating (1820: 54). Her revealing name resembles Hamilton's use of them to identify her characters' follies, while her definition recalls in detail Barker's description of Dorinda, and echoes many others. In Baker's tale, romantic delusion also influences identity. Baker's heroine was christened Amanda by her romantic mother after the heroine of The children of the Abbey (1820: 57). Her romantic name in this case is not chosen by herself, like it happened with Bridgetina, Dorcasina, or Cherubina, but, as with Dorcasina's christening of Harriot, it is the consequence of another woman's romantic delusion. It is inherited down the maternal line, as were Arabella's romances, for instance. In addition, Amanda fully supports her mother's choice and begs her cousins, Elisabeth and Sarah, named after a rich aunt, to change their names to Bertha and Savannah (1820: 57). That is the first example of Amanda's wish to accommodate reality to her literary expectations.

Some other relevant attempts to read reality through the conventions of literature relate to her image as a heroine, to men and to her surroundings, as was the case with other female quixotes. Amanda recalls Catherine when the scenery makes her think of Radcliffe's descriptions in The Mysteries of Udolpho, and she states she longs to be Emily, "with a sick father on one side, and a lover playing the flute on the other" (1820: 55). Amanda longs to become a romantic heroine, to experience her same circumstances, without regard to real life pain or implausibility. She also hopes to follow the example of previous heroines in her behaviour: she states she will be like them and not commit any impropriety, for heroines are "the best regulated people in the world, according to conduct" (1820: 61). In the same conception that Lennox or Green had of heroines of romance, in Baker's tale their virtue is not tainted. Amanda also tries to imitate their attitudes and to be vivacious or lovely in a natural way (1820: 64), once more highlighting the paradox of hoping to display unfeigned traits of character by literary imitation. However, as most quixotes, she is also ludicrously different to her literary models. She does not possess natural curls, which are indispensable in a heroine, therefore she sleeps with a "row of false curls," and, using the hyperbolic expressions of literature, asserts that the "greatest affliction" she has ever met is her hair not curling 
naturally (1820: 63). In this she resembles Dorcasina's use of a wig, Bridgetina's lack of heroic graces, or, surprisingly, Arabella's own fake curls, achieved with so much art by her maid as to seem natural. Amanda also attempts to reproduce art with the appearance of naturalness, although she does not fulfil her purpose. She positions herself to sleep "with studied effect" and "after the fashion of the most approved models," which proves to be very uncomfortable and laughable in the eyes of her cousins (1820: 63-4). Similarly to Barrett's Cherry, her physical reality also overcomes her heroic qualities, in this case, a heroine's small appetite: the narrator explains that she partook of supper with not as much of a heroine as might have been expected, but that it was probably owing to the bracing mountain air through which she had been travelling (1820: 62). This short comment highlights, on the one hand, the more natural, but unheroic nature of Amanda, and, on the other hand, the unnaturalness of the heroines' little appetite after such rambles as those of Radcliffe's Emily, for instance.

In one of the most important traits of female quixotism, Amanda also fantasises about a possible hero. Amanda's sensible cousins tease her when they claim that she may find a hero at dinner; however, the heroic lady rejects anybody who may have a common name, such as John Jones. At the mention of a certain Julian Montgomery, her imagination is excited. She then decides to "charm him" and studies the way to do it, dressing and behaving following her literary models (1820: 64). This hero turns out to be a footman, and a child who was abandoned at the parish's door, other common places of the tradition of female quixotism. While at first Amanda laughs at the joke, the master's praise of the footman's education and manners, together with his statement that his name would make him "a good subject for romance," send her into a rant about the probable noble origins of Julian. Amanda's perception of what is possible and plausible follows once again the law of romance. In her speech she goes through all the clichés of this genre: Julian must be highly born, an aristocrat, who was withdrawn from his parents' house by an evil uncle, and whose parents will one day come back for him (1820: 67-8). Ridiculed by the company, she is finally lectured by her wise aunt, Mrs Evans, on the foolishness of her actions. This lecture leads to her cure, as in Lennox's novel 
or Edgeworth's "Angelina;" however, as happened in those narratives, it is not enough: the cure of her "folly" and the "errors of a bad education" is an arduous task that requires the help of other circumstances (1820: 71). Mrs Evans's lecture then works in alliance with the ridicule and pain that derive from another of Amanda's misreadings: the castle where she stays.

At the beginning of the tale, she visits some relatives only because they live in an "old castellated building" and because their city contains "an extensive circulating library" (1820: 54). She hopes to be accommodated in a gloomy room, with Gothic windows. This mention of architecture is, of course, in reality a reference to her Gothic readings. She then renames the house into a castle, and gives grander names to its rooms; she wishes to exchange "convenience" for spiral flights of stairs, corridors, deserted apartments, picture-galleries and sombre chambers (1820: 56); she expects ghost stories, blood stains, noises, lights flitting about in the darkness, shadowy forms gliding under the moon-beams, sighs breathed on her cheeks and words whispered in her ears by invisible mouths (1820: 59-60). At the height of her delusion, she decides to explore some ruins. The steps she is climbing give in; she falls and breaks a leg. Left alone while her servant runs for help, she discovers that the noises that had impelled her to explore that area were not "the gentle sighs of an 'imprisioned lovely Welch heroine'," but a "large assembly of frogs, and some other reptiles" (1820: 71). Her adventure is almost a replica of the one that befalls Margaret/Margritta in Green's Romance Readers, and is characterised by the comic effect of other heroines' deeds: Cherry's mishaps or Bridgetina's and Dorcasina's ridiculous muddy or beaten appearance after some misadventure. Moreover, her ridicule has on her the same effect it had on previous female quixotes: the aversion to the disgusting creatures, united to her pain, teach her "a lesson she did not easily forget" (1820: 71), that her romantic expectations will be ludicrously challenged by reality. However, one more circumstance is added to her cure: the consequences of her folly on her estate, status or wealth. Her mother's romantic taste leaves her without a considerable inheritance, because it is bequeathed to Elisabeth and Sarah, the plain girls who bear their rich aunt's plain names. The narrator concludes that all these "practical pieces of 
instruction" added "to the judicious tuition" of her aunt achieve to cure Amanda of her romantic taste for literature and men alike, as she takes to Crabbe's moral tales and marries a gentleman who was "more amiable than fascinating -more of a scholar than a 'hero,' and whose name was 'John Jones"' (1820: 72). The quixote is then ready to become a wife and to adopt the literary taste of the more appropriate reading models that the tale offers.

These models are the commonsensical Elisabeth and Sarah. When asked about their literary taste, they both acknowledge reading romances and novels, although "under certain regulations" (1820: 58). These regulations are the following: they seldom read novels, but as recreation after studying; they read out loud to other women while they do needlework, in order to save time; and their mother selects their readings (1820: 58). This last rule, the mentoring of reading, is essential in a moral tale that aims to do the same with its readers. In addition, it is relevant because it is the mother who performs this task, whereas absolutely all paternal figures are absent. Therefore, Baker portrays a similar character not only to More's Urania, but to Lennox's Countess, West's Mrs Evans, or Edgeworth's Lady Frances or the Duchess. The young girls make her mother's mentoring scheme clear:

[mother] says though there are a number of these books not merely useless, but pernicious, yet there are a great many that may be perused both with pleasure and advantage; and if we were left to form our own tastes, we might very probably fix on bad models, so that we consider ourselves fortunate in having the benefit of her judgement and experience to direct us. (1820: 58)

Her mother's taste has directed them to go "through all of Mrs. Radcliffe's romances, Miss Austin's (sic) novels, and Miss Edgeworth's tales," as well as to buy all of Crabbe's works. The choice of appropriate readings echoes Green's or Austen's praise of Radcliffe. It is equally significant that Austen's and Edgeworth's narrative fictions are set as entertaining and moral readings: once more quixotic stories dialogue with other quixotic fictions. Baker's tale also dialogues with Gothic romances in her parody of their traits, and in her quixote's defence of certain quintessential examples of the genre. In contrast with her cousins, Amanda, in her vitiated taste, despises Crabbe's work as "the 
most moral, melancholy, and miserable of all the attempts that were ever made at entertaining" (1820: 59). Instead, Amanda shows her enthusiasm for The children of the Abbey, which she terms a "delightful work" (1820: 57). Moreover, following other quixotic women readers, it is not only what, but how she reads which marks her as an inappropriate model; while her cousins read in company, as was prescribed by moralists, Amanda states no regulations but one: "to throw oneself on a sopha, order oneself to be denied to all visitors, and read from the first page of the first volume, to the last of the fourth or fifth [...] without submitting to a single interruption" (1820: 58). Amanda exemplifies all the dangers of solitary female reading: self-absorption and an oversight of her duties, both social and domestic.

Baker's tale, then, summarises the most recurrent elements in the eighteenthcentury tradition of female quixotism. She also frames her quixotic fiction within didactic tales, in the train of More, and, as did Green in Scotch Novel Reading, places it together with a satire on the literary world, another tale of the collection entitled "He Would be an Author." In this story, the narrator/author addresses her readers to state that she received a letter from an aspiring author, Crispin Sandalls, an "ambitious shoe-maker, anxious for literary honours" who is "under the influence of a species of derangement by no means uncommon, and properly entitled the scribbling mania, a desire of turning author without capital to set up with, being deficient both in genius and education" (1820: 43). This scribbling mania is identified as the literary quackery Green also attacked in her novel, when Crispin states that: "if I could get but anybody to purchase and to read, I should be delighted to engage in any species of composition, from a romance in nine volumes, down to a valentine in as many lines" (1820: 46), while he concludes his epistle asserting that he hopes to be put by the author in "the way of learning the art of book-making, or of writing what may stand a chance of being read, if only by unbreeched boys and pinafore girls" (1820: 52). That is, this aspiring author only seeks popularity and gain, and not quality. Crispin's literary mania also takes the shape of quixotism, when he tries to "stir up [his] sluggard imagination" by hoping to embody other authors' experience or the characteristics of the genres. 
He confesses himself an "enthusiastic admirer" of poets and describes his attempts to write thus:

I have taken innumerable journeys to dwell enraptured on celebrated views-I have sat by stream-lets and fountains $-I$ have gazed on brilliant skies till nearly blinded-I have basked in the sunshine, and shivered 'neath the moon-beams-I have smiled upon blooming young ladies, and have wept over faded flowers, yet all in vain; and once happening to behold a scene highly poetical without being inspired, I have given up versifying, I am afraid, entirely. The scene I allude to was that of a shepherd, in a picturesque dress, and standing on a very romantic spot, bending, in deep sorrow, over the pet of his flock, which he had only just discovered to be dead. "If any thin will do, this must," said I to myself, and took out my pocket-book and began as thus: -

See where the favourite of the lovely flock-

and there I was stuck fast, for I could think of no better line to rhyme with it than this, -

He has given his master a tremendous shock! (1820: 46-7)

These laughable endeavours to reproduce or enact the experience of the true poet emphasise the impossibility of faking what should be a natural inspiration or talent, or the poor artistic results it might produce. In this regard, the focus on what is natural and true can also bring the reader back to Edgeworth's or Austen's discourse, for instance: Virginia and Isabella are types, not people, because they have been taught not to be natural. They are flawed artistic products, as is Crispin's poem or Amanda's curls. Consequently, Baker, as her predecessors in the quixotic tradition, mocks these artistic products to awaken her readers to their flaws, hoping to instruct them in the taste for better performed and more moral readings.

Baker, nevertheless, only resumes the most recognizable traits of characterization and plot and her simple cautionary tale does not allow exploring in depth the generic and gender implications female quixotism had throughout the long eighteenth century. In this sense, at the very doors of the Victorian age, 1831, there is a much more complex approach to the story of a romantically deluded girl, Letitia Elisabeth Landon's Romance and Reality. Landon's first novel was one of the most hyped novels of its day, owing to her popularity as the author of five books of sentimental poems written under the 
name L.E.L. In this customary three-volume novel, she portrays a gallery of romantically imbedded characters: Edward Lorraine, Emily Arundel and Beatrice. Lorraine is a passionate reader of literature and he often discusses the merits of novelists and poets alike. In addition, he is described as an absorbed reader who becomes fascinated with what he reads, and therefore must share his literary impressions with others (1831: II, 186). In one particular occasion, the reading that absorbs his attention is very symptomatic of his taste: $D i$ Vasari, A Tale of Florence, by Charles Edwards and published in Blackwood in 1826. This romance -which includes all the common places of faraway lands, love, and murder- is described by Lorraine as a story of "intense interest -one of passion and poetry" (1831: II, 187), very much the tenets by which he will regulate his own life. Lorraine romances about life, and defends a romantic approach to experience in the face of criticism thus:

I think romance can never take a very high tone but in times of great civilisation. Romance is more matter of feeling than of passion; and if violent passions belong to a barbarous [one], strong feelings belong to a civilised state. Exemption from great bodily exertion is favourable to habits of thought. The refinement of our tastes, of course, is communicated to our sentiments; and we exaggerate, subtilize, and spiritualise -the three chief ingredients of romance. (1831: I, 303)

He criticises current British society for having lost the high values of romance, and fantasises with distant lands. This leads him to travel to Spain, a romanticised country in the British imagination, where he in fact enacts his own romance, living adventures and finding his ideal Spanish lady. While he is the epitome of a sensible and worldly man, Lorraine perceives reality through this romantic veil; like Don Quixote or Arabella, he feels nostalgia for a time and place he has not known and idealises them in the context of an increasingly harrowing industrial society. He moreover intends to behave according to his romantic approach to life, and this tainted perception rules over his literary taste and his attitude towards politics or society. In his appearance and qualities, this romantic young man is also described as fit to be a hero of a novel (1831: II, 149), and finally behaves like one. In this regard, he equally 
resembles female quixotes, such as Arabella, as well as the woman romancer of Landon's novel: Emily.

Both Lorraine and Emily are termed "romanticists" (1831: II, 191) because of their taste in reading: not only do they agree on their delight with Di Vasari, for instance, but also on another romance, Inesilla, or the Tempter: a romance; with other tales (1824), by Charles Ollier, a tale with elements of the supernatural in it. This last romance is said to produce a great impact on Lorraine, who vividly remembers the experience of reading it and how it "took a wonderful hold" on him, so that for weeks after he would look with suspicious eyes on people that reminded him of its evil characters (1831: II, 193). In the same fashion, Emily clearly remembers the book; she states that she likes the heroine very much and that she is impressed by the feelings it rises (1831: II, 193-4). Emily mirrors, then, Lorraine's what and how: she reads romances in an absorbed way. In several occasions, Emily is portrayed absorbed in reading, and Landon develops beautiful and sensuous descriptions of the young girl lost in her books (1831: II, 115-6; II: 274), anticipating the imagery that Flint has identified in the Victorian period. Not only romances, but Scott's poetry or old novels fascinate Emily, and from them she acquires her vision of life, and more importantly, love. She falls in love with Lorraine and instantly idealises him; the intensity and the course of her passion will follow the path that her upbringing and her readings demand:

Nature had given her the keenest sensibility; and the solitude in which much of her life had hitherto been passed had left free scope for the imagination to spiritualise and exalt. [...] Emily's idea of love was of the most romantic and exalted kind. Whether borrowed from the Duchess of Cleves, and the other old novels with which the library abound, where love is a species of idolatry; or from the pages of modern poetry, where all that is spiritual and beautiful is thrown around its nature; -all made love to her a species of religion. (1831: I, 307-8)

As with other female quixotes, her solitary upbringing, her natural sensibility and her taste for literature conspire to deform her approach to love and to idealise it, much in the fashion of romance. In Emily there is thus a blending of literary quixotism and an innate idealism or imagination, which united create 
her romantic vision of the world. The narrator stresses these elements as the narrative unfolds, and, as others before her, provides a possible cure for the heroine's fantasising. Close to the end the narrator states that Emily's "keen feeling" and the "high-toned romance" of her character could have been counterbalanced by the realities of life or by circumstances which required exertion; in that way, instead of morose sentiment these qualities would have been "sweet and kindly guards against the selfishness contracted in the world" (1831: III, 196-7). If properly curbed, her romantic disposition would have made her the ideal and innocent heroine that Arabella was in spite of her quixotism. However, Emily's fate is not so optimistic: "loneliness next gave all the refining exaggeration of utterly unemployed fancy; -and love had become to Emily an imaginary world, where thoughts, hopes, feelings, were all gathered and confided. The wreck was total" (1831: III, 197). Emily's feeling finds its expression in excessive melancholy, as happened with Theresa Morven. Led by disappointed love into becoming a nun in an Italian convent, Emily's fervour, her newly found expression of that sentiment, leads her to remain "between life and death with a brain fever" (1831: II, 191). This fever, as in previous quixotic tales, represents the final struggle towards a cure or a defeat. While Emily later recovers and travels back to England, it is only to die.

Emily's end is different from that of the other woman romancer, Beatrice. Landon describes her as a young girl who also dreams of an ideal lover, first, because it is impossible for a Spanish girl, "whose lute was familiar with all the romantic legends of her own romantic land," not to fantasise and idealise a lover "amid the Paladins of olden time" (1831: III, 89). The picture of romanticised Spain is highlighted in the character of its people with the young heroine and her equally heroic father, and Beatrice is somehow portrayed as inheriting this romantic nature. At the same time, she is brought up in solitude, educated with extensive reading and conversation. As with Emily, the "danger of a youth so spent was, that the mind would become too ideal," that mornings of reading in the midst of the Spanish romantic scenery would "induce habits of romantic dreaming, utterly at variance with the stern necessities of life" (1831: III, 91). However, Beatrice escapes that fate precisely because she "had been forced into a wholesome course of active exertion," she had been 
"obliged to think and to act for herself -to have others dependent on her efforts -to know that each day brought its employment, her mind strengthened by discipline" (1831: III, 91). In Beatrice, "the keen feeling, the delicate taste, were accustomed to subjection, and romance refined, without weakening" (1831: III, 91). Owing to this difference, Beatrice's romancing does not become morose monomania, as it had been the case for Emily, but an idealism that protects her from the debased values of society. Consequently, she does not die of a broken heart, but is rewarded with the love and hand of Lorraine.

Landon emphasises the parallelisms of these two romantic heroines throughout the novel. The English Emily, and the Spanish Beatrice, both live extraordinary adventures; they both conclude their stories in a romantic fashion: in love with the same man, Emily dies without his love, while Beatrice enjoys it; they both are victims of a romantic approach to reality. However, the differences among them are summarised by the narrator as the conclusion to their stories approaches:

Both had strong feelings, poetical imaginations -and both had lived much in solitude; but Emily's feelings had been left to her imagination, and her solitude had been that of reverie and idleness. Beatrice's feelings, curbed by action, had only been allowed to colour, not create circumstance; and her solitude had been one of constant and useful employment. Both had much mental cultivation; but Emily's was accomplishment -Beatrice's was information. (emphasis added, 1831: III, 247)

This description summarises the heroines' traits that have been reinforced throughout the narrative and displays some important characteristics of the tradition of female quixotism. Emily has been brought up in idle solitude, while Beatrice has lived in active isolation with her father; Emily is a passive heroine, while Beatrice is a more active one. This upbringing has given them a particular perception of reality. Both have seen their natural strong feelings and overactive imaginations encouraged by fiction; nevertheless, it has different results in each one of them: Emily is said to create circumstance, while Beatrice only colours her reality. Beatrice learns to love a real man, an Englishman, different to the knights of her imagination, while Emily is not cured from her idealised vision of love. Landon's stance echoes her 
predecessors: women should not be idle; they should lead active and meaningful lives in order to prevent an excessive longing for the ideal, for what they cannot achieve.

Landon then portrays an interesting gallery of romancers which also allows her to deepen in the effects of reading on men and women. As her narrator claims, an over active imagination, indulged and aided by literature, creates in "the common construction of characters and circumstances" an "illusion quite at variance with the realities on which we are to act, and among which we are to live" (1831: II, 147). In a man, this illusion "unfits him for the rough career of life;" this man will "read the novel, till he becomes to himself the very hero of its pages," and he will try to imitate the great examples of history, aggrandizing his image, expecting great difficulties, and becoming incapable of dealing with everyday disappointments (1831: II, 147-8). In women, this illusion takes the customary shape it had in quixotic narratives: idealised love. As the narrator has it, "a woman may indulge this faculty with more impunity, because hers is generally a passive, not an active feeling, and principally confined to the affections; all the risk of beau-idealising a lover too much, is, that of never finding one, or being disappointed when found" (1831: II, 149), both dangers female quixotes encounter. The end for both men and women romancers is the same, disappointment, whether concerned with public or private matters.

Despite this depiction of men and women romancers alike, Landon places more emphasis on women's romantic colouring of reality, not only by means of her heroines, but by mocking this over-romancing of love in two stories and displaying how dangerous, limiting or ridiculous women's circumscription to mere feeling is. First, she portrays an older romantic quixote: Emily's aunt, Mrs Arundel, described as an "inveterate novel-reader" (1831: I, 91). According to the narrator, the deluded "reading misses" belong to the past; women of forty are now the romantic fools. Mrs Arundel, at her advance age, resembles the elder Alice in Green's novel and decides to marry rather impulsively, making a fool of herself in her niece's eyes by her romantic idealisation of herself and her lover. Secondly, she has Lady Manderville tell Emily the story of a youthful attachment in a mock-romantic style. Lady 
Manderville claims she will "enact the heroine of a narrative," although she is "sadly deficient in all the necessary requisites," which she then enumerates:

I have never had a misfortune happen to me -I have never been in such extremes of poverty that I have been obliged to sell even the ruby cross hung around my neck by my mysterious mother -or the locket which contained two braids of hair, one raven black, the other golden, the first love-pledge of my unfortunate parents -I have never had a fever, during which my lover watched every look of my benevolent physician -I have never been given over, and then after a profound sleep recovered -my hair has always come easily out of curl -I never played the harp -and have always been more inclined to laugh than to cry. (1831: II, 140-1)

Despite these heroic deficiencies, the young reader of romances was able to fancy herself in love and conduct her first infatuation much in the style of her readings: fighting her parents' opposition; talking of the sacrifice of happiness to ambition, of "a cottage and content," of "blighted hopes and an early grave;" receiving a love letter through her maid, which talked of her father's barbarity and "eternal constancy;" painting a portrait of her lover, which barely resembled him; and twice catching a sore throat by leaning out of an open window, to watch "the moon shine on the terrace where [they] used to walk" (1831: II, 143-4). Her constant lover is finally, and speedily, married to a wealthier girl, and her love is cured in a period of six months when she sees her cousin, Lord Mandeville, again and marries with the full consent of her family, to her father's mirth at her lack of consistency with the role of a heroine (1831: II, 145-6). She becomes then a different kind of heroine, the less idealistic and worldlier lady of society, intelligent, witty and beautiful, and capable of both admiring and mocking romance.

In this regard, Lady Manderville provides instances of these parodic comments throughout the novel. For instance, at one point Emily and herself are abducted by what seem Italian banditti at the orders of a certain Count Frianchettini. Taken to a ruined castle, their adventure fulfils all the common places of romance: the apparel and discourse of the villain, the forced marriage, the dangers, etc. However, what seems a scene worthy of Radcliffe becomes one Barrett or Austen could have written when Lady Manderville identifies the 
Count as Signor Giulio, her old hairdresser. While Emily is almost paralysed with terror, Lady Manderville can identify the artificial elements of the context, and even promise to patronise the fake Count if he were to come out at Covent Garden. As was the case with Edgeworth's Araminta or with Barrett's actors, there is much of the theatrical in the way in which rogues try to impose on romance readers. In all these examples, there is indeed an awareness of the peculiarities of their romantic audience. Lady Manderville also acknowledges this fact when she states that the hairdresser must have been reading romances in England and must have figured out that a "picturesque chief of banditti would turn any young lady's head" (1831: III, 34). As did another hairdresser, Hamilton's Vallaton, he employs the conventions of the kind of fiction popular among women to try to obtain the hand and wealth of Emily. Lady Manderville then plays along this mock plot, arranging the scenes in her mind: Emily will be dragged to the altar, she will faint to gain time, a sudden noise will be heard, a party of soldiers will rush in, there will be fighting and they will be safe. In addition, she emphasises Emily's role as heroine of a romance when she claims that being rescued by one's husband is too unromantic, so it would correspond a lover, the hero of Emily's romance, Lorraine, to save them (1831: III, 35). Lady Manderville is aware of the conventions of romance, she can identify their artificiality and laugh at them within a real context, as well as use them to write her own mock stories. Lady Manderville is the woman writer, but also the woman critic of the novel. Although she indeed reads romances, even the abovementioned two examples, she mocks the "romanticists's" taste for literature and art in general, stating that she prefers "a gayer and lighter species of reading;" and continues: "[o]f pictures I like portraits -of books I like novels -novels of modern life, times, and manners: even if they are bad, they amuse. I am not sure if laughing at them be not as pleasant as laughing with them" (1831: II, 192). With her gaiety and unromantic taste, she is then an embodiment of Austen's taste for social portraits and for the jocular in society, a similar narrative to the one Landon herself is writing: a tableau of characters and manners, of the social and literary world she was a part of. She is then another in-between character who embodies that praise and rejection of romance that is so recurrent in quixotic fictions, and who signals a transition towards a different kind of narrative announced earlier in the novel. 
This change is perceived when, at the sight of Lorraine next to a table full of novels, he is asked whether he is "in ancient or modern times," that is, in which kind of fiction he is lost. He is asked whether he is absorbed by a plot of romance "aiding some heroine and her ringlets to escape from her prison in a mouldering castle, where her only companions are ghosts; or braving, for the love of her dark eyes, some ferocious banditti, whose muskets and mustaches (sic) are equally long," or whether he is "in ecstasies with some child of simplicity, whose hair curls intuitively, and to whom the harp and the piano, French and Italian, are accomplishments that come by nature," or, on the contrary, whether he has been transported to "those days of prudence and propriety, when the fair lady was lost her lover by waltzing, and the matrimonial quarrel was rendered desperate by the disobedient wife going to a masquerade, to which her husband followed her in the disguise of a domino" (1831: I, 192). This transition from romance to a different kind of fiction is exemplified by the subsequent discussion on the "reign of female authorship" that was the eighteenth century (1831: I, 192). Mrs Robinson, Mrs Smith and Mrs Radcliffe are presented as the rulers over the continents of "sentiment, philosophy, and terror," and their reign is succeeded by "a school of common sense and real life," with Miss Edgeworth, Miss Burney and, above all, Miss Austen (1831: I, 194-5). Despite the praise of the latter, in particular Edgeworth and Austen, there are found wanting in imagination and the feeling "born of it and nursed by it;" according to Landon's diegetic readers, their portraits lack a window into the characters' hearts that is the part of the philosopher or the poet to discover (1831: I, 196). Landon, the poet and the portraitist, seems to aim for a narrative that combines both Edgeworth's and Austen's true pictures of life in her novel of polite manners, and the feeling of Romantic writers such as Scott or Byron, in those of her episodes borrowed from romance.

The result is a queerly hybrid narrative. Despite the abovementioned mock episodes, Landon's critique to romancing is ambiguous because she is, herself, writing a narrative highly imbedded by romance. Her hero and her heroines are most certainly in the midst of a romantic plot. In this sense, Landon's narrative cannot be properly termed a novel, because it is in itself a romance. In its 
idealization of foreign countries, Spain and Italy, and her development of a storyline that includes entrapment in a nunnery, abductions, tragic unrequited love, hardships and dangers endured to be with the loved one, and even a romantic rebellion against tyranny, Landon seems to attempt a contemporary rewriting of one of Radcliffe's romances. However, she must rewrite it overcoming Radcliffe's limitations, such as the "insipidity" of her heroes, the "undeviating sweetness" of her heroines (1831: 194), or the lack of appeal or depth of her character, at the same time she preserves Radcliffe's poetical taste in her descriptions, for instance. That is, Landon hopes to combine Austen's characterization, with Radcliffe's plots and sceneries, together with Edgeworth's social comments and moral endings. This can only be understood by the difference highlighted in the characters of Emily and Beatrice: romantic extremes are condemned, a romantic colouring of reality, condoned. Landon's narrative seems as nostalgic as her hero for a different sort of reality -and literature. Over and over again, her characters voice opinions on the pitiful lack of quality found in romances published in contemporary Britain, praising only some tales for their treatment of nature, of the supernatural, or of feeling. In addition, Landon praises Scott's works and Byron's or Wordsworth's poetry for the feelings they raise in their readers (1831: II, 116-8). As a solution, Landon's hybrid tale colours reality with the poetic and idealistic tincture of romance in the midst of a witty fiction that focuses on her time and place, on the manners of polite society and on the literary taste of her age.

As these late examples manifest, the rich use of literary delusion and of the female quixotic figure is then not lost as the new century advances, but will continue to develop until the present day. The nineteenth century will witness how authors resume the common places of the tradition of female quixotism. It will witness the creation of female characters marked by extreme idealism and naivety such as those portrayed by George Eliot. Both Maggie Tulliver and Dorothea Brooke, the central characters from her novels The Mill on the Floss and Middlemarch respectively, share quixotic traits with previous models of quixotism found in Austen, for instance (Pardo, 2005c: 371; forthcoming, 2013b). The nineteenth century constructs the female quixote as a woman who is at odds with the world around her and who is superior to an undeserving 
society. The germ of this interpretation is, as has been stated, in the tradition that goes from Lennox's to Austen's reading of the quixotic delusion: it is in the rewriting of the quixote as a young girl morally superior to those around her, which allowed eighteenth-century authors to offer a cover story in which quixotism was not completely negative, as their heroines could remain innocent while the non-quixotic girls proved their coquettish and scheming nature. Additionally, the nineteenth-century also drinks from more ridiculous or even pathetic examples, such as West's, Hamilton's, Barrett's or even Landon's, and creates tragic quixotes, such as the aforementioned Maggie Tulliver, or subversive ones that must be chastised by the author's satire (Pardo: forthcoming, 2013b). In this sense, one must agree with Pardo when he states that "la figura del Quijote femenino del XVIII es el eslabón perdido entre el mito de Don Quijote formulado por Cervantes y el tipo de heroína quijotesca del siglo XIX" (2005c: 374). Consequently, the wonderful journey through the tradition of female quixotism does not end here: these last words are the springboard from which to dive into the compelling quixotic tradition of the Victorian age; a literary immersion that will hopefully be undertaken in further endeavours. 



\title{
CONCLUSIONS
}

\author{
The world's male chivalry has perished out, \\ But women are knights-errant to the last; \\ And, if Cervantes had been greater still, \\ He had made his Don a Donna. \\ Elisabeth Barrett Browning, Aurora Leigh, \\ 1856
}

The journey through the many different quixotic texts published in the long eighteenth century has finally concluded on the furthest ripple from Cervantes' novel, at the heroine in a story of female development who anticipates women yet to come. These concluding remarks then aim to become the end of this journey and the beginning of a different one. Hopefully, in this case both the voyage itself and the arrival at this particular Ithaca will prove worth the hardships.

The work that now comes to an end has fulfilled its aim to explore the figure of the female quixote in eighteenth-century British narrative fiction, and how the texts that portray her are part of a still on-going quixotic tradition that started immediately after Cervantes' publication of Don Quixote in 1605, and that becomes richer as years go by. In that way, it has contributed to consolidate the notion stated by previous scholars that the eighteenth century indeed proves the melting pot of essential responses to Cervantes' masterpiece (Pardo, 2007). What is more, it has done so by choosing the road less travelled by in quixotic studies: on the one hand, it has focused on relatively unknown quixotic figures; on the other hand, it has also placed the study of the quixote within the wider frame of the representation of women readers in eighteenth-century literature, especially in fictions penned by women writers, and of the rise of the woman novelist.

Regarding the latter context, a quantitative and a qualitative approach to the works here analysed indeed offers ground to assert that women readers fill the 
pages of eighteenth-century fiction, and that the varied genres they peruse, together with the different modes of reading they display, create a greater and more detailed picture than the one proclaimed by contemporary moralists in their warnings against female reading, in the abstract. In addition to what and how women read, the answers provided to the third question posed at the start, why or what for women read, allows perceiving that women readers were indeed interpreted as a site for rebellion, as women who could potentially exploit the liberating tenets learnt from their readings, and whose restoration to their senses was a call to preserve the status quo. Finally, this last interrogation leads to conclude that women readers were depicted to become the mirror in which both real authors and readers were to be reflected. Women novelists could express the ambiguities of being a woman writer, a being that moved between the public and the private, between what was decorous and what was not, in their reading heroines, who also inhabited that in-between world. Real women readers could see their own reading habits reflected and could be conducted by the fall and restoration of a deluded reader into a taste for a different genre or an awareness of the need for critical interpretation. Therefore, female quixotism becomes particularly relevant in this context. Moreover, the issues revolving around the woman reader and writer add new depths to the already compelling eighteenth-century quixotic tradition in Britain.

In this sense, the already varied and essential rewritings of the quixotic myth described in the first chapter have been enriched by means of the deluded women reader. This fact has positively been proved not only by the number of texts featuring a female quixote, but by the original traits that many of them bring into the tradition: from the varied sources of delusion -whether romances, novels, non-fiction, or intrinsic qualities-, through the manifestations and the consequences of it -admiration, ridicule, ostracism, death, or a combination of any of them-, to the reasons behind the use of it -parodic, satirical, or didactic- the female quixote proves malleable and capable of adapting to the particular literary or ideological craze of the age. Female quixotes spring from that pebble in the pond that is Cervantes' novel, and metamorphose to dwell in those concentric ripples that further displace 
them, away from the centre, towards new approaches and innovative developments of the quixotic myth. Each female quixote proves, thus, different from her sisters: some are literary, others ideological, still others displaced dreamers; some are naturally heroic, others jocularly clownish; some are mainly generic banners, others proclaim political or moral messages; some have happy endings, others conclude their stories in misery and death. Many are even a unique blend of most of these qualities, a quixote created to fit a very particular time, genre and purpose; a uniqueness that has found the space to be acknowledged and analysed in the individual examination of each work.

Despite the differences among the characters and texts that compose the corpus, it is nevertheless possible to ascertain some important common elements that intertwine these narrative fictions into the quixotic tradition they build. It is strikingly obvious, for instance, that the reading of the female quixote that predominates is not the contemptible fool or the satirical butt of the author's attack, but the benevolent interpretation already found in Fielding. His characterization of the young Joseph as the hero of a novel and of Adams as an innocent victim has its echo in the female quixotes of the age, from Lennox onwards. What is more, even before Fielding, this understanding of the female quixote was predominant, as has been evinced by Subligny's romantic and mad Juliet, Steele's vivacious and innocent Biddy, or Barker's tragic fool, Dorinda. Female quixotes are then characters that engage the readers' sympathy, which allows the novelist to take the parallelism between textual and real reader further. Obviously, there are instances in which the quixote becomes the object of the author's heightened ridicule or moral criticism, for instance, Dorcasina in Tenney's novel, and the heroines of anti-Jacobin fiction: Geraldine, Dorothea, Bridgetina, Julia or Cherry. Nevertheless, with the exception of Bridgetina or the early Dorcasina, whether comic or tragic, they are still characterized so as to also be attractive or admirable characters: young and beautiful like Joseph, innocent and good like Adams, deluded women readers are often praiseworthy in spite of their interspersed madness. Consequently, the female quixote, once she abandons her wishful thinking on love and life, becomes a perfect role model for her own readers. 
In addition to this benevolent interpretation of the quixote, women writers also inherited and developed Fielding's comic romance, introducing romantic characters in a clearly anti-romantic environment and expounding the comic results that derive from such a situation. This is particularly clear in Subligny's, Steele's, Lennox's, or Green's narratives, for example. Quixotes such as Juliette, Biddy, Arabella, or Margaret, are deluded by heroic romances. These characters' romantic notions are put to the test of the everyday and fail to provide the quixotes with an appropriate system of reference to understand the world they inhabit, and to adequately interact in it. Instead, they most often stand in ludicrous contrast with reality, which signals at the parodic intentions behind the authors' use of the quixotic figure. While these writers attacked romance, as Cervantes or Fielding had done, throughout the century this genre was by no means the only source of the young reader's quixotism. Female quixotes were also deluded by the perusal of different genres: Geraldine, Dorothea, Bridgetina, or Cherry, by French fiction and by radical pamphlets; Cherry, Catherine, or Amanda by Gothic fiction; and both Mariannes, Theresa, Emma Courtney, Dorcasina, Angelina, Julia Dawkins, Olivia, or Austen's early heroines, by sentimental fiction. In particular, Austen's body of work exemplifies how authors place literary clichés in the midst of the everyday in order to comically allow literary expectations to stand corrected. The female quixotes serve the authors as parodic tools to emphasise the incongruities and lack of aesthetic quality of the genres that they were hoping to overcome in their own fictions. Consequently, they also embody the generic debates of their time.

Moreover, as they are usually deluded by the genres in vogue, the popular ones, they likewise become barometers of the shifts in taste that had or were taking place, of the popularity or decay of certain genres. This fact confirms coeval approaches to women readers as the most important consumers of fiction, and the audience whose good opinion on the aesthetics and the morals of their works authors had to secure. Women readers had to be guided by these novelists into preferring their own fiction to other romances or novels. In other words, recurring to the omnipresent courtship plot and the metaphorical sense with which it was developed in quixotic fictions, women readers had to fall in 
love with the appropriate candidate for their attention, whether a suitor or a narrative fiction. In addition, they had to be seduced by proper readings. In the same manner they should not fall prey to a libertine or a revolutionary, women should not succumb to the allurements of narrative fiction that proved dangerous from a moral or political point of view. In this sense, quixotic narratives are also the vehicles to satirise ideological stances, in particular as the radical/anti-radical debate escalated. In the same manner authors had put literary notions to the test of the everyday, they also highlight the impossibility to fulfil certain philosophical or political aspirations, as well as the immorality most of them entail for a conservative frame of mind. Especially conspicuous in this context are the examples of Dorothea, Bridgetina, and Cherry, radical quixotes in anti-Jacobin novels, or the Francophile Geraldine, Julia and Olivia. Their literary, ideological and sentimental choices once more run parallel and affect the traditional feminocentric plot of courtship and marriage; consequently, they also threat to undermine the core of national identity: the family. The sufferings or tragic endings of the abovementioned quixotic heroines prove that their delusion is no longer merely a benevolent parodic instrument; their quixotism is dangerous and, therefore, it must be not only eradicated, but punished. Quixotic readers once more mirror real ones and the lesson serves for both: to become liberal women undermines the stability of the nation.

Nevertheless, satire does not fall exclusively on the quixote and her aspirations. Female quixotic narratives exploit not only the satirical strain of Butler or Graves, but also of Fielding, and use their quixotes to highlight the shortcomings of society. As a consequence, women writers of quixotic fictions develop the plot of a character whose values are incongruous, but not always despicable. That is, the young female quixote can be praiseworthy not only in spite of her misconceptions, but also precisely because her delusion has prevented her from becoming like everybody else. The abovementioned benevolent nature of the quixotes, added to their circumscribed situation as women, enables the authors to criticise the system of education provided by parents or the shallow accomplishment expected from ladies by the whole of society. From Lennox to Austen, blame for quixotic reading is usually placed 
elsewhere, on ineffectual parents and governesses, or on a society that does not encourage critical thinking in its women. In certain novelists, such as Edgeworth, this criticism at the poor systems of female education can become the core of the quixotic novel.

From an educational point of view, quixotism is particularly relevant in the young woman's life: it is her moment of temporal subversion, of circumscribed freedom from all of those limitations, in her road to integration and acceptance. This moment of madness, once overcome, marks the transition from adolescence to adulthood, from courtship to marriage, from visibility to invisibility. It is the liminal space between the public and the private, between being narratable and unnarratable, between the heroine of a novel and a domestic woman. It is not coincidental that this moment of frenzy coincides with the crucial feminocentric experience: the moment of courtship. At this time women gained not only visibility in fiction, but also allegedly more control over their lives. Quixotic fictions exploit this fact by introducing women who desire to prolong their autonomy or control by their enactment of literary tenets, or by putting into practice idealistic principles, in order to claim prerogatives as heroines of romance or as radical philosophers. In some extreme examples, they claim power and freedom within marriage, like Dorothea, or, like Emma Courtney, they flout all convention, even matrimony itself. In addition, the quixotes' aspirations can relate not only to marriage, but to other areas of life. Women aspire to fame, like Juliette or Arabella; to an education that equals that of men, like Emma Courtney; to political power, like Cherry or Olivia; or to a profession, like Laura. This desire can entail advantages and dangers for the young heroine: the happy or tragic conclusion, the integration or rejection, will depend on how the quixote resolves the conflict between her individual aspirations for love, independence, education, fame, or a profession, and the constraints of society. The eighteenth-century stories of women's development are then peopled by quixotes.

The focus on these feminocentric experiences, on the period of courtship, on the entrance into society, and on the transition towards adulthood, allows a gentle evolution to the early nineteenth-century novel of female development 
in which quixotism is, at last, fully displaced. As the new century advances, the tale of female development or female bildungsroman will progressively abandon literary mania or ideological enthusiasm to signal its heroine's struggle to preserve her unique vision against a pressing uniformity. Instead, it will universalise this feminocentric experience of trying to find an acceptable place in society. The heroine is now only deluded by her own expectations and her own dreams of independence, happiness, or love. With this change, narrative fiction at the turn of the century anticipates the Victorian novels that feature a young girl trying to find a profession, a husband, or both, in the midst of the increasingly anti-romantic reality of industrialised Britain. Thus, they precede the Woman Question and the novels by George Eliot or Elisabeth Gaskell.

To conclude, the present work has offered a comprehensive overview of the long eighteenth century, from Subligny's gallant tales to Austen's novels, and leaves these considerations at the gates of the Victorian quixotes. Defined by scholars as a transitional figure, Jane Austen certainly serves as the best brooch to close the analysis of eighteenth-century female quixotes and to become a bridge which the reader can cross in his or her way to discovering Victorian tales of reading heroines. Her novels masterly conclude the progressive displacement of quixotism away from literature and the universalization of the mistaken notions of the young heroine that has been perceived throughout the century. These traits, as well as the good nature and innocence of the quixotes, will be resumed by Eliot. Her Maggie Tulliver in The Mill on the Floss and Dorothea Brooke in Middlemarch have an exalted vision of life, an extreme idealism that makes them behave like true quixotes. Both are clearly superior to the world they inhabit, both defy conventions in their own way, and both will suffer for it, therefore ascribing to a portrayal of the nineteenth-century heroine that will last well into the following century. As has been stated elsewhere, the nineteenth-century image of the Angel in the house inherits the model of propriety of the previous century, and also demands a cure for female transgressors (Arias et al, 2010: 175). These innocent and idealistic women, like Edith Wharton's Lily Bart in The House of Mirth or Charlotte Perkins Gilman's mad woman in The Yellow Wall-Paper, become deranged, ostracized, 
and even die unfairly. The innocent young woman once more becomes a tragic heroine and the means through which to criticize the crude society she inhabits.

Consequently, one may assume that the complex and varied interpretations of the female quixote in the eighteenth century are inherited by and permeate nineteenth-century literature. The novels that constitute the tradition of female quixotism in Britain, as do the images of woman writers or readers or of Don Quixote himself, may resist easy categorizations, but the labour to study them is one of love, for they provide a fascinating and compelling read, as well as a unique medium to approach eighteenth-century ideology, society and literature. The female quixote, the "knight-errant to the last" of Elisabeth Barrett Browning's poem, indeed proves that the source of inspiration found in Don Quixote is boundless and that it can find some of its best expressions in a particularly complex, challenging, and multi-dimensional character: the reading heroine. 


\section{WORKS CITED}

\section{PRIMARY SOURCES}

Angelica; or Quixote in Petticoats. A Comedy in Two Acts. London: Printed for the Author, 1758.

The Mock-Clelia: being a Comical History of French Gallantries, and Novels, in Imitation of Dom Quixote. London: Printed for I.C, 1678. Translated from A. T. Perdoux de Subligny's La Fause Clélie. Histoires françaises galantes et comiques, 1670.

Austen, Jane. Catherine and Other Writings. Ed. M.A. Doody and Douglas Murray. London: Oxford University Press, 1998.

—. Emma. Ed. Nicola Bradbury. Hertfordshire: Wordsworth Editions Limited, 2000 [1815].

—. Northanger Abbey and Other Works. Ed. John Davie. London: Oxford University Press, 1998 [1818].

—. Pride and Prejudice. Ed. Donald J. Gray. New York: W.W. Norton \& Company, Inc., 1966 [1813].

—. Sense and Sensibility. Ed. James Kinsley and Claire Lamont. Oxford, New York: Oxford University Press, 1984 [1811].

Baker, Caroline. Drawing-Room Tales. Philip and Philippina: He Would be an Author: and The Romance Reader. By Mrs. Baker. London: Published by Shepherd and Sutton, Foster Lane, Cheapside, 1820.

Barker, Jane. A Patch-Work Screen for the Ladies; or, Love and Virtue Recommended in a Collection of Instructive Novels. Related after a Manner intirely (sic) New, and interspersed with Rural Poems, describing the Innocence of a Country-Life. London: Printed for E. Curll and T. Payne, 1723.

- The Lining of the Patch-Work Screen; Design'd for the farther Entertainment of the Ladies. London: Printed for A. Bettersworth, 1726.

Barrett, Eaton Stannard. The Heroine, or, The Adventures of a Fair Romance Reader. London: Henry Forwde, 1909 [1813].

Brown, William Hill. The Power of Sympathy: or, The Triumph of Nature, Founded on Fact. London: Penguin, 1996 [1789].

Brunton, Alexander. "Memoir." Emmeline, with some other pieces. Edinburgh: Printed for Manners and Miller, 1819. 
Brunton, Mary. Self-Control. Edimburgh: Printed for Manners and Miller, 1811 [2nd ed.].

—. Discipline. London: Henry Colburn and Richard Bentley, 1832 [1814].

Bullock, Mrs. Susanna; or, Traits of a Modern Miss: a Novel. London: William Lane, at the Minerva Press, 1795.

- Dorothea; or, A Ray of the New Light. 1801. Ed. Matthew O. Grenby. London: Pickering \& Chatto, 2005 [1801].

Burney, Frances. Evelina or The History of a Young Lady's Entrance into the World. In two volumes. London: Printed for A. K. Newman, 1829 [1778].

—. Evelina or The History of a Young Lady's Entrance into the World. In two volumes. New York: W. W. Norton \& Company, 1965 [1778]. Online text. http://digital.library.upenn.edu/women/burney/evelina/evelina.html

Cecilia, or, Memoirs of an Heiress. By the author of Evelina. In five volumes. London: Printed for T. Payne and Son, at the Newsgate, and T. Cadell in the Strand, 1784 [1782].

Cervantes, Miguel de. Don Quijote de la Mancha. Ed. Francisco Rico. Barcelona: Editorial Crítica, 2001 [1605, 1615].

Colman, George. Polly Honeycombe. A Dramatic Novel of One Act. Edinburgh: Printed for A. Kincaid and J. Bell, 1761.

Edgeworth, Maria. Letters for Literary Ladies. To which is added an essay on selfjustification. London: Printed for J. Johnson, 1795.

- Letters for Literary Ladies. To which is added an essay on self-justification. London: Printed for J. Johnson, 1799 [2nd ed., corrected].

- Whim for Whim. The novels and selected works of Maria Edgeworth. Ed. Marilyn Butler and Mitzi Myers. Vol. 12. London: Pickering \& Chatto, 2003 [1798].

—_. “Angelina or, L’Amie Inconnue.” Moral Tales for Young People. London: Printed for J. Johnson, 1806 [1801].

—. Belinda. Ed. Kathryn J. Kirkpatrick. Oxford: Oxford University Press, 2008 [1801].

—. Leonora. London: Printed for R. Hunter, 1815 [1806].

Edgeworth, Maria and R. L. Edgeworth. Essays on a Practical Education. A new edition in two volumes. London: Printed for R. Hunter, and Baldwin, Cradock, and Joy, 1815 [1799].

Fielding, Henry. Joseph Andrews and Shamela. Ed. Judith Hawley. London: Penguin Books Ltd., 1999 [1742, 1741].

—. Tom Jones. Harmondsworth: Penguin, 1976 [1749]. 
Foster, Hannah Webster. The Coquette; or, The History of Eliza Wharton; a Novel; Founded on Fact. London: Penguin, 1996 [1797].

Green, Sarah. Romance Readers and Romance Writers. Ed. Christopher Goulding. London: Pickering \& Chatto, 2010 [1810].

—. Scotch Novel Reading, or Modern Quackery. A Novel Really Founded on Facts. By a cockney. London: Printed for A. K. Newman and Co., 1824.

Hamilton, Elisabeth. Translation of the Letters of a Hindoo Rajah; Written Previous to, and During the Period of His Residence in England; To Which is Prefixed a Preliminary Dissertation on the History, Religion, and Manners of the Hindoos. London: G. G. and J. Robinson, 1796.

—. Memoirs of Modern Philosophers. Ed. Claire Grogan. Peterborough, On.: Broadview Press, 2000 [1800].

Hays, Mary. “On Reading Romances. No. VII. To Mrs.---." Letters and Essays, Moral and Miscellaneous. Online text. Cambridge: Chadwick-Healey, 1999 [1793]. http://gateway.proquest.com/openurl

—. "Henrietta." Online text. Cambridge: Chadwick-Healey, 1999 [1793]. $\mathrm{http} / / /$ gateway.proquest.com/openurl

- Memoirs of Emma Courtney. Ed. Marilyn L. Brooks. Peterborough, On.: Broadview Press, 2000 [1796].

Jarvis, Charles. The Life and Exploits of the Ingenious Gentleman Don Quixote de la Mancha. Translated from the Original Spanish of Miguel de Cervantes Saavedra. London: Printed for J and R Tonson in the Strand, and for R. Dodsley, in Pall-Mall, 1742 .

Landon, L. E. Romance and Reality. By L. E. L. Author of "The Improvisatrice," "The Venetian Bracelet," \&c. \& c. \& c. In Three Volumes. London: Henry Colburn and Richard Bentley, New Burlington Street, 1831.

Lucas, Charles. The Infernal Quixote. A Tale of the Day. London: Printed at the Minerva-Press, for William Lane, 1801.

More, Hannah. The Search after Happiness: a Pastoral Drama. Bristol: Printed and sold by S.Farley, 1773 [2nd ed.].

Peacock, Thomas L. Nightmare Abbey. Ed. By Lisa Vargo. Peterborough, On.: Broadview Press, 2007 [1818].

Polwhele, Richard. The Unsex'd Females: A Poem. London: Printed for Cadell and Davies, 1798.

Reeve, Clara. The Progress of Romance: through times, countries, and manners; with remarks on the good and bad effects of it, on them respectively; in a course of evening conversations. Printed for the Author by W.Keymer: London: 1785. 
Sansay, Leonora de. Laura. By a Lady of Philadelphia. Ed. Michael J. Drexler. Peterborough, On.: Broadview Press, 2007 [1809].

Sheridan, R.B. The Rivals, a Comedy. As it is acted at the Theatre-Royal in CoventGarden. London: Printed for John Wilkis, 1775 [2nd edition].

Smollett, Tobias. The Adventures of Sir Launcelot Greaves. London: Printed for G.G. J. and J. Robinson, Paternoster Row, 1793 [1760].

Sterne, Laurence. The Life and Opinions of Tristram Shandy, Gentleman. Ed. Melvyn New and Joan New. London: Penguin Classics, 2003 [1759-1767].

Tenney, Tabitha G. Female Quixotism: Exhibited in the Romantic Opinions and Extravagant Adventures of Dorcasina Sheldon. Ed. J. Nienkamp and A. Collins. Oxford: Oxford University Press, 1992 [1801].

Tomlins, Elisabeth S. The Victim of Fancy. A Novel. In Two Volumes. Ed. Daniel Cook. London: Pickering \& Chatto, 2009 [1787].

West, Jane. A Gossip's Story and a Legendary Tale. In two volumes. London: Printed for T. N. Longman, 1798 [1796].

- A Tale of the Times. Ed. Amanda Gilroy. London: Pickering \& Chatto, 2005 [1799].

\section{SECONDARY SOURCES}

The Critical Review, or Annals of Literature. Vol. XIV. London: Printed for A. Hamilton, Fleet-Street, 1795

The Critical Review, or Annals of Literature. Vol. XXXIV. London: Printed by and for S. Hamilton, Fleet-Street, 1802.

The British Critic, a New Review. Vol. V. London: Printed for F. and C. Rivington, 1795.

The Monthly Review, or Literary Journal, enlarged. XXII. London: Printed for R. Griffiths, 1797.

The Monthly Review, or Literary Journal, enlarged. Vol. XXXVII. London: Printed by A. Strahan, 1802.

Addison, Joseph. The Spectator. A New Edition, Carefully Revised, in six volumes. Ed. Alexander Chalmers. New York: D Appleton \& Co, 1861.

Allen, John J. Don Quixote: Hero or Fool? Part I and Part II. Gainsville: University of Florida Press, 1969 \& 1979. 
Aragon, Sandrine. Des liseuses en péril: les images de lectrices dans les textes de fiction de "La Prétieuse" de l'abbé de Pure à "Madame Bovary" de Flaubert (16561856). Paris: Honoré Champion, 2003.

—. "Les images de lectrices dans les textes de fiction français du milieu du XVIIe siècle au milieu du XIXe siècle." Cahiers de Narratologie (en ligne) 11 (2004) http://narratologie.revues.org/6 (Accessed 23 May 2011)

Ardila, J.A.G. "Cervantes y la Quixotic Fiction: el Hibridismo Genérico." Cervantes: Bulletin of the Cervantes Society of America 21.2 (2001a): 5-26.

—. "Cervantes y la Quixotic Fiction: Sucesión episódica y otros recursos narrativos." Cervantes: Bulletin of the Cervantes Society of America, 21.1 (2001b): 43-65.

__ "La influencia de la narrativa del Siglo de Oro en la novela británica del XVIII." Revista de Literatura, 63, 126 (2001c): 401-23.

Arias, Rosario et al. "Tracing Sensation: Women as 'Creatures of Sensation' from the Long Eighteenth Century to the Victorian and Neo-Victorian Novel." A View from the South: Contemporary English and American Studies. Ed. José Francisco Fernández. Almería: Ediciones Universidad de Almería, 2011. 172-9.

Armstrong, Nancy. Desire and Domestic Fiction: a Political History of the Novel. New York: Oxford University Press, 1987.

Avalle-Arce, Juan B. “Quijotes y quijotismos del inglés.” Ojáncano 2 (1989): 58-66.

—. Don Quijote como forma de vida. Alicante: Biblioteca Virtual Miguel de Cervantes, $2002 \quad$ [1976]. http://www.cervantesvirtual.com/servlet/SirveObras/cerv/12593515339033735209624 /index.htm (Accessed May 2010)

Avalle-Arce and E. C. Riley. "Don Quixote." Suma Cervantina. Ed. J. B. Avalle-Arce and E. C. Riley. London: Tamesis, 1973. 47-79.

Backsheider, Paula R. (ed.). Revising Women. Eighteenth-Century "Women's Fiction" and Social Engagement. Baltimore and London: the Johns Hopkins University Press, 2000 .

Baines, Paul. "Green, Sarah (fl. 1790-1825)." Oxford Dictionary of National Biography. Oxford University Press, 2004. Online edn. http://www.oxforddnb.com/view/article/45849 (Accessed August 2009).

Bakhtin, Mikhail. Rabelais and his World. Translated by Hélène Iswolsky. Cambridge, Mass: M.I.T. Press, 1968.

—. "Discourse in the novel." The Dialogic Imagination: Four Essays. Austin: University of Texas Press, 1981. 259-422. 
Ballaster, Ros. "Romancing the novel: Gender and Genre in Early Theories of Narrative." Living by the Pen. Early British Women Writers. Ed. Dale Spender. New York and London: Teachers College Press, Columbia University, 1992a. 188-200.

- Seductive Forms: Women's Amatory Fiction from 1684 to 1740. Oxford: Clarendon Press, 1992b.

_. "Women and the rise of the novel: sexual prescripts." Women and Literature in Britain 1700-1800. Ed. Vivien Jones. Cambridge: Cambridge University Press, 2000. 197-216.

Bannet, Eve Tavor. The Domestic Revolution. Enlightenment Feminisms and the Novel. Baltimore and London: the Johns Hopkins University Press, 2000.

—. "Quixotes, Imitations, and Transatlantic Genres." Eighteenth-Century Studies 40.4 (2007): 553-69.

Barnes, Ruth et al (ed.). Second to None. A Documentary History of American Women. Volume 1: from the 16th Century to 1865. Lincoln, NE.: University of Nebraska Press, 1993.

Batchelor, Jennie and Cora Kaplan (eds.). British Women's Writing in the Long Eighteenth Century. Basingstoke: Palgrave Macmillan, 2005.

Beasley, Jerry C. "Romance and the 'New' Novels of Richardson, Fielding, and Smollett." Studies in English Literature, 1500-1900 16.3 (1976): 437-50.

- "Politics and Moral Idealism: The Achievement of Some Early Women Novelists." Fetter'd or Free? British Women Novelists, 1670-1815. Ed. Mary Anne Schofield and Cecilia Macheski. Athens, Ohio and London: Ohio University Press, 1986. 216-36.

Benger, Elisabeth (ed.). Memoirs of the Late Mrs. Elisabeth Hamilton. With a selection from her correspondence, and other unpublished writings. In two volumes. London: Printed for Longman, Hurst, Rees, Orme, and Brown, 1818.

Binhammer, Katherine. "The Persistence of Reading: Governing Female NovelReading in Memoirs of Emma Courtney and Memoirs of Modern Philosophers." Eighteenth-Century Life 27.2 (2003): 1-22.

Bloch, Tuvia. "Smollett's Quest for Form.” Modern Philology 65.2 (1967): 103-13.

Booth, Wayne. "The Self-Conscious Narrator in Comic Fiction before Tristram Shandy." PMLA 67.2 (1952): 163-85.

—. "Point of View and the Control of Distance in Emma." Nineteenth-Century Fiction 16. 2 (1961): 95-116.

Bour, Isabelle. "Brunton, Mary (1778-1818)." Oxford Dictionary of National Biography. Oxford University Press, 2004. Online edn. http://www.oxforddnb.com/view/article/3781 (Accessed August 2009). 
Bowers, Bege K. and Barbara Brothers (ed.). Reading and Writing Women's Lives: A Study of the Novel of Manners. Ann Arbor and London: UMI Research Press, 1990.

Bray, Joe. The Female Reader in the English Novel. From Burney to Austen. New York and London: Routledge, 2009.

Britton, R.K. "Don Quixote's Fourth Sally: Cervantes and the Eighteenth-Century English Novel." New Comparison 15 (1993): 21-32.

Brodey, Inger Sigrun. "Adventures of a Female Werther: Jane Austen's Revision of Sensibility." Philosophy and Literature. 23.1 (1999): 110-26.

Brophy, Elisabeth Bergen. Women's Lives and the Eighteenth Century. Tampa: University of South Florida Press, 1991.

Brooks, Marilyn L. "Introduction." Memoirs of Emma Courtney. By Mary Hays. Peterborough, On.: Broadview Press, 2000. 7-29.

—. "Hays, Mary (1759-1843)." Oxford Dictionary of National Biography. Oxford University Press, 2004. http://www.oxforddnb.com/view/article/37525 (Accessed 12 August 2009).

Brown, Gillian. "The Quixotic Fallacy.” NOVEL: A Forum on Fiction 32.2 (1999): 250-73.

Burlin, Katrin R. "“At the Crossroads': Sister Authors and Sister Arts." Fetter'd or Free? British Women Novelists, 1670-1815. Ed. Mary Anne Schofield and Cecilia Macheski. Athens, Ohio and London: Ohio University Press, 1986. 60-84.

Butler, Marilyn. Jane Austen and the War of Ideas. Oxford: Clarendon Press, 1987 [1975].

Canavaggio, Jean. Don Quichotte, du livre au mythe: quatre siècles d'errance. París: Fayard, D.L. 2005.

Carlile, Susan. "Charlotte Lennox's Birth Date and Place." Notes and Queries 51.4 (2004): 390-2.

Caro Dugo, Carmen. The importance of the Don Quixote myth in the works of Antonio Buero Vallejo. Lewiston: Mellen University Press, 1995.

Cascardi, Anthony J. "Totality and the Novel." New Literary History 23.3 (1992): 607-27.

—. "Introduction." The Cambridge Companion to Cervantes. Ed. Anthony J. Cascardi. Cambridge: Cambridge University Press, 2002. 1-10.

- "Don Quixote and the invention of the novel." The Cambridge Companion to Cervantes. Ed. Anthony J. Cascardi. Cambridge: Cambridge University Press, 2002. 58-79. 
Castle, Terry. "Introduction." Northanger Abbey, Lady Susan, The Watson and Sanditon. By Jane Austen. Ed. John Davie. London: Oxford University Press, 1998. vii-xxxii.

Cátedra, Pedro. El sueño caballeresco. De la caballería de papel al sueño real de Don Quijote. Madrid: Abada, 2007.

Chaplin, Sue. Law, Sensibility and the Sublime in Eighteenth-Century Women's Fiction: Speaking of Dread. Burlington: Ashgate, 2004.

Chapman, R.W (ed.). Jane Austen. Selected Letters 1796-1817. Oxford: Oxford University Press, 1985.

Chartier, R. The Cultural Uses of Print in Early Modern France. Princeton: Princeton University Press, 1987.

Clery, E.J. The Feminization Debate in Eighteenth-Century England. Literature, Commerce and Luxury. Basingstoke: Palgrave Macmillan, 2004.

Close, Anthony. The Romantic Approach to Don Quixote. Cambridge: Cambridge University Press, 1977.

Colley, Linda. Britons: Forging the Nation, 1707-1837. London and New York: Yale University Press, 1992.

Cook, Daniel. "Introduction." The Victim of Fancy. A Novel. London: Pickering \& Chatto, 2009. xi-xxxi.

Curran, Stuart. "Women readers, women writers." The Cambridge Companion to British Romanticism. Ed. Stuart Curran. Cambridge: Cambridge University Press, 1993. 177-95.

Dalziel, Margaret. "Introduction." The Female Quixote, or, The Adventures of Arabella. By Charlotte Lennox. 1752. London: Oxford University Press, 1973. xiiixviii.

Davidson, Cathy. "Introduction." The Coquette; or, The History of Eliza Wharton; a Novel; Founded on Fact. 1797. By Hannah Webster Foster. Ed. Cathy Davidson. Oxford and Ney York: Oxford University Press, 1986.

Davis, Alex. Chivalry and Romance in the English Renaissance. D.S. Brewer: Cambridge, 2003.

De Ritter, Richard. "Leisure to be Wise': Edgeworthian Education and the Possibilities of Domesticity." Journal for Eighteenth-Century Studies 33.3 (2010): 313-33.

Donovan, Josephine. "Women and the Rise of the Novel: a Feminist-Marxist Theory." Signs 16.3 (1991): 441-62.

"Women and the Framed Novelle: a Tradition of their Own." Signs 22.4 (1997): 947-80. 
Doody, Margaret Ann. "Introduction." The Female Quixote, or, The Adventures of Arabella. By Charlotte Lennox. 1752. Ed. Margaret Dalziel. London: Oxford World's Classics, 1989. xi- xxxii.

- "Samuel Richardson: fiction and knowledge." The Cambridge Companion to the Eighteenth-century Novel. Ed. John Richetti. Cambridge: Cambridge University Press, 1996a.

—. The True History of the Novel. New Brunswick, NJ: Rutgers University Press, 1996b.

—. "Introduction." Catherine and Other Writings. By Jane Austen. Ed. M.A. Doody and Douglas Murray. London: Oxford University Press, 1998. ix-xxxviii.

Drexler, Michael J. "Introduction." Secret History or, the Horrors of St. Domingo and Laura. 1809. By Leonora Sansay. Ed. Michael J. Drexler. Peterborough, On.: Broadview Press, 2007. 10-37.

Driskell, Leon V. "Interpolated Tales in Joseph Andrews and Don Quixote: The Dramatic Method as Instruction." South Atlantic Bulletin 33.3 (1968): 5-8.

Edgeworth, Maria. "Character and writings of Mrs Elizabeth Hamilton." Gentleman's Magazine 86.2 (1816): 623-4.

Eger, Elisabeth. "Representing culture: The Nine Living Muses of England (1779)." Women, Writing and the Public Sphere, 1730-1830. Ed. Elisabeth Eger et al. Cambridge: Cambridge University Press, 2001. 104-32.

Eger, Elisabeth et al. (eds.). Women, Writing and the Public Sphere, 1730-1830. Cambridge: Cambridge University Press, 2001.

Ellis, Lorna. Appearing to Diminish: Female Development and the British Bildungsroman, 1750-1850. London: Associated University Presses, 1999.

Ellis, Markman. The Politics of Sensibility: Race, Gender and Commerce in the Sentimental Novel. Cambridge: Cambridge University Press, 1996.

El-Saffar, Ruth. Distance and Control in Don Quixote: a Study in Narrative Technique. Chapel Hill: University of North Carolina Press, 1975.

Facer, Ruth. "Mary Brunton (1778-1818)." Chawton House Library Biography Online. $\quad$ http://www.chawtonhouse.org/library/biographies/brunton.html\#ref3 (Accessed August 2009).

Farnsworth, Jane. "Defending the King in Cartwright's 'The Lady-Errant' (16361637)." Studies in English Literature, 1500-1900 42.2 (2002): 381-98.

Fergus, Jan. Jane Austen and the Didactic Novel: Northanger Abbey, Sense and Sensibility and Pride and Prejudice. Totowa, N.J.: Barnes and Noble, 1983.

_. "Women readers: a case study." Women and Literature in Britain 1700-1800. Ed. Vivien Jones. Cambridge: Cambridge University Press, 2000. 155-76. 
Fitzmaurice-Kelly, James. Cervantes in England. London: Henry Frowde, 1905.

Flint, Kate. The Woman Reader, 1837-1914. Oxford: Clarendon Press, Oxford University Press, 1993.

Foucault, Michel. Histoire de la folie à l'âge classique. Paris: Editions Gallimard, 1972.

Fraiman, Susan. Unbecoming Women. British Women Writers and the Novel of Development. New York: Columbia University Press, 1993.

Frenzel, Elisabeth. Diccionario de argumentos de la literature universal. Madrid: Gredos, 1976.

Frye, Northrop. Anatomy of Criticism. Princeton, NJ: Princeton University Press, 1971.

- The Secular Scripture. A Study of the Structure of Romance. Cambridge, Mass: Harvard University Press, 1976.

Gallagher, Catherine. Nobody's Story. The Vanishing Acts of Women Writers in the Marketplace. 1670-1820. Oxford: Oxford University Press, 1994.

Gámez Fernández, Cristina. "Descendientes del Quijote en América: Female Quixotism de Tabitha G. Tenney." Cervantes y el ámbito anglosajón. Ed. Diego Martínez Torrón. Madrid: Sial Ediciones, 2005. 91-117.

Gardiner, Ellen. Regulating Readers. Gender and Literary Criticism in the EighteenthCentury Novel. London: Associated University Presses, 1999.

Garside, Peter, James Raven and Rainer Schowerling (eds.). The English Novel, 17701829: a Bibliographical Survey of Prose Fiction Published in the British Isles. 2 vols. Oxford: Oxford University Press, 2000.

Gaylord, Mary. "The Whole Body of Fable with All of its Members: Cervantes, Pinciano, Freud." Quixotic Desire. Psychoanalytical Perspectives on Cervantes. Ed. Ruth Anthony El-Saffar and Diana de Armas Wilson. New York: Cornell University Press, 1993. 117-34.

Gilbert, Sandra M. and Susana Gubar. The Madwoman in the Attic: The Woman Writer and the 19th century Literary Imagination. London: Yale University Press, 1979.

Gilman, Stephen. The Novel according to Cervantes. Berkeley, LA, London: University of California Press, 1989.

Gilroy, Amanda. "Introduction.” A Tale of the Times. 1799. By Jane West. Pickering \& Chatto, 2005. Vii- xxvii.

Glock, Waldo S. "Catherine Morland's Gothic Delusions: A Defense of 'Northanger Abbey'." Rocky Mountain Review of Language and Literature 32.1 (1978): 33-46. 
Goldberg, Homer. "The Interpolated Stories in 'Joseph Andrews' or 'The History of the World in General' Satirically Revised.” Modern Philology 63.4 (1966): 295-310.

Goodman, Joyce. "Undermining or building up the nation? Elisabeth Hamilton (17581816), national identities and an authoritative role for women educationalists." History of Education 28.3 (1999): 279-96.

Gordon, Scott Paul. "The Space of Romance in Lennox's Female Quixote." Studies in English Literature 1500-1900 (1998): 499-516.

_. "Female Quixotism: Charlotte Lennox and Tabitha Tenney." Cervantes in the English-Speaking World: New Essays. Ed. Darío Fernández-Morera and Michael Hanke. Barcelona: Reichenberger, 2005. 127-41.

- The Practice of Quixotism. Postmodern Theory and Eighteenth-Century Women's Writing. New York: Palgrave Macmillan, 2006.

Goulding, Christopher. "Introduction." Romance Readers and Romance Writers. 1810. By Sarah Green. Ed. Christopher Goulding. London: Pickering \& Chatto, 2010. Ix-xxii.

Grenby, Matthew O. The Anti-Jacobin Novel. British Conservatism and the French Revolution. Cambridge: Cambridge University Press, 2001.

—. "Introduction." Dorothea; or, A Ray of the New Light. 1801. By Mrs Bullock. Pickering \& Chatto, 2005. Vii- xxix.

Grogan, Claire. "Identifying Foreign Bodies: New Philosophers and Hottentots in Elisabeth Hamilton's Memoirs of Modern Philosophers." Eighteenth-Century Fiction 18.3 (2006): 305-27.

—. "Introduction." Memoirs of Modern Philosophers. By Elisabeth Hamilton. Ed. Claire Grogan. Peterborough: Broadview Press, 2000. 9-26.

—. "Introduction." Northanger Abbey. By Jane Austen. Ed. Claire Grogan. Peterborough, On.: Broadview Press, 2002. 7-24.

Guest, Harriet. "Eighteenth-century femininity: 'a supposed sexual character'." Women and Literature in Britain 1700-1800. Ed. Vivien Jones. Cambridge: Cambridge University Press, 2000a. 46-68.

—. Small Change: Women, Learning, Patriotism, 1750-1810. Chicago: Chicago University Press, 2000b.

Hackett, Helen. Women and Romance Fiction in the English Renaissance. Cambridge: CUP, 2000.

Haggerty, George. "Self-Love in The Female Quixote: Romancing the Ego." Unnatural Affections. Women and Fiction in the Later Eighteenth Century. Bloomington, IN: Indiana University Press, 1998. 123-36. 
Haigh, John D. "Barrett, Eaton Stannard (1786-1820)." Oxford Dictionary of National Biography, Oxford University 2004. http://www.oxforddnb.com/view/article/1522 (Accessed Aug 2009).

Haley, George. "The Narrator in Don Quixote: Maese Pedro's Puppet Show.” Modern Language Notes 80 (1965): 145-65.

Hammond, Brean S. "Mid-Century English Quixotism and the Defence of the Novel." Eighteenth-Century Fiction 10.3 (1998): 247-68.

Harkin, Maureen. "Mackenzie's Man of Feeling: Embalming Sensibility." ELH 61.2 (1994): 317-40.

Harvey, A.D. "George Walker and the Anti-Revolutionary Novel." The Review of English Studies 111 (1977): 290-300.

Heiser, M.F. “Cervantes in the United States.” Hispanic Review 15.4 (1947): 409-35.

Horner, Avril and Zlosnik, Sue. "Dead Funny. Eaton Stannard Barrett's The Heroine as Comic Gothic." 2000. http://www.cf.ac.uk/encap/corvey/articles/cc05_n02.html (Accessed November 2005).

Iffland, James. "On the Social Destiny of 'Don Quixote': Literature and Ideological Interpellation: Part I." The Journal of the Midwest Modern Language Association 20.1 (1987): 17-36.

—. "On the Social Destiny of 'Don Quixote': Literature and Ideological Interpellation: Part II." The Journal of the Midwest Modern Language Association 20. 2 (1987): 9-27.

—. De fiestas y aguafiestas: risa, locura e ideología en Cervantes y Avellaneda. Madrid: Iberoamericana, 1999.

Isles, Duncan. "Afterword.” The Female Quixote, or, The Adventures of Arabella. By Charlotte Lennox. London: Oxford University Press, 1973. 418-27.

Johns, A. The Nature of the Book: Print and Knowledge in the Making. Chicago and London: Chicago University Press, 1998.

Johnson, Claudia L. "A 'Sweet Face as White as Death': Jane Austen and the Politics of Female Sensibility.” NOVEL: A Forum on Fiction 22. 2 (1989): 159-74.

—_ "'Let Me Make the Novels of a Country': Barbauld's 'The British Novelists' (1810/1820)." NOVEL: A Forum on Fiction 34. 2 (2001): 163-79.

Johnson, Samuel. The Rambler. In Four Volumes. Ed. Arthur Murphy. Princeton, N.J.: Published by D.A. Borrenstein, 1828.

Jones, Vivien (ed.). Women in the Eighteenth Century: Constructions of Femininity. London \& New York: Routledge, 1990.

(ed.) Women and Literature in Britain 1700-1800. Cambridge: Cambridge University Press, 2000. 
Joukovsky, Nicholas. The Letters of Thomas Love Peacock. In two volumes. Oxford: Clarendon Press, 2001.

Kauvar, Elaine M. "Jane Austen and The Female Quixote." Studies in the Novel 2 (1970): 211-21.

Keane, Angela. Women Writers and the English Nation in the 1790s. Romantic Belongings. Cambridge: Cambridge University Press, 2000.

Kelly, Gary. "Unbecoming a Heroine: Novel Reading, Romanticism, and Barrett's The Heroine." Nineteenth-century Literature 45.2 (1990): 220-41.

—. Women, Writing and Revolution. Oxford: Clarendon Press, 2001[1993].

Kenny, Shirley S. (ed.). The Plays of Richard Steele. Oxford: The Clarendon Press, 1971.

Kerber, Linda K. Women of the Republic: Intellect and Ideology in Revolutionary America. University of North Carolina Press, 1997.

King, Kathryn R. "Of Needles and Pens and Women's Works." Tulsa Studies in Women's Literature 14.1 (1995): 77-93.

—. Jane Barker, Exile. A Literary Career, 1675-1725. Oxford: Oxford University Press, 2000.

Knowles, Edwin B. "Don Quixote through English Eyes." Hispania 23.2 (1940):10315.

"Cervantes and English Literature." Cervantes Across the Centuries. Ed. Angel Flores and MJ Bernadete. New York: The Dryden Press, 1947. 267-93.

Krontiris, Tina. "Breaking Barriers of Genre and Gender: Margaret Tyler's Translation of The Mirror of Knighthood." English Literary Renaissance 18.1 (1988): 19-39.

Lamb, Jonathan. "The Comic Sublime and Sterne's Fiction.” ELH 48.1 (1981): 11043.

Lang, Jessica. "Scratching the Surface: Reading Character in Female Quixotism." Texas Studies in Literature and Language 51.2 (2009): 119-41.

Langbauer, Laurie. "Romance Revised: Charlotte Lennox's The Female Quixote." Novel: A Forum on Fiction 18.1 (1984): 29-49.

- Women and Romance. The Consolations of Gender in the English Novel. Ithaca and London: Cornell University Press, 1990.

Lascelles, Mary. Jane Austen and Her Art. London: The Athlone Press, 1995.

Lázaro Carreter, Fernando. "El realismo como concepto crítico-literario." Estudios de Poética. Madrid: Taurus, 1979. 121-42. 
Levi, Albert W. "The Quixotic Quest for Being.” Ethics 66.2 (1956): 132-6.

Levin, Harry. “What Is Realism?” Comparative Literature 3.3 (1951): 193-99.

—_. "The Quixotic Principle: Cervantes and Other Novelists." The Interpretation of Narrative. Theory and Practice. Cambridge, Mass: Harvard University Press, 1970. 45-66.

Levin, Kate. "'The Cure of Arabella's Mind': Charlotte Lennox and the disciplining of the female reader." Women's Writing 2.3 (1995): 271-90.

Levine, George. "Translating the Monstrous: Northanger Abbey." Nineteenth-Century Fiction, 30.3 (1975): 335-50.

Lodge, David. "Composition, distribution, arrangement. Form and structure in Jane Austen's novels." After Bakhtin. Essays on Fiction and Criticism. London and New York: Routledge, 1990.

London, April. "Novel and History in Anti-Jacobin Satire". The Yearbook of English Studies 30 (2000): 71-81.

Looser, Devoney. British Women Writers and the Writing of History. Baltimore \& London: The Johns Hopkins University Press, 2000.

Loveridge, Mark. "Northanger Abbey; Or, Nature and Probability." NineteenthCentury Literature, 46. 1 (1991): 1-29.

Lucas, Caroline. Writing for Women. The Example of Woman as Reader in Elisabethan Romance. Milton Keynes, Phil: Open University Press, 1989.

Lucía Megías, José Manuel. Leer el Quijote en imagines. Hacia una teoría de los modelos iconográficos. Madrid : Calambur, 2006.

Lukács, Georg. The Theory of the Novel. Cambridge, Mass: MIT Press, 1977.

MacCarthy, B.G. Women Writers, their contributions to the English Novel, 16211744. Eire: Cork University Press, 1944.

- The Female Pen. Women Writers and Novelists 1621-1818. Cork University Press, 1994.

Magris, Claudio. "Utopía y desencanto." Don Quijote alrededor del mundo. Madrid: Instituto Cervantes y Círculo de Lectores, 2005. 107-110.

Malina, Debra. "Rereading the Patriarchal Text: The Female Quixote, Northanger Abbey, and the Trace of the Absent Mother." Eighteenth-Century Fiction 8.2 (1996): 271-92.

Mandal, Anthony. Jane Austen and the Popular Novel. The Determined Author. Basingstoke: Palgrave Macmillan, 2007.

Mandel, Oscar. "The Function of the Norm in 'Don Quixote'." Modern Philology 55.3 (1958): 159-63. 
Mander, Jenny. "Introduction." SVEC 2007:10. Remapping the Rise of the European Novel. Ed. Jenny Mander. Oxford: Voltaire Foundation, 2007. 1-22.

Manly, Susan. "Maria Edgeworth (1768-1849)." Chawton House Library Biography Online. http://www.chawton.org/library/biographies/edgeworth.html (Accessed August 2009).

Martin, Mary P. "'High and Noble Adventures': Reading the Novel in The Female Quixote." NOVEL: A Forum on Fiction 31.1 (1997): 45-62.

Mathias, Thomas J. Pursuits of Literature: A Satirical Poem in Four Dialogues. Philadelphia: Printed by H. Maxwell, for A. Dickins, bookseller, North Second Street opposite Christ-Church, 1800.

McKeon, Michael. The Origins of the English Novel, 1600-1740. Baltimore: The Johns Hopkins University Press, 1987.

McKerrow, Mary. Mary Brunton. The Forgotten Scottish Novelist. Kirkwall: Orcadian, 2001.

McMurran, Mary Helen. "National or Transnational? The Eighteenth-Century Novel." The Literary Channel. The Inter-National Invention of the Novel. Ed. Margaret Cohen and Carolyn Dever. Princeton and Oxford: Princeton University Press, 2002. 50-72.

Mellor, Anne K. Romanticism and Gender. London and New York: Routledge, 1993.

—. Mothers of the Nation. Women's Political Writing in England, 1780-1830. Bloomington: Indiana University Press, 2000.

Moskal, Jeanne. "“To speak in Sanchean phrase': Cervantes and the politics of Mary Shelley's History of a Six Weeks' Tour." Mary Shelley in her Times. Ed. Betty T. Bennet and Stuart Curran. Baltimore and London: The Johns Hopkins University Press, 2000: 18-38.

Motooka, Wendy. The Age of Reasons. Quixotism, sentimentalism and political economy in eighteenth-century Britain. London and New York: Routledge, 1998.

Motooka, Wendy. "Coming to a Bad End: Sentimentalism, Hermeneutics, and The Female Quixote." Eighteenth-Century Fiction 8.2 (1996): 251-70.

Mulford, Carla. "Introduction." The Power of Sympathy and The Coquette. 1789, 1797. By William Hill Brown and Hannah Webster Foster. Ed. Carla Mulford. London: Penguin, 1996. Ix-lii.

Müllenbrock, Heinz-Joachim. "Don Quixote and Eighteenth-Century English Literature." Intercultural Encounters: Studies in English Literature. Ed. Anton Heinz and Kevin Cope. Heidelberg: Carl Winter Universitatsverlag, 1999. 197-209.

Myers, Mitzi. "Hannah More's Tracts for the Times: Social Fiction and Female Ideology." Fetter'd or Free? British Women Novelists, 1670-1815. Ed. Mary Anne Schofield and Cecilia Macheski. Athens, Ohio and London: Ohio University Press, 1986. 264-84. 
—_. "Quixotes, Orphans, and Subjectivity: Maria Edgeworth's Georgian Heroinism and the (En)Gendering of Young Adult Fiction." The Lion and the Unicorn 13. 1 (1989): 21-40.

_ . "Daddy's Girl as Motherless Child: Maria Edgeworth and Maternal Romance; An Essay in Reassessment." Living by the Pen. Early British Women Writers. Ed. Dale Spender. New York and London: Teachers College Press, Columbia University, 1992. 137-59.

—. "War Correspondence: Maria Edgeworth and the En-Gendering of Revolution, Rebellion, and Union." Eighteenth-Century Life 22.3 (1998): 74-91.

Nadeau, Carolyn. A. Women of the Prologue: Imitation, Myth and Magic in Don Quixote I. Lewisburg: Bucknell University Press, 2002.

Nardin, Jane. The Elegant Decorums. The Concept of Propriety in Jane Austen's Novels. Albany, NY: State University of New York Press, 1973.

Nienkamp, Jean and Andrea Collins. "Introduction." Female Quixotism: Exhibited in the Romantic Opinions and Extravagant Adventures of Dorcasina Sheldon. 1801. By Tabitha G. Tenney. Ed. J. Nienkamp and A. Collins. Oxford: Oxford University Press, 1992. Xiii-xxviii.

Ortega y Gasset, José. Meditaciones del Quijote. 1914. Madrid: Alianza Editorial, 1987.

Pardo, P. J. "La otra cara de Cervantes en la novela inglesa del siglo XVIII: Tom Jones y Humphry Clinker." Actas del II Congreso Internacional de la Asociación de Cervantistas. Napoli: Societá Editrice Intercontinentale Gallo, 1994. 839-54.

La tradición cervantina en la novela inglesa del siglo XVIII. Unpublished $\mathrm{PhD}$ Thesis. University of Salamanca, 1995.

—. "La novela como juego: La paradoja metaficcional en Cervantes, Fielding y Sterne." Actas del X Simposio de la Sociedad Española de Literatura General y Comparada. Santiago de Compostela: Universidad de Santiago de Compostela, 1996. 203-17.

—. "Formas de imitación del Quijote en la novel inglesa del siglo XVIII: Joseph Andrews y Tristram Shandy.” Anales Cervantinos 33 (1997): 133-64.

- "Huckleberry Finn as a crossroads of myths: the adamic, the quixotic, the picaresque, and the problema of ending." Links \& Letters 8 (2001): 61-74

_. "El quijote femenino como variante del mito quijotesco." Actas del V Congreso Internacional de la Asociación de Cervantistas. Lisboa: Asociación de Cervantistas, 2004. 1627-44.

- "Cervantes, la novela y la metanovela." El hidalgo fuerte: siete miradas al Quijote. Ed. A. Rivas Yanes. Luxembourg: Círculo Cultural Antonio Machado, 2005a. $107-42$. 
—. "Jane Austen." Gran Enciclopedia Cervantina. Ed. Carlos Alvar. Vol. I. Madrid: Castalia, 2005b.

__ . "La heroína quijotesca en la novela inglesa del siglo XIX: Jane Austen, George Eliot y otros novelistas." Cervantes y el ámbito anglosajón. Ed. Diego Martínez Torrón. Madrid: Sial, 2005c. 356-75.

__. "El Quijote y la novela moderna." La ficción novelesca en los siglos de oro y la literatura europea. Ed. Ricardo Senabre Sampere. Madrid: Secretaria General Técnica, Ministerio de Educación y Ciencia, 2005d. 41-56

- "Tobias Smollett's Humphry Clinker and the Cervantine Tradition in Eighteenth-Century English Fiction." Cervantes in the English-Speaking World: New Essays. Ed. Darío Fernández-Morera and Michael Hanke. Barcelona: Reichenberger, 2005e. 81-106.

—. "La tradición cervantina en la novela inglesa: de Henry Fielding a William Thackeray." Entre Shakespeare y Cervantes: sendas del Renacimiento. Ed. Zenón Luis Martínez and Luis Gómez Canseco. Newark: Juan de la Cuesta, 2006. 73-111.

"El siglo de oro del Quijote en la literatura inglesa, 1740-1840." La huella de Cervantes y del Quijote en la cultura anglosajona. Ed. José Manuel Barrio Marco and María José Crespo Allué. Valladolid: Universidad de Valladolid, Secretariado de Publicaciones e Intercambio Editorial, 2007. 133-58.

—. "Cine, literatura y mito: Don Quijote en el cine, más allá de la adaptación." ARBOR Ciencia, Pensamiento y Cultura 187.748 (2011): 237-46.

—. "Reino Unido." Gran Enciclopedia Cervantina. Ed. Carlos Alvar. Madrid: Castalia. Forthcoming, 2013a.

—. "El Quijote filantrópico victoriano: Donna Quixote, de Justin McCarthy." Anales Cervantinos. Forthcoming, 2013b.

Paulson, Ronald. Satire and the Novel in Eighteenth-Century England. New Haven: Yale University Press, 1967.

- Don Quixote in England. The Aesthetics of Laughter. Baltimore and London: Johns Hopkins University Press, 1998.

Pawl, Amy. "Feminine Transformations of the Quixote in Eighteenth-Century England: Lennox's Female Quixote and Her Sisters." Echoes and Inscriptions: Comparative Approaches to Early Modern Spanish Literatures. Ed. Barbara A. Simerka and Christopher B. Weimer. Lewisburg, PA: Bucknell University Press, 2000. 142-59.

Pearson, Jacqueline. Women's Reading in Britain, 1750-1835: a Dangerous Recreation. Cambridge \& New York: Cambridge University Press, 1999.

Perkins, Pam. "Hamilton, Elizabeth (1756?-1816)." Oxford Dictionary of National Biography. Oxford University 2004. http://www.oxforddnb.com/view/article/12062 (Accessed 12 August 2009) 
Poovey, Mary. The Proper Lady and the Woman Writer. Chicago and London: University of Chicago Press, 1984.

Pope, Alexander. The Dunciad, Variorum with the Prolegomena of Scriblerus. London: 1729.

Predmore, Richard L. The World of Don Quixote. Cambridge, Mass: Harvard University Press, 1967.

Price, Fiona. Revolutions in Taste, 1773-1818. Women Writers and the Aesthetics of Romanticism. Farnham: Ashgate, 2009.

Raff, Sarah. "Quixotes, Precepts, and Galateas: the Didactic Novel in Eighteenthcentury Britain." Comparative Literature Studies 43.4 (2006): 466-81.

Rasula, Jed. "When the Exception Is the Rule: Don Quixote as Incitement to Literature." Comparative Literature 51.2 (1999): 123-51.

Raven, James. "The material contours of the English novel 1750-1830." SVEC 2007:10. Remapping the Rise of the European Novel. Ed. Jenny Mander. Oxford: Voltaire Foundation, 2007. 101-26.

Raven, James, Helen Small and Naomi Tadmor (eds.). The Practice and Representation of Reading in England. Cambridge: Cambridge University Press, 1996.

Reed, Walter L. "Joseph Andrews and the Quixotic. The Politics of the Classic." An Exemplary History of the Novel: The Quixotic versus the Picaresque. Chicago: The University of Chicago Press, 1981. 117-36.

—. "Tristram Shandy. Displacement as Signification." An Exemplary History of the Novel: The Quixotic versus the Picaresque. Chicago: The University of Chicago Press, 1981. 137-61.

Richardson, Alan. Literature, Education, and Romanticism. Reading as Social Practice, 1780-1832. Cambridge: Cambridge University Press, 1994.

—. "Reading practices." Jane Austen in Context. Ed. Janet Todd. Cambridge: Cambridge University Press, 2005. 397-405.

Richetti, John. Popular Fiction before Richardson: Narrative Patterns. Oxford: Clarendon, 1969.

- (ed.). The Cambridge Companion to the Eighteenth Century Novel. Cambridge: CUP, 1996.

- The English Novel in History, 1700-1780. London \& New York: Routledge, 1999.

Riley, E.C. "Teoría Literaria." Suma Cervantina. Ed. J. B. Avalle-Arce and E.C. Riley. London: Tamesis, 1973. 293-322.

—. Teoría de la novela en Cervantes. Madrid: Taurus, 1981. 
—. Don Quixote. London: Allen \& Unwin, 1986.

—."Don Quixote: from Text to Icon." 1988. http://www.hnet.org/ cervantes/csa/articw88/riley.htm. (Accessed May 2010)

Rimbault, E.F. (ed.). The Miscellaneous Works in Prose and Verse of Sir Thomas Overbury, Knt. Now first collected. Edited with notes, and a biographical account of the author, by Edward F. Rimbault, LL.D. London: John Russell Smith, Soho Square, 1856.

Roberts, Warren. Jane Austen and the French Revolution. London: The Athlone Press, 1995.

Ross, Deborah. "Mirror, Mirror: The Didactic Dilemma of The Female Quixote." Studies in English Literature, 1500-1900 (1987): 455-73.

- The Excellence of Falsehood: Romance, Realism, and Women's Contribution to the Novel. Lexington: University Press of Kentucky, 1991.

Roulston, Christine. "Histories of Nothing: romance and femininity in Charlotte Lennox's The Female Quixote." Women's Writing 2.1 (1995): 25-42.

Salm, Peter. "Werther and the Sensibility of Estrangement." The German Quaterly 46.1 (1973): 47-55.

Sánchez Tallafigo, Cristina. "Del tópico externo al canon implícito: influencias del Quijote en las formas ficcionales del siglo XVII francés." Mil Seiscientos Dieciséis 11 (2006): 119-28.

Schaub, Melissa. "Irony and Political Education in Northanger Abbey." Persuasions Online 21.1 (2000).

Schellenberg, Betty A. The Professionalization of Women Writers in EighteenthCentury Britain. Cambridge: Cambridge University Press, 2005.

Shepherd, David. "Dialogism." The living handbbook of narratology. Ed. Peter Hühn et al. Hamburg: Hamburg University Press. http://hup.sub.unihamburg.de/lhn/index.php?title=Dialogism\&oldid=1559 (Accessed December 2011).

Sheuermann, Mona. Her Bread to Earn. Women, Money, and Society from Defoe to Austen. Lexington: University Press of Kentucky, 1993.

Schofield, Mary Anne. Masking and Unmasking the Female Mind. Disguising Romances in Feminine Fiction, 1713-1799. London: Associated University Presses, 1990.

Schleiner, Louise. Tudor and Stuart Women Writers. Bloomington: Indiana University Press, 1994.

Skinner, John. "Don Quixote in 18th-Century England: A Study in Reader Response." Cervantes: Bulletin of the Cervantes Society of America 7.1 (1987): 45-57. 
Small, Miriam R. Charlotte Ramsay Lennox. An Eighteenth Century Lady of Letters. New York: Archon Books, 1969.

Smith, Sarah W.R. "Men, Women and Money: The Case of Mary Brunton." Fetter'd or Free? British Women Novelists, 1670-1815. Ed. Mary Anne Schofield and Cecilia Macheski. Athens, Ohio and London: Ohio University Press, 1986. 40-59.

Smith Palo, Sharon. "The Good Effects of a Whimsical Study: Romance and Women's Learning in Charlotte Lennox's The Female Quixote." Eighteenth-Century Fiction 18.2 (2005): 203-28.

Snook, Edith. Women, Reading, and the Cultural Politics of Early Modern England. Ashgate, 2005.

Sobba Green, Katherine. The Courtship Novel, 1740-1820: a Feminized Genre. Kentucky: The University of Kentucky Press, 1991.

Spacks, Patricia Meyer. "Sisters." Fetter'd or Free? British Women Novelists, 16701815. Ed. Mary Anne Schofield and Cecilia Macheski. Athens, Ohio and London: Ohio University Press, 1986. 136-51.

- "The Subtle Sophistry of Desire: Dr. Johnson and 'The Female Quixote'." Modern Philology 85.4 (1988): 532-42.

—. Desire and Truth: Functions of Plot in Eighteenth-Century English Novels. Chicago, IL: University of Chicago Press, 1990.

__. "Oscillations of Sensibility.” New Literary History 25.3 (1994): 505-20.

Spencer, Jane. "Creating the Woman Writer: the Autobiographical Works of Jane Barker.” Tulsa Studies in Women's Literature 2.2 (1983): 165-81.

- The Rise of the Woman Novelist. From Aphra Behn to Jane Austen. Oxford: Basil Blackwell, 1986.

—. "Jane West." A Dictionary of British and American Women Writers 1660-1800. Ed. Janet Todd. London: Methuen \& Co. Ltd, 1987. 319-20.

—. "Women writers and the eighteenth-century novel". The Cambridge Companion to the Eighteenth-Century Novel. Ed. John J. Richetti. Cambridge: Cambridge University Press, 1996. 212-235.

Spender, Dale. Mothers of the Novel. 100 Good Women Writers before Jane Austen. London: Pandora Press, 1986.

- (ed.). Living by the Pen. Early British Women Writers. New York and London: Teachers College Press, Columbia University, 1992.

Starkie, Walter. "Cervantes y la novela inglesa." Homenaje a Cervantes. Ed. Francisco Sánchez-Castañer. Valencia: Mediterráneo, 1950. 351-363.

Staves, Susan. "Don Quixote in Eighteenth-Century England." Comparative Literature 24.3 (1972): 193-214. 
A Literary History of Women's Writing in Britain, 1660-1789. Cambridge: Cambridge University Press, 2006.

Stevens, Geo. Alex. A Lecture on Heads. 1765. London: Printed by T. Bensley, 1799.

Stevens Fields, Polly. "Tomlins, Elisabeth Sophia." Oxford Dictionary of National Biography. 2004. http://www.oxforddnb.com/view/article/27521 (Accessed March 2007).

Sutherland, Kathryn. "Writings on education and culture: arguments for female improvement." Women and Literature in Britain 1700-1800. Ed. Vivien Jones. Cambridge: Cambridge University Press, 2000. 25-45.

—. "Jane Austen and the invention of the serious modern novel." The Cambridge Companion to English Literature 1740-1830. Cambridge: Cambridge University Press, 2004. 244-62.

Tarr, Muriel Mary. Catholicism in Gothic fiction. Michigan: The Catholic University of America Press, 1946.

Tave, Stuart M. The Amiable Humorist. Chicago: University of Chicago Press, 1960.

Thomson, Helen. "Charlotte Lennox's The Female Quixote: a Novel Interrogation." Living by the Pen. Early British Women Writers. Ed. Dale Spender. New York and London: Teachers College Press, Columbia University, 1992. 113-25.

Thompson, Lynda M. The "scandalous memoirists": Constantia Phillips, Laetitia Pilkington and the shame of 'publick Fame'. Manchester: Manchester University Press, 2000.

Todd, Janet. Sensibility. An Introduction. London: Methuen \& Co. Ltd, 1986.

(ed.). A Dictionary of British and American Women Writers 1660-1800. London: Methuen \& Co. Ltd, 1987.

- The Sign of Angellica. Women, Writing, and Fiction 1660-1800. London: Virago Press, 1989.

Tomaselli, Sylvana. "The most public sphere of all: the family." Women, Writing and the Public Sphere, 1730-1830. Ed. Elisabeth Eger et al. Cambridge: Cambridge University Press, 2001. 239-56.

Tompkins, J.M.S. "Mary Hays, Philosophess." The Polite Marriage. Eighteenthcentury Essays. Cambridge: Cambridge University Press, 1938. 150-90.

- The Popular Novel in England. 1770-1800. Westport, Connecticut: Greenwood, 1976.

Turner, Cheryl. Living by the Pen. Women Writers in the Eighteenth Century. London and New York: Routledge, 1994 [1992]. 
Ty, Eleanor. "Breaking the 'Magic Circle'. From Repression to Effusion in Memoirs of Emma Courtney." Unsex'd Revolutionaries: Five Women Novelists of the 1790s. 1993. 46-59.

Unsex'd Revolutionaries. Five Women Novelists of the 1790s. Toronto, Buffalo, London: University of Toronto Press, 1993.

Uddén, Anna. "Narratives and Counter-Narratives- Quixotic Hermeneutics in Eighteenth-Century England: Charlotte Lennox, The Female Quixote." Partial Answers 6.2 (2008): 443-57.

Uman, Deborah and Belén Bistué. "Translation as Collaborative Authorship: Margaret Tyler's The Mirror of Princely Deedes and Knighthood." Comparative Literature Studies 44.3 (2007): 298-323.

Unamuno, Miguel de. Del sentimiento trágico de la vida en los hombres y en los pueblos. Madrid: Renacimiento, 1912.

—. Vida de Don Quijote y Sancho. 1905. Madrid: Cátedra, 2000.

Vargo, Lisa. "Introduction." Nightmare Abbey. Peterborough, On.: Broadview Press, 2007. 9-38.

Vauthier, Bénédicte. "Estudio preliminar." Manual de Quijotismo; Cómo se hace una novella; Epistolario Miguel de Unamuno-Jean Cassou. Salamanca: Ediciones Universidad de Salamanca, 2005.

Vickery, Amanda. The Gentleman's Daughter: Women's Lives in Georgian England. New Haven and London: Yale University Press, 1998.

—. "Introduction." Women, Privilege and Power: British Politics 1750 to the Present. Ed. Amanda Vickery. Stanford: Stanford University Press, 2001. 1-56.

Waldron, Mary. Jane Austen and the Fiction of her Time. Cambridge: Cambridge University Press, 1999.

Walker, Gina Luria. Mary Hays (1759-1843). The Growth of a Woman's Mind. Aldershot, England; Burlington, VT: Ashgate, 2006.

(ed.). The Idea of Being Free. A Mary Hays Reader. Peterborough, On.: Broadview, 2006.

Wallace, Miriam L. "Mary Hays's 'Female Philosopher': Constructing Revolutionary Subjects." Rebellious Hearts. British Women Writers and the French Revolution. Ed. Adriana Craciun and Kari E. Lokke. Albany: State University of New York Press, 2001. 233-59.

Warburton, Penny. "Theorising public opinion: Elisabeth Hamilton's model of self, sympathy and society." Women, Writing and the Public Sphere, 1730-1830. Ed. Elisabeth Eger et al. Cambridge: Cambridge University Press, 2001. 257-73. 
Wardropper, Bruce W. “Don Quixote: story or history?” Modern Philology 63 (1965): $1-11$.

Warner, William B. Licensing Entertainment. The Elevation of Novel Reading in Britain, 1684-1750. Berkeley: University of California, 1998.

Waters, Mary A. British Women Writers and the Profession of Literary Criticism, 1789-1832. Basingstoke: Palgrave Macmillan, 2004.

Watson, George (ed.). The New Cambridge Bibliography of English Literature. 16601800. Vol. II. Cambridge: Cambridge University Press, 1971.

Watson, Nicola. Revolution and the Form of the British Novel, 1790-1825: Intercepted Letters, Interrupted Seductions. Oxford: Clarendon Press, 1994.

Watt, Ian. The Rise of the Novel. Studies in Defoe, Richardson and Fielding. Harmondsworth, England: Penguin, 1957.

—. Myths of Modern Individualism. Cambridge: Cambridge University Press, 1996.

Welsh, Alexander. "Realism as a Practical and Cosmic Joke." Novel: a Forum on Fiction 9.1 (1975): 23-39.

—. Reflections on the Hero as Quixote. Princeton, NJ: Princeton University Press, 1981.

"The Influence of Cervantes." The Cambridge Companion to Cervantes. Ed. Anthony J. Cascardi. Cambridge: Cambridge University Press, 2002. 80-99.

Williams, Ioan (ed.). Novel and Romance 1700-1800: A Documentary Record. London: Routledge, 1970.

Wilson, Carol S. (ed.). The Galesia Trilogy and Selected manuscript Poems of Jane Barker. Ney York, Oxford: Oxford University Press, 1997.

Wilson, Lisa M. "British Women Writing Satirical Novels in the Romantic Period: Gendering Authorship and Narrative Voice." Romantic Textualities: Literature and Print Culture, 1780-1840 17 (2007): 24-46.

Winton, Calhoun (ed.). The Tender Husband. London: Edwards Arnold Publishers, 1967.

Wollstonecraft, Mary. A Vindication of the Rights of Woman. 1792. Ed. Miriam Brody. Harmondsworth: Penguin, 1975.

Wood, Lisa. Modes of Discipline. Women, Conservatism, and the Novel after the French Revolution. Cranbury, NJ; London; Mississauga, On: Associated University Presses, 2003.

Wood, Sarah F. Quixotic fictions of the USA: 1792-1815. Oxford: Oxford University Press, 2005 
QUIXOTIC READERS AND QUIXOTIC WRITERS

Ziolkowski, Eric J. The Sanctification of Don Quixote. From Hidalgo to Priest. Pennsylvania: Pennsylvania State University Press, 1991.

Zorrilla, A. M. "Miguel de Unamuno y Don Quijote. El nuevo mundo del espíritu." Lecturas Cervantinas. 2005.2 Online article. http://asale.org/ASALE/pdf/Lecturascervantinas/Zorrilla.pdf. (Accessed May 2010). 